UNIVERSIDADE DE SÃO PAULO

FACULDADE DE FILOSOFIA, LETRAS E CIÊNCIAS HUMANAS

DEPARTAMENTO DE LETRAS ORIENTAIS

PROGRAMA DE LITERATURA E CULTURA RUSSA

RODRIGO ALVES DO NASCIMENTO

\title{
Tchékhov no Brasil: a construção de uma atualidade
}

Versão corrigida

São Paulo

2013 


\title{
UNIVERSIDADE DE SÃO PAULO \\ FACULDADE DE FILOSOFIA, LETRAS E CIÊNCIAS HUMANAS \\ DEPARTAMENTO DE LETRAS ORIENTAIS \\ PROGRAMA DE LITERATURA E CULTURA RUSSA
}

\section{Tchékhov no Brasil: a construção de uma atualidade}

\begin{abstract}
Rodrigo Alves do Nascimento
Dissertação em versão corrigida apresentada ao Programa de Pós-graduação em Literatura e Cultura Russa do Departamento de Letras Orientais da Faculdade de Filosofia, Letras e Ciências Humanas da Universidade de São Paulo como requisito para obtenção do título de Mestre em Literatura e Cultura Russa. Pesquisa desenvolvida com apoio da Fundação de Amparo à Pesquisa do Estado de São Paulo (FAPESP).
\end{abstract}

De acordo,

Orientador: Prof. Dr. Bruno Barretto Gomide

São Paulo

2013 
Autorizo a reprodução e divulgação total ou parcial deste trabalho, por qualquer meio convencional ou eletrônico, para fins de estudo e pesquisa, desde que citada a fonte.

Catalogação na Publicação

Serviço de Biblioteca e Documentação

Faculdade de Filosofia, Letras e Ciências Humanas da Universidade de São Paulo

Nascimento, Rodrigo Alves do

Tchékhov no Brasil: a construção de uma atualidade / Rodrigo Alves

do Nascimento; orientador Bruno Barretto Gomide. -- São Paulo, 2013.

344 f. ; il.

Dissertação (Mestrado) - Programa de Pós-Graduação em Literatura e

Cultura Russa - Faculdade de Filosofia, Letras e Ciências Humanas da Universidade de São Paulo.

1. Tchékhov, Anton Pávlovitch, 1860-1904. 2. Dramaturgia. 3. Encenações. 4. Teatro Brasileiro. 5. Teatro Russo I. Título. II. Gomide, Bruno Barreto. 


\section{Tchékhov no Brasil: a construção de uma atualidade}

Dissertação de mestrado em versão corrigida presentada ao Programa de pós-graduação em Literatura e Cultura Russa do Departamento de Letras Orientais da Faculdade de Filosofia, Letras e Ciências Humanas da Universidade de São Paulo, aprovada pela Banca Examinadora constituída pelos seguintes professores:

Prof. Dr. Bruno Barretto Gomide

Faculdade de Filosofia, Letras e Ciências Humanas

Universidade de São Paulo

Orientador

Prof. Dr. Luiz Fernando Ramos Escola de Comunicações e Artes Universidade de São Paulo

Prof. Dra. Elena Vássina Faculdade de Filosofia, Letras e Ciências Humanas Universidade de São Paulo 
Para Vilma Arêas,

pelas lições de liberdade. 


\section{AGRADECIMENTOS}

Em primeiro lugar, gostaria de agradecer à FAPESP, pelas bolsas concedidas no Brasil e nos EUA, que me permitiram a dedicação exclusiva a esta pesquisa.

Ao meu orientador, Bruno Barretto Gomide, que me honrou com suas orientações e, sempre à disposição, permitiu-me grande liberdade de trabalho.

Na USP, tive a oportunidade de assitir às aulas de Elena Vássina, Arlete Cavaliere, Fátima Bianchi, Maria Silvia Betti e do professor João Roberto Faria, que me proporcionaram momentos instigantes de formação e em muito contribuíram para este estudo. Além deles, Aurora Fornoni Bernardini, Tatiana Belinky e Boris Schnaiderman cederam longas entrevistas - o que, em si, já vale por todo o trabalho.

$\mathrm{Na}$ Universidade da Califórnia, em Berkeley, tive a oportunidade de tomar contato com as ótimas aulas da professora Anna Muza e com a presença solícita da professora Irina Paperno - responsáveis também por me guiar dentro do acervo fabuloso das bibliotecas americanas. Laurence Senelick e Patrick Miles, especialistas na recepção de Tchékhov nos EUA e no Reino Unido, estiveram à disposição para trocar e-mails e fornecer informações valiosas para esta pesquisa.

No Instituto de Estudos da Linguagem (IEL-UNICAMP), fui beneficiado pelas aulas do professor Antonio Arnoni Prado e pelas presenças fundamentais, tanto pessoal quanto intelectualmente, dos professores Eric Mitchell Sabinson e Vilma Arêas. A professora Vilma, em especial, abriu-me as portas para a seara russa.

No Rio de Janeiro, o diretor de teatro Antonio Gilberto me forneceu preciosas informações sobre a recepção de Tchékhov no Brasil. Márcia Cláudia, funcionária da FUNARTE, aturou-me durante muitos dias e nunca negou qualquer solicitação.

Também os funcionários do AEL-Unicamp, do Centro Cultural São Paulo, da Casa Rui Barbosa e da Biblioteca Jenny Klabin Segall foram sempre solícitos e prestativos. Os funcionários da Pós-Graduação, em especial o Jorge, tornaram o labirinto burocrático das inscrições, prazos e relatórios menos assustador.

Há também os amigos! Fernando e Gracilene Macedo são amigos de primeira hora, salvaram meus dias da monotonia e garantiram as condições para que eu conseguisse trabalhar (e bebericar). Adriana e Anderson, primos, deram-me ótima estadia nos dias de confecção dos capítulos finais. Marcelo Lotufo, mesmo em outro hemisfério, ajudou-me em tudo e é grande parceiro intelectual. Leonel Carneiro deu ótimas indicações para o texto. Larissa Machado enfrentou os arquivos junto comigo. Priscila Nascimento, Deise e Flávia tornaram minha vida nos corredores da FFLCH mais vivas. Lígia, Larissa Higa, Gislaine e Fernanda Valim são insubstituíveis e têm tornado essa etapa de minha vida menos árida. Diogo, Dieguinho, Diego Fernandez, Alexandre Baquero, Lucas Ferreira, Igor Tanaka, Luis Stival, Robson, Paulinha, Priscila, Gabriel e Kauê me brindam com a oportunidade de tê-los como amigos.

Já quase no final, mas não menos importante, agradeço aos meus irmãos Rogério e Reginaldo, a quem amo tanto. Agredeço ao meu pai Sebastião, por ser um maravilhoso contador de histórias - o primeiro grande artista que conheci. E agradeço a minha mãe, Sônia, por ser quem é, por ser um exemplo de luta e por ter me instigado a ler os primeiros livros.

Por fim, agradeço à Patrícia Rocha, companheira que me deu meus melhores anos e que toca em meus dias uma apaixonada sinfonia para o embalo do corpo e das emoções. Aos meus companheiros de militância política e aos meus educandos que, mesmo diante dos percalços (que são muitos), continuam acreditando que é necessário viver de maneira radicalmente diferente da que se vive hoje. Ainda que não o saibam, também pensam um pouco como Tchékhov. 
Poucos escritores estrangeiros são mais intrinsecamente "brasileiros" do que Anton Chekov (sic). E sua obra tem um pungente "brasileirismo" atual. De Dostoiévski ou Tolstoi - os grandes contemporâneos de Chekov - só se pode dizer que sejam brasileiros naquilo que têm de universal: a angústia metafísica, a luta pelo aperfeiçoamento, a preocupação pela injustiça social vista como pecado, etc.

Chekov, não. Equilibrado sensato, cuidadoso das aparências, mais "europeu" do que russo, viu perfeitamente, viu tão bem quanto o grande Dostoiévski, a revolução que se acercava, mas viu-a de forma muito mais nossa: as elites russas não eram elites nenhumas, os fazendeiros e senhores de engenho não eram nem maus nem bons, mas estúpidos $e$ imprevidentes, todo o mundo via o errado de tudo, mas ninguém queria dar-se o trabalho de endireitar nada, todos falavam muito em cultura mas ninguém a conhecia fora dos livros, cultura viva, inventada, fecunda. Sua peça "O Cerejal" ou "O Pomar de Cerejas" ou como a chamemos, podia desenrolar-se numa fazenda de café, assim como "As Três Irmãs" podia acontecer num engenho de açúcar (...)

Antonio Callado, Chekov 
NASCIMENTO, Rodrigo Alves do. Tchékhov no Brasil: a construção de uma atualidade. São Paulo: 2013, 344f. Dissertação (Mestrado em Literatura e Cultura Russa) - Faculdade de Filosofia, Letras e Ciências Humanas, Universidade de São Paulo.

\section{RESUMO}

Anton Pávlovitch Tchékhov (1860-1904) é hoje um dos dramaturgos mais encenados no Brasil e no mundo. A fim de compreender como se deu o processo de afirmação de sua dramaturgia, bem como as interpretações e atualizações feitas por críticos e grupos teatrais, realizaremos um estudo de recepção com foco específico na relação entre texto e cena. Inicialmente, faremos uma breve análise de suas primeiras encenações em solo russo (e a produção pelo Teatro de Arte de Moscou do que se convencionou chamar tchekhovismo), passando pelos palcos europeus e americanos para, finalmente, entender as principais interpretações produzidas em solo brasileiro - foco deste trabalho. Ao final, esperamos que fique evidente que nossa tentativa é menos a de estabelecer uma linha evolutiva de dissolução do mito do tchekhovismo e mais a de mostrar como ao longo da história da recepção do drama de Tchékhov sua atualização constante sofria (e sofre) pressões dos impasses de nossa formação teatral, nossas dificuldades econômicas, sociais e políticas.

Palavras-chave: Anton Tchékhov; Dramaturgia; Encenação; Teatro Brasileiro; Teatro Russo. 
NASCIMENTO, Rodrigo Alves do. Chekhov in Brazil: the building of a presentness. São Paulo: 2013, 344f. Dissertação (Mestrado em Literatura e Cultura Russa) Faculdade de Filosofia, Letras e Ciências Humanas, Universidade de São Paulo.

\begin{abstract}
Anton Pavlovich Chekhov is one of the most staged playwriters of our days both in Brazil and in most of the World. In order to understand how the importance of his dramaturgy came into being, as well as the different interpretations and updatings done by several theater groups, this study will investigate Chekhov's reception, with emphasis to the relation between the text and the stagings. Beginning with an analysis of his Russian reception (and the creation of what we came to call Chekhovism by the Moscow Art Theater), we will then proceed with analysis of his stagings in both Europe and the United States in order to finally approach his Brazilian reception and interpretation - the main focus of this study. We hope, by the end of this inquiry, to have made clear that our intention is not only tracing an evolutionary line of the myth of Chekovism and of its dissolution, but also showing how Checkov's constant reinterpretations suffered (and continues to suffer) pressure from the genesis of our theater tradition and of our social, political and economic struggles.
\end{abstract}

Key Words: Anton Chekhov; Dramaturgy; Stagings; Brazilian Theater; Russian Theater. 


\section{SUMÁRIO}

Introdução 12

1. Como se cria um Tchékhov 22

1.1. Dentro do texto, fora dos palcos 22

1.2. Uma Gaivota de tinturas trágicas 43

1.3. Um Tio Vânia com sofrimento duradouro 51

1.4. Três Irmãs que se sufocam no tédio de província 54

1.5. Um Jardim das Cerejeiras sem riso

1.6. A Revolução varrerá o tédio? 62

2. Tchékhov no Ocidente: entre o exótico e o íntimo 68

2. 1. França: a "alma russa" como espetáculo 70

2. 2. Reino Unido: falar de nossos problemas, à maneira russa 74

2. 3. Estados Unidos: dos círculos alternativos aos comerciais 78

3. Tchékhov no Brasil: primeiros momentos 85

3.1. Rústico e Antiburguês 93

3.2. Estudantil e Amador 95

3.3. O cômico não parece sério 105

3.4. O dramaturgo, o melhor professor $\quad 110$

3.5. Tchekhovismo: momentos decisivos 118

4. Que tem o Brasil a ver com Tchékhov? 124

4.1. O mais brasileiro dos russos 124

$\begin{array}{ll}\text { 4.2. Fissuras na tradição } & 127\end{array}$

$\begin{array}{lr}\text { 4.3. Tchékhov político } & 129\end{array}$

4.4. Política, desbunde e algumas contradições 136

5. Tchékhov, nosso contemporâneo 148

5.1. A tradição posta em questão - Tovstonogov, Éfros, Strehler 148

$\begin{array}{ll}\text { 5.2. Recolhimento e descompasso } & 154\end{array}$

$\begin{array}{ll}\text { 5.3. Sem estranheza de acento } & 164\end{array}$

$\begin{array}{ll}\text { 5.4. Pluralidade de tendências } & 170\end{array}$

$\begin{array}{ll}\text { 5.5. Desconstruindo Tchékhov } & 181\end{array}$

6. Conclusão 195 


\section{Anexos}

Anexo 1 : Índice Cronológico de Montagens para o Teatro 221

Anexo 2: Fichas Técnicas de Encenações, Fontes e Fotos 224

Anexo 3: Edições Brasileiras (Contos e Teatro) 286

Anexo 4: Seleção de Textos Críticos 


\section{Introdução}

Tudo o que escrevi será esquecido em alguns anos. Mas os caminhos que abri ficarão intactos e seguros,

e nisso reside meu único mérito...

(Tchékhov) ${ }^{1}$

Tchékhov permanece o cronista da vida moderna.

(Sábato Magaldi)

Shakespeare reinventou os gregos para os tempos modernos e Tchékhov para o século vinte

$(\text { Peter Stein })^{2}$

Que tipo de interesse temos nós por Tchékhov? Como um dramaturgo tão distante no tempo e no espaço, aparentemente fechado em uma sensibilidade de fim de século, acusado de "melancólico", "inábil" e "decadente" por muitos de seus contemporâneos, pode ainda hoje dizer-nos algo e evocar sentidos possíveis que nos permitam falar de sua atualidade? Dentro da tradição teatral brasileira, em muitos momentos bastante afeita à potência do diálogo, sempre às voltas com o debate sobre sua real "modernização", como essa dramaturgia sem diálogos e ações claras pode se firmar? As perguntas não são simples, mas ao mesmo tempo não é a primeira vez que vêm à baila. Afinal, o teatro é por excelência a arte do presente e vive de seu contato direto com a sensibilidade do público que o experiencia, e pode, por isso, reconceber e reinventar formas aparentemente superadas. Essa premissa é tão decisiva que não à toa Peter Brook chamaria teatro morto aquele feito por atores e assistido por espectadores com interesses meramente comprobatórios, que se dirigem ao teatro para ver as linhas de seu drama preferido corretamente encenadas ("da forma como foi escrito") e experienciar a cena sem nenhuma sensibilidade nova. Segundo ele, "o Teatro Morto trata os clássicos supondo que, em algum lugar alguém já descobriu e definiu como o

\footnotetext{
${ }^{1}$ Máximo Górki citando o que dissera o amigo Tchékhov, em uma de suas últimas conversas com o escritor. (LAFFITTE, Sophie. Tchekhov. Rio de Janeiro: José Olympio, 1993, p. 178).

${ }^{2}$ STEIN, Peter. Entrevista a Amie Ferris-Rotman e Iúri Púchkin em 2010, em Moscou. Disponível em: http://entretenimento.uol.com.br/ultnot/reuters/2010/01/29/ult26u29717.jhtm. Acesso em 29 jan. 2010.
} 
drama deve ser representado" ${ }^{3}$. Pensar na atualidade de Tchékhov é, portanto, pensar como foi possível retrabalhar a força de seu drama através do tempo para que chegasse até nós, dentro de um processo vivo de reinterpretações que só o teatro pode conceber.

E sua presença já é tão evidente, que Anton Pávlovitch se converteu em um dos dramaturgos mais importantes da contemporaneidade; e sua atualidade já é, para muitos, um dado inquestionável.

Em artigo de novembro de 2012, Ben Brantley, crítico de teatro do New York Times, afirmou que só neste ano foram três importantes montagens de Tio Vânia em cartaz em Nova York, com concepções completamente diversas, além de montagens de Ivanov, A Gaivota e as Três Irmãs, que também abundaram nos palcos de Londres ${ }^{4}$. Em 2010, ano de comemoração do $150^{\circ}$ aniversário do dramaturgo, circularam pelo mundo montagens de peso de seus textos ou baseadas em sua vida e obra ${ }^{5}$. Só no Brasil, já é possível mapear suas peças em cartaz em todas as temporadas nos palcos das principais capitais. Tanto que, em 1998, Sérgio de Carvalho afirmava que Tchékhov seria muito provavelmente o autor mais encenado dos palcos brasileiros ${ }^{6}$. E a sintonia dessa dramaturgia com o teatro e o público nacionais teve um de seus pontos altos em 2010, com o Espaço Tchékhov (temporada na FUNARTE-SP com exposição de imagens de encenações brasileiras antológicas, instalações, palestras e montagem de uma peça sob direção do russo Adolf Shapiro ${ }^{7}$ ) que, se não sinaliza qualitativamente o sentido dessa presença, pelo menos nos demonstra o nível de familiaridade de nosso teatro com o dramaturgo russo, que lhe viu rendida uma "homenagem", a qual não se vê com frequência.

\footnotetext{
${ }^{3}$ BROOK, Peter. O teatro e seu espaço. São Paulo: Vozes, 1970, p. 7.

${ }^{4}$ BRANTLEY, Ben. "Chekhov Melancholy, never so welcome". The New York Times. 29 nov. 2012. Disponível em: http://theater.nytimes.com/2012/12/02/theater/ben-brantley-on-chekhov-on-new-yorkstages.html?_r=0. Acesso em 11 de janeiro de 2012.

5 Só neste ano, vieram para o Brasil importantes montagens internacionais, baseadas direta ou indiretamente em sua vida e obra: Donka - uma carta a Tchékhov, dirigida pelo suíço-italiano Daniele Finzi Pasca (que abriu o Festival Internacional Tchékhov e estreou no Brasil em agosto de 2010), Os Irmãos Tchékhov, montagem do russo Alexander Galibin (que estreou em novembro do mesmo ano, em São Paulo) e As Três Irmãs, dirigida pelo escritor e cineasta libanês Wajdi Mouawad (dezembro de 2010). ${ }^{6}$ CARVALHO, Sergio. Tchékhov conta Brasil - por que o dramaturgo russo do século XIX será um dos autores mais encenados neste ano no país. Revista Bravo, n. 07, Ano 1. São Paulo, abr. de 1998, p.106109.

7 "Evento/Espaço" que ocorreu sob curadoria de Elena Vássina (professora da FFLCH USP) entre 17 de setembro e 10 de novembro, com parceria entre a Fundação Nacional de Artes e o Festival Internacional de Teatro Anton Tchekhov, de Moscou. Ver: http://www.funarte.gov.br/teatro/espaco-tchekhov-2010-nafunarte-spl. Acesso em 12 de janeiro de 2012.
} 
Os motivos que levam a esse crescente interesse, a ponto de Laurence Senelick afirmar que Anton Pávlovitch tem se tornado o segundo dramaturgo em reputação depois de Shakespeare ${ }^{8}$, são um ponto decisivo. Isso significa entender como se dão a atualidade dessa forma dramática e das problemáticas por ela apresentadas. Para Sérgio de Carvalho, Tchékhov nos fala de maneira íntima porque sua dramaturgia é o retrato da "crise da ação na vida" e, tal qual a Rússia de fins do XIX, vivemos em um período de intervalo, de aparente "fim das utopias". E o "mecanismo teatral" do dramaturgo, realista e desdramatizado, permite acessar por meio dos desvãos da forma "inacabada", não o retrato do tédio ou apenas a sensibilidade de uma forma abstrata e "cinzenta", e sim os "exemplos negativos" de personagens que mostram que "é possível viver de maneira diferente da que se tem vivido até hoje" 9 .

Já para Ben Brantley, a atualidade do dramaturgo russo está na ambiguidade do desenho ao mesmo cômico e trágico que este "insiste" em fazer da vida, pois, em uma época de transição como a nossa, em que a noção de família (que ao longo dos anos obrigou muitos a amontoarem-se sob o mesmo teto), assim como a das ideologias préfabricadas, são postas em questão - tal qual em sua Rússia pré-revolucionária.

Ainda que estas duas pequenas amostras do riquíssimo debate sobre a atualidade de Tchékhov tenham seu quinhão de interesse, a verdade é que um estudo profundo sobre "por que ainda ler e encenar Tchékhov" é algo a ser feito. Ainda assim, o que se percebe é que todo o século XX, de oriente a ocidente, é um grande palco em que pudemos assistir a uma tentativa constante de mostrar como Tchékhov, um dramaturgo russo de fim de século, que em suas grandes peças era aparentemente descolado de todas as "tradições" e modismos, é um poderoso referencial. É por isso que este trabalho optará por apresentar um percurso sintético, mas (acreditamos) bastante rico, de como diretores, atores e críticos promoveram o diálogo e a atualização de suas peças ao longo dos anos. Ou seja, um estudo de recepção das interpretações produzidas por esses

\footnotetext{
8 "A funny thing has happened. Anton Chekhov, who was judged in his own time to be a playwriter narrowly culture-bound, over-refined and obscure, whose drama was persistently characterized at home and abroad as 'depressing' and 'pessimistic', has become second only to Shakespeare in reputation and in frequency of production. Andrzej Wajda's remark - 'Theatre in our European tradition derives from the word, from literature, the Greeks, Shakespeare, Chekhov - is typical of the regard in which Chekhov is held." Ver: SENELICK, Laurence. The Chekhov Theatre - a Century of Plays in Performance. Cambridge: Cambridge University Press, 2006, p. I.

${ }^{9}$ CARVALHO, Op. Cit, p. 106.
} 
agentes $^{10}$ que desenhará um arco que vai da Rússia imperial e passa por países centrais da Europa, pelos Estados Unidos, até chegar ao Brasil - nosso ponto maior de interesse.

Evidentemente, todos esses países dialogaram direta ou indiretamente com as problematizações de seu tempo histórico, suas condições econômicas, sociais e culturais. E no caso da dramaturgia de Anton Pávlovitch, em que, nas palavras de Raymond Williams, não há "relação precisa entre a organização das palavras e o método de dizê-las" (o que configuraria, na relação texto-cena, uma distância maior do que nos dramas em que o que é dito corresponde à comunicação física), esse diálogo é fundamental, pois por meio dele se abre um inevitável, tenso e rico espaço para a "interpretação" desse texto por diretores e atores ${ }^{11}$. Por isso, somente uma tentativa de mapear esse movimento já será valiosa não só para a compreensão da poética do dramaturgo, como também para o entendimento dos impasses de nosso próprio teatro. Afinal, não se pode conceber uma tradição teatral ou literária em outra perspectiva que não a comparada ${ }^{12}$, fator constitutivo que ganha em interesse quando levamos em conta que se trata justamente do contato entre duas culturas periféricas (Brasil e Rússia). A partir daí, compreender os percalços de leitura, as iluminações produtivas e o papel cumprido pelo filtro autorizado da metrópole (que "descobre", "filtra" e "exporta" uma outra cultura) é algo que pode trazer elementos significativos para os estudos comparados e de recepção ${ }^{13}$, iluminando nossa própria condição cultural.

\footnotetext{
${ }^{10}$ Não nos dedicaremos ao estudo de recepção em grande escala (leitores e espectadores massivos). Ficaremos restritos às interpretações produzidas dentro da relação texto-cena (e, por isso, leituras de diretores e atores), bem como as produzidas por críticos literários e teatrais. Complementarmente, vale a leitura do texto de Patrice Pavis a respeito dos desafios colocados para o teórico de teatro sobe a relação entre texto e cena, sobretudo quando lidamos com uma "peça fora de contexto". PAVIS, Patrice. "Problems of translation for the stage: interculturalism and post-modern theatre". IN: HOLLAND, Peter (ed). The Play Out Of Context - transferring plays from culture to culture. New York: Cambridge University Press, 1989.

${ }^{11}$ WILLIAMS, Raymond. "Discussão: texto e encenação". Drama em Cena. São Paulo: Cosac\&Naify, 2010.

${ }^{12}$ CANDIDO, Antonio. Recortes. Rio de Janeiro: Ouro Sobre Azul, 2004.

${ }^{13} \mathrm{O}$ sentido que atribuímos ao conceito de recepção está diretamente relacionado à tradição, bastante ampla, que busca superar entendimento de recepção enquanto simples estudo das "fontes" ou "influências" de um determinado texto ou autor sobre outras culturas. Buscaremos fincar nossa pesquisa numa concepção na qual a interpretação do texto se dá por um movimento dialético no qual se relacionam elementos da formação social e cultural que envolve o intérprete e/ou leitor e elementos de sua própria formação "intraliterária" ou "intradramática". São tais elementos que definem seu "horizonte de expectativas", e isso pode ser fundamental para que compreendamos porque determinada obra foi entendida de diferentes maneiras em diferentes momentos da história. Pretendemos assim evitar uma concepção extremamente relativista, pois entendemos que cada interpretação do texto se legitima por disposições históricas, sociais, literárias, estéticas e mesmo pessoais. Ao mesmo tempo, de tal enfoque se pode depreender que do conhecimento das sucessivas leituras realizadas podemos tomar conhecimento do que Jauss denomina potencial de sentido da obra, ou seja, o elemento que a torna "permanente" na história literária.NITRINI, Sandra. Literatura Comparada: história, teoria e crítica. São Paulo: EDUSP, 1997, p. 171-172.
} 
Acreditamos que este trabalho visa a trazer interpretações sobre matéria ainda pouco estudada, pois ainda que muito já se tenha dito sobre as relações políticas, econômicas ou culturais entre Brasil e Rússia, e mesmo que haja recente interesse do mercado editorial e de parte expressiva da crítica por "temas" russos, em geral as relações entre Brasil e Rússia são mais "pressentidas e esboçadas" que efetivamente destrinchadas ${ }^{14}$.

No caso da tradição teatral russa, nosso contato com as experiências revolucionárias de inícios do século XX não é desprezível, ainda que não tenham sido de todo exploradas. Por isso, ao dar início a este trabalho comparativo, nossa primeira hipótese foi a de que a genial proposta cênica do Teatro de Arte de Moscou (TAM), justamente por ter sido responsável pela projeção do dramaturgo (que até então sofrera para encontrar suporte cênico adequado para as fissuras que promovia na estrutura do drama), foi também responsável por consolidar algumas linhas de interpretação que perduraram até recentemente, inclusive no Brasil. Galvanizaram um modo específico de se encenar Tchékhov, imprimindo sobre suas personagens a representação do "tédio de província", a "impotência ante os grandes sonhos" e a "melancolia". Isto implicou, em termos cênicos, na adoção de procedimentos então revolucionários, como a criação "atmosfera", "ritmo", "silêncio" e "tragicidade", mas que seriam trabalhados na Rússia e internacionalmente como "tipicamente techekhovianos". Esta tipificação, interpretada de múltiplas maneiras pela tradição teatral ocidental é o que, por suposto, pretendemos historicizar e colocar em discussão.

Evidentemente, inúmeras propostas posteriores se chocaram com as leituras de Stanisláviski /Nemiróvitch-Dântchenko, mas quase sempre se estabeleceram em relação a elas. Isto implica em uma série de questões a respeito da dramaturgia tchekhoviana que são bastante interessantes, dentre elas: a crise das formas dramáticas tradicionais (em fins do XIX) e a historicidade dos problemas a ela vinculados, o lugar do cômico e do trágico nas suas leituras, o trabalho com pausas e silêncios, as possíveis "melancolia permanente", "ausência de utopia" ou "tédio da vida" versus "o sonho", "a vivacidade" e a força "irônica". A escolha de alguns destes pontos como flancos de apoio, ou mesmo

${ }^{14}$ GOMIDE, Bruno. Da Estepe à Caatinga: O Romance Russo no Brasil (1887-1936). Tese IELUNICAMP. Campinas: Instituto de Estudos da Linguagem, 2004, p. 13. Contudo, não se pode dizer que este seja um campo totalmente inexplorado: O primeiro livro de Leonid Shur "Relações Literárias e culturais entre Brasil e Rússia", o livro de Boris Schnaiderman "Projeções: Brasil, Rússia, Itália" e a própria tese de Bruno Barreto Gomide sobre a recepção do romance russo no Brasil entre 1887 e 1936 são estudos de fôlego que ajudam a iluminar este debate. 
sua mescla, pode resultar em encenações e posicionamentos críticos bastante diversos. Nossa intenção é justamente mapear tais escolhas, tentando entendê-las dentro de tendências artísticas, problemas políticos e sociais.

Para que esse percurso fique razoavelmente delineado, optamos por organizar esse processo a partir das primeiras encenações de Tchékhov feitas na Rússia (a partir de 1896), passando pelas principais encenações europeias e americanas, até as montagens feitas no Brasil (em um arco que vai de 1946 a 2008). Por isso, no primeiro capítulo apresentamos de maneira sumária os primeiros contatos do dramaturgo russo com o meio teatral e os movimentos vividos por suas primeiras peças em um ato. Logo após, comentamos o processo de produção de suas quatro grandes peças e a dificuldade de aceitação de seu teatro dentro das condições específicas de encenação na Rússia. A partir daí, será possível enxergar como o surgimento do TAM e a consolidação (bastante tensa, como veremos) de um suporte adequado historicamente para a afirmação de sua dramaturgia serão decisivos para fixar as leituras stanislavskianas, que farão escola na Rússia, mas não deixarão de ser confrontadas por diretores locais pré e pós Revolução de 1917. Este embate, no entanto, será "vitorioso" para Stanislávski, que soube se "mesclar" ao establishment soviético.

No segundo capítulo, tentamos entender como se dá o movimento de projeção da dramaturgia de Tchékhov nos países do Leste Europeu, França, Inglaterra e Estados Unidos. Desde as primeiras traduções de peças de Tchékhov feitas por Antoine, passando pela emigração de artistas e críticos russos, até a consolidação em terreno francês das leituras "exoticizantes" da "alma russa", feitas em montagens de Ludmina e Georgy Pitoëff. Tais encenações, a despeito de tentarem fugir do paradigma ultrarrealista de Stanislávski, pecavam pela fabricação de um outro exótico. Veremos também como as caravanas do TAM pela Europa e EUA contribuíram para gerar um verdadeiro frisson internacional não só pelas novas técnicas de encenação, como também pela força do drama tchekhoviano. No Reino Unido, não só o contato com essas excursões, mas a intervenção de Bernard Shaw (que tentara apresentar o dramaturgo russo como um ácido leitor da sociedade capitalista em crise) e as encenações de Komissarjévski (que souberam retirar Tchékhov das malhas do exótico e aclimatá-lo ao "gosto inglês" pela simplificação elegante e o sentimentalismo). No caso americano, veremos como a lógica do show business e do star system prejudicaram a recepção dessa dramaturgia no início dos anos 20, e o importante papel dos Little Theatres, mais abertos às novas técnicas de encenação e aos trabalhos dramatúrgicos 
mais recentes e de vanguarda, que conseguiram com êxito introduzir o dramaturgo nos palcos fora dos grandes circuitos. Logo após, destacaremos o papel decisivo dos preceitos formativos de Boleslávski, as encenações de Eva Le Gallienne e as diretrizes formativas de Lee Strasberg e Stela Adler - à sua maneira discípulos de Stanislávski e grandes propagadores da dramaturgia de Tchékhov.

Para não prosseguir adiando o fundamental, o terceiro capítulo apresentará um panorama dos momentos iniciais da recepção de Tchékhov no Brasil. Desde as brevíssimas referências a seu nome e as traduções de contos cômicos em periódicos de entretenimento do início do século até as primeiras coletâneas de contos nos anos 30 e 40, que preparam o terreno para os principais textos críticos e encenações que começariam a ser realizados nos anos seguintes. Destacamos o papel fundamental que os grupos de teatro estudantis e amadores tiveram na popularização de suas peças cômicas em um ato, amadurecendo não só uma linhagem do teatro cômico brasileiro, mas também abrindo as portas de nossos palcos para outros dramaturgos internacionais de qualidade artística. E serão também os "amadores" do Tablado os primeiros a enfrentar uma peça longa de Tchékhov, Tio Vânia, seguida de As Três Irmãs, pela Escola de Arte Dramática (EAD) e anos depois pelo grupo A Barca, sob direção de Gianni Ratto, confirmando a interessante tese de Gilda de Mello e Souza de que estaria no dramaturgo russo um fundamental estágio para a formação do ator. Mas a sua projeção nos palcos brasileiros ganharia novo patamar com a encenação de As Três Irmãs pelo Teatro Nacional de Comédia (TNC), em 1960, momento decisivo de propagação no Brasil do que se convencionou chamar tchekhovismo.

Já no quarto capítulo, veremos como a partir daí dá-se o início a um processo de questionamento de Tchékhov "clássico importado", que vem acompanhada da tentativa de atualizar sua obra no contexto brasileiro, levando em conta o efervescente clima de radicalização política e social. Ainda assim, seu teatro passaria por percalços de interpretação e, em um primeiro momento, não seria visto como um dramaturgo de fácil digestão para as sensibilidades revolucionárias. Marco nesse sentido seriam a leitura fora do padrão "tchekhoviano" de O Jardim das Cerejeiras, feita por Ivan Albuquerque, e o desbunde político-tropicalista que o Oficina promoveu com As Três Irmãs. Esta montagem, especificamente, a despeito dos impasses oriundos de suas próprias escolhas formais e políticas, representou a tentativa mais significante de entender como o dramaturgo russo poderia falar de maneira direta ao público brasileiro de então e foi um marco no processo de recepção do teatro de Tchékhov entre nós. 
Por fim, no quinto e último capítulo, há um esquemático panorama de encenações realizadas no exterior nos anos 60 e 70 (sobretudo as de Tovstonogov e Anatoli Éfros, na Rússia, e Giorgio Strehler, na Itália) que já promoviam uma revisão significativa do paradigma do tchekhovismo. Logo após, observamos o ligeiro descompasso vivido pelas encenações brasileiras, que tentavam iluminar pontos novos na dramaturgia de Anton Pávlovitch, mas, ao mesmo tempo, não conseguiram firmar uma tendência interpretativa de peso. As dificuldades que o regime militar colocava aos grupos teatrais nos anos 70 dificultava o amadurecimento de propostas (vide as encenações A Gaivota, por Jorge Lavelli, o Tio Vânia, de Emilio Di Biasi), mas em contrapartida impulsionava-os para que buscassem novas formas de organização e encenação que, como veremos, arejarão as encenações nos anos de abertura (o Platonov, d'O Tablado e o Trágico à Força, de Marcio Aurélio). Os anos 90 e 2000 serão de clara abertura de tendências e demonstram a familiaridade dos palcos brasileiros com uma dramaturgia que, de início, pareceu alheia aos interesses imediatos de nosso teatro. Já é possível encontrar claros "enfrentamentos" aos modelos stanislavskianos e localizamos desde encenações mais afeitas à tentativa de deixar o que é "universal" em Tchékhov falar, às encenações que valorizam sua dimensão política para uma época de transição, ou ainda encenações que privilegiam a pura pesquisa de linguagem, buscando a atualidade do dramaturgo nas fissuras e descompassos de sua forma dramática - utilizando-se de seus textos mais como partitura "jazzística" que dramaturgia.

Ao final, esperamos que fique evidente que nossa tentativa é menos a de estabelecer uma linha evolutiva de "dissolução" do mito do tchekhovismo e mais a de mostrar como ao longo da história da recepção do drama de Tchékhov sua atualização constante sofria (e sofre) pressões dos impasses de nossa formação teatral, de nossas dificuldades econômicas, sociais e políticas. Metodologicamente, tal empreitada apresenta uma série de dificuldades. A primeira delas se refere a como lidar com o fato de que o "fenômeno cênico" se caracteriza justamente pelo acontecimento e pela presentificação da ação cênica, que não pode ser captada pelo simples registro escrito. Se vem daí o fascínio do teatro - pelo que ele tem de presença viva - está aí também um grande problema crítico e historiográfico que, só agora, tem amadurecido como campo de estudos ${ }^{15}$. Nesse sentido, tentaremos entender como se construíram determinadas

\footnotetext{
${ }^{15}$ O Grupo de Trabalho de História e Teatro da ANPUH (Associação Nacional de Pós-Graduação em História) tem se colocado como um de seus problemas fundamentais de investigação para os próximos
} 
leituras de Tchékhov trabalhando a partir do que Carlo Ginzburg denominou paradigma indiciário, ou seja, captar a partir de sinais particulares o sentido que determinado elemento pode ter para a compreensão do movimento geral de uma cultura ou sociedade $^{16}$. Trabalhamos para tentar reconstituir esse universo específico por meio dos documentos (escritos, iconográficos e sonoros), deixando-os que "falassem", ao invés de definir um percurso historiográfico-crítico de antemão.

Ao deixar que tais documentos ganhassem voz, tentamos não nos restringir a apenas um registro sobre determinada encenação (mesmo levando em conta o fato de que isso se torna bastante difícil para as encenações com menor repercussão) ou mesmo não sufocar posições divergentes a respeito de uma mesma montagem - tendo em vista que uma das principais formas de registro que nos dão acesso a uma peça é o discurso do crítico teatral que, como se sabe, é sempre uma interpretação frente ao fenômeno cênico. No entanto, isso não impediu que ao analisarmos o sentido de determinada interpretação de Tchékhov nos posicionássemos também em relação ao que havia de produtivo ou limitador na proposta feita.

Também não deixa de ser importante esclarecer que para a realização deste estudo, foi necessário conciliar o trabalho de pesquisa em arquivo (diários de direção, fotografias, vídeos, notícias, textos críticos publicados em jornais, revistas, folderes de divulgação dos espetáculos etc ${ }^{17}$ com o de estudo teórico-crítico, tanto sobre a recepção de Tchékhov por outras culturas, como ensaios e estudos sobre sua

períodos a discussão sobre as relações entre o Teatro e a Historiografia. A intenção é tentar definir pontos de apoio teóricos e metodológicos que deem conta da especificidade teatral, levando em conta não somente o suporte dramatúrgico-textual como referência.

16 Tomamos como principal referência o texto "Sinais - raízes de um paradigma indiciário", de Carlo Ginzburg (In: Mitos, Emblemas, Sinais. São Paulo: Companhia das Letras, 2003, p. 143-179). Além disso, serve-nos também de inspiração outro estudo de Ginzburg sobre o moleiro Menocchio, condenado pela Inquisição no século XVI. O historiador realiza a análise a partir do estudo minucioso de documentos dos julgamentos realizados, que ajudam, a partir da própria erudição do historiador, a reconstituir todo um universo específico e as tendências de uma época. ( $O$ queijo e os vermes. São Paulo: Companhia das Letras, 1987).

${ }^{17}$ Para chegar a este estágio, foi realizado levantamento inicial de traduções e publicações de contos e peças de Tchékhov nas bibliotecas da Unicamp (Instituto de Estudos da Linguagem, Instituto de Filosofia e Ciências Humanas, Instituto de Artes e Biblioteca Central), da FFLCH-USP, da Biblioteca Nacional, no Rio de Janeiro, da Biblioteca Mario de Andrade, em São Paulo, bem como no Arquivo Edgar Leuenroth (AEL), em Campinas. Além disso, realizei levantamento de montagens e localizei textos críticos na Biblioteca Jenny Klabin Segall e no Centro Cultural São Paulo - Divisão de Arquivos e Multimeios, em São Paulo; no acervo da Fundação Nacional de Artes - FUNARTE (Dep. de Artes Cênicas), na Casa Rui Barbosa (Acervo Maria Jacintha e Acervo Antonio Callado) e da Sociedade Brasileira de Autores Teatrais (SBAT), no Rio. 
dramaturgia e teatro russo e brasileiro ${ }^{18}$. Do primeiro resultou extenso levantamento de traduções e edições, bem como de encenações de peças de Tchékhov realizadas por grupos teatrais profissionais e amadores. As peças foram catalogadas e, em muitos casos, foi possível recuperar notícias, textos críticos e fotos em torno de cada montagem. Todos esses documentos e listas vêm selecionados e transcritos nos anexos ao final do trabalho.

Dificuldades específicas surgiram ao longo da pesquisa, como o mapeamento de documentos referentes a um dramaturgo cujo nome já foi grafado das mais diversas maneiras (Tchékhov, Tchecov, Tchekov, Chekhov, Chekov, Tchehov, Tchekof, Tschecov, Tcheckhov, Checov, Tchecof, Tcheckov, Tchecoff, Tcheckoff...). Problema este que, se em partes dificulta o trabalho de mapeamento, por outro contribui para, como afirma Bruno Gomide, suspeitar de fontes de traduções indiretas ou mesmo referenciais crítico-editoriais.

Por fim, o que esperamos é que este estudo, por vezes demasiado sumário, por vezes enfadonho no detalhe, contribua ao menos para que entendamos um pouco sobre como foi encenado, lido e criticado este dramaturgo que tanto contribuiu para o processo de questionamento das formas dramáticas do século XIX. Suas Arkádinas, Trepliovs, Irinas, Machas, Olgas, Raniévskaias, Trofimovs, Vânias, cravados em tramas com vestígios de ação dramática, donos de diálogos que mais isolam que aproximam, parecem ainda dizer-nos algo. Falam não só sobre formas de sociabilidade que estavam condenadas pela história, como também sobre o que somos hoje.

\footnotetext{
${ }^{18} \mathrm{O}$ trabalho de estudo bibliográfico teve estapa decisiva em meu estágio de pesquisas na Universidade da Califórnia, em Berkeley. Lá pude contar com precioso acervo em eslavística e literatura comparada que me permitiu confeccionar com maior profundidade os dois primeiros capítulos desta dissertação.
} 


\section{Como se cria um Tchékhov.}

\subsection{Dentro do texto, fora dos palcos}

Vista à distância, a obra de Anton Pávlovitch Tchékhov pode levar a crer que o contista e dramaturgo russo gozara desde o início de sua carreira de repercussão positiva junto ao público, à crítica e aos profissionais de teatro. Isto porque, por um lado, um clássico quase sempre nos conduz a uma leitura que tende a tornar absolutas suas qualidades; por outro, porque o próprio estilo do autor, pouco afeito à exuberância formal e programaticamente crítico à falta de objetividade e aos excessos ideológicos ${ }^{19}$, sugere uma gradual afirmação junto ao público: lenta, silenciosa e modesta, com poucas polêmicas ou recusas.

No entanto, o processo de recepção de sua obra fora bastante tortuoso e, inicialmente, bastante intranquilo. No caso específico de sua dramaturgia, que aqui nos interessa de perto, Tchékhov se debateu com toda uma tradição do teatro russo, indo das técnicas de encenação ao gosto público, que não lhe apresentaram as portas abertas para as renovações formais que promovia. Se o dramaturgo não está sozinho nesse processo de crise das formas tradicionais do drama ${ }^{20}$, que marcou inúmeros países da borda europeia em fins do século XIX, no caso russo ele assume tinturas próprias. Alguns momentos desse processo se tornaram populares, por vezes convertidos em verdadeiras lendas. São razoavelmente conhecidos do leitor brasileiro os episódios de estreia de $A$ Gaivota (Чайка) pelo Aleksandrínski, em 1896, mistificada como um absoluto desastre, e que levara o escritor a recusar escrever novamente para o teatro, e a estreia da mesma peça em 1898, pelo Teatro de Arte de Moscou (TAM), um legendário sucesso que consagrou o surgimento do grupo. Ou ainda, relatos das famosas querelas entre Tchékhov e Stanislávski, feitos quase sempre para exaltar os acertos de concepção do

\footnotetext{
19 Tais elementos são decisivos para Tchékhov enquanto premissas de composição. Veremos adiante o quanto tais escolhas lhe renderam uma série de restrições ao seu "excesso de isenção". Para ficar em uma passagem conhecida, que ilustra parte de sua poética, a carta com conselhos de escrita enviada ao irmão Aleksandr P. Tchékhov, em 10 de maio de 1886, é elucidativa: "1. ausência de palavrório prolongado de natureza político-socioeconômica; 2. objetividade total; 3. veracidade nas descrições das personagens e dos objetos; 4. brevidade extrema; 5. ousadia e originalidade - fuja dos chavões; 6. sinceridade". Ver: ANGELIDES, Sophia. A. P. Tchékhov: cartas para uma poética. São Paulo: EDUSP, 1995, p. 52.

${ }^{20}$ Tal discussão será retomada adiante. Por ora, cabe localizá-la dentro da análise sobre as transformações na estrutura dramática ocorrida em fins do século XIX, emblemática em dramaturgos como Ibsen (Noruega), Hauptmann (Alemanha), Maeterlinck (Bélgica), Tchékhov (Rússia) e Strindberg (Suécia), lançada por ROSENFELD, Anatol. O Teatro Épico. São Paulo: Editora Perspectiva, 1985; e também por SZONDI, Peter. Teoria do Drama Moderno: 1880-1950. São Paulo: Cosac\&Naify, 2001.
} 
primeiro e desbastar um certo naturalismo do segundo. Todavia, ainda que apareçam como marcas de uma recepção que põe em debate a produção e as opiniões do autor por seus contemporâneos, o que predomina, sobretudo hoje, é a visão do "clássico imortal", que, se iluminada por sua atual relevância nos meios teatrais (a ponto de no teatro anglo-saxão Tchékhov ser considerado o segundo dramaturgo mais importante depois de Shakespeare), tende a ofuscar entendimento mais exato de suas condições de produção e recepção e, por vezes, restringi-lo a leituras improdutivas de suas peças.

A tarefa de compreensão mais pormenorizada deste processo tem um elemento facilitador que, ao contrário do caso de dramaturgos como Shakespeare, favorece a pesquisa: Tchékhov está envolto em uma historicidade (cultural, ideológica e de classe), mapeável em sua correspondência, comentários de críticos e querelas com gente de teatro, que permite recompor um universo específico. Isto permite a Laurence Senelick afirmar que Tchékhov nos parece por isso mais próximo e, ao contrário de Shakespeare, mais possível de ser pego por "intenções autorais"21.

Tentaremos reconstituir um pouco desse universo (no qual mesclaremos comentários sobre as encenações/concepções de direção, comentários da crítica e o próprio percurso formativo do autor) para nos aproximarmos do que foram as principais contradições internas à formação de sua dramaturgia, os debates em torno dela e, por fim, como determinadas leituras se afirmaram. Não menos problemática que qualquer esforço historiográfico, sobretudo quando se tem como material uma cultura que nos é em grande parte alheia e uma forma de expressão artística - o teatro - que, por sua natureza, se esvai no momento mesmo da encenação, o primeiro impulso será o de entender, no universo teatral, os anos de 1880 - decisivos para o amadurecimento da cena russa e da dramaturgia de Tchékhov. E, apesar de aparentemente tortuoso, este trajeto é necessário e ajudará em muito a entender interpretações de Tchékhov surgidas ali, que repercutirão de maneira decisiva no Ocidente e, em especial, no Brasil.

Começar pelos anos de 1880 não pode ofuscar um processo que já se inicia desde os tempos de adolescente de Anton Pávlovitch, na pequena cidade de Taganrog, perto do mar de Azov, quando começa seu contato com o teatro. Acompanhava com assiduidade e pouco critério as apresentações ocorridas no "Teatro Cívico", aplaudindo espetáculos que iam do "novo drama" ostrosvskiano aos melodramas românticos e

\footnotetext{
${ }^{21}$ Idem, p.1.
} 
comédias ligeiras, então nota predominante nas poucas casas teatrais russas. Ali, ainda cursando os anos finais do colégio, escreve uma peça sem nome, que possivelmente se converteria na versão publicada postumamente, em 1923, e conhecida no Ocidente como Platónov ${ }^{22}$ (Платонов).

A primeira versão fora submetida ao irmão Aleksandr, que já vivia em Moscou e lhe respondeu com duras críticas àquele "drama" com roubo de cavalos e tiros. Os anos de 1878 e 1879 seriam possivelmente aqueles aos quais se dedicou a reescrevê-la, fechando uma versão final somente em 1881. Cortou diálogos, omitiu algumas personagens e, após o trabalho, enviou uma cópia a Maria Iermólova, atriz do Teatro Máli, em Moscou, que, apesar de considerar "aceitável" a jovem viúva Anna Petrovna, personagem de destaque na peça, responde-lhe com a forte recomendação de que rasgasse o texto. A versão que chegou até nós, guardada pelo irmão de Tchékhov, que preservara as cópias enviadas à censura, apresenta uma estrutura e um tom pouco semelhantes ao das produções que marcam o Tchékhov das "quatro grandes peças". A personagem principal, Mikhail Vassiliévitch Platónov, é um professor de província, espécie de Don Juan do interior ${ }^{23}$. A ironia que marca seu perfil impede que se erga como um herói dramático típico, ou mesmo como um protótipo de homem supérfluo, ainda que a própria personagem Glagóliev diga com suas palavras que Platónov é "o mais fino expoente da moderna fraqueza de propósito (...). Ele caiu num beco sem saída, está perdido, não sabe o que focar, não entende..." ${ }^{24}$. É irresistível para as mulheres, mas cheio de idealismo e ceticismo. Tem ambições de ser um "segundo Byron" e não é mesmo formado na universidade. O ambiente é marcado pela decadência da família e as personagens se dividem claramente entre credores e devedores. Há aqui um paralelo destacado por alguns críticos, que veem em Platónov (primeira peça de Tchékhov) e O Jardim das Cerejeiras (última peça), um tom hiperbólico, com forte acento na decadência, expresso no endividamento das famílias

\footnotetext{
${ }^{22}$ Esta peça sem título, ainda não traduzida para o português (Пьеса без названия), além de ser identificada no Ocidente como Platónov, também é conhecida pelo nome Sem Patrimônio ou Sem Herança. Acredita-se que a primeira versão, mostrada para o irmão, teria sido perdida para sempre. No entanto, na impossibilidade da comprovação, fica a hipótese de que a mesma versão foi retrabalhada, culminando na que hoje conhecemos e é aqui citada. A versão lida para esta pesquisa é a traduzida por Laurence Senelick, presente no livro. CHEKHOV, Anton. The Complete Plays. New York/London: WW Norton \& Company, 2006, p. 1-221.

${ }^{23}$ A expressão Don Juan foi usada por BENTLEY, Eric. Chekhov as Playwriter. The Kenyon Review, V11, n 2, Spring, 1949, p. 226-250.

24 " Platonov, as I see it, is the finest exponent of modern infirmity of purpose (...) He has turned up a blind alley, he's lost, he doesn't know what to focus on, he doesn't understand..." Ver. CHEKHOV, Op. Cit., p. 18.
} 
que se entregam à venda do próprio patrimônio ${ }^{25}$. Se há marcas evidentes do drama (no destaque do protagonista, no conflito e diálogo veementes) e mesmo do melodramático (o pirotécnico tiro no peito levado ao final, e em cena, por Platónov), o elemento cômico é que será, aqui, um tímido ponto de ligação com as produções da posteridade a marca vital de uma coesão entre o cômico e o sério, que Tchékhov retrabalhará em toda sua obra, sinal de uma problemática de fundo, que pensa como as aspirações críticas e grandes ideias precisam conviver com o cotidiano sem sentido ${ }^{26}$.

Seria precipitado, como se vê, ver nesta peça que sequer chegou a ser encenada durante a vida de Tchékhov (fora rejeitada pelo Máli em 1882), o desabrochar de uma nova tendência dramatúrgica. No geral ainda bastante vinculada às leis do drama tradicional, ela revela ao menos a propensão do dramaturgo a este universo do cômico, que marcaria suas primeiras produções. E é com contos cômicos que Tchékhov sustentará seus estudos e ajudará sua família nos anos em que estivera em Moscou, logo após mudar-se de Taganrog, em 1880. Até 1887, escreverá para jornais de Moscou e São Petersburgo sob inúmeros pseudônimos (Antocha Tchekhonté, O Doutor Que Perdeu Seus Pacientes, O Irmão do Irmão etc). Neste período, Tchékhov diria que estes contos breves, de humor vaudevillesco, brotavam de sua cabeça numa velocidade absurda, chegando a gastar não mais que um dia em cada um ${ }^{27}$. Aqui, interessa-nos não só a afinidade que desde cedo se estabelece entre o escritor e este gênero, mas também a temática de muitos contos que servem como ponto de partida para nosso campo de interesse: sua crítica ácida aos meios teatrais da época. Os contos de Tchékhov de inícios dos anos de 1880 são recheados de atrizes caprichosas e empresários de teatro que não entendem nada de arte. Esta passagem do conto Fantasiados, no qual ataca diretamente Lentóvski (alvo preferido à época) é ilustrativa:

Seis entradas para carruagem, mil lâmpadas, uma multidão de espectadores, guardas, corretores de ingressos. É um teatro. Lêse sobre as portas, como no Érmitaj de Lentóvski: "Sátira e

\footnotetext{
${ }^{25}$ A respeito desse possível paralelo, ver: RAYFIELD, Donald. Orchards and Gardens in Chekhov. The Slavonic and East European Review, V. 67, N. 4, Oct., 1989, p. 530-545. CHEKHOV, A. Op. Cit., p. 5.

${ }^{27}$ É conhecia a famosa frase de Tchékhov que afirmava ser a literatura, neste período, uma espécie de amante, enquanto a medicina seria sua legítima esposa. A situação ficará insustentável para ele quando, após receber uma carta do então renomado escritor Grigórovitch, é alertado para o desleixo com que vinha tratando suas habilidades literárias. Em 1887, já firme em sua convicção de escritor, escreverá ao irmão: "Já quase não trabalho nas revistas humorísticas, pois elas não servem para a leitura. Não gosto delas. Meu trabalho mais sério está no Nóvoie Vrêmia." Carta de 18 de janeiro de 1887. Ver: ANGELIDES, Op. Cit., p.63.
} 
Moral!". Os ingressos são caríssimos, redigem-se aí longos artigos de crítica, aplaude-se prolongadamente e as vaias são raras... Um templo!

Mas, é um templo fantasiado. Retirando-se a inscrição Sátira e Moral, não será difícil ler: - Cancã e chanchada ${ }^{28}$.

Apesar do pessimismo de Anton Pávlovitch quanto a esse aspecto, o período era de transição e prometia. Em 1882, o Tzar Alexandre III aboliu o monopólio dos Teatros Imperiais (então o Aleksandrínski, em São Petersburgo, e o Máli, em Moscou). Isto permitiu um decisivo arejamento no repertório dos novos grupos (agora mais propensos a textos nacionais, contemporâneos ou mesmo fora dos padrões de expectativas das comissões de repertório). Tal mudança se deu em grande parte pela pressão de grupos amadores que almejavam maior espaço e que se negavam a aceitar os princípios férreos que regiam estas instituições estatais: punições, bloqueio de pagamento, obrigatoriedade para os atores de decorar determinado número de linhas do texto por dia etc ${ }^{29}$; e de novos dramaturgos, desejosos de maior espaço.

A abertura legal, no entanto, não significou movimento rápido em direção à democratização do acesso do público, mudança estrutural na qualidade do repertório ou espaço aberto a todos os interessados em produzir. A plateia ainda era reduzida e os grupos privados nascentes (marcados pelo signo da contradição entre dinamizar o cenário teatral e preocupar-se com as bilheterias), abandonavam muitas vezes o discurso da "iluminação" e se pautavam pelos critérios de empresários preocupados com a bilheteria - o que levou à predominância durante muito tempo de um repertório com peças pirotécnicas e sensacionalistas. No meio teatral moscovita foi assim com um desses principais grupos: o Teatro Skomorokh, liderado por Mikhail Lentósvski (o mesmo ironizado no conto citado acima) e criado em $1881^{30}$. O repertório fora marcado por grandes clássicos, como Shakespeare, Gógol e Ostróvski, mas boa parte das encenações eram peças que privilegiavam a exuberância, os dramas claros e o riso fácil, bem ao gosto da classe média pagante.

\footnotetext{
${ }^{28}$ TCHÉKHOV, Anton. A Dama do Cachorrinho e Outros Contos. Trad. Boris Schanaiderman. São Paulo: Editora 34, 2005, p.30.

${ }^{29}$ Idem, 1999, p. 9.

30 " In 1881 Lentovskii founded The Minstrel (Skomorokh) Theatre intended to bring historical plays to the common people at popular prices; it closed in 1888 owing to poor box office. Lavish spending, combined with the sparseness of the audience, led to financial ruin. His New (Novii) Theatre, devoted to legitimate drama, opened in 1882; meant as a popular playhouse, it became famous for the sumptuousness and imagination of its staging. It was also the first Russian theatre to use electric light on stage." SENELICK, L. Historical Dictionary of Russian Theather. Lanham/Toronto/Plymouth: The Scarecrow Press, Inc, 2007, p. 211.
} 
Por outro lado, o Teatro Púchkin, assumido por Fiódor Korch em 1882, levou mais a sério a política de estímulo aos jovens dramaturgos (tanto que NemiróvitchDântchenko, que tivera intenso trabalho de dramaturgo e crítico antes de atuar com Stanislávski, tivera peças premiadas no Korch, em seu início de carreira ${ }^{31}$ ), para não falar da valorização do drama literário e do encorajamento de Tchékhov a escrever inúmeras peças. Korch também incentivou descontos para estudantes e levou adiante uma política mais definida de formação de plateias. Para Stanislávski, este Teatro desempenhou papel decisivo em sua formação, e seria responsável, segundo ele, por uma espécie de "preparação de terreno" para as inovações posteriores do TAM $^{32}$.

Mas para Tchékhov o problema era sério: tratava-se de um desleixo crônico com a atividade cênica. Laurence Senelick enquadraria esse universo de preocupações em uma espécie de "compromisso com o teatro" ${ }^{33}$, ainda que as manifestações do dramaturgo fossem frequentemente de profundo desgosto. Suas cartas e mesmo comentários em jornais punham abaixo bastidores, sem nenhuma idealização dos atores - presunçosos, vaidosos, ou ainda "vacas que se consideram deusas" ${ }^{34}$.

A solução dada pelo dramaturgo é, como se mapeará com frequência em suas cartas e em sua produção, a preocupação com a "proximidade da vida", o "conhecimento da realidade" e a objetividade, pontos aos quais muitos atores (preocupados que estavam com o brilho individual em detrimento do trabalho de grupo, o gesto fácil, explosivo, sem estudo) eram pouco afeitos. Para ele, "os atores não compreendem, dizem asneiras e não escolhem os papeis adequados" ${ }^{35}$. Em partes, temse um paralelo com muito do que será desenvolvido por Stanislávski, ainda que em chave diferenciada:

Atores nunca observam as pessoas comuns. Eles não conhecem fazendeiros, comerciantes, padres aldeões ou burocratas. Por outro lado, eles podem oferecer verdadeiras personificações de jogadores desonestos, mulheres oportunistas, trapaceiros angustiados, em suma, todo tipo de indivíduos que eles observam em seus passeios por bares e despedidas de solteiro. Algo horrivelmente ignorante ${ }^{36}$.

\footnotetext{
${ }^{31}$ Idem, p. 271.

${ }^{32}$ Ver: STANISLÁVSKI, K. Minha Vida na Arte. Rio de Janeiro: Civilização Brasileira, 1989.

${ }^{33}$ SENELICK, 2006, p. 8-28.

${ }^{34}$ Idem, p. 12.

${ }^{35}$ Carta ao irmão Aleksandr em 24 de outubro de 1887. ANGELIDES, Op. Cit. p.71

36 "Actors never observe ordinary people. They do not know landowners or merchants or village priests or bureaucrats. On the other hand they can give distinguished impersonations of billiard markers, kept women, distressed cardsharps, in short all those individuals whom they observe in their rambles through
} 
Isto no que se refere à prática dos atores. Por outro lado, via uma única solução para a vulgaridade de empresários de teatro, diretores, comissões de censura e mesmo dramaturgos: o amor sincero e o trabalho com a via literária. Esta, no entanto, sem o apontar de caminhos (como queria a intelligentsia) ou preocupações comerciais: "É preciso tentar com todas as forças tirar o teatro dessas grossas mãos e transferi-las para as da literatura, ou então o teatro irá declinar (...). Eu te imploro, apaixone-se pelo teatro" ${ }^{37}$. Para ele, até a massa de populares era mais "elevada e inteligente que o teatro"$^{38}$.

Se suas considerações são duras, e aparentemente muito presas à visão literária, não se pode ignorar sua preocupação evidente com as condições de realização do teatro, o que fica claro não só agora, mas no futuro com seu empenho frequente por acompanhar ensaios e dar orientações a diretores e atores, como veremos adiante. $\mathrm{O}$ que importa é observar seu zelo, ainda que todo o seu trabalho como dramaturgo orbitasse ainda em torno dos jornais.

Os contos de Tchékhov escritos sob inúmeros pseudônimos tinham boa circulação e eram amplamente elogiados pelo público leitor, mas o Tchékhov dramaturgo era conhecido apenas em círculos muito específicos, e identificado única e exclusivamente como humorista. É em meados dos anos de 1880 que ele concebe boa parte de suas peças em um ato, assim como pequenos diálogos e paródias, publicados nos jornais e revistas de Moscou e São Pestersburgo. A noiva, ou O Capitão Aposentado (Дура, или Капитан в отставке) ${ }^{39}$, é a primeira da leva de cenas que jorrarão de sua mão nos próximos anos. Consiste em um pequeno diálogo publicado em Estilhaços (Осколки) em 1883, e assemelha-se muito às cenas de Gógol e Ostróvski, ainda que com um desfecho mais "escabroso" 40 . Como bem constata Arlete Cavaliere, mesmo que não se referindo diretamente a estas pequenas esquetes, muito da produção dita "jovem" de Anton Tchékhov, estabelece uma espécie de fio com a tradição do cômico na Rússia,

pothouses and bachelor parties. Horribly ignorant". Carta a Suvórin em 25 de outubro de 1889. SENELICK, Op. Cit., p. 12.

37 "One must try with all one's might to transfer the theatre from the grocer's hands tho those of literature, or else the theatre will decline (...) I implore you, please fall out of love with the treatre". Carta a Suvorin de 03 de setembro de 1988. Idem, ibidem.

${ }^{38}$ Carta a Leontiév enviada em 11 de outubro de 1888. Idem, p. 13.

${ }^{39}$ Publicada sob o pseudônimo de Antocha Tchekhonté. Ver: CHEKHOV, 2006, p. 267.

${ }^{40}$ Idem, p. 265. 
que será retrabalhada em grande medida em suas "Quatro Grandes Peças"41, como veremos adiante.

Em 1884, ano de produção intensa, Tchékhov escreve a pequena esquete Jovem Нотет (Молодой Человек), publicado em Estilhaços, que surpreendentemente passou pela censura, pois em poucas linhas a irônica personagem - coincidentemente um jovem humorista (!) - alfineta uma série de instituições e oficiais, ante o abobalhado interlocutor. No mesmo ano publica em O Despertador (Будильник) uma paródia de um melodrama alemão ( $O$ Limpo e o Leproso) traduzido para o russo por Tarnóvski. A paródia intitula-se Os Trágicos Impuros e os Dramaturgos Leprosos (Heчucmble трагики и прокаженые драматурги) ${ }^{42}$ e é uma clara sátira às produções de Mikhail Lentóvski que, como vimos, era um importante "cabeça" do meio teatral moscovita. O texto, que joga com o nonsense da cenografia e do jogo entre as personagens, parodia os excessos das produções comerciais de Lentósvski, que se baseavam sobretudo na pirotecnia. Boa parte das personagens levam nomes reais e, anos mais tarde, talvez por avaliar como irresponsável a pequena brincadeira, Tchékhov indicaria que este texto não deveria constar em suas Obras Completas ${ }^{43}$.

Ainda em 1884, em Estilhaços, publica Um Exame Ideal (Идеальный экзамен $)^{44}$, um leve diálogo entre um professor malicioso e persistente e um aluno irredutível. Em outubro publica n'O Despertador o texto Balbúrdia em Roma (Кавардак в Риме $)^{45}$, também numa clara paródia à opereta Carnaval em Roma, de Johann Strauss, produzida pelo Teatro de Lentósvki, em 1884. A esquete recebia o sugestivo subtítulo de "Uma Cômica Excentricidade em Três Atos, Cinco Cenas, com Um Prólogo e Dois Fracassos"46.

Em meio a estas pequenas esquetes, paródias e cenas, surge sua primeira peça em um ato, escrita para o palco (vale lembrar que nenhum dos citados anteriormente fora encenado), intitulada $\mathrm{Na}$ Estrada Real (На большой дороге). O tema para este

\footnotetext{
${ }^{41}$ CAVALIERE, Arlete. Teatro Russo. Percurso para um estudo da paródia e do grotesco. São Paulo: Humanitas/FAPESP, p. 180-213.

${ }^{42}$ Esta pequena cena foi traduzida para o português por Jacó Guinsburg, com auxílio de Boris Schnaiderman. Ver: GUINSBURG, Jacó. Stanislávski e o Teatro de Arte de Moscou. São Paulo: Perspectiva, 2001, p. 151-156. Tchékhov a publicou inicialmente sob o pseudônimo de "O Irmão do Irmão".

${ }^{43}$ Idem, p.151.

${ }^{44}$ Publicada inicialmente sob o pseudônimo de "Antocha Tchekhonté". CHEKHOV, Op. Cit., p. 278.

${ }^{45}$ Idem, p. 281.

${ }^{46}$ Idem, Ibidem.
} 
pequeno "estudo dramático" era o mesmo do conto "Outono", publicado no ano anterior. A história se estrutura em torno de um nobre de perfil melancólico e decadente que, para pagar uma outra dose de vodka, entrega o retrato de sua infiel esposa ao taberneiro. A mesma que, por coincidência, aparece para pedir abrigo e é quase morta por um tiro por Igor Merik, que também sofrera uma desilusão amorosa no passado. A fim de tornar a versão um pouco mais "agitada" em relação ao conto (este para Tchékhov ainda bastante "estático"), o dramaturgo se utilizou de artifícios comuns ao melodrama, como a cena-clímax citada acima. Vê-se, ainda sem definições claras como será a posterior condição de Ivánov (Иванов), um leve debater-se de tendências: entre a construção da "atmosfera", aqui ligada ao tom melancólico, que já se via esboçada em alguns contos desse período, e o apego às formas dramáticas convencionais (muitas das quais ele mesmo era um crítico severo), que recorriam ao efeito fácil, às emoções externas e intensas.

Este pequeno drama, ao qual ele intimamente se referia como "um pouco nonsense para a cena", não chegou a ser publicado. Vítima da censura, fora lançado apenas dez anos após a morte do autor, em 1914. Para o censor, um descendente alemão chamado E. I. Kaiser, a peça tinha uma "penumbra e uma esqualidez" e não poderia ser levada à cena. Este seria um dos primeiros de toda uma linhagem de críticos que reclamaria do "pessimismo" e da "melancolia" de Tchékhov ${ }^{47}$, algo que se converterá, como veremos, em uma verdadeira "cortina de ferro" para um mais profundo entendimento de seu teatro.

Neste momento, o dramaturgo já se encontrava no fim de seu curso de medicina e publica sua primeira coletânea, Contos de Melpômene, além de outras esquetes como Языкв до Киева доведет, que vem do provérbio russo "Quem tem boca vai a Roma"48. A pequena peça O Pequeno Burguês (Доспода Обыватели), também em 1884. A cena Ao pé do leito (У постели больного) е O Caso do Ano de 1884 (Дело о 1884 годе) ${ }^{49}$ foram escritas no mesmo ano e também marcadas pela veia cômica: cenas ligeiras e situações inusitadas, com não mais que duas páginas.

\footnotetext{
${ }^{47}$ Idem, p. 222-223.

${ }^{48}$ Idem, p. 285-286.

${ }^{49}$ Esquete publicada sob o pseudônimo de $O$ Homem sem Spleen, no Estilhaços, em novembro de 1884. Idem, p. 285-293.
} 
Em 1885, Tchékhov faz sua primeira viagem a São Petersburgo e conhece Aleksei Suvórin, editor do gigantesco jornal conservador Novo Tempo ${ }^{50}$ e o pintor Isaac Levitan, com os quais estabelecerá relações duradouras. No ano de 1886, já afastandose de boa parte dos jornais, começa uma contribuição intensiva para o jornal de Suvórin, que será responsável por sua definitiva popularização em grande parte da Rússia. Além disso, publica seu segundo livro de contos que, combinado com a seriedade reivindicada por Grigórovitch, é assinado duplamente como Anton P. Tchékhov e Antoncha Tchekhonté, como que a marcar uma espécie de transição para o definitivo empenho à vida literária. No mesmo impulso surgem a minúscula cena Drama (Драма) e contos como A Corista e Na Estrada.

No entanto, para o teatro, é só em 1886, que os anos começam a se tornar produtivos. Até então Tchékhov não tivera nenhuma peça levada à cena (ainda que $\mathrm{Na}$ Estrada Real tenha sido pensada mais detidamente para o palco). Dividido entre a censura, o receio com a gente de teatro, as tendências comerciais que sufocavam os impulsos "verdadeiramente literários e artísticos" e o trauma de juventude que marcara sua primeira tentativa de fôlego com Platónov, limitara-se a, como vimos, algumas esquetes com publicação, mas sem repercussão nos palcos. Temos até agora, portanto, uma recepção feita apenas por leitores que, se não ajuda a entender o que Tchékhov tem de vinculação com a prática cênica no palco, nos leva por vias indiretas à compreensão de algumas preferências temáticas e formais que marcarão toda sua poética ${ }^{51}$. Isto vai da complexificação que mais adiante dará a noção de comédia, até as querelas evidentes

\footnotetext{
${ }^{50}$ A relação entre Tchékhov e Suvórin é precisamente pontuada no livro organizado por Aurora Bernardini e Homero Freitas: TCHÉKHOV, A. P. Cartas a Suvórin (1886-1891). São Paulo: Edusp, 2002. Na introdução, há um pequeno panorama da relação estabelecida entre o escritor russo e o editor. O diálogo expresso nas cartas reunidas mostra uma crescente relação, alimentada por discussões literárias, cooperação em edições dos contos de Tchékhov e debates políticos. No entanto, após o caso Dreyfus (que estoura em 1984, mas se estende por vários anos e envolve a militância aguerrida de Zola em sua defesa), Tchékhov não concebe a posição reacionária adotada pelo jornal do amigo e a correspondência entre os dois diminui drasticamente. Em carta dirigida ao irmão Aleksandr, em 23 de fevereiro de 1898, Tchékhov diria: "No episódio Zola, Nóvoie Vriémia conduziu-se de modo simplesmente repugnante. Troquei cartas a esse respeito com o velho sábio (ainda que num tom bastante moderado) e agora deixamos de nos corresponder." Idem, p. 30.

${ }^{51}$ Além do estudo de Arlete Cavaliere, já citado, vale a menção ao estudo decisivo de GOTTLIEB, Vera. Chekhov and the vaudeville: A Study of Chekhov's One-Act Plays. Cambridge: Cambridge University Press, 1982. Neste livro, a estudiosa analisa o período "negligenciado" da obra de Tchékhov, mostrando como as peças escritas a partir de 1885 (suas peças em um ato), são decisivas para estabelecer suas principais marcas formais, que refletirão em todas as peças de "maturidade". Para isso, faz uma breve retomada da tradição do vaudeville na Rússia e sua relação com o teatro francês, para evidenciar como Tchékhov se vincula a uma determinada tradição, mas como também inova em seu percurso.
} 
que estabelecerá com Stanislávski quando este propôs um sem-número de soluções cênicas para o que concebera dramaturgicamente.

A cena moscovita estava repleta de peças ágeis e cômicas, bem ao gosto médio, e o Tchékhov escritor começava a ser procurado com mais insistência para escrever peças em um ato. Nos anos que seguiram, dedicou-se à escrita de peças como Os Males do Tabaco (O вреде табака), em sua primeira versão, de $1886^{52}$. A escrita tem em vista a realização cênica, pois Tchékhov concebe a personagem pensando no talentoso comediante Grádov-Sokolov. No entanto, receoso da recusa do ator por ter escrito aquele monólogo em pouco mais que duas horas, enviou-a à Gazeta de Petersburgo, mantendo ainda uma vez mais o pseudônimo de Antocha Tchekhonté ${ }^{53}$. Nesta primeira versão do monólogo (a segunda viria apenas em 1902) Tchékhov parodia os "leitores comuns de ciência" que surgiam naqueles anos de sufoco czarista, em um momento de tentativa de elevação do homem comum e emergência dos raznotchíntzi ${ }^{54}$. O tratamento da matéria dado por Tchékhov nesta primeira versão parece pesar mais para o jogo exterior, em que a personagem se apresenta como o que não é. Em uma palestra que profere por obrigação em um clube de província, Níukhin diz ter sacrificado sua vida em benefício da ciência, apesar de não ser nem catedrático nem pertencer ao meio científico; afirma possuir conhecimento do conteúdo a ser exposto, mas recorre ao "papelucho" constantemente para assegurar-se de fórmulas e malefícios; afirma ser fundamental para o bom funcionamento e a excelência do pensionato conduzido por sua família - já que arruma, leciona e secretaria - no entanto, parece ser a esposa quem tudo gerencia e realmente define o que ele pode e não pode fazer (desde o que e quando comer ou quando sair).

A exterioridade dos procedimentos formais está também na valorização de detalhes sugestivos (trocadilhos, imagens, sonoridades), em si mesmo cômicos: um

\footnotetext{
${ }^{52}$ No Brasil há tradução direta do russo no livro organizado por Homero Freitas de Andrade. TCHÉKHOV, Anton. Os Males do Tabaco e Outras Peças em Um Ato. São Paulo: Ateliê Editorial, 2003. ${ }_{53}^{53}$ CHEKHOV, Op. Cit., p.317-323.

${ }^{54}$ Boris Schnaiderman pontua bem o sentido que esses setores assumiram ao longo do século XIX e o como estiveram abertos a inúmeros debates e transformações na estrutura social pouco móvel da Rússia czarista: "A sociedade russa caracterizou-se durante séculos por uma acentuada estratificação e pela pouca mobilidade entre as diferentes camadas. A partir dos fins do século XVIII, foi-se formando, porém, uma nova camada: a dos que, oriundos das classes inferiores, tinham o nome de raznotchíntzi (singular raznotchínietz). Durante o século XIX, os raznotchíntzi desempenharam importante papel, como a camada mais receptiva às diversas tendências revolucionárias, a menos ligada a uma tradição de estabilidade política e social." SCHNAIDERMAN, Boris. A Poética de Maiakósvski. São Paulo, Perspectiva, 1971, p. 148.
} 
pensionato situado na "esquina da rua Gnátali com a travessa dos Cinco Cachorros, no imóvel do Capitão Maminha"; os gestos exagerados para que saiam da plateia os espectadores indesejados; o desequilibrar para pegar um papel; os bocejos constantes da personagem (que denotam sua velhice sonolenta e conotam o próprio tédio do tema) e o curioso fato de que sua asma começou no dia "treze de setembro de mil oitocentos e sessenta e nove... mesmo dia em que nasceu a filha de minha senhora" ${ }^{55}$. A personagem tem forte acento caricatural e seria equivocado ver ali qualquer jogo entre o cômico e o trágico, como mostraria Tchékhov em sua segunda versão do texto.

Na transição de 1886 para 1887 escreve uma peça que tem como origem um conto homônimo, Calkhas (meses depois reescrita como O Canto do Cisne - лебединая песня/ Калхас) ${ }^{56}$, vinda do mesmo impulso. O "estudo dramático" tinha em mente o ator Vladímir Davídov, o qual Tchékhov insistentemente elogiava em cartas aos $\operatorname{conhecidos}^{57}$. O ator a levaria ao palco do Korch em 19 de fevereiro de 1888. Nesta pequena peça em um ato, temos o breve canto de um ator em fim de carreira. Sozinho no palco escuro rememora seu passado de brilhantes atuações, mas agora é visivelmente um decadente. De grande ator trágico, foi a bufo. E, ainda que tente recuperar com palavras suas grandes intervenções em Hamlet ou Rei Lear, sua aparência ridícula o desabona. Trata-se, como diz Senelick, de tema caro ao dramaturgo pelo resto da carreira: a vida posta em termos, as tentativas de sonho no auge da desilusão. A atuação de Davídov, ainda que não tenha desagradado ao dramaturgo, veio tão recheada de referências a atores do passado inseridas por ele próprio que o texto, de certa forma, descaracterizou-se.

Em agosto de 1887 publica em $O$ Despertador a pequena cena, Antes do Eclipse (перед затмением), que não chegaria a ser representada. Ali, duas personagens insólitas conversam: o Sol e a Lua. Momentos antes do Eclipse, realizam algumas negociações para garantir a consumação do fato, envolvendo rublos e promessas de fama para a Lua que, segundo o Sol, era uma personagem não muito "radiante" ${ }^{58}$.

\footnotetext{
55 TCHÉKHOV, 2003, p. 13-21.

${ }^{56}$ Idem, p. 23

57 "Escrevi uma peça de quatro folhas tipográficas. Ela será representada em quinze ou vinte minutos. É o menor drama do mundo. Vai ser interpretada pelo famoso Davidov, que está agora trabalhando no Teatro Korch. A Saison a está publicando e, por isso, ela será espalhada por toda parte. Em geral, é muito melhor escrever coisas pequenas do que grandes: há pouca pretensão e fazem sucesso... é necessário mais do que isso? Escrevi o meu drama em uma hora e cinco minutos. Comecei outro mas não terminei, pois não tinha tempo." Carta enviada a Maria Kisseliova em 14 de janeiro de 1887. ANGELIDES, Op. Cit. p.61.

${ }^{58}$ CHEKHOV, Op. Cit., p. 295-298.
} 
É em meio a estas inúmeras peças em um ato e contos cômicos que Tchékhov escreve sua primeira peça longa de repercussão no palco. Isto condicionará uma determinada expectativa do público, simbolizada na dúbia recepção no dia de estreia da primeira versão de Ivánov, em 19 de novembro de 1887, no Teatro Korch. Como enredo básico, temos a história de um proprietário de terras que, portador de um passado aristocrático glorioso, vive agora a franca decadência, a ponto de não ter dinheiro para pagar ao tratamento da esposa que, segundo o amigo e doutor Lvov, é vítima da tuberculose. O protagonista vê aos poucos o esfacelamento de seu mundo, sem compreender de fato suas causas, e enreda-se num universo de apatia, mesquinhez, melancolia e fofocas. A montagem foi feita em benefício de Nikolai Svetlov e mereceu apenas quatro ensaios, ainda que Korch houvesse prometido dez. Tchékhov vinha insatisfeito dos ensaios que acompanhava e, como escritor, colocava-se na posição de alguém que deveria zelar pela qualidade do material, e por isso opinava sobre a distribuição dos papeis e a expressão cênica ${ }^{59}$. Sua admiração por Davídov continuava, e a ele atribuiria o papel principal. Mas o descontentamento com o conjunto, como que numa busca pelo acerto de tom geral na produção, era frequente. Mais uma vez, o desleixo dos atores, que pareciam ver ali apenas mais uma peça para incrementar o repertório, o incomodava sobremaneira, o que em certo sentido não deixava de ser o horizonte do próprio condutor do teatro: "Korch é um comerciante, e para ele não importa o sucesso dos artistas e da peça, mas sim a arrecadação total" ${ }^{60}$.

Ainda que Tchékhov tenha tentado pegar a peça de volta (a porto de Korch fazer um "escarcéu"), sua estreia o surpreendera. Em carta enviada ao irmão no dia 20 de novembro, o dramaturgo descreve em detalhes o seu sentimento ao longo de cada ato. Ao final do primeiro, após receber uma coroa de flores sob inúmeros aplausos, chegaria a pensar que "aquela não era sua peça". Depois de altos e baixos, anima-se com a perplexidade momentânea do público em silêncio, que o substitui por aplausos e bater de pés (que abafam algumas vaias):

Os frequentadores de teatro dizem que nunca viram tamanha efervescência nem tantos aplausos e vaias, e nunca antes aconteceu de ouvirem tantas discussões quantas viram e ouviram na minha peça. E no Teatro de Korch não houve outro caso em que o autor tenha sido aclamado após o segundo ato. ${ }^{61}$

\footnotetext{
${ }^{59}$ Carta ao irmão Aleksandr, enviada no dia 24 de outubro de 1887. ANGELIDES, Op. Cit. p. 71.

${ }^{60}$ Carta a Nikolai Léikin, enviada em 04 de novembro de 1887. Idem, p. 74.

${ }^{61}$ Idem, p. 77-79.
} 
No entanto, tal estado de ânimo fora momentâneo. Dias após, o comentário cauteloso de seu outro irmão Mikhail reconhecera os numerosos aplausos, mas destacara o fato de que a peça não fora verdadeiramente compreendida, já que a crítica por um bom tempo ainda precisara "aclarar" o sentido da personagem principal $^{62}$. Tchékhov percebeu que havia ali uma compreensão geral do público, e mesmo de parte da crítica, de que em Ivánov havia um acerto de contas com a geração de 1880 russa. Diante da inércia e incapacidade de ação frente à repressão e o sufocamento pósassassinato de Alexandre II, Ivánov seria uma espécie de "expiação" - seria, nas palavras do populista Mikhailóvski, um "Hamletista", representante de um grupo social que tenta "racionalizar sua inação e depressão", ou seja, um homem supérfluo ${ }^{63}$. Para alguns críticos, que mesmo diante do sucesso de bilheteria mostravam-se profundamente irritados (até porque Davídov era um grande chamariz), a peça era "imoral", uma "repugnante desordem", uma "bobagem cínica"64, sobretudo por mesclar procedimentos de uma tragédia doméstica e um problema sério de época.

O dramaturgo ficara particularmente incomodado com tal repercussão. Inicialmente concebera a peça como expressão de um homem comum, honrado e educado, que tem de lidar com um presente pouco enobrecedor, e todas as expectativas elevadas de uma boa educação ou racionalização da produção na Rússia, que serão frustradas ao longo de sua vida. Sua tentativa é de tentar entender os motivos que levam a personagem a cair em uma espécie de vazio de vida e atitude contemplativa, ao contrário de julgá-la com ferocidade, como pareciam querer as plateias e parte da intelligentsia ${ }^{65}$.

Mas o que também dificultou em grande parte sua empresa foram as próprias incongruências formais com as quais a peça tinha de lidar. $\mathrm{O}$ ataque cardíaco que mata Ivánov ${ }^{66}$ em cena no último ato acentuou o tom melodramático, e levou o público inclinado às suas comédias ao riso fácil. A personagem exigia complexidade na escrita e na encenação, como atestam as próprias intenções de Tchékhov ao concebê-la: "Eu

\footnotetext{
${ }^{62}$ CHEKHOV, Op. Cit., p. 324.

${ }^{63}$ SENELICK, Op. Cit., p. 17

${ }^{64}$ Idem, Ibidem.

${ }^{65}$ A carta enviada a Suvórin em 30 de dezembro de 1888, Tchékhov discute em detalhes quais eram suas reais expectativas com aquele drama, chegando a discorrer sobre cada personagem. Ver: TCHÉKHOV, 2002, p. 137.

${ }^{66}$ Ver primeira versão da peça publicada nas obras completas. CHEKHOV, Op. Cit., p. 324-414.
} 
queria fazer uma extravagância: não criei um malvado, nem anjo algum (mas não consegui me esquivar dos bufões), não condenei ninguém, não absolvi ninguém..." ${ }^{67}$; mas o autor também tem consciência de suas limitações iniciais (mas que, incrivelmente, também serão suas grandes marcas de inovação no futuro):

O argumento é complicado e não é tolo. Termino cada ato como os meus contos: conduzo o ato inteiro de maneira tranquila e mansa, mas ao final dou um tapa na cara do espectador. Usei toda a minha energia em alguns trechos realmente fortes e vivos, mas as pontes que ligam esses trechos são insignificantes, frouxas e estereotipadas. Apesar de tudo estou contente. Mesmo que a peça seja ruim, criei um tipo que tem uma significação literária $(\ldots)^{68}$

Essa frouxidão no alinhavamento do entrecho será decisiva nas peças posteriores de Tchékhov. No entanto, seu foco aqui está no que ficou de estereotipado e inconsistente. Sem forçar a ligação, é possível sentir um leve choque: o do tema que pede uma maior profundidade na abordagem psicológica, com a forma geral que ainda tem de conviver com estratégias dramáticas tradicionais (aqui, no caso, a cena de efeito e o protagonismo do heroi, que criou polarizações indesejadas). O efeito final, para Senelick, parecia indicar que o próprio Tchékhov não tinha definido uma atitude clara em relação à personagem: "Era Ivánov uma paródia ou um tipo de homem supérfluo?"69.

A encenação reforçou o elemento dramático, centrado na figura do heroi central, vítima de uma ardilosa trama de fofocas, diante da qual é apenas um móvel inerte. Frente às fortes críticas recebidas, Tchékhov se dedica a reescrever a peça, chegando mesmo a encará-la como uma forma não definitiva. A primeira medida foi cortar a cena do ataque cardíaco, que parecia um definitivo ponto fora da reta, e substituí-lo por um suicídio nos bastidores (o mesmo recurso será utilizado anos depois em A Gaivota, com Trepliov). Contudo, as mudanças não vêm no sentido de suplantar o choque ao qual nos referimos. Pelo contrário, Tchékhov quis mostrar-se capaz de "operar as leis do drama" (já que muitos acusavam-no do contrário). Substituiu as passagens demasiado lentas,

\footnotetext{
${ }^{67}$ Carta ao irmão Aleksandr, de 24 de outubro de 1887. ANGELIDES, Op. Cit., p.71.

${ }^{68}$ Idem, p. 66-67.

69 "In the first version of Ivanov, unfortunately, he had not managed to clarify his own attitude towards his protagonist: was Ivanov a parody or a type of the 'superfluous man'?" SENELCIK, Op. Cit., p. 17.
} 
irônicas, com detalhes de fundo (o que então chamara de frouxo ou mal alinhavado), por cenas mais dramáticas, ao modelo do que se tinha como bom drama à época. A crise de Ivánov ao final não seria mais inesperada e supérflua - ganharia em integridade e heroificação, com direito a uma espécie de discurso de defesa final, ainda que, como viria a desenvolver futuramente, o "motivo" não fosse diretamente explícito e tivesse fortes marcas de ambiguidade ${ }^{70}$. De peça com veios cômicos, Tchékhov a convertera, com todas suas especificidades, em um drama.

No intermezzo da revisão de Ivánov, Tchékhov deu continuidade ao trabalho de produção de farsas e pequenas cenas cômicas ${ }^{71}$ que definiram seu reconhecimento junto ao público russo. Elas tinham, como disse, "sucesso garantido", mas nem por isso devem ser vistas como menores. Em 1888 escreve O Urso (Медведь) е O pedido de casamento (Предложение) $)^{72}$. A primeira gozou de imediato sucesso junto ao público. Fora representada inclusive sem a permissão do autor em palcos oficiais. Isso porque, meses antes, ao ser submetida à censura, fora acusada de possuir uma "trama indecente" e uma "indecência de tom" ${ }^{73}$. Sua estreia se deu no Teatro Korch, em 28 de outubro de 1888, com Natália Ribtchínskaia no papel de Eliena Popova e o jovem rubro e de voz possante Nikolai Solovstov, no papel de Smirnov. Rapidamente inúmeros atores e teatros russos reivindicavam os direitos de uso do texto para poderem incrementar seu repertório com um ágil vaudeville ${ }^{74}$. Para Nemiróvitch-Dântchenko, à época já um crítico importante e leitor atento de novidades de valor literário, tratava-se de uma "astuta pequena peça", que esbanjava "frescor e originalidade teatral"75. Nela encontramos a peleja de uma viúva e de um proprietário que, entre debates sobre o pagamento de dívidas, terminam por se beijar. O elemento de interesse vem do fato de que as personagens carecem de autoconhecimento, são dois histriônicos que aparentam ser mais do que são. Por trás da viúva frágil e relutante, a mulher feroz; por trás do proprietário varão e firme, o apaixonado de coração mole. O jogo com o inesperado e o

\footnotetext{
${ }^{70}$ GUINSBURG, 2001, p. 82.

${ }^{71}$ Neste ano Tchékhov publicou em 22 de abril, no jornal Novo Tempo a cena dramática (nunca encenada) Declaração feita sob pressão (Вынужденное заявление) ou ainda $A$ repentina morte do cavalo ou $A$ grandeza do povo russo (Ckоропостижная конская смерть, или Великодушие руссково народа). Ver: CHEKHOV, 2006, p. 299-302.

${ }^{72}$ TCHÉKHOV, 2003, p. 39-90.

${ }^{73}$ CHEKHOV, Op. Cit., p. 415.

${ }^{74}$ Esta peça renderá dividendos para Tchékhov até o final de sua vida. Encenada aos quatro cantos do país será lá, e mesmo no Brasil, uma das peças mais encenadas do autor.

75 NEMIROVITCH-DÂNTCHENKO, V. I. Resentsii, ocherki, stati, interviu, zametki 1877-1942. Moscou: Iskusstvo, 1980, p.127 apud SENELICK, Op. Cit., p. 15.
} 
revelar brusco da face desconhecida de cada um é o que torna o jogo dramático de falas ágeis um prato cheio para os palcos da época. Como pano de fundo, mas em outra chave, a mesma vida de província, com as crises financeiras individuais ou familiares que marcavam a vida russa da época e atravessarão peças como Ivánov, Tio Vânia e o Jardim das Cerejeiras ${ }^{76}$.

Do mesmo sucesso imediato gozou $O$ Pedido de Casamento $^{77}$. Sua primeira encenação se deu no dia 9 de agosto de 1889, na Residência Imperial em Tzarskoie Selo. Como Lómov, Pavel Svobodin; como Natália, Maria Ilínskaia e o como Tchubúkov o reconhecido comediante Varlámov. A peça, que joga astutamente com uma série de desentendidos, constrói um clímax claro e logo após, retorna aos maus entendidos. $\mathrm{O}$ pedido de casamento se consuma nas condições mais estranhas e parece já abrir uma nova qualidade de quiproquós ${ }^{78}$. Tchékhov a desdenhava, como desdenhava inúmeros de seus trabalhos, tratando-a como um "vulgar vaudeville"79.

Como se vê, Tchékhov cambiava no trabalho com diferentes formas dramáticas, revolvendo a tradição, suplantando-a, ou a ela retornando; explorando a face cômica na dramática, ou separando-as absolutamente, como que numa luta ("testada" e avaliada em suas realizações de palco). Se não temos configurados ainda os elementos que levariam Peter Szondi a qualificá-lo como dramaturgo da crise do drama, temos um terreno bastante interessante de estudo, que antecipa fissuras e mostra linhas de continuidade, que marcarão todas suas peças futuras.

E é com a segunda versão de Ivánov que o dramaturgo convive mais intensamente com as contradições da matéria e da fatura, revelando incessantemente a Suvórin o quanto o trabalho com Ivánov já o irrita e desgasta ${ }^{80}$. A reestreia em São Petersburgo, no Aleksandrínski, deu-se em 31 de janeiro de 1889, em um teatro pouco afeito a experimentações. Mas a preocupação de Fiédorov, então à frente da instituição,

\footnotetext{
${ }^{76}$ CHEKHOV, Op. Cit. p. 415-416.

${ }^{77}$ No Brasil esta fora provavelmente a peça mais encenada de Tchékhov, por grupos profissionais e, sobretudo, amadores.

${ }^{78} \mathrm{O}$ recurso era bastante comum nas comédias do século XIX e aqui vem entendido no sentido apresentado pelo Dicionário do Teatro Brasileiro: "Recurso, em geral cômico, através do qual as personagens, por problemas de comunicação, interpretam erradamente o sentido dos diálogos ou o comportamento de outras personagens. Esses problemas de comunicação podem decorrer de ignorância, de deficiência auditiva de redação deficiente ou por quaisquer outros motivos." Cf. GUINSBURG, J.; FARIA, J.; LIMA, M. A. Dicionário do Teatro Brasileiro: temas, formas e conceitos. São Paulo: Perspectiva/SESC, 2006, p. 257.

${ }^{79}$ Idem, p.434.

80 "Se agora não aceitarem a minha peça, jogo-a no fogo e escrevo uma novela chamada 'Chega'!". Carta a Suvórin de 5 ou 6 de outubro de 1888. TCHÉKHOV, 2002, p.70.
} 
de trazer novos dramas, favoreceu Tchékhov. Em sua correspondência com Suvórin, bastante intensa ao longo desse ano, o dramaturgo demonstra sua insatisfação com os ensaios: "Eu nunca mais hei de escrever peças tão cerebrais e intragáveis como Ivánov. Não me surpreenderei se ela não for encenada, e não culparei ninguém por intrigas e tramas." ${ }^{81}$ Estava ainda bastante inseguro com a atuação de Davídov, a quem gostaria de ver novamente no papel, mas que relutava em assumir o novo perfil delineado para Ivánov. Tchékhov acreditava que tinha habilidade para tratar Ivánov com a nuança agora necessária: "Por acaso Davídov é capaz de ser ao mesmo tempo doce e violento? Quando desempenha papeis sérios, ele tem uma máquina de moer na garganta, rouca e monótona, que representa no lugar dele..." ${ }^{82}$. E o que ocorreu na estreia, em verdade, fora justamente a dificuldade no acerto de tom. Davídov dera uma lentidão e melancolia excessivas aos dois primeiros atos (aqueles que, não por coincidência, Tchékhov vinha considerando os de maior acerto formal, por mergulharem em um cotidiano e seu fluxo específico). Nos últimos atos, o ator dera um tom altamente romântico à sua intervenção, sobretudo no momento em que descobre que sua mulher está fadada à morte ${ }^{83}$. Maria Sávina, atriz de relevo à época, desejava encenar Sacha, a moça apaixonada por Ivánov, personagem que lhe parecia mais jovem e atrativa. As exigências da atriz fizeram com que no processo de reelaboração do texto o dramaturgo tivesse de dar um maior destaque à personagem que, até então, não teria a proeminência da versão final. Aqui tratamos, evidentemente, de atores que, na história do teatro russo, gozaram de destaque. Para não alongarmos, basta dizer que a sensação de Tchékhov era a de que, de modo geral, a maioria deles encarava seu texto apenas como um trampolim para o brilho individual, e isso o ressentia. Em sua opinião, a única que "viveu" o papel foi Striépetova, atuando como Anna ${ }^{84}$. Momentaneamente, contudo, o dramaturgo rendeu-se ao sucesso da estreia em São Petersburgo ${ }^{85}$. No longo prazo, a insatisfação retornaria: seja nas sucessivas alterações que continuaria fazendo no texto (elas cessarão somente em 1901), seja nas cartas que envia aos conhecidos, questionando veementemente as interpretações que continuam julgando seu Ivánov um "deprimido",

\footnotetext{
${ }^{81}$ Idem, p. 123.

${ }^{82}$ Idem, p. 159.

${ }^{83}$ SENELICK, 2006, p. 22.

${ }^{84}$ Idem, p. 22-23.

85 "Depois que atuaram no meu Ivánov, considero todos como parentes meus. Eles estão tão próximos de mim como os doentes que curei, ou as crianças às quais dei aulas em outros tempos. Não posso esquecer que Striépetova estava chorando depois do terceiro ato e que todos os atores vagavam de alegria como sombras; muitas coisas eu não posso esquecer (...)".Carta a Suvórin de 4 de fevereiro de 1889, dias após a estreia em São Petersburgo. TCHEKHOV, 2002, p. 165-166.
} 
um apologeta da desistência. A chave irônica, se não foi de todo eliminada, estava ofuscada pelo que há de dramático, e os dramas finais vividos pelo protagonista teriam supostamente estimulado um jovem russo a se $\operatorname{matar}^{86}$.

Neste período, Tchékhov pensara inúmeras vezes em publicar esclarecimentos a respeito de suas intenções iniciais com Ivánov. A peça o desgostava cada vez mais e, muitas vezes, revelara a Suvórin o prazer maior que sentia com a escrita de contos. Nesse período, tinha alguns pequenos recantos de prazer com a escrita de Uma História Enfadonha e da peça $O$ Silvano (Лemuŭ $)^{87}$, com os quais estava às voltas mesmo antes de entregar a versão de Ivánov que fora encenada pelo Aleksandrínski. O Silvano ${ }^{88}$, encenada em outubro de 1889 no Teatro de Abrâmova, foi recebida com indiferença e rechaço. O texto gozou de parcas cinco apresentações e fora retomado pelo dramaturgo apenas em 1897, sendo reescrito e republicado sob o nome de Tio Vânia. Inicialmente, Tchékhov tinha a sensação de não ter nenhuma personagem "sobrando" 89 em seu conjunto. A insegurança com relação às leis do drama, no entanto, era uma outra questão. Tinha dúvidas reais de se tratar de uma peça encenável, dada a matéria tão prosaica que, justamente por se vincular aos fios cumulativos que tecem o cotidiano das personagens, necessita de um tempo estendido, uma ambientação específica, que o drama tradicional parecia não suportar:

Que o Silvano serviria para um romance eu também acho, mas para um romance sou eu que não tenho forças. Os ventos ainda são favoráveis. Já uma novela curta eu consigo escrever.

Fora justamente este o elemento que o Comitê de Repertório de São Petersburgo utilizara para negar a encenação da peça no Aleksandrínski. Grigórovitch, convidado

\footnotetext{
86 "Recebo a propósito de Ivánov cartas anônimas e não anônimas. Certo socialista (ao que tudo indica) indigna-se em sua carta anônima e lança-me uma acusação amarga; escreve que depois de minha peça um jovem morreu, que minha peça é nociva e assim por diante." Carta a Suvórin de 8 de fevereiro de 1889. Idem, p. 169-170.

87 "Em seguida, mal tive tempo de terminar a novela, extremamente cansado, tomei impulso e, por inércia, escrevi O Silvano, de quatro atos; escrevi de novo, depois de ter destruído tudo o que havia sido escrito na primavera. Trabalhei com grande satisfação, até mesmo com deleite, apesar de ter ficado com dor no braço e com a vista embaralhada de tanto escrever. " Carta a Suvórin de 13 de outubro de 1889. ANGELIDES, $O p$. Cit, p. 153. No Brasil, esta versão foi traduzida por Tatiana Lárkina: TCHEKHOV, Anton. O Silvano: comédia em quatro atos. Trad., Posfácio e Notas de Tatiana Lárkina. São Paulo: Ed. Globo, 2005.

${ }^{88}$ A peça inicialmente fora concebida conjuntamente por Tchékhov e Suvórin. No entanto, este último abandonou o projeto inicial (amplamente discutido por Tchékhov no mapa de personagens presente em carta enviada em 18 de outubro de 1888).

${ }^{89}$ SENELICK, Op. Cit., p. 24.
} 
para o comitê, dissera que a peça poderia promover certa confusão no gosto público e que, definitivamente, não se tratava de uma comédia, como pretendia o autor. $\mathrm{O}$ ator Pável Svobodin, que levara a peça para ser julgada, repassou o aviso ao dramaturgo: "não havia os efeitos fáceis, nem as situações repisadas, nem as banalidades que invadiam o Teatro Aleksandrínski" ${ }^{90}$. Em Moscou tinham a mesma opinião, e o renomado ator Aleksandr Liênski, então no Máli, diria: "escreva ficção. Você tem muito desdém para com a cena e a forma dramática, você as respeita muito pouco para escrever um drama" 91 .

Tchékhov embebeu-se de inúmeros conselhos, sobretudo os de NemiróvitchDântchenko, que lhe recomendou não ignorar de todo as regras do drama, para assim aproximar-se mais do público ${ }^{92}$. Ainda assim, a peça aceita pela atriz e empresária Maria Abrâmova não gozou de sucesso em Moscou. Ainda que o dramaturgo estivesse crente de que os problemas eram únicos e exclusivos do texto, não se podia levar a sério a gorda atriz Maria Gliébova que, na disputa pelo papel da bela Elena, não se deu pelo desabono de sua aparência, o que levou o público às gargalhadas quando o ator Roschín-Insárov exclamou por sua beleza. Isto afora a audiência prosaica que, diante do título $O$ Silvano, esperou literalmente pelo aparecimento do verdadeiro Espírito da Floresta, ou do Deus dos Bosques ${ }^{93}$.

Como se vê, o adjetivo tchekhoviano, hoje tão comum nos meios teatrais, seria aqui uma impropriedade. Não só pela ausência de relativo consenso (hoje quase dado), mas também pelos procedimentos que ainda careciam de uma depuração de tom, que aparentemente já vinha se dando com maior clareza em seus contos e novelas. Estes já eram responsáveis em grande parte pela estabilidade financeira do escritor; sem excluir suas farsas, e mesmo Ivánov, que já rendiam muito nos palcos de província.

O dramaturgo via-se agora imerso nos planos de viagem a Sakhalina, mas mesmo assim encontra tempo para a escrita de mais duas farsas - Trágico à Força

\footnotetext{
${ }^{90}$ ANGELIDES, Op. Cit. p. 154.

${ }^{91}$ No original: "write fiction. You have too cavalier an attitude toward the stage and dramatic form, you respect them too little to write a drama." SENELICK, 2006, p. 26.

92 Carta a Suvórin de 27 de dezembro de 1889. TCHÉKHOV, 2002, p. 263-265.

93 O que se entende por "Silvano" é uma espécie de entidade ou deus típico da floresta, oriundo da mitologia romana. A intenção de Tchékhov era não destacar o que há aí de insólito ou excêntrico, mas justamente o que há na imagem de campesino ou rural. SENELICK, Op. Cit., p. 24-27 e Dicionario de mitologia greco-romana. São Paulo: Abril Cultural, 1973.
} 
(Трагик поневоле) е As Bodas (Свадьба $)^{94}$ e um pequeno drama, espécie de cópia de um homônimo escrito por Suvórin: Tatiana Répina (Татьяна Репина). Este último, estranhamente, é tema de inúmeras cartas trocadas com o poderoso editor. Tchékhov se impressionara com esta peça escrita pelo amigo, que reproduzia quase que literalmente uma história verdadeira e configurava um típico drama: uma atriz é abandonada pelo amante e, no auge de seu desespero, envenena-se antes do início da peça, para cair desfalecida apenas no último ato. A versão de Suvórin ganha os palcos e Tchékhov se torna responsável por acompanhar ensaios e garantir a efetividade da montagem em Moscou. Mais tarde, animado pelo mote, escreve uma peça homônima, mantendo praticamente o mesmo enredo. A abordagem que dá ao suicídio, no entanto, tem tom levemente diferenciado. Depois de Ivánov, passaria a encarar o suicídio como uma espécie de fraqueza diante das demandas da vida (aqui, em Répina, com o Trepliov de $A$ Gaivota, ou ainda a tentativa de suicídio com morfina por Vânia), sem, no entanto, acentuar qualquer tom de julgamento. Se aqui ainda marca a força do melodrama, ela não deixa de conviver com o painel de personagens e situações que puxam a peça para os tons pasteis: pequenas cenas de jogos, conversas banais, carreiras falidas, relações em frangalhos, conflitos que se dissolveram no fluxo normalizador do cotidiano... ${ }^{95}$

Após a experiência de Sakhalina, e o tortuoso caminho de Ivánov, o dramaturgo dedicara-se ao campo que, até então, trazia-lhe menos turbulências: $o$ conto. Durante alguns anos continuaria a pensar cenas e pequenas peças que não levará a cabo ${ }^{96}$. Mas o período não seria improdutivo para o teatro, se dali subtraímos um momento de maturação que mais tarde se converteria em sua primeira peça de impacto e, possivelmente, só naqueles fins de XIX teria condições para realizar-se.

\footnotetext{
${ }^{94}$ Também conhecidas do público brasileiro são estas duas peças em um ato de Tchékhov. Estão no livro organizado por Homero Freitas de Andrade. TCHÉKHOV, 2003, p. 91-130.

${ }^{95}$ CHEKHOV, 2006, p.533-534.

${ }^{96}$ Exceção para a peça O Jиbileu (Юбилей), escrita entre 1892 e 1893. TCHEKHOV, 2003, p. 131.
} 


\subsection{Uma Gaivota de tinturas trágicas}

Como explicar que no intervalo de apenas dois anos a encenação de A Gaivota pelo Aleksandrínski (1896) fosse suplantada pelo estrondoso sucesso de A Gaivota, pelo TAM (1898)? A pergunta hoje parece não encontrar dificuldades para ser respondida. A verdade, no entanto, é que o papel decisivo cumprido pelo Teatro de Arte de Moscou, sob a batuta de Konstantin Stanislávski e Nemiróvitch-Dântchenko, tendeu em muitos casos a distorcer ou mesmo idealizar situações e processos. Não podemos esquecer que, no cenário russo, o TAM surge também como alternativa ao papel cumprido pelos teatros imperiais e que seria natural a tentativa de estar a sua frente na escolha de repertório, nas técnicas de encenação e mesmo nos sucessos de bilheteria ${ }^{97}$.

A encenação de A Gaivota pelo Aleksandrínski, dirigida por Kárpov, precisa ser retomada hoje sem a lente estabelecida pelo TAM, sem, contudo, ignorar o papel realmente catalisador cumprido por este.

Como competia a boa parte dos dramaturgos russos da época, e à Tchékhov que se mostrava cada vez mais preocupado com a relação entre seus textos e as montagens que lhes eram dadas - a despeito e talvez por sua própria insatisfação com as condições de produção - o dramaturgo acompanhava de perto os ensaios. Indicava atores, opinava sobre soluções de cenário e atuação. Não fora diferente com a encenação do Aleksandrínski. No início, inclusive, estava bastante disposto: o grande Davídov estaria no papel de Sorin e a reconhecida Vera Komissarjévskaia ${ }^{98}$ como Nina ${ }^{99}$. Some-se a isso o fato de que, para além da noite de estreia de A Gaivota, realmente fracassada, e que marcara profundamente o dramaturgo, as noites seguintes foram recebidas de maneira diferente pelo público: a plateia estava atenta e os atores gradualmente se empenhavam mais. Na segunda noite, por exemplo, aplaudiram entusiasticamente após o terceiro ato e convocaram o autor ausente ao proscênio. A carta que lhe enviou Komissarjévskaia destaca o "completo, unânime sucesso" ${ }^{100}$.

\footnotetext{
${ }^{97}$ GUISBURG, Jacó. Stanislávski e o Teatro de Arte de Moscou - do realismo externo ao tchekhovismo. São Paulo: Perspectiva, 2001, p. 16-17.

${ }^{98} \mathrm{O}$ primeiro grande sucesso de Vera Komissarjévskaia vinha já desde 1892, atuando como Betsy em "Frutos do Esclarecimento". Ao longo da década passou por inúmeras produções e atraía espectadores pela sinceridade e profunda paixão com que encenava. Nos primeiros ensaios de A Gaivota, Tchékhov ficara particularmente impressionado com sua corajosa interpretação de Nina. SENELICK, 2007, p. 189. ${ }^{99}$ CHEKHOV, Op. Cit., p.734.

${ }^{100}$ SENELICK, 2006, p. 37.
} 
A despeito destes elementos, foi a noite de estreia que ficou para a história como momento decisivo: traumatizara o autor e serviria na posteridade como comparativo para elevar o TAM. Mas seus problemas não podem ser ofuscados. O público esperava uma comédia ao estilo do que Antocha Tchekhonté publicava nos jornais nos últimos anos e, sobretudo, um texto bem leve ao modo do que a atriz Vera Levkeiva, que comprou os direitos de uso da peça, estabilizou ${ }^{101}$. A intelligentsia não era majoritária na plateia, pois o Aleksandrínski era um teatro pouco afeito aos autores nacionais (seguindo a linha refratária dos czares) e com repertório bastante eclético. Os atores, que nos últimos ensaios mostravam-se pouco empenhados na construção dos papeis (de início custaram a decorar as falas e serem pontuais aos ensaios), vinham regidos pela direção de Kárpov, que explorava pouco as nuances que as personagens exigiam. $\mathrm{O}$ Trepliov de Roman Apollonski tinha o andar tranquilo (para o desespero de Tchékhov); a Arkádina de Diújikova era inteligente e bondosa e o Trigórin de Sazónov era um típico bufão. Em linhas gerais, o estudo limitado do conjunto do texto e do sentido de cada personagem culminava numa prática comum dos atores da época: agarrar a personagem em retratações gerais, bem ao estilo do teatro bufo ao qual estavam acostumados ${ }^{102}$. Estas limitações, somadas às expectativas do público, criaram uma série de equívocos na estreia: os risos começavam diante de qualquer detalhe. As gargalhadas desabaram quando, no $1^{\circ}$ Ato, Arkádina ironicamente diz que a peça encenada por Nina cheirava a "enxofre". Além disso, a cenografia previa alguns auxiliares na cena de Nina, vestidos de preto, assemelhavam-se a fantasmas no pequeno palco de jardim e soavam algo grotesco. O público ria e se desconsertava com a gaivota trazida morta por Trepliov no $2^{\circ}$ Ato e, ao final do $4^{\circ}$ Ato, não havia palmas, só chios, estalos e risos.

Tchékhov fora profundamente atingido por esta noite de estreia e pela repercussão fortemente negativa junto à crítica. Suvórin já havia escrito antecipadamente um artigo elogioso para o Novo Tempo, mas teve de reescrevê-lo às pressas destacando a "pouca ação, pouco desenvolvimento dramático, personagens desinteressantes"103. Aleksandr Kugel, fazendo coro com o conjunto de críticos que via

\footnotetext{
101 Levkeiva possuía uma legião de "seguidores", conhecidos à época como gostinodvorians, comerciantes, pequenos empresários, gente da classe média, que adoravam suas representações de farsas e sua atuação bufônica. Idem, p. 33-34.

${ }^{102}$ Idem, p.31.

${ }^{103}$ Ibidem, p. 35.
} 
ali uma verdadeira "demência", fora duro destacando que "só há diálogos, não há pontos definidos" 104 .

Diante daquela estranha experiência, os críticos manifestavam-se com posições que hoje já se pode observar dentro de uma perspectiva mais organizada. O príncipe Urússov, que por aqueles anos se destacava como uma importante figura patrocinadora e crítica dentro do meio teatral, não estava de todo errado ao ver o tom geral dos críticos, já sob a influência da luminosidade do TAM, como a recusa dos velhos ao novo procedimento de Tchékhov. Para ele, o dramaturgo estabelecia uma forte interface com as tendências nascentes do simbolismo ${ }^{105}$ (Maeterlinck era então persona non grata para críticos tradicionais), com um texto de forte acento pessimista, envolvido em clima poético, com remodelação dos inícios e fins de atos. O crítico ainda destacaria, em leitura geral, que a ousadia com que o autor revelava os segredos vergonhosos da vida, por meio de personagens psicologicamente complexas, que repeliam julgamentos fáceis, mostrava a podridão escondida por trás de "sólidos edifícios". ${ }^{106}$

Mas, ainda que pontualmente algumas figuras fizessem ressalvas à atuação individual de Komissarjévskaia, que concebera bem a figura de Nina como alma sincera do campo em contato com vulgaridade da vida ao redor, o tom geral era de reprovação. E, ainda que a peça fizesse relativo em montagens do interior do país, Tchékhov preferiria vê-la como comprovação decisiva de que o palco não era o lugar para sua pena.

Em contraposição, a encenação do TAM foi poderosa. Em meio a uma história de percalços e frustrações acumulados pelo dramaturgo (no que se referia a suas peças longas, ou ainda, "sérias"), foi possível encontrar ali uma chave interpretativa e procedimentos que, justamente por sua força, revelavam perigos: mostraram a necessidade histórica de novas técnicas de encenação, que dessem conta da complexidade da proposta tchekhoviana (mais depurada, mas ainda não de todo

\footnotetext{
${ }^{104}$ Ibidem, p. 35-36.

105 Sobre certo veio simbolista de Tchékhov, temos um amplo campo em discussão. Colocado nos termos de Urusov, a discussão parece pertinente. No entanto, como bem pontua Jacó Guinsburg, a figura de Trepliov é dúbia: se nela há uma tentativa de ruptura com as formas tradicionais ("Novas Formas!" é sua ideia fixa), há também uma ponta de ironia de Tchékhov ao mostrá-lo como estetizante ou mesmo decadentista. Ver: GUINSBURG, Op. Cit., p. 88-89. Laurence Senelick destaca também que muitos simbolistas não admitiam esta classificação para Tchékhov, tendo em vista o caráter não programático de sua poética. SENELICK, Op. Cit., p. 35-36.

${ }^{106}$ URUSOV, A. I., Stati o teatre, literature i ob iskússtve. Moscou: I. N. Kolchev, 1907, p. 34-35 apud SENELICK, 2006, p. 35.
} 
consciente); e a capacidade que teriam, mesmo depois de muitos anos, de enrijecer uma leitura específica de como se deveria encenar Tchékhov, ou o que o seria ou não tchekhoviano.

Mas de imediato o contato inicial do texto tchekhoviano com o que até aquele momento vinha se desenvolvendo no TAM não fora tranquilo. Stanislávski reconhecia certo valor literário nas peças do dramaturgo, mas achava-o "arrogante" e tinha sérias preocupações quanto a sua possível repercussão junto ao público. Tinha em mente a noite de estreia do Aleksandrínski e queria para aquela primeira temporada do TAM peças que marcassem os novos procedimentos do então nascente grupo. Dentre elas, havia títulos de destaque, como $O$ Mercador de Veneza, de Shakespeare e $O$ Sino Submerso, de Gerhart Hauptmann. Mas é a estreia com Czar Fiódor, de Alexei Tolstói, em 14 de outubro de 1898 que destacou a identidade inovadora do grupo, que escolheu esta peça histórica pelo que ela permitiria de "reconstrução histórica" e "poder evocativo das imagens". Muito disso vem da própria formulação bielinskiana, rapidamente identificável pela intelligentsia: "arte é pensar por imagens". E o TAM levava a sério tal premissa - no que ela poderia promover de renovação da dinâmica cênica e também do gosto público $^{107}$.

Como se pode perceber, esse desejo de Stanislávski e Nemiróvitch-Dântchenko vinha de uma demanda concreta do teatro russo (e mesmo Ocidental). O episódio lendário da conversa entre os dois, que teria se iniciado numa tarde em Moscou e terminara ao final da madrugada, na casa de campo de Stanislávski ${ }^{108}$, partia exatamente desta pergunta: "como renovar a cena russa?"; ou ainda "como tirar o teatro das soluções artificiais, artificialmente importadas e redutoras?”. Tal intenção vinha diretamente vinculada a práticas concretas, até então pouquíssimo exploradas no Oriente e no Ocidente, como a racionalização do trabalho com o conjunto, levando atores, cenografia e sonoplastia a trabalharem sob um mesmo eixo interpretativo. Os elementos da encenação, no caso de Czar Fiódor, foram valorizados em seus mínimos detalhes (objetos de época, vestimentas e cenário resgatados à exaustão).

Se esta concepção sugere um esquema externalizante, ou mesmo naturalista, de encenação, é preciso tomar cuidado com a classificação. Mais tarde Nemiróvitch-

\footnotetext{
107 "Era uma linguagem cênica que procurava presentificar de pronto o universo-objeto, ou sua sugestão, por encantação plástica projetada como 'real', graças às 'artes' de um virtuosismo diretorial a exibir-se a solta, por paradoxal que isso possa parecer". $C f$. GUINSBURG, $O p$. Cit. p.61.

${ }^{108}$ STANISLÁVSKI, 1989.
} 
Dântchenko afirmaria haver aqui muito das técnicas herdadas dos Meininger, só que levadas ao extremo ${ }^{109}$. No entanto, reduzir tais procedimentos à taxação de naturalistas, serve mais a uma preocupação contemporânea de desbastar qualquer projeto realista ou crítico de encenação do que a um real entendimento das inovações em curso naquele período. A trajetória do TAM e as propostas de Stanislávski sofrem tanto quando são reduzidas à simples ideia de "método"110 quanto quando são reduzidas à ideia de "naturalismo". Isto porque não se pode ignorar que havia um percurso bastante sinuoso de trabalho, que pode ser em partes observado num outro flanco que opera dentro de sua concepção: a união dos elementos deve funcionar como numa orquestra, para a construção da "atmosfera", não só no que isso tem de externo, mas também de interno $^{111}$. Daí a emergência de trabalhos mais psicológicos, como A Gaivota, estreada no dia 17 de dezembro do mesmo ano, que criavam não a sensação de um quadro histórico-estático, mas a sensação de um trabalho de pontilhismo, ou ainda, nas palavras de Meyerhold, um cênico impressionismo ${ }^{112}$.

A Gaivota cabe, portanto, em um projeto que, talvez mesmo por ela, ganhará em qualidade. De início, a resistência de Stanislávski fora suplantada pela sensibilidade literária de Nemiróvitch-Dântchenko, então preocupado com o estabelecimento de uma relação mais profunda com o público. Buscou firmar entre atores e plateia uma ponte que não fosse mais mecânica ou fácil, mas que partisse de um estudo preciso e da criação na cena do ânimo e da atmosfera adequados. Tchékhov, dentre todos os dramaturgos, parecia o mais adequado para isso. ${ }^{113}$

Mas, em conjunto com a precaução de Nemiróvitch-Dântchenko, que imporia a necessidade do estudo do conjunto, do estabelecimento de uma linha organizadora para a encenação, isso não significa estar preso à ideia de uma "intenção textual estrita".

\footnotetext{
${ }^{109}$ Os Meininger, assim como o Theâtre Libre de Antoine e as experiências da Freie Bühne de Otto Bralim vinha no impulso de fins do século XIX de tornar o teatro objeto de estudo específico, livre da intuição e dos arroubos individuais, e torná-lo objeto da ciência. Para muitas de suas peças, o naturalismo da cena era conquistado com minucioso estudo histórico de reconstituição, regido por novas formas de direção, cenário e iluminação. Cf. GUINSBURG, Op. Cit., p. 15-16.

${ }^{110}$ Seria mais pertinente falar em termos de "sistema". Sobre a discussão do "congelamento" do trabalho de Stanislávski em um "método" desligado de historicidade, que ignora o percurso rico de seu trabalho no TAM, marcado por peças realistas, simbolistas e mesmo experimentais, e mesmo o fato de que ele não deixara nenhum método publicado em obra durante sua vida, alguns ensaios merecem consulta. ROSENFELD, Anatol. "Stanislávski sem Método". In: Prismas do Teatro. São Paulo: Perspectiva, 1993, p. 113-120. GUINSBURG, Jacó. "O Sistema de Stanislávski". In: Stanislávski, Meierhold \& Cia. São Paulo: Perspectiva, p. 311-316. CAVALIERE, A.;VÁSSINA, E. " A herança de Stanislávski no teatro norte-americano: caminhos e descaminhos". In: Revista Crop 7, 2001, p. 307-327.

${ }^{111}$ Ibidem, p. 59-62.

${ }^{112}$ SENELICK, 2006, p. 40-41.

${ }^{113}$ COSTA, Iná Camargo. Aproximação e distanciamento: o interesse de Brecht por Stanislávski. Revista Sala Preta, São Paulo, p. 49-60.
} 
Stanislávski contribui com a leitura decisiva de que se trata de uma encenação de diretor, não de autor ${ }^{114}$. Kárpov, como vimos, contribuíra para a ideia de que os atores estavam ali para dizer algo de relevante, ou apenas contar (bem ao modo dos diálogos tradicionais), o que exigia pouco estudo da cena ou de criação de um "mood" unificador (elementos estes, como sabemos, decisivos para a poética tchekhoviana) - daí muito das limitações da encenação do Aleksandrínski. Agora, ao contrário, é preciso manipular o material, manipular as trivialidades do cotidiano que ali abundam, para criar a intuição sobre o que não é dito, para o que está para além dos diálogos e envolver o espectador sensitivamente, transmitindo verdade psicológica.

Raymond Williams abordará de maneira precisa este ponto. Para ele, Tchékhov estrutura diálogos, que, pela natureza do material a ser abordado, não dão conta do conjunto de experiências a serem transmitidas. Em suas próprias palavras "há um consenso de que, se ele tivesse escrito todos os detalhes necessários [para expressar a experiência], quando a peça chegasse àquela encenação específica, teria escrito algo diferente de qualquer texto dramático anterior, e algo muito mais parecido com um romance"115. Daí a angústia que crescia há tempos entre os críticos, que viam nas peças de Tchékhov um material impossível de ser encenado. Essa separação entre a fala formal e a ação cênica teria papel estruturante no drama moderno, pois, mudam-se as experiências de época e mudam-se também as formas dramáticas. Stanislávski e Nemiróvitch-Dântchenko, por serem os primeiros a sistematizarem com maior consciência a especificidade do "fenômeno teatral"116 são os que dão conta, com todos os percalços, de apresentar uma chave precisa o então estranho drama tchekhoviano. $\mathrm{O}$ resultado, como se sabe, foi de ordem revolucionária.

Por isso não é de se espantar que a estreia de A Gaivota tenha impactado de tal maneira a história do teatro ocidental. Naquela noite, algo de novo se apresentava já no primeiro ato. Sentadas em um banco, as personagens assistiam à pequena peça de Nina,

\footnotetext{
${ }^{114}$ Raymond Williams entrará no nervo desta questão ao mostrar o quanto se desenvolve aqui um eixo decisivo do drama moderno: "Sem o talento de Stanislávski, a encenação do tipo de escrita dramática de Tchekhov talvez fosse impossível. Mas também devemos nos lembrar de que, quando Tchekhov viu este tipo de produção, ficou 'bem agitado' e insistiu no fato de que alguns trechos então encenados não de fato 'sua peça'. Esse tipo de reação se tornou característica e o importante é que o debate não se degenere numa queixa mútua entre o dramaturgo e o encenador. A única questão produtiva diz respeito à forma dramática". Cf. WILLIAMS, Raymond. Drama em Cena. São Paulo: Cosac \& Naify, p. 172.

115 Ibidem, p. 173.

116 Aqui trabalhamos com o conceito no modo com que é exposto por Anatol Rosenfeld em "A Essência do Teatro". In: Prismas do Teatro. São Paulo: Perspectiva, 1993, p. 21-26.
} 
num palco improvisado no jardim, de costas para o público ${ }^{117}$. Era como se a plateia estivesse ao mesmo tempo dentro e fora da peça, observando ali o transcorrer de vidas, uma tranche de $v i e^{118}$. A cenografia, apesar de um pouco mais presa à minúcia da ambientação em comparação com a encenação do Aleksandrínski, produzia um curioso efeito de estratificação, com algumas partes escuras, outras luminosas e um rico jardim arborizado. Reiterava-se o "estado de ânimo" nos detalhes de cena e nos pequenos ruídos (vento, badalar de sinos ao longe, música de fundo), que emergiam nos intervalos de fala das personagens. Trepliov, ao contrário da concepção do Kárpov, fora concebido como uma personagem tensa, à maneira de um poeta decadentista; e Nina, uma inocente enganada por Trigórin. A divisão, bem aos moldes melodramáticos, achatou um pouco da ambiguidade das personagens, mas foi atenuada pelo que a encenação explorou de silêncios, pausas e indecisões, ofuscando os contrastes. Estes recursos, fortemente explorados nos dois primeiros atos, foram deixados de lado no terceiro, para que os diálogos frente a frente entre Arkádina e Sórin, Arkádina e Trepliov e Arkádina e Trigórin ficassem mais limpos e ganhassem em "efetividade teatral e verdade psicológica"119. Diante da intensidade dos "embates", e do realismo do conflito entre Arkádina e seu filho o teatro desabou em aplausos pela primeira vez naquela noite ${ }^{120}$.

No quarto ato Stanislávski retomou as pausas e silêncios, intensificando-as a ponto de atingirem quinze segundos cada. Ao contrário da encenação de Kárpov, em que atores apresentavam um texto, havia aqui a criação de uma realidade cênica. Para Stanislávski, o público deveria perceber que por trás daqueles diálogos banais ocorria algo subterraneamente. Com relação a este ponto, Raymond Williams analisa em detalhe o Caderno de Direção de Stanislávski e dá destaque para uma cena que o diretor considerava decisiva no quarto ato: o momento em que, depois de anos longe de Trepliov, Nina retorna como uma gaivota abatida e tem uma rápida conversa com o jovem. As rubricas que surgem sucintas no texto de Tchékhov são interpretadas de maneira específica por Stanislávski. Após o discurso de Nina seguiu-se o solitário barulho do vento e, após sua despedida, Trepliov permaneceu em silêncio por aproximadamente quinze segundos, deixando o copo cair de suas mãos em seguida. $\mathrm{Na}$

\footnotetext{
${ }^{117}$ Não se pode ignorar, contudo, que colocar os atores de costas para o público, como que a acentuar o efeito da quarta parede, de uma realidade que transcorre em sua perfeita integridade, já fora utilizada em Czar Fiódor.

${ }^{118}$ A expressão é de RIPELLINO, Angelo Maria. O Truque e a Alma. São Paulo: Perspectiva, 1996, p. $12-49$.

${ }^{119}$ SENELICK, 2006, p. 45-46.

${ }^{120}$ Idem, p. 45.
} 
leitura do diretor, este momento, apesar de não ser indicado diretamente pelo autor, deveria marcar a decisão do suicídio, posteriormente levado a cabo pelo jovem ${ }^{121}$. Aqui, como se vê, o texto abre um campo de possibilidades interpretativas, que foram criativamente lidas pelo diretor e trabalhadas em cena dentro de seu eixo organizador.

Esses não são pontos que nos podem escapar. A harmonia do conjunto, trabalhada menos em termos de "realismo cru" e mais em termos de criação do que é intuído, somada àqueles silêncios profundos, com forte significado, traziam algo de poderoso para o palco russo. Os intervalos sem diálogo expressavam uma espécie de sentimento doloroso, alongavam o suspense junto ao público e desafiavam os espectadores:

Em algumas cenas... as personagens estão em silêncio por alguns minutos, o que pode ser visto no geral como uma heresia não-dramática, despedaçando a mais elementar técnica de palavras que significam algo na cena... $\mathrm{Na}$ vida às vezes as pessoas estão em silêncio por horas ou sempre, e este silêncio muitas vezes é o mais profundo sentido. ${ }^{122}$

Esta fora a interpretação de Stanislávski, corretamente captada por Serguei Glagol, e que aquele elenco jovem, mas disciplinado, esforçou-se por dar conta. O público estarrecido captara a encenação nesses exatos termos e, embebido por aquela atmosfera, permaneceu em breve silêncio ao fechar das cortinas, explodindo em palmas logo em seguida. Intelectuais presentes afirmaram ter a sensação de "viver o presente" ao assistir aquela peça, mas a plateia da estreia não era composta em sua maioria desse setor da sociedade. A classe média "em fase de ilustração", a mesma antes tão ironizada por Tchékhov, era a que ali se fascinava com um novo drama e novas técnicas de encenação. E, ainda que muitos críticos pontuassem a "morbidez" da encenação, ou vissem ali um universo de "individualidades desviantes", como em um "consultório para pacientes com problemas mentais"123; e ainda que Tchékhov estivesse bastante insatisfeito com o Trigórin "sedutor e confiante" de Stanislávski, assim como com o Trepliov demasiadamente angustiado de Meyerhold, sua sensação era a de alívio. Em

${ }^{121}$ WILLIAMS, Op. Cit. p. 169-171.

122 "In some scenes... the characters are silent for a few minutes, which may seem almost a non-dramatic heresy, shattering the most elementary technique of works meant for the stage... In life sometimes people are silent for hours on end, and this silence often has a most profound meaning." GLAGOL, Serguei. Kurer. 1898. apud SENELICK, Op. Cit, p. 47.

${ }^{123}$ SENELICK, 2006, p. 49. 
carta a Olga Knipper, o dramaturgo diria otimista ser aquele o momento de "fazer um acordo com o teatro e a vida contemporânea" ${ }^{124}$.

A repercussão positiva desta encenação é a que conhecemos hoje. E é desta encenação também que emergem questões com as quais lidaremos aqui mais diretamente: projetou-se uma forma específica de interpretação e encenação do drama tchekhoviano $^{125}$, necessária historicamente, e que, como veremos, terá repercussões produções ao longo de todo o século XX, inclusive no Brasil ${ }^{126}$.

\subsection{Um Tio Vânia com sofrimento duradouro}

Acredita-se que Tchékhov já estava às voltas com a finalização de Tio Vânia (Дядя Ваня) semanas após o término de A Gaivota. Isto porque o sucesso da estreia desta peça estimulara Nemiróvitch-Dântchenko a solicitar um novo texto ao dramaturgo que, no entanto, já o havia prometido ao Máli em $1897^{127}$. Tchékhov não deixava de pontuar as restrições que tinha a algumas escolhas cênicas do TAM com a encenação de A Gaivota, mas aos poucos reconhecia estarem ali as condições para a realização de suas peças. Muito disso veio graças às discussões improdutivas que tinha sobre Tio Vânia com Kárpov, que a requeria para uma encenação no Aleksandrínski (mesmo diante da temporada controversa com A Gaivota, Kárpov via no TAM apenas uma "modinha e por isso solicitou a peça a Tchékhov) e pela encenação não autorizada, feita pelo grupo amador na Sociedade Artística para Leituras e Música de São Petersburgo, dirigido por Davídov. A encenação se deu em 1900, não agradou ao dramaturgo e, ante

\footnotetext{
${ }^{124}$ Ibidem, p. 51.

${ }^{125}$ Angelo Maria Ripellino será preciso em pontuar esta leitura feita por Stanislávski em A Gaivota: "O desmoronamento das esperanças é o tema precípuo do Tchékhov de Stanislávski. Por isto ele corta, do último monólogo de Nina, as palavras: 'Eu sou uma gaivota... Não. Sou uma atriz', palavras que no texto ela pronuncia erguendo a cabeça, como na certeza de ter encontrado sua vocação. Para Stanislávski, ao contrário, prostrada pelas explosões de risadas que chegam da sala de jantar, Nina pronuncia o monólogo imóvel, exausta, apoiando-se sem forças à porta, inclinando a cabeça cansada entre as mãos. Konstantin Sierguiêievitch tende, portanto, nas obras de Tchékhov, a exacerbar a pena e a desfeita das criaturas líricas" RIPELLINO, Op. Cit., p. 30.

${ }^{126}$ Como prévia desta discussão, sobre a qual nos alongaremos nos próximos capítulos, basta a afirmação de Meyerhold de que durante muito tempo Tchékhov seria tratado no TAM como "teatro de atmosfera", algo que definia uma abordagem mais emocional de sua dramaturgia, com ritmos e efeitos específicos. $C f$ Ibidem, p. 39.

${ }^{127}$ No entanto, o Máli não chegara a encenar esta peça de Tchékhov. O Comitê de Literatura do teatro, composto por dois professores da Universidade de Moscou, por Sumbátov e Nemiróvitch-Dântchenko não a aprovou, apesar da insistência dos dois últimos. Para os professores, a imagem que Tchékhov criara de Serebriákov - personagem que representa a frustração de um importante catedrático - era demasiadamente ofensiva. Cf. CHEKHOV, 2006, p. 811.
} 
a relação com o TAM, negou a autorização ao Aleksandrínski. Isso contribuiu para que Tchékhov estabelecesse uma relação mais intensa com o grupo, que já tinha estreado a peça em 26 de outubro de 1899 e, mesmo sem a vibração que marcara A Gaivota, tinha algumas soluções de encenação que o $\operatorname{agradavam}^{128}$.

A peça recebia como subtítulo o curioso "cenas da vida rural". Isto estimulou Stanislávski a fechar a leitura geral de que se tratava de uma representação da "futilidade da vida de província". Tal leitura se materializou em grande medida nas escolhas cenográficas e na valorização dos detalhes que acentuavam o arrastar de vidas mediocrizadas no interior (a mobília envelhecida, o cenário recheado pelo trabalho com diferentes detalhes). No entanto, para Laurence Senelick, Tchékhov parecia concebê-la mais em termos de "afinidades" e "proximidades" que se estabelecem entre sujeitos que vivem juntos em um mesmo espaço e as tensões que dali advém. $\mathrm{O}$ crítico estende um comentário feito por Tchékhov a respeito de uma peça de Hauptmann também para Tio Vânia: "Hoje em dia quase toda pessoa civilizada, mesmo a mais saudável, não vive a experiência da irritação tanto quanto em sua própria casa, em sua própria família, e a discórdia entre presente e passado é sentida primeiro e mais fortemente na família" ${ }^{129}$. Nada parece indicar, como se vê, que este seja o elemento sobressaltado na concepção de Stanislávski. Para ele, o essencial era destacar o que há de rotineiro na vida e por isso, como mostra Senelick, o contínuo matar de mosquitos que infestou o primeiro ato $^{130}$.

A despeito disso, Tchékhov pareceu particularmente satisfeito com as interpretações de Stanislávski, como Astrov, concebido em faceta levemente cínica, portadora de sonhos belos e poética sensibilidade, mas como que contendo "perigosas forças". Maria Lilina, como Sônia, também tocou o dramaturgo e o público. Vassíli Lújski, como Serebriákov, acentuou o sotaque germânico da personagem, como que a reproduzir o tom catedrático dos professores da Universidade de Moscou, o que rapidamente criou pontes de identificação com a plateia, fortemente composta por membros da intelligentsia moscovita. E este público ficara particularmente tocado com

\footnotetext{
${ }^{128}$ Nemiróvitch-Dântchenko enviaria uma carta entusiástica ao dramaturgo após a estreia destacando o quanto ele via a peça como um momento decisivo para a relação que se construía entre ele e para o "novo teatro" que se afirmava: a peça tem "considerável importância para a existência do meu teatro. Eu vi a encenação menos como diretor que como o fundador de um teatro consciente do futuro". Cf. SENELICK, 2006, p. 53.

${ }^{129}$ Carta de Tchékhov enviada a Meyerhold em outubro de 1899: "nowadays almost every civilized person, even the most healthy, experiences such irritation nowhere so much as in his own home, his own family, for the discord between present and past is felt first and foremost in the family." Idem, p. 54.

${ }^{130}$ Ibidem, p. 55.
} 
a encenação de Tio Vânia e aquilo que Stanislávski quisera destacar do "fogo que arde nas mais ordinárias pessoas" e que depois é ferozmente engolido pelas pequenas rotinas domésticas, jogos e afazeres. Um médico conhecido de Tchékhov que vira a encenação revelaria ao dramaturgo: "Eu me senti quase fisicamente doente (...). Senti como se todo mundo estivesse me deixando e eu estivesse ali sentado e fazendo contas..." ${ }^{131}$.

Aqui, como se vê, a encenação já parece ganhar em homogeneidade e uma proposta cênica se define mais claramente em relação ao texto tchekhoviano. Mesmo estando às voltas com $O$ Silvano desde antes do fim de A Gaivota, não se pode negar que fora com a encenação desta que o dramaturgo pode também repensar alguns de seus procedimentos para, apenas a partir daí trabalhar um novo texto. Tio Vânia não é, portanto, só a versão final de $O$ Silvano: o universo de personagens é condensado e supera visivelmente o que havia de melodramático nesta última, trazendo um trabalho mais sutil de relação entre as personagens. Aliás, em Tio Vânia, a proximidade que se estabelece entre as personagens não é casual. A combinação pode parecer estranha (um médico, a mãe de sua falecida esposa, a filha de seu primeiro casamento, a nova esposa, o irmão da antiga esposa, um médico amigo da família...), mas como diria Ossip Mandelstam, a "combinação é um fator decisivo em Tchékhov. Não há ação em seu drama, há somente uma proximidade com as resultantes inconveniências" ${ }^{132}$. Isto, somado à depuração da personalidade de cada personagem, agora mais dúbia e repelindo um julgamento imediato, só as técnicas do TAM, independentemente de leitura diferente da que teria intentado Tchékhov, poderiam captar ao explorar nuanças e silêncios. Nesse contexto, as peças do dramaturgo gradativamente deixavam de ser vistas como literariamente imprecisas ou irresponsáveis com as regras do drama e passavam a ser vistas em termos de necessidade de expressão de uma época. Tchékhov e o TAM, mesmo com divergências, necessitavam-se. ${ }^{133}$

\footnotetext{
${ }^{131}$ A imagem se refere, evidentemente, à última cena de Tio Vânia, na qual, após a partida de Serebriákov e Elena, Sônia e Vânia sentam-se à mesa, sozinhos e, em meio a suas falas profundamente amarguradas, fazem a contabilidade da propriedade. Ibidem, p. 55.

132 "Combination is the decisive factor in Chekhov. There is no action in his drama, there is only propinquity with its resultant unpleasantness". MANDELSTAM, Ossip. "O piesie A. Tchekhova 'Diadia Vania'". In: Sobranie sochienia. Paris: YMCA Press, IV, p. 107-109 apud SENELICK, 2006, p. 812.

${ }^{133}$ Stanislávski teria dito mais tarde a respeito da relação que se criava entre eles o dramaturgo: "Nosso destino estava nas mãos de Anton Pávlovitch: se ele nos dava uma peça, nós tínhamos uma temporada; se ele não dava, o teatro perdia um peculiar aroma." STANISLÁVSKI, Op. Cit.
} 


\subsection{Três Irmãs que se sufocam no tédio de província}

Com As Três Irmãs (Tpu cecmpbl) a relação com o TAM estava oficializada. Tchékhov concebera o texto em fins de 1900 e o levou para a leitura com o elenco e os diretores. Inicialmente, o dramaturgo antecipou tratar-se de uma "alegre comédia". Ao final da leitura, no entanto, os leitores estavam profundamente abalados e insistiam em se tratar de um verdadeiro drama ${ }^{134}$. Outros, visivelmente desapontados, disseram não se tratar de uma peça, mas apenas de um esboço ${ }^{135}$.

Havia motivos evidentes para que pensassem dessa maneira. Tchekhov não só complexificava o trabalho com o cômico, linhagem da qual nunca se desvencilharia ${ }^{136}$, como também estruturou o texto em bases diferenciadas. Não mais o sobressaltar de algumas personalidades (Ivánov, Trepliov, Vânia), mas três irmãs, que configuravam um painel conjunto, mas com personalidades bem diversas. Além disso, estavam ausentes as cenas de embate de figuras, como ocorria em Ivánov, A Gaivota ou Tio Vânia $^{137}$. As curvas do drama, variáveis em intensidade, pareciam decisivamente ofuscadas.

Para tornar a situação ainda mais complexa tratava-se de um drama em que, definitivamente, o presente da ação, a força do diálogo e a possibilidade de por meio deles desencadear novas situações de conflito ${ }^{138}$, não estavam dados. As personagens estão comprimidas entre a força do passado e a utopia do futuro - o presente é, definitivamente, opressor. Tem-se o receituário para a implosão de qualquer regra do drama, entendido no sentido do que até então se tinha como tradição. Se há algo dele ainda, e Tchékhov não o destrói por completo, ele aparece na forma de rudimento, para

\footnotetext{
${ }^{134}$ SENELICK, Op. Cit. p. XX

135 CHEKHOV, 2006, p. 874.

${ }^{136}$ Como evidência deste elemento, guardando as devidas diferenças entre riso, comicidade e ironia, em As Três Irmãs, o modo por vezes irônico com que as personagens se autoanalisam, imersas em uma imobilidade prosaica, mas envoltos em sonhos (e por isso mesmo talvez não tão dignos de elevação pura), projetam um riso amargo, que Tchékhov possivelmente intentava destacar.

${ }^{137}$ CHEKHOV, Op. Cit., p. 875.

138 "Mas mesmo o diálogo não tem peso algum; é, por assim dizer, a cor pálida do fundo do qual se destacam os monólogos debruados de réplicas (...). Não são monólogos no sentido tradicional do termo. Em sua origem não se encontra a situação, mas a temática. O monólogo dramático (como explicou G. Lukács) não formula nada que se subtraia em princípio à comunicação (...). É diferente aqui. As palavras são pronunciadas em sociedade, não no isolamento. Mas elas isolam o que expressam. Quase que imperceptivelmente, o diálogo inessencial transita desse modo para os solilóquios essenciais." SZONDI, Op. Cit., p. 50.
} 
que uma temática tenha um "pouco de movimento e possibilite o diálogo", ainda que este não tenha peso algum ${ }^{139}$.

Mesmo a impressão inicial de Stanislávski fora bastante negativa: via ali algo "sem ressonância, sem vida, longo e aborrecido". Demorou a aceitar que naquele conjunto de atos "mal amarrados" e aparentemente sem propósito também havia algum desejo de vida, alegria e riso ${ }^{140}$.

Diante do espanto, Tchékhov ainda alterou algumas passagens da peça. Para se ter uma ideia, no plano inicial Macha não constaria na cena final ${ }^{141}$. Esta e mais outras alterações vieram acompanhadas da insistência do dramaturgo em assistir aos ensaios. Primeiro, porque já se incomodava particularmente com a recorrência de efeitos sonoros e excessivos detalhes de cenografia, cada vez mais levados à exaustão por Stanislávski. E também porque lhe desgostavam as superdramatizações que vinham em sintonia com a leitura trágica da peça que dela fazia o diretor ${ }^{142}$.

Contudo, a presença de Tchékhov não impediu que Stanislávski a concebesse como uma peça de diretor. Sublinhou uma leitura que já se consolidava: a da mesquinhez do cotidiano de província e seu poder devastador dos sonhos e projetos de $v i^{143}{ }^{143}$ O aspecto provinciano fora acentuado pela cenografia de Símov, com decoração bastante detalhista (ocupando todo o espaço) e objetos típicos ${ }^{144}$. A produção acentuou uma divisão que durante muito tempo perduraria em inúmeras produções de As Três Irmãs: sufocadas na província, viam seus sonhos afundarem-se com o passar do tempo e, como elemento agudizador, Natacha, o pólo do presente burguês que tudo arrasta, ganhava espaço.

Esta leitura teve repercussão na interpretação dos atores. Tchékhov manteve correspondência com Olga Knipper, no papel de Macha, pedindo-lhe que evitasse o excesso de tragicidade e buscasse o que também havia de sonho de vontade de vida na personagem. Meyerhold (antes de deixar o TAM), criticado por muitos, fizera um Tuzenbach com fortes acentos desesperados e certa tragicidade. Já a Natacha de Maria Lílina possuía falas pausadas, andar calmo e certa doçura que tornavam sua presença mais "apavorante"145.

\footnotetext{
139 Ibidem, p. 49-50.

${ }^{140}$ SENELICK, Op. Cit., p. 59.

${ }^{141}$ CHEKHOV, 2006, p. 874.

${ }^{142}$ GUINSBURG, Op. Cit. p. 123.

${ }^{143}$ SENELICK, Op. Cit., p. 60.

${ }^{144}$ Idem, Ibidem.

145 Ibidem, p. 61.
} 
Mas esta polarização não fora criada nas fórmulas do drama tradicional - era apenas um recurso para entendimento do "estar no mundo" daqueles sujeitos, ainda que concentrando o foco nas irmãs, impedia-se, em certo sentido, entender como as demais personagens contribuíam para essa condição. Por isso, para não recair na teatralidade excessiva, e evitar o nivelamento psicológico, Stanislávski e Nemiróvitch-Dântchenko operaram o conjunto sob a ideia de "encontrar a poesia no cotidiano", trabalhando a encenação quase em termos musicais ${ }^{146}$, buscando nuances e tonalidades. Górki diria: "é música, não atuação" ${ }^{147}$

Na noite de estreia, em 31 de janeiro de 1901, o público permaneceu morno ao final do primeiro ato, mas explodiu em aplausos ao final do segundo. A crítica destacaria nos dias seguintes o definitivo enlace entre o TAM e a dramaturgia de Tchékhov. A grande maioria sublinhou o "tom envolvente" e o "sentimento de vida real" - era como se fossem até o teatro não para ver uma peça, mas " para visitar as Irmãs"148.

Por outro lado, ainda que aquele fosse um dos pontos altos da dramaturgia tchekhoviana e da proposta do TAM, é interessante ressaltar que o processo de redefinição ideológica pelo qual passavam os movimentos sociais russos trazia também para a crítica e o público opiniões renovadas. Nikolai Russánov criticaria o imobilismo das irmãs e Lunatchárski criticaria o decadentismo da peça, que apresentava personagens que não atuavam como na vida real: pessoas reais deveriam "sacrificar suas almas por uma grande causa" ${ }^{149}$. Do outro lado da arena, o conservador Suvórin também não poupara o antigo amigo em seu diário: ainda que o público se deliciasse, havia algo de deletério na peça, que mostrava o desejo de libertação da vulgaridade, mas não humanizava, apenas "estupidificava"150.

Ainda que hoje possamos olhar para tais comentários com fortes restrições pelo que eles têm de preso ao tempo, não podemos ignorar que muito do que o TAM privilegiara como tom também definira este tipo de recepção. O "brilho", o "desejo de

\footnotetext{
${ }^{146}$ A respeito do tom "poético-musical" estabelecido para a montagem de Stanislávski, é decisiva a leitura das Partituras de Encenação escritas pelo diretor, traduzidas e comentadas minuciosamente em português por Tieza Tissi. TISSI, Tieza. As partituras de Stanislávski para As Três Irmãs, de Tchékhov: tradução e análise da composição espacial da encenação. São Paulo, 2012, 598p. Dissertação (Mestrado em Literatura e Cultura Russa) - Faculdade de Filosofia Letras e Ciências Humanas, Universidade de São Paulo.

${ }^{147}$ Ibidem, p. 62.

${ }^{148}$ CHEKHOV, 2006, p. 875.

${ }^{149}$ KARLINSKI, Simon. Russian anti-Chekhovians. Russian Literature, n.15, 1984, p. 191-192.

${ }^{150}$ SUVORIN, A. S. Dnevnik. Moscou: I.D. Frenkel, 1923 apud SENELICK, Op, Cit., p. 64.
} 
vida", e mesmo a comicidade que Tchékhov insistia para que os atores valorizassem nas personagens foi esmaecido pelo tom tragicizante da encenação.

Mas este eixo interpretativo estabelecido pelo TAM, se mais uma vez se mostrava ser apenas uma das leituras possíveis do texto, ganhava também em amadurecimento e mostrou ser o cume das possibilidades técnicas no campo do que Jacó Guinsburg chamaria de tchekhovismo. O grupo saía de uma fase de intensa exploração dos elementos externalizantes, herança dos Meininger, e ganhava em profundidade no trabalho com a atmosfera, a dimensão interna das personagens e o aprofundamento psicológico sob a harmonização do ensemble. Para ele, "não por acaso que o espetáculo [As Três Irmãs], no TAM, bateria todos os recordes de permanência em cartaz (...) maturidade cênica do tchekhovismo." ${ }^{151}$ Contraditoriamente, como vimos, é também neste "apogeu" que emergirão determinados procedimentos cênicos, de leve inclinação naturalista, que incomodarão profundamente Tchékhov em $O$ Jardim das Cerejeiras.

\subsection{Um Jardim das Cerejeiras sem riso}

O Jardim das Cerejeiras (Вишнёвый сад) foi a última peça longa de Anton Pávlovitch. Antes de finalizá-la, dedicara-se também à sua segunda versão do monólogo Os Males do Tabaco, de $1902^{152}$. Naqueles anos já estava bastante debilitado pela tuberculose e passou a residir em Ialta, onde o clima ameno contribuía para o tratamento. Mas a despeito de sua melancólica condição (ou talvez por ela mesmo) Tchékhov declarou em carta a sua esposa Olga Knipper que, depois de As Três Irmãs

\footnotetext{
${ }^{151}$ GUINSBURG, Op. Cit., p. 117-119.

${ }^{152}$ Esta segunda versão do monólogo Os Males do Tabaco também se encontra traduzida na coletânea de peças em um ato organizada por Homero Freitas de Andrade Cf TCHÉKHOV, 2003, p.157. Em linhas gerais, neste monólogo, Tchékhov operará mais intensamente com o jogo entre o cômico e o trágico e entre a identificação lírica e o distanciamento. A personagem Niúkhin aqui está mais próximo do clown que do bufão. O curioso é que Tchékhov mantém o mesmo roteiro (ou fábula) - subverterá o procedimento. Ecoam aqui ainda os trejeitos da personagem (gestos largos, pompa, tom retórico) e mantêm-se algumas simbologias (as filhas associadas ao azar - agora mais explícito - do número treze). Esse recurso mantém a personagem à distância do espectador, que ri mais uma vez desse desencontro entre a forma pomposa e a inconveniência do discurso (fuga do tema da palestra) e da verdade de uma vida ordinária e, agora, opressiva. No entanto, ocorre que nesta peça o sentido dado à solidão da personagem é recoberto de profundo lirismo, marcadamente melancólico. Cf. NASCIMENTO, Rodrigo. Quando o riso se esfacela - estudo comparativo de duas peças em um ato de Anton Tchékhov. Congresso "Literatura e Vida Social". UNESP-Assis, 2011.
} 
escreveria algo "definitivamente divertido, muito divertido, ao menos em conceito" ${ }^{153}$. A comicidade não surge gratuitamente e parece resultado de um duplo movimento: do amadurecimento de uma poética do riso presente já em seus primeiros textos e, ao mesmo tempo, sua complexificação dentro de uma lente artística que "não pretende acusar ou resolver os grandes problemas éticos, filosóficos, religiosos e sociais que alimentavam a dinâmica da história literária do seu tempo, mas simplesmente os expor" $^{154}$. Trata-se de uma leitura que hoje nos parece mais acertada, sobretudo porque privilegia os movimentos de continuidade da dramaturgia de Tchékhov e, ao mesmo tempo, o coloca em perspectiva na relação que estabelecera com o seu tempo e de que modo isso se sedimentou em forma.

Mas para seus contemporâneos a questão não se apresentava como tranquila. $\mathrm{O}$ TAM que, como vimos, tinha se convertido em espécie de porta-voz do dramaturgo, constituíra uma linha própria de interpretação de suas peças e por isso mesmo já se colocava na posição de principal debatedor das propostas de Tchékhov. Stanislávski ficara profundamente estarrecido com a leitura da peça (e já havia solicitado tempos antes uma verdadeira tragédia):

Isto não é uma comédia, nem uma farsa, como você escreveu - é uma tragédia; independentemente das possibilidades de uma vida melhor que você revela no último ato. Eu posso ouvir você dizendo: 'Desculpe-me, é mesmo uma farsa'... Não, para uma pessoa comum isto é uma tragédia. ${ }^{155}$

Stanislávski não podia conceber que aquele mundo que desmoronava, com a propriedade que marcara os melhores momentos daquela família sendo vendida em leilão para ser convertida em lotes de estação de veraneio, pudesse ser abordada com comicidade. Mas Tchékhov, antes de acentuar tinturas dicotômicas, queria destacar o que havia de dúbio neste processo. Se para o diretor, mais uma vez, o foco estava nas esperanças e no lirismo que são sufocados, para Tchékhov o trágico não poderia ser a nota predominante. Daí a comicidade aproxima e distancia: não nega o desespero da

\footnotetext{
${ }^{153}$ CHEKHOV, 2006, p. 971.

${ }^{154}$ CAVALIERE, Op. Cit., p. 211.

155 "It's not a comedy, nor a farce, as you wrote - it's a tragedy; whatever outlet into a better life you revealed in the last act. I can hear you saying: 'Excuse me, it's really a farce'... No, for an ordinary person it's a tragedy". SENELICK, Op, Cit., p.67.
} 
beleza que é destruída, mas não pode ver com seriedade as temporárias ações humanas, pois tudo muda.

Estas divergências de tom intensificaram a correspondência entre autor e diretor. Tchékhov expôs a Nemiróvitch-Dântchenko e Stanislávski suas intenções com cada personagem: Ranévskaia deveria simplesmente "caminhar com um sorriso e saber se vestir"156; Lopakhin, deveria mostrar delicadeza por debaixo de uma rudez exterior; Gáev deveria ser um aristocrata, com ar envelhecido e Ánia uma jovem luminosa. Mas os atores terminaram por atribuir feições um pouco diferentes a cada um. Olga Knipper, inicialmente pensada para o papel da cômica Charlotta, ficou com Ranévskaia e privilegiou o tom sentimental, de forte apego à terra natal (sua atração pelo amante em Paris fora minimizada); Stanislávski ficara com Gáev (apesar de Tchékhov querê-lo como Lopákhin, por seu passado "burguês") ${ }^{157}$, e imprimira-lhe uma delicadeza e certo conjunto de gestos (como limpar as unhas com o lenço) que irritou alguns críticos. Mas, afora tais pontuações, o dramaturgo "silenciou" para as demais interpretações.

Na noite da estreia, em 17 de janeiro de 1904, Tchékhov esteve presente, bastante debilitado. O TAM registrava em suas cortinas a gaivota como símbolo da companhia e, em homenagem ao dramaturgo, Nemiróvitch-Dântchenko diria: "Este é o seu teatro". Para Stanislávski aquele era definitivamente o "canto do cisne" do autor ${ }^{158}$. Mas a cerimônia e as condições de saúde do dramaturgo não impediram de analisar com dureza a encenação. O luxo e a riqueza previstos para a cenografia foram convertidos em um ambiente decadente, com o piso rangendo e pedaços de gesso caindo do teto. $\mathrm{O}$ dramaturgo fora mordaz nas cartas solicitando para que o diretor retirasse os barulhos de sapos, pássaros e mesmo de um trem que apareceria no segundo ato. Stanislávski no entanto não os eliminara de todo e seu ateliê de minúcias ${ }^{159}$ foi aqui levado a um dos pontos mais altos das encenações que fizera do dramaturgo (durante o monólogo de Tofímov, por exemplo, surgiram em curto intervalo de tempo barulhos de cavalos, carroças e pessoas falando ao fundo) ${ }^{160}$. Para ele, para criar a sensação de um real microcosmo, era necessário destacar os detalhes apenas sugeridos pelo texto (aos quais também muitas vezes Tchékhov se apegava, como bem destaca Guinsburg) ${ }^{161}$.

\footnotetext{
${ }^{156}$ Idem, p. 68-69.

157 Idem, Ibidem.

158 MUZA, Anna. "Chekhov's Jubilee and the Jubilee in Chekhov". In: The Bulletin of the North American Chekhov Society. Vol. XVII, n. 2, 2010, p. 1-3.

${ }^{159}$ A expressão é delicadamente empregada por Angelo Maria Ripellino em O Truque e a Alma.

${ }^{160}$ SENELICK, Op. Cit., p. 74.

${ }^{161}$ GUINSBURG, Op. Cit., p. 135.
} 
E conjunto cenográfico e sonoro, trabalhando mais uma vez para a criação de uma atmosfera específica, se antes contribuía para a criação de um terreno onde emergiam as personalidades cindidas, agora parecia mais nivelada, homogeneizante, criando um compasso sem pressa que sobrepunha as interioridades. A peça, que não se mostrava propícia ao arroubo dramático, tinha dentro da chave trágica stanislavskiana o compasso "arrastado" quase como única solução cênica.

A despeito disso, o público impressionara-se profundamente com a estreia. A intelligentsia representava boa parte da plateia ${ }^{162} \mathrm{e}$, em partes por seguir a onda de simpatia por TAM-Tchékhov, que só crescia, e em partes pelo impressionante efeito promovido pelo "pedaço de vida" ali representado, o sucesso percorrera rapidamente a cidade e a temporada seguiu cheia. No entanto, a impressão do dramaturgo, dos próprios diretores e de alguns setores da crítica fora diferente. Os dois primeiros, talvez pelo desgaste gerado que, ao final, parece ter produzido um resultado de "meio-termo". Já para parte da crítica, o problema estava na virtuosidade dos efeitos e no nivelamento trágico do tom. Nikolaév, como que a demandar soluções épicas para a encenação, ficara incomodado com o excesso de detalhes que impediam a emergência de diferentes planos e que faziam com que o público ali mergulhado não fosse capaz de "observar criticamente as mudanças e investigar as personagens" ${ }^{163}$. Para ele, perdia-se assim a coisa mais substancial: a razão por que se vai ao teatro. Para Meyerhold, que já havia saído do TAM, a marca da incompreensão de Stanislávski- Nemiróvitch-Dântchenko estava na cena do baile. Para ele, havia algo de terrificante naquele momento, uma "apavorante dança de bonecos em uma farsa"164 e não só o tom melancólico de uma festa final.

Ao retomarmos este episódio e sua posterior repercussão, parece ser natural a tendência em pensarmos nos acertos de concepção de Tchékhov, que parecia sinalizar uma encenação mais refinada. Se parte desse raciocínio parece plausível, o que não se pode ignorar é que o dramaturgo também não era isento de certos caprichos detalhistas ${ }^{165}$, assim como também nunca manifestara discordâncias que pudessem redefinir por completo a dinâmica da cena. Discordava no tom, no uso de determinados

\footnotetext{
${ }^{162}$ MUZA, Op. Cit. p. 1-3.

${ }^{163}$ NIKOLAEV, N. I. Efemeridi. Kiev: Izd. Kievskago Obshchestva Iskusstva i Liteaturi, 1912, p. 145 apud SENELICK, Op. Cit., p. 77.

${ }^{164}$ Carta de Meyerhold a Tchékhov em 8 de Maio de 1904. MEYERHOLD, V. Perepiska 1896-1939. Moscou: Iskusstvo, 1976 apud SENELICK, Op. Cit., p. 78.

${ }^{165}$ Sua insistência durante os ensaios de As Três Irmãs para que um general estivesse à plateia, a fim de acompanhar os gestos, verificar as vestimentas e uso dos objetos.
} 
procedimentos, mas no fundo sabia estarem ali as possibilidades históricas de realização de um drama que estava nas raias do próprio drama, nas raias do cômico e do trágico, do realismo e do simbolismo ${ }^{166}$ e, também, o desejo sincero de superar as soluções esclerosadas e convencionais do teatro ${ }^{167}$.

Tal conclusão se baseia inclusive nas restrições que o próprio dramaturgo fizera a outras instituições ao final de sua vida. Afora seus vaudevilles, o Máli ficaria sem representar suas peças até a década de 1960 (em começos de 1900 era comum ouvi-los recomendar aos atores que fugissem de qualquer recurso utilizado pelo TAM). $\mathrm{O}$ Aleksandrínski, que mantivera durante muito tempo a linhagem de grandes atores que trabalhavam em detrimento do ensemble, tinha sérias restrições à linha da "ditadura do diretor", instalada pelo Teatro de Arte. Mesmo em 1902, quando Teliakóvski, administrador dos teatros imperiais, decidiu proclamar a "entrada de Tchékhov no século XX"168, o dramaturgo recusou o pedido para encenação de A Gaivota. No entanto, voltou atrás logo após. O diretor Mikhail Dárski, mesmo estando no Aleksandrínski, não deixou de utilizar as "novíssimas" técnicas do TAM: pediu para os atores evitarem excessos, virou as suas costas para a plateia e trabalhou pausas e "atmosfera à la Stanislávski"169. A cenografia praticamente copiou as formulações do TAM. Contudo, para Laurence Senelick, as proporções gigantescas do Aleksandrínski pareciam oprimir aquelas personalidades fragilizadas, e o senso do cotidiano perdia$\mathrm{se}^{170}$.

Este exemplo sintetiza bem o poder de influência que tivera o Teatro de Arte em inícios do século XX. Isto, evidentemente, imprimiu com força sua maneira de encenar Tchékhov. No Aleksandrínski, a necessidade de um diretor para preparar os atores e dirigir um espetáculo parecia agora evidente. Os vaudevilles de Tchékhov perdiam espaço e o Tchékhov das grandes peças sobressaía com sua "particular atmosfera" ${ }^{171}$.

No interior do país Tchékhov já tinha se convertido em unanimidade. Não só por seus vaudevilles, que sempre foram os campeões de popularidade e número de encenações, mas também pelas personagens marcantes de suas grandes peças. Em geral,

\footnotetext{
${ }^{166}$ Arlete Cavaliere pontua o atual estágio do debate bibliográfico a respeito do Tchékhov "poeta da passagem" e de sua difícil classificação em estilos, escolas ou tendências. Cf. CAVALIERE, Op. Cit., p. 211-212.

${ }^{167}$ GUINSBURG, Op. Cit., p. 105.

${ }^{168}$ SENELICK, Op. Cit., p. 83-85.

${ }^{169}$ Idem, Ibidem.

${ }^{170}$ Idem, Ibidem.

${ }^{171}$ TELIAKÓVSKI. Literatúrnoie nasliedstvo. Tchekhov. 63. Moscou: Nauka, 1960, p. 516-517 apud SENELICK, Op. Cit., p. 86-87.
} 
o público identificava de pronto as figuras da intelligentsia, as turbulências de Trepliov ou a melancolia de Vânia. E muitos diretores, como Gaidebúrov, que possuía uma companhia itinerante, montou Tio Vânia em 1901 e, a despeito de algumas idiossincrasias (como evitar a cenografia realista), tinha como premissa encenar Tchékhov para "melhorar a vida através da arte". E essa mesma negação do realismo detalhista de Stanislávski foi o que lhe permitiu, em certo sentido, "desnaturalizar" as encenações moscovitas e conquistar a tão cara "simplicidade" objetivada por Tchékhov ${ }^{172}$.

A face grotesca desse movimento, no entanto, vinha em igual medida. $\mathrm{Na}$ tentativa de representar um Tchékhov oficial e de sucesso garantido, muitas companhias tentavam reproduzir nos mínimos detalhes os recursos empregados por Stanislávski. Contudo, sem possuírem a estrutura e formação adequadas, boa parte das encenações caía no grotesco. Kárpov diria ter visto em Ialta uma trupe de Sebastopol encenando $O$ Jardim com cerejeiras tortas, feitas de papel, quase caindo. Na tentativa de reproduzir o painel de sonoridades, o assistente de direção suplantava a voz dos atores com os assovios, cantos de pássaros e coaxares e, muitas vezes, pausas surgiam forçosamente na tentativa de criar a famosa "atmosfera" ${ }^{173}$.

\subsection{A Revolução varrerá o tédio?}

Se as encenações de Gaideburov trouxeram um elemento novo para a recepção de Tchékhov, o impacto decisivo, no entanto, será o acirramento do processo de luta de classes na Rússia, mais visível a partir do ano de 1905. A encenação de O Jardim das Cerejeiras pelo TAM em 1904, ainda que com forte acento trágico e simpática ao desespero de Ranévskaia já tinha os adeptos do "progressismo" de Lopakhin: aquele que supera a velha ordem aristocrática e anuncia os novos tempos.

No entanto, a leitura do TAM tornara-se de tal modo hegemônica que o Tchékhov "poeta do crepúsculo", "melancólico" e identificado com as "personalidades sufocadas na província" não era bem quisto pelos novos protagonistas dos processos

\footnotetext{
172 Idem, p. 95.

${ }^{173}$ KÁRPOV, E. "Dve polednie vstrechi s Ant. Pav. Tchekhovim". In: Ezhegodnik imperatorskikh teatrov 5, 1909, p. 1-9 apud SENELICK, Op. Cit., p. 92-93.
} 
sociais em curso na Rússia, que não admitiam um artista ainda tão preso a valores cada vez mais "retrógrados".

Em junho de 1914, Maiakóvski publicaria em Vida Nova (Nóvaia Jizn), em comemoração ao $10^{\circ}$ aniversário da morte do contista e dramaturgo, um artigo polêmico, tentando resgatar desse "engessamento interpretativo", um outro Tchékhov:

Ouçam! Vocês com certeza conhecem um outro Tchékhov. Os sinais de respeito de vocês, os epítetos elogiosos, são bons para um prefeito municipal (...), e eu falo de um outro Tchékhov. (...) eu quero saudá-lo com dignidade, como a um membro da dinastia dos "Reis da Palavra". (...) Por trás do vulto, conhecido do filisteu, de um choramingas que não se contenta com nada, de um defensor, perante a sociedade, dos homens "ridículos", do Tchékhov "cantor do crepúsculo", despontam as linhas de um outro Tchékhov: o alegre e vigoroso artista da palavra"174.

A atitude vanguardista do poeta, bem marcada pelo que ela tem de negação da tradição e pelo que tem de vinculada a sua própria proposta estética (centrada na palavra e no seu poder renovador), tem um viés bastante curioso: Tchékhov era abordado em perspectiva nova e aspectos de sua poética, até então pouco acentuados, ganhavam agora o primeiro plano. Mas o manifesto de Maiakóvski não tivera a repercussão esperada (sofrera ressalva dos editores já na própria edição) ${ }^{175}$, e as plateias oriundas das classes populares, assim como a intelectualidade cada vez mais sintonizada ao ideário marxista, tinha ali um dramaturgo fora da ordem do dia.

Tio Vânia já não vinha à cena desde 1913. Tida por muitos como de interesse puramente histórico, fora retomada pelo TAM em 1918, mas visivelmente já não era possível retomá-la nas mesmas tinturas. Nemiróvitch-Dântchenko e Stanislávski, dias após a revolução, já se mostravam atentos às transformações em curso, ainda que em essência, seu estilo de produção teatral não sofresse mudanças significativas. Para eles, a tarefa do novo tempo era educar/refinar o gosto das plateias populares agora frequentadoras do teatro (para isso faziam panfletos orientando o proletariado a como se portar na entrada, quando manter o silêncio e quando bater palmas) ${ }^{176}$. Isto não impedia,

\footnotetext{
${ }^{174}$ MAIAKÓSVSKI, V. "Os Dois Tchékhov". In: SCHNAIDERMAN, Boris. A Poética de Maiakósvski. São Paulo, Perspectiva, 1971, p. 139-147.

${ }_{175}$ Ver nota de Boris Schnaiderman. Cf Idem, p. 147.

${ }^{176}$ SENELICK, Op. Cit., p. 112.
} 
contudo, que manifestações surgissem nos espetáculos. Certa vez um marinheiro se pronunciara durante a apresentação de Tio Vânia: "Você me aborrece, Tio Vânia!"177.

O ator Lújski, que interpretava o professor Serebriákov na estreia de 1898 pelo TAM, notaria sensíveis diferenças no sentido de Tio Vânia antes e após a Revolução. Antes havia simpatia da intelligênstsia por Serebriákov e seu vazio, e certo incômodo com o desrespeito de Vânia. Após 1917, o público proletário era mais simpático ao sofrimento de Vânia e Sônia ${ }^{178}$, e muitos iam mesmo às lágrimas ao verem a cena final na qual os dois sentam-se à mesa para fazerem as contas da propriedade e lançam mensagens desesperadas em direção a um futuro opressivo.

Mas se Tio Vânia ainda possuía alguma repercussão, Ivánov teria estreia silenciosa na estação de 1918-1919 do TAM. Para os bolcheviques, o público estava em um novo tempo, agora distante dos dramas pessoais fracassados e de pessoas desanimadas. $\mathrm{O}$ "homem supérfluo" era agora apenas um tipo representante de dramas de um tempo passado. Trótski, de sensibilidade mais refinada, ainda preferia o contista e dramaturgo russo (assim como preferia Tolstói, Shakespeare, Púchkin) por ver na sua expressividade uma preocupação com a clareza e acessibilidade às massas. Mas, para ficar na terminologia do próprio revolucionário, muitos outros bolcheviques viam o Tchékhov "melancólico" e "decadentista" ou mesmo "simbolista" não como um "companheiro de viagem", ou seja, um escritor ao lado do processo histórico em curso, mas um "insular" que, ainda que possuidor de técnica elevada, parecia projetar em suas personagens o estranhamento e a incapacidade de ação diante da realidade ${ }^{179}$.

O que sustentava suas peças em grande medida era não só a respeitabilidade do TAM, que conseguiu astutamente atravessar mesmo os períodos duros do estalinismo, mas também a política de Lunatchárski ${ }^{180}$ (depois levada ao extremo sufocante com Stálin) de que era preciso reconhecer a "boa herança burguesa" no campo da arte. Em certo sentido, significava reconhecer suas contribuições para a história da literatura, mas saber fazer ressalvas críticas a sentimentos e experiências transmitidas que não

\footnotetext{
177 Idem, p. 113.

178 Idem, Ibidem.

179 TRÓTSKI, Leon. Literatura e Revolução. Trad. Luiz Alberto Moniz Bandeira. São Paulo: Zahar, 2007, p. 63-100.

${ }^{180}$ Após a Revolução, Anatóli Lunatchárski foi nomeado Comissário do Povo para a Educação, iniciando políticas de "depuração" da arte soviética. Em geral é considerado um perfil de maior abertura a algumas inovações formais do períodos (como a poesia de Maiakóvski, ou as experimentações de Meyerhold), ao contrário de Trótski. Com a morte de Lênin, perdeu em influência no governo e abandonou o Comissariado em 1929.
} 
constituíssem um flanco positivo para a sensibilidade dos novos tempos, datando o que fosse necessário $^{181}$.

Neste período, Meyerhold fora um dos primeiros artistas a aderirem à revolução programaticamente, pois, assim como Maiakóvski, via ali a possibilidade não só da transformação geral das estruturas econômicas e de relações sociais, mas o cenário produtivo para a revolução e superação de padrões estéticos conservadores ${ }^{182}$. No entanto, de início, ao contrário do que fizera o poeta, preferira considerar Tchékhov um dramaturgo irrelevante para o período, com um "pessimismo fora de moda"183. O encenador só retornaria ao dramaturgo em 1935 , por conta das comemorações do $75^{\circ}$ aniversário de nascimento de Tchékhov. Neste período, já bastante sufocado e perseguido pela política estalinista (acusado de formalismo excessivo e por discordar frontalmente da política do "realismo socialista"), Meyerhold encena o trio O Jubileu/O Urso/O Pedido de Casamento, intitulando-os 33 Baques. A tentativa era ressaltar a neurastenia burguesa e a apatia dos anos de 1880, quando as pequenas farsas foram escritas. De quebra, uma possível analogia com o sufocamento dos anos estalinistas também era possível. A cenografia, nos moldes construtivistas, tinha painéis moventes e bastante funcionalidade. Sua limpeza tentava varrer todo naturalismo cru e centrar na capacidade física e expressiva dos atores, assim como em sua relação com os objetos, mais voltada para o jogo clownesco ${ }^{184}$ que para a bufonaria. Havia aqui uma leitura bastante nova do que significava a proposta cômica de Tchékhov. Meyerhold observava suas peças em conjunto, analisando a fundo as transformações sofridas por esse elemento ao longo de toda a obra do dramaturgo. $O$ Urso tivera particular sucesso. $\mathrm{O}$ encenador, que não estava plenamente satisfeito, intentou ainda assim mostrá-la para o antigo mestre Stanislávski. No entanto, a política estalinista efetuou sua prisão antes mesmo que levasse a cabo seu intento ${ }^{185}$.

\footnotetext{
${ }^{181}$ SENELICK, Op. Cit., p. 116-122.

${ }^{182}$ A efervescência teatral dos primeiros anos de Revolução, que produziram movimentos decisivos para a compreensão dos procedimentos cênicos da contemporaneidade, materializado em experiências como as de Meyerhold e Vakhtângov, vêm profundamente descritas no livro de Konstantin RUDNITSKY. Russian and Soviet Theatre. Tradition and the Avant-Garde. New York: Thames \& Hudson, 2000, p. 4160.

${ }^{183}$ SENELICK, Op. Cit., p. 115.

${ }^{184}$ Não seria a primeira vez que o encenador usaria este recurso dos "manequins" ou "bonecos humanos". A respeito do jogo comum nas direções de Meyerhold com o grotesco e a comicidade, manobrando personagens para mostrar o que há de mecânico e sem sentido na vida cotidiana, o estudo de Arlete Cavaliere sobre a encenação de O Inspetor Geral merece ser visto. Cf. CAVALIERE, Arlete. $O$ inspetor geral de Gogol/Meyerhold : um espetaculo sintese. São Paulo: Perspectiva, 1996.

${ }^{185}$ SENELICK, Op. Cit., p. 126-129.
} 
A experiência vanguardista com as peças de Tchékhov não se restringira apenas a Meyerhold. Alguns anos antes Vakhtangov (eleito após a revolução para ser representante da Diretoria de Teatro do Comissariado do Povo para a Educação), já havia investido em novas leituras do teatro de Tchékhov. Para ele, não bastava apenas exibir o drama dos Prózorovs, era preciso colocar o público de frente com o universo aberto pelo dramaturgo e o que ele permitia explorarem tecnicamente os atores. Por isso, retornou às peças em um ato (As Bodas e O Jubileu, encenadas na Noite Tchékhov, em setembro de 1920) e buscou nelas o que havia de limpo e dinâmico em cada frase. Ao invés do tom "fechado" do TAM ou da comicidade bufa, preferiu explorar a coexistência de sensibilidades na busca pelo grotesco: "Atores de personagens não eram mais necessários - o trabalho com o grotesco revela, ao mesmo tempo, o cômico e o trágico" ${ }^{186}$. Mas a primeira encenação de As Bodas não levou o público ao paroxismo, como intentou o diretor. Por isso, na segunda versão, tentou trabalhar as personagens como marionetes (sem, no entanto transformá-las em brinquedos vivos), seguindo os preceitos de Sologub, de tentar revelar o que há de inanimado ou morto nos seres vivos, sem aprová-los ou condená-los ${ }^{187}$.

A encenação começava com uma "quadrilha maníaca" e um músico tocando um piano alucinada e freneticamente até terminar batendo a cabeça no teclado, desesperadamente. Após isso, olha para o público, com ar fantasmagórico. O general, representado inicialmente de maneira arejada e cômica, conquista uma leve simpatia ao entrar em seus devaneios e projetar com a mesa de jantar um navio. No entanto, ao saber que suas expectativas do que era aquele jantar estavam fracassadas, é como se o sonho "evaporasse" e ele grita desesperadamente, olhando para a plateia: "Homeeeeeeeeeem!"188

Ao final, a audiência estarrecida, e com a sensibilidade completamente desconcertada, aplaudiu com força. No entanto, para muitos, aquela não era uma maneira conveniente de "revisitar" um clássico. Vakhtângov valorizava a linhagem do insólito e do grotesco, vinda de Gógol, que mesmo parecendo completamente nova e produtiva, não fora bem vista. Michael Tchékhov ficara impressionado com a encenação, mas seu comentário foi dúbio: "Você fez algo doentio!"189.

\footnotetext{
${ }^{186}$ Idem, p. 117-118.

${ }^{187}$ Idem, ibidem.

${ }^{188}$ Idem, p.120.

${ }^{189}$ Idem, ibidem.
} 
Dentro desse movimento, é interessante perceber que o mesmo Tchékhov preso à melancolia de um fin-de-siècle russo, que restringe sua temporalidade e o distancia dos novos tempos, também não pode ser resgatado por outras perspectivas, acusadas que serão de formalismo. O terreno, aos poucos, restará apenas ao velho TAM que, "congelado e sem força renovadora" ${ }^{190}$ em tempos de estalinismo, seguirá a linha de representação dos grandes clássicos da tradição. Para o caso de Tchékhov, mudará algumas chaves de interpretação. Se a maioria das peças do dramaturgo parece "ultrapassada" (ainda que encenações fossem feitas, mas mais como peças de museu), a única que parecia resistir ao poder seletivo da lente "revolucionária" era O Jardim das Cerejeiras. Por isso Stanislávski a retoma em 1928, mas mesmo já direcionando um maior refinamento à concepção de Lopakhin (visto por muitos bolcheviques como a figura progressista da peça, em contraposição ao conservadorismo lírico de Ranévskaia), a peça não gozará de grande repercussão.

O que abalaria o monopólio do TAM por algumas temporadas seria a encenação decisiva de $O$ Jardim, feita por Andrei Lobánov, em 1934. Mantendo a linha experimental de Vakhtangov, o diretor ressaltou os elementos ali presentes do vaudeville e do jogo tragicômico. Ranévskaia mostrava-se não só como terna e lírica, mas também como egoísta e decadente; e o conjunto das personagens, buscadas em sua complexidade através do mesmo efeito, chegavam ao espectador por meio de pequenos choques de contradição, que dificultavam a identificação. O público respondera muito positivamente à encenação, que permanecera em cartaz durante alguns anos ${ }^{191}$.

O monopólio do TAM, no entanto, continuava. E experimentações deste tipo eram cada vez mais vistas como resquícios de puerilidades vanguardistas dos anos 20 . O Tchékhov do TAM (atmosférico, retratista do tédio de província, antes trágico que cômico) já tinha se convertido em pedra de toque e, agora, já servia como modelo para consumo internacional.

\footnotetext{
${ }^{190}$ A referência a essa estagnação produtiva do TAM no período estalinista é comentada brevemente por Iná Camargo COSTA. Op. Cit., p. 49-60.

${ }^{191}$ Idem, p. 123-125.
} 


\section{Tchékhov no Ocidente: entre o exótico e íntimo}

Pode-se dizer que Tchékhov passou a ser conhecido no Ocidente como dramaturgo na medida em que o TAM começou suas turnês mundo afora e em meio à bagagem representativa de seus grandes êxitos tinha como vestimenta principal as peças de Anton Pávlovitch. Isto significa que as leituras iniciais de suas peças, e as encenações delas derivadas, foram em grande medida filtradas pela lente de Stanisláviski- Nemiróvitch-Dântchenko. E, se o processo não se deu por vias diretas, deu-se, como veremos, também por vias indiretas: intelectuais, atores emigrados, pesquisadores, alunos do TAM ou interessados que assistiram a suas apresentações e conferências sobre o "sistema" cuidaram de divulgar suas ideias, muitas vezes com alterações decisivas.

A "ida para o Ocidente" se deu primeiramente nos países do Leste Europeu, mais próximos da Rússia e ainda sob forte jugo das forças imperialistas czaristas. A dominação política e econômica tinha repercussão direta nas relações culturais, sobretudo em países como as atuais Polônia e República Tcheca. Para se ter uma ideia da força deste elemento, a primeira encenação de Tio Vânia feita pelo TAM, no Teatro Nacional de Varsóvia, fora abordada pelo Jornal de Varsóvia como "o trabalho mais aborrecedor da literatura"192. Em certo sentido, reconhecer-se nas crises de Vânia, no cenário "rural" e nas crises do catedrático Serebriákov, assim como legitimar aquelas técnicas cênicas nascentes na Rússia, seria encarado em termos de "traição patriótica" 193 naqueles países que lutavam por autonomia. Apenas com a independência polonesa em 1918 a situação se tornaria menos sufocante para os diálogos com a dramaturgia e a cena russas.

Ali, assim como em outros países da região (e esta será uma tendência marcante de boa parte dos países no processo de recepção de sua dramaturgia), as peças que até então haviam circulado com razoável repercussão foram as suas peças em um ato, encaradas como mais um texto cômico para preenchimento de repertório, bem ao modo como se encaravam inúmeros vaudevilles franceses. Por isso, acredita-se que somente

\footnotetext{
192 "in ordem to criticize one more time... the most boring work in literatura". SENELICK, 2006, p. 97.

193 Para uma leitura mais detalhada do sentido que tivera a visita do TAM à Polônia (tida como um verdadeiro fracasso, já que inúmeras encenações foram literalmente boicotadas pelo público), ver: TYZKA, Juliusz. Stanislavsky in Poland: ethics and politics of the Method. New Theatre Quarterly v.5, n.20. Nov. 1989, p. 361.
} 
em meados e fins da década de 10 que encenações mais encorpadas de suas peças longas passaram a ser realizadas.

No entanto, logo veio a Revolução Russa de 1917 e, ainda que República Tcheca e Polônia passassem a gozar de autonomia e pudessem estar mais livres de pressões nacionalistas no campo da cultura, o brilho das experimentações artísticas de vanguarda já aparecia naqueles países, e as poucas tentativas de encenação do dramaturgo vieram sufocadas pela ideia de que se tratava de um "cantor da atmosfera morna e cinza", de uma Rússia que se foi, e, com a influência deslumbrante do futurismo, aquele "naturalista" parecia demodé.

Mas a decisiva divulgação de Tchékhov se daria com a breve visita de um grupo de importantes atores do TAM que residira durante alguns meses em Tiflis, o conhecido "Grupo de Praga". Após as tentativas fracassadas de saída do país para a realização de uma grande turnê do Teatro de Arte, o grupo composto por Vassíli Katchálov, Olga Knipper Tchekhova, Maria Guermanova - esta mais tarde substituiria Boleslávski em seu Laboratório nos EUA- e outros, circulara pelo sul da Rússia e pela Ucrânica, contando no repertório com peças como O Jardim das Cerejeiras e Tio Vânia. E em 1922, quando o TAM reorganizou sua próxima temporada, Kachalov e Knipper retornaram, de modo que o grupo restante, já com repertório próprio, dedicou-se a um trabalho mais orgânico, sem abandonar os preceitos razoavelmente sistematizados do Teatro de Arte. Em certo sentido, suas encenações mantiveram as interpretações feitas por Stanislávski dos textos de Tchékhov, de modo que para muitos emigrados (não só do Leste Europeu, mas também os que porventura encontrariam em Paris, Londres ou nos EUA) eles se tornariam verdadeiros "arautos" da tradição (e encenações como $O$ Jardim das Cerejeiras se tornariam verdadeiros símbolos para emigrados que viam na queda de Ranévskaia o degradar da velha Rússia assolada pelos ventos da Revolução).

O "sistema" razoavelmente cultivado pelo Grupo, somado ao sempre presente saudosismo dos emigrados pela "mãe Rússia" seria sempre um ingrediente polvoroso nos países por onde a dramaturgia de Tchékhov passaria. Tais elementos, em choque ou em diálogo com a resistência velada de muitos países ocidentais ao que é estrangeiro (sobretudo ao russo "distante", "exótico", "filho da barbárie") geraria resultados interessantes, inclusive na cena brasileira. 


\subsection{França: a "alma russa" como espetáculo}

Na França, o teatro de Tchékhov chegaria com relativo atraso. Durante muito tempo, o interesse dos franceses pelas "coisas russas" veio sufocado pela imagem da barbárie (um retrocesso ao progressismo das "Luzes") que faziam daquelas regiões orientais. Ainda que houvesse aqui e ali pontos de interesse por escritores russos em fins do século XIX, somente com a aliança franco-russa de 1892, e com o decisivo livro $O$ Romance Russo, de Eugéne Melchior de Vogüé (reunião de textos publicados na Revue des Deux Mondes entre 1883-1886), que a literatura russa passou a ser componente fundamental dos círculos literários e dos debates estéticos do período ${ }^{194}$. Ainda assim, boa parte das atenções estava voltada ao chamado "romance russo", espécie de alternativa redentora ao cientificismo positivista de época e ao naturalismo estrito de Zola. Para contistas como Tchékhov ou Górki, não haveria muito espaço: seja pela dimensão pouco lisonjeira do conto, seja por não possuírem a força moral (quase religiosa) reivindicada por Vogüé em Tolstói ou Dostoiévski, ou ainda pelo fato de o ensaísta ver no primeiro uma espécie de naturalismo "médico" e no segundo um certo "neorromantismo"195 - características, evidentemente, bastante negativas.

Em 1900 é que teremos as primeiras circulações em meios ainda restritos de peças e excertos de Tchékhov. André Antoine iniciou nesse ano a introdução no meio teatral do dramaturgo russo com tradução encomendada de Tio Vânia e em 1902 trouxe da Rússia a atriz Lidia Yavórskaia, que representou trechos de A Gaivota e de Os Pequenos Burgueses, de Górki ${ }^{196}$. No entanto, tratavam-se de referências pontuais e, durante toda esta década prevaleceria a leitura de Vogüé feita no ensaio "Anton Tchekhof"197, publicado na Revue des deux Mondes, de que Tchékhov era um "realista amargo", que apresentava a sociedade russa em pinceladas discretas, em "pontos cinzentos", marcados por "pessimismo". Ainda que reconhecesse algum mérito no contista de "paleta vasta" e "justeza na observação", para ele a ausência de ilusão de mundo seria um nó perigoso. Após discorrer sobre cada uma das grandes peças do

\footnotetext{
${ }^{194}$ GOMIDE, Bruno Barreto. Da Estepe à Caatinga: O Romance Russo no Brasil (1887-1936). Tese IELUNICAMP. Campinas: Instituto de Estudos da Linguagem, 2004, p. 25-40.

${ }^{195}$ Idem, Ibidem, p. 96.

${ }^{196}$ SENELICK, Op. Cit., p. 108.

${ }^{197}$ VOGÜÉ, E. M. Anton Tchekhof. Revue des Deux Mondes. Jan-Fev 1902, p. 201-216.
} 
dramaturgo, praticamente desconhecidas na França, chega à conclusão de que há uma "embrionária filosofia" em seu teatro: falta de coragem quanto ao presente, corrigido por um vago milenarismo (para este ponto lhes serviam as cenas finais de Tio Vânia e As Três Irmãs), mas de tinturas pessimistas, sem claridade ${ }^{198}$. Ao final do ensaio, chegaria ao ponto de dizer que o "pólo histórico e filosófico" em direção ao qual o os escritores russos de fins do XIX (Tchékhov em menor conta) pareciam naturalmente caminhar, era o do budismo ${ }^{199}$.

Esta complexa "salada" crítica preparada por Vogüé, se contribuía para a divulgação do dramaturgo (não tanto quanto contribuía para a difusão dos romances), fabricava também uma leitura já então bastante forte de uma certa "orientalidade", exótica e primitiva. Se Dostoiévski e Tolstói pareciam muito mais "enquadráveis" nesse universo de expectativas, temática e formalmente Tchékhov parecia pouco inserido e, talvez, por isso, menos russo ${ }^{200}$. O "naturalismo superior" presente nos escritores preferidos por Vogüé parecia não ter lugar neste escritor "menor".

E a primeira encenação de Tchékhov viria marcada exatamente pelo signo do exotismo (que Vogüé projetara sobre os outros escritores, mas que resvalava no "menos russo" deles). Em 1908, a propósito da estreia da peça em um ato Um Pedido de Casamento pelo Teatro de Arte de Jules Berny, o programa mostrava ilustrações de cabanas ucranianas, ícones, personagens folclóricos com vestimentas russas "genéricas", representando o ambiente "tipicamente russo" e alimentando expectativas iconográficas do que seria aquele lugar.

Mas ao longo da década de 10 e 20 a homogeneidade de tal leitura começará a sofrer com sérias contradições. Georgy Pitoev (Pitoëff) ${ }^{201}$ encenou a convite de Copeau Tio Vânia, em 21 de abril de 1921, no Le Vieux-Colombier, em Paris ${ }^{202}$. A estreia foi bem recebida, apesar de o grupo carecer de homogeneidade e Copeau ter alertado para o

\footnotetext{
${ }^{198}$ Idem, Ibidem, p. 211-216.

199 Idem, Ibidem.

${ }^{200}$ Sobre este ponto, especificamente, vale a pena perceber o quanto perdura até hoje certa discussão a respeito do fato de que seria Tchékhov um dos "menos russos dentre os russos", ou ainda, o "mais Ocidental dentre os russos". Se não é neste momento que se tem a matriz da discussão, não podemos perder de vista que se trata de um dos períodos-chave de alavancamento dessa leitura.

${ }^{201}$ Era conhecido também como Pitoëff. Vivera em Moscou durante sua formação em matemática e direito, apaixonara-se pelo trabalho do TAM. Em 1908 se envolveu com a companhia de Komissarjévskaia e depois com a Companhia de Gaideburov (Teatro Itinerante), com a qual encenou Ivanov, O Jardim das Cerejeiras e dirigiu As Três Irmãs. Em 1914 foi a Paris e conheceu Ludmilla Sonia. Encenou Tio Vânia em instituições de caridade e, em viagem à Itália, que o convidou para encenações na França. Idem, Historical Dicitonary of Russian Theather, p. 295.

${ }^{202}$ Para uma lista completa das encenações de Pitoëff, que se tornaria um dos principais divulgadores da obra de Tchékhov na França, ver: BATAILLON, M. Quand la France découvre Anton Tchékhov. Silex n.16, 1980, p. 56-58.
} 
excesso de destaque dado aos papeis de Pitoëff (como Astrov) e Ludmila (como Sonia). Para críticos como Marcel Archard, tratava-se de um verdadeiro documento do "povo russo". Mais tarde, na encenação da mesma peça no Théâtre des Champs-Élysées, em 04 de abril de 1922, apesar das tentativas de afrancesar o texto (adaptando nomes, trocando objetos) e das evidentes simplificações de cenário feitas pelo diretor (que era pouco afeito aos excessos cenográficos e o "ultrarrealismo" de Stanislávski), a crítica insistia em tentar converter Tchékhov na expressão pura da "alma russa": "tudo é russo nessa peça, irresistivelmente... inexoravelmente. A atmosfera é russa. As personagens são russas... E russos são o silêncio e a neve, que desempenham grandes papeis. E russo também é o cenário." 203

Mas Pitoëff, a despeito de tentar minimizar a "plasticidade cênica" de Stanislávski, o que faria supor uma "anulação" do elemento exótico russo, acentuava outros detalhes que alimentavam essa expectativa da crítica. Seja dando destaque aos fortes sotaques russos (que ele e Ludmila em especial possuíam), seja assumindo teoricamente esta interpretação, de modo a "surfar" sobre a vaga russa. A respeito de $A$ Gaivota, teria dito: "No reino da criatividade artística, o ser humano é eterno, livre; mas no dia a dia é condenado a perecer. (...) A Arte é uma imposição de Deus, uma missão que ele concede a certos eleitos." ${ }^{204}$. Aqui, o elemento religioso tem forte paralelo com as leituras de Vogüé, que buscavam na literatura russa a saída "espiritual" para a civilização ocidental. Somado a isso, alimentava-se um conjunto de outros estereótipos, que durante muito tempo configurariam a imagem do fin de siècle russo e os afastava de uma "sensibilidade civilizada". A respeito da encenação de A Gaivota, em abril de 1923, o jornal Le Temps destacaria que o prazer sentido pela crítica pelo fato de que a peça era completamente diferente do que teria sentido o público russo: para a incerteza deste, a convicção daqueles, para "sua confusão, nossa claridade, para sua apatia, nossa atividade..." ${ }^{205}$.

Ptoëff já se convertia aos poucos no principal nome russo dos meios teatrais franceses. Com a visita do TAM à Paris em 1922 e a encenação de O Jardim das Cerejeiras, assumiria-se um filho "pródigo, mas orgulhoso" daquela tradição do realismo stanislavskiano ${ }^{206}$. Naquele período, visitas como essa se tornavam verdadeiros eventos. Não só porque muitos emigrados russos já representavam contingente

\footnotetext{
${ }^{203}$ Idem, Ibidem.

${ }^{204}$ PITOËFF, G. Notre Théâtre. Paris: Ed. Messages, 1949, p. 48.

${ }^{205}$ LAFITTE, S. Chekhov v Frantsii, p. 712 apud SENELICK, Op. Cit., p. 166.

${ }^{206}$ Idem, Ibidem, p. 167.
} 
expressivo da população parisiense (e que via em visitas como aquela do TAM a oportunidade de tomar contato com "sua terra" ${ }^{207}$, mas também porque faziam sucesso certos espetáculos de cabaré, denominados "Revue Russe", que apresentavam mulheres, danças e pequenas cenas da vida russa, por vezes com forte matiz dramático ${ }^{208}$, que mobilizavam um número expressivo de público.

Nesse contexto, as encenações de Pitoëff começaram a ser converter em verdadeiros acontecimentos. Sua montagem de As Três Irmãs de 1929 tornou-se um marco da mise-en-scène francesa e foi considerada por Antoine algo inédito pela qualidade do trabalho de grupo e pelo "movimento leve e harmonioso dos atores". Neste ponto, Pitoëf se diferenciava de Stanislávski apenas pela economia de recursos, pois herdara do diretor e potencializara a dedicação à "concentração interior" 209 . Ainda que houvesse críticos renitentes na questão da "falta de dramaticidade", na falta de "amarração", ou ainda, no "esoterismo" e "excentricidade" do dramaturgo, com peças que representavam uma verdadeira "neurastenia coletiva" ${ }^{210}$, seu trabalho se destacava pela naturalidade da expressão, que superava o cientificismo naturalista e a cena tradicional, ainda bastante baseados no declamatório e no sistema das grandes estrelas. O diretor, desvalorizado em inícios dos anos 20, era agora figura obrigatória, e tinha Tchékhov como sua principal dramaturgia. Conseguiu imprimir seu modo de trabalho (em grande parte herança de sua admiração pelo TAM), mas também não deixou alimentar a ideia ali frequente de uma "alma russa". Tchékhov em suas mãos, encenado sob esta chave, era agora no teatro o "mais russo dos russos". Para os franceses, seria uma maneira de continuar a busca por uma nova intimidade, que contribuía subterraneamente para o amadurecimento de sua própria cena, mas sempre mantendo o outro à distância pelo que se cria dele de diferença e exotismo.

\footnotetext{
${ }^{207}$ Durante muito tempo O Jardim das Cerejeiras seria considerada a peça símbolo dos emigrados ou ainda de pessoas ligadas ao "Exército Branco". Evidentemente uma leitura em disputa (pois muitos bolcheviques também considerariam esta sua peça favorita), estes emigrados viam ali o símbolo saudosista da antiga aristrocracia e dos antigos valores que se perderam. Em certo sentido, tal interpretação está diretamente ligada à ideia de um Tchékhov "Cantor do Crepúsculo".

${ }^{208}$ CAVALIERE, 2010, p. 313.

209 Boa parte dos procedimentos adotados por Pitoëf em suas montagens, assim como uma breve exposição a respeito do modo como se relacionava com a tradição stanislavskiana encontra-se em JOMARON, Jacqueline. Georges Pitoëff metteur en scène. Lausanne: L'Age d'homme, 1979.

${ }^{210}$ Estas e outras manifestações da crítica foi reunida por TOWARNICKI, Frédéric. Quand Paris découvre Tchékhov. Spetacles I, 1960, p. 58-59.
} 


\subsection{Reino Unido: falar de nossos problemas, à maneira russa.}

Tchékhov ainda era um dramaturgo "exótico" no Reino Unido até os decisivos comentários sobre suas peças feitos por Bernard Shaw. Antes mesmo que se pudesse ter acesso às prodigiosas encenações do TAM, e antes mesmo que qualquer estudo sistemático sobre suas experimentações na Rússia chegasse ao país (para além dos animadores comentários de Gordon Craig a respeito do encenador) ${ }^{211}$, o engajado escritor de Heartbreak House (peça que tinha como subtítulo o curioso epíteto "A fantasy in the Russian manner on English themes"212), vinha com um alentado prefácio de 1919 refletindo sobre a força premonitória do dramaturgo russo, que expressava de maneira decisiva em suas peças (sobretudo em $O$ Jardim) a decadência da sociedade burguesa. Para Shaw, Tchékhov era mais que um pessimista, era um descrente da capacidade daquelas pessoas "charmosas" de "desembaraçarem a si mesmas" de suas intrincadas condições ${ }^{213}$. E isso teria paralelo decisivo com a Inglaterra pré e pós Guerra. A decadência de Ranévskaia e a posterior ascensão mesquinha de Lopákhin tinham paralelo em solo inglês, com a incapacidade das classes dirigentes de gerir seus próprios negócios e de ver um mundo ruir diante de si.

Trata-se de leitura decisiva para a divulgação do dramaturgo. Sobretudo porque vinha distante da interpretação que seria comum em boa parte do Ocidente de que se tratavam de peças fechadas na "alma russa", no "melancólico" e "passivo" universo eslavo. Antes deste ensaio algumas encenações com relativa repercussão haviam sido feitas. Em 1909 deu-se a primeira encenação em Glasgow: A Gaivota, formalmente dirigida por Alfred Wareing, mas guiada na prática e traduzida por Calderon. Este tentou varrer as marcas de naturalismo da peça e atribuir-lhe uma atmosfera de sonho. Mesmo sem conseguir realizar um trabalho harmonioso de grupo e uma investigação psicológica mais profunda (como pedia sua leitura), a encenação fora bastante elogiada pela crítica, ainda que o dramaturgo fosse "muito novo" 214.

Em Londres, reafirmando a tendência da chegada inicial com peças cômicas em um ato, Tchékhov foi encenado pela primeira vez em 1911, com O Urso, no Kingsway

\footnotetext{
${ }^{211}$ BARTOSHEVICH, Aleksey. The 'inevitability' of Chekhov: Anglo-Russian theatrical contacts in the 1910's. Chekhov on The British Stage. London: Cambridge University Press, 1993, p. 20.

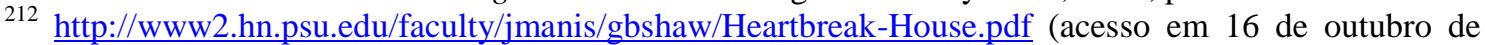
2011)

${ }^{213}$ Idem, ibidem, p. 4.

${ }^{214}$ SENELICK, Op. Cit., p. 132.
} 
Theatre. No mesmo ano, no Aldwych Theatre, O Jardim das Cerejeiras foi encenada sob direção de Kenelm Foss e contou com importantes atores no elenco. A encenação não agradara muito à crítica, que em comentário discretamente xenófobo levou em conta que mesmo Tchékhov sendo um "estrangeiro", não poderia ser "tão tolo como a versão inglesa de sua comédia", vista como "excessivamente lenta". Este desgosto gerou certa sensação de que a peça só poderia ser "decifrada" por russos, acostumados à "apatia" e à "indolência"215.

Esta leitura estava razoavelmente difundida, de modo que quando Calderon publicou suas traduções de Tchékhov, o Times Literary Supplent opinaria de maneira categórica:

\begin{abstract}
A melancolia russa nós conhecemos; sua futilidade pode ser o outro lado disso - um trágico desamparo que foi observado por Hubert Parry em algumas músicas russas. Mas este não é um sentimento compartilhado por nós na Europa Ocidental $(. . .)^{216}$
\end{abstract}

A encenação de Tio Vânia em 1914, no Aldwych Theatre, pelo Incorporated Stage Society, teve amplo reconhecimento e marcara profundamente Bernard Shaw, então às voltas com a escrita de Hertbreak House. Para ele, por trás daquela "melancolia e futilidade", já verdadeiras tópicas na leitura inglesa de Tchékhov, haveria algo de profundamente político. Shaw cuidaria para, a partir desta encenação, divulgar Tchékhov sob sua lente atrelando-o diretamente ao mal-estar que marcava os inícios da Primeira Grande Guerra e o esfacelamento da cosmética sociedade inglesa.

Visto com o olhar de hoje, o ponto de vista de Bernard Shaw pode parecer bastante restritivo (até porque a clareza com que parecia indicar problemas e soluções em suas peças não era tão evidente em Tchékhov), no entanto, não podemos perder de vista que o inglês fora pioneiro em ver com certa objetividade o dramaturgo russo, valorizando-lhe a dimensão trágica dentro do que ela tinha de cômico: era preciso olhar a passagem do tempo e o estado de coisas com relativo distanciamento e ironia. Isto definitivamente os unificava, tanto que para Anna Obraztsova os dois podem ser

\footnotetext{
${ }^{215}$ MACDONALD, Jan. Chekhov, naturalism and the drama of dissent: productions of Chekhov's plays in Britain before 1914. Chekhov on the British Stage. London: Cambridge University Press, 1993, p. 2932 .

216 "Russian melancholy we know; this futility may be another side to it - a tragic helplessness; which has been observed by Sir Hubert Parry in some Russian music. But it is not a feeling which we share in Western Europe (...)" SENELICK, Op. Cit., p. 133-134.
} 
considerados os dramaturgos que mais contribuíram para redimensionar a comédia na virada do XIX para o $\mathrm{XX}^{217}$.

Entretanto, isto não bastou para que a imagem de um Tchékhov "melancólico" e retratista do "tédio" fosse dissolvida. Em inícios dos anos 20 esta leitura fora azeitada pelo maior contato com diretores emigrados e gente de teatro (assim como a turnê do TAM em 1922-23), que contribuíram para que o trabalho com a "atmosfera" e o "ritmo" desenvolvidos por Stanislávski fossem filtrados por esta ótica "inglesa". Some-se a isso as traduções de Constance Garnet publicadas a partir de 1923 das quatro grandes peças do dramaturgo, que tornavam personagens e situações mais "suavizados", "elegantes", "sonoros" e "atmosféricos" 218 . Isto fora em grande medida um prato cheio para a leitura da neozelandeza Katherine Mansfield, que num verdadeiro movimento de "criação de seus próprios precursores", se autointitularia "filha de Tchékhov" ao considerá-lo o pai dos "contos de atmosfera" e dos "estados d'alma"219.

Neste período importantes encenações foram feitas, com relativo sucesso, como O Jardim das Cerejeiras, de J. B. Fagan, no Lyric Hammersmith, em 1925; assim como a A Gaivota, dirigida por John Gielgud, no Little Theatre, também no mesmo ano. Mas o marco decisivo para a popularização (e de reafirmação dessa leitura cênica do dramaturgo) foram as encenações de Komissarjévski, diretor emigrado russo que se tornaria verdadeiro "representante" das peças do dramaturgo. Em geral, Komis (como era conhecido no meio teatral), gostava de dar um toque exótico a suas encenações (no acento russo de algumas personagens, em detalhes diferenciadores de cenografia), algo que vinha mesclado com um senso comum de que as personagens tchekhovianas eram melancólicas e representavam uma maceração constante de frustrações (e vale reiterar que Pitoëff, na França, também não contribuíra dissolver as leituras restritas então em voga).

Komissarjévski já havia encenado Tio Vânia em 1921, no Court Theatre e para muitos críticos fora uma encenação importante para "domesticar" a selvageria russa à

\footnotetext{
217 ABRAZTSOVA, Anna. Bernard Shaw's dialogue with Chekhov. In: Chekhov on the British Stage. London: Cambridge University Press, 1993, p. 45-46.

${ }^{218}$ RYAPOLOVA, Valentina. "English translations of Chekhov's plays: a Russian view". In: Chekhov on the British Stage. London: Cambridge University Press, 1993, p. 226-229.

${ }^{219}$ No Brasil, Otto Maria Carpeaux seria um crítico ferrenho desta leitura de Katherine Mansfield. Em sua opinião, isto consolidou a ideia de que Tchékhov seria um contista sem enredo, narrador de "atmosferas". Em sua opinião, o que ocorre de fato é a mudança de acento tônico na construção: "Apenas acontece que o ponto do conto não necessariamente coincide com o ponto essencial do enredo". CARPEAUX, O. M. "Introdução". In : Antologia do Conto Russo - Vol. VI (Anton Pávlovitch Tchékhov). Rio de Janeiro: Editora LUX Ltda, 1962, p. 22.
} 
"decência" inglesa ${ }^{220}$. Em dezembro de 1925, dirigira e interpretara Ivanov, no Incorporated Stage Society. O diretor emigrado optou por conceber o protagonista como um heroi falho e rebelde contra a inércia que o rodeava. E, apesar da leitura de J. T. Grein, que via ali o protesto de contra o desânimo e a apatia (o que também seria um chamado aos ingleses), fora visto pela massa de críticos como um "típico caso russo", de um homem carente de tratamento, e o The Times seria duro ao afirmar que o caso teria sido resolvido se ele tivesse "recebido a atenção médica adequada" ${ }^{221}$.

Isto não impediu, contudo, que o diretor se afirmasse com uma referência, sobretudo por implementar o trabalho harmonioso de direção, até então muito pouco explorado nos termos stanislávskianos. No entanto, o diretor não seguia à risca as lições do mestre que o renegara ${ }^{222}$ : ao invés de explorar a fundo psicologias, preferia trabalhar a harmonia de conjunto com a valorização do ritmo e da musicalidade. Isto se aperfeiçoou na encenação posterior de Tio Vânia, em janeiro de 1926, na qual o diretor optou por dar maior universalidade à concepção das personagens e estabelecer um certo "compasso geral" para a ação cênica. Para Laurence Senelick, em certo sentido Komissarjévski percebia que a reiteração do "exotismo" russo já estava se convertendo em empecilho ${ }^{223}$. Para isso, o diretor cortou os já comuns detalhes "russificantes" (como os bigodes de Astrov) e optou por cortar inúmeros trechos do texto que pareciam exagerar o elemento trágico e serem muito "sentimentais" (como as referências aos anjos feitas por Sônia no monólogo final). Estes cortes, que vinham no sentido de "amaciar" e tornar mais "musical" e "elegante" a encenação, mostraram-se ainda mais evidentes em sua encenação de As Três Irmãs, em 16 de fevereiro de 1926. Em estudo detalhado sobre os sentidos destes cortes, Robert Tracy mostra o quanto as escolhas de Komissarjévski apenas acentuavam o que Constance Garnet já fizera com a tradução: anglicizava o dramaturgo. Isto vinha na forma de cortes de patronímicos, trocas de nomes como Dobroulíubov (que se tornou Balzac), explicitação das paixões de Verchinin e Tuzenbach; e mesmo o corte de inúmeras referências a épocas, atributos geográficos, sociais e projeções para o futuro ${ }^{224}$. Para Tracy, esse processo de adaptação esteve por trás da primeira grande encenação de Tchékhov no mundo anglo-saxão e

\footnotetext{
${ }^{220}$ SENELICK, Op. Cit., p. 154.

${ }^{221}$ Idem, ibidem, p. 155.

${ }^{222}$ Stanislávski não era simpático a Komissarjévski, dado o fato de que este publicara um livro "sintetizando" o seu "método" que se tornou bibliografia bastante controversa.

${ }^{223}$ Idem, Ibidem.

${ }^{224}$ TRACY, Robert. Komissarjevsky's 1926 'Three Sisters'. In: Chekhov on the British Stage. London: Cambridge University Press, 1993, p. 65-68.
} 
muito de seu sucesso talvez advenha justamente disso: ao sair do clichê "tipicamente russo", Komissarjévski optou por "simplificar", "romantizar" e mesmo "sentimentalizar" o dramaturgo - que "preparou o caminho para sua admissão no cânone teatral"225.

Além dos cortes, Komissarjévski optou também por uma redução dos "momentos de inação", evitando marcar a maneira que Tchékhov indica a passagem do tempo (algo que no caso de As Três Irmãs se configura como um elemento central). Em certo sentido, tinha-se a impressão de que se tratava de uma adequação ao drama tradicional e de classe média: elegante, pouco irônico ou mordaz e com o acentuado toque das paixões. Para Laurence Senelick, essa fora a tônica de todas as outras encenações do diretor (O Jardim - 1926; As Três Irmãs - 1929 e A Gaivota - 1936) ${ }^{226}$.

Dentro de todo este processo, marcado, por um lado, pelo sentido histórico que o dramaturgo assumia em solo anglo-saxão, por outro pelo diálogo direto (pelos desafios que lançara e pelas duras aclimatações que sofrera), Tchékhov já havia se tornado o "principal dramaturgo estrangeiro" quando o Grupo de Praga visitou Londres para encenar $O$ Pedido de Casamento e $O$ Jardim das Cerejeiras, em 1931. A visita fora importante para submeter a leitura de Komissarjévski a uma releitura comparativa, ainda que qualquer questionamento às grandes linhas de interpretação predominantes ainda estivesse um pouco longe de ocorrer.

\subsection{Estados Unidos: dos círculos alternativos aos comerciais}

Assim se manifestou a revista The Dramatist, em artigo não assinado em julho de 1915, a propósito da primeira tradução de O Jardim das Cerejeiras inserida na coletânea Chief Contemporary Dramatists, editada por T.H. Dickinson:

Ao invés de personagens, temos um estudo de natureza morta de passivas baboseiras. Ao invés do desenvolvimento de uma trama, há o mero retrato de uma circunstância inepta. E ao invés de uma história, não há nada, só o interesse desconectado de inúmeros bonecos. Ficamos com uma impressão vacilante da total incapacidade de aristocratas saciados resolverem seus

\footnotetext{
${ }^{225}$ Idem, Ibidem, p. 75-76.

${ }^{226}$ Ver listagem em MILES, Patrick; YOUNG, Stuart. A Selective chronology of British professional productions of Chekhov's plays 1909 - 1991. In: Chekhov on the British Stage. London: Cambridge University Press 1993, p. 237-240 e comentários em SENELICK, Op. Cit., p. 160.
} 
problemas financeiros; mas é tudo tão misturado com outras insignificâncias que o conjunto reflete mais as fraquezas do autor que qualquer outro código ou modismo do drama contemporâneo... é a antítese do teatro dramático. ${ }^{227}$

O julgamento é duro. E diz muito sobre os momentos iniciais de recepção da dramaturgia de Tchékhov nos EUA. Esta revista era conhecida por avaliar a "rentabilidade" dos textos e sua capacidade de fazer sucesso junto ao público. Em certo sentido, não destoava do que era em grande parte o cenário teatral americano de inícios do século XX, pouco afeito aos dramas de fins do século XIX, que rompiam justamente com o que o corpo editorial tinha como "teatro dramático". Dominado basicamente pelo show business, a maioria dos espetáculos ainda se sustentava na lógica do star system. Isso implicava em espetáculos concebidos em ritmo fabril: hierarquias funcionais (centradas em algumas estrelas nos espetáculos), poucos ensaios e salários reduzidíssimos a atores do "segundo escalão" 228.

Por isso, ainda que algumas traduções dos textos de Tchékhov já viessem sendo feitas desde 1908 (neste ano The Cherry Garden, por Max Mandell e The Bear; em 1912 a coletânea de Marian Fell com Uncle Vanya, Ivanov, Seagull e Swan Song) havia ainda uma séria resistência ao seu teatro.

Os primeiros grupos a colocarem suas peças no repertório foram justamente aqueles que tentavam romper com o grande negócio teatral, dominado por pequenos grupos e de repertório bastante fechado. Os "Teatrinhos" (Little Theatres) se propunham a uma divulgação da nova dramaturgia e tentavam muitas vezes mostrar sua "viabilidade de público" ${ }^{229}$. Em 1915 foram as encenações de Um Pedido de Casamento (A Marriage Proposal) pelo Neighborhood Playhouse, O Urso (The Bear) e A Gaivota

\footnotetext{
227 "In place of character, we have still-life study of passive vapidities. In a place of plot development there is a mere portrayal of inept circumstance. And in place of story there is nothing but the disconnected interests of several pair of puppets. We get a faltering impression of the utter inability of satiated aristocrats to solve their financial straits, but it is all so beautifully jumbled with other insipidities that the whole reflects more the infirmities of the author than any other code or fad in contemporary drama...the antithesis of dramatic drama." EMELJANOW, Victor. Anton Chekhov: the critical heritage. London: Routledge, 1997, p. 133.

${ }^{228}$ Iná Camargo Costa expõe em detalhes o funcionamento do "negócio teatral" no início do século XX nos EUA em "Stanislávski na Cena Americana". In: Revista de Estudos Avançados da USP 16(46), 2002. Disponível em http://www.scielo.br/scielo.php?script=sci_arttext\&pid=S0103-40142002000300008 (Acesso em 05 de outubro de 2011)

${ }^{229}$ Boa parte das peças encenadas por esses grupos vem descrita no texto "Projeções Tchekhovianas no Teatro do Norte" de Maria Silvia Betti, publicado em: CAVALIERE, Arlete e VÁSSINA, Elena (orgs). Teatro Russo: literatura e espetáculo. São Paulo: Ateliê Editorial, 2011, p. 259-276. Além desta fonte, há uma lista bastante detalhada disponível na Internet Broadway Database: http://www.ibdb.com/production.php?id=8152 (visita em 05 de outubro de 2011)
} 
(Seagull), em 1916, pelo Whashington Square Players. Ainda que em meio a temporadas com peças de gênero variado, concomitante às peças de Tchékhov os grupos encenaram também Schnitzler, Maeterlinck, Musset e Wedekind. No entanto, a repercussão de Tchékhov, especificamente, não agradara. A respeito da estreia de $A$ Gaivota, a revista novaiorquina Tribune fora dura afirmando que aquela peça russa não tinha nada que ver com a sensibilidade americana: "após o primeiro ato a peça parece estar constantemente vestindo negro, como que para alertar o público para não esquecer da miséria absoluta do estado de espírito da Rússia" ${ }^{230}$.

Em certo sentido, muito da recusa a sua dramaturgia vem das próprias dificuldades encontradas por esses grupos nascentes em consolidar um trabalho cênico aprofundado. A legítima necessidade de rompimento com os padrões comerciais não era acompanhada pela pesquisa e pelo trabalho de direção e ensemble. Muitos atores, dramaturgos e diretores tinha consciência disso, de modo que "uma nova maneira de interpretar", já relativamente conhecida na Europa e apenas rumorizada nos EUA ${ }^{231}$ era esperada com a visita anunciada do TAM aos EUA em 1923.

A visita do TAM superou todas as expectativas. Além das encenações de $A s$ Três Irmãs, O Jardim das Cerejeiras (que constituiu um terço de todas as encenações, dado seu grande sucesso), Tio Vânia e Ivánov, Stanislávski, assessorado em solo americano por seu antigo discípulo Boleslávski ${ }^{232}$, realizou uma série de conferências e seu principal público era, evidentemente, a gente de teatro disposta a fundar o teatro americano sobre novas bases. Para Iná Camargo Costa, a imprensa noticiou em uníssono a sintonia do público com a proposta do TAM:

(...) a barreira lingüística não prejudicou a fruição dos espetáculos porque se tratava de entender e sentir o que acontecia em cena; no palco assistia-se a uma fatia de vida e não a uma peça de teatro; os atores vivem seus papéis, não

\footnotetext{
230 "After the first act the play seems constantly to be wearing black lest the audience forget that utter wretchedness in the perennial state of mind in Russia".Tribune. New York, 29 maio, 1916, p. 11 apud EMELJANOW, Op. Cit., p. 141.

${ }^{231}$ Gordon Craig já havia manifestado profunda admiração por Stanislávski em seu "Da Arte do Teatro", publicado em 1911 e a Revolução de 1917 havia despertado profundo interesse nos meios teatrais americanos que lutavam contra as grandes empresas do entretenimento. A revista Drama Magazine já fazia diferenciações em 1919 entre a proposta de Stanislávski e a de Meyerhold. COSTA, Op. Cit.

${ }^{232}$ Boleslávski fora membro do Primeiro Estúdio, criado por Stanislávski em 1912. Dele participaram Leopold Sulierjitski, Mikhail Tchékhov, Vakhtângov e outros. Com a Revolução, abandona o país com Mikhail Tchékhov. Encontram-se com o grupo do TAM em Praga. Vai após para a Alemanha, a França (onde trabalha dirigindo as famosas "Revues Russes" e, em 1922, vai para Nova Iorque. CAVALIERE, Arlete; VÁSSINA, Elena. A herança de Stanislávski no teatro norte-americano: caminhos e descaminhos. Revista CROP 7, 2001, p. 312-313.
} 
os interpretam; e, independentemente de haver hierarquização das personagens, todos os atores têm igual importância na realização do espetáculo, o que resulta do trabalho conjunto (ensemble), coisa jamais vista nos Estados Unidos. ${ }^{233}$

A leitura do TAM das peças de Tchékhov se tornaria canônica. Em termos técnicos, a audiência ficara profundamente impressionada com a afinação do trabalho de grupo e o efeito de "atmosfera" criado. Ao contrário da "escuridão" que permeara as encenações anteriores, a montagem de Stanislávski privilegiou a luminosidade, a fim de dar destaque ao trabalho dos atores. A luminosidade, no entanto, não pretendia ofuscar o pessimismo e mesmo a tragicidade da leitura stanislavskiana. A resposta do público e da crítica veio exatamente neste universo de expectativas. Anos mais tarde, Edmund Wilson se recordaria destas encenações nos seguintes termos: "como abraçamos ao nosso coração o pessimismo delicioso do russo, que já estava se tornando um 'velho chapeu' na Rússia!"234.

Além dessa "atmosfera russa", que teria apelo decisivo, o público americano mostrou-se muito receptivo as encenações realistas de Tchékhov pelo que elas tinham de minúcia cenográfica e sonora. $\mathrm{O}$ "pedaço de vida" ali representado em sua opinião ganhava em realismo - e a moda do "alto naturalismo" ali então em voga pelas tecnologias avançadas de produção de efeitos, implementadas por Belasco, criava um terreno receptivo. A combinação deste trabalho com o entorno e a preparação dos atores arrebatou as plateias imediatamente para o lirismo de Tchékhov ${ }^{235}$.

No que se refere especificamente ao dramaturgo, pois a vinda de Stanislávski fora decisiva para o surgimento de laboratórios e grupos dispostos a seguir seu sistema (ou o "método", como viriam a chamar) ${ }^{236}$, foram as encenações de Três Irmãs (1926), O Jardim das Cerejeiras(1928) e A Gaivota (1929), pelo Eva Le Gallienne's Civic Repertory Theatre. Já familiarizada ao "sistema" de Stanislávski, pois seu trabalho com os atores vinha em grande medida pautado pela leitura de Boleslávski da "memória

\footnotetext{
${ }^{233}$ Idem, Ibidem.

234 " how we hugged to our hearts the delicious pessimism of the Russian who were already becoming very old hat in Russia ". WILSON, Edmund. The Twenties from notebooks and diaries of the period. NY: Farrar, 1975, p. 322 apud SENELICK, Op. Cit., p. 175.

${ }^{235}$ SENELICK, Op. Cit, p. 174.

${ }^{236}$ Sobre as posteriores formações de grupos como o American Laboratory Theatre, conduzido por Boleslávski (que daria especial atenção ao ponto da "memória afetiva" do ator), que geraria mais tarde o Civic Repertory Theatre (1926), conduzido por Eva Gallienne, assim como o Group Theatre, do qual participavam Stella Adler, Lee Strasberg e Harold Cluman. Para maiores detalhes desse processo, ver: COSTA, Op. Cit
} 
afetiva" e o trabalho com a subjetividade, o Tchékhov de Gallienne veio espelhado nas encenações que o TAM fizera anos antes. Isto mesmo no que se referia ao detalhismo da cenografia, da sonoplastia e, sobretudo, do ritmo e do trabalho com os silêncios. A despeito da disposição da diretora, suas capacidades de produção do espetáculo e preparação do grupo não estiveram à altura das demandas trazidas pelo texto, de modo que muitos críticos consideraram sua boa disposição (e as encenações foram bastante prestigiadas), mas a qualidade era de "segunda categoria". Os atores pareciam muito preocupados com estender os silêncios e muitas vezes isso gerava compassos $\operatorname{artificiais}^{237}$. O que muitos críticos salvaram de suas encenações foram performances individuais, como as de Alla Nazimova (Ranévskaia) n'O Jardim e a de Jacob Ben-Ami (Trigórin) em A Gaivota.

A visita do TAM, a recorrente referência de diretores e gente de teatro emigrados à força do "nosso Tchékhov", assim como a dificuldade de adequá-lo de maneira expressiva à cena americana, reforçava com o passar dos anos a ideia de que Tchékhov era um verdadeiro desafio para encenadores e atores, espécie de teste para o "grande teatro". E o fato de numa mesma temporada em 1930 Tchékhov ser encenado por Galliene (Três Irmãs e O Jardim), por Jed Harris (Tio Vânia) e por Bulgakov no Comedy Theatre (A Gaivota) representava algo incomum para os críticos. Para Brooks Akinson, do New York Times, tratava-se de algo "surpreendente", sobretudo porque um dramaturgo anos antes encarado como "tedioso", "decadente" e "excessivamente experimental" era agora um dos mais "idolatrados de Nova Iorque". ${ }^{238}$. Inicialmente, o crítico parecia entender o fenômeno como puramente restrito ao meio teatral, que talvez visse em suas peças uma espécie de paralelo entre a estagnação social na Rússia e a estagnação pela qual passava o meio teatral estadunidense. Logo após, passou a reconhecer que boa parte dos frequentadores do teatro o admiravam, ainda que para o público médio parecesse muito "entediante" e "abstrato", talvez porque Tchékhov oferecesse menos respostas, ou fosse menos estrito do que muitos dramaturgos aos quais estavam acostumados ${ }^{239}$.

Muito deste espírito também está diretamente relacionado ao mal-estar que marca o início da década de 1930. Ainda que Bernard Shaw na Inglaterra tenha sido peremptório ao enxergar a força premonitória e a crítica mordaz de Tchékhov aos

\footnotetext{
${ }^{237}$ SENELICK, Op. Cit., 177.

238 ATKINSON, Brooks. "Concerning Chekhov". New York Times, 4 de maio de 1930 apud EMELJANOW, Op. Cit., p. 180.

${ }^{239}$ Idem, Ibidem.
} 
padrões de sociabilidade da sociedade capitalista em crise, este ainda não era $o$ dramaturgo preferido naqueles anos de instabilidade econômica e social para setores mais engajados do teatro. Para Laurence Senelick, isto talvez explique a curiosa ausência do dramaturgo do repertório Group Theatre (à época com Lee Strassberg, Stella Adler, Harold Clurman e outros). Ainda que o grupo estivesse bastante vinculado aos propósitos renovadores do TAM, suas preferências de repertório estavam voltadas para dramas de relevo social e que oferecessem "mensagens políticas" mais evidentes para seu público ${ }^{240}$. E, ainda que Clifford Odets (preferido pelo Group) visse em Tchékhov muito do desânimo que varria a intelectualidade estadunidense, Harold Cluman tendia a compará-lo a estes dramaturgos e ver um certo tom "acadêmico, vazio e inútil" no russo.

Isto talvez justifique o seu "empossamento" pelo star system nova-iorquino. Ainda que muitos reivindicassem o retorno da montagem de $O$ Jardim, de Eva Le Gallienne, que se esforçava pelo trabalho com o ensemble e reestreou em 1933 no New Amsterdam Theatre ${ }^{241}$, a afirmação do dramaturgo nesta cidade (e que se espraiaria por todo o país) seria dada ao longo dos anos 30 e 40 pelos grupos comerciais da metrópole estadunidense. Em 1938 uma versão de A Gaivota, com suntuoso cenário e figurinos luxuosos estreou no Theatre Guild, sob direção formal de Robert Milton, mas conduzida na prática pelos Lunts. No elenco havia nomes de peso como Lynn Fontanne (Arkádina), Alfred Lunt (Trigorin), Uta Hagen (Nina) e Richard Whorf (Trepliov). A encenação, que percorreu várias cidades, optou por trabalhar em menor grau a "atmosfera", tendo em vista a falta de paciência do público. Em contrapartida, acentuou os elementos cômicos da peça e trabalhou sua "luminosidade", deixando, na opinião dos críticos, um conjunto elegante, harmonioso, com um estranho humor, mas nem por isso "desumano ou cruel" ${ }^{242}$. O espetáculo teve 41 apresentações e foi bastante elogiado pela crítica como um "excitante teatro", à maneira de Komissarjévski.

Mas a encenação que marcaria de maneira decisiva o processo de introdução da dramaturgia de Tchékhov no teatro profissional americano seria As Três Irmãs, dirigida por Guthrie McClintic, e que estreou em 21 de dezembro de 1942, na Broadway. O diretor tinha no elenco atores de formações diversas, acostumados a papeis de peso, como Ruth Gordon (como Natacha), Judith Anderson (como Olga), Katharine Cornell

\footnotetext{
${ }^{240}$ SENELICK, Op. Cit., p.183.

${ }^{241}$ Fonte: Internet Broadway Database - http://www.ibdb.com/production.php?id=11735 (Acesso em 05 de outubro de 2011)

${ }^{242}$ BROWN, Jared. The Fabulous Lunts. New York: Athenaeum, 1986 apud SENELICK, Op, Cit., p.185.
} 
(como Macha). Como interpretação geral para a peça, manteve a mesma linha de Stanislávski: três lindas irmãs que sofrem com a pressão de uma outra, a mesquinha opositora. Dentro da concepção geral, coube ainda uma astuta adequação do diretor, que levou em conta o gosto comum de época para questões relativas à guerra: tratou de forma heroica a partida dos soldados no final da peça e atribuiu solenidade à despedida das irmãs. O que em Tchékhov poderia ter acento irônico vem aqui com uma forte interferência histórica, que eleva sua "respeitabilidade" e retira-lhe mesmo a crueldade (pois como ignorar que, em As Três Irmãs, os soldados vão para um lugar melhor?) ${ }^{243}$.

A estreia foi um sucesso (muitos oficiais a assistiram) e para o período representou uma das maiores e mais longas temporadas de Tchékhov. A revista Life a anunciaria como um exuberante drama de "atmosfera sombria"244, muito mais potente que qualquer comédia ou musical em cartaz. E seria justamente este tom "atmosférico" e "sombrio" (criticado mais tarde por Eva Le Gallienne como desgastado nas montagens, por estabelecer ritmos e silêncios imobilizadores), que ficaria como marca registrada das leituras feitas do dramaturgo naquele período: delicado, sensível, marcado pelo luto e pelo tratamento respeitosamente contido.

Os ecos de todas as leituras (russa, americana e europeia), direta ou indiretamente evidentes, marcarão a entrada de Tchékhov no Brasil. Seja pela referência direta que o palco brasileiro tem na cena europeia nos anos 40 (quando o dramaturgo ainda é um ilustre desconhecido no Brasil e começam a ocorrer as primeiras encenações de suas peças), seja pela vinda de diretores refugiados (da Itália ou do Leste Europeu) que, à maneira do que ocorreu em outros países, trarão na bagagem toda esta concepção do "tchekhovismo".

\footnotetext{
${ }^{243}$ SENELICK, Op. Cit., p. 185.

${ }^{244}$ EMELJANOW, Op. Cit., p. 190.
} 


\section{Tchékhov no Brasil: primeiros momentos}

Quando pensamos o início da relação do teatro de Tchékhov com os palcos brasileiros é inevitável a dupla constatação: um diálogo tardio e repleto de altos e baixos. Não há como negar que, por um lado, há muito de verdade neste diagnóstico. Em comparação com outros países e mesmo com outras artes que fizeram parte da Semana de 22, nosso teatro tardou a conformar um sistema funcional que dialogasse, à luz de nossas condições sociais e culturais, com as mais modernas práticas cênicas então em franco desenvolvimento na Europa e nos Estados Unidos ${ }^{245}$. E no caso da dramaturgia de Tchékhov, como vimos, o desenvolvimento das técnicas de direção e atuação na Rússia foram fundamentais para a afirmação de seu teatro, que exigia, entre outras coisas, estudo dramatúrgico, preparação de atores, ensaios sistemáticos elementos até meados da década de quarenta trabalhados embrionariamente por grupos brasileiros. Por outro lado, a generalização dificulta atravessarmos a especificidade do processo, que de fato vem cingido pelas marcas da cultura periférica em posição de "galho secundário" 246 , mas que também conseguiu desenhar aos poucos um diálogo com o teatro tchekhoviano de marcas muito interessantes, reveladoras de nossa própria busca pela constituição de uma "modernidade teatral".

Isto posto, não há demérito em adiantar que talvez resida nesse processo inicial de recepção (em que a dramaturgia escrita na Rússia periférica precisa do filtro autorizado do centro europeu para firmar-se aqui na outra borda) a chave para o entendimento do que diferem as leituras brasileiras daquelas que Laurence Senelick classificou apenas como "epígonos de Stanislávski". Se há a nota dominante da imitação (pois era preciso saber como liam e encenavam Tchékhov no exterior para que assim o fizéssemos também ${ }^{247}$ ), há também o desconforto com tal postura que se desenvolve e

\footnotetext{
${ }^{245}$ O ensaio "O teatro e o modernismo", de Décio de Almeida Prado, entra no centro desta questão e ilumina o problema específico das condições de produção cênica no Brasil ao longo do século XX, buscando compreender não os eventos isolados ou as marcas de ruptura, mas os elos de continuidade que levam a uma compreensão do processo em perspectiva de formação. PRADO, Décio. O teatro e o Modernismo. In: Peças, Pessoas, Personagens - o teatro brasileiro de Procópio Ferreira a Cacilda Becker. São Paulo: Companhia das Letras, 1993.

${ }^{246}$ A expressão é de Antonio Candido e foi apresentada no livro Formação da Literatura brasileira para exemplificar, sem ignorar especificidades, o imbricado processo de formação do sistema "produção, circulação e recepção" de obras literárias no nosso país. Em suas palavras, a literatura brasileira "é recente, gerou no seio da portuguesa e dependeu da influência de mais duas ou três para se constituir." CANDIDO, Antonio. Prefácio da $1^{\text {a }}$ Edição. In: Formação da Literatura Brasileira - momentos decisivos. São Paulo: Martins, p. 9.

${ }^{247}$ É razoavelmente conhecida a intenção de Franco Zampari, empresário paulista à frente da criação do Teatro Brasileiro de Comédia (TBC) e da Companhia Cinematográfica Vera Cruz, de converter a cidade
} 
amadurece ao longo dos anos, puxando para caminhos novos (ainda não sem romantismos e contradições), que explorarão a potencialidade do teatro tchekhoviano tão ou mais intensamente que em países europeus.

Até inícios dos anos 40, Tchékhov era um ilustre desconhecido no Brasil. Se nos palcos da Europa e dos Estados Unidos seu nome já figurava entre os principais destaques de repertório (já tendo caminhado do "exótico russo", passado pelo dramaturgo que iluminava os problemas nacionais e chegado às raias do "universal"), aqui até mesmo seus contos careciam de popularização.

Antes de 1900 as referências a seu nome eram raríssimas, feitas de segunda mão e com reconhecível desconhecimento de seus textos. Como vimos, Eugène Melchior de Vogüé seria um dos grandes catalisadores da difusão da literatura russa no Ocidente na década de 80 do século XIX e não via com bons olhos a "literatura menor" de Tchékhov. Sempre à sombra dos gigantes Dostoiévski, Tolstói e Turguêniev, escritores como Górki e Tchékhov representavam "tendências esfaceladoras" das soluções importantes que haviam sido dadas pelos outros romancistas.

E as posições críticas de Vogüé não podem ser caracterizadas com desprezo. Bruno Gomide já relatou o papel elementar que o seu paradigma crítico determinaria para a recepção da literatura russa, em especial o romance, no Ocidente. E o crítico, ainda que visse em Tchékhov a "vastidão da paleta" no tratamento dos caracteres, acreditava que seu acentuado pessimismo (nota dominante em muitos romances naturalistas) retirava de seu texto a necessária ilusão e transcendência ${ }^{248}$.

No entanto, isso não impediu que contos do escritor russo aparecessem amiúde em periódicos brasileiros. Longe de ofuscar as presenças agigantadas de Tolstói e Dostoiévski (o primeiro ainda vivo), os pequenos contos de Tchékhov poderiam representar registros apequenados, mas vivos, de romance russo ${ }^{249}$. E já aparecia com “O sarcófago" no Diário popular, em 1897 e, mais tarde, em 1907, com "Olhos de

de São Paulo no palco para as iniciativas teatrais e cinematográficas sintonizadas com as mais atualizadas tendências estrangeiras, para que a elite paulistana não precisasse ir a Nova Iorque ou Paris para ver um espetáculo de qualidade. "A fórmula do novo mecenas era simples: o cosmopolitismo de São Paulo reclama uma atividade cênica semelhante à de Paris, Londres ou Nova Iorque (..). O grupo [TBC] logo se profissionalizou dentro do esquema obrigatório: entregue a direção artística a um diretor estrangeiro". MAGALDI, Sábato. Panorama do Teatro Brasileiro. São Paulo: Global, p. 209.

${ }_{248}$ VOGÜÉ, E. M. Anton Tchekhof. Revue des Deux Mondes. Jan-Fev. 1902, p. 201-216.

${ }^{249}$ GOMIDE, Op. Cit., p. 168. 
sono" no Leitura para todos ${ }^{250}$. Se por um lado surgem estas produções, por outro, não há qualquer especificação crítica ou frequência de publicações que permitissem um conhecimento mais aprofundado do escritor.

Isto ocorre bem no início do século e de maneira tímida. Euclides da Cunha, um dos primeiros a registrar o nome de Tchékhov em nossa recepção crítica, seguiu a mesma tendência de Vogüé, mas via esse naturalismo do contista em chave diversa. Em "A Missão da Rússia", escrito sob o impacto da guerra russo-japonesa de 1905, o autor afirma que Tchkkorf (sic) seria, junto com Turguenieff (sic), com Dostoiewski (sic) e Tolstoi representante de um naturalismo popular "repassado de um forte sentimento da raça, que tanto contrasta com a organização social e política da Rússia" ${ }^{251}$. Operando na chave teórica repelida por Vogüé, Euclides da Cunha prefere conceber Tchékhov como um escritor popular da "raça", apegado ao "solo eslavo", mas por razões advindas mais da ciência que do espírito.

Nesta corrente, como um subproduto da vaga naturalista, há a tendência patologizante das leituras críticas da belle époque. O interesse de Euclides da Cunha também vem filtrado pelas leituras já bastante difundidas de um exotismo russo (vinda de Vogüé, mas em outra direção) com uma "tendência natural" dos eslavos ao visceral, ao descontrolado e mesmo ao criminoso. As personagens de Dostoiévski seriam um prato cheio para estas abordagens, e, como ocorre na tese do Dr. Luiz Ribeiro do Valle, apresentada em 1917 à cadeira de psiquiatria da faculdade de medicina do Rio de Janeiro, o autor ressalta esta hipótese e dedica duas páginas de seu estudo aos casos de "patologia da vontade" na obra de Fiódor Mikháilovitch. E autores como Tolstói, Tchékhov e Koroliênko vêm citados de fontes indiretas (como Ossip-Lourier) e resumidamente dentro do mesmo enquadramento ${ }^{252}$.

\footnotetext{
${ }^{250}$ Agradeço ao orientador pelo mapeamento precioso e dificílimo feito por sua tese de doutoramento, que localizou inúmeras publicações de textos russos em periódicos literários desde 1880 a 1930. Segundo ele, "a publicação em periódicos brasileiros de inícios do século vinte de narrativas curtas corresponde ao mesmo fenômeno detectado por George Schanzer no mundo hispânico: o formato breve das parábolas de Tolstói ou dos contos de Andrêiev era perfeito para editores de revistas literárias, que assim, num breve espaço, podiam obter pedacinhos do 'romance russo' e de seus prodigiosos efeitos morais." Em nota, afirma que "publicava-se mais Tolstói e Górki porque eram duas figuras vivas e atuantes, e porque, nas múltiplas conexões que tinham com o ideário anarquista, faziam apelo a vários tipos de público consumidor." Idem, p. 168-169.

${ }^{251}$ Disponível em: http://www.bibvirt.futuro.usp.br/index.php/content/view/full/1627\#x. Acesso em $10 \mathrm{de}$ agosto de 2012. A respeito dos comentários tecidos por Euclides da Cunha sobre a força do novo fenômeno "romance russo", que centralizaria as leituras feitas inclusive de autores não romancistas, como Tchékhov, ver GOMIDE, Op. Cit, p. 60.

${ }^{252}$ Idem, p. 261-263.
} 
O quadro para os contos de Tchékhov até 1920 (e aqui sequer nos referimos ao seu teatro, que estaria longe de ser traduzido) é o da compressão entre dois pólos: entre a presença esmagadora da "febre romance russo", que funcionava como espécie de metonímia da cultura russa e tornava dificultado o acesso aos gêneros "menores" (conto e teatro), e a presença tímida por meio de traduções esparsas e comentários críticos acachapantes.

Evidentemente, é com a Revolução de 1917 que uma vaga renovada se inicia. Como vimos, o evento não significou o marco zero para a relação da intelectualidade brasileira com o universo russo, mas contribuiu sem sombra de dúvidas para ao despertar de um interesse pormenorizado pelo que lá era produzido. A partir dos anos 20, começam a circular com maior intensidade traduções de autores russos (contemporâneos ou do século XIX), como Andréiev, Avierchênko, Zóschenko e Górki. Tchékhov a partir daí emergia com traduções em periódicos os mais diversos: em 1923, “O álbum” em A maçã, "Os ataúdes” na Revista popular brasileira; em 1925 “A língua comprida" n'A maçã; em 1928, "A família camponesa" na Primeira: a revista por excelência; em 1929, “A máscara”, também na Primeira ${ }^{253}$.

A preferência é quase generalizada pelos contos humorísticos do início de sua carreira. Em alguns casos, o autor é mesmo apresentado como "novo humorista russo". Isto parece justificar sua presença em revistas de caráter bastante variado, como na semierótica A Maçã. No conto "Commédia d'um presente indesejado", publicado em 06 de novembro de 1927 no carioca $O$ Jornal, o escritor ainda não recebe especificação crítica (nota comum em suas traduções) e vem sob a classificação genérica: "conto russo, especialmente traduzido para O Jornal" ${ }^{254}$. Ainda que pareça prematuro afirmá-lo, a leitura crítica naturalista de Euclides da Cunha (feita de segunda mão) já não repercute, e o Tchékhov que emerge na prática é o das situações cômicas, dos textos escritos em seu início de carreia, feitos sob encomenda e formalmente tradicionais. Estamos longe ainda de vê-lo aqui como já era conhecido em muitos lugares: como renovador das formas do conto ou como dramaturgo da "crise do drama".

\footnotetext{
${ }^{253}$ Boa parte deste levantamento, também realizado por Bruno Gomide, continua nos anos 30: "A mágoa de Gregório Petrov". Trad. El Gar. Revista do Globo, ano V, n. 4. Porto Alegre, 8 mar. 1933; "A conferência". Revista do Globo, ano V, n. 6. Porto Alegre, 5 abr. 1933; "Alma querida". A nação ilustrada, n. 28. Rio de Janeiro, 8 jul. 1934. GOMIDE, p. 487

${ }^{254}$ Tchehov (sic), Anton. "Comedia d'um presente indesejado". O Jornal. Rio de Janeiro, 06 de nov. de 1927. Agradeço a João Bittencourt pela indicação da referência.
} 
Mas é nos anos trinta que Tchékhov receberá pela primeira vez uma atenção específica. Dentro da euforia editorial do período, são lançadas as primeiras coletâneas de contos do autor, Os Inimigos e Pavilhão $n^{o} 6^{255}$, traduzidas "de acordo com os originais" pelo editor russo Zéltzov, que adotou o nome afrancesado de Georges Selzoff (a língua é também o indício do passaporte para o universo autorizado) ${ }^{256}$. Vale destacar que as coletâneas reuniam contos de momentos variados da trajetória do contista, como "O Estudante" (já escrito nos últimos anos de vida de Tchékhov e tido por ele como um de seus prediletos) e o próprio "Pavilhão n 6", pela primeira vez publicados no Brasil e que apresentavam uma outra face do seu trabalho. Os livros apresentam um mesmo prefácio que cuida de colocar Tchékhov em posição de relevo dentro do contexto cultural russo e europeu. No entanto, os comentários críticos ainda se restringem a citar sua "compaixão pelas personagens", "piedade imensa por seus destinos" e o "pessimismo com forte esperança no futuro" ${ }^{257}$, pontos que futuramente serão bastante explorados pela crítica, mas que ainda não clarificam em que sentido a fatura estética tem de nova e moderna. Sem nenhuma intenção de sobrevalorizar o autor, a publicação é parte da coleção "Biblioteca de Autores Russos", que ainda cuidaria de publicar outros autores, como Turguêniev, Dostoiévski e Tolstói.

A edição, apesar de importante para mostrar alternativas à repisada tecla de que a cultura russa se resumia à grandiloquência ético-literária de seus romances, não consegue suplantá-la. Pelo contrário, a década de 30 vem para iniciar o processo de dissolução do paradigma crítico de Vogüé, que agora precisa dividir sala com as leituras modernistas, mas, ao mesmo tempo, continuar a concentração sobre o romance, sobretudo o de Dostoiévski:

Outro caminho em que a crítica literária diferia do paradigma finissecular $e$ da febre de eslavismo da década de 1930 foi, em

\footnotetext{
${ }^{255}$ TCHECOFF, Anton. Os Inimigos - Contos. Trad. Georges Selzoff e F. Olandim. São Paulo: Edições Cultura - Georges Selzoff, 1931. Contém os contos: Os inimigos/ Delírio (Gussieff)/ Algazarra em família/ No carro/ Verotchka/ Estudante/ Lenda Sueca (o conto do jardineiro chefe)/ Zinotchka/ Uma noite atroz. Acervo: Biblioteca do IEL - UNICAMP/ Coleção AIDA COSTA. E TCHECOFF, Anton. $O$ Pavilhão $n^{\circ}$ 6. São Paulo: Bibliotheca de Auctores Russos, 1931. Contém os contos e novelas: O Pavilhão ${ }^{\circ}$ 6, A Desgraça, A Felicidade, A Obra de Arte, Os Simuladores. Acervo: Obras Gerais Biblioteca Nacional - RJ.

${ }^{256} \mathrm{O}$ afrancesamento do nome de Zéltzov merece destaque. O mesmo ocorrera com Ptoëff, na França, que necessitaria trabalhar uma versão europeia de seu nome para convertê-lo em produto autorizado nos meios culturais. Isso diz muito do que significam os processos de significação da cultura periférica no centro europeu nos séculos XIX e inícios do XX.

${ }^{257}$ Anton Tchecoff. TCHECOFF, Anton. O Pavilhão $n^{o}$ 6. São Paulo: Bibliotheca de Auctores Russos, 1931, p. 3-7.
} 
contraposição à vertigem editorial em que tudo era permitido, $a$ concentração enfática de forças no estudo de Dostoiévski. Tolstói, Gógol, a Águia negra de Púchkin, Tchékhov, Górki e diversos autores do período soviético brotavam das prensas, mas quem levava a palma nos principais estudos críticos era Fiódor Mikháilovitch. Confirmava-se a perspectiva que já vinha de Vicente Licínio Cardoso e dos intelectuais católicos: o autor de Os demônios era o principal alvo das mais recentes abordagens da literatura russa. ${ }^{258}$

E assim seguirão os contos de Tchékhov, publicados aqui e ali em periódicos especializados, mas sem nenhuma leitura ou apresentação de fôlego. Ao longo da década de 40 já circulariam com mais frequência edições portuguesas do autor (como A Estepe, com tradução de Cordeiro de Brito ${ }^{259}$ ) e importantes coletâneas, variadas na gama de contos selecionados, mas ainda com forte destaque para as produções de veio cômico e ligeiro. Seria assim com as publicações de "Amor Impossível", com tradução de Marina Salles Goulart de Andrade e Gilberto Galvão, pela carioca Casa Editora Vecchi, em 1945; e com "Olhos Mortos de Sono", traduzido por Carlos M. A. Bittencourt e publicado pela editora paulista Assunção Limitada, também em 1945. Todas estas traduções feitas a partir do francês vinham sem qualquer comentário crítico de fôlego para além das constantemente citadas referências à amizade do contista com Tolstói e Górki ou ao fato de possuir contos cômicos muito populares na Rússia.

As duas edições de inícios da década de 50 seguem esta linha. Tanto a edição casada com contos de Zola e Tchékhov feita pela Tecnoprint em $1951^{260}$, traduzida do francês e sem nenhum texto biográfico ou crítico e a edição de 1955 da novela O Duelo $^{261}$, traduzida do francês por Otto Schneider e parte da coleção "Novelas do Mundo". Na pequena nota introdutória, a recorrência à tópica da "alma russa", remanescente da febre eslava e dos comentários críticos de Vogüé em fins do XIX:

\footnotetext{
${ }^{258}$ GOMIDE, Op. Cit., p. 414.

${ }^{259}$ TCHECKOFF, Anton. A Estepe. Trad. do francês de Cordeiro de Brito. Lisboa: Editorial Inquérito, 1940. Acervo: Biblioteca do IEL - UNICAMP.

${ }^{260}$ TCHEKOW, A. e ZOLA, E. O Banho e Outros Contos (Zola)/ O Beijo e outros contos (Tchekow). Rio de Janeiro: Edições Segredo/ Ed Tecnoprint, 1951. Contém os contos de Tchékhov: O Beijo/ Uma Obra de Arte/ O Escândalo/ Uma Ocorrência Trivial/ Depois do Teatro/ O Menino Malvado/ A Velhice. Acervo: Obras Gerais - Biblioteca Nacional - Rio de Janeiro.

${ }^{261}$ TCHEKHOV, Anton. O Duelo. Trad. Otto Schneider. São Paulo: Edições Melhoramentos, 1955. Acervo: Obras Gerais - Biblioteca Nacional - Rio de Janeiro.
} 
Quanto às conclusões, essas ficam por conta do leitor inteligente. Tchékhov limita-se a alusões (...) Mas o caminho rumo à verdade é esboçado. E Basta. Com um realismo igual ao de Tchekhov, só mesmo Gogol, Dostoievski, Tolstoi e Gorki interpretavam a melancolia, o desespero e o misticismo próprios da alma eslava, metade Dom Quixote, metade Hamlet. ${ }^{262}$

Só em fins da década de 50 é que poderemos dizer que houve um verdadeiro ponto de virada na recepção da produção tchekhoviana no Brasil. Se por um lado este destaque pode desmerecer a lenta inserção de seus textos em periódicos e nas publicações já citadas, por outro, é só agora que traduções diretas e cuidadosas do russo serão feitas ${ }^{263}$. Além disso, são desse período os primeiros comentários críticos mais acurados, responsáveis por mesclar em pormenor detalhes biográficos relevantes com o debate sobre a especificidade da forma literária tchekhoviana.

Boris Schnaiderman (ucraniano que veio para o Brasil ainda criança, por volta de 1925), responsável pela organização de contos mais trabalhada até então feita no Brasil, reuniu em sua publicação mais de trinta contos, todos eles acompanhados de notas cuidadosas sobre o processo de criação, dados biográficos e discussão a respeito da poética do autor. Este destaque não é gratuito. Para um ambiente editorial bastante efervescente, com arejada e moderna produção de contos por grupo vasto de autores brasileiros (indo de Mário de Andrade a João Guimarães Rosa), o contista russo chega em momento no qual a atenção para seus textos pode emergir na medida certa. Em "A Dama do Cachorrinho" ${ }^{264}$, Boris acrescenta um posfácio breve, mas que definiria a linha do que até hoje se discute a respeito do autor entre nós. De um lado, a capacidade que Anton Tchékhov teve de renovar as formas do conto moderno, subvertendo a linha de seus mais destacados antecessores na arte do conto, Poe e Maupassant, que haviam feito escola e marcavam até então os padrões de composição. Para o tradutor, enquanto o primeiro buscou constituir uma filosofia para o conto, com a organização do enredo para a construção de um efeito "singular e único", o segundo (menos programático), buscou articular realidade e banalidade com desdobramentos singulares, em um forte

\footnotetext{
262 "Introdução". In: Idem, p.6

263 As traduções de Zéltzov foram em boa parte referenciadas nos originais russos, já que o editor dominava o russo, sua língua materna. Mas sua parceria nas traduções com Orígenes Lessa e Brito Broca, estes exímios dominadores do francês, mas completamente leigos em russo, levam a crer que boa parte dos textos passaram pelo crivo francês.

${ }^{264}$ TCHEKHOV, A. P. A dama do cachorrinho e outros contos. Trad. Boris Schnaiderman. Rio de Janeiro: Civilização Brasileira, 1959. Acervo: Biblioteca do IEL - UNICAMP.
} 
rompimento com a forma e o conteúdo grandiloquentes que marcaram as formas românticas. E Tchékhov alteraria esta concepção do conto como "acontecimento" ou "caso". Há uma mudança de foco. Ao invés do desfecho, o processo; ao invés do acontecimento em concentrado, a própria narrativa como concentração ${ }^{265}$.

Esta demarcação crítica alimenta uma tendência já existente, mas também demarca um foco orientado e novo para a recepção dos contos de Tchékhov, que se abriria a partir daí. E no mesmo ano há a publicação de outra coletânea de contos, também traduzida acuradamente do russo por Tatiana Belinky, russa que, assim como Boris Schnaiderman, viera pra o Brasil ainda muito jovem. A coleção "Os Maiores Contistas de Todos os Tempos" ${ }^{266}$ revela algo de importante: trata-se de nova vertente de recepção da literatura russa, que já não se prende exclusivamente ao romance russo e abre espaço para outros gêneros, ainda que não em força de igualdade. A publicação, mesmo que apresente apenas uma breve nota biográfica, já pressupõe um interesse do leitor brasileiro pelo "clássico", que está para além do exótico e parece também ter a dizer algo sobre nós. Daí não soar da mesma maneira a própria seleção feita por Belinky: se antes encontrávamos contos cômicos do autor publicados em periódicos como algo genericamente "russo", aqui, a preferência pelas histórias breves com quiproquós vêm cingidas pelo que têm de moderno, de dinâmico e, já em nota biográfica, a tradutora afirma que parecem sintonizados com o que temos em nossos quiproquós brasileiros: na grotesca burocracia estatal e na pobreza que gera projeções de vida e cotidianos bizarros. ${ }^{267}$

Mas ainda será cedo para dizermos que Tchékhov fazia parte do debate crítico e dominava preferências editoriais, como o foram Dostoiévski e Tolstói. O que temos, em verdade, é um ponto de virada importante, acelerador do processo, que prepara, ilumina e reflete o movimento que se iniciava no teatro.

\footnotetext{
${ }^{265}$ SCHNAIDERMAN, Boris. "Posfácio". In: TCHEKHOV, A. P. A dama do cachorrinho e outros contos. Trad. Boris Schnaiderman. Rio de Janeiro: Civilização Brasileira, 1959.

${ }^{266}$ TSCHECOV (sic), Anton. Histórias Imortais. Trad. do russo por Tatiana Belinky. São Paulo: Editôra Cultrix LTDA, 1959. Contém os contos: A morte do funcionário/ Menino Malvado/ No departamento dos correios/ O Malfeitor/ Vanka/ Brincadeira/ Senhoras/ Gricha/ O vingador/ A mulher do farmacêutico/ Camaleão/ Um homem conhecido/ Falta de que fazer (Romance de férias)/ Veraneiro/ Aniuta/ Sobrenome Cavalar/ Inimigos/ Angústia/ A descoberta/ Ninharias da vida/ A corista/ O marido/ Libertinagem/ O investigador/ Meninos/Zinotchka/ O bilhete de loteria/ O médico/ O mendigo/ Inadvertência/A duquesa/ Do amor/ A aposta/ "Amorzinho"/ A esposa/ Ana no pescoço. Acervo: Biblioteca do Instituto de Artes UNICAMP.

${ }^{267}$ Idem, p. 12.
} 


\subsection{Rústico e antiburguês}

A primeira encenação de uma peça de Tchékhov no Brasil da qual temos registro foi feita em 13 de abril de 1946. Em um palco improvisado na biblioteca da Faculdade de Direito do Recife, um grupo de estudantes juntou duas mesas e, sobre elas, com cenário simulando uma sala de estar intencionalmente desproporcional e improvisada, encenou $O$ Urso. Na direção, Hermilo Borba Filho ${ }^{268}$.

A situação algo pitoresca e quase lendária, marca uma introdução curiosa do dramaturgo russo nos palcos brasileiros. O Teatro do Estudante de Pernambuco (TEP) estava em momento de renovação e pretendia lançar novas bases para o teatro feito na capital e no nordeste. Cansados das encenações "sentimentais e burguesas" e das peças com caráter exclusivamente "digestivo" feitas pelo Teatro de Amadores de Pernambuco (TAP), o TEP se propunha a uma aproximação do povo buscando compreender suas "aspirações", sem tratá-lo como "apático"269. E naquela noite, o grupo de estudantes, a fim de tornar públicas sua crítica e suas convicções, apresentou o documento "Teatro, Arte do Povo", escrito e lido por Hermilo. Para ele, a conferência fora "chata e longuíssima, todo mundo dormia" e "a parte reacionária do público vaiou, mas a democracia 'venceu' naquela noite" ${ }^{270}$. Na prática, a vitória se deu tanto pela repercussão positiva das proposições apresentadas no texto, que se propunha a uma superação do elitismo no teatro, quanto pelas duas encenações apresentadas na sequência. Primeiro, $O$ Urso de Tchékhov, escolhida em sua opinião pelo valor estético que possuía; em seguida, "O Segredo", de Ramón Sender, escolhida por ter perfil antinazista e expressar o anseio "democratizante" da juventude pós- $45^{271}$.

Estes elementos são reveladores de uma leitura diferenciada da peça de Tchékhov. Por um lado, fora escolhida por seu valor estético (o que revela uma preocupação de ordem formal do grupo), mas também é encenada em um momento decisivo, em que a ideia de superação do repertório "digestivo" é palavra de ordem. Ora, O Urso é uma peça curta de Tchékhov, com estruturação farsesca, muito próxima do vaudeville francês (então gênero de muito sucesso na Rússia de fins do XIX). O TEP

\footnotetext{
268 Também fizeram parte da encenação Termutis Carvalho (Elena), Epitácio Gadelha (Luka) e Milton Persivo Cunha (Gregory).

${ }^{269}$ CARVALHEIRA, Luiz Maurício Britto. Por um teatro do povo e da terra. Hermilo Borba Filho e o Teatro do Estudante de Pernambuco. Recife: FUNDARPE: 1986, p. 113-115.

270 "Hermilo - a longa luta por um teatro popular" Entrevista. In: Boletim INACEN. Rio de Janeiro, p. 37, n06, 01 jul. 1984.

${ }^{271}$ Idem, p. 36-37.
} 
antagonizava justamente com as farsas, vaudevilles, chanchadas (cariocas ou estrangeiras) que dominavam as casas de espetáculo recifenses. Mas sua leitura de Tchékhov diferia dessa tendência. Ainda que vaudevillhesca, a peça importava pelo que tinha de dinamismo e depuração dos diálogos. Não havia desleixo ou apelação para o humor fácil. E os quiproquós dali emergentes tinham muito de "nosso". Por isso, se uma encenação burguesa pediria um cenário realista, o concebido por Lula Cardoso Ayres era intencionalmente desleixado e desproporcional, para distanciar-se ao máximo possível da bem comportada "sala gabinete" ${ }^{272}$.

A encenação teve acolhida bastante positiva e no mês seguinte era apresentada para operários e seus familiares no Centro Educativo Operário, na cidade do Recife, também com ampla repercussão ${ }^{273}$.

Mas por que esta peça de Tchékhov? Como Hermilo chegara a ela? As respostas para essas perguntas só podem emergir por caminhos imprecisos. Hermilo Borba, como se sabe, tivera papel decisivo no período como impulsionador do teatro popular e estudantil. Convertera-se em estudante da Faculdade de Direito unicamente para poder trabalhar com teatro. Naquele período, lia vorazmente tudo que lhe vinha à mão e, anos antes, em 1944, tivera contato próximo com o diretor polonês Zigmunt Turkov, que dirigiu em curta temporada na cidade "A Comédia do Coração", de Paulo Gonçalves. Possivelmente, foi o polonês quem apresentara a Hermilo o universo russo. E, anos mais tarde, ao publicar Cartilhas de Teatro, o recifense deixa claro seu conhecimento das encenações de Pitoëff feitas na França e das suntuosas montagens de Komisarjevsky (sic) na Inglaterra ${ }^{274} \mathrm{e}$, como já dito, é evidente o atrelamento destes diretores estrangeiros a publicização e estandardização de um determinado padrão de encenação das peças de Tchékhov.

Muito provavelmente, a pecinha de Anton Pavlovitch surgiu entre esses contatos e leituras frenéticas. Suas peças maiores, ainda não traduzidas para o português e ainda impróprias para a situação e os padrões de gosto do público da época, evidentemente não cabiam naquela noite. E se o TEP se propunha a "privilegiar as coisas de massa"275, para a construção de um teatro "brasileiro e universal", o quiproquó em $O$ Urso parecia bastante próximo do gosto popular de tradição ibérica pelos desentendimentos e

\footnotetext{
${ }^{272}$ CARVALHEIRA, Op. Cit., p. 115.

${ }^{273}$ Idem, ibidem.

${ }^{274}$ BORBA, Hermilo; PAIVA, B. Cartilhas de Teatro I. História do Espetáculo. Rio de Janeiro: Serviço Nacional de Teatro, 1973, p. 119-157.

${ }^{275}$ CARVALHEIRA, Op. Cit., p. 104.
} 
situações espalhafatosas $^{276}$. O ambiente tinha muito de comum: se na peça temos um proprietário de terras, um serviçal e uma viúva em luto pelo marido morto, não há como não pensar nas grandes propriedades canavieiras, nas carolas católicas e nos empregados caricatos (à maneira de um "demônio familiar"277) que marcaram o imaginário das peças cômicas brasileiras até então.

Curiosamente, esta encenação arejada, rústica e antiburguesa de $O$ Urso teria similares em encenações de outros grupos amadores e estudantis - decisivos para os primeiros momentos de Tchékhov no Brasil. E o gosto pelo lado farsesco das peças em um ato do dramaturgo continuarão sendo nota dominante em sua recepção brasileira durante longos anos.

\subsection{Estudantil e amador}

Os grupos de teatro estudantis foram peça importante no processo de modernização do teatro brasileiro. Ligados a ambientes universitários e da intelectualidade, imbuídos da busca de alternativas ao teatro comercial, digestivo e sem rigor de estudo, seriam eles os responsáveis por muitas vezes buscarem textos fora do circuito das chanchadas e peças comercais que marcavam o repertório das casas de espetáculo das principais capitais. Obviamente, a generalização não pode ignorar o fato de que boa parte desses mesmos grupos via-se quase sempre perseguido pelo fantasma da sobrevivência financeira, da busca sempre tortuosa do "nacional" e do "popular" ou com a preocupação muitas vezes pouco clara por "novas formas". De todo modo, o que percebemos é que até 1960, ainda que com as pontuais encenações do TBC de Um Pedido de Casamento, as peças em um ato de Tchékhov (e amiúde suas peças maiores) percorrerão o Brasil no repertório desses grupos estudantis e amadores. O tamanho reduzido dessas farsas em um ato (que facilitavam a condução de ensaios e mesmo a improvisação de espaços para apresentação), o dinamismo dos diálogos, a comicidade

\footnotetext{
${ }^{276}$ A trajetória de Hermilo na busca pela afirmação do teatro realmente popular será longa e cheia de revisitações de conceitos e propostas. Anos mais tarde, fundaria com Ariano Suassuna o TPN (Teatro Popular do Nordeste), iniciativa mais profissional (ao contrário do intencional amadorismo do TEP). Nesse momento, fica evidente a formulação que os dois alcançam de que arte popular é sinônimo de arte nacional, e que o popular resulta justamente da mescla entre a tradição ibérica erudita e o popular negro e indígena brasileiros. Idem, p. 40-41.

277 Aqui nos referimos à personagem de O Demonio Familiar, de José Alencar. O escravo Pedro, que se propõe a casar seus patrões, mas acaba por se tornar uma espécie de "capeta" na trama.
} 
nada apelativa e por vezes temperada de trágico, ofereciam um prato cheio para os grupos desejosos de "coisas novas", fora dos roteiros laudatórios das encenações vigentes.

É com esse espírito que o jornalista Juvenal Passos saúda o "Festival Tchékhov" em matéria publicada na Revista do Globo, em julho de 1949: "seleção bastante definidora do 'preciso realismo e objetivismo, da extrema concisão, do invulgar domínio do diálogo e do delicado e muitas vezes trágico senso de humor' que Anton Tchekhov colocou em sua obra" ${ }^{278}$. Os comentários, que revelam relativo conhecimento da poética de Tchékhov, não parecem abordar uma escolha aleatória de repertório. O Festival, organizado pelo Teatro do Estudante do Rio Grande do Sul, fora encabeçado pelo escritor e historiador Guilhermino César, que há dois anos os orientava e constantemente realizava estudos sobre dramaturgia. Para esta montagem, o grupo juntou no espetáculo duas farsas: $O$ Selvagem (com tradução mais consolidada como $O$ Urso) e Um Pedido de Casamento, acompanhadas do estudo dramático O Canto do Cisne. O grupo já trazia em seu histórico de oito anos de funcionamento uma série de encenações dos mais atualizados dramaturgos. Encenara "A Mulher Sem Pecado", de Nelson Rodrigues, peças de Anouilh, como "O Viajante sem Bagagem" e "Antígona" e "Hedda Gabler", de Ibsen. Sua preocupação em "modernizar" o repertório sulino se inspirava no ímpeto do Teatro do Estudante, conduzido por Paschoal Carlos Magno, no Rio de Janeiro e que servia de experiência modelar para a maioria dos teatros estudantis $^{279}$. Era preciso renovar o gosto público e o modo de fazer teatro, e mesmo a imprensa da época já saudava o perfil do grupo: " O Teatro do Estudante está divorciado dos problemas comuns dos teatros profissionais. Ele não foi criado para simplesmente divertir. Tem finalidades culturais elevadas. É real, consistente e conta com elementos compenetrados de que o teatro é uma arte que deve refletir ao vivo as lutas íntimas da natureza humana". 280

A encenação dessas pequenas farsas de Tchékhov vinha carregada do dinamismo farsesco do "teatro popular do século passado" 281 , trazendo tom "familiar" à encenação que fugiu de uma caracterização "russificante" do cenário (como ícones, roupas de frio ou janelas com neve). Pelo contrário, na pintura de fundo pouco alterada

\footnotetext{
${ }^{278}$ PASSOS, Juvenal. Festival Tchekhov. Revista do Globo. Porto Alegre, 23 jul. 1949, p. 36-37.

${ }^{279}$ MAGNO, Paschoal. "O Teatro do Estudante". In: Revista Dionysos - Teatro do Estudante do Brasil e Teatro Universitário - Teatro Duse n²3. Rio de Janeiro: MEC/DAC/FUNARTE/SNT, 1978, p3-11.

${ }^{280}$ É proibido suicidar-se na primavera. Revista do Globo. Porto Alegre, 13 nov. 1943.

${ }^{281}$ Idem, p. 36.
} 
entre as duas farsas havia as paredes de uma casa de madeira, as imagens pintadas de um galo, um bode e pequenos quadros. Sem pretensão realista, ainda que "sóbria", segundo os jornais, a cenografia delineava formas distorcidas das portas e janelas que davam ao conjunto uma sensação dinâmica de um arejado desenho animado.

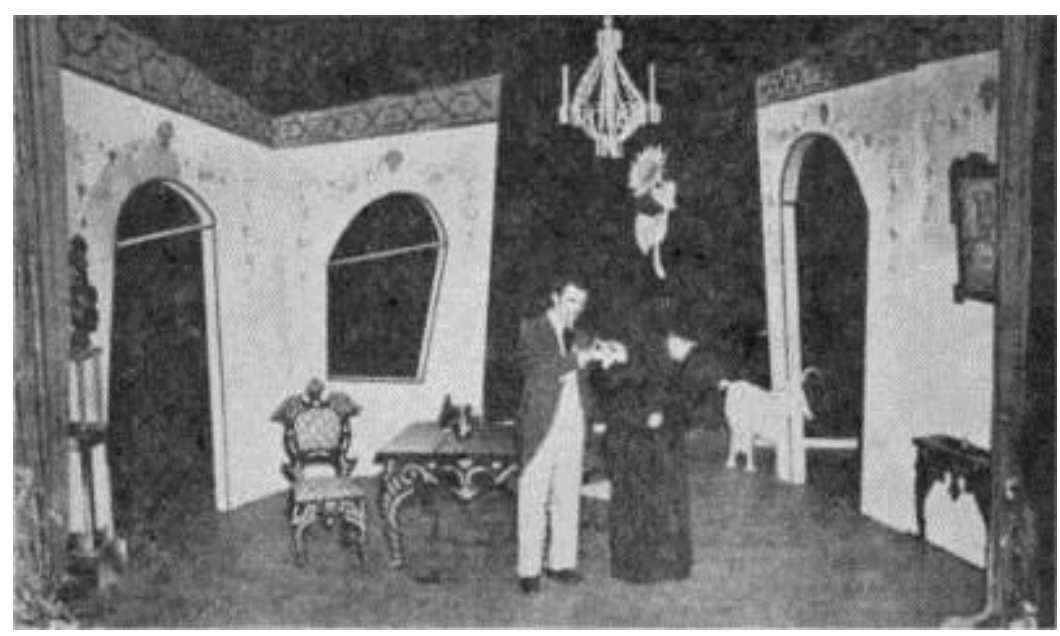

Cena de $O$ Selvagem ( $O$ Urso). Destaque para a cenografia de Carlos Alberto Petrucci. À esquerda, Loris Melecchi (Smirnov) e à direita Enilda Lopes (Eliena). Foto: Flavio Damm. Fonte: Revista do Globo, 23 jul. 1949.

O elenco era composto basicamente por estudantes ${ }^{282}$, sob a direção de Guilhermino César. A noite de estreia tivera grande repercussão e, durante a encenação de "O Canto do Cisne", a interpretação com forte carga dramática conduzida por Olavo Hengel arrancara aplausos do público mais de uma vez durante o espetáculo.

Tais grupos estudantis, presentes nas principais capitais, eram inicialmente vinculados às entidades estaduais ou a grêmios de representação estudantil. Muitos deles, tempos depois, dedicaram-se exclusivamente ao teatro, independentes da entidade. E a existência dessa rede de interesses (institucionais e políticos) gerava possibilidade de intercâmbio no plano cultural e teatral (de textos, artistas e iniciativas), o que permitia uma razoável circulação de informações ${ }^{283}$. Tanto que um novo "Festival

\footnotetext{
${ }^{282}$ O elenco das três peças revezava-se em torno dos seguintes nomes: Enilda Lopes, Olavo Hengel, Loris Melecchi, Linneu Dias, Flávio Romero e Galvão Loureiro.

${ }^{283}$ Basta atentar para o fato de que, no embrião da criação do Teatro do Estudante do Brasil (TEB), marco no processo de modernização do teatro brasileiro tem seu embrião nas viagens de mobilização e "recrutamento" realizadas por Paschoal Carlos Magno antes de sua viagem à Europa: "Andou por todo o país contatando grêmios estudantis para a fundação da Casa do Estudante do Brasil, instituição idealizada por Ana Amélia Carneiro de Mendonça. Foi nomeado pelo Itamaraty a um cargo diplomático na Inglaterra e, assim, passou alguns anos afastado. Ao retornar, em 1937, decidiu criar um grupo de teatro na Casa do Estudante". Fonte: http://www.antaprofana.com.br/materia atual.asp?mat=161 . Acessado em 11 set. 2012.
} 
Tchékhov" seria realizado no Rio de Janeiro, no Teatro Duse (pequeno teatro com cem lugares criado na garagem da casa de Paschoal Carlos Magno, no bairro de Santa Teresa). O espetáculo, que rapidamente tomou as colunas dos jornais cariocas, era composto por três farsas de Tchékhov (O Urso, Um Pedido de Casamento e $O$ Aniversário $^{284}$ e foi feito também em homenagem ao Teatro de Amadores de Pernambuco (TAP), que estava em temporada breve pela cidade. Na direção de todas as peças do festival estava Nina Ranevsky, antiga atriz do Teatro de Arte de Moscou que viera ao Brasil havia alguns anos e, naquele momento, tinha residência fixa no Rio. A diretora, antes de sair da Rússia, fora professora no Conservatório de Moscou e de 1917 a 1934 havia sido atriz, atuando em importantes peças de repertório do $\mathrm{TAM}^{285}$. Essa experiência em solo russo contribui sem sombra de dúvidas para que esse dramaturgo, especificamente, fosse escolhido. $\mathrm{E}$ as pequenas farsas tinham o ingrediente necessário para "funcionar" com aquele grupo de estudantes-atores que, sob a batuta de Paschoal Carlos Magno, vinha com trabalho já longo e a séria pretensão de renovar a cena carioca e brasileira, buscando a todo momento dialogar com as mais encenadas ou atuais dramaturgias do exterior.

A contribuição de Nina para a direção do grupo, ainda que não tenha feito escola e não tivesse a sistematização de um trabalho de longo prazo, dava maior coesão ao trabalho de direção e treinamento dos atores. Tal iniciativa vinha ao encontro do propósito de superar o teatro da "velha geração" (que ainda tinha seguidores fervorosos nos meios culturais cariocas), representantes do "teatro de astro", concentrado em algumas figuras de brilho, como Procópio Ferreira e Jardel Jércolis. Ora, a proposta de Stanislávski se baseia acima de tudo na organicidade do trabalho cênico, que só pode ser conquistado com o trabalho em grupo sob a orientação de uma diretriz unificadora do diretor e Nina Ranevsky contribuía para a inserção desses elementos. Mas a reflexão sobre eles ainda era bastante insipiente e vinha mais como um conhecimento complementar que um projeto a ser destrinchado. Tanto que sua passagem pelo Teatro do Estudante fora breve e este Festival, especificamente, de curta temporada ${ }^{286}$.

\footnotetext{
${ }^{284}$ Elenco, por peça e por ordem de entrada: "O Urso" - Ana Edler (Popova), Fernando Cesar (Luka), Armando Carlos Magno (Grigori), Ney Modanesi (Jardineiro); "O Aniversário" - José Leandro (Kusmá Quirian), José Maria Monteiro (Andrei Shipuchin), Celme Silva (Tatiana Alexeievna), Consuelo Leandro (Nastasia Marchutkina), La-Fayette Galvão (Porteiro), Moacir Deriquem (Acionista); "Um pedido de Casamento" - Edson Silva (Stepan Chubukov), La-Fayette Galvão (Ivan V. Lomov), Geny Borges (Natalia Steptonova).

${ }^{285}$ Ver: Programa de Peça - "Festival Tchecov - no Teatro Duse" - Rio de Janeiro, 1952, p.1.

${ }^{286}$ Apresentações foram feitas nos dias 29 e 30 de dezembro de 1952 e nos dias 2,3,4,5 e 6 de janeiro de 1953, no Teatro Duse. Idem, ibidem.
} 
A cenografia do espetáculo, feita pela também russa Rada, então com 22 anos, foi basicamente pintada e inspirada nos interiores russos, de modo a situar as pequenas farsas naquele contexto ${ }^{287}$. Sem muitas interfaces com o cotidiano brasileiro ou carioca, as três montagens carregavam toda a movimentação frenética do vaudeville, de longa tradição na Rússia. E nos jornais, que saudaram o "bom espetáculo", caberia apenas a paráfrase à citação de Tchékhov, feita de forma descontextualizada e mais pertinente a suas peças longas: "Nas peças de teatro, afirmava Tchekov, tem-se que pintar a vida como é, e as pessoas como são. Na vida real, a gente não se mata, nem se enforca, nem faz declarações de amor a todo instante, nem tão pouco são ditas coisas inteligentes a cada passo. O que se faz, realmente, é comer, beber, galantear e dizer tolices; e isso é o que se deve dizer no palco" 288 .

E assim, a conta-gotas, dava-se a introdução do dramaturgo russo em pequenos palcos das capitais. O Pedido de Casamento, nestes primeiros anos de "aparecimento" de Tchekhov no Brasil, seria de longe a peça mais encenada. Não há registros de que a tradução que circulara por entre esses grupos estudantis tenha sido a mesma. No entanto, a preferência por suas farsas, e em especial esta, é evidente. Em 1950, Adacto Filho (que já vinha de ligação com as iniciativas modernizantes do Teatro de Brinquedo de Álvaro Moreira e com Os Comediantes, no Rio), dirigiu em Salvador (BA), com o Teatrinho de Amadores de Fantoches (TAF) o texto de Tchékhov. O "Teatrinho", espécie de laboratório de formação do "Fantoches da Euterpe", grupo de renome na capital, optou pela encenação dessa comédia de Tchékhov como etapa preparatória para a temporada que se abriria no Cine Guarani de encenação de textos maiores, com um "repertório dos melhores autores internacionais" ${ }^{289}$. O grupo, ainda que timidamente, tentava trazer inovações importantes para cena soteropolitana, e a presença de Adacto Filho seria fundamental para a constituição da mentalidade "que se revela na escolha dos textos para irem ao palco e principalmente pela forma como se configura a poética da cena" ${ }^{290}$. O diretor, com fortes influências do trabalho de Copeau, buscava em cada encenação constituir uma "atmosfera específica". Este tipo de trabalho, inovador para a cena da capital baiana, assumiu picos importantes, quando da encenação de Um Pedido

\footnotetext{
${ }^{287}$ Idem, p.2.

288 "Tchekov, pelo Teatro de Estudante, amanhã no Duse". Folha Carioca. Rio de Janeiro, 26 dez. 1952. Vale observar o curioso desencontro entre a estreia anunciada no panfleto e a nota divulgada no jornal. 289 "Um Pedido de Casamento pelo Teatro Íntimo de Fantoches". A Tarde. Salvador, 15 mar. 1950.

${ }^{290}$ LEÃO, Raimundo Matos de. Ações para o Teatro: a autoconstituição dos sujeitos no ambiente cultural soteropolitano. Diálogos \& Ciência - Revista da Faculdade de Tecnologia e Ciências. Ano 9, n. 25, mar. 2011, p. 6-7.
} 
de Casamento, realizada no salão da "Agremiação" dos Fantoches da Euterpe, que galgou popularidade e lotou o espaço. O público, já há alguns meses acompanhador assíduo da iniciativa de apresentação de textos internacionais do grupo ${ }^{291}$, aprovou amplamente a montagem, que naquela temporada vinha com a inovadora medida de deixar o público na penumbra, algo então nunca visto: "A deliciosa comédia burlesca (...) constituiu mais um pleno sucesso"292. E a atuação de Hildegardes Cantolino Viana, no papel de Natacha (no original, Natalia), mereceu destaque nos jornais pela "destreza" e "naturalidade", quase "profissionais" 293.

No ano seguinte, na curta temporada com estreia em 24 de novembro de 1951, o Grupo de Amadores Bandeirantes, sobre direção de Osmar Rodrigues Cruz, encenaria a mesma peça em São Paulo ${ }^{294}$. O texto, com tradução do diretor, se transformaria em uma das primeiras traduções de Um Pedido de Casamento, publicada pela Livraria Teixeira $^{295}$. O Grupo de Amadores já vinha de uma série de apresentações no Clube de Teatro, todas em torno de textos breves e cômicos, como Amor por Anexins, de Arthur Azevedo, em julho do mesmo ano.

Esta tradução de Adacto Filho seria fundamental no processo de popularização da peça de Tchékhov. No ano seguinte, $1952^{296}$, a mesma tradução seria utilizada na encenação de Um Pedido de Casamento realizada pelo "Teatro Experimental do Pessoal da Caixa Econômica", apresentada em sessão única no dia 08 de setembro de 1952, no Teatro Serrador, no Rio Janeiro ${ }^{297}$. Curiosamente, a encenação amadora do grupo, sob direção de Expedito Pôrto e cenários de Santa Rosa, seria a primeira montagem de Tchékhov a ser levada para a TV. A exibição foi realizada no dia 27 do mesmo mês, às

\footnotetext{
${ }^{291}$ A temporada ainda contou com as apresentações de "Eterna Anedota" de Bernard Shaw, "Sonho de Uma Noite de Verão", de William Shakespeare e "A Importância de Ser Franco", de Oscar Wilde. Idem, p. 7.

${ }^{292}$ Um Pedido de Casamento pelo Teatro Íntimo de Fantoches. A Tarde. Salvador, 16 mar. 1950. ${ }^{293}$ Idem, ibidem.

${ }^{294}$ No elenco: Nelson Gonçalves (Ivan), Rafael Franceschi (Stefan) e Luisa Cristófaro (Natalia). Ver: Programa de Peça - Clube de Teatro. São Paulo, Ano 1, n.7, nov. 1951.

${ }^{295}$ Ainda que não tenhamos encontrado a publicação deste texto para consulta, é feita uma referência a esta edição em: LUCIA, Maria. Osmar Cruz completa trinta anos de teatro. A Gazeta. São Paulo, 14 out. 1975.

${ }^{296}$ Vale lembrar que, em julho deste ano Ruggero Jacobbi dirigiu "Um Pedido de Casamento", com produção da Escola de Arte Dramática (EAD). A estreia foi no Sanatório Otávio de Freitas, no Recife. Sem muitas repercussões junto ao público e a crítica, o espetáculo teve curtíssima temporada. Ver. BERENICE, Raulino. Ruggero Jaccobi: presença italiana no teatro brasileiro. São Paulo: Perspectiva/Fapesp, 2002, p. 178.

${ }^{297}$ Na mesma noite, foram encenadas pelo mesmo grupo as peças "A Medalha", de Moisés Duék, e "Tudo está perdido", "drama plangente, em 1 ato, de autoria de um colega". No elenco da peça de Tchékhov: Donaldson Golçalves (Tchubukov), Vicente Cosale (Ivan Lomov) e Isa de Macedo (Natalia Stephanova). Ver: Programa da Peça - Associação do Pessoal da Caixa Econômica. Rio de Janeiro, set. 1952.
} 
20h, com gravação no "Teatrinho Kibon", palco televisivo no qual eram encenadas peças para exibição televisiva.

A peça de Tchékhov continuaria percorrendo os palcos de cinemas, teatros, agremiações e clubes amadores até fins da década de 1960. E é interessante notar que fenômeno bastante semelhante se dera na Rússia. As peças em um ato do dramaturgo fizeram enorme sucesso em clubes de província e nos palcos improvisados de grupos amadores por todo país ${ }^{298}$. Como vimos, estas produções estavam em sintonia com o trabalho de produção de contos humorísticos do autor que aos poucos caminhavam para um novo tom. Tanto que suas peças maiores, se podem ser recuperadas em um mesmo fio dentro de seu trabalho bastante específico com a comicidade, operariam em chave diversa e, inicialmente, dependeriam de novas condições da cena para se afirmar. No Brasil, como se vê, tais farsas em um ato emergem em um contexto de renovação dos palcos das principais capitais do país e seu papel é ambíguo. Se por um lado há o movimento que adere estas farsas a uma busca por uma linguagem nova, diferenciada, pelo que têm de próximo da dinâmica linguagem popular e de tradições do cômico; por outro, emergem no repertório de alguns grupos apenas pela facilidade da encenação e praticidade do texto, que se em uma mão podem ser bem aproveitados, por outra, podem servir a um gosto puramente digestivo e comercial.

É entre esses dois polos que caminharão as encenações dos "quiproquós" tchekhovianos dos próximos anos, espalhados por todo país. São muitas, com maior ou menor repercussão. Em novembro de 1952, a encenação de O Urso e Um Pedido de Casamento pela Agremiação Goiana de Teatro. Em 21 de setembro de 1957, no Distrito Federal, a versão abrasileirada desta última peça, recontextualizando-a no interior de uma fazenda brasileira, feita pelo Teatro Rural do Estudante, em homenagem ao Dia do Lavrador. Nesta montagem, em interessante direção de B. de Paiva, emergem as personagens Juliano, Ivo e Natália, ao invés de Stepan Stepánovitch Tchubúkov, Natália Stepánova e Ivan Vassílievitch, abrasileirando o nome como um recurso de familiarização.

Em 1958, O Tablado, que se configuraria como o principal grupo amador do país, levaria à cena no Rio de Janeiro $O$ Jubileu, com direção de Rubens Corrêa. Fazia parte do mesmo espetáculo a peça cômica de Gógol, $O$ Matrimônio, esta dirigida por

${ }^{298}$ GOTLIEB, Op. Cit., p. 41-46. 
Maria Clara Machado ${ }^{299}$. No programa das montagens, o grupo apresentava a peça de Tchékhov como "uma espécie de exercício feito à maneira de 'vaudeville"'300. No entanto, diferentemente de montagens anteriores das farsas tchekhovianas, esta montagem do Tablado explorou as nuances da comicidade que seria marca decisiva da poética do dramaturgo. Iluminando esse texto curto pela luz de suas peças maiores, o grupo buscou na leveza e graça dessa peça o limite entre o cômico e o "sério":

(...) e realizou esta 'brincadeira em um ato', uma pequena obra prima de ironia e humor; a ambientação e as personagens lembram muito os seus contos humorísticos, e o tema da saturação humana provocada por temperamentos, emoções, necessidades e fraquezas opostas, que foi também explorado em outras cinco peças: 'O pedido de Casamento', 'O Urso', 'Trágico à Força', 'Sobre o dano que provoca o fumo' e 'O Casamento'. ${ }^{301}$

A concepção cênica, que fugiu à simples reprodução de receitas do universo farsesco, tentou trabalhar com os atores em formação uma linguagem mais clara, direta, sem qualquer recurso a uma impostação "importada". Rubens Corrêa, que dirigia ali seu primeiro e último espetáculo n'O Tablado, trouxe para esta encenação, que teve tradução exclusiva do texto feita por Eugênio Kusnet ${ }^{302}$, uma leve marca que lhe seria profundamente cara: a de explorar nas situações cotidianas o que elas têm de grotesco $^{303}$, o que colocava a peça de Tchékhov em sintonia com o universo de Gógol, que fazia parte do mesmo espetáculo.

O cenário não trazia grandes inovações para além do realismo da ambientação antiquada, de fins do século XIX. A recepção fora positiva, ainda que sem grandes repercussões, e, em seu geral, vinha no mesmo espírito que marcava uma das frentes do trabalho do Tablado ao longo dos anos precedentes: garantir o contato do público com

299 "O Jubileu". Cenários: Joel de Carvalho; Figurinos: Kalma Murtinho; Elenco: Germano Filho (Kurmá Hirin), Ivan de Albuquerque (Andrei Chiputchin), Jacqueline Laurence (Tatiana), Maria Miranda (Nastassia), Carlos Sagrillo ( $1^{\circ}$ Funcionário), Ugo Barbieri ( $2^{\circ}$ Funcionário), Paulo Matias (Contínuo), João Sérgio Nunes ( $1^{\circ}$ Acionista), Fernando José ( $2^{\circ}$ Acionista), Sérgio Belmonte ( $3^{\circ}$ Acionista), Karl Studart ( $4^{\circ}$ Acionista) e Ruy Pereira ( $5^{\circ}$ Acionista).

${ }^{300}$ Programa da Peça - O Tablado. Rio de Janeiro, 1958, p. 3.

${ }^{301}$ Idem, ibidem.

${ }^{302}$ FONTA, Sergio. Rubens Corrêa - um salto para dentro da luz. Col. Aplauso. São Paulo: Imprensa Oficial, 2010, p. 67.

${ }^{303}$ Anos mais tarde, Rubens Corrêa diria, referindo-se a sua participação em Tio Vânia, mas estendendo a afirmação ao patamar de gosto geral: "Sem querer, por intuição também, que achei um pouco meu forte no teatro. Eu me encontro muito no grotesco do ser humano, que te emociona e que te faz rir, dando a dimensão da pessoa no seu total." Ver: Rubens Correa - 'os ciganos sempre sobreviverão'. Entrevista com Rubens Corrêa. Jornal Refletor. Rio de Janeiro, Ano 1, nº 6, set. 1982. 
autores até então virtual ou inteiramente desconhecidos. Tanto que, para Yan Michalski, O Tablado se converteria em um dos grandes divulgadores da dramaturgia russa entre nós ${ }^{304}$. Tratava-se de projeto do grupo, ao contrário do que ocorrera com o Teatro Brasileiro de Comédia (TBC), não fazer "qualquer concessão do tipo comercial, qualquer boulevard (...). Mesmo os grandes sucessos (...) não foram pensados em função de um provável êxito de público, e sim porque o grupo tinha vontade de montálos." ${ }^{305}$, daí a necessidade de buscar no repertório estrangeiro textos de renome e qualidade literária.

A afirmação de Yan Michalski é verdadeira no que se refere ao alcance das peças de Tchékhov para o grande público. Entretanto, entre os grupos teatrais, profissionais e amadores, as farsas do autor russo a essa altura já gozavam de razoável popularidade e já se desenvolviam para um estágio de compreensão da poética de Tchékhov que estava para além da simples incorporação de seu texto dentro do que seriam os padrões "europeus" ou stanislavskianos de encenação. Curioso notar que este questionamento surge com a encenação de suas peças em um ato, talvez justamente porque fora do tchekhovismo que rondava suas peças maiores. A esta altura, as peças grandes de Tchékhov em ritmo lento começavam a ganhar os palcos das capitais e, junto a elas, uma concepção específica de encenação. As peças em um ato pareciam ao mesmo tempo constituir um universo específico, que tinha muito de diálogo com a própria comédia de costumes brasileira e, talvez porque um "gênero menor" ${ }^{306}$, mais aberta a dialogar com o Tchékhov estandardizado e, concomitantemente, dele se distanciar. É com esse espírito de deslocamento declarado que algumas encenações dessas farsas emergirão nesse período. Anteriormente, tais questionamentos aos padrões de encenação surgiam pouco delineados, sem caráter programático (como vimos com o TEP ou com O Tablado). Agora, explicitam-se:

Não nos preocupam, nessas farsas, os famosos estados de alma tchekhovianos. Nelas, Tchekov revive a tradição de um teatro popular: o da comicidade crua e direta e da expressão simples e imediata. Seu valor fundamental é a vitalidade frenética que as

\footnotetext{
${ }^{304}$ No repertório do grupo, teriam sido ao total cinco peças russas ("Tio Vânia", "O Jubileu" e "Platonov" de Tchékhov; "O Matrimônio", de Gógol, "Vassa Geleznova", de Górki. No quadro geral do repertório do grupo, os textos russos estavam atrás somente da dramaturgia francesa.

${ }^{305}$ MICHALSKI, Yan. O repertório adulto: ecumênico e conservador. In: Dionysos 26. Rio de Janeiro: MinC/INACEN, 1986, p. 69-71.

${ }^{306}$ Aqui me refiro a já conhecida expressão de Aristóteles que, ao deixar a comédia fora de sua Poética, classificou-a como "gênero de homens menores". Ver: ARISTÓTELES. Arte Retórica e Arte Poética. Trad. Antonio Pinto de Carvalho. Rio de Janeiro: Ediouro,S/D.
} 
anima. Esse foi o valor fundamental escolhido para ser projetado para a plateia pelo espetáculo. Trata-se de fazer justiça não a um Tchékhov metafísico, convertido pela generalização teórica numa ideia platônica, mas a um Tchekov real, i. e. aos termos em que se manifesta a vida de suas peças. ${ }^{307}$

É este o espírito de ruptura por trás das encenações do Festival Tchékhov, realizado em abril de 1962, em Salvador, pelo grupo A Barca, parte da União dos Estudantes da Bahia. O diretor Luiz Carlos Maciel (que mais tarde seria um crítico feroz das encenações "bem comportadas" de Tchékhov) esclarecia no programa que a intenção das encenações era tornar o autor russo menos intelectualizado e distante dos "manuais" de interpretação. Para ele, era preciso acabar com a ideia destruidora de uma "fidelidade ao texto". Nesse sentido, todo o trabalho de direção é um trabalho de interpretação e o trabalho do crítico, por consequência, deve ser o de analisar experiências interpretativas concretas, e não abstratas, de encenação. E sua interpretação para os textos de Tchékhov é clara: produzir uma encenação limpa, direta, sem esteticismos, "endereçar seu espetáculo a um público maior, numa linguagem que não seja compreendida apenas pelos privilegiados capazes de usufruir os encantos estéticos das sutilezas e do bom-gosto" ${ }^{\prime 308}$. Por isso, todo o conjunto do espetáculo trabalhou para resultar em "obviedade" cênica. O cenário simplificado, reduzido ao funcional, possuía pequenos elementos de contextualização das peças no ambiente russo. A força estava concentrada na intensidade dos diálogos, destacados antes de tudo para garantir a força de comunicação das peças. E o objetivo foi amplamente atingido, lotando o Teatro Santo Antonio com um público jovem e uma quantidade expressiva de trabalhadores. Tanto que o mesmo Festival fora apresentando no IV Festival Nacional de Teatros de Estudantes, realizado no mesmo ano, em Porto Alegre, também com amplo sucesso.

O mesmo espírito de comunicabilidade, que tinha acentuado teor político e que ser tornava cada vez mais um imperativo de época (por se propor a ampliar o alcance do teatro como arte popular), marcou as encenações de Um Pedido de Casamento feitas por Luiz Nagib Amary, em agosto de 1962 no XI Festival Universitário de Arte de Minas Gerais, em Belo Horizonte. Ou ainda, no Festival Tchecov dirigido por Sergio Mibielle, que estreou em 11 de setembro de 1964, no Teatro da Rádio Itatiaia de Belo Horizonte com os espetáculos O Canto do Cisne, O Urso e Os Males que o Fumo Produz. E, daí em diante, a lista se estenderia a ponto de tornar exaustivo o comentário. Pode-se dizer

\footnotetext{
${ }^{307}$ Programa da Peça - Festival Tchekhov - A Barca. Salvador, abr. 1962.

${ }^{308}$ Idem, ibidem.
} 
que as pequenas peças em um ato de Tchékhov já corriam com popularidade entre os grupos culturais das principais capitais teatrais do país ${ }^{309}$. Ora servindo a propósitos de engajamento e popularização do teatro, ora à necessidade de um texto de qualidade e inegável apelo popular, ora à tentativa profunda de estabelecer conexões entre as tradições da comédia brasileira e russa. De fato, o que se vê, é que esse filão da dramaturgia de Tchékhov parece ter sido o que, inicialmente, galgou maior popularidade no Brasil. Fenômeno curioso, pois nos dias de hoje são justamente suas peças maiores as que gozam de amplo reconhecimento do público e da crítica, a ponto de, para muitos, suas peças em um ato serem consideradas terreno desconhecido ${ }^{310}$.

\subsection{O cômico não parece sério}

Um dos motivos para que as peças em um ato de Tchékhov tenham se convertido em "área menor" de seu teatro pode estar no modo secundarizado com que a comédia sempre foi tratada frente a outras formas dramáticas. O fenômeno não é apenas brasileiro. Na Rússia, após a consagração de seu teatro pelas encenações do TAM, suas farsas passaram a ser consideradas "peças de juventude", "ligeiros vaudevilles", sem o peso dramático-ético de suas peças maiores. Na Europa e nos Estados Unidos, sequer passaram por essa etapa preparatória, já que a introdução do teatro de Tchékhov se dera por suas quatro grandes peças vindas no repertório das grandes companhias em excursão ou nas temporadas de diretores emigrados. No Brasil, ainda que nossa tradição da comédia esteja na matriz da formação de nosso próprio teatro, a valorização do gênero como algo "sério", pelo críticos e pelos grupos profissionais, é recente. Tanto que este fenômeno introduz e impulsiona e o estudo sobre o caso específico de Martins Pena, no qual Vilma Arêas constata uma dura realidade:

\footnotetext{
${ }^{309}$ Muitas seriam as encenações de suas peças em ato até fins de 1970. Depois desta data, sua frequência diminui e a atenção dos artistas e do público se volta para suas peças maiores. 1962 - Tio ânia. Alberto D'Aversa/EAD, São Paulo. / 1962 - Um Pedido de Casamento. Luiz Nagib Amary, Belo Horizonte./ 1964 - Festival Tchecov. Sérgio Mibielle, Belo Horizonte./ 1965 - Festival Anton Tchekov Grupo Dramático do SESI, São Paulo./ 1966 - Três Comédias em Um ato Maria Clara Machado/Teatro do Conservatório, Rio de Janeiro./ 1966 - Um Pedido de Casamento/ O Aniversário. Cláudio Heemann/CAD, Porto Alegre/ 1966 - O Pedido de Casamento.Maria H. Magalhães, Rio de Janeiro./ 1966 - Pedido de Casamento.Grupo de Teatro André Luiz (GATAL), Marília. / 1967 - Um Pedido de Casamento/ O Jubileu. Dulcina de Moraes/ FBT, Rio de Janeiro./ 1969 - Trágico à Força/O Urso. João Ribeiro Chaves/ Grupo Casarão, SP.

${ }^{310}$ Ver nota introdutória no livro organizado por Homero Freitas de Andrade. TCHEKHOV, Anton. Os Males do Tabaco e outras peças em um ato. São Paulo: Ateliê, 2003, p. 9-10.
} 
ausência quase absoluta de suas peças nos repertórios profissionais, ficando relegadas ao empenho dos amadores. Certamente isso se dá segundo o consenso de sua propalada facilidade, decorrente de uma preconceituosa noção de farsa e comédia, frente às formas dramáticas mais respeitadas. ${ }^{311}$

Tal diagnóstico é confirmado também por Beti Rabetti:

Durante toda uma etapa do processo de 'modernização teatral' (e concentradamente nos anos 40) o objetivo de colocar o teatro brasileiro 'em dia' com o teatro internacional foi percebido como necessária negação a uma sorte de obscura tradição, cômica e popular. $^{312}$

É o que fica evidente pela ausência prática das peças em um ato de Tchékhov do repertório dos grupos profissionais. A única encenação de Um Pedido de Casamento, que reinaria praticamente isolada até a década de 80, caberia ao Teatro Brasileiro de Comédia (TBC).

O grupo impulsionado por Franco Zampari já vinha se afirmando na cena paulistana como emprendimento sério que se profissionalizava desde "Nick Bar", em 1949. E na noite de 24 de janeiro de 1950 se dá a estreia de dois espetáculos: Huis Clos ("Entre Quatro Predes"), de Sarte e Um Pedido de Casamento, de Tchékhov, que seriam o marco da efetiva profissionalização do grupo, agora com um elenco fixo de doze atores $^{313}$. A noite, portanto, era esperada e prometia.

Isto ficou evidente com a repercussão posterior, que rapidamente ocupou o espaço dos jornais. A peça de Sartre fora considerada imoral e unificou, ao mesmo tempo, as vozes da Igreja e do Partido Comunista. Os atores chegaram mesmo a ter de se confessar diante dos padres antes das próximas encenações, dado o grau de incômodo gerado por aquela peça em que três personagens em um sufocante ambiente gradualmente revelam-se e enfrentam-se.

\footnotetext{
311 ARÊAS, Vilma. Na Tapera de Santa Cruz - uma leitura de Martins Pena. São Paulo: Martins Fontes, 1987, p. 1.

312 RABETTI, Beti (Maria de Lurdes Rabetti) (Org.). Teatro e Comicidades: estudos sobre Ariano Suassuna e outros ensaios. Rio de Janeiro: 7 Letras, 2005. p. 31.

${ }^{313}$ PEREIRA, Maria Lúcia. Antecedentes e História Cotidiana do TBC. In: Dionysos $n^{o} 25$. Rio de Janeiro: Ministério da Educação e Cultura/SEAC/FUNARTE/SNT, 1980, p. 78.
} 
Por isso, é curioso pensar o que levara o TBC a colocar em uma mesma noite duas peças de naturezas tão diferentes. Se por um lado a peça de Sartre traz evidente carga dramática e levanta explicitamente questões de ordem ética e moral, a peça de Tchékhov não parece ter sido escolhida com o mesmo propósito. Possivelmente, a seleção se dera a fim de suavizar o fechamento do espetáculo com um "boulevart" de qualidade (o que por fim poderia amortecer o próprio impacto desejado pelo texto de Sartre) e preencher a noite com uma peça curta que garantisse o tempo padrão de permanência do público no recinto. É o que fica evidente nas escolhas de direção que guiaram a montagem. $\mathrm{O}$ diretor Adolfo Celi acentuou o caráter farsesco da peça, de "comédia de pastelão com grandes barbas postiças e belíssimos fraques de ocasião" ${ }^{314}$. A cenografia de Carlos Giacchiéri ressaltava com o realismo os interiores russos. Os figurinos também preferiram a tipificação farsesca e caracterizaram as personagens no contexto eslavo: o pai de família com barbas longas e traje a "túnica" camponesa, a filha Natália como uma típica camponesa de rosto embonecado e lenços na cabeça e o pretendente Lomov no característico terno.

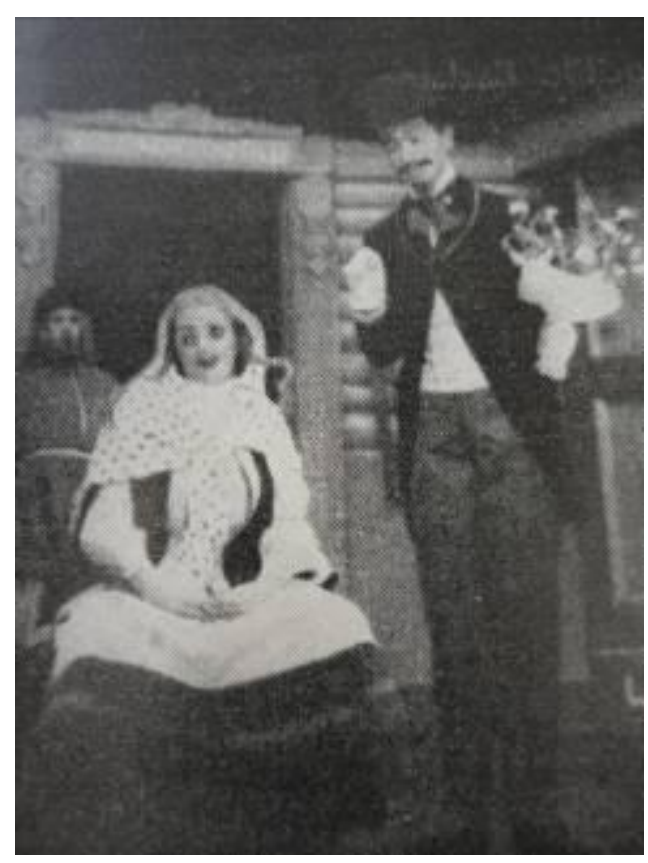

Da esquerda para a direita, Waldermar Wey (Ciubicov - sic), Célia Biar (Natália) e Ruy Affonso (Lomov). Foto - fonte: Encarte TBC - Suas origens (s/d).

\footnotetext{
314 PRADO, Décio de Almeida. Entre Quatro Paredes e O Pedido de Casamento. In: Apresentação do Teatro Brasileiro Moderno 1947-1955. São Paulo: Martins, 1956, p. 249-251.
} 
A encenação teve dois elencos diferentes. Sérgio Cardoso-Cacilda BeckerWaldemar Wey e Ruy Affonso- Célia Biar- Waldemar Wey. Na noite da estreia, a atuação de Sergio Cardoso destacou-se pelo virtuosismo frenético com que concebeu ser personagem Ivan Vasilievitch Lomov. Para Décio de Almeia Prado, este mesmo virtuosismo seria responsável por um tratamento muito excessivo que, visto à distância, evidenciava não o amor pela personagem ("a ponto de se perder nela como Charles Chaplin se esquece e se perde em Carlitos" ${ }^{315}$ ), mas um tratamento exterior , que parodia e caçoa dela. Cacilda Becker (como Natália) fora versátil no tratamento da personagem e Waldemar Wey tivera dificuldade em fugir do bufônico excessivo, que impedia mediações necessárias. Em suma, uma apresentação respeitável e bem cuidada (como queria firmar o TBC), mas com dificuldade em encontrar tons "pasteis" (mesma crítica feia à montagem de Sartre), que permitissem ao conjunto revelar em um crescente os absurdos e contradições das relações humanas em jogo. É como se a crítica de Décio demandasse para estas farsas ligeiras de Tchékhov a sutileza no jogo com o cômico que é evidente em seus textos maiores. Por trás o inocente pedido de casamento, a emergência de ressentimentos antigos, de vaidades e disputas, que pedem uma abordagem ao menos "não isenta de malícia" ${ }^{316}$.

Por um lado, é inegável que a encenação de Celi ganhou rápida repercussão e fora vista por centenas de pessoas. Graças ao êxito, a popularização do autor russo (em partes bastante limitada se restrita apenas ao universo amador) acelerava-se, a ponto da tradução feita por Victor Miérinov, especialmente para esta montagem, rapidamente ser utilizada em inúmeras encenações. Por outro, a sensação de um estranho deslocamento do autor. Muito dele advém do ecletismo que marcava as opções dramatúrgicas do TBC (sempre dividido entre um repertório "artístico" e as peças de boa bilheteria), que se reflete na combinação estranha daquela noite inaugural do ano de 1950. Abafado pela interessante repercussão de Huis-Clos, Tchékhov, contraditoriamente, ganhava espaço como um digestivo farsesco para o fim da noite.

Mas a crítica de Décio parece ter repercutido fundo, ao menos em tese. De modo que, quatro anos depois, quando o TBC voltou a encenar a mesma peça sob a direção de Celi, o diretor faria questão de ressaltar no programa o novo tom nela empregado: "Nós que alguns anos atrás tínhamos encenado a peça num tom declaradamente 'de farsa', preferimos encontrar nessa nova 'mise en scene' o substrato da fraqueza do homem

\footnotetext{
315 Idem, p. 250.

${ }^{316}$ Idem, ibidem.
} 
comum, com as suas manias, os seus tiques, o seu ridículo orgulho" ${ }^{317}$. E a montagem do TBC galgou tanto sucesso que, alguns meses antes, estivera em São Paulo, sob direção de Ziembínski ${ }^{318}$ no "teatro das segundas-feiras" e, meses depois, no Rio, para a temporada carioca do TBC, sob a direção de Celi $^{319}$. Ocorre que, na prática, a crítica ainda veria a encenação sob a direção de Ziembínski como extremamente limitada. Em que pese a aparente banalidade do texto, já há ali a presença da ironia tchekhoviana que, segundo a revista Anhembi, foi completamente suplantada pelos atores em nome de uma gesticulação excessiva que tornava a expressão das personagens exterior e artificial. A recitação burlesca de Cleyde Yáconis (como Natália Stepánovna) e Luis Calderaro (como Tchubúkov) teriam explorado melhor a comicidade da peça se conseguissem, a um só tempo, respeitar o ritmo de "bailado" da trama e ver em cada ação individualista das personagens que, longe de quererem provar algo filosófico, expõem-nos, em um só gesto, o ridículo e o trágico de suas ações ${ }^{320}$. Mais uma vez, pecava-se pela falta de sutileza que, nas palavras do crítico, estaria presente mesmo no "teatro menor" de Tchékhov: "No grande livro da humanidade não se encontram posições absolutas. Fato que os atores do TBC não parecem ter levado muito em conta" ${ }^{321}$.

Curioso notar que, ainda que nenhuma das grandes peças de Tchékhov tivesse sido encenada no Brasil, o encarte já propalava uma concepção muito específica do tchekhovismo, que ficaria patente em uma das encenações antológicas de As Três Irmãs, feita por Ziembínski cinco anos mais tarde: "Nada se encontra no 'O Pedido de Casamento' daquela íntima e crepuscular melancolia tão querida ao autor de Tio Vânia" ${ }^{322}$. Em certo sentido, trata-se de ver no desenvolvimento da dramaturgia de Tchékhov não fios de continuidade que parecem ligar os diferentes momentos, pelo contrário: o dramaturgo farsesco é de outra natureza, menos incisiva e profunda. Não à toa o TBC opta por, mais uma vez, promover uma combinação particular para as noites cariocas do grupo, já que em um mesmo espetáculo estavam a peça de Tchékhov e "Antigone", de Anouilh que trazia no elenco, entre outros, Paulo Autran, Cleyde Yáconis e Cacilda Becker.

\footnotetext{
${ }^{317}$ Encarte com histórico do Teatro Brasileiro de Comédia - de São Paulo no Ginástico-RJ. 1954, p. 16.

318 Elenco da temporada paulistana, sob direção de Ziembínski: Luis Calderaro (Ciubocov); Benedito Corsi (Lomov); Cleyde Yáconis/ Célia Biar (Natália).

319 Elenco da temporada carioca, sob direção de Adolfo Celi: Benedito Corsi (Lomov); Luis Calderaro (Ciubcov (sic)); Célia Biar (Natalia).

${ }^{320}$ Um pedido de casamento. Anhembi. São Paulo, v.15, no 43, p.120, jun. 1954.

${ }^{321}$ Idem, Ibidem.

${ }^{322}$ Encarte..., Op. Cit, p. 16.
} 


\subsection{O dramaturgo, o melhor professor}

Mais uma vez é com os grupos amadores que Tchékhov promoverá seu encontro com a cena brasileira. As suas grandes peças, escritas por ele há mais de cinquenta anos, em cartaz e com sucesso de público nas principais capitais europeias, eram aqui ainda matéria de conversas restritas, de pessoas que porventura tomaram contato com antológicas encenações no exterior ou que delas ficaram sabendo por leituras de segunda mão. Exceção para a temporada de 1954 da companhia francesa Louis Barrault-Madeleine Renaud, que em sua penúltima récita da temporada apresentou $L a$ Cerisaie ( $O$ Jardim das Cerejeiras) e, dada a limitação dos preços e da língua, esteve restrita a um público muito seleto ${ }^{323}$. Curiosamente, já se tratava de peça que revisava o exotismo restritivo das encenações de Ptoëff e erguia o dramaturgo russo ao patamar de universal, pois falava da inexorável "passagem do tempo", e isso poderia ser dito e entendido por qualquer pessoa, de qualquer nacionalidade ${ }^{324}$.

Em verdade, o fato é que até meados da década de 50 ainda não havia em circulação nenhuma tradução em edição brasileira de tais textos, sequer em tradução informal de grupos teatrais. Em comentários críticos, a referência a elas emergia rapidamente, e já com alguma cristalização. Ecos do tchekhovismo aproximavam-se antes mesmo da própria leitura dos textos. Seja pela sensação produzida por encenações internacionais (e já vimos como Pitoëff, Eva Le Gallienne e outros - ativos neste período - contribuíam para esse paradigma), seja pela própria perspectiva cênica trazida por diretores emigrados, que ou passaram rapidamente pelo Brasil (como Jouvet e Turkov) ou que aqui residiam e faziam escola. Para este exemplo, ficou patente a voz autorizada de Adolfo Celi, italiano radicado no Brasil, num rápido comentário em programa de peça do TBC, em que deixava algumas marcas a respeito de sua leitura das grandes peças de Tchékhov: "íntimas" e "crepusculares".

Ora, não pareciam de imediato convidativas estas peças de tom melancólico e ritmo lento, a despeito de seu sucesso internacional. E para grupos profissionais, então em formação no Brasil e lidando com a constante pressão da bilheteria, seria muito arriscado ir de encontro ao gosto público, mais simpático à intensidade e à ação dramática. O Tchékhov "farsesco", ainda que lido em chave redutora, tinha aqui seu

\footnotetext{
${ }^{323}$ CARVALHO, Martinho (org.). Paschoal Carlos Magno: Crítica Teatral e outras Histórias. Rio de Janeiro: FUNARTE, 2006, p. 258-260.

${ }_{324}$ BARRAULT, Jean-Louis. Why The Cherry Orchard?. The Theatre of Jean-Louis Barrult. London: Barrie and Rockliff, 1959, p. 104-105.
} 
quinhão de "nosso". Mas o Tchékhov "crepuscular", "eslavo", "sem dramaticidade", seria um risco tremendo aos atores de carreiras promissoras e aos grupos desejosos de se firmar com sucessos de bilheteria.

Nesse sentido, não é de se estranhar que a primeira encenação de uma peça grande do dramaturgo, Tio Vânia, tenha sido encenada por um de nossos principais grupos amadores: O Tablado. Ainda que a opção não deixasse de gerar constantes intrigas, o grupo paulatinamente firmava sua orientação amadora como uma escolha, e as razões eram muitas: para tornar o trabalho um aprendizado, para não sofrer pressão por prazos de estreia, para respeitar os tempos de formação do grupo ${ }^{325}$. E isto, curiosamente, parecia um terreno propício para o amadurecimento do estudo sobre uma dramaturgia que repele a falta de cuidado e a ausência de trabalho de conjunto.

E foi um trabalho cuidadoso de quatro meses de ensaios que culminou na estreia de 8 de dezembro de 1955. O diretor Geraldo Queiroz, que ao longo de toda sua carreira sempre estaria dividido entre as funções de diretor e crítico, tratou de conduzir o trabalho desde o início. Acompanhou passo a passo o processo de tradução feita do francês por Aníbal Machado, que a um só fôlego fez a versão para o português, pois assim teria condições de "estudar profundamente a peça". No elenco, atuavam, entre outros, Claudio Correia e Castro (como Vânia), Beatriz Veiga (como Yelena (sic)), Maria Clara Machado (como Sonya) e Rubens Corrêa (como Telyegin (sic)) ${ }^{326}$. Para muitos deles, tratava-se de oportunidade ímpar, pois o grupo atravessava um dos seus melhores anos, com encenações que foram verdadeiros sucessos de público e com boa repercussão na crítica. Já haviam encenado Baile dos Ladrões, de Anouilh, A história de Tobias e de Sara, de Paul Claudel, Pluft, o fantasminha, de Maria Clara Machado, e, agora, Tio Vânia ${ }^{327}$. O espetáculo fora tão decisivo que, para atores como Rubens Corrêa, aquela temporada serviu de primeiro grande marco na carreira. Jovem ator de 24 anos, tivera a incumbência, depois de uma série de testes, de representar Telêguin senhor de terras decadente com quase oitenta anos (!). A atuação fora bastante elogiada e o ator faria questão de voltar com carinho a Tchékhov anos mais tarde.

\footnotetext{
${ }^{325}$ MACHADO, Maria Clara. "Profissionalização e Outros problemas do Grupo Amador". In: Revista Dionysos - O Tablado $n^{o} 27$. Rio de Janeiro: MinC/ INACEN, 1986, p. 51-54.

${ }^{326}$ Elenco completo: Elenco: Carmem Silvia Murgel (Marina); Napoleão Moniz Freire (Mihail Astrov); Cláudio Corrêa e Castro (Tio Vânia); Nelson Mariani (Alexandre Serebryakov); Maria Clara Machado (Sonya); Beatriz Veiga (Yelena Andreyevna); Sônia Cavalcanti (Marya Vassilyevna); Denis Estill (Yefin). Ver: Programa de peça. Tio Vânia. O Tablado. Rio de Janeiro, 1955, p. 5-6.

${ }^{327}$ MICHALSKI, Op. Cit., 1986, p. 69-71.
} 


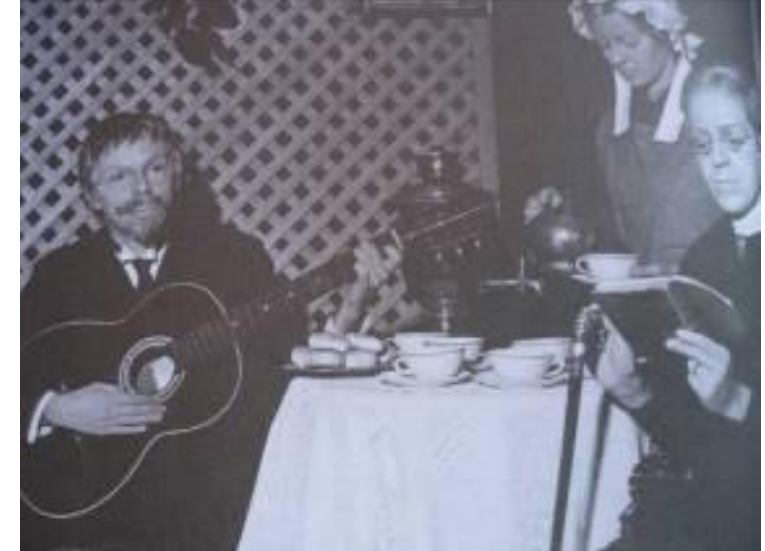

Da esquerda para a direita: Rubens Corrêa (Telyegin (sic)), Carmem Silvia Murgel (Marina) e Sônia Cavalcanti (Marya Vassilyevna (sic)). Fonte: FONTA, Op. Cit, p. 61.

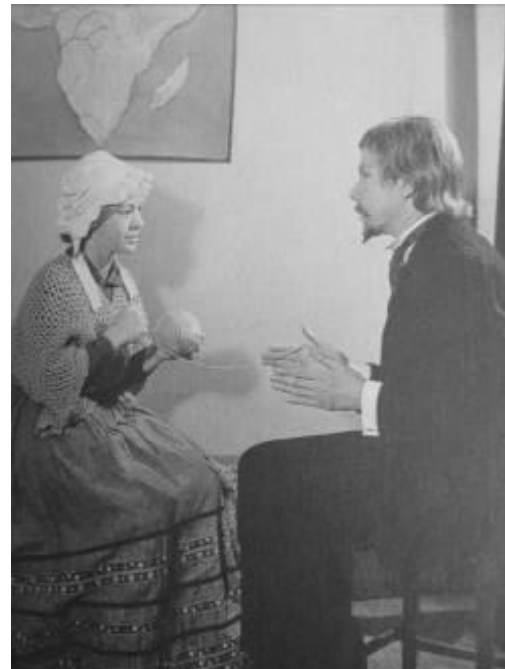

Da esquerda para a direita: Carmem Silvia Murgel (Marina) e Rubens Corrêa (Telyegin (sic)).Fonte: FONTA, Op. Cit., p. 62.

O empenho dos atores no processo de concepção das peças e nos ensaios era evidente. E o diretor Geraldo Queiroz percebia a empolgação geral, a ponto apenas reforçar o ponto de vista de que não se tratava de empecilho montar uma peça como Tio Vânia com um grupo amador. Em entrevista, contestara o entrevistador:

Não. A este propósito [montar Tio Vânia com um grupo amador], nada melhor que reproduzir uma opinião de Eva Le Gallienne, no prefácio da edição inglesa das obras de Tchekhov: 'os grupos amadores extremamente ligados por um ideal e cujos membros se conheçam intimamente, podem obter de Tchekhov espetáculos muito mais homogêneos que grandes elencos, onde cada grande ator procura projetar mais alto a sua interpretação. ${ }^{328}$

E a orientação que os guiava era de "buscar o ritmo mais adequado dentro de sua linha" ${ }^{329}$. Muito dessa concepção advinha, possivelmente, das experiências do diretor Geraldo Queiroz com as encenações que tivera a oportunidade de ver na Europa. Vira as versões italiana de As Três Irmãs, com direção de Luchino Visconti, e inglesa, que tinha em seu elenco atores como Celia Johnson, Ralph Richardson e Margareth Leighton. Reconhecia que o "ritmo russo" era difícil e que mesmo diretores como Ptoëff

\footnotetext{
328 'Tio Vânia e seu diretor. Entrevista sem localização da fonte. 08 dez. 1955. Disponível no Acervo de Teatro da FUNARTE - Pasta "Tio Vânia".

${ }^{329}$ Idem, Ibidem.
} 
e Barrault tiveram de dar-lhe maior aceleração para torná-lo mais "acessível" ao público europeu.

A encenação galgou razoável repercussão de público e crítica, permitiu o acesso a uma peça desconhecida dos palcos brasileiros e abriu espaço para atores que, anos mais tarde, comporiam lugares de peso em nossa constelação; mas, no geral, parece ter ficado para a posteridade com a marca do que o diretor aparentemente tentara evitar. Três anos mais tarde, Paulo Francis se lembraria que a montagem aderiu a um ritmo que, se não é a "linha" do dramaturgo, é pelo menos o que fizeram dele: "acompanhamento de luzes mortiças, véus, só faltando realmente o gongo, para que nos sentíssemos transportados a uma atmosfera de mistério oriental, visto por Holywood." ${ }^{330}$. Este ritmo arrastado, à la "Greta Garbo", fazia com que a expressão "alma eslava" emergisse na cabeça dos espectadores a todo momento durante a encenação. Segundo ele, acontecia na interpretação brasileira o mesmo que se via de maneira proliferada nos palcos europeus: uma tentativa de suplantar o "excesso de trivialidade" na vida daquelas personagens com silêncios abusivos e uma aura quase "mística", num irônico exercício de justificar a grandeza do dramaturgo buscando efeitos onde não há.

Mas se as duras palavras do crítico, que assim como o diretor Geraldo Queiroz tinha experiência com as tendências internacionais, possuem grande parcela de interesse e verdade, não podem ignorar que, ainda que amador, O Tablado, como o TBC e outros, dependia do filtro autorizado das encenações europeias para que assim também concebêssemos as nossas. No programa da peça emergem citações de La Galienne e, em seus depoimentos, referências constantes às encenações dos Ptöeff (responsáveis, como vimos, pela ampla divulgação de Tchékhov na França, com encenações que ganharam com a produção da "alma eslava"). Evidentemente, o crítico já antecipa em sua crítica um ponto de vista de, se não era o "nacional", era o que exigia uma maior liberdade interpretativa a esses modelos internacionais.

Em concepção bastante parecida também viria a encenação de As Três Irmãs, feita pela Escola de Arte Dramática (EAD) de São Paulo, já no ano seguinte. A peça, que estreou nas solenidades do centenário da cidade de Ribeirão Preto, subiu ao palco do Teatro de Exposição no dia 24 de agosto. A direção era de Alfredo Mesquita e no elenco, entre outros, Cecília Carneiro (Olga), Glória Sampaio (Irina), Cândida Teixeira

\footnotetext{
${ }^{330}$ FRANCIS, Paulo. "Tchekhov e seus admiradores (1958)". In: Opinião Pessoal (Cultura e Política). Rio de Janeiro: Civilização Brasileira, 1966, p. 117-126.
} 
(Macha) e Francisco Cuoco (Ivane (sic)). Os ensaios foram conduzidos nas aulas da disciplina de "Comédia", conduzidas pelo próprio diretor ao longo do ano. Menos como espetáculo de bilheteria e mais como exercício de atuação, a peça vinha com a marca do que Maria Thereza Vargas chamaria de "anos teatralmente calmos" ${ }^{331}$. A prioridade era buscar a forma mais clara e límpida de emitir o texto (até então inédito nos palcos brasileiros) e concentrar os esforços no trabalho de estudo da personagem. A tradução do texto, feita por Esther Mesquita exclusivamente para a montagem, tinha forte veio literário. Nesse sentido, o contato com Tchékhov era antes formativo e de divulgação que de ambição de projeto. Questões como esta, para o bem e para o mal, só seriam colocadas para a EAD a partir de 58, quando emergiram dramaturgos "nacionais e contemporâneos", de problemática emancipatória, e seriam propalados os textos de Bertold Brecht ${ }^{332}$.

Por isso, ainda que elogiada pelo empenho e cuidado da encenação, a montagem não teve repercussões maiores e, em seu conjunto, trazia um pouco da concepção que marcaria as montagens de Tchékhov daquele período: uma preocupação demasiada com a tradição (que se verificava no "artificial estilo de época" de figurinos e cenografia, que exigiam do público "apenas um trabalho de identificação" ${ }^{333}$ ) e no ritmo arrastado que, no caso específico de As Três Irmãs, podia chegar ao comprometimento geral da proposta. Tratava-se, evidentemente, de uma concepção crítica e de direção. Alfredo Mesquita era frequentador dos teatros franceses e tivera contato com as principais encenações dos Ptoëff e, no programa da peça, o texto de apresentação de Nelson Xavier destacava o fato de que nas peças de Tchékhov o "supérfluo toma conta do essencial" ${ }^{334}$ e não resta nada senão um profundo sentimento de desolação. Explorou-se menos o modo irônico como as personagens se autoanalisam e acentuou-se a dimensão trágica da peça, por meio de silêncios marcados e a criação de uma atmosfera desoladora: "No fim de um espetáculo de Tchekhov eu acho que deve permanecer no espírito do espectador uma profunda tristeza, uma impressão profunda de que nada vale e que tudo está perdido." ${ }^{335}$

\footnotetext{
${ }^{331}$ VARGAS, Maria Thereza. História da EAD - A vitalidade de uma escola. In: Dionysos - Escola de Arte Dramática $n^{o}$ 29. Rio de Janeiro: MinC/ FUNDACEN, 1989, p. 57.

${ }^{332}$ Idem, p. 59.

${ }^{333}$ FERRARA, José Armando. A cena na Escola - O Curso de Cenografia. In: Dionysos - Escola de Arte Dramática $n^{\circ}$ 29. Rio de Janeiro: MinC/ FUNDACEN, 1989, p. 128.

${ }_{334}^{334}$ XAVIER, Nélson. Sem título. Programa da Peça - As Três Irmãs - EAD, ago. 1956. p. 2.

${ }^{335}$ Idem, Ibidem.
} 

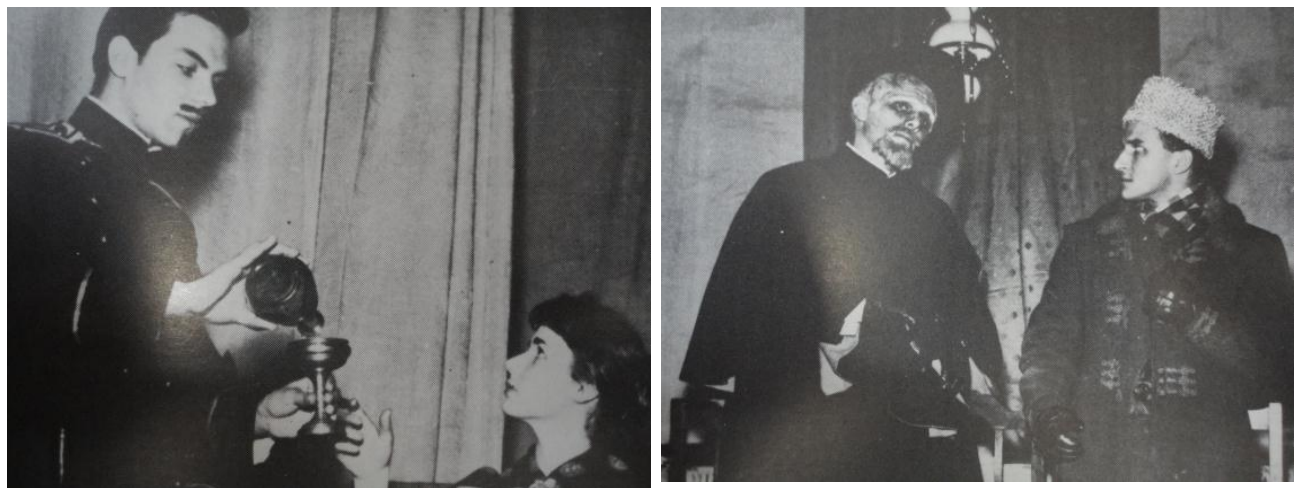

Foto à Esquerda: Samuel Penido (Vassili) e Miriam Mehler (Nathalia). Foto à Direita: Francisco Cuoco (Ivane (sic)) e Alceu Nunes (Andrey) . Fonte: EAD 48-68 - Alfredo Mesquita . São Paulo, S. Est. da Cultura, 1985, p.65 - Arq. EAD)

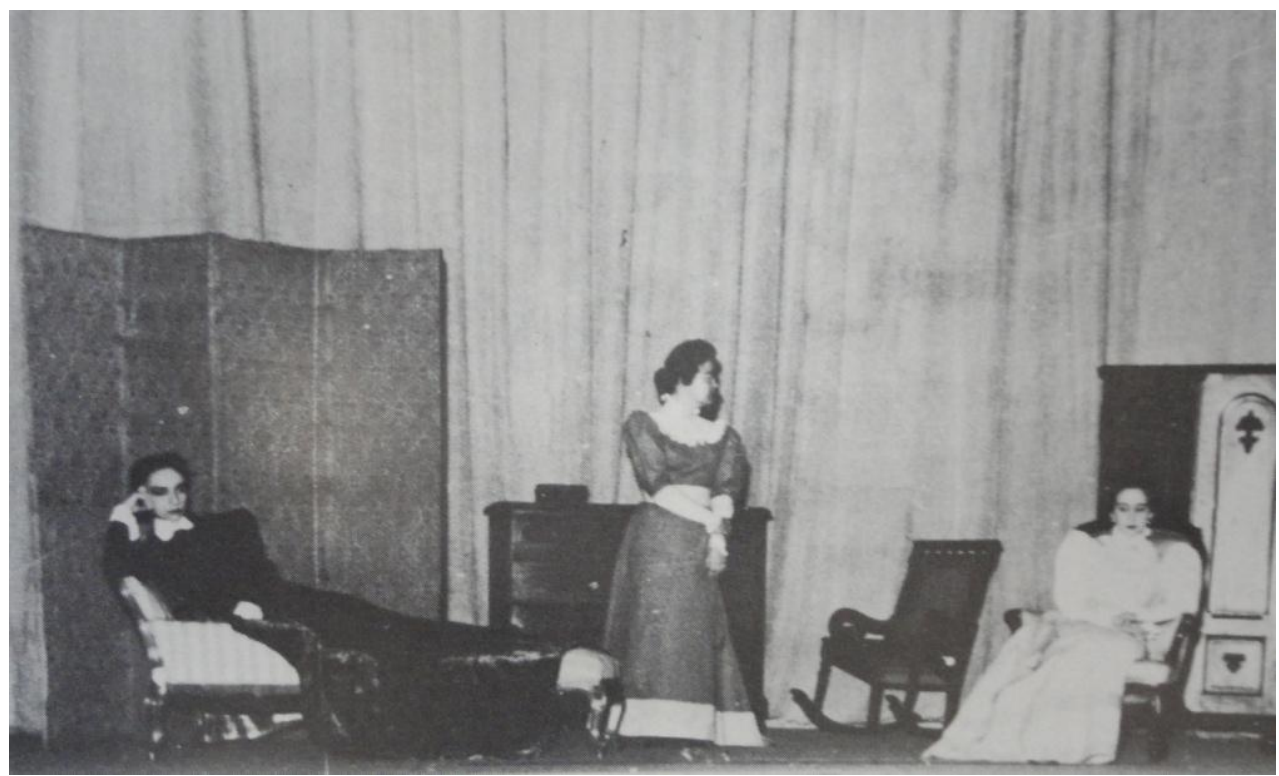

Da esquerda para a direita: Cândida Teixeira (Macha); Cecília Carneiro (Olga); Glória Sampaio (Irina). Fonte: EAD 48-68 Alfredo Mesquita . São Paulo, S. Est. da Cultura, 1985, p.65Arq. EAD)

Ora, é justamente sobre a necessidade de entendimento desses diferentes ritmos presentes em As Três Irmãs que falará Gilda de Mello e Souza que, partindo do entendimento das limitações da encenação da EAD, abre uma das principais reflexões sobre esta peça feita no Brasil. No artigo intitulado As Três Irmãs, publicado dois meses depois da montagem no Suplemento Literário do Estado de São Paulo, Gilda observa que a encenação não fora "impecável" e suas lacunas serviam para abrir reflexões necessárias. Em sua opinião, há diferentes "tempos" para os grupos de personagens presentes na peça. As três irmãs e Andrei representariam, em conjunto, o apego ao que já foi: "O seu tema é ir para Moscou, ou melhor, voltar para Moscou, rever os lugares antigos em que se morou, as ruas de que ainda guardam os nomes. Moscou é o tema da 
memória e do passado" 336 . Já os oficiais Verchinin e Tuzenbach têm desejo de futuro. Ao longo da trama, suas intervenções sempre apontam para o que virá e o desejo de que seja um momento de redenção dos erros do passado: "O seu tema é trabalhar; é sufocar na tarefa cumprida com esforço o sentimento de culpa de sua classe, o remorso das botas outrora tiradas pelo mordomo" ${ }^{337}$. Por fim, a figura de Natacha, esposa de Andrei, a única a "mover-se no presente". Seu pensamento é prático e, enquanto alguns se remoem em lembranças, ela ocupa o espaço da casa, planeja a reorganização dos móveis, instala o amante na sala: "Só ela persegue, determinada, a realização de um fim, só ela se afirma colocando-se no primeiro plano, em detrimento dos demais." ${ }^{338}$ Esta dinâmica parece não ter sido valorizada na encenação da $\mathrm{EAD}$, demasiado presa a criação de uma "atmosfera" e preocupada em garantir a clareza na transmissão do texto. Os diferentes tempos para os grupos, mesclados à individualidade de cada uma das irmãs e das demais personagens, impele a um ritmo bastante difícil que deve ser, a um só tempo, medida geral e expressão das vozes individuais que ora se cruzam, ora se repelem. Nesse sentido, ainda que Gilda constate, de modo geral, que a peça representa um "quadro impressionista" constituído por uma "galeria dos vencidos", melancólica e repleta de desencanto, não se deve derivar daí uma encenação monocórdica, sem sutileza, de ritmo arrastado. Pelo contrário, o desafio será conquistar o tom exato na valorização do detalhe, compreendendo aí os diferentes movimentos dentro de uma mesma "sinfonia".

De todo modo, o mérito da encenação, como o é também o do Tablado, é o de ter trazido para os palcos brasileiros peças até então completamente desconhecidas do público. Nélson Xavier já o reconhece antes mesmo da estreia de As Três Irmãs e afirma no programa da peça:

A dificuldade de representação de Tchékhov, tantas vezes provada, impede que uma companhia se aventure a realizá-la sob pena de um estrondoso fracasso financeiro. Imune a estas consequências e consciente daquelas dificuldades, a Escola de Arte Dramática espera, quando menos, poder divulgar a obra do mestre russo. ${ }^{339}$

\footnotetext{
${ }^{336}$ MELLO E SOUZA, Gilda de. As Três Irmãs. In: Suplemento Literário do Estado de São Paulo. São Paulo, 13 out. 1956.

${ }^{337}$ Idem, Ibidem.

338 Idem, Ibidem.

${ }^{339}$ XAVIER, Op. Cit., p. 2.
} 
Na mesma direção vai Gilda de Mello e Souza que, a despeito dos impasses da encenação, reconhece o interessante fato de que foram a EAD e O Tablado, grupos amadores, os primeiros a explorar as peças maiores de Tchékhov. A explicação estaria no fato de que, ainda que o dramaturgo russo já gozasse reconhecimento internacional e de relativo respeito no Brasil, diretores e grupos profissionais sempre encararam suas peças com veneração e medo. Sua montagem demandaria condições de encenação que, podem constituir o "auge de carreira" e, ao mesmo tempo, podem colocar a perder toda uma temporada. E, para o modo como se constituíam nossas principais empresas teatrais profissionais no Brasil (entre a necessidade de garantir a bilheteria e representar textos de repercussão), Tchékhov se convertia em risco. Em sua dramaturgia, a ausência de enredo, de conflitos evidentes, de personagens de exceção e de imagens fortes, vinha preenchida por uma verdadeira galeria de anti-heróis, envolvidos em diálogos desencontrados e em situações de aparente irrelevância dramática. Nesse universo, o risco da monotonia e do tom equivocado são frequentes - daí o interesse dos grupos amadores. Além de não se prenderem à amarra inicial dos prazos e bilheterias, Tchékhov seria um precioso professor e suas peças um excelente "campo de pesquisa". Ao invés do brilho individual, o trabalho de conjunto, a busca pelos nexos invisíveis que conectam e afastam cada uma das personagens. Ao invés do arrebatamento, localizável já em um primeiro momento, a necessidade de estudo detido e incessante busca dos tons e nuances, possíveis apenas em costura de grupo. Enfim, uma experiência do mais alto valor pedagógico, em um contexto teatral no qual aos poucos superávamos a realidade dos espetáculos construídos às pressas, feitos para um só ator e sem cuidado com a totalidade. Aqui, como na Rússia em fins de XIX, Tchékhov, entre incompreensões e tropeços, contribuía para a renovação de nosso teatro. Se ainda não emergia em encenações que valorizassem a riqueza de sua linguagem, ao menos operava (discretamente, como sempre lhe coube) como mestre da técnica. Nas palavras de Gilda de Mello e Souza: "Neste sentido, Tchecov é uma disciplina admirável." ${ }^{340}$.

\footnotetext{
${ }^{340}$ MELLO E SOUZA, Op. Cit.
} 


\subsection{Tchekhovismo: momentos decisivos}

Seria apressado falarmos em auge do tchekhovismo para a trajetória de peças que só recentemente haviam sido encenadas? O primeiro texto longo de Tchékhov foi encenado por um grupo brasileiro mal havia cinco anos. Comentários críticos de relevância só agora eram publicados em jornais. No entanto, ainda que estivéssemos no início da recepção de seu teatro por nossos palcos, será em inícios dos anos 60 que veremos um dos pontos altos desta concepção do tchekhovismo. Se ela emergia em encenações de repercussão relativa em teatros cariocas e paulistas, agora, com a montagem de As Três irmãs pelo Teatro Nacional de Comédia (TNC), sob direção de Ziembínski, pontos decisivos dessa trajetória de recepção estariam delineados de tal maneira que repercutiriam como referência ao longo dos próximos anos. A montagem tornou-se modelar por inúmeros motivos. O TNC era, naquele momento, espécie de companhia oficial do Serviço Nacional de Teatro. Ao longo dos últimos meses vinha sofrendo com críticas sistemáticas nos jornais cariocas pelo perfil que apresentava de fragilidade de repertório, de concessão às peças comerciais, de inconstância de elenco. Para uma companhia sustentada com verbas públicas, assentada em uma das principais capitais culturais do país, era óbvio ter para si todas as miras apontadas e concentrar todo tipo de expectativa da crítica ansiosa por ver estabelecida uma tradição teatral consistente, como as que se via em outros países.

O TNC vinha de uma temporada difícil, apresentando antes outras duas peças: A Beata Maria do Egito, de Rachel de Queiroz e D. João Tenório, de Zorrilla. A crítica aos espetáculos ia desde a escolha equivocada de um texto dramático ruim de Rachel de Queiroz ao disparate de convidarem um diretor "simpatizante do general Franco" para a peça de Zorrilla ${ }^{341}$. E a peça de Tchékhov, que destoava dentro desse conjunto, seria dirigida por ninguém menos que Ziembínski (que anos antes concentrara para si todos os holofotes da direção de Vestido de Noiva) e já era reconhecida por muitos como verdadeiro desafio de encenação. Isto alimentava a esperança da crítica que, de um lado, oscilava entre o desejo de ver o TNC lançar-se ao desafio de montar apenas clássicos de

\footnotetext{
${ }^{341}$ Ver crítica demolidora de Paulo Francis à $4^{\text {a }}$ Temporada do TNC (1959-1960). Para ele, o texto de Rachel de Queiroz não é teatral e a autora parece distante às principais demandas políticas e sociais do tempo, ainda que completamente imersa nas contradições do contexto nordestino. Já a peça "D. João Tenório" seria de um romantismo decadente, concebida com "cenários horrendo e horrendamente executados por Salvador Dalí". Em ambos os casos, segundo ele, a crítica fora implacável e o teatro estivera entregue às moscas. FRANCIS, Paulo. Teatro Nacional de Comédia é contra o povo e fracassa. Última Hora. Rio de Janeiro, jan. 1960.
} 
maneira popular (seguindo o modelo de Jan Villar, na França), por outro lado, dedicarse à nascente dramaturgia nacional, aos autores preocupados com os problemas do presente $^{342}$.

Assentada nesta corda bamba, a encenação de Ziembínski, feita a partir da tradução elogiada de Maria Jacintha, poderia receber tiros de todos os lados. Seu saldo final foi o de que dividiu opiniões quanto ao sucesso ou ao fracasso, mas de todas recebeu uma ressalva comum: era de uma lentidão angustiante. Augusto Maurício, que escrevera uma nítida crítica laudatória para o TNC, fizera a ressalva ao ritmo escolhido pelo diretor. A encenação durara ao todo quatro horas, começando às $21 \mathrm{~h}$ e terminando à $1 h(!)$. Em sua opinião, a peça

poderia ter sido aparada sem prejuízo para o texto, ao contrário, em seu próprio benefício (...). Se houvessem sido reduzidas as grandes pausas na ação de representação e imprimido ritmo menos compassado ao desenrolar das cenas, estaria a obra mais dentro do nosso entendimento, da nossa compreensão de povo latino. $^{343}$

Este compasso definido por Ziembínski seguia mais ou menos à risca a concepção de Stanislávski de que As Três Irmãs era uma verdadeira sinfonia, e de que de suas linhas emergia a música do sonho decaído das irmãs. E a influência não era pequena: o diretor tivera formação na Polônia e, mais de uma vez, tomara contato com encenações de Tchékhov antes de vir refugiado para o Brasil. Ainda que não apresentasse para os atores suas concepções de cena em forma de "método", jamais chegando a elaborá-las enquanto tal, muito da leitura de Stanislávski rodeava suas encenações $^{344}$. O ritmo arrastado, neste caso, soa como herança direta da leitura "crepuscular" propalada pelo diretor russo.

Mas este problema não seria peculiaridade do diretor polonês. Paschoal Carlos Magno, que estivera na estreia de As Três Irmãs no Serrador acusara o caráter implacavelmente lento da montagem, em nada diverso do que já tinha visto em Londres, Atenas e Milão. Em sua opinião, a produção do TNC nivelava os diferentes ritmos inerentes à peça de Tchékhov sob uma concepção de que todo o conjunto das

\footnotetext{
342 Idem, Ibidem.

${ }^{343}$ MAURICIO, Augusto. As Três Irmãs. Jornal do Brasil. Rio de Janeiro, 09 fev. 1960.

${ }^{344}$ Ziembínski - Entrevista. Depoimentos VI. Rio de Janeiro: MEC/SNT, 1982, p. 171-190.
} 
personagens apenas ruminava "revoltas, desesperos". No entanto, cada um deles é "uma confissão ambulante", específica:

ou não se mascara diante dos que o rodeiam, debatendo seus problemas, procurando descobrir ou sabendo que não encontrará nunca soluções para suas angústias. Essa extroversão [grifo nosso] - que está sempre presente em todos os tipos do teatro tchekhoviano - era para diminuir o ar soturno, sombrio, como os não-russos têm realizado os russos no palco. ${ }^{345}$

O problema do ritmo tinha relação direta com uma compreensão d'As Três Irmãs como tragédia ${ }^{346}$, fechando as brechas que permitiriam explorar o que Peter Szondi entendeu como capacidade das personagens se autoanalisarem de forma irônica ${ }^{347}$. Ou seja, não se trata de abordar vidas que se esvaem e veem seus sonhos se desvanecerem de maneira inconsciente. As personagens desta peça assumem-se gradativamente e relutam com sua própria consciência o tempo todo. E a ironia só pode brotar em um terreno em que é possível se colocar em perspectiva analítica em relação ao mundo. Em Tchékhov, e nisto reside sua beleza, esta dimensão amarga vem combinada com forte dose de sonho e esperança, desbastando de vez qualquer possibilidade naturalista e empurrando as personagens para o futuro, momento no qual os erros do passado seriam redimidos. Em conversa com Nina Ranevsky, que anos antes dirigira o Festival Tchékhov, no Rio, Paschoal Carlos Magno ouvira da diretora a angústia pela direção de Ziembínski, que ignorou que nas peças de Tchékhov "há uma esperança constante, uma alegria diferente pois cada personagem sabe porque sofre e assim mesmo quer continuar vivendo." 348

Concorriam para esta leitura tragicizante do diretor polonês a cenografia e a iluminação de José Maria dos Santos, nas quais predominaram a penumbra e o ambiente pesado (como a parede cinza e maciça ao fundo, no $1^{\mathrm{o}}$ ato) negligenciando mesmo as instruções dadas na rubrica, logo no primeiro ato, de que era "um meio dia ensolarado

\footnotetext{
${ }^{345}$ MAGNO, Paschoal Carlos. 'As Três Irmãs', no Serrador. Correio da Manhã. Rio de Janeiro, 16 jan. 1960.

${ }^{346}$ Outros críticos ainda fariam referência a ao ritmo exageradamente lento, como Edigar de Alencar no artigo "As Três Irmãs", publicado no jornal A Notícia, em 06 de janeiro de 1960.

${ }_{347}^{34}$ SZONDI, Op. Cit., p. 46-52.

${ }^{348}$ MAGNO, Op. Cit.
} 
na casa dos Prózorov" ${ }^{349}$. Ao mesmo tempo, pareciam conviver, de maneira incômoda, o realismo da cenografia no primeiro ato, com a luz vermelha intermitente, mesmo quando foi anunciado o fim do incêndio, que deu um clima expressionista a todo o terceiro ato.

Ao mesmo tempo, a crítica Barbara Heliodora reivindicava um equilíbrio de elenco que o espetáculo não apresentava. Segundo ela, Ziembínski não formara seus atores no "método" de Stanislávski e, a todo momento, ainda que predominasse o pesado clima trágico, não havia homogeneidade de intenção - elemento determinante para qualquer encenação de Tchékhov. As atuações individuais pareciam não caminhar para um mesmo objetivo, que deveria ser construído não por marcas exteriores e formais, mas antes por uma intenção orgânica interior ${ }^{350}$. E este aspecto, destacado também pela crítica demolidora de Paulo Francis (que culpara o pouco tempo de ensaio do grupo, que teve de ceder espaço para os ensaios do diretor de D. João Tenório) ${ }^{351}$, era acentuado pelo fato do TNC não conseguir formar um elenco estável e com formação comum - aspecto essencial para dar conta de um tipo de dramaturgia que confronta diretamente com o drama (este gênero então muito mais palatável entre nós), pois não há peripécias e a força do diálogo é reduzida a uma escala ínfima ${ }^{352}$.

Paschoal Carlos Magno, Edigar Alencar e Astério de Campos ${ }^{353}$ seriam também críticos do que se acreditava ser o ritmo estabelecido por Stanislávski (Astério chegaria a dizer que a peça não era para auditório comum já que este, de tanta monotonia, "cabecearia de sono"), mas reconheceriam desempenhos importantes de atrizes, como Glauce Rocha (Olga), Vanda Lacerda (Macha) e Elizabeth Gallotti (Irina) que conseguiram, cada uma a seu modo, "captar" a "verdade" de cada personagem. Se não concorriam para uma organicidade do espetáculo (aspecto que não discutem), merecem ser valorizadas para que não desapareçam sob a motoniveladora da crítica.

Ainda assim, esta última peça da $4^{\mathrm{a}}$ Temporada do TNC tivera relativo sucesso e fora obrigada a estender sua temporada por mais uma semana. Isto, nas condições vividas pelo grupo, era atípico. O Serrador era teatro alugado e, às vésperas do limite máximo de contrato, recebera por mais alguns dias o espetáculo. Muito disso advinha da novidade da peça e, a despeito das críticas, do cuidado com a encenação (como a

\footnotetext{
${ }^{349}$ HELIODORA, Barbara. Tchecov, Stanislawsky e alguns problemas. Jornal do Brasil. Rio de Janeiro, 23 fev. 1960.

${ }^{350}$ Idem, Ibidem.

${ }^{351}$ FRANCIS, Op. Cit.

${ }^{352}$ FRANCIS, Paulo. Elenco e Política do TNC. Última Hora. Rio de Janeiro, 20 fev . 1960.

${ }^{353}$ CAMPOS, Astério. As Três Irmãs. Gazeta de Notícias. Rio de Janeiro, 16 jan. 1960.
} 
plasticidade de algumas cenas e os silêncios bem pensados que, se não fossem levados ao paroxismo, tinham sua real importância) ${ }^{354}$.
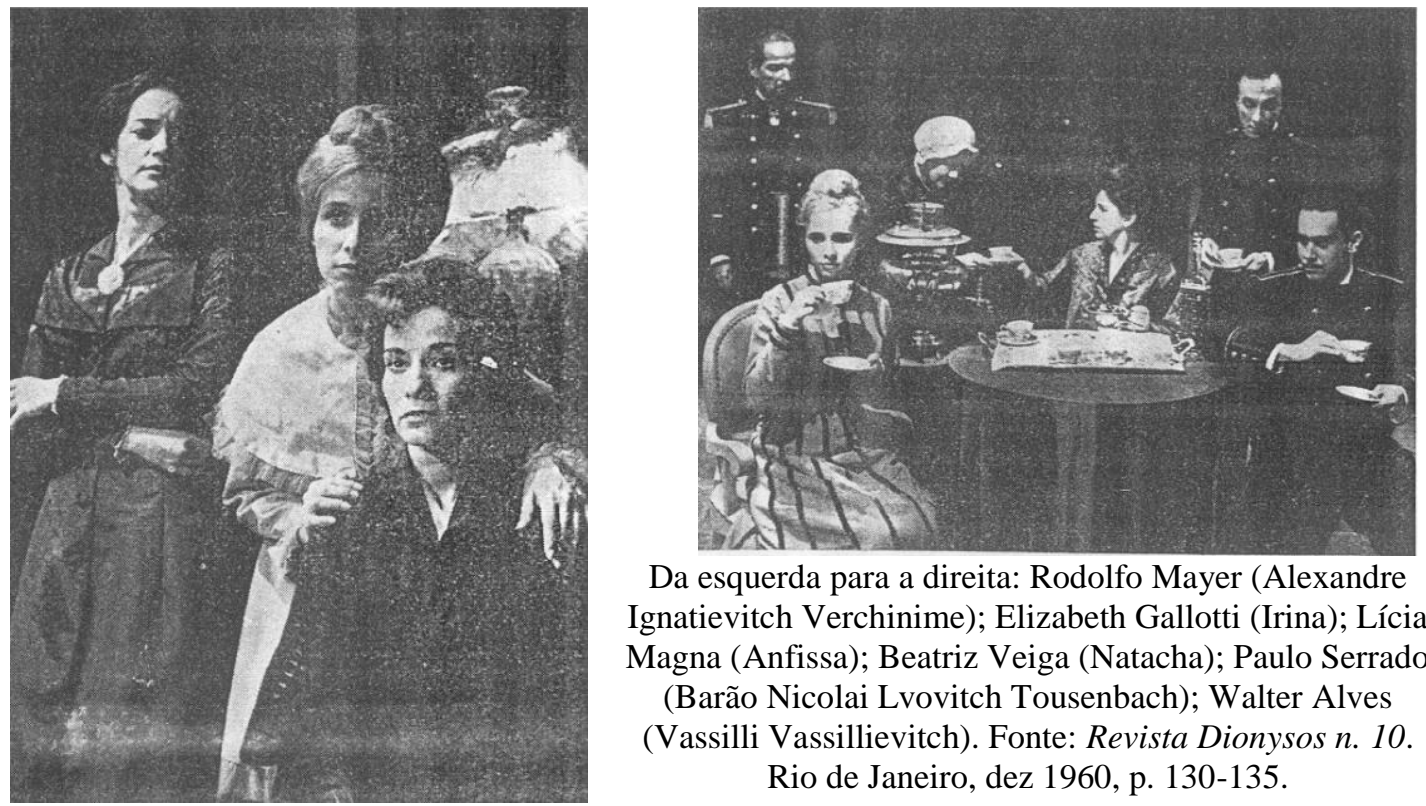

Da esquerda para a direita: Rodolfo Mayer (Alexandre Ignatievitch Verchinime); Elizabeth Gallotti (Irina); Lícia Magna (Anfissa); Beatriz Veiga (Natacha); Paulo Serrado (Barão Nicolai Lvovitch Tousenbach); Walter Alves (Vassilli Vassillievitch). Fonte: Revista Dionysos n. 10. Rio de Janeiro, dez 1960, p. 130-135.

Da esquerda para a direita: Glauce Rocha (Olga); Elizabeth Gallotti (Irina) e Wanda Lacerda (Macha). Fonte: Revista Dionysos $n^{\circ}$ 10. Rio de Janeiro, dez 1960, p. 130-135.

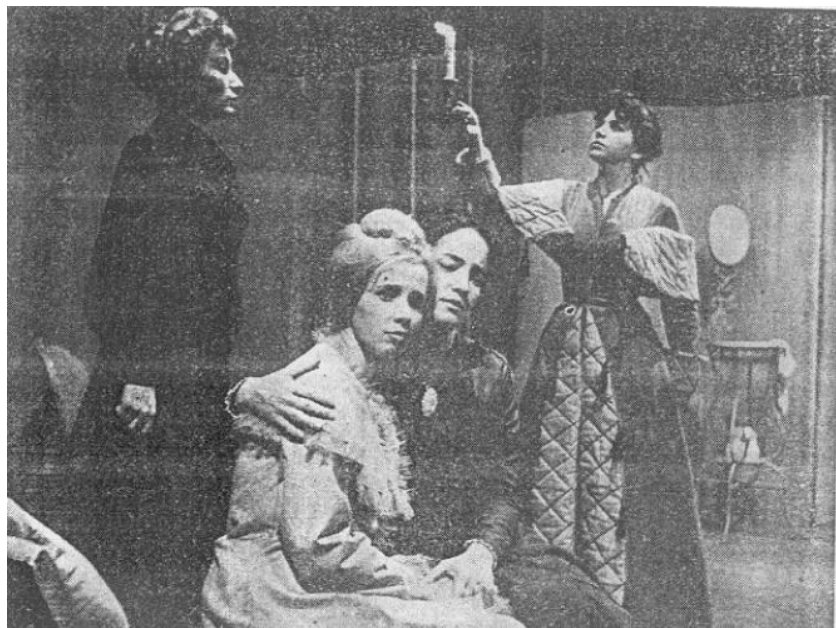

Da esquerda para a direita: Elenco: Wanda Lacerda (Macha); Glauce Rocha (Olga); Elizabeth Gallotti (Irina); Beatriz Veiga (Natacha). Fonte: Revista Dionysos $N^{o}$ 10. Rio de Janeiro, dez 1960, p. 130-135.

Por fim, em que pesasse o ritmo arrastado, que comprometia a montagem de tal maneira a torná-la restritiva mesmo para o público leigo, havia "amor e interesse" evidentes, que desculpavam, segundo os críticos, os muitos problemas ${ }^{355}$. Problemas esses que não se restringem apenas a fruto do gênio individual de um diretor ou de uma

\footnotetext{
${ }^{354}$ MAGNO, Op. Cit.
}

${ }^{355}$ Idem, Ibidem. 
leitura do dramaturgo que insistia em acabar com as potencialidades da peça (mesmo porque, como vimos, o tchekhovismo também produzira montagens antológicas), mas tinha muito a dever para as condições de realização de nosso próprio teatro. Grupos profissionais com repertórios ecléticos, trabalho de grupo que avança, mas que sofre para definir-se, sistematizar-se, questionar-se. Ou grupos amadores que, mais livres para a formação e o estudo (e mesmo a definição de um perfil sem preocupações comerciais), veem-se muitas vezes frente a frente com a inconstância do trabalho e a perda de elencos inteiros. E, ponto comum para os críticos da época, era a maturidade teatral exigida pelas peças de Tchékhov que, menos que aparato técnico excessivo, pedia, ao menos, trabalho prolongado de estudo, ensaio e preparação. Algo que, em um contexto fragmentário de formação teatral, com escolas em formação e elencos instáveis (ou, quando estáveis, na encruzilhada pela pressão das bilheterias), era algo problemático. Sendo assim, como encená-las? Valeria a opção de deixá-las de lado, esperando um ilusório futuro de pleno amadurecimento de nossos palcos? Ou ainda, seguir à risca o conselho de Barbara Heliodora para o TNC de que "próximo Tchecov (sic) que montar chegue um pouco mais naturalmente, e após uma série de outros clássicos seja preparado o caminho para essa sublimação do realismo que tanto honra o teatro universal." 356 ?

Muito certamente, não. Se as condições de amadurecimento e modernização do nosso teatro continuariam candentes durante muito tempo, e se não há receituário propedêutico que permita numa escala evolutiva ordenar um estilo para preparar o outro, não devem ser buscadas aí as respostas para o problema. Tchékhov continuaria sendo desejo de realização cênica de boa parte de nossos grandes diretores (então em formação) e, cada vez mais, o desafio de encená-lo seria aceito. Ao mesmo tempo, era como se o autor tivesse algo a nos dizer sobre nossas próprias condições de vida. Nos próximos anos, estaremos no centro nervoso do debate sobre sua necessidade em nossos palcos. Não se trata mais da pergunta "é possível encená-lo?", mas sim, "por que encená-lo?" e "como encená-lo?". Agitava-se em patamares inéditos a vida social, política e cultural do país, e Tchékhov estaria, discretamente (como mais uma vez lhe cabia), no centro desse turbilhão.

\footnotetext{
${ }^{356}$ HELIODORA, Op. Cit.
} 


\section{Que tem o Brasil a ver com Tchékhov?}

\subsection{O mais brasileiro dos russos}

A partir de 1960, o teatro brasileiro viveu transformações intensas. Se nos anos anteriores esteve envolvido em vivas lutas com as condições para sua "modernização", nesses próximos anos, ainda que tal problema não tivesse nem de longe superado, as questões seriam outras e gravitariam, em maior e menor grau, em torno da pergunta: "qual a orientação da modernização necessária?".

Evidentemente, tal questão tem terreno histórico. Acompanhava a efervescência social que, guardadas as devidas proporções, assemelhava-se a da geração de 1860, na Rússia. Surgiam organizações campesinas em luta pela Reforma Agrária (sobretudo no Nordeste e no Sul), organizações estudantis (as mesmas que serviram de impulsionadoras para o teatro estudantil e amador ao longo das últimas décadas) sincronizavam seu horizonte político e radicalizavam seu discurso de luta contra o imperialismo e organizações operárias recolocavam a agenda trabalhadora em perspectiva nacional ${ }^{357}$. No plano da cultura, este ambiente teve impacto decisivo. Em fins de 1961 surge o Centro Popular de Cultura (que se ligaria à UNE), o Teatro de Arena já havia surgido e colocava o problema do "autor nacional" e da presença em cena do "homem brasileiro" (obtendo êxito estrondoso como Eles Não Usam Black Tie $)^{358}$ e o cinema, em igual medida, colocava-se como imperativo a presença do cotidiano do marginalizado ${ }^{359}$.

Em um ambiente de tal natureza, palco de polarizações crescentes, que espaço haveria para um dramaturgo estrangeiro que proclamava, antes de tudo, a necessidade do escritor de manter-se objetivo e imparcial ante os acontecimentos? Com suas peças de pouca ação dramática, marcadas pelo dúbio olhar de quem repudia e ama uma aristocracia decadente que lentamente desaparece, como dizer algo ao público brasileiro, aparentemente mais simpático aos contrastes dramáticos vivos e, agora, aos contrastes ideológicos claros?

\footnotetext{
${ }^{357}$ SCHWARZ, Roberto. Cultura e Política de 64 a 69. In: O Pai de Família e Outros Estudos. São Paulo: Paz e Terra, 1978.

${ }^{358}$ GARCIA, Silvana. Teatro da Militância. São Paulo: Perspectiva, 2004, p. 102.

359 BERNADET, Jean-Claude. Brasil em Tempo de Cinema. Rio de Janeiro: Civilização Brasileira, 1967.
} 
As perguntas não chegaram a se converter em pauta de debate, mas operavam com alguma clareza por trás de julgamentos críticos e escolhas de grupos teatrais. No entanto, na tentativa de fazer com que a questão não girasse em falso, Antonio Callado publicou em setembro de 1960 um artigo intitulado "Chekov" ${ }^{360}$, publicado em setembro de 1960, no Correio da Manhã, no qual afirmava reiteradamente que Tchékhov "é o mais brasileiro dos russos". O problema, colocado nesses termos, despertava interesse.

Tchékhov, mais que Tolstói ou Dostoiévski, conseguia apresentar os problemas por uma ótica brasileira:

A força centrípeda de Moscou causando o êxodo rural, a cegueira das elites, as revoltas de estudantes, tudo do Brasil de hoje está em Chekov (sic). ${ }^{361}$

Ou ainda:

(...) as elites russas não eram elites nenhumas, os fazendeiros e senhores de engenho não eram nem maus nem bons, mas estúpidos e imprevidentes, todo o mundo via o errado de tudo, mas ninguém queria dar-se o trabalho de endireitar nada, todos falavam muito em cultura mas ninguém a conhecia fora dos livros, cultura viva, inventada, fecunda. ${ }^{362}$

Ou seja, a objetividade de Tchékhov fazia com que em seus contos e peças emergissem o cotidiano de proprietários de terras e aristocratas sem a poluição da lente religiosa e mistificadora, permitindo o acesso à complexidade da realidade como ela é. O dramaturgo russo seria muito mais um cronista de técnica ficcional e dramatúrgica altamente moderna ("estilo câmera eye") do que o autor trágico e obscuro com que fora impresso por Stanislávski e que, tendo feito sucesso, virou receita reproduzível em todo mundo. Daí os palcos, inclusive brasileiros, estarem repletos de "russismo": "atmosfera enfumaçada por samovares enormes, luz difusa, vozes estranguladas". Para ele, Tchékhov deveria" ser servido nature, sem molho de Stanislávski"363.

\footnotetext{
${ }^{360}$ CALladO, Antonio. Chekov. Correio da Manhã. Rio de Janeiro, Set. 1960. Série de artigos encontrada no Acervo de Antonio Callado na Fundação Casa de Rui Barbosa, no Rio de Janeiro.

${ }^{361}$ Idem, Ibidem.

${ }^{362}$ Idem, Ibidem.

${ }^{363}$ Idem, Ibidem.
} 
O problema, colocado nestes termos, é novo. Barbara Heliodora não via no "tom" impresso por Stanislávski e, por decorrência (vale supor), pelo Actor's Studio (lembremos que a crítica teatral tivera bacharelado em Artes nos EUA na década de 40) um problema de fundo. Tanto que residiria na dificuldade de preparação técnica e de coerência de repertório (e nisso Stanislávski era também um modelo) nosso principal entrave ao encontro "adequado" com o dramaturgo russo ${ }^{364}$. Para Callado, esta consideração procede, mas de nada adiantaria o acerto técnico com uma leitura ordenadora equivocada. Afinal, a impecabilidade cênica continuaria a trazer problemas, pois o dramaturgo, apesar de reconhecido internacionalmente (e por isso desejado), continuaria sendo um estranho, tão artificialmente digerido.

Callado expressa de maneira clara as demandas do tempo. Em sua opinião, Tchékhov respondia da mesma maneira aos problemas de seu tempo como os brasileiros respondiam aos impasses vividos pela geração de 60:

(...) ninguém a descreveu tão bem e tão do ponto de vista brasileiro, que foi o seu, de quem não se mete, de quem espera, contra a razão, que reformas nasçam em galho de árvores e não custem suor e sangue. Ouçam, em Trofimov, a disposição brasileira de falaram mal do Brasil: "Onde estão as creches de que tanto se fala, e as bibliotecas? Só existem nos romances: na vida real, nada. Na vida real há sujeira, vulgaridade e apatia asiática". E Lopahin: "Às vezes fico acordado de noite e penso: 'Oh, Deus, vós nos destes florestas imensas, planícies ilimitadas, os mais largos horizontes. Vivendo aqui, nós devíamos ser verdadeiros gigantes". E a resposta de Lyubov: "Olha ele pedindo gigantes! Eles só servem nas histórias infantis; na vida real assustam ${ }^{365}$.

Uma lente que assim vê a realidade só poderia ter efeito no Brasil em chave irônica, pois, tragicamente apresentada, recairia no inevitável turbilhão da desesperança pela falta de alternativas. Ora, em nosso país os tempos eram de aspirações revolucionárias (tal qual a Rússia pré-revolucionária na qual Tchékhov vivera nos últimos anos de sua vida) e, por isso, as encenações até então feitas caíam no equívoco profundo de não captar o que o dramaturgo realmente tinha a dizer ao nosso tempo.

\footnotetext{
${ }^{364}$ HELIODORA, Op. Cit.

${ }^{365}$ CALLADO, Op, Cit.
} 
A demanda é evidente: tornar contemporâneo um dramaturgo que, distante de nós no tempo e no espaço, deveria ser atual não apenas pela simples abstração de ser "clássico" e "universal", mas por ter de funcionar em nosso contexto nacional. Se esta formulação parece dizer muito em termos de conteúdo, como solução técnica concreta para a cena, Callado diz pouco. Em um período em que a maioria dos grupos engajados já se via às voltas com as formulações do teatro brechtiano (digerido vorazmente e com altos e baixos) $)^{366}$, que oferecia soluções práticas razoavelmente eficazes para as demandas políticos-culturais levantadas, ficaria a dúvida de como lidar com o peso da tradição ao redor do dramaturgo russo. Com relação a esse aspecto, Callado dá apenas pistas que, se nunca chegaram a ser concretizadas (e mesmo seu texto tivera repercussão restrita), interessam pela força da imagem sugerida e seu desejo de atualização:

O remédio é, talvez, agora que temos tantos diretores jovens e brilhantes, escolher o mais brilhante e mais chucro desses meninos e lhe entregar uma adaptação de "Cerejal", por exemplo, passando-se a ação da peça num engenho de açúcar em Pernambuco. Sairá uma obra-prima. O moderno teatro brasileiro pode renovar Chekov para o mundo inteiro. ${ }^{367}$

\subsection{Fissuras na tradição}

O ensaio de Antonio Callado, ainda que sintonizado com os mais avançados espíritos de época, não se converteu de imediato em gesto concreto nos palcos e parece não ter sido convincente o suficiente a ponto de orientar as escolhas de grupos teatrais preocupados com as questões políticas do momento. As peças longas de Tchékhov, dado o peso da tradição cênica do tchekhovismo aderido a elas, ficariam fora do repertório dos grupos profissionais por oito anos. Após a encenação do TNC, apenas as montagens restritas ao universo das escolas de teatro voltariam ao dramaturgo ${ }^{368}$. Yan Michalski chegaria a dizer, em 1968, que o senso-comum generalizado era o de que Tchékhov era um dramaturgo "ultrapassado" ${ }^{369}$. Estamos justamente nos anos

\footnotetext{
${ }^{366}$ A esse respeito ver o estudo de COSTA, Iná Camargo. Teatro Épico no Brasil. São Paulo: Graal, 1996.

${ }^{367}$ CALLADO, Op. Cit.

${ }^{368}$ Citar as encenações de Haydée bittencourt e de Alberto D'Aversa.

${ }^{369}$ MICHALSKI, Yan. "Tchecov em Curitiba (I)". Jornal do Brasil. Rio de Janeiro, 04 jun. 1968.
} 
incandescentes em que há pouco tempo estavam todos às voltas com as luminosas Reformas de Base e, agora, de olhos ou corpos postos na guerrilha que responde armada à Contrarrevolução promovida pela Ditadura Militar.

As pressões históricas eram tamanhas que, também de maneira inovadora, Yan Michalski tentaria provar a "atualidade" do dramaturgo apontando o que havia de "brechtiano" no texto de Tchékhov. Sem se referir ao dramaturgo alemão (ainda que saibamos que a formulação a ela faz referência), Michalski aponta o quanto o dramaturgo russo é moderno, por se utilizar ora do desencontro de linguagem (efeito imediato dos monólogos interiores e da impossibilidade do diálogo dramático), ora pelo efeito de simpatia ingênua que gera sobre uma personagem que, segundos depois, pode ser substituído pela sensação do ridículo. Ambos, combinados, geram um distanciamento crítico do espectador que, sem poder identificar-se com tais personagens e situações, analisa criticamente o que ocorre ${ }^{370}$.

Aqui, mais uma vez, estamos diante de um ponto de interesse. Se antes Callado nos deslocava para um problema de conteúdo, aqui, Michalski dá relevo ao procedimento formal tchekhoviano, que complexifica a própria compreensão de suas peças. A um só tempo, o movimento social empurrava as leituras do dramaturgo para o que ele tinha de nacional é épico, de observador e crítico.

É com esta chave que o crítico teatral analisa a encenação de Tio Vânia feita pelo Teatro de Comédia do Paraná (TCP), em 23 de maio de 1968, no pequeno auditório do Teatro Guaíra, em Curitiba. Para ele, o espetáculo sofria por um problema evidente que atravessava todos os principais elencos brasileiros e tornava qualquer encenação de Tchékhov sempre um grande desafio: a homogeneidade do grupo, a dificuldade de estabelecimento de desempenhos razoáveis em igual medida. Esses problemas seriam responsáveis por tirar a montagem da lista dos melhores desempenhos do TCP, ainda que tivesse méritos importantes. E, dentre eles, estaria um de ordem fundamental: o diretor Claudio Correia e Castro, que treze anos antes atuara nesta mesma peça n'O Tablado, tirara de Tchékhov todo ritmo arrastado, toda autopiedade e sentimentalismo excessivo que marcaram as grandes encenações anteriores. Estabeleceu, ao contrário, "ritmo normal e descontraído", que seguia "as pulsações do texto". E o trabalho com o cômico (coerente com as próprias orientações do dramaturgo russo) dava leveza à encenação sem cair na "comédia rasgada" ${ }^{371}$. A iluminação prezou

\footnotetext{
${ }^{370}$ Idem, Ibidem.

${ }^{371}$ Idem, Ibidem.
} 
pela clareza do ambiente e a cenografia apenas demarcava objetos importantes, sem excessos naturalistas. Para ele, o diretor deixara o texto falar, de maneira limpa, o que permitia a emergência desse "distanciamento tchekhoviano", arma da crítica para os novos tempos. Tal linha de raciocínio levou o crítico a citar, inclusive, o livro de Robert Brustein, "O Teatro de Protesto", em que Tchékhov seria destacado dentro desta linhagem política justamente pelo seu poder de elevação da "função humana" do teatro $^{372}$.

Mas a encenação de Claudio Correia e Castro, que mereceu duas críticas publicadas em jornal carioca feitas por Michalski, tivera temporada curta, restrita a Curitiba. E, ao final, ainda que apresentasse inovações em relação aos espetáculos até então feitos no Brasil, fora ofuscada diante das dificuldades do elenco que expôs "os seus atores a essa perigosa mas útil aprendizagem que o desempenho de um papel techekhoviano"373. A encenação de O Jardim das Cerejeiras, feita por Ivan Albuquerque meses depois no Rio, seguiria a mesma direção apontada por esta montagem, de rompimento com o que até então se concebia como tchekhovismo. Seu propósito, no entanto, não será de pura confrontação formal. A comicidade, aqui, teria papel profundamente político.

\subsection{Tchékhov político}

Iná Camargo Costa já comentou sobre a dificuldade do teatro brasileiro em assimilar a dramaturgia de Tchékhov ${ }^{374}$. Em sua opinião, o apego de nosso teatro e do público às situações de conflito claro e dramaticidade evidente tornaria o terreno pouco acessível aos textos do dramaturgo russo que, longe de trazer uma problemática alienígena ou "profundamente eslava", trazia antes uma problematização da forma do drama burguês que, pelo menos neste período ao qual nos referimos, nosso teatro ensaiava realizar. Por outro lado, o acirramento dos conflitos político trazia exigências para o teatro que exigiam respostas dos diretores seja no repertório, seja nas formas de tratamento cênico do material. Fenômeno bastante semelhante vivera a Rússia pré e

\footnotetext{
${ }^{372}$ Idem, Ibidem.

${ }^{373}$ MICHALSKI, Yan. Tchecov em Curitiba (II). Jornal do Brasil. Rio de Janeiro, 05 jun. 1968.

${ }^{374}$ COSTA, Iná Camargo. Transições. In: Nem uma lágrima: teatro épico em perspectiva dialética. São Paulo: Nankin/ Expressão Popular, 2012, p. 62-65.
} 
pós-Revolucionária, período no qual emergiu com força altamente inventiva o teatro de agit-prop e as demandas por encenações que colocassem em perspectiva a superação das relações de opressão (ou a comemoração pelo seu fim). Como vimos, a dramaturgia de Tchékhov, pelo menos como a concebera o TAM, não fora de imediato digerida neste período. No entanto, Stanislávski e Nemiróvitch-Dântchenko rapidamente "captaram" o espírito de época e colocaram O Jardim das Cerejeiras como um de seus principais destaques de repertório e que parece ter resistido a vaga de negação daqueles anos. Não que a abordagem trágica que tanto irritara Tchékhov tivesse sido suplantada. Mas a simples apresentação da decadência econômica da velha aristocracia, o surgimento de uma nova classe burguesa, objetiva e dinâmica, e a simbologia por trás do jovem Trofimov, representante das aspirações por transformação no início do século, já interessava ao público daqueles anos revolucionários. Tratava-se de uma espécie de crônica da história recente narrada por um dramaturgo de renome.

Por isso, é curioso notar que uma das principais montagens de Tchékhov desses anos de forte agitação política no Brasil tenha sido justamente $O$ Jardim das Cerejeiras. Cinco meses após a montagem de Claudio Correia e Castro, o Grupo do Rio, então liderado por Ivan Albuquerque e Rubens Correa, apresentou a primeira encenação brasileira desta peça. Quatorze anos antes, Barrault trouxera ao Brasil a montagem francesa que, segundo alguns críticos, estava atrás da versão carioca ${ }^{375}$. E o fato de se tratar da encenação que abriria o "Ciclo Russo" (composto ainda por Diário de Um Louco, de Gógol e A Mãe, de Brecht/Górki), a ser estreado na noite de inauguração do Teatro Ipanema, alimentou as expectativas do público carioca.

A montagem trazia no elenco nomes conhecidos, como Vanda Lacerda (Lhubóv Andreivna Ranhévskaia), Vera Gertel (Vária), Hélio Ari (Leonid Andrêievitch Gáiev) e Rubens Corrêa (Piotr Seguêievitch Trofimov). E o trabalho do diretor fora de tal modo longo e bem cuidado que, de maneira generalizada, a crítica elogiou o desempenho do elenco. Tratava-se de fator inédito na história da recepção de Tchékhov que, como a crítica sempre fizera questão de destacar, sofria pelos elencos desequilibrados ou vítimas de ensaios apressados para cumprir temporadas. Yan Michalski não deixaria de destacar que, ainda assim, não estaríamos à altura dos elencos europeus, aparentemente muito mais "aptos" a lidar com Tchékhov; mas aquele elenco, com irrisórios problemas, conseguira segundo ele atingir o "especialíssimo clima da peça, todo ele feito de meios-

\footnotetext{
${ }^{375}$ LEITE, Luiza Barreto. O Jardim das Cerejeiras. Jornal do Comércio. Rio de Janeiro, 27 out. 1968.
} 
tons, de subentendidos, de ternura, de sorriso amargo, de gestos esboçados e não acabados"376. Aparentemente, segundo Luiza Barreto Leite, essa façanha só fora possível pelo fato do jovem Grupo ainda não ter se rendido as pressões do repertório fácil e comercial e por se dedicar com afinco ao estudo e ensaio de peças de "real valor" $\operatorname{artístico~}^{377}$. Pressões essas que, como sabemos, eram então realidade predominante para a maioria dos grupos de peso no Brasil.

Mas a preocupação de Ivan Albuquerque não parecia ser unicamente com a "qualidade artística" do repertório. A escolha daquelas três peças para a inauguração daquele que seria um dos grandes empreendimentos de sua vida, não era algo gratuito. Apresentar um "Ciclo Russo" no ano em que a repressão militar se intensificava ainda mais mostrava ousadia não só estética, mas política. E, mesmo tratando de Tchékhov, o diretor optaria por imprimir à sua leitura uma chave sintonizada com esse empenho de ideológico.

A apresentação de Ivan ganhava nesse aspecto não por transformar o espetáculo em exposição de uma tese. Seu recurso principal foi subverter a leitura stanislavskiana de Tchékhov então predominante e valorizar acima de tudo a comicidade desta peça. Isto por si já tivera efeito político decisivo. Já no programa da peça observamos o longo texto de I. Beguèlis, a propósito da montagem d'O Jardim feita por Simonov, em 1934: "Não se deve esquecer que o Jardim das Cerejeiras é a última peça de Tchekhov. A revisão do tratamento cênico desta peça é um trabalho honroso e indispensável. Um dos "netos" do Teatro de Arte, o teatro de Simonov, aceita esta tarefa e este ano vai nos mostrar 'Jardim das Cerejeiras' como uma comédia ${ }^{378 " . ~ E s t e ~ f o i ~ o ~ p r o p o ́ s i t o ~ q u e ~ I v a n ~ d e ~}$ Albuquerque tinha por um lado, o desejo de resgatar a intenção inicial do dramaturgo russo, e que fora motivo de longas discussões com Stanislávski, de ver sua peça encenada como uma comédia. Por outro, representava uma leitura de época mais marcada de que aquela era uma época para a qual deveríamos olhar com a dupla sensação de simpatia pelos sentimentos que se perdem, mas com satisfação por ver uma classe social ociosa ser superada pela História.

Este propósito, somado à cenografia de Marcos Flaksman, que fora completamente limpa e marcada pela troca de objetos em cena, bem à maneira brechtiana, bateu forte na crítica e dividiu opiniões.

\footnotetext{
${ }^{376}$ MICHALSKI, Yan. Um Jardim Florido e Amigo (I). Jornal do Brasil. Rio de Janeiro, 20 out. 1968. ${ }^{377}$ LEITE, Op. Cit.

${ }^{378}$ Ver: Programa da Peça - Ciclo Russo. Grupo do Rio. Rio de Janeiro, 1968, p. 12.
} 
Yan Michalski seria o grande entusiasta da encenação, dedicando três artigos para comentar a montagem do Grupo do Rio. Para ele, aquela "Comédia de um mundo em transformação" deu a exata dimensão das transformações em curso na Rússia, feitas de modo "profético e imparcial" por Tchékhov. Nesse sentido, o grupo conseguiu, a um só tempo, criar o clima adequado para a encenação, dosando de maneira convincente e "realmente tchekhoviana" os tons doloridos e cômicos. O ritmo era firme e evitava os silêncios arrastados. E a criação do "clima" vinha acompanhada de profunda humanização das personagens ${ }^{379}$. Em sua opinião, em que pesassem pequenos deslizes de interpretação, largamente discutidos no terceiro artigo dedicado ao espetáculo ${ }^{380}$, o grande mérito estava no trabalho de organicidade do grupo, que permitiu o acerto de tom na encenação (sempre difícil em espetáculos brasileiros e essencial em um tipo de teatro em que o diálogo dramático é ineficaz). E este tom se expressava justamente no uso adequado do sorriso, que cada ator imprimira com sensibilidade em sua personagem:

especial qualidade do sorriso ocupa um lugar importantíssimo na densidade de ambiente que foi conseguida; esse sorriso, que é expressão de um certo tipo de alegria e ternura, mas também disfarce de um profundo sentimento de frustração, de angústia e de medo, e que está sempre pronto a desmanchar em lágrimas, acaba por se transformar em uma espécie de leitmotiv da encenação. ${ }^{381}$

E assim também o viram Luiza Barreto Leite ${ }^{382}$ e Henrique Oscar ${ }^{383}$ que, observando a leitura inovadora e a organicidade do corpo de atores, definiriam essa montagem como um dos marcos da encenação de Tchékhov no Brasil e um dos pontos altos da trajetória do grupo.

\footnotetext{
${ }^{379}$ MICHALSKI, Yan. Um Jardim Florido e Amigo (II). Jornal do Brasil. Rio de Janeiro, 23 out. 1968.

${ }^{380}$ MICHALSKI, Yan. Um Jardim Florido e Amigo (III). Jornal do Brasil. Rio de Janeiro, 24 out. 1968.

${ }^{381}$ MICHALSKI, Op. Cit (II).

382 LEITE, Op. Cit.

${ }^{383}$ OSCAR, Henrique. Tchekhov em Ipanema. Diário de Notícias. Rio de Janeiro, 23 out. 1968.
} 


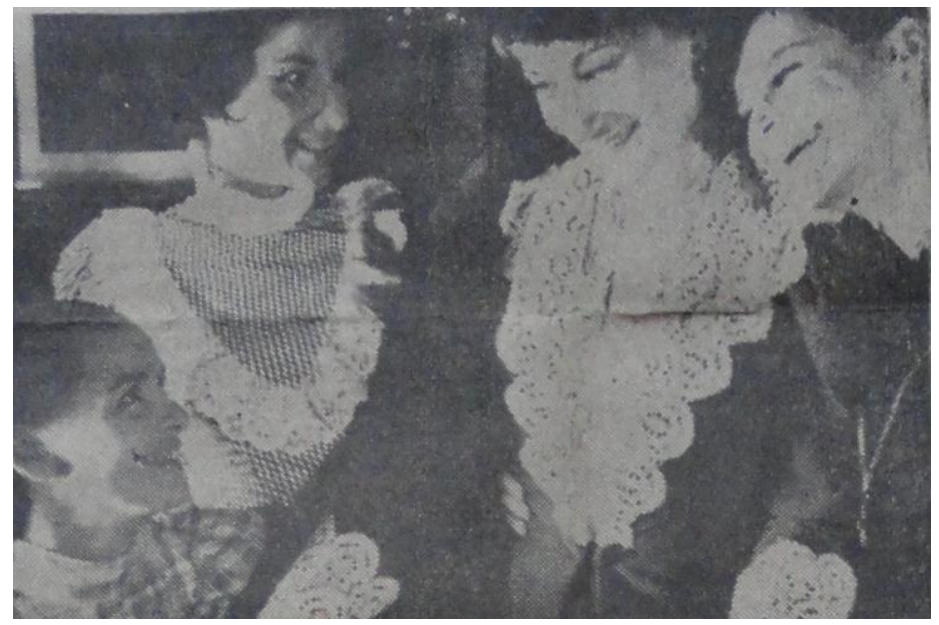

Da esquerda para a direita: Leila Ribeiro, Susana de Morais, Vanda Lacerda e Vera Gertel.

(Foto de notícia " O jardim das cerejeiras ou A comédia do mundo em transformação", Jornal do Brasil, Rio de Janeiro, 07 out. 1968 - sem créditos)

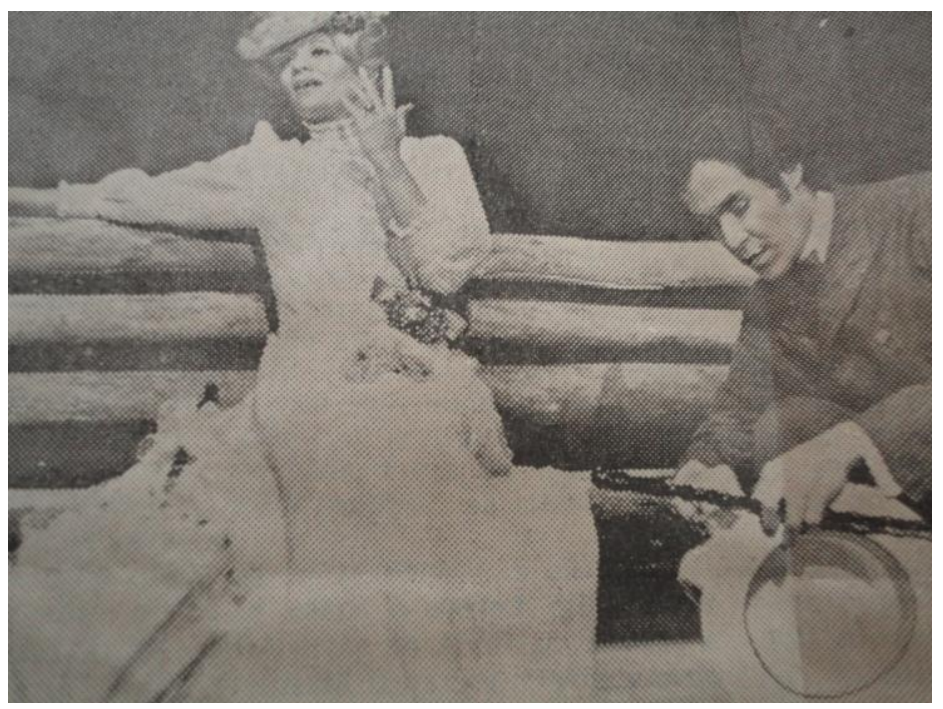

Vanda Lacerda (Ranhévskaia ) e Ênio Carvalho (Iacha) em Cena de $O$ Jardim das Cerejeiras (Foto de notícia "O Jardim das Cerejeiras", Jornal do Comércio, Rio de Janeiro, 27 out. 1968 - sem créditos)

No entanto, ainda que a crítica reconhecesse de maneira geral o cuidado da encenação e bom trabalho de grupo, a leitura dela feita pelo diretor não fora consensual. Para Tato Taborda ${ }^{384}$, a opção de Ivan Albuquerque em destacar as personagens Ania (filha de Raniévskaia) e Trofimov (o "eterno estudante" que simbolizava a vida nova) demarcavam excessivamente uma opção pelo "futuro" que não era a lente de Tchékhov. Segundo o crítico, o diretor pode ter seguido a interpretação do diretor soviético Stanistsyn, que também valorizara estes "personagens secundários", como que a

\footnotetext{
${ }^{384}$ TABORDA, Tato. Cerejeiras em Flor. Última Hora. Rio de Janeiro, 11 out. 1968.
} 
demarcar posição frente a aristocracia que desaparecia e a burguesia que emergia. Frente aos dois, nem um nem outro: ficariam com os jovens, aqueles que estariam "na primeira fila" das grandes transformações que viriam.

Assim também não o aprovariam Van Jafa ${ }^{385}$ e Fausto Wolff ${ }^{386}$, que, a despeito de elogiarem o empenho pela organicidade do elenco, não concordaram com o "excesso de valorização do cômico" ${ }^{387}$ e a fixação do diretor em evitar a identificação do grupo com as personagens aristocráticas. De maneira geral, a conotação política impressa no texto não era recomendável: seja porque sua "brechtianização" fora superficial, seja porque se o diretor tivesse "intervido pouco" os paralelos políticos "viriam naturalmente" do texto de Tchékhov. Para Fausto Wolff, era preciso superar o "modismo juvenil" que representavam aquelas técnicas de distanciamento e entender que "Com Tchékhov só se chega a Brecht através de Stanislávsky"388.

Se os dois últimos parecem destacar pontos de maneira algo conservadora ao tratarem do texto de Tchékhov, no que se refere principalmente a fechar no texto as possibilidades de sua realização e limitar a ação criativa do diretor, haveria ainda posições críticas que, no oposto dessa tendência, veriam exatamente fora do texto os elementos que serviriam para sua recusa.

Se Ivan Albuquerque estabeleceu parâmetros que buscavam tornar sua montagem contemporânea (não necessariamente abrasileirando-a, como seriam tendências vigentes então no Teatro de Arena), isso não seria o suficiente ainda para aqueles que continuariam vendo em Tchékhov a expressão de problemas superados. Para Elisa Schaffman, esse "olhar dúbio" de reconhecimento da necessidade da venda e simpatia pelo cerejal parecia "estéril e sem sentido" para aqueles tempos. A presença do burguês Lopakhin, na era do "self-made man" já não tinha nada a acrescentar e, mesmo Trofimov, que poderia ser a esperança de um futuro revolucionário, apresenta suas ideias sem a força e a profundidade necessárias: "o fato é que suas palavras resumem-se a um palavrório inconsequente e uma bravata desprovida de verdadeira coragem" ${ }^{389}$. Além disso, para ela, a encenação do Grupo do Rio não convencera quanto à "atmosfera" e as catástrofes eram apresentadas com um "bom-humor desconcertante":

\footnotetext{
${ }^{385}$ JAFA, Van. O Jardim das Cerejeiras. Correio da Manhã. Rio de Janeiro, 26 out. 1968.

${ }^{386}$ WOLFF, Fausto. Com Tchecov só se chega a Brecht através de Stanislávsky. Tribuna da Imprensa. Rio de Janeiro, 31 out. 1968.

${ }^{387}$ JAFA, Op. Cit.

${ }^{388}$ WOLFF, Op. Cit.

${ }^{389}$ SCHAFFMAN, Elisa. O Jardim das Cerejeiras. Jornal do Comércio. Rio de Janeiro, 24 out. 1968.
} 
Liuba parte para a França com seu sorriso como se fosse um alívio ver-se livre do Cerejal. O abandono da propriedade que significava a derrocada de todo um modo de vida, o desmoronamento de uma sociedade, é efetuado dentro de um ambiente festivo, e parece que todos estão se preparando para ir passar as férias à beira-mar. Enfim, se era tão pouco importante derrubar o Cerejal, para que desperdiçar duas horas afiando o machado $?^{390}$

A crítica de Luiz Carlos Maciel $^{391}$, que anos antes dirigira peças curtas do dramaturgo no Festival Tchékhov na Escola de Teatro da Universidade da Bahia, fora ainda mais acachapante. Para o polêmico crítico e diretor, já estávamos em um tempo em que os espetáculos bem acabados e competentes (o "tebecismo" como se vê, já era xingamento) já haviam sido superados. E, ainda que Ivan Albuquerque trouxesse contribuições pontuais para superar esse esteticismo, a própria escolha daquela dramaturgia parecia fora de propósito. Ou seja, não adiantava a elaboração cômica, o destaque para as personagens que projetam o "futuro revolucionário" ou mesmo a combinação do texto dentro de um Ciclo Russo evidentemente engajado: a própria peça não tinha a dizer nada de relevante para a época. É como se Luiz Carlos Maciel ratificasse a sentença já em voga citada por Michalski: Tchékhov estava superado. Peças como Roda Viva e Os Fuzis, encenadas pelo Oficina, propunham-se a comunicar com o público um balanço sobre o presente. Estava aí o caminho:

Não há mistificação, incompetência ou morna rotina em $\mathrm{O}$ Jardim das Cerejeiras. Há apenas um pouco de inocência, a dose de sensação de que basta ao teatro de hoje rir de seus próprios velhos enganos. Não acredito nessa inocência. $\mathrm{O}$ teatro deve ir além disso, encontrar sua época, nas suas mais profundas e perigosas cavernas." 392

No entanto, ainda que as peças apontadas por Luiz Carlos Maciel tivessem algo de atual a dizer para o publico (muito mais que Tchékhov), será o próprio Oficina (à frente de polêmicas, mas inegavelmente políticas montagens) a aceitar o desafio de, naqueles anos, converter o dramaturgo russo em leitor ácido da realidade brasileira.

\footnotetext{
390 Idem, Ibidem.

${ }^{391}$ MACIEL, Luis Carlos. O Jardim das Cerejeiras. O Paiz. Rio de Janeiro, 09 nov. 1968.

${ }^{392}$ Idem, Ibidem.
} 


\subsection{Política, desbunde e algumas contradições}

"Que tem o Oficina a ver com este texto?" Foi com essa pergunta que o próprio José Celso intitulou artigo de divulgação da estreia de As Três Irmãs, de Anton Tchékhov, encenada pelo grupo em dezembro de $1972^{393}$. A pergunta não é gratuita, e o diretor já antecipava em artigo a resposta para o estranhamento que esta escolha de repertório gerava em críticos e no público jovem, este já um frequentador assíduo do teatro da Rua Jaceguai.

Seria a adesão constrangida, depois de anos de experimentação e da recente declaração da "morte do Teatro", ao tradicionalismo stanislavskiano? Seria um aparente retorno ao teatrão realista dos anos 50 e 60 (burguês em sua opinião), com vistas a depois rompê-lo e comprovar mais uma vez o poder de reinvenção do grupo? Apesar de variadas, e assumindo nuances específicas a depender do crítico, as perguntas não deixam de ter fundamento. E não deixam de revelar duas premissas interessantes de interpretação, que valem ser discutidas em igual medida: 1) a de que havia um "modo correto" ou "específico", que se não era apresentado em termos de "verdade do texto", pelo menos vinha se configurando enquanto padrão de representação cênica do texto tchekhoviano; 2) a de que o Oficina, ainda que demonstrando sempre sua capacidade de busca do "novo" e do "teatro vivo" parecia vinculado também a um universo específico de textos e escolhas cênicas, colocando de lado outras tradições.

Ora, como se sabe, neste momento Tchékhov já havia se consolidado no Brasil como um dramaturgo diretamente vinculado ao "método Stanislávski" ${ }^{394}$. Aos poucos, tal vinculação era questionada, mas não sem resistências. E esta ligação, se tem respaldo histórico na relação tensa e produtiva que o escritor e o encenador russo tiveram, é apoiada também no fato de que as primeiras encenações profissionais de suas peças no Brasil se deram justamente pelo Teatro Brasileiro de Comédia (TBC) e pelo Teatro Nacional de Comédia (TNC). Os dois grupos tiveram à frente diretores emigrados que,

\footnotetext{
393 Artigo escrito por José Celso Martinez Corrêa em especial de O Estado de São Paulo, em 26 de dezembro de 1972, dia de estreia de As Três Irmãs, em São Paulo. O especial vinha também com os artigos "Conheça Macha, Irina e Olga: As Três Irmãs", "O Elenco, os Preços, tudo muito popular", também escritos por José Celso.

${ }^{394}$ Uso aqui a expressão apenas para me ater a uma leitura bastante comum na época, a saber, a de que Stanislávski havia constituído um "método" próprio de encenação. Tal leitura, consolidada pelos ensinamentos de Stella Adler e Lee Strasberg, tinha também no Brasil o nome de Eugênio Kusnet como um dos grandes difusores. Sabemos hoje que tão concepção não deixa de ser polêmica, já que enrigecer Stanislávski em termos de método é algo que exclui sua oscilante trajetória de encenador, cheia de percalços e aparentemente sem um "apogeu metodológico declarado". O próprio "método" também nunca fora escrito. Ver CAVALIERE, Arlete e VÁSSINA, Elena. Op. Cit., 2001.
} 
na tentativa de aqui atualizar nosso repertório e práticas de encenação, trouxeram leituras do dramaturgo bastante vinculadas ao tipo de encenação "realista-naturalista" europeu. Afora as peças cômicas em um ato (popularíssimas entre grupos amadores e também parte do repertório de companhias como o TBC), valorizadas sempre em seu aspecto farsesco, predominava a leitura em certo sentido importada de um Tchékhov "trágico", "poeta do crepúsculo", leitor da "inércia e melancolia" de uma classe social que perde espaço gradualmente. Isso implicava, como vimos, em encenações repletas de pausas sugestivas, em ritmo lento, na tentativa de valorizar qualquer subtexto psicologizante e camadas de interpretação que não se evidenciariam em uma encenação externalizante.

O que ocorre é que, na maioria das vezes, a recepção de tais encenações estigmatizava um Tchékhov "monótono" e "cansativo", sobretudo em encenações com pouca homogeneidade de elenco.

Em suma, esta era a "aura" que cercava o dramaturgo: burlesco em suas peças curtas; dramático, "pesado" e lento em suas peças maiores. Não entraremos a fundo nesta separação, mas ressaltar sua existência neste período mostra o grau de estranhamento manifestado pela crítica diante da escolha do Teatro Oficina.

Este grupo de São Paulo, neste momento o mais significativo e atuante na cena teatral brasileira, atravessava uma crise que marcaria profundamente seus próximos anos. Afinal, que teria a ver Tchékhov com a morte do teatro (talvez ele então um dos maiores símbolos desse teatro)? Que poderia ele oferecer à política de protesto ou, agora mais do que nunca, ao desbunde do Oficina?

Para responder a essas questões, é esclarecedora a divisão estabelecida pelo próprio José Celso, que via nos anos posteriores a 1967-68 o período decisivo de sua formação. Antes disso, o Oficina se afirmava junto ao público como alternativa que muito prometia, mas com repertório oscilando entre produções de textos de peso (muitos de forte teor político-agitativo) e montagens "leves". Tecnicamente, a maioria das encenações se baseava nas orientações fornecidas por diretores como Eugênio Kusnet (que em partes sanou as crises do grupo com os esquematismos de uma leitura importada do "método Stanislávski e até inícios de 1970 forneceu aulas para aqueles jovens atores) ${ }^{395}$. E é justamente nesses anos de efervescência e radicalização política

\footnotetext{
${ }^{395}$ SILVA, Armando Sérgio da. Oficina: do teatro ao te-ato. São Paulo: Perspectiva, 2008, p.114-129. Vale a pena ressaltar que o livro de Armando Silva descreve com maior riqueza o percurso formativo do Oficina, aqui bastante esquematizado apenas para os fins do trabalho.
} 
no contexto brasileiro que o grupo enveredaria por caminhos altamente produtivos e polêmicos. O processo de operação de quebra com o "ilusionismo realista", já subterrâneo desde 64 com experiências antiilusionistas timidamente assimiladas, intensifica-se em 1967, com a encenação de $O$ Rei da Vela, texto até então "impossível" de ser colocado em cena e que só o Oficina, agora em processo de forte ruptura com a tradição, emplacava. Em 68 vem Roda-Viva, e o perfil polemizante do grupo se firma de maneira definitiva. $\mathrm{O}$ objetivo agora é problematizar a postura de seu próprio público, da "classe média inteligente", vítima passiva e complacente do sufocamento social e político. Neste caso, a opção pelo gesto "irracional" na encenação rendia debates cada vez mais acirrados, sobretudo no campo marxista, que questionavam o real alcance de uma "porrada simbólica" desferida no público (no estômago, não na cabeça) e até que ponto sua aparente celebração do "contraditório brasileiro" e do enfrentamento dos recalques pelo gesto antropofágico não seriam ingredientes facilmente assimiláveis pela indústria cultural ${ }^{396}$.

O aparente intermezzo épico com Galileu, Galilei em 1969, que explorava um Brecht "anárquico e explosivo", reunia forças em verdade para o grande estouro de 1972: a estreia de Gracias, Senõr. Após período de intensas experiências na longa viagem pelo interior do Nordeste (o famoso "Saldo para o Salto") e já familiarizado com as experiências grotowskianas, o grupo prometia algo definitivo para os "filhos prediletos" da classe média inteligente e "progressista". A justificativa racionalizada, complacente, cartilhesca e recuada não bastava mais para aquele período de inércia generalizada. E por isso a instituição teatral se mostrava inócua enquanto "expressão urgente dos corpos" ou da pulsão de liberação. Eliminado qualquer tipo de barreira entre público e atores, Gracias, Señor seria o choque direto: a plateia na parede levada a refletir, envolvida, entregue, mas visivelmente acuada pela força do enquadramento.

No entanto, antes que qualquer balanço de fôlego pudesse ser feito sobre as poucas experiências desse "Te-Ato", o espetáculo foi severamente proibido pela censura $^{397}$.

\footnotetext{
${ }^{396}$ Para entendimento mais aprofundado deste debate, altamente esclarecedor, ver: SCHWARZ, Roberto. Cultura e Política de 64 a 69. In: O Pai de Família e Outros Estudos. São Paulo: Paz e Terra, 1978, p. 6192; e também: ROSENFELD, Antol. O teatro agressivo. In: Texto/Contexto. $3^{\text {a }}$ ed. São Paulo: Perspectiva, 1976, p. 49.

${ }^{397}$ SILVA (2008, p. 197-214). Vale destacar que a imagem do Oficina frente a muitos críticos de peso de São Paulo e do Brasil já vinha fortemente desgastada. Alguns tomaram partido direto frente à polêmica entre o diretor José Celso e o crítico Sábato Magaldi, o que serviu para corroborar a ideia de que o Oficina "pagava" pelo desastre ofensivo que fora Gracias, Señor, espécie de cume da vaga irracionalista,
} 
É neste cenário, já com o grupo em um momento limite, que se encerra o ano de 1972. A opção por um "teatro alternativo" que, em certo sentido, rompia com a necessidade do público pagante e "consumidor" do velho TBC, que se preocupava antes com a busca urgente de experiências significavas (ainda que estas demandassem pesquisa interminável e trabalho longo), trouxera forte impacto financeiro, e as dívidas avultavam. Restavam então apenas dois remanescentes das formações iniciais do Oficina: José Celso Martinez Corrêa e Renato Borghi. E restavam também dúvidas empilhadas sobre a real efetividade das últimas experiências (sufocadas sem os devidos desdobramentos) e os próximos passos definitivamente não estavam claros. José Celso parecia estar convicto de que a saída naquele momento era partir para o exterior, para ambiente mais receptivo e menos sufocante para o seu teatro.

É neste ambiente de incertezas que o grupo decide pela encenação de As Três Irmãs em dezembro de 1972.

Anos mais tarde, José Celso revelaria que a insistência por Tchékhov vinha já de tempos por Renato Borghi, numa espécie de busca deste ator e alguns ao seu redor pelo "retorno ao teatro" e pela crença ainda viva no "poder da palavra". Como se viu, a proibição de Gracias, Señor servira para um questionamento profundo dos rumos tomados pelo grupo e, mais uma vez, a escolha do texto não se dava por motivos pragmáticos - revelava também as intenções, o momento e a sensibilidade vividas pela trupe. Há aqui um ponto que merece destaque: encenar Tchékhov seria então, na visão de uma parte específica do Oficina, uma peça para "voltar ao palco" ${ }^{398}$. O dramaturgo demandaria um estilo de encenação pouco propício à experimentação e poderia servir, portanto, como um "adestrador" das sensibilidades anarquizantes ${ }^{399}$.

Contudo, a aceitação do texto por todo o grupo não parece completamente vinculada à leitura de Borghi e Tchékhov ganharia nas mãos do Oficina uma encenação bastante inovadora em relação ao que se tinha visto do dramaturgo até então.

O trabalho com o texto de Tchékhov começou como uma espécie de "revelação". Se o caminho no teatro tradicional seria o do trabalho de mesa, de pesquisa

que pretensiosamente se colocava como única fonte do "novo" e "livre" ("Ato Extra". O Dia, Terezina, 25 de setembro de 1972.)

398 As expressões entre aspas citadas neste parágrafo atendem diretamente à fala de José Celso, em entrevista concedida em 1995. MARTINEZ CORRÊA, José Celso. Tchecov é um cogumelo. In: Primeiro ato: cadernos, depoimentos, entrevistas (1959-1972)/ José Celso Martinez Correa; seleção, organização e notas de Ana Helena Camargo de Staal. São Paulo: Ed 34, 1998, p. 230.

${ }^{399}$ Era assim que muitos esperavam a estreia de As Três Irmãs. Em anúncio no jornal Última Hora de 17 out. 1972, vem escrito: "José Celso em recaída habitual: vai montar (e a montagem será comportadíssima) As Três Irmãs, de Tchecov". 
racionalizada e com exercícios cênicos com vista a um realismo "pedido pelo texto", aqui o caminho é outro:

enfim, nós decidimos tomar um ácido, uma pérola negra, e começamos a viajar pelo teatro todo até chegarmos num beco sem saída, nessa parede do fundo, que dá para o estacionamento do Silvio Santos. Quando paramos ali, nós nos demos a mão, desenhamos um círculo cruzado - do norte ao sul e do leste ao oeste - e, marcamos o centro. (...) De repente, aquele círculo me mostrou um caminho totalmente novo, e como eu estava pensando em As Três Irmãs, nós começamos a ler o texto e a descobrir o seu outro lado, a sua parte esotérica, a perceber que os seus quatro atos eram, também, quatro movimentos, 'quatro tempos ${ }^{400}$

A "parte exotérica" do texto tchekhoviano, definitivamente, era um "outro lado" não explorado no Brasil e nas principais encenações europeias. Tal descoberta definiu o ritmo dos ensaios. O primeiro deles, realizado durante uma madrugada na praia de Boraceia, foi regado a mescalinas e contribuiu para definir o tom ritualístico dos próximos encontros: após o estouro intencional e mortal de Gracias, Señor, havia a necessidade de resgate do trabalho em uníssono, da união dos corpos e vozes ${ }^{401}$. A peça serviria, então, para reunir os cacos e contribuir para que os novos caminhos fossem trilhados coletivamente.
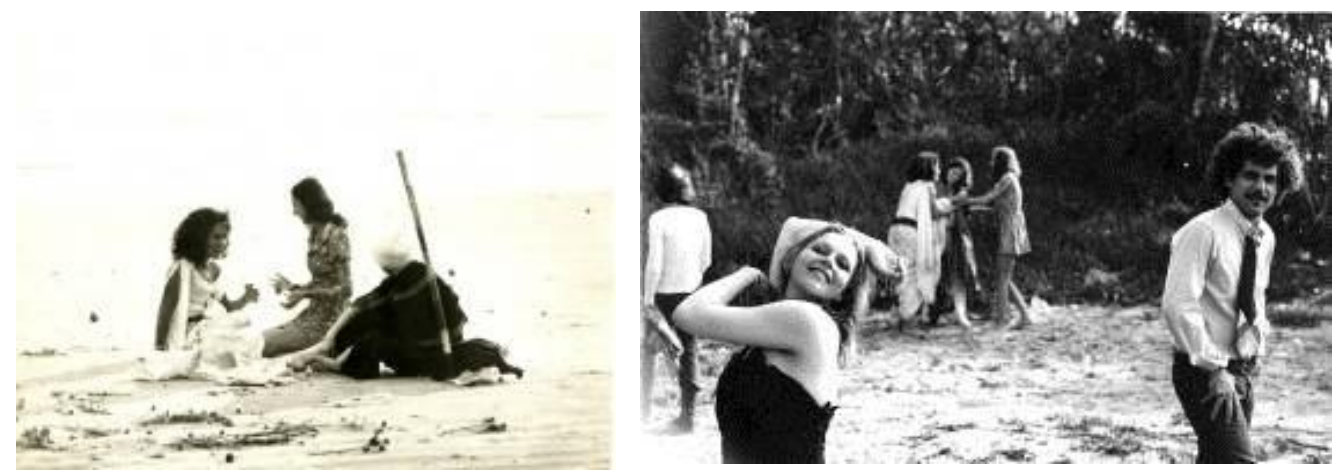

"O Tchecov é completamente esotérico, totalmente ecologista. (...) Nós preparamos de tal maneira os ensaios que a peça se transformou numa coisa orgânica, viva, cheia de respiração." - Fotos de ensaios na praia da Boraceia (Fonte: Fundo do Teatro Oficina, AEL-Unicamp)

\footnotetext{
${ }^{400}$ MARTINEZ CORRÊA, Op. Cit.,1998, p. 230.

${ }^{401}$ São ilustrativas as anotações de direção de José Celso, presentes nos cadernos de anotação dos ensaios. Entre as diretrizes norteadoras estariam: "Ato de Ritualismo e Sacrifício - Linguagem Universal - Fim da Babel - União dos Corpos - Ritmo e Vontade Geral" (Fonte: Pastas 31, 32, 90, 91, 137 e 149. Fundo Teatro Oficina - Acervo AEL-Unicamp).
} 
Os ensaios colocavam em sintonia não só diferentes gerações do teatro (os novatos do Oficina, os convidados de formação sólida no "teatrão" e os remanescentes das primeiras formações do grupo), mas também representavam uma concepção que lutava por se afirmar, com altos e baixos: a do teatro como ato vivo, ampliado para a vida (para além dos espaços da pequena burguesia e das instituições), que não se fechasse em ensaios cronometrados (e o "Saldo para o Salto" representara esse esforço; e muito das experiências posteriores, já após o fim do grupo, viriam nesse sentido).

A "revelação" inicial também tivera impacto decisivo em todos os outros componentes estruturais do espetáculo. A cenografia se baseou na imagem da mandala, associada aos quatro elementos da natureza e ao relógio, como símbolo conhecido da "passagem do tempo". O fundo do teatro estava à mostra, ainda repleto das cicatrizes do incêndio que o abatera na década de 60, e no meio do plano térreo um grande círculo de madeira limpa, que concentrava toda a ação cênica. Aqui, a forma circular tem não só essa significação específica, mas, mais uma vez, associa-se à história do grupo. A mandala dividida em quatro partes representa os quatro atos, que são "as quatro fases pelas quais o corpo passa para se completar: nascimento, espera, quebra, morte" 402 e, mais ainda, fecha o círculo de autocrítica dos últimos quatro anos da trupe. O $1^{\circ}$ Ato é o Oficina dos anos 67-68: Festa de Irina, nascimento, cor branca do vestuário da personagem e iluminação clara - anos de euforia e tropicalismo com O Rei da Vela e Roda Viva; o $2^{\circ}$ Ato é o momento da espera, com a lenta ascensão de Natacha - o azul é a iluminação predominante e representa a escuridão de 1969 de Galileu, Galilei e Na Selva das Cidades; o $3^{\circ}$ Ato é a quebra, a explosão, o palco enche-se de vermelho, pois casas da pequena cidade onde vivem As Três Irmãs estão pegando fogo. Representa a ruptura com o teatro tradicional e a experimentação nos anos 70 e 71 com o Living Theater e o Grupo Lobo; o $4^{\circ}$ Ato, ano de 1972, é a "morte do teatro e de tudo" ${ }^{403}$, representados pelo espetáculo Gracias, Señor. O $5^{\circ}$ Tempo, inexistente no texto original, seria a continuação, fora da mandala, que impulsionaria o elenco e o público a "continuarem". A música não se interrompia ao final do $4^{\circ}$ Ato e prosseguia durante muito tempo.

A cenografia também se aproveitou das paredes manchadas para ali registrar mensagens sobre a passagem do tempo e seu poder corrosivo ("o ambiente ao redor

\footnotetext{
402 Idem, Conheça Macha, Irina e Olga, 1972.

${ }^{403}$ Idem, Que tem o Oficina a ver com esta peça?, 1972.
} 
delas está se desintegrando" ${ }^{404}$ ). Em certo sentido, essa foi a "pedra de toque" (o Tempo é a grande personagem) do espetáculo, e o símbolo seguia reiterado no grande relógio de parede ao fundo, na empregada Anfissa (Cecilia Rabelo) que carregava com insistência uma ampulheta, no chão com o formato de um grande relógio e também nas insistentes pausas após as falas das personagens. O "coro dos mendigos"/ músicos, composto por Carlos Hartleb e Ricardo Rizek, garantia que entre uma fala e outra, entre um e outro "round", o silêncio fosse preenchido por uma música contínua, que seguia após o espetáculo. Com o compasso desesperador do tempo que se esvai, na medida em que o "tédio" se acentua, ao longo do espetáculo a ação cênica ia se comprimindo em pequenos "quadrantes" do relógio simbólico ao chão, criando a sensação de sufoco. Ao mesmo tempo, Mariângela Alves de Lima bem observa que a compressão espacial, somada à música constante que interligava os diferentes atos, contribuía para criar a sensação de um grande processo. E, se por um lado ele marca um crescente de opressão também revela, ao final, que se a música continua é também porque a vida continua, ainda que comprimida e sufocante ${ }^{405}$.
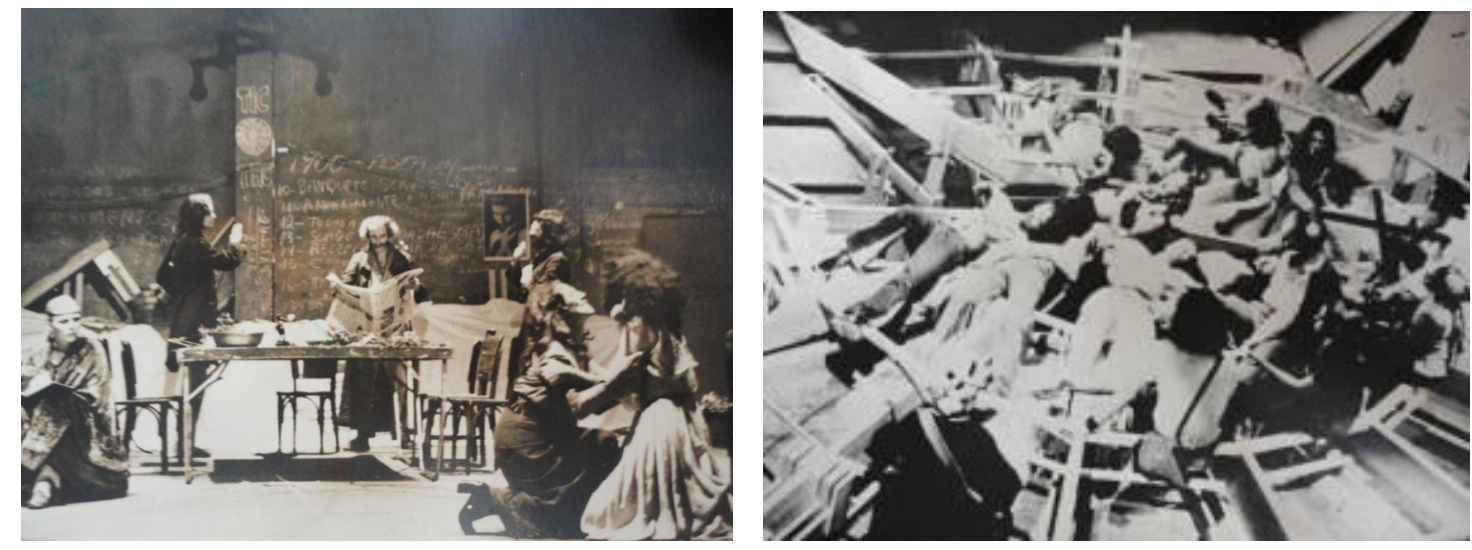

À Esquerda, cena do primeiro ato (atenção para imagem do relógio e inscrições como "Tic-Tac" na parede ao fundo. José Celso está no centro, com jornal em mãos). À Direita, montagem do palco circular pelos atores do Oficina. (Fonte: Fundo do Teatro Oficina, AEL-Unicamp)

José Celso também se encarregou da distribuição dos "papeis" e o critério era claro: o ator precisa ter relações vivas com a personagem. Para garantir a efetividade da

\footnotetext{
${ }^{404}$ Idem, Ibidem.

${ }^{405}$ LIMA, Mariângela Alves de. "O Oficina revigora a atualidade da peça". O Estado de São Paulo, 28 de dez 1972.
} 
experiência como símbolo da trajetória do grupo e como carga individual, era preciso "viver" As Três Irmãs. Maria Fernanda (por muitos considerada a grande estrela da montagem), formada no teatro tradicional e sóbrio, ficaria com a voz da "consciência" e do "raciocínio", o azul sóbrio de Olga. Kate Hansen, em partes familiarizada com a linguagem específica do grupo e bastante disposta à experimentação, seria a "sensibilidade" e o amor de Macha. Analu Prestes, uma das mais jovens atrizes do elenco, representava a energia e o impulso para o trabalho da jovem Irina. Todas elas, em conjunto, seriam para José Celso o "equilíbrio" da mandala ${ }^{406}$. Renato Borghi, como André, seria a divisão e a esquizofrenia ("do que poderia ter sido e o que se tornou" seria também ele o símbolo da ruptura posterior? A concentração dos nervos para o estouro diante dos rumos que o grupo tomou?); Lourival Parisi, como Verchinin, é a "esperança no futuro e o que vem de fora"; Othon Bastos, da formação "tradicional", é "a vontade de mudar, a bondade e todo impedimento de classe" de Tousenbach. A lista assim se estende pelas 14 personagens da peça. Interessante notar o modo como o próprio José Celso considera sua relação com Tchebutikin: "espécie de feiticeiro. De certa maneira, é quem conduz os acontecimentos, sempre em segundo plano". Para ele é um pouco do próprio Tchékhov e "um pouco de mim". Nos artigos "Conheça Macha, Irina e Olga: As Três Irmãs" esta explanação a respeito das personagens mostra as escolhas do diretor e esclarece bastante a respeito de sua leitura. Causa estranhamento observar a centralidade e a leitura dada por José Celso à figura de Tchebutikin, aparentemente relegado a um segundo plano em outras encenações. E, se comparado às outras personagens masculinas, como Solioni (de uma força destrutiva e um deslocamento social que chama a atenção), ou com um Verchinin (repleto de sonhos e que desloca a atenção das irmãs para o que vem de fora, realimentando seus sonhos), ou ainda Tousenbach (a força que puxa para a permanência, ainda que não o admita, e que, não intencionalmente, aplaca os sonhos de Irina em um casamento de província, que não se realiza), Tchebutikin, aparentemente, não possui a centralidade a ele dada por José Celso e, seu aspecto "Feiticeiro", ressoa aqui com algum estranhamento. Certo mal-estar continua quando José Celso, no afã de encaixar as personagens na "sacada" do relógio que define a cenografia, considera serem importantes apenas 12 personagens (os 12 algarismos do relógio) e relega a Anfissa e Feraponte, os serviçais, que são "homens do povo", ao segundo plano. Evidentemente, Tchékhov concentra a ação da peça em

\footnotetext{
${ }^{406}$ Três Irmãs. As Forças Sitiadas. Jornal do Brasil, Rio de Janeiro, 1973 (sem dia e mês especificados. Fonte: Acervo AEL-Unicamp).
} 
torno de uma classe, suas expectativas e frustrações, mas Anfissa e Feraponte, já velhos e "encostados", são também o símbolo da passagem do tempo e servem como forte contraponto à força avassaladora do presente, representado por Natacha ${ }^{407}$.

Cenografia, música e personagens são apenas peças de um grande quebracabeças que necessita, evidentemente, da mão organizadora do diretor que, além dos pontos levantados, tinha uma intenção clara, ou uma "ideologia" (para ficar em uma expressão sua, usada ao longo dos ensaios), que, se é rica pelo que traz de novo na interpretação de Tchékhov no Brasil, será o ponto problemático da encenação: As Três Irmãs analisa uma "determinada camada social, informada e inútil à sociedade". As personagens ali viventes seriam, então, uma espécie de "aborto de época": vivem em um século, mas amarrados "ao que passou" ${ }^{408}$. Portanto, para José Celso, tratava-se não só de fazer um balanço da experiência do Oficina por meio de tal peça (balanço ainda não concluso, dado que as tensões internas continuavam e os rumos ainda não haviam se definido), mas também de passar a limpo a história recente do Brasil. Aqui encontramos um elemento fortemente político da escolha do diretor, que acentua mais uma vez sua tentativa de atualização da peça frente aos problemas de época: era preciso colocar nossa "inteligência de classe média" frente a frente com sua atual inércia (ou compactuação com o estado de coisas). Feito o golpe, sendo perseguidas e massacradas as principais frentes de resistência (armadas ou não), era preciso passar a limpo as teses de que "era preciso acumular forças" ou "esperar os bons tempos que virão". Se Gracias, Señor fora violento nessa crítica, As Três Irmãs a retoma, mostrando a esse setor da sociedade sua identidade com os Prózorov: responsáveis omissos (quiçá diretos) pelo atual estado de coisas. Aos de inteligência progressista, ao teatro progressista, reafirmava-se a pergunta: "de que adianta o compasso de espera?"

O contraexemplo era a intenção do próprio Oficina: reinventar o real, colocar abaixo a burguesia com suas mercadorias e recalques, sem adesão aos velhos métodos (Ultrapassados? Burocráticos? Ineficazes?) - e isso deveria ser feito no presente, no agora. Tal diretriz trazia soluções evidentes para a cena: pairava sobre os Prózorov a sensação de um forte julgamento - afinal, aquela família e seu entorno seriam os responsáveis diretos por sua própria situação (e do mundo ao seu redor). No entanto, como ignorar a individualidade dada por Tchékhov a cada personagem? Como ignorar sua famosa "compaixão" pelas personagens, o lirismo, o sonho ou a Utopia de uma

\footnotetext{
${ }^{407}$ Idem, Conheça Macha, Irina e Olga, 1972

${ }^{408}$ Checov ficará dez dias no Teatro Oficina. Folha de São Paulo, São Paulo, 19 de dez. de 1972
} 
Moscou brilhante (ponte entre o passado e o futuro, ainda que solapada pela motoniveladora do presente?). Com relação a este aspecto, Yan Michalski destaca:

outro motivo da indecisão do espetáculo é o irremediável conflito entre o amor que Tchecov tinha pelas suas personagens e o ódio que José Celso lhes dedica. Para o autor, os personagens são, antes de mais nada, indivíduos, os quais a cada ele cerca de notável carinho; e só secundariamente eles são representantes de uma classe social, ainda assim apresentados como vítimas quase inocentes das pressões que se abatem sobre essa classe. ${ }^{409}$

Por mais que política e ideologicamente a diretriz de José Celso revele alto interesse, formalmente ela trazia problemas de difícil solução. Se por um lado o trabalho cenográfico e a música destacavam modernamente uma prioridade do TEMPO como grande agente corrosivo das vidas reais, por outro estabelecia uma relação com suas personagens de difícil solução: de nada valeriam todas as suas expectativas? Não mereceriam sequer nosso olhar compreensivo para trás? Segundo alguns críticos, este questionamento ganha força ao mapearmos que parte significativa da crítica ressaltou o ritmo extremamente cansativo do espetáculo. As quatro horas praticamente se arrastavam, as pausas excessivas pareciam pedir ao leitor para captar cada detalhe, cada sensibilidade, cada subtexto. No entanto, como conciliar essa tentativa de salvamento com o julgamento sumário que disputava a interpretação geral? Como conciliar um ritmo moroso e lento com a pergunta de Tchebutikin/José Celso que fechava o ato: "De que vale tudo isso? De que vale tudo isso?".

O impasse ganha força se levamos em conta que a tensão que assolava o grupo, não só financeira, mas também ideológica e estética, não se resolvia: Gracias, Señor havia declarado a morte do teatro realista, tradicional, burguês e "morto". Mas uma parte do grupo (capitaneada por Renato Borghi) exigia um retorno mediado à possibilidade de ainda poder dizer, à força da palavra no teatro. Tchékhov os afastava ou lhes pedia um olhar compreensivo para esse teatro (exigindo, inclusive, que a generalização entre realismo e morte não fosse tão direta)? Se por um lado o espetáculo respeitava o texto tchekhoviano (a tradução de José Celso a partir do francês e do inglês

409 MICHALSKI, Yan. As Três Irmãs: Vítimas ou Culpadas? Jornal do Brasil, Rio de Janeiro, 16 jan. 1973. 
fizera mínimas alterações), a tentativa de envergar o espetáculo para uma diretriz moderna e eficaz para a antropofagia e o desbunde, não se realizava por completo. E o novo de algumas escolhas era sufocado pelo ritmo lento que, em certo sentido, em nada diferenciava o Oficina das encenações "melancólicas", tradicionais e "mortas" (para ficar em sua terminologia $)^{410}$, feitas no Brasil e no exterior.

O auge dos impasses se deu justamente na noite de 31 de dezembro de 1972. Às $24 \mathrm{~h}$ do último dia do ano iniciava-se o $3^{\circ}$ Ato, no qual as três irmãs se deparam, no começo da madrugada, com um incêndio que toma conta do vilarejo, Olga (Maria Fernanda) deveria entrar em cena, com um pequeno lenço vermelho, gritando: "Fogo, fogo!". No entanto, automaticamente, como em um ritual (não previsto e não ensaiado), os atores começaram a se dirigir para o meio da plateia e para diversos pontos do palco, com inúmeras tochas. Criava-se um clima envolvente, místico, surgido da "necessidade dos corpos". Se tal "improviso" agradou sobremaneira a José Celso, que via ali o rumo a ser seguido pelo grupo, para Renato Borghi e atores como Othon Bastos, era a gota d'água: ao final, do meio da plateia, estes atores afirmaram estar cansados disso tudo e declararam sua saída do espetáculo e do grupo. Sai a última parte do par remanescente das formações originais do Oficina. E aqui, mais uma vez, observamos a capacidade do grupo de jogar criativa e inesperadamente com a tradição: o ritmo até então moroso ao qual se referia boa parte da crítica não pode e não deve ser visto somente nos termos do teatro tradicional. O "improviso" e o ritual promovidos com as tochas acentuavam a dimensão ritualística do espetáculo que não pode ser pensada com os critérios com os quais boa parte dos críticos estava acostumada a julgar. Como bem destacou Mariângela Alves de Lima, ao invés de incair no tradicional "arrastamento" e no resultado final de ordem pessimista, o destacado "compasso de espera", a presença das tochas que "incendiavam o palco" e a insistente pergunta de Tchebutikin "Que importância tem isso? que importância terá tudo isso?" eram prova da eficácia da montagem para as questões do seu tempo:

Essas respostas cabem ao espectador. Mas a importância desse trabalho do Oficina é positivamente indiscutível. Mostra que o teatro pode ser bem feito, pode contar ideias e pode ser vanguarda sem perder pontos em nenhum campo. Um

\footnotetext{
410 A expressão é também influência do termo clássico cunhado no livro The Empty Space, de Peter Brook.
} 
argumento contra quem acredita na adaptação e no
conformismo.

Como avaliar, portanto, este espetáculo? Seria o caso então de julgar definitivamente uma inaptidão do Oficina para as peças de Tchékhov, como fizeram alguns críticos? Não parece ser o caso, ainda que impasses como o julgamento sumário das personagens seja evidente. O momento de definição do grupo, altamente tenso, como vimos, polarizava pontos de vista e criava soluções controversas, mas inovadoras. Estas advinham do momento histórico que colocava demandas diretas para as "inteligências progressistas" - e o Oficina consolidava um modo específico de encarálas e resolvê-las. Ao final, mesmo com as respostas de José Celso, continua a pergunta, com outra qualidade: "Que tem o Oficina a ver com esta peça?". Sua autoproclamada vanguarda (da política, da ideologia e da ruptura com os recalques) não fora demasiado dura ao revisitar o passado, a tradição e o olhar duro, mas amoroso, de Tchékhov ${ }^{412}$ ? Se tais perguntas põem em questão as próprias escolhas do Oficina e sua alternativa para um "teatro vivo", não se pode negar que, talvez pela primeira vez na história do teatro brasileiro, Tchékhov parecia lutar para funcionar dentro do contexto teatral e político específico, espécie de leitor do estágio vivido pela inteligência brasileira, para além de um simples "clássico importado" no repertório de grandes companhias.

\footnotetext{
${ }^{411}$ LIMA, Op. Cit. 1972.

${ }^{412}$ A respeito da postura por vezes autoritária que pode assumir a vanguarda antropofágica, ao negar o passado e valorizar um presentismo "inocente", que celebra o contraditório com o desbunde, ver: SCHWARZ, Roberto. A Carroça, o Bonde e o Poeta Modernista. In: Que Horas São?. São Paulo: Companhia das Letras, 1989, p. 11.
} 


\section{Tchékhov, nosso contemporâneo}

\subsection{A tradição posta em questão - Tovstonogov, Éfros, Strehler}

Nos anos 70, Tchékhov já era parada obrigatória para qualquer programa de formação dramatúrgica e referência de estudo para muitos grupos de expressão internacional. Na União Soviética, sua relevância era inquestionável, ainda que até então, para adequá-lo às diretrizes do heroísmo épico e da positividade de perspectiva apontados como necessários pelo Partido, fosse imperioso um grande contorcionismo de interpretação. Isso significava não só a tentativa de ler suas peças pela lente do "velho mundo que se esvai" (as antigas ordens feudal e burguesa) ou das "três irmãs que sonham com um mundo novo" (leia-se o Socialismo então existente) como também o silencioso ofuscamento de peças que pareciam não se enquadrar em nenhuma perspectiva positiva, como A Gaivota. Para Pavel Markov, era curioso notar que o Teatro de Arte de Moscou, responsável por canonizar sua dramaturgia e por adequar Tchékhov a uma linguagem aceitável para o sistema, tenha encenado A Gaivota 110 vezes até 1958, apenas dois por cento de todas as encenações do dramaturgo no período $^{413}$. Mas isso só era necessário porque já não se podia ignorar sua força canônica. $\mathrm{Na}$ Europa Ocidental, pode-se dizer que era de se estranhar que diretores como Peter Brook, que tivera contato com elencos brilhantes da Inglaterra nos anos 50 e 60, e que já tinha feito análise de fôlego em seu The Empty Space ${ }^{414}$ contra a leitura stanislavskiana de Tchékhov como expositor de "tranches de vie", ainda não o tivessem colocado em cena $^{415}$.

Neste momento, o desejo de atualização do dramaturgo russo era nota dominante na maioria das encenações feitas nos países centrais do capitalismo. Tornava-se comum, não sem algum reducionismo e distorção, a tentativa de superação das concepções stanislavskianas e a identificação dessa leitura com um naturalismo estreito. Em 1965, Tovstonogov $^{416}$ realizou uma das encenações que mais contribuiu para o início do

\footnotetext{
${ }^{413}$ MARKOV, Pavel. New trends in the interpretation of Chekhov. World Theatre n. 9. Summer, 1960, p. 107-108.

${ }^{414}$ BROOK, Peter. Op. Cit.

415 A encenação de Peter Brook de O Jardim das Cerejeiras só viria a acontecer em 1981.

416 Georgy Alexandrovitch Tovstonogov (1913-1989) graduou-se em direção pelo GITIS (Academia Russa de Artes Teatrais) em 1938. Começou sua carreira no Teatro Dramático Griboiedov. Em 1949 foi indicado para o cargo de diretor-geral do Teatro Lênin, em Moscou, onde dirigiu a antiestalinista montagem A Tragédia Otimista, com a qual ganhou o Prêmio Lênin. Em 1956 tornou-se diretor do Teatro
} 
processo de revisão das leituras dominantes de Tchékhov na Rússia. Em As Três Irmãs, o diretor pretendia investigar a potência desse texto para a compreensão do seu tempo. Ao longo dos ensaios, seguia os procedimentos de preparação e treinamento dos atores de acordo com os preceitos de Stanislávski. No entanto, sua leitura retirava das personagens o peso da culpa que a elas atribuía a crítica soviética. Mais do que culpá-las por sua inação, Tovstonogov pretendia entender qual a dialética entre a impiedosa crítica a um modo de vida que se provava injusto e improdutivo e a simpatia que Tchékhov reservava às personagens dele representantes. Isso implicava em caminhar no difícil movimento entre uma investigação da interioridade das personagens (herança do sistema de Stanislávski, sem, no entanto, assumir sua leitura de diretor) e uma capacidade de analisá-las em perspectiva crítica (como propunha Brecht). Para Tovstonogov, era o caso de entender dialeticamente o "destrutivo poder da inação e o protesto de Tchékhov contra ela"417.

Dois anos depois, na esteira desse espírito de renovação, o enfant terrible Anatoli Éfros ${ }^{418}$ produziu a mesma peça. No entanto, ao contrário do descarte unilateral feito por boa parte da crítica soviética e também da crítica dialética de Tovstonogov à inação e à inevitabilidade da derrota, a proposta de Éfros apontava para o extremo oposto e construía uma espécie de "elegia da ruína" ${ }^{419}$. Todo o lirismo, todo sonho e desejo de mudança presentes nos discursos dos oficiais e das três irmãs fora suplantado por pesada atmosfera. Um dos grandes choques iniciais dessa interpretação fora a cenografia. No centro do palco, uma imensa árvore com folhas de metal douradas. Árvores pretas foram pintadas no muro ao fundo. As personagens pareciam perecer e agonizar naquele limbo beckettiano, em uma vida sem contornos e sem perspectivas. $\mathrm{O}$

Bolshoi, no qual amadurece suas pesquisas e desenvolve a popular síntese entre os preceitos de Stanislávski, Meyerhold e Brecht. Ficou famoso por direções que revisitavam clássicos russos, imprimindo-lhes novas leituras. Além disso, também ficou conhecido posteriormente por sua capacidade de conviver criativamente com o controle ideológico-estético do Partido. Ver: Historical Dictionary of Russian Theater, p. 406-407.

${ }^{417}$ TOVSTONOGOV. Krug mislei, p. 155 apud SENELICK, L. Op. Cit., p. 205.

${ }^{418}$ Anatoli Vassilievitch Éfros (1925-1987) foi um diretor russo também formado pelo GITIS em 1951. Entre 1963 e 1967 dirigiu o Teatro Lênin, onde estreou 104 Páginas de Amor e Fazendo um Filme. Neste período também dirigiu a inventiva e antilírica montagem de A Gaivota. Aos poucos consolidava sua fama de "terrível" nos meios artísticos, o que ficou evidente com a antológica e polêmica montagem de As Três Irmãs em 1967, que gerou protestos abertos de atores do TAM. Sempre foi um grande admirador de Stanislávski e propunha um sistema de trabalho e preparação dos atores que partia da ideia de que a verdade da atuação deveria emergir da improvisação - um claro enfrentamento ao engessado "método". Na década de 70 suas montagens eram disputadíssimas e possuía grande habilidade na condução de diferentes grupos de atores. No final de sua vida já não gozava do mesmo prestígio de décadas anteriores e atravessou duros conflitos na lida com os atores do Teatro Taganka. Ver: Historical Dictionary of Russian Theater, p. 106-107.

${ }^{419}$ A expressão é de David Allen em Performing Chekhov. New York: Routledge, 2000, p. 88. 
monólogo de Tuzenbach fora especificamente um dos grandes pontos de polêmica. Ao invés de envolver suas ideias em um clima de esperança diante do crescente desespero das irmãs, Éfros optou por, após a reflexão dessa personagem, fazer com que Tchebutikin socasse o piano desdenhosamente, seguido do leve olhar de ironia das personagens. A crítica soviética encarou este movimento como uma leitura niveladora do diretor que, além de suplantar toda as expectativas de superação daquele mundo "crepuscular", zombou dos momentos em que essa expectativa emergia. Éfros mais tarde negou qualquer intenção semelhante afirmando que o amor de Tuzenbach pelo trabalho e pela mudança era também o amor dele e dos atores. A resposta não convenceu e a produção permaneceu em cartaz por apenas seis meses ${ }^{420}$.

Tal sufocamento promovido por parte da crítica fazia parte de uma retomada dos velhos representantes do estalinismo dos anos 40 e 50. Após o $20^{\circ}$ Congresso do Partido Comunista, no qual Nikita Khruschióv denunciou os crimes de Stálin, o clima no meio teatral era de experimentação e ousadia. Isso significava um enfrentamento direto ao falso otimismo do Realismo Socialista. No entanto, a Primavera de Praga e ação deletéria das forças soviéticas abriu condições para a retomada da tradição engessada do período anterior, o que fez com que diretores e atores buscassem estratégias para contornar a ação da censura. Dentre elas estava a da apropriação de elementos críticos da cultura popular e a revisitação de clássicos, na esteira do movimento promovido por Brecht $^{421}$. Isso de imediato evitava a ojeriza do Partido às experimentações vanguardistas, mas não necessariamente blindava os diretores de ações censoras posteriores, como a realizada sobre a montagem de As Três Irmãs, de Éfros. O mesmo se daria com sua montagem de 1975 de O Jardim das Cerejeiras. À frente de um difuso movimento que via a atual realidade soviética com causticidade e desilusão, Éfros dirigiu a peça como uma espécie de enfrentamento não só ao regime, mas também aos padrões de interpretação do TAM. O diretor explorou a dimensão grotesca da peça e dirigiu os atores do Teatro Málaia Brónnaia "em específicos, às vezes mecânicos movimentos, às vezes contidos e estilizados, às vezes exageradamente emocionais, tornando o conjunto ridículo e patético". No entanto, ainda que se tratasse de umas das

\footnotetext{
${ }^{420}$ Idem, p. 88-89.

${ }^{421}$ LOEHLIN, James N. Chekhov - The Cherry Orchard - plays in production. New York: Cambridge University Press, 2006, p. 148.
} 
mais importante encenações desta peça de Tchékhov após a encenação do TAM de 1904, o diretor sofrera severas críticas por parte da crítica oficial ${ }^{422}$.

Se na União Soviética o ambiente sufocante não era capaz de limar por completo o processo de atualização da dramaturgia de Tchékhov, na Europa e nos EUA o impulso era o mesmo, ainda que com maior receptividade crítica. Como ponto em comum estava o de que a sua dramaturgia lançava problemas fundamentais para o entendimento do tempo presente, o que implicava em formalmente também concebê-lo de acordo com uma linguagem viabilizasse essa potencialidade. Como auge desse processo esteve a encenação de Giorgio Strehler de O Jardim das Cerejeiras, em 1974, no Piccolo Teatro, em Milão. Pode-se dizer que essa encenação se converteu em verdadeira referência de revisão da leitura stanislavskiana no século XX.

Segundo o diretor italiano, era preciso entender a peça de Tchékhov além de seus limites de origem no tempo e no espaço, sem, no entanto, negá-los. Para isso, concebeu $O$ Jardim como "três caixas chinesas", que englobavam umas às outras. A caixa mais interna seria a referente à "Realidade", à narrativa mesma, ou seja, o drama de Raniévskaia, a venda da propriedade e os negócios almejados por Lopakhin. A segunda caixa, maior que a primeira, era relativa à "História", ou seja, o processo social de mudança que caracterizava a passagem de um modo de sociabilidade à outro. Por fim, a última caixa, maior, responsável por englobar as demais: a "Vida". Esta seria a esfera das ações "universais", que se situam historicamente, mas abarcam ao mesmo tempo toda a "saga humana": o nascimento, o amor, a morte, a partida... ${ }^{423}$

Com tal leitura ambiciosa, seria necessária uma abordagem múltipla, que conseguisse sintetizar diferentes linguagens e, a um só tempo, operassem simultaneamente sem se sobreporem. Para Strehler, boa parte das encenações feitas de Tchékhov na Europa pecavam por um dos três excessos. Seja pela excessiva dedicação ao detalhe e à minúcia de figurinos, sons, gestos e feições (à maneira do "ateliê de minúcias" stanislvaskiano), seja pelo excessivo enquadramento histórico-crítico da trama (à maneira de um Brecht carregado), seja pelo desejo conservador de abstração e universalização extremas, que tornavam a força poético-crítica de Tchékhov pasteurizada $^{424}$. Equilibrando-se entre esses diferentes eixos, o diretor conseguiria não só manter-se vinculado ao impulso politizador e existencial do período (como Brecht e

\footnotetext{
${ }^{422}$ Idem, p. 151-154.

${ }^{423}$ STREHLER, Giorgio. Per un Teatro Umano apud SENELICK, L. Anton Chekhov's Selected Plays. New York: Norton, 2005, p. 614-615.

${ }^{424}$ LOEHLIN. Op. Cit., p. 139.
} 
Pirandello), mas também a sua formação na poética de Shakespeare e na commedia dell'arte.

As "três caixas" operavam simultaneamente não só na ação dos atores, como também na cenografia. Strehler partiu da ideia de que o jardim era em si um problema fundamental e seguiu a diretriz que Tchékhov sinalizou em carta a Stanislávski, do dia 05 de fevereiro de 1903:

(...) Estou contando em escrever a peça depois do dia vinte de fevereiro e devo terminá-la por volta de 20 de março. Já está pronta em minha cabeça. Chama-se $O$ Jardim das Cerejeiras, tem quatro atos, e no Primeiro Ato as cerejeiras podem ser vistas em flor através das janelas, todo pomar é uma massa branca. E há senhoras vestidas de branco. (...)

Essa "massa branca" aparece de maneira decisiva na concepção cênica de Strehler. Além da brancura do solo, foi erguido acima dos atores um gigantesco véu, sobre o qual se acumularam milhares de pétalas de papel cortado. As pétalas caiam eventualmente, em ritmo variável, a depender da atmosfera e da estação, simbolizando ora a branca neve, ora as pétalas de cerejeiras em flor. Este conjunto, imponente e erguido acima de tudo e todos, representava a esfera da "Vida". A mobília foi reduzida ao essencial e funcionava simbolicamente, como indicador de classe, à maneira de Brecht, representando a esfera da "História". Já os atores puderam selecionar seu próprio figurino, com todos apetrechos escolhidos com minúcia e ao gosto, mas unicamente dentro da opção de cor branca - a esfera da "Realidade".

O primeiro ato já apresentava a curiosa inovação de expor as personagens a um ambiente semelhante a um "quarto de criança", com mobília diminuta e um pequenino aparelho de chá. O conjunto contrastava com um grande armário, símbolo da imponência de uma vida aristocrática. O sentido gerado era dúbio: se por um lado poderia sinalizar um amesquinhamento e apequenamento daquele modo de vida, poderia também, com a mesma intensidade, sugerir a ternura nutrida por ele. Tanto que, em determinado momento, Gaiev esbarra no armário, que se abre e revela inúmeros

\footnotetext{
${ }^{425}$ TAKEDA, Cristiane Layher. O Cotidiano de uma Lenda - Cartas do Teatro de Arte de Moscou. São Paulo: Perspectiva, 2003, p. 243.
} 
objetos de um quarto de criança. Escapa um carrinho de bebê, que desliza e imediatamente leva Raniévskaia às lágrimas ${ }^{426}$.

No segundo ato, o tema do "quarto de crianças" retorna, agora por meio de um pequeno trem de ferro que, em determinado momento, passa por trás das personagens e de repente cruza o proscênio, momentos após o discurso de Lopakhin em que este afirma rezar todas as noites: "Meu bom Deus nas alturas, o Senhor nos deu florestas enormes, terras sem fim, campos imensos, mas a nós, homens, que vivemos no centro de tudo, não nos criou gigantes e condizentes com isso!" ${ }^{427}$. Instantes depois de seu discurso, ocorre uma prolongada e angustiante pausa das personagens, combinada com a lenta passagem do trem, que assovia. O trem surgia como a tentativa de potencializar o sentido da fala de Lopakhin, reflexão sobre os alcances dessa ambição do homem na terra, mas também como suplemento a um difícil elemento lançado por Tchékhov: o barulho da corda que se arrebenta. Instantes após a fala do negociante, as personagens permanecem em silêncio e surge um som, como que vindo do céu, que "ressoa triste e agonizante como a corda de um instrumento ao romper-se" ${ }^{428}$. Esta problemática indicação do dramaturgo, sempre enfrentada com dificuldade por diretores, foi aqui solucionada pelo diretor não em termos sonoros, mas imagéticos. Para Strehler, as personagens ouvem o som, angustiam-se, mas os espectadores têm acesso apenas à imagem do trem, que a ele remete.

Já o terceiro ato explora a absurdidade da situação como elementos cômicos. A festa, o auge do desespero, são simbolizadas por inúmeras cadeiras de diferentes modelos e épocas (destacando sua historicidade) que ocupam o palco. As personagens dançam com elas, esbarram e derrubam-nas, como em uma estranha brincadeira. Sua presença tinha múltiplos sentidos: da demarcação histórica, da tensão gerada pela presença de tantos assentos sem pessoas, de sua disposição como que a interagir absurdamente com as personagens (Lopakhin derruba uma cadeira no primeiro ato e, no terceiro, chega mesmo a simulá-las como cerejeiras, convidando o público a vê-lo lançar o machado sobre as árvores). Acentuou-se o ambiente cômico com curiosa "dança" que Pichtchik realiza com a cadeira ao cochilar e a caracterização de Charlotta, criada da família que tivera passado circense, vestida com um casaco de proporções extras e um sapato grande, sugerindo a vestimenta de um palhaço. É como que se para

\footnotetext{
${ }^{426}$ LOEHLIN, Op. Cit., p. 104-143.

${ }^{427}$ TCHEKHOV, Anton. As Três Irmãs/ O Jardim das Cerejeiras. Tradução Gabor Aranyi. São Paulo: Ed. Veredas, 2003, p. 94.

${ }^{428}$ Idem, Ibidem.
} 
ressaltar a absurdidade da festa, Strehler se utilizasse de sua conhecida orientação para o trabalho com a commedia dell'arte, que já o consagrara anos antes com as encenações de peças de Goldoni.

No último ato, assim como no inicial, Raniévskaia, vivida por Valentina Cortese, ganha especial contorno. Sua personalidade foi traçada à maneira de um "eletrocardiograma" ${ }^{429}$ : gestos rápidos, ajustando constantemente o cabelo, tirando e pondo o chapéu, colocando flores sobre a cabeça, mexendo insistentemente no para-sol, às vezes sorrindo e chorando sucessivamente. Se por um lado isso envolve o público afetivamente em seu turbilhão emocional, também serve para caracterizá-la socialmente, já que denota também sua condição de aristocrata imersa em uma condição econômica degradante e, por isso, tensa. À brechtiana, concebe-se a personagem em suas contradições pessoais e sociais, definindo um Gestus específico ${ }^{430}$. E, a despeito de seu profundo desejo de vida, manifesto também nas falas de Ánia e Trofimov, ao final prevalece seu desespero. A brancura do conjunto contrasta com as personagens que, vagarosamente, ao saírem da propriedade vendida, colocam casacos e coberturas negras sobre suas vestimentas brancas. Raniévskaia é a última a sair, recobrindo toda a sala com um olhar pesaroso. Firs fecha a cena, descobrindo que fora esquecido pelos proprietários, ao som dos primeiros machados cortando as árvores e ao mesmo tempo que o grande véu se rompe, lançando sobre sua cabeça e sobre o palco as decaídas pétalas do jardim das cerejeiras ${ }^{431}$.

\subsection{Recolhimento e descompasso}

Neste período, nomes como os de Tovstonogov e Éfros tinham circulação muitíssimo restrita entre nós. E diretores como Strehler eram conhecidos apenas por um grupo restrito de críticos e artistas que, ou faziam viagens ao exterior para acompanhar as temporadas internacionais, ou liam de orelhada seus nomes em periódicos de área. Tanto que, muito desse movimento de revisão da tradição interpretativa sobre Tchékhov

\footnotetext{
${ }^{429}$ A expressão é de Laurence Senelick, apud LOEHLIN, Op. Cit., p. 141.

${ }^{430}$ KLEBER, Pia. The Whole of Italy is our Orchard: Strehler's Cherry Orchard. Modern Drama n. 42, 1999, p. 589-590. Para Brecht, "as atitudes que as personagens tomam umas com as outras constituem o que denominamos domínio gestual. Atitudes corporais, entonações, jogos fisionômicos são determinados por um gestus social: as personagens se xingam, se cumprimentam, trocam conselhos etc" . BRECHT, B. apud PAVIS, Patrice. Dicionário de Teatro. São Paulo: Ed Perspectiva, 2008, p. 187.

${ }^{431}$ LOEHLIN, Op. Cit., p. 145-146.
} 
chegava de maneira genérica até nós, sem condições de impactar em termos específicos sobre nossas concepções críticas ou investigações formais. Basta ver como Barbara Heliodora, então uma das maiores críticas teatrais ativas no Rio, referira-se a encenação de Éfros, em artigo publicado no Jornal do Brasil, em setembro de 1968:

(...) mas, ainda este ano, a produção de As Três Irmãs, de Tchékhov, por um jovem diretor que fazia experiências com o texto, foi precipitadamente tirada de cartaz em Moscou, apesar de ter tido excelente recepção por parte do público, por ser considerada desrespeitosa em relação ao mestre, e entrar em conflito com Stanislávski. Essa foi aparentemente a razão dada; mas parece que houve um pouco de entusiasmo excessivo em relação a certas passagens consideradas muito revolucionárias... $(\ldots)^{432}$

No entanto, não há motivo para "culpar" esse descompasso. Afinal, nosso teatro vivia um momento riquíssimo de investigação sobre o sentido de nossa modernização teatral, o que, em alguns casos específicos (como o do Arena) implicou no direcionamento das atenções para a dramaturgia nacional e a investigação de formas produtivas que explorassem a problemática da superação de nossa condição de periferia econômica e cultural. Em suma: a medida de nosso compasso era outra. Como já vimos, isso implicou em escolhas dramatúrgicas e teóricas específicas e Tchékhov, em muito vinculado a uma tradição teatral tradicional e "aburguesada" da "peça bem feita", parecia demasiado "arrastado" e "crepuscular" para as demandas do tempo. Falar de sua atualização parecia ainda algo restrito ao interesse de alguns poucos.

É visível que os anos 60 e 70 na Rússia e na Europa já eram marcados por um processo de revisão da tradição stanislavskiana e das leituras da dramaturgia de Tchékhov a ela vinculadas, tanto que após a encenação de Strehler, diretores importantes já realizavam revisões ainda mais radicais pelo mundo, como André Gregory, Joseph Chaikin e Jean Claude Van Itallie, em 1975, em Nova York; Andrei Serban, em 1977, em Nova York e Trevor Griffiths e Richard Eyre, na Inglaterra, em $1977^{433}$. Em terras brasileiras, nesse mesmo período, Ivan Albuquerque dirigia uma

\footnotetext{
432 HELIODORA, Barbara. Teatro Russo, Teatro Revolucionário, Teatro Soviético. Escritos Sobre Teatro. São Paulo: Ed Perspectiva, 2007, p. 294.

${ }^{433}$ Segundo Laurence Senelick (Op. Cit., 1997, p. 292-293), boa parte dessa encenações estadunidenses vinha carregada do espírito de época, que o crítico traduziu como "Make Chekhov, not War". E para James Loehlin (Op. Cit. p. 147-170), o fundamental de tais encenações, na esteira da encenação de Éfros de $O$ Jardim das Cerejeiras, foi a realização de um processo de revisão ainda mais radical da tradição
} 
versão cuidadosa e marcante de $O$ Jardim das Cerejeiras (1968) que dava um passo além da leitura tragicizante e realista vinculada ao TAM, sem, no entanto, inaugurar uma tendência de fôlego. O grupo Oficina, como vimos, lançou em 1972 pela primeira vez, ao encenar As Três Irmãs, o problema da "atualidade" de Tchékhov para a realidade brasileira. Mas, se por um lado a encenação trazia uma problemática e um trabalho formal até então inéditos na trajetória de recepção do teatro de Tchékhov, por outro lado recaiu na dificuldade dar consequência às próprias escolhas formais que promovia (desequilibrando-se entre o "teatrão" que negava e as experimentações que proclamava, ou sendo demasiado cruel com personagens que pediam um tratamento mediado e sutil). Mas este problema em si não pode fechar uma proposta que, se pecava por algumas contradições, teria por outro lado condições de amadurecimento garantidas não fossem as crises internas vividas pelo grupo e as pressões da censura militar.

Após a encenação do Teatro Oficina, pode-se dizer que a primeira metade da década de 70 reuniu representações importantes, mas que sua segunda metade representou um intervalo razoável na história da recepção do teatro de Tchékhov. A virada vivida pelo próprio teatro brasileiro, que sofrera duro golpe ao ver boa parte das companhias e grupos estáveis da década de 60 se esfacelarem (como o Arena em 1971 e o Oficina em 1973) é decisiva para a compreensão desse processo. A censura sobre alguns artistas e grupos, assim como as dificuldades de sobrevivência financeira ante um universo cada vez mais cerceado, dificultaram o amadurecimento de linguagem e, no caso paulista, "a atividade teatral passara a desenvolver-se preferencialmente como produção isolada" ${ }^{434}$, muitas vezes com pouca disposição à experimentação e mais propensa às pressões mercadológicas dos produtores.

Nesse sentido, entende-se a desaceleração sofrida pelo movimento de recepção da dramaturgia de Tchékhov que, antes, sinalizava crescimento. Se nos anos 50 e 60 dezenas de encenações por grupos profissionais e amadores de expressão foram realizados, nos anos 70 o número de encenações de suas peças farsescas reduziu significativamente e, mesmo suas peças maiores, já traduzidas e relativamente conhecidas nos meios teatrais, não aumentou ${ }^{435}$. As peças em um ato do dramaturgo

stanislavskiana - algo que, para a cena americana e inglesa tinha impacto decisivo - e a atualização política do dramaturgo.

${ }^{434}$ FERNANDES, Silvia. Grupos Teatrais - Anos 70. Campinas: Editora da Unicamp, 2000, p. 13.

435 De acordo com o levantamento realizado, que segue em anexo, é possível mapear mais vinte encenações de peças farsescas (em festivais e em encenações avulsas) nas décadas de 50 e 60. Suas peças maiores, tiveram encenações feitas por grupos de expressão (amadores e profissionais) nas principais 
russo já não eram fonte de interesse direto dos grupos. Seja porque boa parte dos grupos estudantis (inicialmente os principais difusores desse filão) já haviam desdobrado suas pesquisas temáticas e formais rumo a outros caminhos, seja porque o Tchékhov farsesco não parecia de imediato produtivo para o debate político então sufocado, ou ainda porque sua dramaturgia de fôlego, das "quatro grandes peças", já estava razoavelmente difundida entre nós e se tornava símbolo do "verdadeiro" lado do dramaturgo. Nesse sentido, as encenações de $O$ Jubileu, por Beto Diniz, em 1975, no Rio de Janeiro, de Um Pedido de Casamento, por J. B. Galvão (Grupo Atard), em 1975, em Brasília, de Um Pedido de Casamento, O Urso e Sobre os Males que traz o Tabaco, pelo TECA, em 1976, em Araraquara, de O Urso, por José Guilherme de Castro Alves, em 1976, em Vitória, de O Casamento de Natalina (adaptação de Um Pedido de Casamento feita por Célia Helena), por Carlos Augusto Strazzer, em 1977, em São Paulo e de Um Pedido de Casamento e O Urso pelo Grupo Anhangá, em $1977^{436}$, em São Paulo, realizadas, como se vê, por grupos amadores e estudantis, vêm marcadas pelo interesse ligeiro e sem maiores propósitos por essa dramaturgia, tendo em vista os programas de peça que apontavam apenas dados biográficos genéricos e o fato de que as encenações eram realizadas na maioria das vezes em noites que reuniam a apresentação de outras pequenas cenas de autores natureza bastante diversa ${ }^{437}$. Diferentemente das pesquisas que predominaram no período anterior, como as de Hermilo Borba (que o levaram a Tchékhov tendo em vista as investigações sobre a comédia e o popular) ou como as de Luiz Carlos Maciel e Maria Clara Machado, interessados que estavam em explorar nessas farsas seja seu poder comunicativo com o público, seja seu dinamismo para a formação de jovens atores.

Em contrapartida, encenações de fôlego das grandes peças de Tchékhov foram feitas ao longo da década de 70, sem, no entanto, lançarem novas tendências. Não só a do Oficina, em 1972, mas também a montagem de A Gaivota, por Jorge Lavelli, representou um momento importante dessa trajetória. O jovem diretor, nascido na Argentina, mas hoje já com longos anos de residência na França, era conhecido por encenações que fugiam ao padrão realista e valorizavam a experimentação formal (em

capitais, totalizando aproximadamente 10 encenações. Na década de 70, aproximadamente 07 encenações das peças farsescas e 4 encenações de suas peças maiores com relativa repercussão.

${ }^{436} \mathrm{O}$ detalhamento das fichas técnicas de todas essas peças vem em Anexo.

${ }^{437}$ No programa do TECA (Teatro Experimental de Comédia de Araraquara) é possível ver, em uma mesma noite, uma peça de Tchékhov e "Se os homens jogassem cartas como as mulheres", de George Kaufmann. Ver. Programa de Peças - Teca (Teatro Experimental de Comédia de Araraquara), 1976, p. 1-4) 
alguns casos, bastante físicas e violentas). Por isso, quando de sua passagem pelo teatro brasileiro, decidiu reunir atores em torno da montagem de uma peça de Tchékhov escolha que causou frisson ${ }^{438}$. O burburinho, estipula-se, vem não só de uma prédefinição de muitos do que deveria ser a forma correta de se lidar com o texto tchekhoviano, mas também de uma certa reticência ao teatro visceral e participativo que afirmava-se com altos e baixos no solo do Oficina e de grupos de vanguarda.

Mas a escolha de Lavelli aparentemente acalmou as angústias da crítica. Em primeiro lugar porque o diretor optou por uma encenação que deixou o texto "falar", ou, segundo suas palavras, "a vedeta é o texto". Ao contrário do Oficina, que respeitou o texto integral mas realizou escolhas cênicas que iam muito além das rubricas do dramaturgo (como, por exemplo, o momento em que os atores entram com tochas nas mãos para representar o incêndio do $3^{\circ}$ ato), ou escolhas como as de Strehler (com objetos simbólicos como o trem ou mobília diminuta, dando outras camadas de significado à encenação), Lavelli optou por uma direção mais "verbal", com cenário limpo, reduzido ao essencial, com foco na atuação e na capacidade dos atores de dizer. Nas palavras de Yan Michalski, isso significou uma escolha importante, pois ao mesmo tempo em que a montagem não se superiorizou ao texto (com "brilharecos"), também não se inferiorizou (gerando efeitos rebarbativos em cena até então tratados como "tipicamente tchekhovianos") ${ }^{439}$. Além disso, o diretor optou por manter-se distante de qualquer contextualização sociopolítica, como tinha se tornado nota dominante em boa parte das encenações do período. Ao contrário de Ivan Albuquerque, que evidentemente tinha orientações políticas ao promover o "Ciclo Russo", ou José Celso, que via na saga das três irmãs um claro paralelo com a inércia da intelectualidade "progressista" do nosso período pós-Golpe de 64, Lavelli ensejou uma encenação mais abstrata que, antes de qualquer contextualização, apontava para uma "investigação do ser humano, uma síntese que defina a dificuldade de viver, as frustrações etc" ${ }^{440}$.

Esta orientação do diretor argentino implicou em diretrizes formais específicas. A primeira delas era a limpeza de iluminação, figurino e cenografia. A sensação deveria ser a de uma "primeira leitura" do texto tchekhoviano. Sem efeitos espetaculares, o conjunto funcionaria como um "comentário poético-visual" diante do profundo vazio

\footnotetext{
${ }^{438}$ Yan Michalski lança em um de seus artigos sobre a montagem o comentário de que dada a formação e a tendência de suas últimas montagens, sua escolha poderia causar estranhamento, já que havia muitas "exigências limitadoras do realismo tchekhoviano". MICHALSKI, Yan. A Gaivota: rigor e liberdade. Jornal do Brasil. Rio de Janeiro, 03 abr. 1974.

${ }^{439}$ MICHALSKI, Op. Cit., 1974.

${ }^{440}$ GONÇALVES, Esmeraldo. Jorge Lavelli \& Gaivota. O Jornal. Rio de Janeiro, 24 mar. 1974.
} 
existencial daquelas personagens que, antes de serem melancólicas, são frustradas com seu modo de vida e se "acostumaram a viver com suas frustrações" ${ }^{441}$. E esta orientação era reforçada pelo contraste da limpeza do palco preenchida apenas por troncos de árvores secas ao fundo. E o figurino, predominantemente branco (à maneira do que vinham fazendo algumas encenações no exterior) destacava, em oposição, a vivacidade e o sonho dessas vidas que, mesmo sufocadas, ambicionam uma nova realidade.

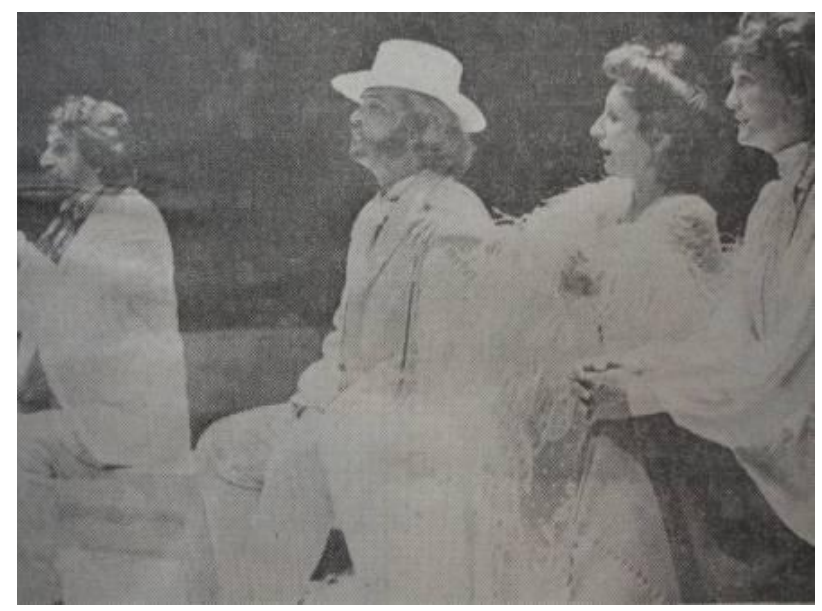

Foto: Cena do $1^{\circ}$ Ato de A Gaivota - Da esquerda para a direita - Luis de Lima (Sorin), Sérgio Britto (Dr Dorn), Tereza Raquel (Arkádina) e Monah Delacy (Paulina). (Fonte: Jornal do Brasil, Rio de Janeiro, 03 abr. 1974 sem créditos)

A segunda diretriz era o rigor geométrico na direção dos atores, como se o diretor estivesse a criar uma composição que, a um só tempo, gerasse um tom único, mas também revelasse as próprias dificuldades em se fazer teatro (este, no limite, um dos temas centrais de $A$ Gaivota $)^{442}$. Somado a esse rigor, a liberdade dos atores para, dentro dos limites criados, poderem buscar "leveza e espontaneidade". Contudo, essa busca não seguia a chave que mais tarde seria levada à radicalidade pelas teatralidades contemporâneas (como a vinculação da ação espontânea a experiências reais e particulares dos atores), pelo contrário, tinha motivação stanislavskiana: "o que cada intérprete parece procurar é incorporar na sua própria maneira de ser, de se comportar e se comunicar com os outros as sugestões dramáticas decorrentes da situação e da vivência da respectiva personagem" ${ }^{443}$. Ou seja, se por um lado Lavelli combatia a noção de "pontilhismo" cênico das montagens de Stanislávski, por outro mantinha um

\footnotetext{
${ }^{441}$ Opinião de Sérgio Britto em Uma 'Gaivota' com visão argentina. $O$ Globo. Rio de Janeiro, 22 mar. 1974.

${ }^{442}$ MICHALSKI, Op. Cit., 1974.

${ }^{443}$ Idem, ibidem.
} 
procedimento de trabalho com os atores ainda vinculado ao mestre russo. Como bem apontara Gilberto Tumscitz: "O quadro visual é lindo e beira o abstrato. Mas a marcação cênica é naturalista" ${ }^{444}$.

Assim opinou em uníssono a crítica. A concepção cênica de Lavelli, somada à cenografia cuidadosa de Cláudio Segovia, que transformou o enorme espaço do Teatro Municipal em uma arena, para dar àquela amplitude um ar mais íntimo ${ }^{445}$, como convinha à peça, eram modernos e arejados. Isso por si era um questionando aos pressupostos engessados, como os da montagem do TNC. No entanto, a atuação dos atores (a princípio o eixo determinante para o diretor, que desejava ouvir o texto "falar") deixou a desejar. A direção milimétrica teria melhor repercussão se o elenco atendesse à homogeneidade esperada. Ainda que atuações como as de Renata Sorrah (Nina), Sérgio Britto (Dr. Dorn), Monah Delacy (Paulina), Tereza Rachel (Raniévskaia) e Cecil Thiré (Trigorin) tenham sido destacadas como bastante originais e profundas (sobretudo a de Tereza Rachel, que conseguiu conceber uma Raniévskaia com toques sutis de bondade e crueldade ${ }^{446}$ ), outras atuações oscilaram bastante e dividiram a crítica, como as de René de Vielmond (Macha) e Augusto Strazzer (Trepliov), ainda bastante jovens.

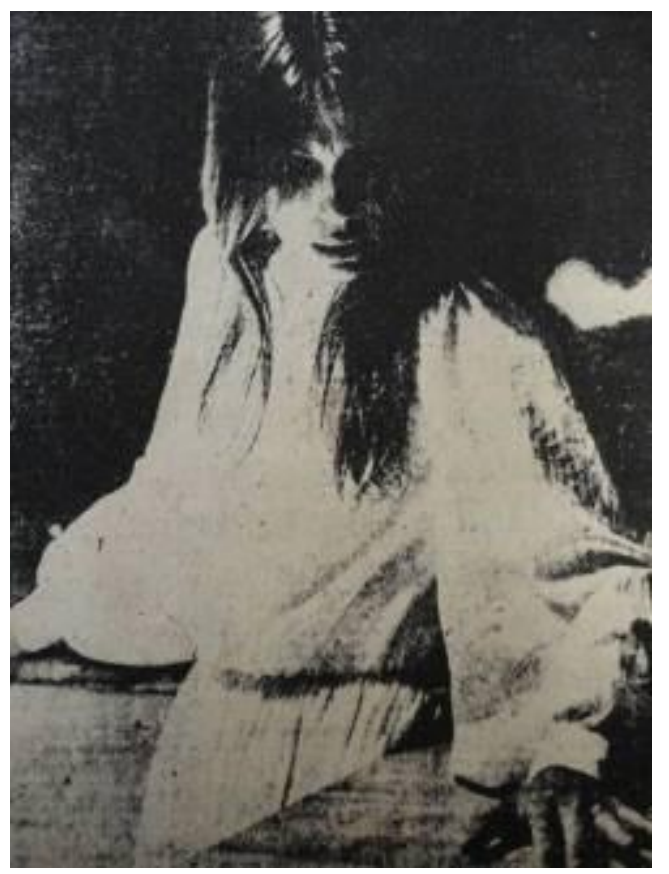

Foto: Renata Sorah (Nina) em cena do $1^{\circ}$ Ato de $A$ Gaivota (Fonte: O Diário do Espírito Santo, Vitória, 29 de março de 1974.

\footnotetext{
${ }^{444}$ TUMSCITZ, Gilberto. "Lavelli realiza Gaivota exemplar". O Globo. Rio de Janeiro, 30 mar. 1974. 445 "Na Gaivota, atores e público juntos no palco". O Globo. Rio de Janeiro, 23 mar. 1974. ${ }^{446}$ MICHALSKI, Op. Cit., 1974.
} 
O ponto alto da montagem, na opinião dos críticos, fora a cena final, trabalhada com profundo intimismo. O diálogo de Nina e Trepliov ocorre a um canto da arena, em uma parte rebaixada, construída tal qual um porão, dentro de um tule, como se o diretor tivesse "pudor"447 em mostrá-la. De maneira bastante refinada, inverteu o sentido grandiloquente e retórico que a cena poderia invocar e investiu em seu inverso, como que a apostar no minimalismo para potencializar sua força. Somente a presença desses atributos já seria o bastante para, segundo Sergio Britto, considerarem a presença de Lavelli e seu Tchékhov "uma renovação do teatro brasileiro"448. Já para Aldomar Conrado, esta montagem, junto com Um Grito Parado no Ar, de Guarnieri, eram a retomada do "teatro enquanto depoimento" 449.

Tratava-se da primeira encenação de A Gaivota em palcos brasileiros. E, ainda que com esta exposição sumária, é possível perceber que mesmo com percalços pontuais no que se referia à interpretação dos atores, a direção de Jorge Lavelli contribuía em muito para o processo de arejamento das encenações de Tchékhov feitas entre nós. A tradução de Barbara Heliodora (feita a partir do francês e do inglês) e a presença de atores de sólida formação davam estatura à montagem. E, ainda que o diretor não estivesse em sintonia com o movimento de forte revisão das tradições de leitura de Tchékhov (mesmo tendo trabalhado longamente na França que, curiosamente, também era o país com tradição teatral mais distante dessa "nova recepção" de Tchékhov), e mesmo que sua montagem tenha optado por uma abordagem abstrata e "atemporal", ao contrário do movimento de politização de Tchékhov visto nessas mesmas montagens internacionais e no teatro brasileiro, seu trabalho coroava com refinamento as tentativas de superação de alguns paradigmas de interpretação que engessavam Tchékhov no calabouço "crepuscular".

A mesma força não parece ter emergido das outras duas montagens de Tio Vânia feitas ao longo dos anos 70. A versão do Teatro Livre da Bahia, dirigida por Álvaro Guimarães e estreada em junho de 1974, no Teatro Vila Velha, em Salvador, funcionou mais como exercício de grupo e teve pouca repercussão. E Tio Vânia, do Grupo Heros, dirigida por Emilio di Biasi e apresentada em maio de 1975 em São Paulo e Santos,

\footnotetext{
${ }^{447}$ A expressão é de Sérgio Britto em A Gaivota de Tchecov já está no municipal - Veja. Última Hora. Rio de Janeiro, 30 mar. 1974.

${ }^{448} \mathrm{Na}$ Gaivota, atores e público juntos no palco. O Globo. Rio de Janeiro, 23 mar. 1974.

${ }^{449}$ CONRADO, Aldomar. A Rússia de Tchecov no municipal. Diário de Notícias. Rio de Janeiro, 31 mar. 1974.
} 
mostrou força de proposta, mas dificuldades práticas de realização. O grupo recémcriado, que já tinha enveredado por Nelson Rodrigues e Oswald de Andrade, apresentava um elenco jovem, todos com experiência recente no teatro profissional ${ }^{450}$. Tinham como propósito enfrentar as dificuldades econômicas impostas pelo subfinanciamento das artes no país através da ação coletiva, sem a intervenção de empresários e produtores. Isso trazia certa liberdade de escolhas ao grupo que, por um lado, podia entregar-se com relativa flexibilidade a textos artísticos e pesquisa de linguagem, mas por outro, carecia de condições para que os atores se dedicassem integralmente à atividade e pudessem financiar os elementos necessários para a viabilização do espetáculo, o que, sem dúvidas, gerou visíveis desníveis no trabalho dos atores. $^{451}$

Emilio di Biasi concebeu Tio Vânia como uma espécie de manifesto contra a apatia e a acomodação. Estava aí um ponto de profundo interesse que, a um só tempo, mostra o desejo de atualização da peça para os problemas do tempo e justifica a presença de um elenco tão jovem para a realização de papeis aparentemente "velhos". O diretor não negou a estranheza que causava no público e na crítica a presença de um elenco quase adolescente para os papeis. Mas, segundo seu ponto de vista, atores mais velhos não teriam condições de expressar com tanta intensidade sua mensagem, pois "muito mais terrível é um jovem decadente que não percebe nada a sua volta e sonha com um futuro mais feliz" ${ }^{452}$. Tratava-se de um balanço da geração que sofrera os duros impactos da repressão pós-68.

No entanto, para boa parte da crítica paulistana o espetáculo ficou aquém das expectativas, a despeito da inovação de sua mensagem. Sobretudo pelo fato de que, justamente por sua juventude, o elenco não estava preparado para trabalhar as nuances da trama e das personagens. Tendo em vista que o diretor optou por uma direção intimista, em espaço diminuto, com cenografia e figurinos enxutos, mas marcados historicamente, os atores precisariam dar conta de apresentar uma crescente de angústia pelas "vidas que se esvaem". Para Mariângela Alves de Lima, o tédio das personagens já estava presente desde o começo e permaneceu no mesmo tom até o fim, expressando

${ }^{450}$ Elenco: Bri Fiocca (Marina); Odilon Fagner (Mihail Lvovich Astrov); Walter Martins (Ivan Petrovich Voinitzki - Vânia); Raimundo Matos (Alexandre V. Serebriakov); Stela Freitas (Sofia Alexandrovna Sonia); Thereza Freitas (Helena Andreiévna); Maria Alice Costa (Maria Vassilievna Voinitzkaia); Carlos Alberto Seidl (Iliá Ilitch Teleguine); Carlos Fischer (Efin).

${ }^{451}$ LIMA, Mariângela Alves de. Interpretação não consegue expressar sentido de 'Tio Vânia'. $O$ Estado de São Paulo. São Paulo, 15 maio 1975.

${ }_{452}$ Grupo Heros mostra a visão amarga do cotidiano de Tchecov. A Tribuna de Santos. Santos, 27 jul. 1975. 
a grande dificuldade de modulação dos atores ${ }^{453}$. Já para Sábado Magaldi, o "meio tom" da vida dessas personagens, que sugere uma espécie de "pulverização impressionista", não se realizava com alguns atores que, justamente por serem jovens e não terem tido condições de trabalhar a contento suas personagens, pareciam "brigar" com elas ${ }^{454}$.

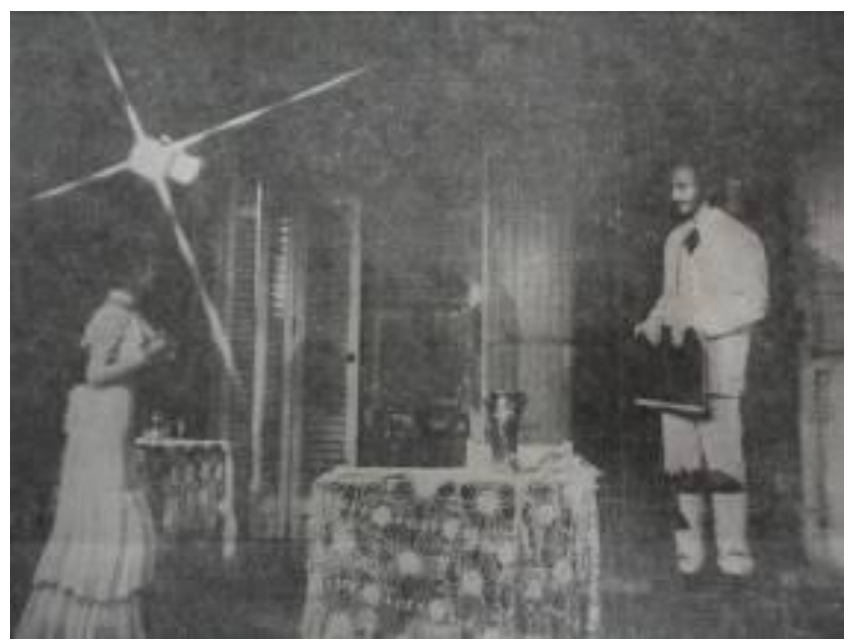

Foto: Thereza Freitas (Helena) e Odilon Fagner (Astrov) (Fonte: notícia Dois dias para ver o teatro de Tchecov, A Tribuna de Santos, em 23 jul. de 1975 - sem créditos)

Mais uma vez, não nos cabe encontrar "culpados". É como se por trás dessas encenações, que ora tateiam, ora realizam de maneira bastante convincente uma nova leitura (sem, no entanto, convertê-la em tendência ou diretriz clara que estimulasse o debate frente a outras encenações do dramaturgo russo) estivessem as dificuldades lançadas pelo próprio tempo: repressão política, escassez econômica, esfacelamento de grupos, dificuldades para a continuidade de trabalhos, empreendimentos isolados e passageiros, iniciativas de grupo com sérias limitações financeiras... E, se por um lado essas condições serviram de fermento para o surgimento de iniciativas bastante criativas (que lidaram sobretudo com uma dramaturgia própria), consolidando a tendência para a produção coletiva de peças $^{455}$, por outro lado, do ponto de vista da recepção da dramaturgia de Tchékhov, foram anos de afirmação tímida de novas perspectivas.

\footnotetext{
${ }^{453}$ LIMA, Op. Cit., 1975.

${ }^{454}$ MAGALDI, Sábato. Tchecov não acharia ruim se houvesse um pouco mais de experiência cênica. Jornal da Tarde. São Paulo, 15 maio 1975.

${ }^{455}$ Ver o trabalho de Silvia Fernandes sobre uma parcela expressiva dos grupos teatrais dos anos 70, como o Asdrúbal Trouxe o Trombone, Ornitorrinco, Ventoforte, Pod Minoga, Mambembe e outros, que tiveram como marca o teatro independente e o sistema cooperativo de produção. FERNANDES, Op. Cit., p. 13-32.
} 


\subsection{Sem estranheza de acento}

Boa parte dos anos 70 evocaram a imagem do sufocamento e da desilusão. Mas ainda que esse fosse o tom junto a muitos setores da vanguarda artística (não à toa as montagens tímidas de Tchékhov, como as de Emilio di Biasi, lançavam um protesto contra a desistência, à maneira de um "grito parado no ar"), vimos que iniciativas arejadas surgiam fora do esquema das grandes produções. Ao mesmo tempo, a vida política brasileira já dava seus sinais de renovação, com o surgimento de renovadas organizações operárias e camponesas. É nessa esteira que Maria Clara Machado estreava com otimismo o seu "teatro adulto" dos anos 80 .

Como amostra de que se abriam novos tempos, optou pela escolha de um texto inédito de Tchékhov e praticamente desconhecido por nossa crítica: Platónov. Em termos gerais, ainda que a peça também simbolizasse a imagem da impotência do professor de província que se vê incapaz de alterar a rota de sua vida, a escolha vinha como uma lufada de ar fresco na trajetória de recepção autor russo - menos pelo sucesso da montagem (que fora reduzido), e mais pelas perspectivas que abria. Para a diretora de raízes mineiras que morava no Rio, o momento vivido pela sociedade e pelo teatro brasileiros dava a impressão de que um "tumor tinha sido furado" ${ }^{456}$. O cenário ainda era de crise e dificuldades, mas permitiu, em sua opinião, que o monopólio dos produtores e das peças comerciais fosse cindido e que as iniciativas de cooperativas se convertessem em solução. Para ela, era isso que permitia que grupos amadores como o seu, ou aqueles não presos às rédeas da bilheteria, pudessem encenar uma peça como Platónov - dramaturgia de juventude do autor russo, completamente fora dos modismos cênicos e, em termos de público, "arriscada economicamente" 457 .

Atravessada por dificuldades, a montagem de Maria Clara Machado, que estreou em maio de 1980 no Teatro Tablado, no Rio, trazia nova perspectiva sobre o texto tchekhoviano. A diretora trabalhou com aqueles atores amadores não o Tchékhov "pesadão, como as pessoas gostam de ver encenado" 458 , mas um Tchékhov leve, "mais travesso". Agregou a ele o que acreditava haver de "mineirice" ${ }^{459}$ na temática de suas

\footnotetext{
${ }^{456}$ O teatro brasileiro está em crise. Última Hora. Rio de Janeiro, 06 jun. 1980.

${ }^{457}$ MICHALSKI, Yan. Um D. Juan de província. Jornal do Brasil, Rio de Janeiro, 03 jun. 1980.

${ }^{458}$ Trecho de entrevista presente em: COUTINHO, Wilson N. Leveza Russa - Tchekov encenado do modo como ele preferia. Revista VEJA. São Paulo, 04 jun. 1980.

${ }^{459}$ MARINHO, Flavio. Retrato de uma raça. No Tablado, Tchecov estreante. O Globo. Rio de Janeiro, 24 maio 1980.
} 
peças - aquilo que é decadente, falsamente importante e ao mesmo tempo simpático. Sem dúvidas, isto representava um discreto mas importante ponto de inflexão em nossa trajetória de recepção por, ao mesmo tempo, questionar não só o viés tragicizante de suas peças, mas também encontrar na sua dicção as marcas locais.

A diretora demarcou bem sua escolha ao pontuar, sobretudo no último ato, o tom do vaudeville francês, gênero que fizera escola na Rússia e marcara as peças em um ato do dramaturgo. Deu ritmo levemente acelerado às cenas finais e, nos momentos entreatos apresentava cenas de filmes de Chaplin, como que a destacar o tragicômico das personagens tchekhovianas daquela dramaturgia ainda "impura" ${ }^{460}$. Para a diretora, estavam apenas seguindo o que sempre fora uma intenção do dramaturgo: ver suas peças encenadas como comédias. Para o crítico Wilson Coutinho, o respeito a essa diretriz do dramaturgo foi o que permitiu à encenação de Maria Clara transmitir ao público a ideia de que "a leveza de seu espetáculo apenas ressalta os tormentos das personagens" 461 .

A cenografia de Helio Eichbauer era enxuta e preferiu a demarcação histórica clara de tempo e local. Os figurinos de Kalma Murtinho foram unanimemente elogiados pelo cuidado com a combinação de cores. No entanto, ainda que o conjunto prezasse pelo esmero e pela inovação de proposta, para boa parte da crítica, a peça carecia de definição clara de tom. Na polêmica opinião de Flávio Marinho, o problema estava na própria debilidade do texto de Tchékhov: peça de juventude, sem foco claro, cheia de monólogos desnecessários e ainda bastante tributária de um romantismo decadente ${ }^{462}$. A opinião também é em partes compartilhada por Yan Michalski, que opinou afirmando que a peça de Tchékhov ainda não conseguira assimilar a fundo o melodrama romântico e que muitas cenas beiravam o "grotesco involuntário" ${ }^{463}$. E a dificuldade de acerto de tom do grupo acentuou o que, na opinião dos críticos, já era uma debilidade desse "drama mal resolvido". Segundo Michalski, a diretora não conseguira construir a ação cênica para caminhar num crescente de tensão, que pudesse acentuar o sufoco da personagem - ao contrário, apresentava cada um dos perfis psicológicos de maneira quase inalterada do começo ao fim da encenação. E o desnível de formação dos atores

\footnotetext{
${ }^{460}$ A expressão é de COUTINHO, Op. Cit., 1980.

461 Idem, Ibidem.

${ }^{462}$ MARINHO, Flavio. Jovem Tchecov - muito cuidado, pouco texto. Revista Visão. Rio de Janeiro, 16 jun. 1980.

${ }^{463}$ MICHALSKI, Op. Cit., 1980.
} 
não conseguiu insuflar "cor" e "vida" em personagens que, por si só, já são "esboços"464.

Mas a escolha de Maria Clara Machado, em que pesem todas as dificuldades de montagem que ela, de quebra, reconhecia, acrescenta elementos novos a uma trajetória da recepção de Tchékhov no Brasil. Explorar a dinâmica cômica do dramaturgo poderia funcionar como um balanço irônico e crítico de nossa experiência cultural e social dos últimos anos. Além disso, significaria enriquecer as possibilidades de interpretação de um dramaturgo que atravessara décadas sendo enquadrado em grande parte dentro da perspectiva tragicizante do TAM e do TBC (que fizeram seguidores no palco e na crítica) - o que, talvez por isso mesmo, tornava o dramaturgo alguém ainda alheio a nossa experiência cultural e social.

O que não se pode dizer é que a montagem de $O$ Jardim das Cerejeiras, feita no ano seguinte por Jorge Takla, com estreia em São Paulo, no Teatro Anchieta, tenha se preocupado tanto com uma "atualização" do dramaturgo ou, pelo menos, em encontrarse com ele em outra perspectiva. Ainda que a crítica de Sábato Magaldi tenha valorizado o poder do diretor de garantir a força dos pontos de vista das diferentes personagens e apresentar uma atmosfera de irrealidade que desbastou o sociologismo e ressaltou o lirismo ${ }^{465}$, de um modo geral Takla esteve preso a soluções cênicas muito tradicionais.

Jeferson Del Rios criticou a "falta de audácia" do diretor ${ }^{466}$ e Paulo de Lara, que elogia a preocupação com a qualidade artística do espetáculo, reprova a indecisão de posição do diretor frente à peça, como se este fugisse das demandas do tempo: "Resta saber agora, como deve ser encarado esse clássico do teatro naturalista. Sob uma perspectiva mais humanística ou mais política?" ${ }^{467}$. Isto ficou evidente, segundo eles, tanto na dificuldade de promover o espetáculo entre os dois polos, como em cacoetes individuais dos atores (que por vezes exageravam em risos e gritos, como que a reforçar uma "histeria da decadência", que logo era contradita) desequilibrando sobremaneira o espetáculo.

\footnotetext{
${ }^{464}$ Idem, Ibidem.

${ }^{465}$ MAGALDI, Sábato. O Jardim das Cerejeiras - um raro requinte. Jornal da Tarde. São Paulo, 18 fev. 1982.

${ }^{466}$ RIOS, Jeferson Del. Cerejeiras floridas no fim de uma época. Folha de São Paulo. São Paulo, 16 jan. 1982.

${ }^{467}$ LARA, Paulo. Um Checov inverossímil no palco do Anchieta. Folha da Tarde. São Paulo, 02 fev. 1982.
} 
De toda maneira, a proposta de Maria Clara não reinou sozinha nessa década. $\mathrm{O}$ que confirma essa tendência de valorização da tradição cômica é o espetáculo Trágico à Força, de Marcio Aurelio, que veio aos palcos de São Paulo em 1982, no Teatro Studio São Pedro. A montagem reuniu inicialmente as peças Os Males do Tabaco, O Pedido de Casamento, O Urso, Trágico à Força e O Canto do Cisne. No entanto, depois das duas primeiras apresentações o grupo retirou esta última peça do espetáculo.

Como conjunto, a montagem operou de maneira bastante uniforme e a busca de um tom comum para todas as pecinhas foi conquistada por meio de um eixo temático bastante claro: o casamento como expressão da opressão de Estado no nível familiar ${ }^{468}$. Marcio Aurélio enxergava nessa problemática não só um fio que costurava todos os textos, mas também um dado de atualidade do dramaturgo. Em sua opinião, tratava-se de exacerbar questões que já soavam cômicas em fins do XIX e que, agora, mereciam ser levadas ao grotesco: o interesse mesquinho do dinheiro sobre os desejos e realizações, as imposições de um casamento opressivo e as convenções sociais. Partindo da ideia de que "toda emoção é datada", o grupo quis entender quais as questões candentes da época de Tchékhov e transpô-las para os dias atuais ${ }^{469}$.

Nessa linha, o grupo estudou durante quatro meses para constituir uma proposta formal produtiva que operasse e potencializa essa diretriz. Pesquisaram experiências recentes de grupos como Mambembe, Pessoal do Vitor, Asdrúbal Trouxe o Trombone e veio daí a ideia de trabalho colaborativo (o estudo, as adaptações textuais, as improvisações em grupo, os cenários e - tudo realizado conjuntamente pelo elenco) $)^{470} \mathrm{e}$ muito também de recursos expressivos da tradição cômica. Reconhecendo o desejo do próprio dramaturgo de ver suas peças cômicas livres de qualquer peso trágico, optaram por varrer a montagem de qualquer indício de psicologismo - revisão direta da herança stanislavskiana - e encontraram nas formas do cinema mudo, da caricatura e do teatro de variedades contribuições decisivas. Isso significou apostar em um grande dinamismo da cena e em um trabalho expressivo dos atores focado mais na força da expressão física que da sutiliza irônica do diálogo ${ }^{471}$. Edith Siqueira, atriz que contracenou nos papeis femininos) chegou mesmo a afirmar que "a pausa tchekhoviana é a mãe do

\footnotetext{
${ }^{468}$ LARA, Paulo de. Obras de Checov num só espetáculo. Folha da Tarde. São Paulo, 23 jun. 1982.

${ }^{469}$ Proposta de Montagem (mimeo). CEDOC - FUNARTE (Pasta "Trágico à Força" - Marcio Aurélio)

${ }^{470}$ FILHO, Antonio G. No São Pedro, o mundo tragicômico de Tchecov. Folha de São Paulo. São Paulo, 23 jun. 1982.

${ }^{471}$ RIOS, Jefferson Del. Tchecov visitado pelo humor de Groucho Marx. Folha de São Paulo. São Paulo, 30 jun. 1982.
} 
distanciamento", e por isso fora utilizada sem psicologismos e dentro de outra dinâmica, a fim de potencializar o grotesco e o poder crítico do espetáculo ${ }^{472}$.

A cenografia coletiva foi reduzida ao essencial: palco limpo, para garantir a mudança rápida e eficaz (para o distanciamento, mas também bem à maneira do teatro de variedades), com a presença apenas de objetos simples, alguns exercendo funções variadas, outros demarcando a historicidade da situação. A iluminação foi pensada para eliminar qualquer "atmosfera" ou psicologismo, e por isso era dura - o mais clara possível $^{473}$. Tato Fischer, ao piano (que atuou com destaque como Niukhin, n'Os Males do Tabaco), pontilhava comicamente suas músicas não só para realizar a transição entre as diferentes pecinhas (enquanto os atores operavam as sutis mudanças de cenário), mas também para potencializar a própria ação cênica. De maneira geral, mereceram destaque as atuações de Elias Andreato (sobretudo como Smirnov, em O Urso, sabendo dar potência física à personagem) e Edith Siqueira (como Eliena Popova, em $O$ Urso).
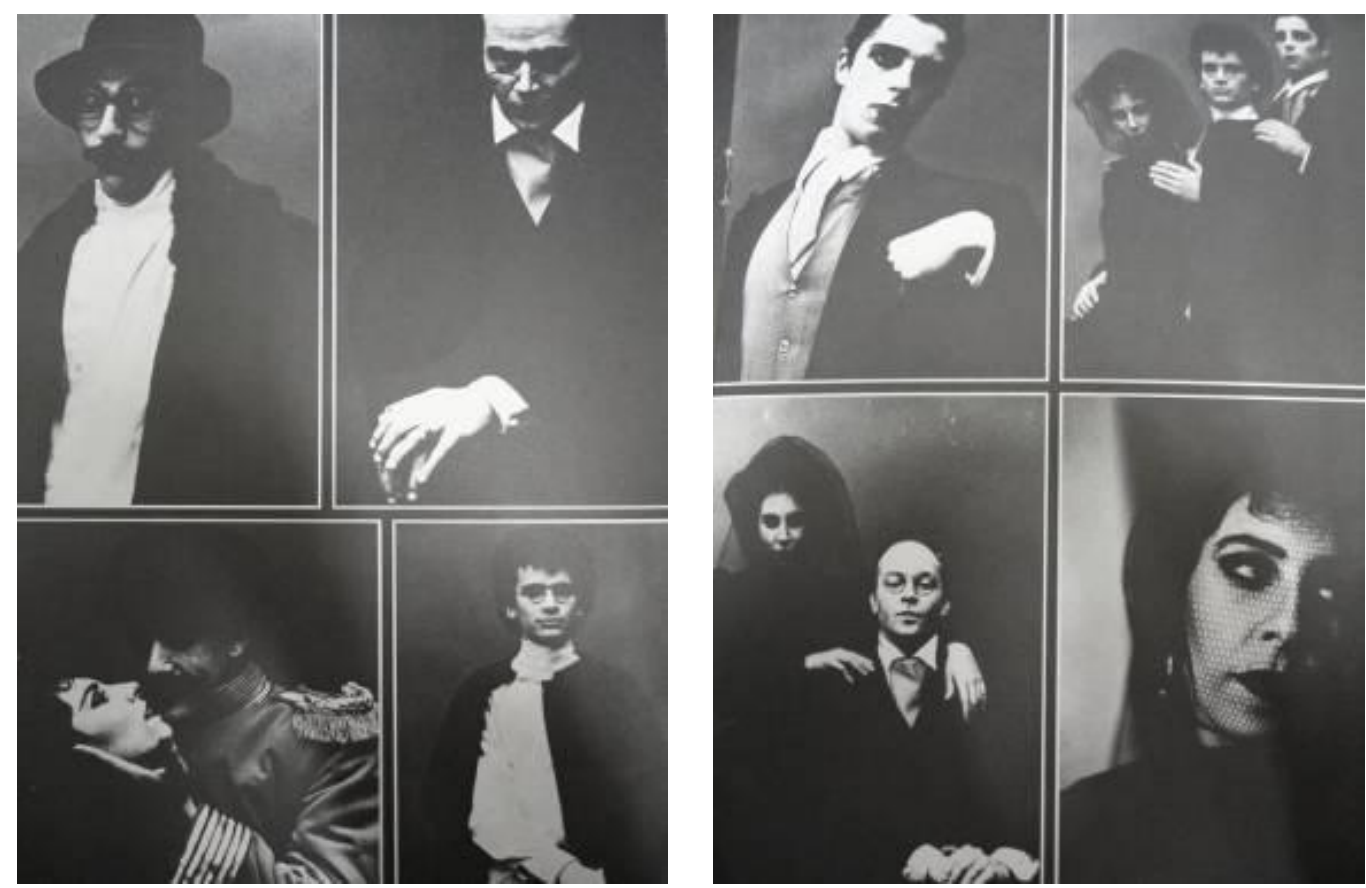

Foto: (à esquerda): Elias Andreato (esquerda, acima), Tato Fischer (direita, acima), Edith Siqueira e Elias Andreato (esquerda, abaixo), Mauricio Maia (direita, abaixo). Foto 2 (à direita): Rodrigo Mateus (esquerda, acima), Edith Siqueira, Maurício Maia e Rodrigo Mateus (direita, acima), Edith Siqueira e Tato Fischer (esquerda, abaixo) e Edith Siqueira (direita, abaixo) (Fonte: Programa da Peça - Seção de Fotos do Elenco/Personagens)

\footnotetext{
${ }^{472}$ FILHO, Op. Cit., 1982.

${ }^{473}$ Proposta de Montagem, Idem.
} 
Na opinião de boa parte da crítica, a peça merecia ser vista pelo seu poder de divertimento e por sua pegada crítica. Mas não indicava, ao mesmo tempo, ter o estatuto do "grande teatro" tchekhoviano. Se há aí muito da subestimação da comédia enquanto gênero (que via nas peças em um ato do dramaturgo mais um esboço do grande teatro, sintonizado com suas produções contísticas ligeiras para jornais), há também a cristalização de uma ideia de "atmosfera" tchekhoviana, bastante vinculada à versão "americana" de Stanislávski de aprofundamento da "psicologia da personagem", que imprimiam demandas alienígenas a esta montagem de Marcio Aurélio. Nesse sentido, a crítica de Sábato Magaldi ao espetáculo reconhece que ele não recorreu à "comicidade vulgar", mas, ao mesmo tempo, recai no erro de dizer que este não é o verdadeiro teatro de "ambição artística" do dramaturgo. O crítico ainda pontua, sintonizado com os comentários de Clóvis Garcia ${ }^{474}$, que por vezes o elenco abusa do histrionismo como recurso para gerar o riso, tornando o gesto bastante exterior e sublinhando a "caricatura dos traços" 475 .

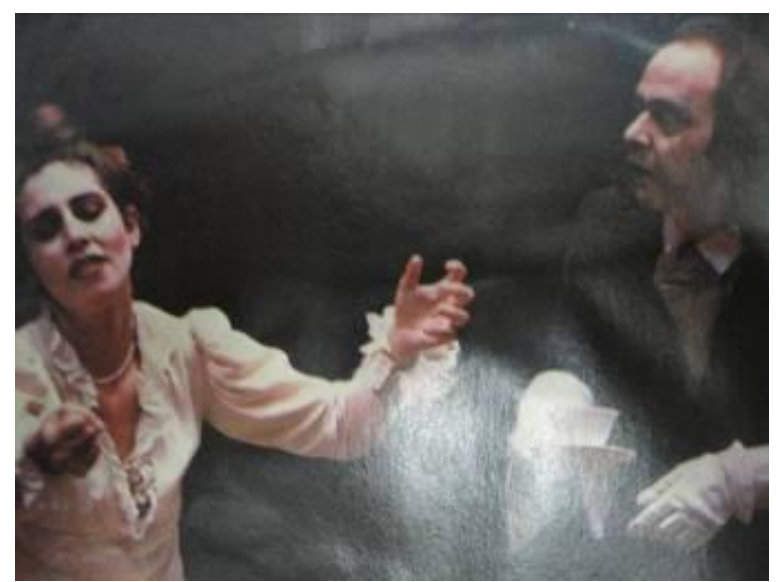

Foto: Edith Siqueira e Tato Fischer em Trágico à Força. (Fonte: A alentadora volta aos clássicos, Revista Isto É, 07 jul. 1982 - Foto: Renata Falzoni)

O que podemos dizer, contudo, é que, a despeito das questões levantadas, Marcio Aurelio e o Grupo Setra exploravam uma dimensão nova do texto tchekhoviano, incorporando, ao mesmo tempo, o que havia de melhor no teatro de grupo brasileiro (sobretudo o oriundo dos anos 70) e da tradição cômica. E, se exageraram na concepção

\footnotetext{
${ }^{474}$ GARCIA, Clóvis. A comédia de Tchecov em 'Trágico à Força'. O Estado de São Paulo. São Paulo, 09 jul. 1982.

${ }_{475}$ MAGALDI, Sábato. Neste O Trágico à Força, deliciosos momentos de Tchecov. Jornal da Tarde. São Paulo, 09 jul. 1982.
} 
algo "exterior" das personagens, ganharam também em força crítica e mostraram a um só tempo a capacidade de suas peças aparentemente despretensiosas de dialogarem com o Brasil e as questões de nosso tempo ${ }^{476}$. Como se vê, já não se pode falar em recantos inexplorados de Tchékhov, seja o farsesco, seja o das quatro grandes peças. Entre uma e outra encenação, entre altos e baixos, já não há tendência cômica ou trágica, naturalista ou vanguardista que não tenha sido investigada. Tchékhov já faz parte do grande repertório, sem estranheza de acento.

\subsection{Pluralidade de tendências}

Já em meados da década de 80 e ao longo da década de 90, onde começamos a entrar com este panorama, começa a se tornar difícil o mapeamento e mesmo a discussão crítica aprofundada sobre as principais encenações de Tchékhov feitas Brasil afora. Só ao longo desses vintes anos, é possível contabilizar mais de quarenta encenações que tiveram razoável repercussão, número praticamente igual a tudo que tivemos desde os momentos iniciais de recepção, iniciada em fins da década de 40 . Ainda que com os corriqueiros percalços financeiros, que sempre permearam a atividade teatral e dificultam o amadurecimento da pesquisa e a sobrevivência de artistas e grupos, começam a se disseminar programas universitários de formação em artes cênicas e mais grupos desenvolvem trabalhos nas capitais - algo que só favorece o processo de formação, debate e pesquisa teatral que, como sabemos, é algo fundamental diante de uma dramaturgia formalmente complexa como a do russo Anton Pávlovitch.

Tal cenário também faz com que teorias e experiências em voga ao redor do mundo cheguem aqui com maior velocidade e, em alguns casos, sejam absorvidas com extrema facilidade. Isso repercute diretamente na recepção de Tchékhov e, não à toa, o que temos ao longo desses anos é uma verdadeira pluralidade de tendências

\footnotetext{
${ }^{476}$ Vale destacar que dois anos depois de Trágico à Força, Domingos Oliveira também promoveria uma valorização das peças em um ato com $O$ Urso, de Tchékhov, dentro do espetáculo A Irresistível Aventura, que congregava inúmeras pequenas peças, dentre elas: O Amor de D. Prelimplim com Belissa em seu Jardim, de Federico Garcia Lorca; O Oráculo, de Artur Azevedo; A Dama da Lavanda, de Tennessee Williams. Estreou em 09 de agosto de 1984, no Teatro de Arena, Rio de Janeiro. A peça percorreu diferentes estados, dentre eles Manaus, Belém, São Luiz, Fortaleza, Natal, Recife, Vitória, Goiânia, Brasília, Porto Alegre, Belo Horizonte, Curitiba, São Paulo. Também o fariam Ronaldo Brandão em 1988 com Os Males que o Fumo Produz, em Belo Horizonte; Antonio Oliveirra em 1988, com O Urso, em Porto Alegre; Elpídio Navarro, em 1988, com Pedido de Casamento, em João Pessoa e Roberto Parkinson, em 1989, com Um Pedido de Casamento, em Brasília (DF).
} 
interpretativas de sua dramaturgia. Essa condição, se por um lado demonstra o esforço de atualização de pesquisadores universitários, artistas e grupos, por outro pode suplantar processos de pesquisa mais condizentes com nossa experiência local e tenham um ciclo interrompido antes mesmo de poderem se dizer amadurecidos ${ }^{477}$.

Por isso, os comentários que seguem a respeito das montagens desse período, justamente por serem muitas e de caráter bastante diverso, serão algo sumários e virão organizados dentro de algumas tendências que, salvo engano, foi possível mapear.

Em primeiro lugar, vale a pena destacar as montagens que valorizaram a leitura de um Tchékhov "universal", levemente preocupado com as questões do tempo, mas, acima de tudo, leitor da "alma humana". Nesse perfil estão as encenações realizadas pelo Teatro dos 4, encabeçado por Sérgio Britto e Paulo Mamede. Em 1984, o grupo estreou Tio Vânia, no Rio de Janeiro. Britto pensou em eliminar o que durante muito tempo ficou conhecido como clima "grandiloquente" e "ritmo lento" em Tchékhov. O diretor preferiu valorizar os elementos da comédia presentes no texto e pensou os atos em diferentes variações de "clima": o primeiro com um tom mais "elegante" ${ }^{478}$ realizou uma espécie de "apresentação das personagens". Nos demais atos, foi em busca do "subtexto individual" de cada personagem e por isso pensou em um trabalho de preparação dos atores mais "realista", já que, segundo ele, em Tchékhov o tom exato das palavras é fundamental, pois elas não estão ali à toa e guardam dentro de si camadas profundas de subjetividade que precisam ser investigadas em minúcia. Já para o trabalho de direção, fugiu da chave realista e optou pela criação de "climas cênicos" que, abrindo mão de qualquer parafernália cenográfica (o palco estava limpo o tempo todo), criavam espaços específicos (de acordo com a subjetividade em jogo das personagens), por meio da iluminação e da música. Ou seja, havia uma espécie de partitura cênica impressionista que deixava para o público a construção do quadro geral $^{479}$.

O desempenho dos atores é que, por vezes, impediu essa direção "cromática" de encontrar seu tom exato (já que alguns atores optaram por interpretações pouco nuançadas e acabaram por cair numa atuação monocórdia, como Cristiane Torloni, que atuou como Helena) ${ }^{480}$, exceção feita para Denise Weimberg (Sônia), unanimemente

\footnotetext{
477 A esse respeito, ver artigo de Roberto Schwarz: Nacional por subtração. In: Que Horas São?. São Paulo: Companhia das Letras, 1989

${ }^{478}$ Ver Entrevista com Sergio Britto no Programa da Peça Tio Vânia.

${ }^{479}$ LUIZ, Macksen. Impossibilidades. Jornal do Brasil. Rio de Janeiro, 13 jul. 1984.

${ }^{480}$ Tio Vânia - um clássico de sóbria beleza. Revista desfile. Rio de Janeiro, 10 ago. 1984.
} 
elogiada pela crítica por delinear uma Sônia levemente abandonada de formalismos e muito intensa ${ }^{481}$. Além disso, aquilo que era para funcionar como uma combinação nova (grosso modo, uma mescla de naturalismo com impressionismo), também foi criticado por Macksen Luiz, que viu no jogo cênico naturalista dos atores a criação de uma diretriz muito planejada e mecânica, que criou uma forte sensação causalidade entre o que era dito, o que se sentia e o que acontecia em cena ${ }^{482}$.

A mesma chave "universalizante" esteve na montagem de $O$ Jardim das Cerejeiras, de 1989, também promovida pelo Teatro dos 4, com estreia no Rio de Janeiro e agora com direção de Paulo Mamede. No programa da peça, fica evidente a leitura intencionada pelo grupo: "mostrar que o ser humano é atemporal, eterno, pois apesar das fantásticas conquistas técnicas e científicas feitas até hoje, o homem e a mulher continuam a procura de uma conquista: o outro." Nesse sentido, ainda que a montagem intentasse leves constextualizações, como a cenografia composta basicamente de papelão ondulado, em clara referência ao corte das árvores e à questão ambiental (como em Tio Vânia) ${ }^{483}$, o que se quis enfatizar é o problema da "decadência humana" em um mundo em que cada vez mais nos distanciamos do "outro". Tanto que, para Macksen Luiz, a escolha de Mamede e de Teatro dos 4 vem da constatação de que nem a Revolução Russa (vislumbrada nas peças de Tchékhov) foi capaz de superar problemas universais como o da distância entre os homens e sua incapacidade de lidar com o outro.

A cenografia era limpa e, à maneira de Peter Brook em sua montagem de $O$ Jardim das Cerejeiras (em cartaz de 1981 a 1989) ${ }^{484}$, os atores sentaram-se no chão. No geral, valorizou-se a iluminação em tons diáfanos e as vestimentas elegantes e limpas em tom bege. Mas essa "rapsódia em bege" 485 ou a "brancura hospitalar" ${ }^{486}$, em versão pejorativa, não foi suficiente para que o espetáculo superasse certa "frieza" em sua dinâmica - a mesma presente na anterior e mapeada por Macksen Luiz. A direção minuciosa dos atores, visando a preencher o vazio do espaço com a intensidade do jogo

\footnotetext{
${ }^{481}$ MARINHO, Flávio. Tio Vânia - espetáculo muitos furos acima da média. O Globo. Rio de Janeiro, 17 jul. 1984.

${ }_{482}$ LUIZ, Macksen, Op. Cit.

${ }^{483}$ CEZIMBRA, Márcia. Comédia da decadência. Jornal do Brasil. Rio de Janeiro, 25 jul. 1989.

${ }^{484}$ Para detalhes sobre essa encenação de Brook, que representou um momento decisivo na trajetória de recepção das peças de Tchékhov, justamente por conceber altamente polifônica e em claro embate com a tradição naturalista, ver LOEHLIN, James. Op. Cit, p. 171-181.

485 FARIA, Marcos Ribas de. Tchekhov um adeus de comovente beleza. O Estado de São Paulo. São Paulo, 26 jul. 1989.

${ }^{486}$ HELIODORA, Barbara. Tchekov é Tchekov. Jornal do Brasil. Rio de Janeiro, 28 jul. 1989.
} 
entre as personagens, não conseguiu evocar os necessários contrapontos de lirismo, que também estão no drama de Tchékhov. Isto também trouxe uma certa frieza expositiva no espetáculo, que dele tirou uma envolvência lírica ou uma sensação da perda que também estão em Tchékhov ${ }^{487}$.

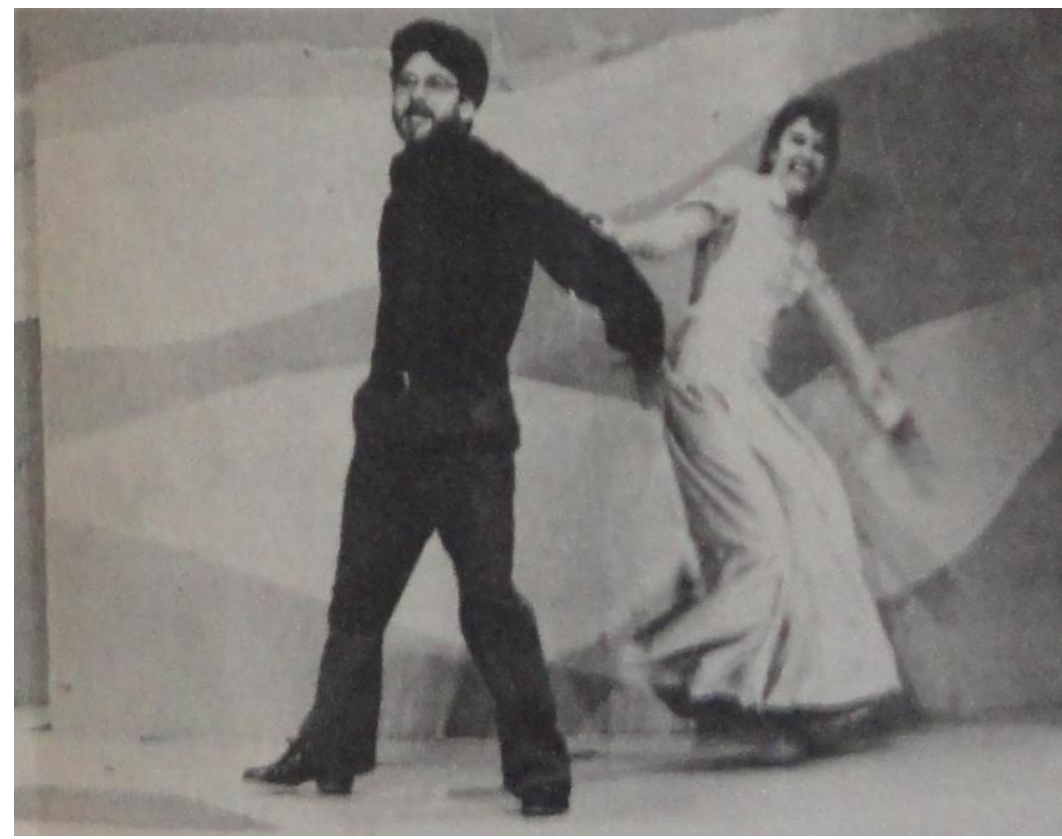

Foto: Edwin Luisi (Trofimov) e Clarisse Derzié (Ania) em cena de $O$ Jardim das Cerejeiras (Fonte: LOYOLA, Cecília. Pelo viés da memória. Tribuna da Imprensa. Rio de Janeiro, 07 ago. 1989)

A dimensão da "universalidade contemporânea" do dramaturgo também foi buscada em importante direção de A Gaivota realizada em 1994, a primeira feita em São Paulo e dirigida por Francisco (Chico) Medeiros. Marco Ricca, produtor e ator na peça, lançou de antemão o motivo que os levou eleger Tchékhov: sua capacidade de "se manter com uma visão atual da natureza humana". Comparando-o a Shakespeare, diretor e produtor viam no texto uma reflexão sobre o homem contemporâneo e o papel da arte. À maneira do que já vinha ocorrendo com boa parte das montagens dos últimos anos, a cenografia optou pelo cenário limpo (com alguns galhos secos e poucas caixas nas laterais), que, no caso do subsolo do Centro Cultural São Paulo, gerou sutil simbiose entre os tijolos da moderna construção paulistana e o improviso da pequena peça de Trepliov $^{488}$. Este era sem dúvidas um dos pontos altos da montagem, que não tinha

\footnotetext{
${ }^{487}$ LUIZ, Macksen. Tempo dos gestos inúteis. Jornal do Brasil. Rio de Janeiro, 27 jul. 1989.

488 SÁ, Nelson de. 'A Gaivota' prova atualidade de Tchecov. Folha de São Paulo. São Paulo, 18 jan. 1994.
} 
problema algum em subverter a rubrica de Tchékhov (que sugeria a montagem da pecinha de Trepliov em um palco no jardim): "assim como Tchékhov colocou a ação no campo, para enfatizar a disponibilidade das personagens em férias, nós fomos ao subterrâneo, para frisar a discussão existencial que ele propõe" ${ }^{489}$. O efeito final foi de profundo sufoco das personagens e para isso não foi necessário nenhum artifício teatral, já que o diretor optou por "deixar o texto falar", a fim de que a cadência e a individualidade da fala de cada personagem pudessem emergir ${ }^{490}$.

Na mesma linha também esteve a montagem de A Gaivota, realizada por Jorge Takla, que, neste caso, preferiu um retorno mais declarado ao cenário e figurinos tradicionais ("quase realistas", segundo Barbara Heliodora ${ }^{491}$ ). A justificativa para essa escolha é genérica, mas vem atravessada pela construção de uma ideia "universalista" do dramaturgo: "Eu já me preocupei muito com essa questão, mas desconfio hoje de tudo que se chame vanguarda. O que me interessa é o coração do texto, e faço espetáculos para o coração das pessoas" ${ }^{492}$. A virada do diretor, que já havia dirigido com fortes toques de experimentação formal O Jardim das Cerejeiras em 1982 e Lago 21, em 1988, no qual mescla diálogos de Hamlet e A Gaivota, vem justificada pelo fato de que já estava "mais velho" e talvez isso estivesse em sintonia com o próprio tema da peça, na qual emerge o problema da passagem do tempo, o conflito de gerações e o choque de diferentes estéticas. A leitura mais clássica e a valorização da "experiência com o texto" e "trabalho de ator" 493 não significaram, entretanto, uma reprodução do que seriam as montagens stanislavskianas. O ritmo aqui é levemente acelerado, a fim de que os famosos "estados d'alma" não se convertessem em uma montagem arrastada. No entanto, o conjunto do elenco não gozou de harmonia suficiente para a criação de um clima adequado, com exceção das atuações de Walderez de Barros, como Arkádina, e Elias Andreatto, como Trigórin. E este critério de avaliação não é menor se levamos em conta que a linha mestra de Takla, que gira justamente em torno de uma valorização do trabalho do ator sobre o texto, é o que norteou o espírito da montagem.

Por fim, dentro desta tendência, vale destacar a montagem de Tio Vânia, feita por Aderbal Freire-Filho em 2003, no Rio de Janeiro. O diretor, que ainda não dirigira

\footnotetext{
${ }^{489}$ MEDEIROS, Jotabê. Anton Tchecov ressurge com força nos palcos paulistanos. O Estado de São Paulo. São Paulo, 02 abr. 1994.

${ }^{490}$ LIMA, Mariângela Alves de. 'A Gaivota' tem atmosfera poética". O Estado de São Paulo. São Paulo, 19 maio 1994.

${ }^{491}$ HELIODORA, Barbara. Os abalos sísmicos do cotidiano. O Globo. Rio de Janeiro, 15 jan. 1996.

492 "'A Gaivota' traz ninho de voos frustrados". O Globo. Rio de Janeiro, 12 jan. 1996.

493 JANSEN, Roberta. Takla faz voo artístico com 'A Gaivota'. O Estado de São Paulo. São Paulo, 27 dez. 1996
} 
Tchékhov, também optou por uma direção que não poluísse o texto e que fugisse da tradicional melancolia impressa em muitas montagens do dramaturgo: "procuramos nos ater ao caráter humano do texto, que, muitas vezes, é desperdiçado em prol de uma certa melancolia"494. E a inovação da montagem (que também optou por um trabalho mais realista com os atores) esteve no curioso aproveitamento do espaço, explorando a partir dele novas significações (seja pela sua limpeza, seja pela busca de locais alternativos), assim como se deu em montagens anteriores, como vimos. A cenografia de Daniela Tomas aproveitou o jardim do palacete situado no Parque Lage e, em diálogo com o ambiente bucólico, fizeram a contextualização da fazenda onde vivia Vânia e, de quebra, ofereciam uma espécie de libelo em defesa do meio ambiente (em sintonia com os discursos do médico Astrov) ${ }^{495}$. As atuações de Diogo Vilela (Vânia) e Débora Bloch (Helena) foram especialmente destacadas pela crítica, com exceção da cena final em que, durante o discurso final de Sônia, Vilela optou por uma lamentação em tom excessivamente melodramático, fazendo que a personagem perdesse em sutiliza em um de seus momentos decisivos.

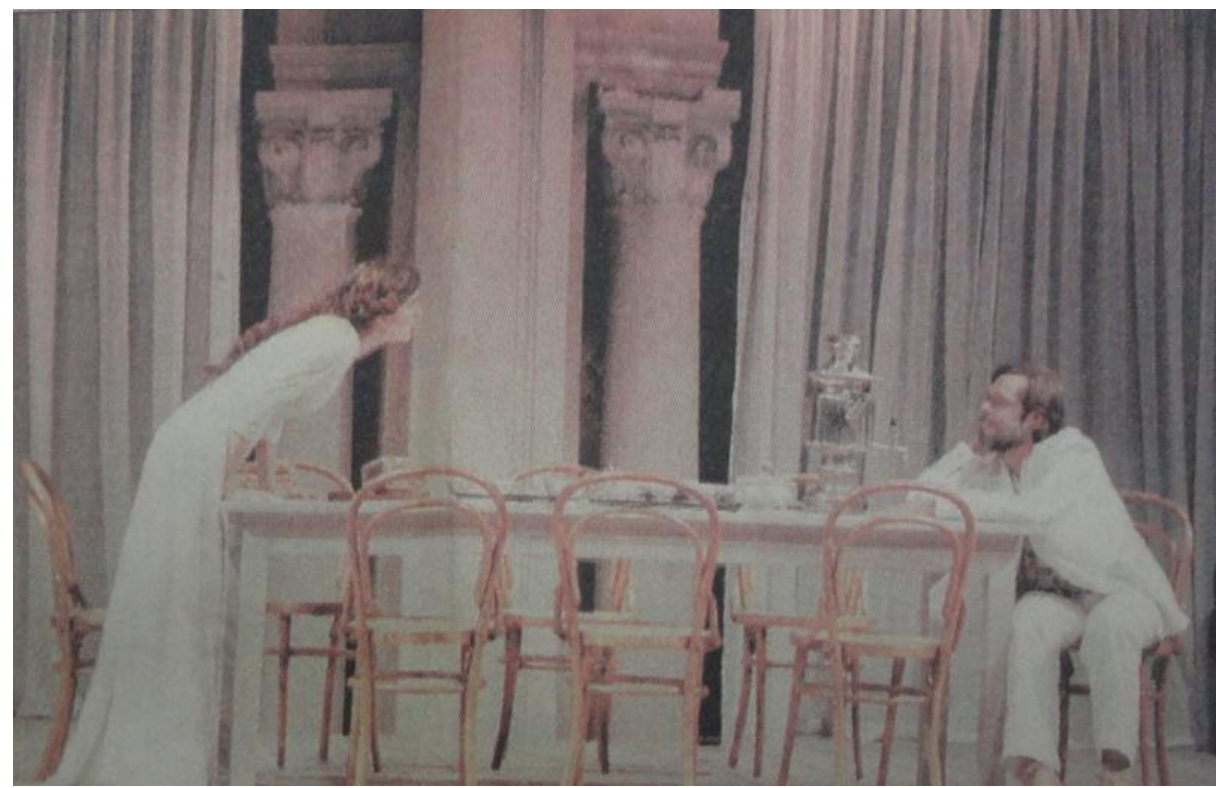

Foto: Débora Bloch (Helena) e Diogo Vilela (Vânia) em cena de Tio Vânia. (Fonte: Foto de Divulgação em BRASIL, Ubiratan. 'Tio Vânia' fala do fracasso do homem contemporâneo. O Estado de São Paulo. São Paulo, 08 ago. 2003)

\footnotetext{
${ }^{494}$ ALMEIDA, Rachel. Infelizes para sempre. Encarte Programa - Jornal do Brasil, ano19, n.10. Rio de Janeiro, 06 a 12 jun. 2003.

${ }^{495} \mathrm{O}$ espaço, por outro lado, poderia perder prejudicar a tensão entre as personagens ao gerar certo esgarçamento, dadas as dimensões do palacete no jardim do Parque Lage, como comentou a crítica Barbara Heliodora, em Um belo espetáculo para Tchekov. O Globo. Rio de Janeiro, 13 jun. 2003.
} 
Como outra vertente visível desse período, encontramos as leituras que valorizaram a dimensão crítica ou mesmo política do dramaturgo, como se Tchékhov oferecesse um cuidadoso "olhar de fora" para iluminar nossa realidade. Se já foi possível encontrar encenações tributárias dessa tendência dentro o e fora do Brasil (como as de José Celso Martinez, Ivan Albuquerque, Giorgio Strehler e mesmo Peter Stein), agora elas emergirão em versões mais difusas, mas ainda sim potentes cenicamente.

Élcio Nogueira Seixas em sua direção de Tio Vânia, em 1998, com estreia em Curitiba, explorou de maneira um pouco mais explícita a necessidade de abrir o palco para entender os mecanismos que rondavam a condição das personagens de Tio Vânia. Se a encenação não é declaradamente política, evidencia pelo menos uma posição racional e crítica frente ao material encenado. Tanto que para Renato Borghi (Vânia), que comemorava 40 anos de atuação nessa encenação, Tchékhov poderia muito bem ter escrito um "depoimento sobre o Brasil", dadas as similaridades entre as crises vividas pelas personagens naquele tempo histórico e as nossas. Segundo ele, além do momento de inércia ideológica e social que marcava as duas temporalidades, "todo mundo está querendo fazer alguma coisa, mas os alvos procurados são falsos. Alvos de dinheiro, de ganhar uma grana" 496 .

As personagens ocupam o proscênio e em diferentes momentos as cortinas que o contornam se abrem para exibir a movimentação dos atores-personagens - recurso que na semipenumbra distanciava levemente o espectador, o qual, frente a frente com a estrutura cênica desvelada, pode olhar analisar com maior atenção as situações. Em sintonia com tais elementos, a abordagem não poderia ser outra que não a que ressaltasse a força autoirônica das personagens e o tragicômico, combatendo qualquer possibilidade de arrebatamento ou absorção melancólica. Além disso, Élcio Nogueira Seixas promoveu verdadeira inovação ao não deixar que se criassem pausas entre as falas das personagens, na intenção de impedir que resvalasse qualquer pendor sentimental $^{497}$.

No entanto, para Macksen Luiz, estaria justamente aí o problema dessa leitura enfocada em situações. Segundo ele, o enfoque excessivo nas situações e o desleixo no trabalho de tom fizeram com que a montagem não alcançasse a "realidade interior" das

\footnotetext{
${ }^{496}$ Tio Vânia, como o Brasil, está em crise. Jornal do Comércio. Porto Alegre, 25 set. 1998.

${ }^{497}$ SANTOS, Mario Vitor. Peça dá leveza a Tchékhov. Folha de São Paulo. São Paulo, 23 abr. 1998.
} 
personagens, oscilando o tom geral ora entre o simples melodrama, ora entre a banal tragicomédia ${ }^{498}$.

Já Alberto Guzik situaria esse problema apenas no primeiro ato. Segundo ele, Élcio Nogueira Seixas consegue adequar-se a um tom exato para a encenação ao abandonar as marcações realistas do primeiro momento e dedicar-se a uma direção mais simbólica nos demais atos ${ }^{499}$.

De qualquer modo, o ponto forte da encenação vem do questionamento que faz a toda uma tradição de um Vânia melancólico e "arrastado" e a tentativa de contextualização de sua indignação dentro das necessidades do tempo presente. Para Mariângela Alves de Lima, é isso que tornava o Vânia de Renato Borghi uma figura altamente atraente: sua indignação sem respeito por si mesmo ou pelos que o cercavam e o despeito que se acumulou com o tempo explodiam "os cacos de um mundo que não vale a pena consertar" ${ }^{\prime 500}$. Ao final, segundo ela, é como se o Teatro Promíscuo tivesse demonstrado a força crítica de uma peça que antevê a própria explosão revolucionária:

Uma peça de Tchékhov dilacerada, em alta voltagem, sugerindo mais a explosão do que o ponto final, escapa certamente às concepções canônicas do mundo tchekhoviano. E é bom ver, neste espetáculo que exalta e poetiza o caos que se segue à desilusão, que há nessas magníficas peças, latentes, coisas inexploradas. ${ }^{501}$

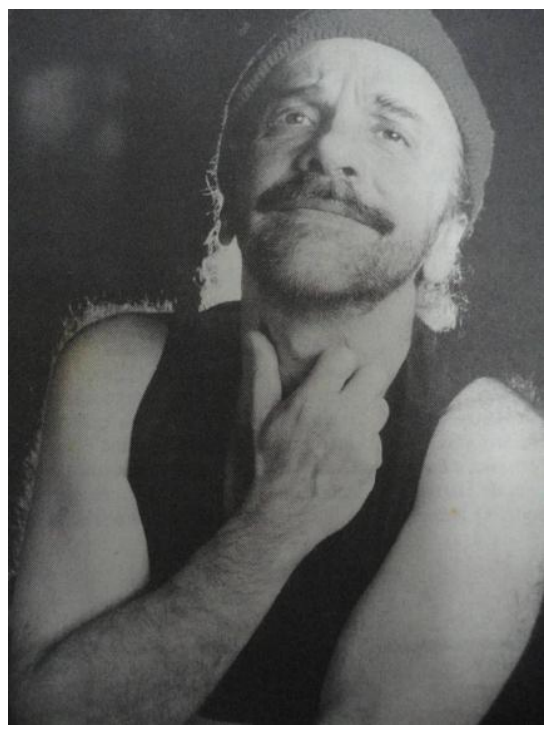

Foto: Renato

Boghi como

Vânia. (Fonte:

Foto de

Divulgação)

\footnotetext{
${ }^{498}$ LUIZ, Macksen. Desencontros inspirados em Tchecov. Jornal do Brasil. Rio de Janeiro, 12 set. 1998. ${ }^{499}$ GUZIK, Alberto. Chekhov ganha asas longe do realismo. Jornal da Tarde. São Paulo, 28 abr. 1998.

${ }^{500}$ LIMA, Mariângela Alves de. Há algo de inexplorado em 'Tio Vânia'. O Estado de São Paulo. São Paulo, 24 abr. 1998.

${ }^{501}$ Idem, Ibidem.
} 
Já O Jardim das Cerejeiras, também dirigido por Élcio Nogueira Seixas, com estreia em 2000, em São Paulo, não gozou da mesma realização que Tio Vânia. O diretor buscou explorar o problema da passagem de uma época (o fim do próprio jardim) abrindo um diálogo entre as diferentes gerações do teatro brasileiro que se encontrariam em cena (Tônia Carrero, como Raniévskaia, Renato Borghi, como Gaiev, e Beth Goulart, como Vária). Além disso, destacou o que também seria a despedida apiedada de um modo de vida já improdutivo e o anúncio vibrante dos novos tempos (evidente no delicado figurino que, ao final, veste de preto a maioria das personagens e contrasta com um único elemento vermelho em cena - no limite, símbolo da própria revolução ${ }^{502}$ ). Contudo, a direção demasiado "exterior" dos atores não encontrou os mesmos impulsos de emoção como em Tio Vânia (que funcionaram como contrapeso) e a montagem perdeu em intensidade de mensagem e sutileza, ainda que o poético e simbólico da cenografia (rampas, lápides, um pequeno armário que se converte em palco) gerassem suave amargura ${ }^{503}$.

Em chave diferenciada havia aparecido alguns anos antes a montagem de Ivánov (Curitiba, 1998), de Eduardo Tolentino, que investiu na dramaturgia de Tchékhov com vistas claras a iluminar o seu próprio processo de pesquisa sobre a realidade brasileira $^{504}$. Sem pretensões de realizar uma leitura deliberadamente política do dramaturgo a encenação representou o ponto alto de um longo processo de estudo da dramaturgia realista brasileira, ao qual o grupo se dedicava havia mais de quatro anos. No caso específico de Ivánov, o TAPA envolveu-se na compreensão do conjunto da obra do autor russo, assim como no processo de tradução da peça então inédita no Brasil, realizada por Arlete Cavaliere. E, para o diretor, este não representou um momento alheio às pesquisas que haviam caracterizado o grupo até então, pelo contrário: Tchékhov poderia ser um "'olhar de fora', que revelaria o Brasil de hoje" ${ }^{505}$.

\footnotetext{
${ }^{502}$ LUIZ, Macksen. Na contramão da sutileza de Tchecov. Jornal do Brasil. Rio de Janeiro, 08 abr. 2001.

${ }^{503}$ LIMA, Mariângela Alves de. Peça de Chekov promove o encontro de delicadeza e humor. O Estado de São Paulo. São Paulo, 19 jan. 2001.

${ }^{504} \mathrm{O}$ diretor se esforça para fazer paralelos entre as duas realidades: "Aqui, como lá, a geração dos anos 70 e 80 passou pela ressaca e pela repressão, após os movimentos liberais da década de 60 (...). Há também uma descrença na classe intelectual e uma nova classe que só fala em dinheiro e investimentos." VELLOSO, Beatriz. Grupo Tapa vai encenar obra de Chekhov. O Estado de São Paulo. São Paulo, 02 set. 1997.

${ }^{505}$ COELHO, Sérgio. O olhar do outro: Grupo TAPA acerta ao usar texto de Tchékhov para refletir sobre o Brasil. Revista Bravo, 07, Ano 1, abr. 1998, p. 102.
} 
A preocupação em tonar o material ficcional apresentado pelo dramaturgo russo um estímulo para o exame da contemporaneidade fica evidente já na primeira apresentação da peça, feita em caráter de esboço para a população da favela de Monte Azul. Ivánov (Zecarlos Machado) e Anna Petrovna (Denise Weinberg) pareciam vivos para o público da comunidade, que entendeu rapidamente a peça e riu dos destinos algo trágicos e cômicos dessas personagens. Para Eduardo Tolentino, "o patético nessas personagens é que elas sofrem muito por problemas reversíveis, exatamente como a maioria de nós, daí a empatia com o público" ${ }^{506}$. E essa leveza aberta ao riso, que ao mesmo tempo não negligencia o peso do drama vivido por Ivanov, que se suicida ao final, advém também das opções da direção, que se preocupou, antes de mais nada, com a homogeneidade do trabalho do grupo e uma cenografia limpa e leve (ainda que com demarcações históricas claras). Mas, se conhecemos tais pressupostos do diretor de antemão, é preciso deixar claro que sua encenação optou por deixar o texto falar. Nesse sentido, qualquer paralelo entre a fábula de Tchékhov e os dramas da sociedade brasileira presente deveriam vir exclusivamente dos espectadores.

Ainda assim, segundo ele, as associações seriam imediatas, pois o clima de desmotivação que cercava Ivanov era o mesmo dos tempos de Fernando Henrique Cardoso e do neoliberalismo ${ }^{507}$, e a individualidade de cada personagem, profundamente estudada e matizada nos meses de trabalho de preparação dos atores, era também símbolo do todo social que opera no fundo da peça. Para Mariângela Alves de Lima, tratava-se de raro encontro de uma visão de mundo com um autor em $\operatorname{particular}^{508}$.

Como último exemplo emblemático das interpretações de Tchékhov mais empenhadas criticamente está Tio Vânia, de Celso Frateschi. O diretor, que em 1989 já havia dirigido o texto com alunos da EAD, voltaria agora em 2000 em uma montagem que representou o ponto alto dessa tendência e, ao mesmo tempo, um dos momentos mais importantes da recepção do dramaturgo entre nós. O espetáculo, resultado do processo de trabalho com alunos do teatro-escola Ágora, vem atravessado pelas marcas de formação dos fundadores Frateschi e Roberto Lage: uma proposta humanista e

\footnotetext{
${ }^{506}$ NÉSPOLI, Beth. Ivanov aposta na força da fábula de Chekhov. O Estado de São Paulo. São Paulo, 16 abr. 1998.

${ }^{507}$ GUZIK, Albert. Grupo TAPA aproxima Chekhov do Brasil atual. Jornal da Tarde. São Paulo, 16 abr. 1998.

${ }^{508}$ LIMA, Mariângela Alves de. TAPA atualiza a narrativa de Chekhov em 'Ivanov'. O Estado de São Paulo. São Paulo, 08 maio 1998.
} 
política, inspirada nas formulações de Stanislávski, Brecht e Peter Brook. E, se para o Ágora a palavra de ordem era realizar encenações que ajudassem a entender o homem contemporâneo, isso não significava que um autor clássico não pudesse trazer contribuições decisivas $^{509}$. Afirma Frateschi: "Partindo da conclusão óbvia de que Tchékhov é melhor do que nós, então ele é o próprio paradigma de nossa pesquisa. Não imprimimos um ritmo ou dinâmica contemporâneos ao espetáculo." ${ }^{510}$ Nesse sentido, deixar o texto falar já é estabelecer uma comunicação com o presente.

A sala do teatro Ágora abrigou um espetáculo sem excessos cenográficos, limpa e enxuta, a fim de que a atenção se concentrasse no "trabalho intelectual da encenação", com um grande relógio projetado representando a tópica "tipicamente tchekhoviana" da passagem do tempo. O espetáculo faz opção clara ao cortar os trechos referentes ao passado de Vânia, de modo a valorizar apenas o jogo entre as personagens no presente, e não "o que foi e o que poderia ter sido" ${ }^{511}$. Em certo sentido, é como se o diretor seguisse uma tendência aberta anos antes por Daniela Thomas, que chegou a eliminar metade das personagens de A Gaivota a fim de garantir um trabalho mais concentrado de investigação das personagens pelos atores. Ainda que em chave geral diferenciada, o princípio da primazia da personagem prevalecia: nada que lhe fosse exterior deveria prevalecer, ou seja, "ser e parecer são, nessa concepção, uma coisa só e não há indicações de que essas pessoas possuam uma vida interior mais densa do que aquela que são capazes de manifestar pela palavra" ${ }^{512}$. O diretor conseguiu, assim, dedicar-se a um trabalho mais intenso com a palavra dessas "vidas em decadência", para que a sutileza da atuação predominasse, dando mais força aos momentos de tensão ${ }^{513}$. Luzes e cores ficaram menos intensas ao longo do espetáculo, de modo a paulatinamente recaírem em leve penumbra ao final. Neste momento, Vânia e Sônia também realizam seu monólogo final espremidos a um canto do palco. No último ato, a sensação de sufoco e desespero amontoa-se em camadas de tensão reprimida.

Mas como não poderia deixar de ser para o grupo, a investigação sobre a possibilidade da uma utopia não está ausente. Se há algo de levemente utópico na última

\footnotetext{
${ }^{509}$ OLIVEIRA, Roberta. Ágora apresenta no Planetário a sua versão de 'Tio Vânia', de Tchecov. $O$ Globo. Rio de Janeiro, 19 jun. 2006.

${ }^{510}$ SANTOS, Valmir. Ágora monta 'Tio Vânia' fiel ao tempo de Tchecov. Folha de São Paulo. São Paulo, 25 nov. 2000.

${ }^{511}$ LIMA, Mariângela Alves de. Ágora põe em cena um Chekhov impecável. O Estado de São Paulo. São Paulo, 16 fev. 2001.

${ }^{512}$ Idem, Ibidem.

${ }^{513}$ LUIZ, Macksen. Tchecov, na essência - Montagem de Tio Vânia conserva a sutileza típica da obra do autor. Jornal do Brasil. Rio de Janeiro, 25 jul. 2002.
} 
fala de Sônia (Nádia de Lion), é o Astrov de Mario Augelli, feito sem nuances, para que a mensagem positiva fosse mais efetiva, quem dá a mensagem decisiva dos que acreditam que é possível aprender com as misérias do presente para que as coisas no futuro sejam diferentes: "Aqueles que hão de viver cem ou 200 anos depois de nós, para os quais estamos lutando a fim de construir um novo caminho, será que se lembrarão de nós e dirão uma boa palavra em nosso favor?" ${ }^{514}$

\subsection{Desconstruindo Tchékhov}

O fim dos anos 90 e boa parte dos anos 2000 têm sido marcados por um terceiro veio de montagens que se caracterizam pelo rompimento com uma ideia de "fidelidade ao texto original" de Tchékhov. Em sintonia com as pesquisas teatrais contemporâneas (em muitos casos, mas não em todos, reverberações diretas das pesquisas de Artaud, Grotowsky e Eugenio Barba) ${ }^{515}$ tais espetáculos buscam especificar o material da linguagem teatral e exploram mais a fundo a construção de significados por meio do trabalho dos atores com seu próprio corpo, objetos e recursos multimídia. A zona de investigação que esses elementos abrem, permitem o questionamento de uma série de pressupostos durante muito tempo tidos como intocados: a relação ator-personagem, a noção de peça "bem feita", a centralidade da palavra ou mesmo os limites entre o real e o ficcional.

Dentro desse universo livre das amarras convencionais, a atualização do dramaturgo já não se dá pela ideia de que o texto por si só terá algo a dizer e será sensível às demandas do nosso tempo. Por isso, muitas montagens desse período buscaram a própria explosão da tessitura do drama para abri-la a um sem-número de significações possíveis que ficam por conta do espectador - seja eliminando personagens, seja rompendo com qualquer cronologia ou causalidade, seja enfrentando diretamente ritmos que porventura pudessem ser sugeridos pela sua dramaturgia. Muitas vezes, interessará mais a construção que se faz do presente sobre a peça, que da peça para o presente; ou ainda, uma construção com Tchékhov que de Tchékhov.

\footnotetext{
${ }^{514}$ ABREU. Montagem de 'Tio Vânia', de Tchecov, retoma a utopia perdida. Folha de São Paulo. São Paulo, 03 mar. 2001.

${ }_{515}$ RAMOS, Luis Fernando; FERNANDES, Silvia. Diálogo da Gaivota" In: Revista Sala Preta v. 7, 2007, p. 227.
} 
Estas montagens estão em sintonia com experimentações formalmente radicalizadas que já ocorrem desde inícios dos anos 90 nos EUA, como Brace Up!, montada em 1991, pelo The Wooster Group e baseada na peça As Três Irmãs. O grupo americano, liderado por Elizabeth LeCompte, parece ter selecionado As Três Irmãs de Tchékhov quase aleatoriamente. Em um palco retangular, havia microfones e aparelhos de televisão que trabalhavam ora harmonicamente em diálogo com o texto, ora gerando ruídos sem propósito imediato, mas que, em conjunto, pareciam simbolizar o caráter massificador da cultura contemporânea. No início, um narrador lê a rubrica inicial da peça e apresenta cada um dos atores, com seus respectivos papeis. Os atorespersonagens realizam leves discussões com o narrador e é como se a montagem fosse uma longa leitura não "do" texto tchekhoviano, mas sim "com" ele - um retrato de "Tchékhov e o Wooster Group", feita de modo antinaturalista e mesmo, "antiteatral" ${ }^{516}$. Intencionalmente, o tom geral é o de uma montagem amadora, uma espécie de ensaio. Em determinado momento pedem desculpas porque a atriz que atua como Macha ainda não está em cena... Há trechos que foram integralmente cortados e o monólogo inicial de Olga, por exemplo, foi convertido em um jogo de perguntas e respostas entre narrador e ator-personagem, gerando a sensação de algo não aurático e casual. E seguindo a linha estabelecida com outras montagens de LeCompte, Brace Up! funcionava como uma coreografia e a trilha sonora uma espécie de contraponto irônico aos comentários utópicos das personagens.

Nesse sentido, a escolha quase "randômica" do texto de Tchékhov (LeCompte chegaria a afirmar até que desconhecia o texto antes do grupo pretender encená-lo) não tem a ver com uma "tradição" ou uma tentativa de buscar em Tchékhov uma lente específica para a leitura dos problemas da sociedade atual. Os objetivos do grupo são, antes de mais nada, "negar a ilusão teatral e criar a ideia de que a encenação ela mesma é algo inacabado, instável, improvisado, mais que algo bem polido ou perfeito" ${ }^{517}$. Para Laurence Senelick, as palavras proferidas pelo grupo ("O Wooster Group está desafiando a interpretação de Stanislávski") dão a entender, dado o conjunto da encenação, que é como se todos eles tivessem nascido ontem e negassem a longa tradição de revisão das interpretações naturalistas.

\footnotetext{
${ }^{516}$ ALLEN, Op. Cit., 148.

${ }^{517}$ Idem, 149.
} 
Sem a mesma pretensão de negação iconoclasta ou de autoproclamação ahistórica, encenações como as de Bia Lessa (As Três Irmãs, 1998) e de Enrique Diaz (As Três Irmãs, 1999, e Gaivota, tema para um conto curto, 2006) trazem pontos de convergência com a vaga desconstrucionista que tem no The Wooster Group um grande símbolo.

A montagem carioca de Bia Lessa, curiosamente em cartaz quase ao mesmo tempo que a encenação de As Três Irmãs de Enrique Diaz, traz como ponto em comum com a montagem do grupo americano o uso de recursos audiovisuais e a "dessacralização" do clássico, imprimindo-lhe um tom prosaico. Sem adesão ao puro formalismo daquele, Bia Lessa tenta trabalhar um ponto de vista mais claro: "O homem distanciou o discurso de suas necessidades reais". E, em sua opinião, Tchékhov seria exatamente isso: em suas peças "as pessoas falam e não conseguem agir." ${ }^{518}$ Além disso, havia pontos diretos de contato entre o seu universo e o nosso (brasileiros e russos teriam uma propensão comum ao alegre e festivo $)^{519}$ e a construção de sua atualidade estava dada pela negação da aura pesada do clássico, buscando tirar da fala das personagens toda e qualquer impostação. Os sussurros são frequentes e, por isso mesmo, a diretora recorre a um telão lateral que, nessas circunstâncias, apresenta legendas com as falas que não podem ser ouvidas em alto som.

A negação da "aura clássica" é construída com a máxima coloquialização da encenação. Paradoxalmente, impregnou-se do naturalismo para negá-lo. Para isso, realizou os ensaios da peça em um grande casarão em Santa Tereza, no qual os atores tinham de atuar como que realizando tarefas cotidianas dentro de casa: lavando pratos, escovando os dentes, tomando banho... Isso, em sua opinião, teria o efeito decisivo de "desglamurizar" Tchékhov e torna-lo mais próximo de nosso dia a dia ${ }^{520}$.

\footnotetext{
${ }^{518}$ KOSLINSKI, Daniel. As mulheres de Tchecov em ação. Encarte Programa - Jornal do Brasil - n 28 , ano14. Rio de Janeiro, 09 out. 1998.

${ }^{519}$ NAME, Daniela. 'As Três Irmãs' na banalidade cotidina. O Globo. Rio de Janeiro, 09 out. 1998.

${ }^{520}$ As Três Irmãs retrata cotidiano. Folha de São Paulo. São Paulo: 09 out. 1998.
} 


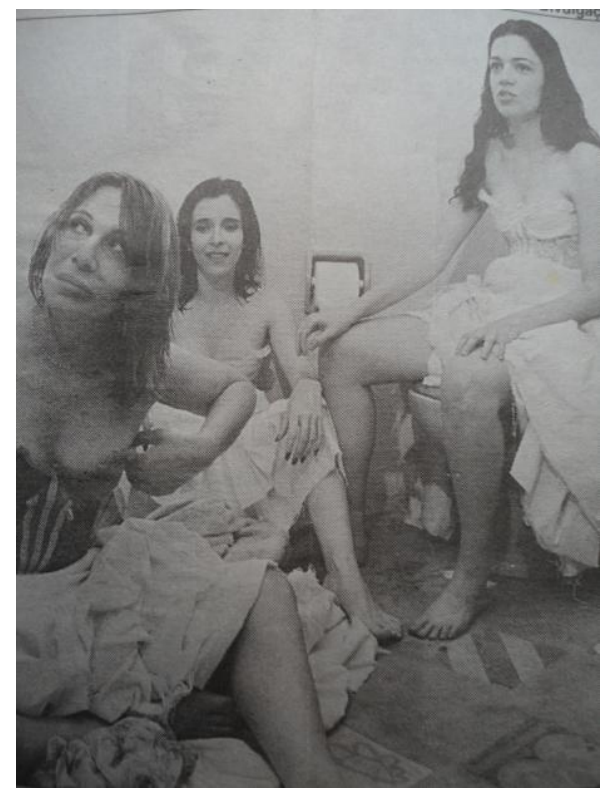

Destaque para as atrizes dentro do banheiro da mansão em Santa Tereza. Da esquerda para a direita: Renata Sorrah (Olga), Deborah Evelyn (Macha) e Lorena da Silva (Irina). Foto de Divulgação. Retirada de DRATOVSKY, Flávia. Tchekov sem artifícios. O Dia. Rio de Janeiro, 09 out. 1998.

Já sua tentativa de romper com o padrão naturalista (ao qual curiosamente parece recorrer no ensaio com os atores) vem também da cenografia simbólica, estruturada em torno de grandes prateleiras que tomavam conta das laterais e do fundo, funcionando como portas inusitadas ou "praticáveis" pelos quais eventualmente os atores subiam e desciam. Além disso, o cenógrafo Gringo Cardia também optou por forrar todo o chão com sete toneladas de raspas de pneu, que criavam a pesada sensação de uma neve negra a cobrir todo o palco. Mas a tentativa de rompimento se dá, sobretudo, pelo ritmo impresso à encenação. As personagens foram concebidas de um modo geral dentro de uma subversão da cadência "outonal" ou "arrastada" que marcou muitas encenações pelo mundo e também no Brasil. A diretora explorou uma fisicalidade que fazia "explodir" intenções e desejos que, até então, eram compreendidos vagamente pelo que se convencionou chamar "atmosfera tchekhoviana", construída a partir do que não é dito pelos diálogos.

Se tal proposta carrega em si um arejamento que está em sintonia com muito do que fazem as encenações contemporâneas, questionando diretamente a ideia de uma representação fiel de um modo de vida datado historicamente (o que, em suma, seria a representação de uma peça de museu), há também os problemas inerentes a esse próprio 
intento: a valorização dos detalhes cotidianos não vinha amarrada por nenhum fio interpretativo que pudesse, ao menos, estar em sintonia com os intentos da diretora (anunciados inicialmente em torno de um ponto de vista por ela proclamado). Isto, em uma dramaturgia que já não aposta na transparência do diálogo (sequer em sua integridade) pode gerar descompassos inesperados. Para Barbara Heliodora, em que pesassem as atuações delicadas das atrizes Renata Sorrah (Olga), Deborah Evelyn (Macha) e Lorena da Silva (Irina), os detalhes que imprimiam um novo ritmo à encenação eram de todo equivocados e eliminavam qualquer sutileza conquistada pelas atuações individuais: gritos, atores que caem no chão e empurrões imprimiam uma cadência que não estava em sintonia com a ideia de que há um desejo contido (e quanto mais reprimido, mais potente) na vida daquelas personagens. ${ }^{521}$ As irmãs que são tão cultas (e o telão lateral - incorporação tipicamente contemporânea das diferentes mídias - trazia as eventuais legendas para os momentos em que elas citavam expressões em outras línguas) parecem não funcionar com um ritmo que, ao invés de focalizar seu sufoco e a intensidade do sonho que não se converte em gesto, privilegiava uma externalidade física e agitada, fazendo o conjunto perder em potência de sentido.

Curiosamente, a montagem de Enrique Diaz, em cartaz algumas semanas depois da estreia de As Três Irmãs de Bia Lessa, fora criticada pelo mesmo motivo: a excessiva aceleração do ritmo fez a montagem perder em força e sutileza.

Diaz, que em encontro com o diretor José Celso Martinez e Bia Lessa afirmou que "sempre achou que Tchékhov devia ser algo misterioso e chato" ${ }^{522}$, descobriu no dramaturgo um potente leitor da contemporaneidade. E, para romper com o que em sua opinião seria um equivoco das leituras anteriores, optou não por um autor lento, arrastado, como se costuma ver, mas por um veloz: "A compreensão que em geral se tem das peças de Chekhov (sic) é de um certo marasmo, como se o tempo não passasse, mas eu diria que na verdade ele passa num ritmo vertiginoso" ${ }^{\text {"523. }}$.

Por isso, sua cenografia, aos cuidados de Helio Eichbauer apostou na limpeza e na concentração sobre alguns objetos (como os brinquedos do filho de Natasha), enfocados pela iluminação básica e clara de Maneco Quinderé. Esse enfoque em brinquedos e objetos, explorando uma espécie de ludicidade da peça, tinha também por

\footnotetext{
${ }^{521}$ HELIODORA, Barbara. Agitação além da dose resulta em montagem inexpressiva. O Globo. Rio de Janeiro, 26 out. 1998.

${ }_{522}$ OLIVEIRA, Roberta. 3 vezes Tchekov. O Globo. Rio de Janeiro, 16 nov. 1998.

${ }^{523}$ NÉSPOLI, Beth. Montagem de 'As Três Irmãs' varre penumbra do palco. O Estado de São Paulo. São Paulo, 4 jan. 1999.
} 
objetivo suplantar qualquer subtexto sentimental e geravam uma espécie de "comentário crítico" a cada um dos devaneios das personagens ${ }^{524}$. Tudo isso acompanhado de um compasso acelerado na fala de todas as personagens, afastando qualquer semelhança com o que tradicionalmente se tinha como compasso típico de As Três Irmãs.

No entanto, a despeito da insistência nesse novo elemento que, como vimos, tem sua parcela de arejamento e sintonia com a velocidade de nosso tempo, para Mariângela Alves de Lima o espetáculo peca ao ser injusto com o próprio dramaturgo que, ironicamente, Diaz afirmava estar respeitando ao evitar uma direção muito "autoral". Para ela, apesar da polifonia de subjetividades das personagens, há um desejo em sintonia das irmãs, que se constrói na tentativa do diálogo. Diálogo este que não encontra as palavras exatas justamente porque construído num ambiente de ociosidade e fruto de uma elaboração do momento, sempre adiada ou interrompida pelos imprevistos do cotidiano. A encenação de Diaz, ao estabelecer um ritmo acelerado para as falas das personagens, é como se negasse às personagens o direito de elaborar suas próprias palavras. Em suma, é como se o que elas dissessem fosse dito sem reflexão. O diretor evita o encontro das personagens e acentua-lhes apenas a medida do monólogo interior. "Como consequência, o sofrimento das criaturas em cena parece-nos também uma exasperação momentânea, um mero descompasso entre a situação dramática, o aprisionamento em um 'lugar social' como a sala de estar e o desejo de escapulir de um pequeno constrangimento" ${ }^{25}$. Ainda para Mariângela, ao afirmar que "a era do naturalismo já passou" e que essas personagens "rodeadas de sono podem recompor-se mesmo depois de seu autor tê-las condenado à morte ou ao exílio" o diretor tem algo de legítimo. No entanto, essa afirmação guarda também seu outro lado: dela podemos deduzir que não vale a pena apiedar-se desses destinos e isso, no caso de Tchékhov, seria dolorosa distorção.

\footnotetext{
${ }^{524}$ LUIZ, Macksen. "Tchecov numa encenação radicalmente lúdica". Jornal do Brasil. Rio de Janeiro, 18 jan. 1999.

${ }_{525}$ LIMA, Mariângela Alves de. "'As Três Irmãs' traz descompasso dramático". O Estado de São Paulo. São Paulo, 26 mar. 1999.
} 


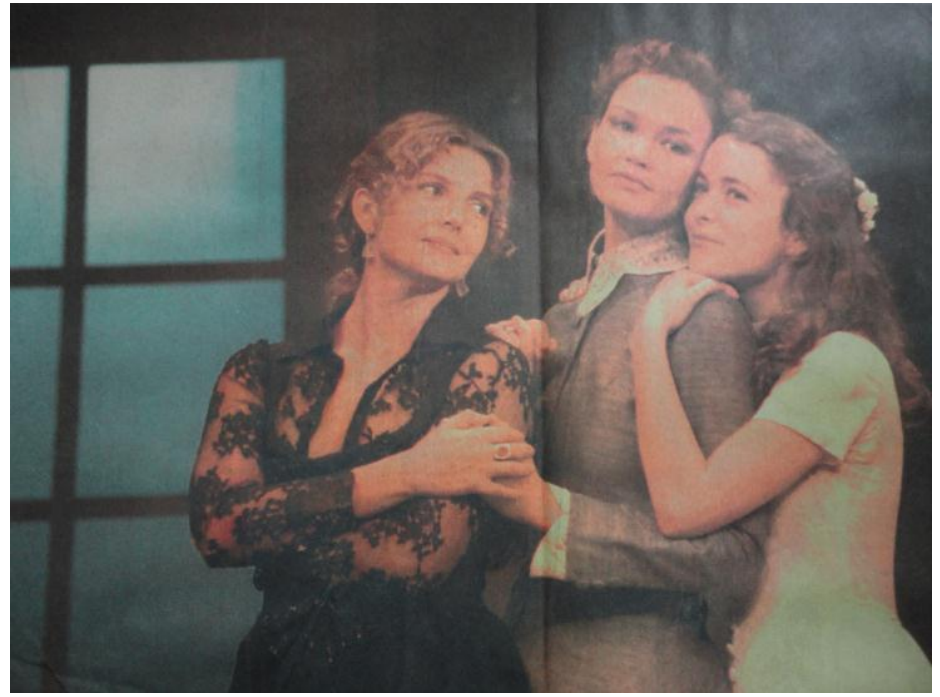

Da esquerda para a direita, Maria Padilha (Macha), Julia Lemmertz (Olga) e Claudia Abreu (Irina). Foto de Ana Branco. OLIVEIRA, Roberta. Amizade em família. O Globo. Rio de Janeiro, 02 jan. 1999.

Mas o ponto alto da "desconstrução" do teatro de Tchékhov não está nessas duas encenações que, a seu modo, como vimos, ainda tinham a dramaturgia como ponto de partida (ainda que questionado) para a encenação. Gaivota, tema para um conto curto (Rio de Janeiro, 2007), pode ser considerado momento decisivo dessa etapa da recepção do russo entre nós. É como se também simbolizasse o alto grau de intimidade alcançado entre Tchékhov e nosso teatro - tanto que se torna possível uma encenação que prescinde do texto (ou pelo menos do que seria sua "lógica interna"), ao mesmo tempo que o comenta e dele depende para que o universo de referências ganhe em profundidade. Assim, a fábula de A Gaivota pode ser mapeada fragmentariamente em determinados momentos, mas dentro de um espetáculo que não se propõe fabulesco e, por isso mesmo, impossível de ser reconstituído aqui nesses termos.

Enrique Diaz conduziu junto ao coletivo de atores (formalmente ligados à Companhia dos Atores, que não assinou esta peça diretamente) um processo de pesquisa intensa de linguagem, em grande parte aberto com Ensaio.Hamlet (2004), caracterizado por ele da seguinte maneira:

(...) continuação de uma pesquisa de narrativa, de desconstrução, de uma relação particular com os clássicos, com os objetos e sobretudo com o tempo. Como articular de forma instigante o tempo "de lá" com o tempo "de cá"? Como falar de nós mesmos, hoje, e nos lembrarmos do tempo como instância maior (...) $?^{526}$.

\footnotetext{
${ }^{526}$ Programa da Peça Gaivota - Tema para um Conto Curto, p. 11.
} 
Para responder a essas indagações, ou melhor, para potencializá-las enquanto questões (já que produzir um sentido único não é o objetivo), o grupo conduziu um trabalho de criação coletiva, em grande parte herdeiro da tradição aberta pelos grupos cariocas como Asdrúbal Trouxe o Trombone e Manhas e Manias. No entanto, aqui opera levando esse processo à radicalidade, já que parte da problematização da relação ator-personagem e incorpora "uma função próxima do performer, por seu caráter híbrido, que funciona como fusão de diversas propostas contemporâneas de atuação" ${ }^{527}$. É essa configuração que possibilita uma outra qualidade de relação com o texto de Tchékhov, que busca antes não sua "verdade" ou sua "transposição" para a cena, mas sim a especulação sobre sua "gramática" e os sentidos que abre para o próprio ator. Este, através de um processo de pesquisa sobre o universo da peça, dialoga com ela, trazendo para cada personagem seu "material interno". Por isso é também frequente ver o jogo de alternância entre a primeira e a terceira pessoas do discurso, na fala de um mesmo ator, que joga com a transitoriedade da condição da personagem e a analisa: “Agora você é Medvedenko, tem 32 anos e já tem os cabelos grisalhos, é professor (...) você vai encontrar Macha. Macha, porque você anda sempre de preto?"528. Assim, Enrique Diaz é encenador-ator, mas são também atores-criadores ${ }^{529}$ Bel Garcia, Emílio de Mello, Felipe Rocha, Gilberto Gowrinski, Isabel Teixeira, Mariana Lima, que compõem o espetáculo e para ele trazem seus materiais pessoais, para além de uma simples composição da personagem ${ }^{530}$.

Tal procedimento é o que funciona como pedra de toque da atualização do drama tchekhoviano, promovido pelo grupo encabeçado por Diaz. A intenção não é representar Tchékhov como ele o foi no século XIX, mas ir muito além e incorporar na tessitura de seu drama o processo de elaboração da encenação (todas as dúvidas, angústias, problematizações e relações trabalhadas no processo de pesquisa emergiram no "mal acabado produto final"), mas também as questões relativas sobre o que significa voltar a essa obra, ou atualizá-la, passado praticamente um século. Como relação a este

527 FERNANDES, Silvia. O Discurso Cênico da Companhia dos Atores. In: Teatralidades Contemporâneas. São Paulo: Perspectiva, 2010, p. 131.

${ }^{528}$ OLIVEIRA, Lígia Souza. Gaivota - tema para um conto curto: a temporalidade na releitura de Anton Tchekhov. Anais - $1^{\circ}$ Colóquio Internacional de Estudos Linguísticos e Literários - UEM - Maringá, 2010, p. 1-9.

${ }_{529}$ A conceituação é de Silvia Fernandes. Idem, p. 133.

${ }^{530}$ Para Silvia Fernandes, "No caso do espetáculo de Enrique Diaz, o que mais interessa é mostrar como o ator chega à personagem a partir de si mesmo, e não como lança mão de uma série de procedimentos para chegar à construção de uma personagem específica, que o precede enquanto concepção e conformação dramática.". RAMOS, Luis Fernando; FERNANDES, Silvia. Diálogo da Gaivota. In: Revista Sala Preta v. 7, 2007, p. 227. 
último ponto, é ilustrativo que em determinado momento do espetáculo Diaz, que atua de maneira diferenciada, à maneira de um comentador de personagens e ações (sempre com um texto na mão, como que a substituir alguém que repentinamente não compareceu) afirme:

Passaram-se dois anos. Passaram-se cem anos. Cento e dez. Faz quase um ano que a gente está ensaiando esta peça. Que horas são? Alguém sabe que horas são? Passou o século XX. Inventaram o celular, a televisão, o fax, o AZT. Clonaram uma ovelha, um macaco, um coelho. Fizeram um coelho fosforescente, que de noite fica aceso.... Duas guerras mundiais, uns shows de rock muito bons... ${ }^{531}$

Por isso, o que os públicos carioca, paulista, assim como os de inúmeras outras capitais do Brasil e do mundo viram no início de Gaivota foi um palco limpo, forrado com linóleo e com fundo branco; e os figurinos não insistiram em demarcar qualquer historicidade. Tais escolhas tinham a ver justamente com a necessidade de limpar a cena do peso realista e ceder espaço para que essa mistura de temporalidades (da fábula de Tchékhov e dos quase 110 anos da escrita da peça) e materiais (do conjunto de experiências, problematizações e signos que são trazidos do processo de pesquisa) pudesse operar.

Aqui, como se vê, já não se trata de uma relação direta com o texto de Tchékhov, mas de sua explosão, com fins à elaboração não de uma interpretação de Tchékhov, mas com Tchékhov. E, para Luis Fernando Ramos, ao não seguir o texto, o espetáculo "se torna tão ou mais fiel ao original" ${ }^{532}$.

Evidentemente, trabalha-se com uma outra ideia de "fidelidade", ou seja, ao eleger o que se tem como problema central na dramaturgia e ao se estabelecer o vínculo com o que se acredita ser um eixo determinante da contemporaneidade, tem-se a construção de uma "fidelidade" - mais pensada em termos de força no presente que em termos de "lógica interna do texto". Assim, fica evidente o porquê do enfoque deliberado do grupo sobre o problema da encenação fracassada de Trepliov no primeiro ato, assim como o problema da passagem do tempo, expressa no conflito entre

\footnotetext{
${ }^{531}$ Gravação do espetáculo exibido no Rio de Janeiro, no Teatro Poeira, em 2007. Gaivota - tema para um conto curto. Direção: Enrique Diaz. Produção: Emílio de Melo, Enrique Diaz e Centro de Empreendimentos Artísticos Barca Ltda.

${ }^{532}$ RAMOS, Luis Fernando, Op. Cit., p. 225-228.
} 
gerações (Arkádina versus Trepliov, Realismo versus Simbolismo). Isso permitiu que os temas centrais da montagem (para além do enfoque no texto do dramaturgo russo) fossem também esse jogo deliberado com a força do tempo e a própria realização do espetáculo, como se ele próprio a todo momento estivesse próximo de sucumbir, à beira do abismo ${ }^{533}$.

Tal instabilidade já fica evidente nos momentos iniciais. Todos os atores estão sentados de frente para o público em uma grande fila, ao fundo do palco limpo, estão entregues ao contato com o público, às incertezas e à potência do fazer teatral que aposta, sobretudo, na ação e no tempo presentes. Mariana Lima lança a indagação que poderia funcionar muito bem como um grande epíteto para o espetáculo: "Eu me pergunto como começar uma peça que fala justamente do fracasso de uma peça. Eu me pergunto como encenar o tempo. Eu me pergunto como fazer com que personagens assim em tempos tão distintos convivam, habitem no mesmo tempo e espaço",534. A dúvida não é retórica e norteia todos os movimentos que se articularão a partir daí, sempre em direção ao questionamento do próprio fazer teatral e da possibilidade de realizar o encontro dessas temporalidades.

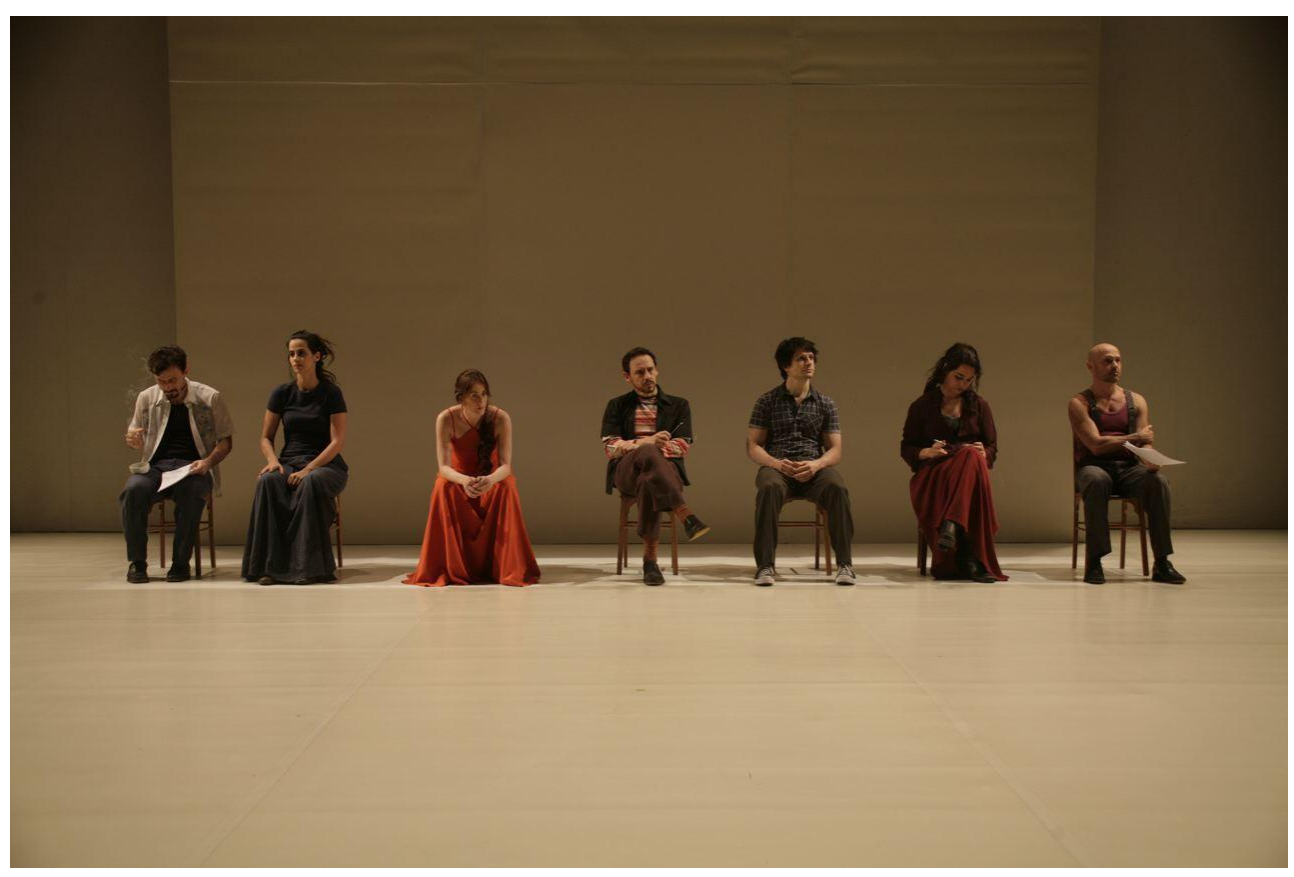

Elenco de Gaivota - Tema Para Um Conto Curto. Da esquerda para a direita: Enrique Diaz, Mariana Lima, Bel Garcia, Emilio de Melo, Felipe Rocha, Isabel Teixeira e Gilberto Gawronski. Fonte: 〈http://feliperocha-gaivota.blogspot.com/2009/10/equipe.html>

\footnotetext{
${ }^{533}$ Idem, p. 226.

${ }^{534}$ Gravação do espetáculo Gaivota - tema para um conto curto.
} 
Por isso o trabalho desses atores em cena não é o da representação. Para o grupo, essa premissa está posta em questão e não pode sobreviver em um tempo em que os limites de realidade e ficção se esfumaçam. Decorrente dessa ideia, o gesto cênico será sempre fugidio, jamais "figurativo" ${ }^{535}$. A gaivota emerge em diferentes momentos do espetáculo, mas sempre pela sugestão dos objetos (alimentos, cadeiras, plantas...), que, por meio da convenção de linguagem, constroem e desconstroem simbologias. Há momentos de significativa beleza como aquele em que o café derramado sugere um lago de águas turvas ou quando Mariana Lima ergue uma planta que exibe suas raízes e dela retira a imagem da cabeça de Trepliov. Ao mesmo tempo, assume-se essa estilização pois ela "evita o maneirismo do teatro tchekhoviano [ou o que se acreditava até então que ele era $]^{536}$, que transforma o ato de atuar num passivo experienciar de emoções e reduz imensamente a criatividade do ator..." ${ }^{537}$. A construção de símbolos por meio do trabalho do ator com o corpo e com os objetos inverte o processo que antes o escondia por trás da personagem. Agora, cada personagem pode ser evocada por diferentes atores e, em algumas situações, há vários que se apodeream ao mesmo tempo de sua voz, como em uma espécie de coro. O resultado: não só o jogo com o simbólico se enriquece pela multiplicidade de formas que assume, como também pela abundância de pontos de vista que, antes de responderem a um problema, aumentam a potência dos questionamentos, que se amontoam ${ }^{538}$. Assume-se, assim, a condição instável, mutante e provisória da forma cênica e, ao mesmo tempo, como dissemos, reconhece-se a dificuldade de sua realização.

\footnotetext{
${ }^{535}$ RAMOS, Op. Cit, p. 226.

${ }^{536}$ A observação é nossa.

${ }^{537}$ GUSSON, Joelson. A relação performer/espectador na cena contemporânea. Monografia apresentada à Universidade Federal do Rio de Janeiro - UNIRIO - como requisito parcial à obtenção do título de Bacharel em Teoria do Teatro. Rio de Janeiro: UNIRIO, 2009, p. 11-20.

538 "A coisa pronta, o ponto final e a procura do sentido unívoco são, ao que parece, fantasmagorias de uma etapa da história da arte que o grupo contesta por meio de espetáculos onde se sobrepõem efeitos visuais e sonoros, afirmações filosóficas e elocuções impregnadas de emotividade. De um modo geral, seus trabalhos enfatizam a pluralidade de sentidos contidos nos signos teatrais.". LIMA, Mariângela Alves de. "Liberdade da Arte faz Gaivota voar alto". Folha de São Paulo. São Paulo, 11 jul. 2007.
} 


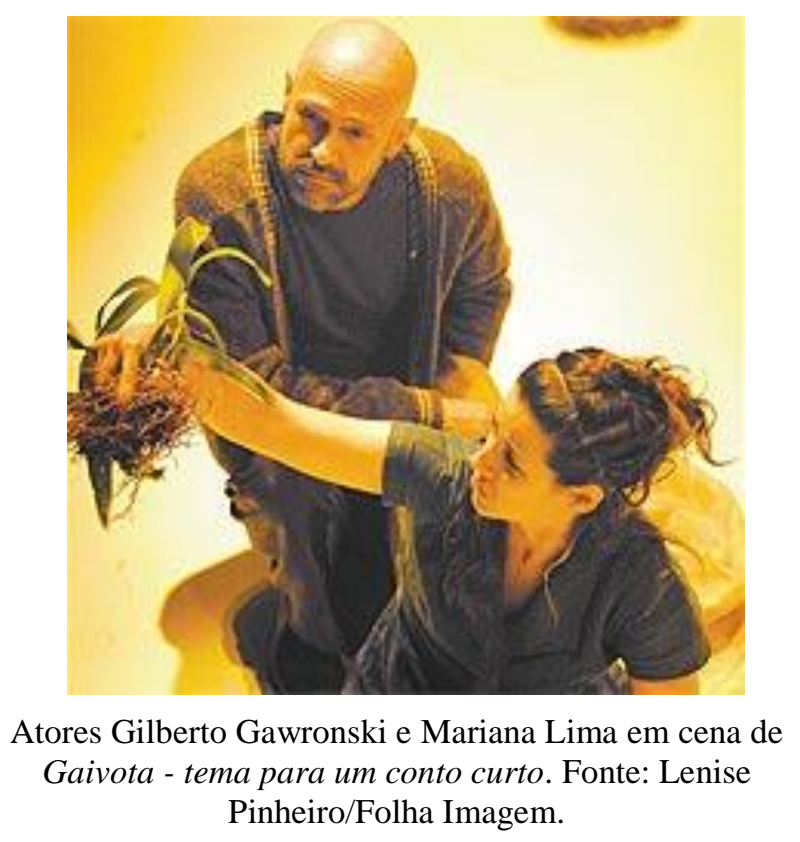

Como outro eixo fundamental, está o problema da passagem do tempo. Este tópico, considerado por muitos como verdadeiro leitmotiv tchekhoviano é complexificado pela sua problematização em diferentes planos. Na peça de Tchékhov há o embate de gerações (Arkádina- Trepliov, Trepliov-Trigórin, Arkádina-Nina), que é também o embate de estéticas, e que aparece aqui mesclado aos questionamentos geracionais e estéticos dos próprios atores. Para Bel Garcia, seu questionamento a respeito do tempo veio de um comentário de seu próprio filho, que teria dito que antes de nascer ele "estava morrido". Para Mariana Lima, a problematização vem em um dos momentos que atua como Arkádina, no qual mescla sua experiência pessoal de antiga atriz de novelas da TV Globo ao passado de atriz personagem, que tinha trabalhado no "teatrão" realista russo - um claro jogo entre o presente da atriz que olha para seu passado e repensa o presente e o passado da personagem. Ou o balanço de todo o tempo que passou da escrita dessa peça e de sua inicial encenação, com a atual, promovida por aqueles atores, em um palco, no Rio, em São Paulo, ou em qualquer lugar. E esse balanço vinha na menção à fracassada estreia da peça de Tchékhov em 1898, no Alexandrínski; na reflexão de Diaz sobre as coisas surpreendentes que a humanidade conquistou ou promoveu naqueles quase 110 anos anos ou, ainda, na mescla sutil de elementos de diferentes temporalidades, como quando refletem sobre o sentido da obra do escritor Trigórin, personagem de A Gaivota:

É bom... É bom se você quer ler no banheiro ou então antes de dormir... Ele ganha o dinheiro dele, ganha bem... Agora, depois 
que você lê Joyce, você lê Beckett, Saramago, Rimbaud ou Sérgio Santanaou... Cortázar, Dostoiévski, Turguêniev, Miltom Hatoum... Por que ler Trigórin? ${ }^{539}$

Como se vê, a preocupação com o tempo da fábula é deixada de lado e, quando aparece, sua importância está em pé de igualdade com outras temporalidades. Todos esses elementos, em conjunto, exigem um outro grau de participação do público, que não pode mais esperar uma absorção catártica e a apresentação de respostas a problemas vindos de antemão ${ }^{540}$. O que temos é a construção e a desconstrução de uma temática, à qual a fábula de A Gaivota serve se inspiração, mas que não surge de maneira estável e exige do espectador um constante esforço para o estabelecimento de relações. Talvez por isso mesmo o espetáculo de Enrique Diaz não seja de imediato de fácil recepção para um público amplo, ainda que seu sucesso junto à crítica (nacional e internacional) tenha sido considerável.

Ao final, a sensação de que estamos diante de um espetáculo emblemático, seja por sua força demolidora, seja pela relação muito específica que estabelece em relação à dramaturgia de Tchékhov. Se autor russo não pretendia oferecer respostas aos espectadores de suas peças, não se pode dizer por outro lado que sua forma dramática fosse em si a explosão da ideia de representação e que suas personagens fossem apenas indagações. Para o dramaturgo, as temporalidades não se mesclam em pé de igualdade e mesmo passado, presente e futuro jogam entre si de modo a construir relações que não apontam para a simples relativização. Como afirmou Peter Szondi, Tchékhov ainda apostava no drama, apesar de em sua dramaturgia a forma dramática já se mostrar em evidente crise. É daí, em grande parte, que advém sua riqueza. E suas personagens, se estão sempre às voltas com a impossibilidade de realização de suas vontades no presente, ainda têm algo a dizer sobre suas expectativas de futuro, mesmo que o diálogo entre elas seja fracassado e que o passado (e as escolhas que fizeram) pesem sobre suas costas. Por isso, ir a Tchékhov para torná-lo instrumento de reflexão metalinguística (e em partes apenas relativizar a possibilidade de que é possível afirmar e dizer) é, em partes, esvaziá-lo.

\footnotetext{
${ }^{539}$ Gravação do espetáculo Gaivota - tema para um conto curto.

540 "Neste espetáculo nenhum tempo prevalece, nem em detrimento da história e nem da verossimilhança. O que se percebe na montagem é o uso de alguns procedimentos que levam à tematização explícita do tempo, tornando o espetáculo uma comunicação incerta de temporalidade flutuante. Esses apontamentos refletem na transformação da condição do tempo, saindo da situação de significado caminhando para o nível de significante." OLIVEIRA, Lígia Souza, Op. Cit., p. 8.
} 
Por outro lado, se há percalços, é inegável que temos um momento exuberante e decisivo de uma trajetória de recepção do teatro tchekhoviano que começou muitos anos antes e vinha marcada pela ideia de que Tchékhov não seria um dramaturgo potente para falar-nos de maneira íntima. Ou ainda, sequer teríamos condições para que nossa cena, sempre candidatando-se à modernização de seus temas e formas, desse conta de uma dramaturgia que era a expressão clara da crise do próprio drama. Enrique Diaz e seu grupo não só tratam essas questões como superadas, como já têm como pressuposto que Tchékhov é um dado formador de nosso teatro e, por que não, de nossa cultura. Por isso mesmo não voltaram a sua Gaivota para representá-la como "deveria ser", mas para mostrar como ela bem lhes parecia, ou ainda, como tocou a cada um. 


\section{Conclusão}

Após a encenação de Enrique Diaz, inúmeras foram as montagens de Tchékhov que continuaram a marcar os palcos brasileiros. E, na medida em que avançam os anos, torna-se difícil mapeá-las e discuti-las a contento - seja porque já não se pode dizer que as principais montagens se deem exclusivamente nas capitais, seja porque Tchékhov tem se tornado nome comum nos cursos de artes cênicas e no repertório de boa parte das companhias. Desde grupos e diretores mais voltados para uma pesquisa teatral engajada, como Celso Frateschi, àqueles que se voltam para uma pesquisa formal e metateatral mais intensa, como a Companhia dos Atores, Tchékhov se tornou ponto de referência. Tanto que, mais recentemente, Eduardo Coutinho produziu o importante documentário Moscou, que aborda justamente os bastidores do processo de pesquisa para a montagem de As Três Irmãs, não só para investigar o jogo metalinguístico entre representação e realidade no teatro (e na vida), mas também porque, em sua opinião, Tchékhov é um leitor potente da época distópica que vivemos ${ }^{541}$. Para não falar de eventos como o Festival Tchékhov (realizado em 2010, em São Paulo) e inúmeras adaptações e montagens que partem de correspondências e mesmo de sua biografia, mostrando o crescente interesse por seu universo, que vai além de suas peças.

Curiosamente, Tchékhov era descrente da força de sua dramaturgia que, como vimos, teve dificuldades em afirmar-se de início e estabelecera ao mesmo tempo relação tensa (mas produtiva) com as propostas de encenação de Stanislávski. No entanto, não só alcançou a estatura de cânone como atravessou o século e, para muitos diretores e atores, tornou-se desafio de auge de carreira ${ }^{542}$.

Tal condição não é gratuita. Como vimos, a complexidade da forma dramática de Tchékhov abriu polêmicas que atravessaram os anos e perduram. Hoje, pode-se dizer, por exemplo, que a recepção de peças como Tio Vânia ou O Jardim das Cerejeiras cindiu-se ao redor de todo o mundo entre abordagens cômicas e trágicas, gerando duas linhagens de espetáculos completamente diversos ${ }^{543}$. No Brasil, como vimos, não foi diferente. Em outro flanco, abre-se também o problema de como enfrentar personagens que, reunidas no mesmo tempo e espaço, não conseguem resolver

\footnotetext{
${ }^{541}$ Ver: "Eduardo Coutinho lamenta o fim das utopias". http://ultimosegundo.ig.com.br/mauricio_stycer/2009/04/01/eduardo+coutinho+lamenta+o+fim+das+utop ias+5255022.html. Acesso em 30 jan. 2013.

542 A afirmação, como vimos, é de dona Gida de Mello e Souza (Op. Cit., 2002, p. 322).

${ }^{543}$ A respeito dessa problemática, o livro de James Loehlin (Op. cit., 2006) é elucidativo.
} 
seus dramas interiores por meio do diálogo e vivem negando a motoniveladora do presente, comprimidas entre um passado vibrante e um futuro utópico. Tal problema é, como vimos, a especificidade da forma dramática tchekhoviana e representa a crise do próprio drama burguês, que pode ainda hoje ser interpretado tanto nos termos do "ateliê de minúcias" stanislavskiano, quanto nos termos da desconstrução pós-moderna pautada na ideia de crise da representação. Muitas vezes as duas abordagens convivendo numa mesma temporada e numa mesma cidade.

Mas como o teatro é por excelência a arte da interpretação e do presente, é natural que tais polêmicas venham à tona e se tornem muito mais complexas e interessantes porque atravessadas por especificidades políticas, sociais e culturais de cada país, região ou grupo.

Por isso, foi pensando na força com que se evoca a dramaturgia de Anton Tchékhov hoje e também pensando na riqueza de informações sobre as diferentes interpretações de suas peças, que conduzimos este estudo. Acreditamos que foi possível delimitar, ainda que sumariamente, algumas ideias-chave sobre a recepção de sua obra. Fizemos um rápido mapeamento de como se constituiu o "mito do tchekhovismo" na Rússia, na Europa e nos EUA, seguido de sua influência nos primeiros anos de recepção das peças de Tchékhov no Brasil e sua posterior e nada linear dissolução. Tal construção, que tem valor histórico decisivo, ao longo dos anos tornou-se camisa de força interpretativa e, em muitos casos, foi responsável até mesmo pelo empobrecimento de algumas montagens. Observamos também como nosso teatro conseguiu projetar em suas montagens de Tchékhov os impasses vividos por ele próprio, todos eles frutos das questões candentes de cada momento histórico. E analisamos como algumas montagens de Tchékhov entre nós - que se tornaram emblemáticas por motivos diversos - lidaram com a necessidade constante de atualização daquela dramaturgia. Logo após, confrontamos os anseios proclamados por grupos, atores e diretores com os resultados cênicos práticos, a fim de desenhar também um mapa crítico com as encenações que encontraram (ou não) soluções interpretativas novas e produtivas frente a sua dramaturgia.

Evidentemente, como todo panorama, este estudo pode ter pecado por ausências, omissões, ou mesmo por julgamentos sumários que, se não mentem de todo sobre as encenações estudadas, faltam quanto à capacidade de uma análise mais nuançada (o que é de se esperar em um estudo de recepção que trata de montagens do passado, sobre as quais chegam até nós apenas vestígios parciais e, por vezes, demasiado fragmentários). 
Contudo, esperamos ao menos que ao final tenha ficado evidente que ao estudarmos a trajetória de recepção do dramaturgo russo nos palcos brasileiros não encontramos um receituário prático para que as gerações futuras encontrem um modo correto de ler, interpretar e encenar Tchékhov. Se verificamos soluções que pecaram por subestimar a riqueza de seu drama ou por exagerar aspectos que, no limite, mentiam sobre sua forma, localizamos também a urgência de "resgatá-lo" seja de formas realistas desgastadas, seja da simples pesquisa de linguagem que, no limite, também esvazia o dramaturgo de sua potencialidade crítica. Mas como diria Stanislávski, o estudo final sobre a especificidade de toda sua obra e os mecanismos internos que operam para torná-la sempre atual ainda está por ser escrito - o que nos dá a incômoda sensação de que nos despedimos de Tchékhov antes da hora ${ }^{544}$.

${ }^{544}$ ALLEN, Op. Cit., p. 214. 


\section{Referências Bibliográficas}

\section{De Tchékhov (em livros ou jornais, citados ao longo do texto ou consultados)}

CHEJOV, Anton. Cuentos Completos. Madrid: Aguilar, 1957.

CHEKHOV, Anton. The Complete Plays. Trad. and Org. Laurence Senelick. New York/London: WW Norton \& Company, 2006.

TCHECKOFF, Anton. A Estepe. Trad. Cordeiro de Brito. Lisboa: Editorial Inquérito, 1940.

TCHECOFF, Anton. O Pavilhão $n^{\circ}$ 6. São Paulo: Bibliotheca de Autores Russos, 1931.

TCHECOFF, Anton. Os Inimigos - Contos. Trad. Georges Selzoff e F. Olandim. São Paulo: Edições Cultura - Georges Selzoff, 1931.

TCHÉKHOV, A. P. Cartas a Suvórin (1886-1891). Trad. e Org. Aurora Bernardini e Homero Freitas de Andrade. São Paulo: Edusp, 2002.

TCHÉKHOV, Anton. A Dama do Cachorrinho e Outros Contos. Trad. Boris Schnaiderman. São Paulo: Editora 34, 2005.

TCHEKHOV, Anton. A Gaivota/ Tio Vânia. Tradução Gabor Aranyi. São Paulo: Ed. Veredas, 2007.

TCHÉKHOV, Anton. Antologia do Conto Russo - Vol. VI Org. Otto Maria Carpeaux. Rio de Janeiro: Editora LUX Ltda, 1962.

TCHEKHOV, Anton. As Três Irmãs / Contos. Tradução: Maria Jacintha / Boris Schnaiderman. São Paulo: Abril Cultural, 1979.

TCHEKHOV, Anton. As Três Irmãs/ O Jardim das Cerejeiras. Tradução Gabor Aranyi. São Paulo: Ed. Veredas, 2003.

TCHEKHOV, Anton. O Duelo. Trad. Otto Schneider. São Paulo: Edições Melhoramentos, 1955.

TCHÉKHOV, Anton. O jardim das cerejeiras seguido de Tio Vânia. Trad. Millôr Fernandes. Porto Alegre, L\&PM Pocket, 2009.

TCHEKHOV, Anton. O Silvano: comédia em quatro atos. Trad., Posfácio e Notas de Tatiana Lárkina. São Paulo: Ed. Globo, 2005.

TCHÉKHOV, Anton. Os Males do Tabaco e Outras Peças em Um Ato. Org. Homero Freitas de Andrade. São Paulo: Ateliê Editorial, 2003.

TCHEKHOV, Anton. A conferência. Revista do Globo, ano V, n. 6. Porto Alegre, 5 abr. 1933; A mágoa de Gregório Petrov. Trad. El Gar. Revista do Globo, ano V, n. 4. Porto Alegre, 8 mar. 1933. .Alma querida. A nação ilustrada, n. 28. Rio de Janeiro, 8 jul. 1934. .Comedia d'um presente indesejado. O Jornal. Rio de Janeiro, 06 de nov. de 1927. 
"É proibido suicidar-se na primavera". Revista do Globo. Porto Alegre, 13 nov. 1943.

TCHEKOW, A.; ZOLA, E. O Banho e Outros Contos (Zola)/ O Beijo e outros contos (Tchekow). Rio de Janeiro: Edições Segredo/ Ed Tecnoprint, 1951.

TSCHECOV (sic), Anton. Histórias Imortais. Trad. do russo por Tatiana Belinky. São Paulo: Editôra Cultrix LTDA, 1959.

\section{Sobre Tchékhov}

ALLEN, David. Performing Chekhov. New York: Routledge, 2000.

ANGELIDES, Sophia. A. P. Tchékhov: cartas para uma poética. São Paulo: EDUSP, 1995.

CLAYTON, J Doulas (ed). Chekhov Then and Now - The Reception of Chekhov in World Culture. New York: Peter Lang, 1997.

DEBRECZENY, Paul (ed). Chekhov's Art of Writing - a collection of critical essays. Columbus: Slavica Publishers Inc, 1977.

EMELJANOW, Victor. Anton Chekhov: the critical heritage. London: Routledge, 1997.

GOMIDE, Bruno. Da Estepe à Caatinga: O Romance Russo no Brasil (1887-1936). Tese IELUNICAMP. Campinas: Instituto de Estudos da Linguagem, 2004.

GOTTLIEB, Vera. Chekhov and the vaudeville: A Study of Chekhov's One-Act Plays. Cambridge: Cambridge University Press, 1982. . Chekhov in performance in Russia and Soviet Russia. Teaneck N.J., 1984

GOTTLIEB, Vera; ALlAIN, Paul. The Cambridge Companion to Chekhov. New York: Cambridge University Press, 2008.

HERRERIAS, Priscila. A poética dramática de Tchékhov: um olhar sobre os problemas de comunicação. Dissertação de mestrado apresentada na FFLCH USP. São Paulo, 2010.

HINGLEY, Ronald. Chekhov: A Biographical and Critical Study. Oxford: Oxford University Press, 1950.

LAFFITTE, Sophie. Tchekhov. Rio de Janeiro: José Olympio, 1993.

LOEHLIN, James N. Chekhov - The Cherry Orchard - plays in production. New York: Cambridge University Press, 2006.

MAC VAY, Gordon. Chekhov's Three Sisters. Bristol: Bristol Classical Press, 1995.

MAGARSHACK, David. Chekhov the Dramatist. New York: Hill and Wang, 1960.

MILES, Patrick (Org.). Chekhov on The British Stage. London: Cambridge University Press, 1993.

. Chekhov on British stage, 1909-198 - an essay in cultural exchange.England: Sam\&Sam, 1987. 
RAYFIELD, Donald. Understanding Chekhov. Wisconsin: The University of Wisconsin Press, 1999.

The Cherry Orchard - Catastrophe and Comedy. New York: Twaine Publishers, 1994.

SENELICK, Laurence. The Chekhov Theatre - a Century of Plays in Performance. Cambridge: Cambridge University Press, 1997.

STEIN, Peter. Mon Tchekhov. Paris: Actes Sud-Papiers, 2002.

STYAN, J. L. Chekhov in Performance. Cambridge: Cambridge University Press, 1971.

TULLOCH, John. Shakespeare and Chekhov in Production and Reception. Iowa: University of Iowa Press, 2005.

VALENCY, Maurice. The Breaking String - the plays of Anton Chekhov. New York: Oxford University Press, 1966.

VLADMIR, Kataev. If Only We Could Know! An Interpretation of Chekhov. Chicago: Ivan R Dee, 2002.

\section{Sobre Literatura, Teatro, História e Cultura Russas}

CAVALIERE, Arlete. $O$ inspetor geral de Gogol/Meyerhold : um espetáculo síntese. São Paulo: Ed Perspectiva, 1996.

.Teatro Russo. Percurso para um estudo da paródia e do grotesco. São Paulo: Humanitas/FAPESP, 2009.

CAVALIERE, Arlete e VÁSSINA, Elena (orgs). Teatro Russo: literatura e espetáculo. São Paulo: Ateliê Editorial, 2011.

GUINSBURG, Jacó. Stanislávski e o Teatro de Arte de Moscou. São Paulo: Perspectiva, 2001. Stanislávski, Meierhold \& Cia. São Paulo: Perspectiva, 2008.

RIPELLINO, Angelo Maria. O Truque e a Alma. São Paulo: Perspectiva, 1996.

RUDNITSKY, Konstantin. Russian and Soviet Theatre. Tradition and the Avant-Garde. New York: Thames \& Hudson, 2000.

RZHEVSKY, Nicholas. The Modern Russian Theatre. New York: M.E. Sharpe, 1984.

SCHNAIDERMAN, Boris. A Poética de Maiakósvski. São Paulo, Perspectiva, 1971. .Projeções: Rússia/ Brasil/ Itália. São Paulo: Ed. Perspectiva, 1978.

SENELICK, L. Historical Dictionary of Russian Theather. Lanham/Toronto/Plymouth: The Scarecrow Press, Inc, 2007.

SHUR, Leonid. Relações literárias e culturais entre Brasil e Rússia. São Paulo: Perspectiva, 1986.

STANISLÁVSKI, K. Minha Vida na Arte. Rio de Janeiro: Civilização Brasileira, 1989. 
TAKEDA, Cristiane Layher. O Cotidiano de uma Lenda - Cartas do Teatro de Arte de Moscou. São Paulo: Perspectiva, 2003.

TRÓTSKI, Leon. Literatura e Revolução. Trad. Luiz Alberto Moniz Bandeira. São Paulo: Zahar, 2007.

VARNEKE, B. V. History of the Russian Theatre. New York: The Macmillan Company, 1951.

\section{Gerais}

ARÊAS, Vilma. Iniciação à Comédia. São Paulo: Jorge Zahar Editor, 1990. . Na Tapera de Santa Cruz - uma leitura de Martins Pena. São Paulo: Martins Fontes, 1987.

ARISTÓTELES. Arte Retórica e Arte Poética. Trad. Antonio Pinto de Carvalho. Rio de Janeiro: Ediouro,S/D.

BERENICE, Raulino. Ruggero Jaccobi: presença italiana no teatro brasileiro. São Paulo: Perspectiva/Fapesp, 2002.

BERNADET, Jean-Claude. Brasil em Tempo de Cinema. Rio de Janeiro: Civilização Brasileira, 1967.

BERTOLD, Margot. História Mundial do Teatro. São Paulo: Ed. Perspectiva, 2010.

BORBA, Hermilo; PAIVA, B. Cartilhas de Teatro I. História do Espetáculo. Rio de Janeiro: Serviço Nacional de Teatro, 1973.

BROOK, Peter. O teatro e seu espaço. São Paulo: Vozes, 1970.

CANDIDO, Antonio. Formação da Literatura Brasileira - momentos decisivos. São Paulo: Martins, 1969.

CANDIDO, Antonio. Recortes. Rio de Janeiro: Ouro Sobre Azul, 2004.

CARDOSO, Ciro Flamarion; VAINFAS, Ronaldo. Domínios da História - ensaios de Teoria e Metodologia. Rio de Janeiro: Campus, 1997.

CARVAlHEIRA, Luiz Maurício Britto. Por um teatro do povo e da terra. Hermilo Borba Filho e o Teatro do Estudante de Pernambuco. Recife: FUNDARPE: 1986.

CARVALHO, Martinho (org.). Paschoal Carlos Magno: Crítica Teatral e outras Histórias. Rio de Janeiro: FUNARTE, 2006.

COSTA, Iná Camargo. Teatro Épico no Brasil. São Paulo: Graal, 1996. Nem uma lágrima - teatro épico em perspectiva dialética. São Paulo: Expressão Popular/ Nanquim Editorial, 2012.

Depoimentos II. Rio de Janeiro: MEC/SNT, 1977.

Depoimentos VI. Rio de Janeiro: MEC/SNT, 1982.

Dicionario de mitologia greco-romana. São Paulo: Abril Cultural, 1973. 
FARIA, João Roberto de (Org.). História do Teatro Brasileiro - das origens ao teatro profissional da primeira metade do século XX. São Paulo: Ed. SESC/ Ed. Perspectiva, 2012.

FERNANDES, Silvia. Teatralidades Contemporâneas. São Paulo: Perspectiva, 2010. Grupos Teatrais - Anos 70. Campinas: Ed. da Unicamp, 2000.

FILHO, Daniel Aarão Reis. As Revoluções Russas e o Socialismo Soviético. São Paulo: Ed UNESP, 2003.

FONTA, Sergio. Rubens Corrêa - um salto para dentro da luz. Col. Aplauso. São Paulo: Imprensa Oficial, 2010.

FRANCIS, Paulo. Opinião Pessoal (Cultura e Política). Rio de Janeiro: Civilização Brasileira, 1966.

GARCIA, Silvana. Teatro da Militância. São Paulo: Perspectiva, 2004.

GINZBURG, Carlo. Mitos, Emblemas, Sinais. São Paulo: Companhia das Letras, 2003. O queijo e os vermes. São Paulo: Companhia das Letras, 1987.

GUINSBURG, J.; FARIA, J.; LIMA, M. A. Dicionário do Teatro Brasileiro: temas, formas e conceitos. São Paulo: Perspectiva/SESC, 2006.

GUSSON, Joelson. A relação performer/espectador na cena contemporânea. Monografia apresentada à Universidade Federal do Rio de Janeiro - UNIRIO - como requisito parcial à obtenção do título de Bacharel em Teoria do Teatro. Rio de Janeiro: UNIRIO, 2009.

GUZIK, Alberto. TBC: Crônica de um sonho. São Paulo: Ed. Perspectiva, 1986.

HOLLAND, Peter (ed). The Play Out Of Context - transferring plays from culture to culture. New York: Cambridge University Press, 1989.

JOMARON, Jacqueline. Georges Pitoëff metteur en scène. Lausanne: L'Age d'homme, 1979.

MAGALDI, Sábato. Panorama do Teatro Brasileiro. São Paulo: Global, 1997.

MANN, Thomas. Ensaios. São Paulo: Ed. Perspectiva, 1988.

MARTINEZ CORRÊA, José Celso. Primeiro ato: cadernos, depoimentos, entrevistas (19591972)/ José Celso Martinez Correa; seleção, organização e notas de Ana Helena Camargo de Staal. São Paulo: Ed 34, 1998.

NITRINI, Sandra. Literatura Comparada: história, teoria e crítica. São Paulo: EDUSP, 1997.

PAVIS, Patrice. A encenação contemporânea. São Paulo: Ed. Perspectiva, 2010.

PAVIS, Patrice. Dicionário de Teatro. São Paulo: Ed Perspectiva, 2008.

PITOËFF, G. Notre Théâtre. Paris: Ed. Messages, 1949.

PRADO, Décio de Almeida. Apresentação do Teatro Brasileiro Moderno 1947-1955. São Paulo: Martins, 1956.

Peças, Pessoas, Personagens - o teatro brasileiro de Procópio Ferreira a Cacilda Becker. São Paulo: Companhia das Letras, 1993. 
RABETTI, Beti (Maria de Lurdes Rabetti) (Org.). Teatro e Comicidades: estudos sobre Ariano Suassuna e outros ensaios. Rio de Janeiro: 7 Letras, 2005.

Revista Dionysos, $n$. 17, Rio de Janeiro, SNT/MEC, 1969.

Revista Dionysos (Teatro do Estudante do Brasil e Teatro Universitário - Teatro Duse) n.23, Rio de Janeiro, MEC/DAC/FUNARTE/SNT, 1978.

Revista Dionysos (TBC), n.25, Rio de Janeiro, MEC/SEAC/FUNARTE/SNT, 1980.

Revista Dionysos (Teatro Oficina), n. 26, MEC-SEC-SNT, Rio de Janeiro, 1982.

Revista Dionysos (O Tablado), n. 27, Minc/INACEN, Rio de Janeiro, 1986.

Revista Dionysos (EAD), n. 29, Minc/INACEN, Rio de Janeiro, 1989.

ROSENFELD, Anatol. O Teatro Épico. São Paulo: Editora Perspectiva, 1985.

Prismas do Teatro. São Paulo: Perspectiva, 1993. Texto/Contexto. $3^{\text {a }}$ ed. São Paulo: Perspectiva, 1976.

SCHWARZ, Roberto. O Pai de Família e Outros Estudos. São Paulo: Paz e Terra, 1978. Que Horas São?. São Paulo: Companhia das Letras, 1989.

SILVA, Armando Sérgio da. Oficina: do teatro ao te-ato. São Paulo: Perspectiva, 2008.

SZONDI, Peter. Teoria do Drama Moderno: 1880-1950. São Paulo: Cosac\&Naify, 2001.

VASCONCELLOS, Luiz Paulo. Dicionário de Teatro. Porto Alegre: L\&PM Pocket, 2009.

WILLIAMS, Raymond. Drama em Cena. São Paulo: Cosac\&Naify, 2010.

\section{Artigos em geral}

ALMEIDA, Rachel. Infelizes para sempre Encarte Programa - Jornal do Brasil, ano19, n.10. Rio de Janeiro, 06 a 12 jun. 2003.

BARRAULT, Jean-Louis. Why The Cherry Orchard?. The Theatre of Jean-Louis Barrult. London: Barrie and Rockliff, 1959.

BATAILLON, M. Quand la France découvre Anton Tchékhov.Silex, n.16, 1980.

BENTLEY, Eric. Chekhov as Playwriter. The Kenyon Review, v.11, n. 2, Spring, 1949.

BRANTLEY, Ben. Chekhov Melancholy, never so welcome. The New York Times, New York, 29 nov. 2012.

CALlADO, Antonio. Chekov. Set. 1960. Série de artigos encontrados no Acervo de Antonio Callado na Fundação Casa de Rui Barbosa, no Rio de Janeiro.

CAMPOS, Astério. As Três Irmãs. Gazeta de Notícias, Rio de Janeiro, 16 jan. 1960.

CARVALHO, Sergio. Tchekhov conta Brasil - por que o dramaturgo russo do século XIX será um dos autores mais encenados neste ano no país. Revista Bravo, n. 07, Ano 1. São Paulo, abr. 1998.

CAVALIERE, A.;VÁSSINA, E. A herança de Stanislávski no teatro norte-americano: caminhos e descaminhos. Revista Crop 7, 2001 
COSTA, Iná Camargo. Aproximação e distanciamento: o interesse de Brecht por Stanislávski. Revista Sala Preta, São Paulo, v.2, n.2, 2002. Stanislávski na Cena Americana. Revista de Estudos Avançados da USP v. 16, n.46, 2002.

GOURFINKEL, N. Tchékhov au théâtre artistique de Moscou. Revue de la société d'histoire du théâtre. n. 4, 1954.

HELIODORA, Barbara. Tchekov é Tchekov. Jornal do Brasil, Rio de Janeiro, 28 jul. 1989. Teatro Russo, Teatro Revolucionário, Teatro Soviético. Escritos Sobre Teatro. São Paulo: Ed Perspectiva, 2007.

KARLINSKI, Simon. Russian anti-Chekhovians. In: Russian Literature, n. 15, 1984.

KLEBER, Pia. The Whole of Italy is our Orchard: Strehler's Cherry Orchard. Modern Drama n.42, 1999.

LEÃO, Raimundo Matos de. Ações para o Teatro: a autoconstituição dos sujeitos no ambiente cultural soteropolitano. Diálogos \& Ciência - Revista da Faculdade de Tecnologia e Ciências. Ano 9, n. 25, mar. 2011.

LUCIA, Maria. Osmar Cruz completa trinta anos de teatro. A Gazeta, São Paulo, 14 out. 1975.

LUIZ, Macksen. Tempo dos gestos inúteis. Jornal do Brasil, Rio de Janeiro, 27 jul. 1989.

MARKOV, Pavel. New trends in the interpretation of Chekhov. World Theatre n. 9, Summer, 1960.

MEDEIROS, Jotabê. Anton Tchecov ressurge com força nos palcos paulistanos. O Estado de São Paulo, São Paulo, 02 abr. 1994.

MELLO E SOUZA, Gilda de.As Três Irmãs. Suplemento Literário do Estado de São Paulo. São Paulo, 13 out. 1956.

MUZA, Anna. Chekhov's Jubilee and the Jubilee in Chekhov. The Bulletin of the North American Chekhov Society . v. XVII, N. 2, 2010.

NASCIMENTO, Rodrigo. Quando o riso se esfacela - estudo comparativo de duas peças em um ato de Anton Tchékhov. Caderno de Resumos e Programação - Congresso "Literatura e Vida Social". UNESP-Assis, mai. 2011.

NICOLESCO, T. Tchékhov en Romaine 1895-1960. Bibliographie Littéraire sélective. Bucharest: Editions de l'Académie de La République Populaire Roumaine, 1960.

OLIVEIRA, Lígia Souza. "Gaivota - tema para um conto curto: a temporalidade na releitura de Anton Tchekhov". Anais - $1^{\circ}$ Colóquio Internacional de Estudos Linguísticos e Literários - UEM - Maringá, 2010.

RAMOS, Luis Fernando; FERNANDES, Silvia. Diálogo da Gaivota. Revista Sala Preta, São Paulo, v. 7, 2007.

RAYFIELD, Donald. Orchards and Gardens in Chekhov. The Slavonic and East European Review, v. 67, n. 4, oct. 1989. 
TOWARNICKI, Frédéric. Quand Paris découvre Tchékhov. Spetacles I, 1960.

TYZKA, Juliusz. Stanislavsky in Poland: ethics and politics of the Method. New Theatre Quarterly v.20, n.5, 20 nov. 1989.

VOGÜÉ, E. M. Anton Tchekhof. Revue des Deux Mondes, Paris, jan-fev 1902.

\section{Sem autores}

Hermilo - a longa luta por um teatro popular - Entrevista. Boletim INACEN, Rio de Janeiro, n.06, 01 jul. 1984.

Rubens Correa - 'os ciganos sempre sobreviverão'. Entrevista com Rubens Corrêa. Jornal Refletor, Rio de Janeiro, Ano 1, n.6, set. 1982.

Tio Vânia - um clássico de sóbria beleza. Revista desfile, Rio de Janeiro, 10 ago. 1984.

Um pedido de casamento. Anhembi. São Paulo, v.15, no 43, jun. 1954.

Notícias de Jornal, artigos de revistas, programas de peças e relatórios de grupos (organizados dentro do grupo referente a cada encenação)

\section{A GAIVOTA - Jorge Lavelli - Rio de Janeiro, 1974.}

Programa da Peça. Rio de Janeiro, 1974.

A Gaivota de Tchecov já está no municipal - Veja. Última Hora. Rio de Janeiro, 30 mar. 1974.

A Gaivota - Uma paisagem sobre um lago e cinco tonalidades de amor. A Notícia, Rio de Janeiro, 28 mar. 1974.

Na 'Gaivota', atores e público juntos no palco. O Globo, Rio de Janeiro, 28 mar. 1974.

Uma 'Gaivota' com visão argentina. O Globo, Rio de Janeiro, 22 mar. 1974.

A Gaivota de Tchecov estreia hoje no Rio. Diário do Espírito Santo, Vitória, 29 mar. 1974.

'A Gaivota' de Tchecov já está no Municipal - Veja. Última Hora, Rio de Janeiro, 30 mar. 1974.

CLETO, Roberto de. O lindo vôo da Gaivota. Última Hora, Rio de Janeiro, 11 abr. 1974.

CONRADO, Aldomar. A Rússia de Tchecov no Municipal. Diário de Notícias, Rio de Janeiro, 31 mar. 1974.

GONÇALVES, Esmeraldo. Jorge Lavelli \& Gaivota. O Jornal, Rio de Janeiro, 24 mar. 1974.

MICHALSKI, Yan. 'A Gaivota' rigor e liberdade . Jornal do Brasil, Rio de Janeiro, 03 abr. 1974.

. 'Gaivota' em outro ninho. Jornal do Brasil, Rio de Janeiro, 09 mai.1974.

TUMSCITZ, Gilberto. A estreia de hoje - A Gaivota. O Globo, Rio de Janeiro, 29 mar. 1974. Lavelli realiza gaivota exemplar. O Globo, Rio de Janeiro, 30 mar. 1974. 
A GAIVOTA - Luiz Paulo Vasconcellos - Porto Alegre, 1989.

'A Gaivota' de Tchecov estreia hoje na Epatur . Jornal do Comércio, Porto Alegre, s/d 1989.

A GAIVOTA - Francisco (Chico) Medeiros - São Paulo, 1994.

Folder de Divulgação da Peça. São Paulo, 1994.

CHIARETTI, Marco. A Gaivota mistura vida e criação artística. Folha de São Paulo, São Paulo, 16 mai. 1994.

GUZIK, Aberto. Dramas do Cotidiano. Jornal da Tarde, São Paulo, 16 mai. 1994. . Um porão para a gaivota. Jornal da Tarde, São Paulo, 18 abr. 1994.

LIMA, Mariangela Alves de. A Gaivota tem atmosfera poética. O Estado de São Paulo, São Paulo, 19 mai. 1994.

MEDEIROS, Jotabê. A Gaivota é encenada pela primeira vez em São Paulo. O Estado de São Paulo, São Paulo, 16 mai. 1994. Anton Tchecov ressurge com força nos palcos paulistanos. O Estado de São Paulo, São Paulo, 02 abr. 1994.

SÁ, Nelson. 'A Gaivota' prova atualidade de Tchecov. Folha de São Paulo, São Paulo, 18 jan. 1994.

A GAIVOTA - David Hermann - Rio de Janeiro, 1995.

HELIODORA, Barbara. Uma leitura fiel de Tchecov. O Globo, Rio de Janeiro, 06 dez. 1995.

\section{A GAIVOTA - Jorge Takla - Rio de Janeiro, 1996.}

Programa da Peça. Rio de Janeiro, 1996.

'A Gaivota' Tchekov por Jorge Takla, numa montagem cheia de emoção como pede o texto centenário. Revista Programa, 12 jan. 1996.

'A Gaivota' traz ninho de voos frustrados. O Globo, Rio de Janeiro, 12 jan. 1996.

CAMARGO, Maria Silvia. Sucessos Importados. Revista Veja, Rio de Janeiro, 10 jan. 1996.

ESCÓSSIA, Fernanda da. 'A Gaivota' discute conflito de gerações. Folha de São Paulo, São Paulo, 10 jan. 1996.

HELIODORA, Barbara. Os abalos sísmicos do cotidiano. O Globo, Rio de Janeiro, 15 jan. 1996.

JANSEN, Roberta. Takla faz voo artístico com 'A Gaivota'. O Estado de São Paulo, São Paulo, 27 dez. 1995.

VIANNA, Luiz Fernando. Novo voo da gaivota. O Globo, Rio de Janeiro, 19 dez. 1995.

DA GAIVOTA - Daniela Thomas - Rio de Janeiro, 1998.

Programa da Peça. Rio de Janeiro, 1998. 
'Gaivota' opõe no palco gerações da arte. Folha de São Paulo, São Paulo 10 jul. 1998.

LUIZ, Macksen. Opção pelo anti-realismo. Jornal do Brasil, Rio de Janeiro, 03 ago. 1998.

LYRA, Marcelo. Multishow exibe especial sobre teatro. O Estado de São Paulo, São Paulo, 28 dez. 2000.

OLIVEIRA, Roberta. Unidos por Tchekov. O Globo, Rio de Janeiro, 15 jul. 1998

VELlOSO, Beatriz. Daniela Thomas é parceira de Chekhov. O Estado de São Paulo, São Paulo, 12 fev. 1997.

GAIVOTA - TEMA PARA UM CONTO CURTO - Enrique Diaz, Rio de Janeiro, 2006.

Programa da Peça. Rio de Janeiro, 2006.

Enrique Diaz relê texto de Tchecov em 'Gaivota - tema para um conto curto'. Folha de São Paulo, São Paulo, 15 jun. 2007.

LIMA, Mariangela Alves de. Liberdade da arte faz A Gaivota voar alto. O Estado de São Paulo, São Paulo, 11 jul. 2007.

MELLÃO, Gabriela. Tchekov vezes quatro. Revista Bravo, São Paulo, ago 2010..

AS TRÊS IRMÃS - Escola de Arte Dramática (EAD)/Alfredo Mesquita - São Paulo, 1956.

Relatório do Nono Ano Letivo da Escola de Arte Dramática. São Paulo, 1956.

AS TRÊS IRMÃS - A Barca/ Gianni Ratto - Salvador, 1960.

Programa da Peça. Salvador, 1958.

AS TRÊS IRMÃS - Teatro Nacional de Comédia/ Ziembínski - Rio de Janeiro, 1960.

Programa da Peça. Rio de Janeiro, 1960.

ALENCAR, Edigar. As Três Irmãs. A Notícia, Rio de Janeiro, 06 jan. 1960.

FRANCIS, Paulo. Elenco e Política do TNC. Última Hora. Rio de Janeiro, 20 fev. 1960.

FRANCIS, Paulo. Teatro Nacional de Comédia é Contra o povo e fracassa. Última Hora, Rio de Janeiro, s/d 1960.

HELIODORA, Barbara. Tchecov, Stanislawsky e alguns problemas. Jornal do Brasil, Rio de Janeiro, 23 fev. 1960.

MAGNO, Paschoal Carlos. As Três Irmãs, no Serrador. Correio da Manhã, Rio de Janeiro, 16 jan. 1960.

MAURICIO, Augusto. As Três Irmãs. Jornal do Brasil. Rio de Janeiro, 09 fev. 1960.

AS TRÊS IRMÃS - Teatro Universitário da UFMG/Haydée Bittencourt - Belo Horizonte, 1967.

Programa da Peça. Belo Horizonte, 1967. 
Haydée encenará Tchekov. Correio Braziliense, Belo Horizonte, 01 set. 1967.

Haydée ganha medalha. Diário da Tarde, Belo Horizonte, 16 abr. 1981.

Três Irmãs. Estado de Minas, Belo Horizonte, 09 ago. 1967.

FELIPE, Carlos. A paixão de Haidée. Estado de Minas, Belo Horizonte, 24 ago. 1980.

MARIA, Anna. As Três Irmãs. Diário da Tarde, Belo Horizonte, 10 ago. 1967.

SANTOS, Jorge Fernando dos. Haidée Bittencourt - uma vida dedicada ao teatro. Estado de Minas, Belo Horizonte, 03 ago. 1983

\section{AS TRÊS IRMÃS - Teatro Oficina/ José Celso Martinez Correa - São Paulo, 1972.}

A grande missão das Três Irmãs. Última Hora, Rio de Janeiro, 21 jan. 1973.

Anúncio. Última Hora. São Paulo, 17 out. 1972

As Três Irmãs - Uma história de coragem num cenário de ruínas. Jornal da Tarde, São Paulo, 26 dez. 1972.

Ato Extra. O Dia, Teresina, 25 set. 1972.

Checov ficará dez dias no Teatro Oficina. Folha de São Paulo, São Paulo, 19 dez. 1972.

Entrevista com Jose Celso. Revista Politika, São Paulo, n.22, 26 mar. 1972.

Oficina - Maria Fernanda e As Três Irmãs. Cidade de Santos, Santos 28 dez. 1972.

Oficina, um novo voo da Gaivota. Jornal do Brasil, Rio de Janeiro, 25 jan. 1973.

Oficina - um sonho, uma crise. Última Hora, Rio de Janeiro, 25 jan. 1973.

Três Irmãs - As Forças Sitiadas. Jornal do Brasil, Rio de Janeiro, 1973.

CLETO, Roberto de. As Três Irmãs. Última Hora, Rio de Janeiro, 12 jan. 1973.

FUSER, Fausto. "Uma meia-volta encerra o ano". 1972 (s/ fonte - notícia armazenada no Fundo Oficina - AEL - Unicamp)

LIMA, Mariângela Alves de. O Oficina Revigora a Atualidade da Peça. O Estado de São Paulo, 28 dez. 1972.

MAGNO, Pascoal Carlos. As Três Irmãs, no Serrador. Correio da Manhã, Rio de janeiro, 16 jan. 1960.

MARTINEZ CORRÊA, José Celso. Conheça Macha, Irina e Olga: As Três Irmãs. O Estado de São Paulo, São Paulo, 26 dez. 1972.

O Elenco, os Preços, tudo muito popular. O Estado de São Paulo, São Paulo, 26 dez. 1972

MELINA, Geórgia. A crise do Oficina. Última Hora, Rio de Janeiro, 22 jan. 1973.

MENDES, Oswaldo. As Três Irmãs do Oficina: um recuo? Revista Desfile, no 41, fev. 1973.

MICHALSKI, Yan. As Três Irmãs: Vítimas ou Culpadas? Jornal do Brasil, Rio de Janeiro, 16 fev. 1973.

PEIXOTO, Fernando. Teatro Brasileiro, Experiências. A Saída, Onde Está a Saída? Jornal Opinião, 17 dez. 1973. 
Lobos Fechados em Salas Pequenas. Jornal Opinião, 17 dez. 1973.

SENNA, Orlando. E agora, José Celso? Correio da Manhã, Rio de Janeiro, 22 out. 1972.1

TUMSCITZ, Gilberto. "Ainda uma vez, quatro horas com o Oficina". O Globo, Rio de Janeiro, $13 / 01 / 1973$.

\section{AS TRÊS IRMÃ̃ - Bia Lessa - Rio de Janeiro, 1998.}

Programa da Peça. Rio de Janeiro, 1998.

'As Três Irmãs' retrata cotidiano. Folha de São Paulo, São Paulo, 09 out. 1998.

Natacha, a quarta mulher de Tchecov. O Globo, Rio de Janeiro, 09 out. 1998.

DRATOVSKY, Flávia. Tchekov sem artifícios. O Dia, Rio de Janeiro, 09 out. 1998.

GUZIK, Alberto. Bia Lessa tromba com Chekhov em 'Três Irmãs'. Jornal da Tarde, São Paulo, 13 ago. 1999.

HELIODORA, Barbara. Agitação além da dose resulta em montagem inexpressiva. O Globo, Rio de Janeiro, 26 out. 1998.

KOLINSKI, Daniel. As mulheres de Tchecov em ação. Encarte Programa do Jornal do Brasil, Rio de Janeiro, ano.14, n. 28, 09 out. 1998.

LIMA, Mariangela Alves de. 'As Três Irmãs' tem direção ostensiva de Bia Lessa. O Estado de São Paulo, São Paulo, 30 jul. 1999.

NAME, Daniela. As Três Irmãs' na banalidade cotidiana. O Globo. Rio de Janeiro, 09 out. 1998. NÉSPOLI, Beth. Chekhov volta à cidade na visão de Bia Lessa. O Estado de São Paulo, São Paulo, 16 jul. 1999.

OLIVEIRA, Roberta. 3 vezes Tchekov. O Globo, Rio de Janeiro, 16 nov. 1998. . A arte do cotidiano. O Globo, Rio de Janeiro, 19 set. 1998. Renata Sorrah diz entender melhor textos de Tchekov. $O$ Globo, Rio de Janeiro, 19 set. 1998.

RAGAZZI, Ana Paula. 'As Três Irmãs' marca retorno de Bia Lessa. Folha de São Paulo, São Paulo, 16 jul. 1999.

SÁ, Nelson. Outra chance contra o 'tedium vitae'. Folha de São Paulo, São Paulo, 16 jul. 1999.

\section{AS TRÊS IRMÃS - Enrique Diaz - Rio de Janeiro, 1999.}

Programa da Peça. Rio de Janeiro, 1999.

'Três Irmãs', do russo Tchecov estreia hoje em São Paulo. Folha de São Paulo, São Paulo, 12 mar.1999.

KOLINSKI, Daniel. Encarte Programa do Jornal do Brasil. Rio de Janeiro, Ano 14, n.4, 15 jan. 1999.

LIMA, Mariangela Alves de. 'As Três Irmãs' traz descompasso dramático. O Estado de São Paulo, São Paulo, 26 mar. 1999. 
LUIZ, Macksen. Tchecov numa encenação radicalmente lúdica. Jornal do Brasil, Rio de Janeiro, 18 jan. 1999.

NÉSPOLI, Beth. Elenco de estrelas encena peça clássica de Chekhov. O Estado de São Paulo, São Paulo, 12 mar. 1999.

Montagem de 'As Três Irmãs' varre penumbra do palco. O Estado dedo de São Paulo, 14 jan. 1999.

OLIVEIRA, Roberta. Amizade em Família. O Globo, Rio de Janeiro, 02 jan. 1999.

SÁ, Nelson. Duas atrizes encantam em 'As Três Irmãs'. Folha de São Paulo, São Paulo, 28 mar. 1999.

SALUM, Erika. Olga, Macha e Irina. Folha de São Paulo, São Paulo, 01 jan. 1999.

\section{TIO VÂNIA - Geraldo Queiroz/ Tablado - Rio de Janeiro, 1955}

Programa da Peça. Rio de Janeiro, 1955.

O crítico teatral que montou 'Tio Vânia'. Jornal do Brasil, Rio de Janeiro, 24 ago. 2004.

\section{TIO VÂNIA - Cláudio Correa e Castro. Curitiba, 1968}

Programa da Peça. Curitiba, 1968.

No Guaíra, temporada de 'Tio Vânia'. O Estado do Paraná, Curitiba, 21 maio 1968.

MICHALSKI, Yan. Tchecov em Curitiba (I). Jornal do Brasil, Rio de Janeiro, 04 jul. 1968. Tchecov em Curitiba (II). Jornal do Brasil, Rio de Janeiro, 05 jul. 1968.

RODRIGUES, Neiva. Um ator que se angustia com o personagem. Última Hora, Rio de Janeiro, 03 ago. 1984.

\section{TIO VÂNIA - Álvaro Guimarães/ Teatro Livre da Bahia. Salvador, 1974}

Programa da Peça. Salvador, 1974.

\section{TIO VÂNIA - Emilio di Biasi/ Grupo Heros. São Paulo, 1975}

Programa da Peça. São Paulo, 1975

Dois dias para ver o teatro de Tchecov. A Tribuna, Santos, 23 jul. 1975.

Grupo Heros mostra a visão amarga do cotidiano de Tchecov. A Tribuna, Santos, 27 jul. 1975.

O jovem no teatro. A Tribuna, Santos, 30 ago. 1975.

Uma peça famosa, que quase ninguém viu. Jornal da Tarde, São Paulo, 09 maio 1975.

LARA, Paulo. 'Tio Vânia' - a versão moderna de uma obra clássica de Checov. Folha da Tarde, São Paulo, 05 maio 1975.

Ver 'Tio Vânia' é sua opção. Folha da Tarde, São Paulo, 23 maio 1975.

LIMA, Mariangela Alves de. Interpretação não consegue expressar sentido de 'Tio Vânia'. $O$ Estado de São Paulo, São Paulo, 15 de maio de 1975. 
MAGALDI, Sábato. Tchecov não acharia ruim se houvesse um pouco mais de experiência cênica. Jornal da Tarde, São Paulo15 de maio de 1975.

VIANA, Hilton. No palco, um sonho de Anton Tchecov. Diário de São Paulo, São Paulo, 18 maio 1975.

\section{TIO VÂNIA - Sérgio Britto/ Teatro dos 4. Rio de Janeiro, 1984}

Programa da Peça. Rio de Janeiro, 1984.

'Tio Vânia' continua com música fora do programa. O Globo, Rio de Janeiro, 14 jul. 1984.

Uma dupla comemoração no teatro dos quatro. O Dia, Rio de Janeiro, 11 jul. 1984.

BOAS, Luciana Villas. Revista Clássico de volta, Veja, Rio de Janeiro, 18 jul. 1984.

BRANDÃO, Tânia. Uma feliz mistura de ilusão e ironia. Revista Isto É, São Paulo, 25 jul. 184.

LUIZ, Macksen. Impossibilidades, Jornal do Brasil, Rio de Janeiro, 13 jul. 1984.

MARINHO, Flavio. Com 'Tio Vânia', os 50 anos de Norma Geraldy. O Globo, 18 set. 1984.

. 'Tio Vânia', a comemoração dos seis anos (férteis) do Teatro dos Quatro. $O$ Globo, 02 jul. 1984.

'Tio Vânia', clássico do Tchecov sobre os contrastes do relacionamento humano. O Globo, Rio de Janeiro, 11 jul. 1984.

'Tio Vânia'-espetáculo muitos furos acima da média. $O$ Globo, Rio de Janeiro, 17 jul. 1984.

MASCARENHAS, Eduardo Mascarenhas. Tio Vânia. Última Hora, Rio de Janeiro, $1^{\circ}$ set. 1984.

SCHILD, Susana. 'Tio Vania' - o tempo de espera de personagens sem passado e sem futuro. Jornal do Brasil, Rio de Janeiro, 10 jul. 1984.

\section{TIO VÂNIEA - Celso Frateschi/ EAD. São Paulo, 1989}

Estreia de "Tio Vânia" de Tchekov. A mais recente montagem da EAD. Folha de São Paulo, São Paulo, 02 mar. 1989.

VELOSO, Marco. Direção de Celso Frateschi acerta no tempo cênico de 'Tio Vânia'. Folha de São Paulo, São Paulo, 08 mar. 1989.

\section{TIO VÂNIA - Élcio Nogueira Seixas/ Teatro Promíscuo. Curitiba/São Paulo, 1998}

Programa da Peça. Curitiba/São Paulo, 1998.

O Vânia de Borghi. Jornal do Brasil (Revista de Domingo), Rio de Janeiro, 11 a 17 set. 1988.

Tio Vânia, como o Brasil, está em crise. Jornal do Comércio, Porto Alegre, 25 set. 1988.

GUZIK, Alberto. Chekov ganha asas longe do realismo. Jornal da Tarde, São Paulo, 28 abr. 1998. 
LIMA, Mariangela Alves de. Há algo de inexplorado em 'Tio Vânia'. O Estado de São Paulo, São Paulo, 24 abr. 1998.

LUIZ, Macksen. Desencontros inspirados em Tchecov. Jornal do Brasil, Rio de Janeiro, 12 set. 1998.

SANTOS, Mario Vitor. Peça dá leveza a Tchekov. Folha de São Paulo, São Paulo, 23 abr. 1998.

\section{TIO VÂNIA - Celso Frateschi/ Teatro Ágora. São Paulo, 2000}

Programa da Peça. São Paulo, 2000.

Tudo pela família. Jornal do Brasil, Rio de Janeiro, 21 jun. 2002.

ABREU. Montagem de 'Tio Vânia', de Tchecov, retoma a utopia perdida. Folha de São Paulo, São Paulo, 03 mar. 2001.

LIMA, Mariângela Alves de. Ágora põe em cena um Chekhov impecável. O Estado de São Paulo, São Paulo, 16 fev. 2001.

LUIZ, Macksen. Tchecov, na essência - Montagem de Tio Vânia conserva a sutileza típica da obra do autor. Jornal do Brasil, Rio de Janeiro, 25 jul. 2002.

OLIVEIRA, Roberta. Ágora apresenta no Planetário a sua versão de 'Tio Vânia', de Tchecov. $O$ Globo, Rio de Janeiro, 19 jun. 2002.

SANTOS, Valmir. Ágora monta 'Tio Vânia' fiel ao tempo de Tchecov. Folha de São Paulo, São Paulo, 25 nov. 2000.

\section{TIO VÂNIA - Aderbal Freire Filho. Rio de Janeiro, 2003}

Programa da Peça. Rio de Janeiro, 2003.

BRASIL, Ubiratan. 'Tio Vânia' fala do fracasso do homem contemporâneo. O Estado de São Paulo, São Paulo, 08 ago. 2003.

GUZIK, Alberto. Vilela encara 'Tio Vânia'. Valor Econômico, São Paulo, 30-31 maio e 01 abr. 2003.

HELIODORA, Barbara. Um belo espetáculo para Tchekov. $O$ Globo, Rio de Janeiro, 13 jun. 2003.

MACKSEN, Luiz. Um 'Tio Vânia' mais duro. Jornal do Brasil, Rio de Janeiro, 13 jun. 2003.

OLIVEIRA, Roberta. 'Tio Vânia' a preços populares no João Caetano. O Globo, Rio de Janeiro, 22 jan. 2004.

\section{O JARDIM DAS CEREJRIAS - Ivan Albuquerque/ Grupo Rio. Rio de Janeiro, 1968}

Programa Ciclo Russo. Rio de Janeiro, 1968.

O Cerejal de Tchekhov. Diário de Notícias, Rio de Janeiro, 22 out. 1968. 
O jardim das cerejeiras ou A comédia do mundo em transformação. Jornal do Brasil, Rio de Janeiro, 07 out. 1968.

LEITE, Luiza B. O jardim das cerejeiras, Jornal do Comércio, Rio de Janeiro, 27 out. 1968.

LOPES, Rosita Thomas. As cerejeiras de Ipanema. Correio da Manhã, Rio de Janeiro, 13 out. 1968.

MACIEL, Luiz Carlos. O jardim das cerejeiras, O Paiz, Rio de Janeiro, 09 nov. 1968.

MICHALSKI, Yan. Um jardim florido e amigo (I). Jornal do Brasil, Rio de Janeiro, 22 out. 1968.

Um jardim florido e amigo (II). Jornal do Brasil, Rio de Janeiro, 23 out.

1968.

. Um jardim florido e amigo (III). Jornal do Brasil, Rio de Janeiro, 24 out.

1968.

OSCAR, Henrique. Tchekhov em Ipanema. Diário de Notícias, Rio de Janeiro, 23 out. 1968.

. Teatro Inaugura com Tchekhov. Diário de Notícias, Rio de Janeiro, 09 out.

1968.

SCHAFFMAN, Elisa. O jardim das Cerejeiras. Jornal do Comércio, Rio de Janeiro, 24 out. 1968.

TABORDA, Tato. Cerejeiras quase sem flor. Última Hora, Rio de Janeiro, 11 out. 1968.

JAFA, Van. Lançamento - O Jardim das Cerejeiras. Correio da Manhã, Rio de Janeiro, 02 out. 1968 O Jardim das cerejeiras. Correio da Manhã, Rio de Janeiro, 26 out. 1968.

WOLFF, Fausto. O Cerejal - com Tchekhov só se chega a Brecht através de Stanislavsky. Tribuna da Imprensa, Rio de janeiro, 31 out. 1968.

\section{O JARDIM DAS CEREJRIAS - Layla Schneider. Curitiba, 1980}

Programa da Peça. Curitiba, 1980.

\section{O JARDIM DAS CEREJRIAS - Jorge Takla. São Paulo, 1982}

Programa da Peça. São Paulo, 1982.

Anúncio para a estreia de janeiro. Diário Popular, São Paulo, 29 dez. 1981.

O Jardim estreia hoje no Anchieta. Folha de São Paulo, São Paulo, 14 jan. 1982.

Tchekov a burguesia falida, medrosa e hipócrita. Cidade de Santos, Santos, 13 jun. 1982.

Um bom momento. Diário Popular, São Paulo, 04 mar. 1982.

Um Jardim das Cerejeiras Muito fiel a Chekov. Jornal Da Tarde, São Paulo, 14 jan. 1982.

Viagem à Rússia pré-Revolucionária. O Estado de São Paulo, São Paulo, 14 jan. 1982.

LARA, Paulo. Um Chekov inverossímel no palco do Anchieta, Folha da Tarde, São Paulo, 02 fev. 1982. 
MAGALDI, Requinte_Sábato. O Jardim das Cerejeiras Um Raro, Jornal da Tarde, São Paulo, 18 fev. 1982.

RIOS, Jeferson Del. Alguns reparos no 'Jardim'. Folha de São Paulo, 19 jan. 1982. Cerejeiras Floridas no fim de uma época. Folha de São Paulo, 16 jan. 1982.

\section{O JARDIM DAS CEREJRIAS - Paulo Mamede. Rio de Janeiro, 1989}

Programa da Peça. Rio de Janeiro, 1989.

José Leugoy. Última Hora, Rio de Janeiro, 25 jul. 1989.

José Lewgoy volta aos palcos em montagem de peça de Tchekhov. Folha de São Paulo, São Paulo, 25 jul. 1989.

ARARIPE, Ana Paula. Teatro dos Quatro Mostra Jardim das Cerejeiras. O Dia, Rio de Janeiro, 21 jul. 1989.

BLANCO, Armindo. Um Tchekhov em bege. O Dia, Rio de Janeiro, 29 jul. 1989.

CEZIMBRA, Márcia. Comédia da Decadência, Jornal do Brasil, Rio de Janeiro, 25 jul. 1989.

FARIA, Marcos Ribas de. Tchekhov um adeus de comovente beleza. O Estado de São Paulo, São Paulo, 26 jul. 1989.

GARAMBONE, Sidney. Julho é mês de Tchekov. Jornal do Brasil (Revista de Domingo), Rio de Janeiro, 11 jun. 1989.

GIRAFA, Roberto. Aristocracia Decadente. Última Hora, Rio de Janeiro, 25 jul. 1989.

KAPLAN, Sheila. Muito Além de um Simples Jardim. O Globo, Rio de Janeiro, 27 jul. 1989.

LOYOLA, Cecília. Pelo Viés da Memória. Tribuna da Imprensa, Rio de Janeiro, 07 ago. 1989.

MACKSEN Luiz. Tempo dos gestos inúteis, Jornal do Brasil, Rio de Janeiro, 27 jul. 1989.

\section{O JARDIM DAS CEREJRIAS - Companhia de Teatro Serphin. Recife, 1990}

Programa da Peça. Recife, 1990.

\section{O JARDIM DAS CEREJRIAS - Élcio Nogueira Seixas/ Teatro Promíscuo. São Paulo, 2000}

Programa da Peça. São Paulo, 2000.

CANDEIAS, Manuel. Tchekhov no Rio, Gazeta Mercantil, Rio de Janeiro, 29 mar. 2001.

HELIODORA, Bárbara. Peça tem mais enganos que acertos. $O$ Globo, Rio de Janeiro, 02 abr. 2001.

LIMA, Mariangela Alves de. Peça de Chekov promove o encontro de delicadeza e humor. $O$ Estado de São Paulo, São Paulo, 19 jan. 2001.

LUIZ, Macksen. Na contramão da sutileza de Tchecov. Jornal do Brasil, Rio de Janeiro, 08 abr. 2001. 
O JARDIM DAS CEREJRIAS - Moacir Chaves. Rio de Janeiro, 2008

Programa da Peça. Rio de Janeiro, 2008.

Da cabine de luz para a cena aberta. O Globo, Rio de Janeiro, 08 maio 2011.

HELIODORA, Bárbara; LESSA, Jeferson; BRANDÃO, Tânia; MIRANDA, Stella. Visões sobre Tchékhov. O Globo, Rio de Janeiro, 11 maio 2008.

\section{A PROPOSTA - Rodolfo García Vázquez. São Paulo, 2003}

BRASIL, Ubiratan. Chekhov na visão bem-humorada dos Bravos Atores. O Estado de São Paulo, São Paulo, 02 abr. 2003.

LIMA, Mariangela Alves de. 'A Proposta' mostra com graça clichês do poder. O Estado de São Paulo, São Paulo, 24 ago. 2002.

\section{A PROPOSTA - Daniel Gaggini. Rio de Janeiro, 2008}

Tchekov e uma comédia sobre o casamento. Metromagazine, Niteroi, 07 mar. 2008.

HELIODORA, Bárbara. Nome de Tchecov é usado em vão. $O$ Globo, Rio de Janeiro, 30 jan. 2009.

FESTIVAL ANTON TCHEKHOV. Bahia e Porto Alegre, 1962

Programa da Peça (Festival). Bahia e Porto Alegre, 1962

FESTIVAL TCHEKHOV - Guilhermino Cesar. Porto Alegre, 1949.

PASSOS, Juvenal. "Festival Tchekhov". Revista do Globo, Porto Alegre, 23 jul. 1949.

IVANOV - Eduardo Tolentino/ Grupo TAPA. São Paulo, 1998.

COELHO, Sérgio. O olhar do outro: Grupo TAPA acerta ao usar texto de Tchékhov para refletir sobre o Brasil. Revista Bravo, 07, Ano 1, ab. de 1998.

GUZIK, Alberto. Grupo TAPA aproxima Chekhov do Brasil atual. Jornal da Tarde, São Paulo, 16 abr. 1998.

LIMA, Mariângela Alves de. TAPA atualiza a narrativa de Chekhov em 'Ivanov'. O Estado de São Paulo, São Paulo, 08 maio 1998.

NÉSPOLI, Beth. Ivanov aposta na força da fábula de Chekhov. O Estado de São Paulo, São Paulo, 16 abr. 1998.

VELLOSO, Beatriz. Grupo Tapa vai encenar obra de Chekhov. O Estado de São Paulo, São Paulo, 02 set. 1997.

O CAMALEÃo (adaptação) - Renata Pallottini/ Lux in Tenebris. São Paulo, 1985.

Programa da Peça. São Paulo, 1985. 
Teatro: a estreia de O Camaleão. Jornal da Tarde, São Paulo, 26 set. 1985.

CANTO DO CISNE - Vadim Nikitin. São Paulo, 1997

NÉSPOLI, Beth. A cidade é o cenário da 'Canção do Cisne'. O Estado de São Paulo, São Paulo, 11 mai. 1999.

SÁ, Nelson. 'Canção' é laço entre o palco e a vida. Folha de São Paulo, São Paulo, 17 out. 1997.

O JUBILEU - Maria Clara Machado/Rubens Correa/ O Tablado. Rio de Janeiro, 1958

Programa da Peça. Rio de Janeiro, 1958.

Entrevista com Rubens Correa. Jornal Refletor, Rio de Janeiro, n. 6, set. 1982.

O URSO/ O PEDIDO DE CASAMENTO - Agremiação Goiana de Teatro. Goiânia, 1952

Programa da Peça. Goiânia, 1952.

O URO E OUTRAS DE TCHEKHOV (FESTIVAL TCHEKHOV) - Nina Ranevsky. Rio de Janeiro, 1952

Programa da Peça. Rio de Janeiro, 1952.

Tchekov, pelo Teatro do Estudante, amanhã, no DUSE. Folha Carioca, Rio de Janeiro, 26 dez. 1952.

O URSO - Maria Clara Machado/ Teatro do Conservatório. Rio de Janeiro, 1966-67

Programa da Peça. Rio de Janeiro, 1966-67.

No TNC. O Estado de São Paulo, 01 nov. 1966.

Urso, Salamanca e Laranjas. O Jornal, Rio de Janeiro, 13 nov. 1966.

Uma estréia. Gazeta de Notícias, Rio de Janeiro, 29 dez. 1966.

MICHALSKI, Yan. Três Peças no Conservatório, Jornal do Brasil, Rio de Janeiro, 03 jan. 1967.

LEITE, Luiza. Próximas Estréias. Jornal do Comércio, Rio de Janeiro, 13 dez. 1966.

GONÇALVES, Martim. Espetáculo no Conservatório. O Globo, Rio de Janeiro, 04 jan. 1967.

VAN JAFA. Comédia em 1 Ato. Correio da Manhã, Rio de Janeiro, 17 jan. 1967.

O URSO/ SOBRE OS DANOS QUE TRAZ O TABACO E UM PEDIDO DE CASAMENTO - Teatro Experimental de Comédia de Araraquara, Araraquara, 1976(?)

Programa da Peça. Araraquara, 1976.

O URSO - José Guilherme de Castro Alves. Vitória, 1976. 
Programa da Peça. Vitória, 1976.

Teatro. A Gazeta, Vitória, 21 out. 1976.

IRRESISTÍVEL AVENTURA (inúmeras peças, dentre elas O URSO) - Domingos Oliveira. Rio de Janeiro, 1985

Programa da Peça.

BRANDÃO, Tânia. Um belo momento de Dina Sfat. Revista ISTO É, São Paulo, 29 ago. 1984.

LUIZ, Macksen. 'Irresistível Aventura'. Jornal do Brasil, Rio de Janeiro, 14 ago. 1984. Os vencedores do Mambembe. Jornal do Brasil, Rio de Janeiro, 12 mar. 1985.

MARINHO, Flavio. Dina e Domingos dão aula de sensibilidade. $O$ Globo, Rio de Janeiro, 11 ago. 1984.

\section{O URSO - Antonio Oliveira/O Grupo. Porto Alegre, 1988}

'O Urso' no Porto de Elis. Zero Hora. Porto Alegre, 08 fev. 1988

Peça de Tchecov no bar Porto de Elis. Jornal do Comércio, Porto Alegre, 08 fev. 1988.

Texto de Tchekhov estréia em montagem não-realista. Diário do Sul, Porto Alegre, 08 fev. 1988.

O URSO - José Henrique. Rio de Janeiro, 1998.

LUIZ, Macksen. Modesta versão de Tchecov. Jornal do Brasil, Rio de Janeiro, 11 dez. 1998.

\section{O ANIVERSÁRIO - Grupo Dramático do Sesi. São Paulo, 1965}

Festival Tchecov. Diário Popular, São Paulo, 24 nov. 1965.

Teatro Leopoldo Froes. A Gazeta, São Paulo, 26 nov. 1965.

\section{OS MALES QUE O FUMO PRODUZ - Ronaldo Brandão. Belo Horizonte, 1988}

De volta 'Os Males que o Fumo Produz'. Estado de Minas, Belo Horizonte, 17 jan. 1989.

Hoje em O eterno desejo da felicidade volta à cena em Os Males que o Fumo Produz Dia, Belo Horizonte, 18 jan. 1989.

Teatro. Diário da Tarde, Belo Horizonte, 10 mar. 1989.

Teatro de Bolso. Estado de Minas, Belo Horizonte, 17 jan. 1989.

\section{PLATONOV - Maria Clara Machado/ O Tablado. Rio de Janeiro, 1980}

Programa da Peça. Rio de Janeiro, 1980.

O teatro brasileiro está em crise - entrevista com Maria Clara Machado. Última Hora, Rio de Janeiro, 06 jun. 1980 
COUTINHO, Wilson N. Leveza Russa - Tchekhov encenado como ele queria. Revista Veja, 04 jun. 1980.

GROPILLO, Ciléa. Maria Clara Machado, a direção para adultos. Jornal do Brasil, Rio de Janeiro, 03 jun. 1980.

MARINHO, Flávio. A busca de uma nova vida. O Globo, Rio de Janeiro, 28 maio 1980. Jovem Tchecov - muito cuidado, pouco texto. Revista Visão, Rio de Janeiro, v. 29 n.19, 16 jun. 1980.

Retrato de um fim de raça. O Globo, Rio de Janeiro, 24 maio 1980.

MICHALSKI, Yan. Um 'Don Juan' de província. Jornal do Brasil, Rio de Janeiro, 03 jun. 1980.

\section{O TRÁGICO À FORÇA - MARCIO AURÉLIO. São Paulo, 1982}

Programa da Peça. São Paulo, 1982

Dois novos espetáculos teatrais. O Estado de São Paulo, São Paulo, 18 jun. 1982.

Espetáculo Teatral avacalha casamento. Notícias Populares, São Paulo, 23 jun. 1982.

Nas minúcias do cotidiano, um painel de crise. Folha de São Paulo, São Paulo, 23 jun. 1982.

O lado cômico de Tchekov em 'O Trágico à força'. Folha de São Paulo, São Paulo, 23 jun. 1982.

O Trágico à Força em novo endereço. Folha da Tarde, São Paulo, 07 out. 1982.

RIOS, Jefferson Del. Tchecov visitado pelo humor de Groucho Marx. Folha de São Paulo, São Paulo, 30 jun. 1982.

FILHO, Antonio G. No São Pedro, o mundo tragicômico de Tchecov. Folha de São Paulo, São Paulo, 23 jun. 1982.

GARCIA, Clóvis. A comédia de Tchecov em 'Trágico à Força'. O Estado de São Paulo, São Paulo, 09 jul. 1982.

GODOY, Carlos Ernesto de. A alentadora volta aos clássicos. Revista Isto É, São Paulo, 07 jul. 1982.

GUIMARÃES, Carmelinda. Rindo do Casamento. Revista Visão, São Paulo, 26 jul. 1982.

LARA, Paulo. Cinco peças de Checov, desde ontem, no São Pedro. Folha da Tarde, São Paulo, 24 jun. 1982.

. Obras de Checov num só espetáculo. Folha da Tarde, São Paulo, 23 jun. 1982.

MAGALDI, Sábato. Neste O Trágico à Força, deliciosos momentos de Tchecov. Jornal da Tarde, São Paulo, 09 jul. 1982.

UM PEDIDO DE CASAMENTO - Adolfo Celi/ TBC. São Paulo, 1950

Programa da Peça. São Paulo, 1950. 
UM PEDIDO DE CASAMENTO - Adacto Filho/ Teatro Íntimo de Fantoches. Salvador, 1950

'Um pedido de casamento', pelo Teatrinho Íntimo de Fantoches. A Tarde, Salvador, 16 mar. 1950.

UM PEDIDO DE CASAMENTO - Osmar Rodrigues Cruz/ Grupo de Amadores Bandeirantes. São Paulo, 1951

Programa da Peça. São Paulo, 1951.

LUCIA, Maria. Osmar Completa 30 anos de Teatro. A Gazeta, São Paulo, 14 out. 1975.

UM PEDIDO DE CASAMENTO - Expedito Porto/ Teatro Experimental do Pessoal da Caixa Econômica. Rio de Janeiro, 1952

Programa da Peça. Rio de Janeiro, 1952.

UM PEDIDO DE CASAMENTO - Adolfo Celi/ TBC. Rio de Janeiro, 1954

Programa da Peça. Rio de Janeiro, 1954.

UM PEDIDO DE CASAMENTO - B de Paiva/ Teatro Rural do Estudante. DF, 1957

Programa da Peça. DF, 1957.

O MATRIMÔNIO (UM PEDIDO DE CASAMENTO) - Rubens Correa/Maria Clara Machado/ O Tablado. Rio de Janeiro, 1958

Programa da Peça. Rio de Janeiro, 1958.

UM PEDIDO DE CASAMENTO - Grupo de Teatro dos alunos do Estúdio Raquel Levi. Rio de janeiro, 1966

Programa da Peça. Rio de Janeiro, 1966.

UM PEDIDO DE CASAMENTO - Claudio Heemann/ Curso de Arte Dramática da UFRGS. Porto Alegre, 1966

Programa da Peça. Porto Alegre, 1966

Tchecov pelo CAD. Folha da Tarde, Porto Alegre, 05 jul. 1966.

Teatro Cômico de Tchekov pelo CAD . Correio do Povo, Porto Alegre, 05 jul. 1966.

UM PEDIDO DE CASAMENTO - J B Galvão/ ATARD. DF, 1975

Programa da Peça. DF, 1975. 
UM PEDIDO DE CASAMENTO/ O URSO - Grupo de Teatro Anhangá. São Paulo/ Belo Horizonte, 1977.

Duas peças de Tchekov no Teatro Marilia. Diário da Tarde, Belo Horizonte, 27 maio 1977.

Um espetáculo de Tchecov. Diário do Comércio, Belo Horizonte, 02 jun. 1977.

UM PEDIDO DE CASAMENTO - Adalberto Nunes. Rio de Janeiro, 1982

LUIZ, Macksen. Tchekhov Massacrado, Jornal do Brasil, Rio de Janeiro, 30 nov. 1982.

MARINHO, Flávio. 'Pedido de Casamento', um equívoco com Anton Tchecov. O Globo, Rio de Janeiro, 30 nov. 1982.

UM PEDIDO DE CASAMENTO - Roberto Parkinson. DF, 1989

Os clichês de um pedido de casamento. Jornal de Brasília, Brasília, 08 jun. 1989. 


\section{ANEXO 1: \\ Índice Cronológico \\ Montagem: Teatro ${ }^{545}$}

$$
\begin{aligned}
& 1946 \text { - O Urso. } \\
& 1949 \text { - Festival Tchekhov. } \\
& 1950 \text { - Um Pedido de Casamento. } \\
& 1950 \text { - Um Pedido de Casamento. } \\
& 1951 \text { - Um Pedido de Casamento. } \\
& 1952 \text { - Um Pedido de Casamento. } \\
& 1952 \text { - Um Pedido de Casamento. } \\
& 1952 \text { - O Ursol } \\
& \text { Um Pedido de Casamento. } \\
& 1953 \text { - Festival Tchékhov. } \\
& 1954 \text { - Um Pedido de Casamento. } \\
& 1954 \text { - Um Pedido de Casamento. } \\
& 1955 \text { - Tio Vânia. } \\
& 1956 \text { - As Três Irmãs. } \\
& 1957 \text { - Um Pedido de Casamento. } \\
& 1958 \text { - O Jubileu. } \\
& 1958 \text { - As Três Irmãs. } \\
& 1960 \text { - As Três Irmãs: } \\
& 1962 \text { - Anton Tchékhov-Um Festival. } \\
& 1962 \text { - Tio Vânia. } \\
& 1962 \text { - Um Pedido de Casamento. } \\
& 1964 \text { - Festival Tchecov. } \\
& 1966 \text { - Um Pedido de Casamentol } \\
& \text { O Aniversário. } \\
& 1966 \text { - O Pedido de Casamento. } \\
& 1966 \text { - Pedido de Casamento. }
\end{aligned}
$$$$
\begin{aligned}
& 1967 \text { - Um Pedido de Casamentol } \\
& \text { O Jubileu. }
\end{aligned}
$$$$
1967 \text { - As Três Irmãs. }
$$$$
1968 \text { - Tio Vânia. }
$$$$
1968 \text { - O Jardim das Cerejeiras. }
$$$$
1969 \text { - Trágico à Forçal }
$$$$
\text { O Urso. }
$$

1972 - As Três Irmãs.

1974 - A Gaivota.

1974 - Tio Vânia.

1975 - O Jubileu.

1975 - Um Pedido de Casamento.

1975 - Tio Vânia.

1976 - Um Pedido de Casamentol O Ursol

Sobre os Males que traz o Tabaco
Hermilo Borba Filho/ TEP, Recife.

Guilhermino César/ TERGS, Porto Alegre.

Adolfo Celi/ TBC, São Paulo.

Adacto Filho/ TAF, Salvador.

Osmar R. Cruz/ Clube de Teatro, SP.

Ruggero Jacobbi/ EAD, Recife.

Expedito Pôrto/ TEPCE, Rio de Janeiro.

Agremiação Goiânia de Teatro, Goiânia.

Nina Ranevsky, Rio de Janeiro.

Ziembínski/ TBC, São Paulo.

Adolfo Celi/ TBC, Rio de Janeiro.

Geraldo Queiroz/ O Tablado. RJ.

Alfredo Mesquita/ EAD, Ribeirão Preto.

S. de Paiva/ TRE, DF, Rio de Janeiro.

Rubens Corrêa/ O Tablado, Rio de Janeiro

Gianni Ratto/ A Barca, Salvador.

Ziembínski/ TNC, Rio de Janeiro.

Luiz Carlos Maciel/A Barca, Salvador.

Alberto D'Aversa/EAD, São Paulo.

Luiz Nagib Amary/ Belo Horizonte.

Sérgio Mibielle/ Belo Horizonte.

Cláudio Heemann/CAD, Porto Alegre

Maria H. Magalhães, Rio de Janeiro.

Grupo de Teatro André Luiz (GATAL),

Marília.

Dulcina de Moraes/ FBT, Rio de Janeiro.

Haydée Bittencourt, Belo Horizonte.

Cláudio Correa e Castro/ Curitiba.

Ivan de Albuquerque/ Grupo do Rio, RJ.

João Ribeiro Chaves/ Grupo Casarão, SP. José Celso Martinez Correa/ Oficina, SP. Jorge Lavelli/ Rio de Janeiro.

Álvaro Guimarães/ Salvador.

Beto Diniz/ Rio de Janeiro.

J. B. Galvão/ ATARD, Brasília (DF)

Emilio Di Biasi/Grupo Heros, São Paulo.

TECA/ Araraquara.

\footnotetext{
${ }^{545}$ Manteremos o nome das peças, bem como a grafia dos nomes russos de acordo com o que cada montagem apresentou.
} 
1976 - O Urso.

1977 - O Casamento de Natalina (adap).

1977 - Pedido de Casamentol O Urso

1980 - Platonov.

1982 - O Jardim das Cerejeiras.

1982 - O Trágico à Força.

1982 - O Pedido de Casamento.

1984 - O Jardim das Cerejeiras.

1984 - Tio Vânia.

1984 - Irresistível Aventura (adap.)

1985 - O Camaleão

1987 - Natasha (adap.)

1988 - Os Males que o Fumo Produz.

1988 - O Urso.

1988 - Lago 21 (adap).

1988 - Pedido de Casamento.

1989 - Tio Vânia.

1989 - Um Pedido de Casamento.

1989 - O Jardim das Cerejeiras.

1989 - A Gaivota.

1990 - O Jardim das Cerejeiras.

1991 - A Proposta (adap).

1992 - Seraphins Revisões Jardim das Cerejeiras.

1994 - A Gaivota.

1995 - A Gaivota.

1996 - A Gaivota.

1996 - Um Pedido de Casamento.

1997 - A Arte de Dizer Não (adap).

1997 - O Malfeitor (adap).

1998 - Tio Vânia.

1998 - O Urso.

1998 - Ivanov.

1998 - Da Gaivota.

1998 - As Três Irmãs.

1999 - As Três Irmãs.

2000 - Tio Vânia.

2000 - O Jardim das Cerejeiras.

2002 - A Proposta (adap).

2003 - Tio Vânia.

2006 - Gaivota -

tema para um conto curto(adap).

2007 - A Farsa (adap.).
José Guilherme de Castro Alves/ Vitória.

Carlos Augusto Strazzer/ São Paulo.

Pedro Marcos/Grupo Anhangá, São Paulo.

Maria Clara Machado/ O Tablado, RJ.

Jorge Takla/ São Paulo.

Marcio Aurélio/ São Paulo.

Adalberto Nunes/ Rio de Janeiro.

Lala Schneider/ Curitiba.

Sérgio Britto/ Teatro dos Quatro, RJ.

Domingos Oliveira/ Rio de Janeiro.

Reinaldo Santiago/ Lux in Tenebris, SP.

Zelia Hurman/Cia Molière, Curitiba.

Ronaldo Brandão/ Belo Horizonte.

Antonio Oliveira/ Porto Alegre.

Jorge Takla/ São Paulo.

Elpídio Navarro/ João Pessoa.

Celso Frateschi/ EAD-USP, São Paulo.

Roberto Parkinson, Brasília (DF).

Paulo Mamede/ Teatro dos Quatro, SJo.

Luiz Paulo Vasconcellos, Porto Alegre.

Antonio Cadengue/ Cia de Teatro

Seraphim, Recife.

Rodolfo García Vázquez /Os Satyros, SP.

Antonio Candengue/ Cia de Teatro

Seraphin, Recife.

Francisco Medeiros/Cia. do Bexiga, São

Paulo.

David Herman/ Rio de Janeiro.

Jorge Takla/ Rio de Janeiro.

Marcus Alvisi/ Rio de Janeiro.

Maria Lúcia Pereira/ São Paulo.

Rosyane Trotta/ Rio de Janeiro.

Élcio Nogueira Seixas/ Teatro Promíscuo,

Curitiba.

José Henrique/ Rio de Janeiro.

Eduardo Tolentino/ Grupo Tapa,

Curitiba/SP.

Daniela Thomas/ Curitiba.

Bia Lessa/ Rio de Janeiro.

Enrique Diaz/ Rio de Janeiro.

Celso Frateschi/Grupo Ágora, São Paulo.

Élcio Nogueira Seixas/ São Paulo.

Os Satyros/ São Paulo.

Aderbal Freire-Filho/ Rio de Janeiro.

Enrique Diaz/ Cia dos Atores, Rio de Janeiro.

Luis Artur Nunes/ Porto Alegre. 
2008 - O Jardim das Cerejeiras. 2008 - Tio Vânia.
Moacir Chaves/ Rio de Janeiro.

Celso Frateschi/ Grupo Ágora. São Paulo. 


\section{ANEXO 2:}

\section{Fichas Técnicas das Encenações, Fontes e Fotos. ${ }^{546}$}

O material aqui reunido foi coletado em pesquisa realizada nos arquivos da FUNARTE-Rio de Janeiro, Biblioteca Jenny Klabin Segall - São Paulo, Centro Cultural São Paulo, Sociedade Brasileira de Autores Teatrais (SBAT- Rio de Janeiro) e Arquivo Edgard Leuenroth/UNICAMP.

\section{O URSO. Recife, 1946}

Produção: Teatro do Estudante de Pernambuco (TEP)

Direção: Hermilo Borba Filho

Cenário e Figurinos: Lula Cardoso Ayres

Estreia em palco improvisado na biblioteca da Faculdade de Direito do Recife. Primeiramente, Hermilo Borba Filho realiza a leitura do histórico documento Teatro, Arte do Povo e, em seguida, tem início o espetáculo, composto das peças $O$ Urso, de Tchékhov e O Segredo, de Ramon J. Sender, que faziam parte do mesmo espetáculo.

DOCUMENTOS ICONOGRÁFICOS: 1 registro (Enciclopédia de Teatro Itaú Cultural); Entrevista Diário Oficial de Pernambuco - Ano IX, no07. Recife, 1996 (Acervo: Centro de Documentação e Informação em Arte da FUNARTE - RJ);

\section{FESTIVAL TCHEKHOV. Porto Alegre, 1949.}

Produção: Teatro do Estudante do Rio Grande do Sul Direção: Guilhermino César

Elenco: Enilda Lopes, Olavo Engel, Loris Melecchi, Linneu Dias, Flávio Romero e Galvão Loureiro.

Cenografia: Carlos Alberto Petrucci

Estreia em 1949, no Theatro São Pedro, Porto Alegre.

DOCUMENTOS ICONOGRÁFICOS: 1 Registro ( Enciclopédia de Teatro Itaú Cultural: http://www.itaucultural.org.br/aplicexternas/ enciclopedia_teatro/Enc_Cias/dsp_dados_evento.cfm?id_evento=514102 \&st_evento=Festival\%20Tchekhov). Notícia: "Festival Tchékhov". Revista do Globo. Porto Alegre, 23 jul. 1949, p. 36-37.

\footnotetext{
${ }^{546}$ Manteremos o nome das peças, bem como a grafia dos nomes russos de acordo com o que cada montagem apresentou.
} 
UM PEDIDO DE CASAMENTO. São Paulo, 1950.

Produção: Teatro Brasileiro de Comédia (TBC)

Direção: Adolfo Celi

Tradução: Victor Merinov

Elenco: Sérgio Cardoso/Ruy Affonso (Lomov); Waldemar Wey (Ciubocov); Cacilda Becker/ Célia Biar (Natália)

Cenografia: Bessano Vaccarini e Carlos Giacchieri; Figurinos: Aldo Calvo; Maquilagem e Cabeleiras: Victor Merinov; Assistente de Direção: Ruy Affonso.

Estreia em 24 de janeiro de 1950 no TBC, São Paulo.

Esta peça em um ato de Tchékhov compunha com Entre Quatro Paredes, de Jean-Paul Sarte, um mesmo espetáculo.

DOCUMENTOS ICONOGRÁFICOS: 01 Programa de Peça (Acervo: Centro Cultural São Paulo - Arquivo Multimeios). Ficha Técnica na Revista Dionysos "Teatro Brasileiro de Comédia" (09/1980, no 25, p.207); Encarte "TBC - suas origens" (Acervo: Centro de Documentação e Informação em Arte da FUNARTE RJ)

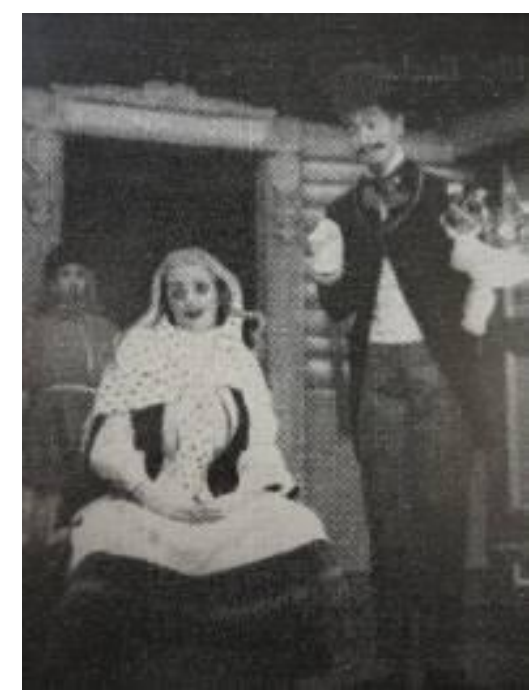

Da esquerda para a direita: Waldemar Wey (Ciubicov), Célia Biar (Natália) e Ruy Affonso (Lomov). (Fonte: Encarte "Teatro Brasileiro de Comédia". Acervo: Centro de Documentação e Informação em Arte da FUNARTE RJ)

\section{UM PEDIDO DE CASAMENTO. Salvador, 1950.}

Produção: Teatro de Amadores de Fantoches (TAF)

Direção: Prof. Adacto Filho

Tradução: Adacto Filho

Elenco: Mário Hart (Ivan Lomow (sic)); Gilberto Baraúna (Tchubukow (sic)); Hildegardes Cantolino Viana (Natáck (sic)). 
Estreia em 14 de março de 1950, no Clube Fantoches da Euterpe, Salvador.

DOCUMENTOS ICONOGRÁFICOS: 1 Notícia (Acervo: Centro de Documentação e Informação em Arte da FUNARTE RJ)

\section{UM PEDIDO DE CASAMENTO. São Paulo, 1951}

Produção: Clube de Teatro/Grupo de Amadores Bandeirantes

Direção: Osmar Rodrigues Cruz

Elenco: Nelson Gonçalves (Ivan); Rafael Franceschi (Stefan); Luísa Cristófaro (Natalia).

Apresentação da peça, seguida de Uma Véspera de Reis, de Artur Azevedo, , em 24 de novembro de 1951 no Auditorium do Instituto de Educação Caetano de Campos, São Paulo.

DOCUMENTOS ICONOGRÁFICOS: Programa da peça (Acervo: Centro de Documentação e Informação em Arte da FUNARTE RJ)

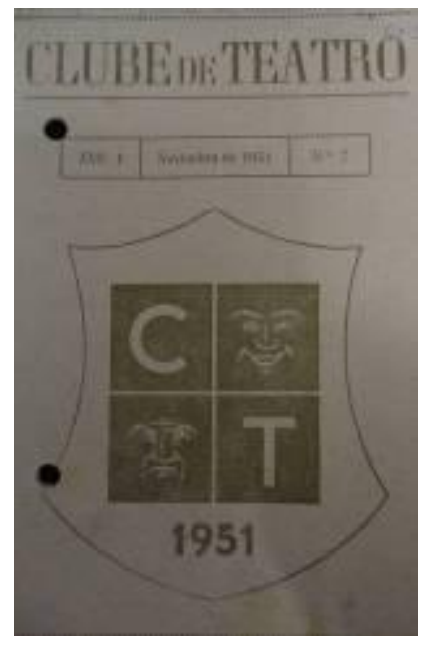

Programa da Peça. Um Pedido de Casamento e Uma Véspera de Reis, dir. Osmar Rodrigues Cruz, São Paulo, 1951.

\section{UM PEDIDO DE CASAMENTO. Recife, 1952.}

Produção: Escola de Arte Dramática - EAD

Direção: Ruggero Jacobbi

Tradução: Victor Merinov

Elenco: Armando Pedro (Ciubocov); Eduardo Bueno (Lomov); Floramy Pinheiro (Natália).

Estreia em 13 de julho de 1952 no Sanatório Otávio de Freitas, Recife.

DOCUMENTOS ICONOGRÁFICOS: Livro EAD 48-68 (Centro Cultural São Paulo - Arquivo Multimeios) e Registro no site Enciclopédia de Teatro Itaú Cultural:

http://www.itaucultural.org.br/aplicexternas/enciclopedia_teatro/Enc_Cias/ds 
p_dados_evento.cfm?id_evento $=567460 \&$ st_evento $=\mathrm{Um} \% 20 \mathrm{Pedido} \% 20 \mathrm{de} \%$ 20Casamento

\section{UM PEDIDO DE CASAMENTO. Rio de Janeiro, 1952}

Produção: Teatro Experimental do Pessoal da Caixa Econômica (TEPCE).

Direção: Expedito Pôrto

Tradução: Adacto Filho

Elenco: Vicente Cosate (Ivan Lomov); Donaldson Gonçalves (Stephan Stephanovitch Tchubukov); Isa de Macedo (Natalia Stephanovna).

Cenografia: Santa Rosa; Maquinista: Pilade Romano; Eletricista: Hermelindo Linhares.

Estreia no dia 08 de setembro de 1952, acompanhada de outras duas peças: $A$ Medalha, de Moisés Duék e Nem Tudo Está Perdido, de autoria de "um colega".

Estreia em 08 de Setembro de 1952, no Teatro Serrador, Rio de Janeiro. Em 27 de setembro de 1952, seguiu com outros grupos para apresentação no TEATRINHO KIBON da TV TUPI.

DOCUMENTOS ICONOGRÁFICOS: Programa da peça (Acervo: Centro de Documentação e Informação em Arte da FUNARTE RJ).

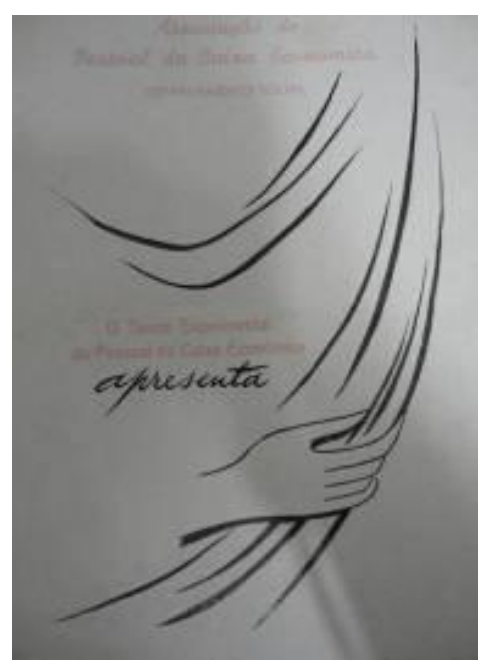

Programa da Peça. Um pedido de Casamento,

Rio de Janeiro, 1952.

\section{O URSO/ O PEDIDO DE CASAMENTO. Goiânia, 1952.}

Produção: Agremiação Goiana de Teatro.

Elenco (O Urso): Iwolney Gomes (Luka); Edna Machado (Popova); Osires Teixeiras (Gregory Smirnov). 
Elenco (O Pedido de Casamento): Otavinho Arantes (Lomov); Taufic Sebba (Ciubcov (sic)); Ivanilde Aves (Natacha)

Estreia em 05 de novembro de 1952, no Cine Goiás, Goiânia. Na mesma noite, estrearam no Primeiro Festival da Agremiação Goiana de Teatro as peças $O$ Urso, de Tchékhov, O Banquete, de Lucia Benedetti e O Pedido de Casamento, de Tchékhov.

DOCUMENTOS ICONOGRÁFICOS: Panfleto de Divulgação (Acervo: Centro de Documentação e Informação em Arte da FUNARTE RJ)

\section{FESTIVAL TCHEKOV (Teatro Duse). Rio de Janeiro, 1952/1953.}

Produção: Paschoal Carlos Magno/ Teatro do Estudante

Direção: Nina Ranevsky

\section{O Urso}

Elenco: Ana Edler (Elena Ivanova Poppva (sic)); Fernando Cesar (Luka); Armando Carlos Magno (Grigori Smirnov); Ney Modanesi (Jardineiro).

\section{O Aniversário}

Elenco: José Leandro (Kusmá Quirian); José Maria Monteiro (Andrei Schpuchin); Celme Silva (Tatiana Alexeievna); Consuelo Leandro (Nastasia Marchutkina (sic)); La-Fayette Galvão (Porteiro); Moacir Deriquem (Acionista).

\section{Pedido de Casamento}

Elenco: Edson Silva (Stepan Chubukov); La-Fayette Galvão (Ivan Lomov); Geny Borges (Natalia Steptnovna (sic)).

Cenários e Figurinos: Rada; Chefe do Guarda-Roupa: Rosa Carlos Magno; Vestiaria: Nina Argentero; Maquinista: Souza; Eletricista: Moreira; Administração: Orlanda Carlos Magno e Deisy Del Negri; Publicidade: Aureo Nonato; Contra-Regra: Terezinha Austregesilo; Caracterização: Professor José Jansen.

Sessões dias 29 e 30 de dezembro de 1952 e 2, 3, 4, 5 e 6 de janeiro de 1956, no Teatro Duse, Rio de Janeiro.

DOCUMENTOS ICONOGRÁFICOS: Panfleto de Divulgação e 1 Notícia "Tchekov, pelo Teatro de Estudante", amanhã no Duse (Acervo: Centro de Documentação e Informação em Arte da FUNARTE RJ). 
UM PEDIDO DE CASAMENTO. São Paulo, 1954.

Produção: Teatro Brasileiro de Comédia (TBC).

Direção: Ziembínski

Tradução: Victor Merinov

Elenco: Luis Calderaro (Ciubocov); Benedito Corsi (Lomov); Cleyde Yáconis/ Célia Biar (Natália).

Cenografia: Bassano Vaccarini e Carlos Giacchieri.; Figurinista: Aldo Calvo.

Estreia em 04 de maio de 1954, no TBC, em São Paulo.

Peça integrante da experimentação "Teatro das Segundas-Feiras", que, em pouco tempo, constituiu verdadeiro sucesso de bilheteria para o TBC.

DOCUMENTOS ICONOGRÁFICOS: Ficha Técnica na Revista Dionysos "Teatro Brasileiro de Comédia" (09/1980, $n^{\circ}$ 25, p.207); Encarte "TBC suas origens" (Acervo: Centro de Documentação e Informação em Arte da FUNARTE RJ)

\section{UM PEDIDO DE CASAMENTO. Rio de Janeiro, 1954.}

Produção: Teatro Brasileiro de Comédia (TBC).

Direção: Adolfo Celi

Tradução: Victor Merinov

Elenco: Benedito Corsi (Lomov); Luis Calderaro (Ciubcov (sic)); Célia Biar (Natalia)

Cenografia: Mauro Francini; Figurinos: Benedito Corsi; Assistente de Direção (Benedito Corsi); Direção de Cena (Pedro Petersen); Contra-Regra (Eduardo Santiago).

No momento desta temporada carioca do TBC, parte do elenco permanecia em São Paulo, sob direção de Ziembínski. Estreia no Teatro Ginástico, Rio de Janeiro.

DOCUMENTOS ICONOGRÁFICOS: Programa da Peça com Breve Histórico e biografia de todo o elenco (Acervo: Centro de Documentação e Informação em Arte da FUNARTE RJ)

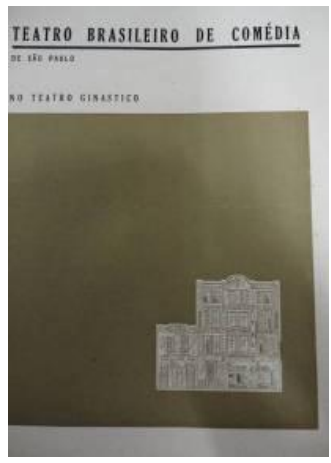

Encarte com informações sobre o

TBC e Ficha Técnica da Peça. Um

Pedido de Casamento, dir. Adolfo

Celi, São Paulo, 1954. 


\section{TIO VÂNIA. Rio de Janeiro, 1955.}

Produção: O Tablado

Direção: Geraldo Queiroz

Tradução: Aníbal Machado

Elenco: Carmem Silvia Murgel (Marina); Napoleão Moniz Freire (Mihail Astrov); Cláudio Corrêa e Castro (Tio Vânia); Nelson Mariani (Alexandre Serebryakov); Maria Clara Machado (Sonya); Beatriz Veiga (Yelena Andreyevna); Sônia Cavalcanti (Marya Vassilyevna); Denis Estill (Yefin), Rubens Corrêa (Telyegin).

Cenário e Figurinos: Athos Bulcão; Programa e Cartaz: Ana Letícia; Assistente de Direção: Roberto de Cleto; Contra-regra: Eddy Rezende; Sonoplastia: João Augusto; Caracterizações: Fred Amaral; Eletricista: Carlos Augusto Nem; Chefe Maquinista: Paulo Araújo; Cabeleiras: Eric Rzepecki; Canção: Fred Amaral.

Estreia dia 8 de dezembro de 1955 no Tablado, Rio de Janeiro.

DOCUMENTOS ICONOGRÁFICOS: Ficha Técnica da peça em Revista Dionysos "O Tablado" no 27, 1986, p. 82-83.

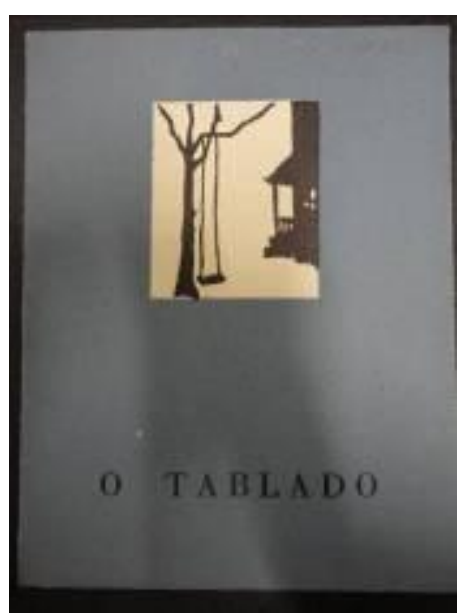

Programa da Peça. Tio Vânia, dir. Geraldo Queiroz, Rio de Janeiro, 1955.

(Acervo: Centro de Documentação e Informação em Arte da FUNARTE RJ)

\section{AS TRÊS IRMÃS. Ribeirão Preto, 1956.}

Produção: Escola de Arte Dramática (EAD) de São Paulo.

Direção: Alfredo Mesquita

Tradução: Esther Mesquita

Elenco: Cecília Carneiro (Olga); Glória Sampaio (Irina); Cândida Teixeira (Macha); Francisco Cuoco (Ivane (sic)); Nelson Xavier (Nicolai); Samuel Penido (Vassili); Jade Pirstelis (Anfissa); Francisco Martins (Feraponte); Eduardo Waddington (Verchinine); Alceu Nunes (Andrey); Aroldo Bedin (Fiodor); Miriam Mehler (Nathalia); Francisco Martins (Fedotik); Vladimir (Orlando Duarte). 
Cenário e Figurino: Alfredo Mesquita; Assitência: Cândida Teixeira, Maria José Campos Lima, Sara Perissionotto e Orlando Duarte.

Estreia em 24 de agosto de 1956. Montagem da EAD que foi apresentada dentro das comemorações do centenário da cidade de Ribeirão Preto/SP, no Teatro da Exposição, a convite da Associação Cultural Brasil-Estados Unidos.

DOCUMENTOS ICONOGRÁFICOS: Ficha Técnica da peça em livro "EAD 48-68 - Alfredo Mesquita", Sem autor. (Acervo: Centro de Documentação e Informação em Arte da FUNARTE RJ)

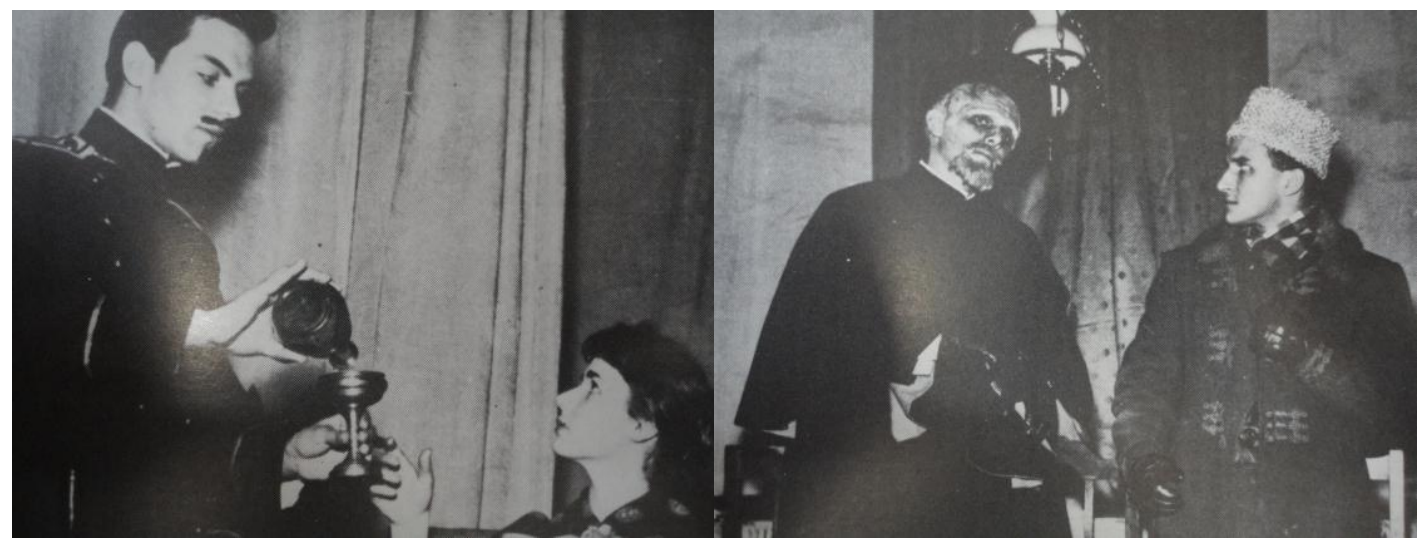

Foto à Esquerda: Samuel Penido (Vassili) e Miriam Mehler (Nathalia). Foto à Direita: Francisco Cuoco (Ivane (sic)) e Alceu Nunes (Andrey) (Fonte: Livro EAD 48-68 - Alfredo Mesquita . São Paulo, S. Est. da Cultura, 1985, p.65 - Arq. EAD)

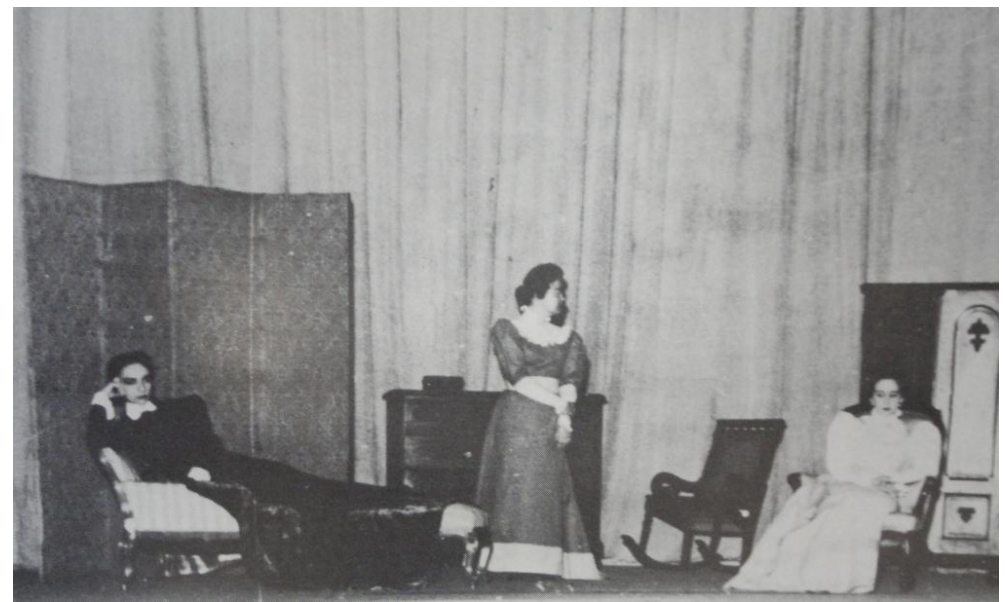

Da esquerda para a direita: Cândida Teixeira (Macha); Cecília Carneiro (Olga); Glória Sampaio (Irina). ((Fonte: Livro EAD 48-68 Alfredo Mesquita . São Paulo, S. Est. da Cultura, 1985, p.65 Arq. EAD) 


\section{UM PEDIDO DE CASAMENTO. Distrito Federal/Rio de Janeiro,} 1957.

Produção: Teatro Rural do Estudante.

Direção: S. de Paiva.

Elenco: Wilson Dray (Juliano (sic)); Rogério Fróes (Ivo); Regina Pierrini (Natália).

Estreia em 21 de setembro de 1957, na Festa da Lavoura do Distrito Federal/Rio de Janeiro, no Teatro Arthur Azevedo (bairro Campo Grande).

DOCUMENTOS ICONOGRÁFICOS: 01 Programa de Peça (Acervo: Centro de Documentação e Informação em Arte da FUNARTE RJ)

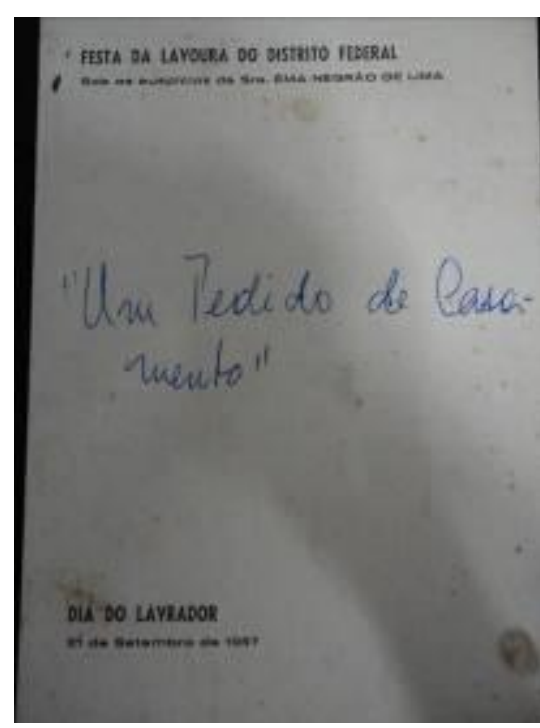

Capa do Programa -

Um Pedido de

Casamento, dir. S. de

Paiva, DF, 1957.

(Acervo: Centro de

Documentação $e$

Informação em Arte da

FUNARTE RJ)

O JUBILEU. Rio de Janeiro, 1958.

Produção: O Tablado

Direção: Rubens Correa

Tradução: Eugênio Kusnet e Brutus Pedreira

Elenco: Germano Filho (Kurmá Hirin); Ivan de Albuquerque (Andrei Chiputchin); Jacqueline Laurence (Tatiana); Maria Miranda (Nastassia); Carlos Sagrillo ( ${ }^{\circ}$ Funcionário); Ugo Barbieri ( $2^{\circ}$ Funcionário); Paulo Mathias (Contínuo); João Sérgio Nunes ( $1^{\circ}$ Acionista); Fernando José $\left(2^{\circ}\right.$ Acionista); Sérgio Belmonte ( $3^{\circ}$ Acionista); Karl Stuart (4 Acionista) Ruy Pereira ( $5^{\circ}$ Acionista);

Cenografia: Joel de Carvalho Figurinos: Kalma Murtinho; Iluminação: Carlos Augusto Nem; Contra-Regra: Anna Maria Magnus; Sonoplastia: Edelvira Fernandes; Caracterizações: Fred Amaral.

Estreia no Teatro do Tablado em 1958. 
Apresentação realizada em conjunto com a peça $O$ Matrimônio, de Gogol. Sem data da estreia

DOCUMENTOS ICONOGRÁFICOS: Ficha Técnica da peça em Revista Dionysos "O Tablado" (no 27, 1986, p. 86-87)

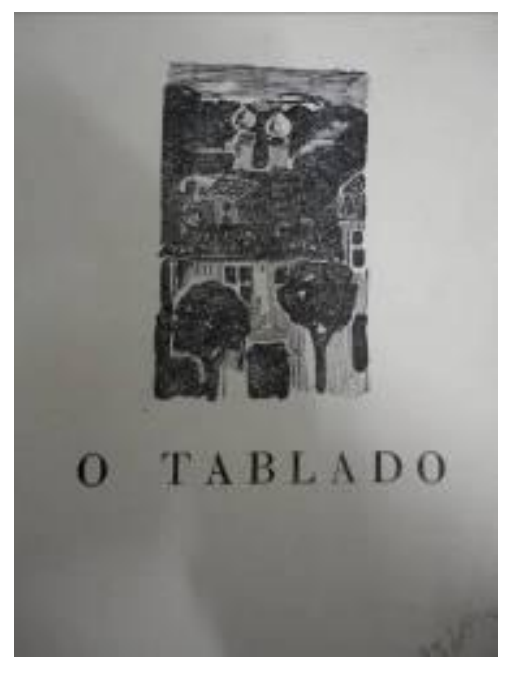

Programa da Peça. $O$ Jubileu, de Tchekhov e $O$ Matrimônio, de Gógol, dir. Rubens Correa, 1958. (Acervo: Centro de Documentação e Informação em Arte da FUNARTE RJ)

\section{AS TRÊES IRMÃS. Salvador, 1958.}

Produção: Grupo A Barca/ Escola de Teatro da Universidade Federal da Bahia Direção Gianni Ratto

Tradução: Otávio Alvarenga

Elenco: Othon Bastos (Andrey Sergueievitch Prosorov); Nilda Spencer (Olga); Domitilla Amaral (Maria); Sonia Robato (Irina); Nevolanda Amorim (Natália Ivanovna); Cláudio Reis (Fiódor Ilitch Kouliguin); Antonio Patiño (Alexander Ignatievitch Verchinin); Carlos Petrovitch (Nicolai Lvovitch Tchbutykin); Echio Reis (Vanissilly Vassilievitch Salioniy); João Gama (Ivan Romanovitch Tchebutykin); Otoniel Serra (Alexiey Petróvitch Fedótik); Mario Gadelha (Vladimir Carlovitch); Carmem Bittencourt (Anfisa); Joana de Castro (Empregada)

Newton Sobral (Fierapont); Anatólio Oliveira (Ordenança); Maria Anita (Uma menina); Flávio Rocha (Um velho)

Cenografia: Gianni Ratto; Figurinos: Luciana Petruccelli; Carpintaria: José Maria Daltro; Eletricista: José Américo Genê; Assistente de Direção: Jurema Penna; Diretor de Cena: João Augusto; Música: Rosita Salgado Góes; Dança: Yanka Rudzka.

Estreia em setembro de 1958, no Teatro Santo Antonio da Escola de Teatro da Universidade Federal da Bahia, Salvador. 
DOCUMENTOS ICONOGRÁFICOS: 1 Programa Resumido e 1 Programa Completo (Acervo: Centro de Documentação e Informação em Arte da FUNARTE RJ)

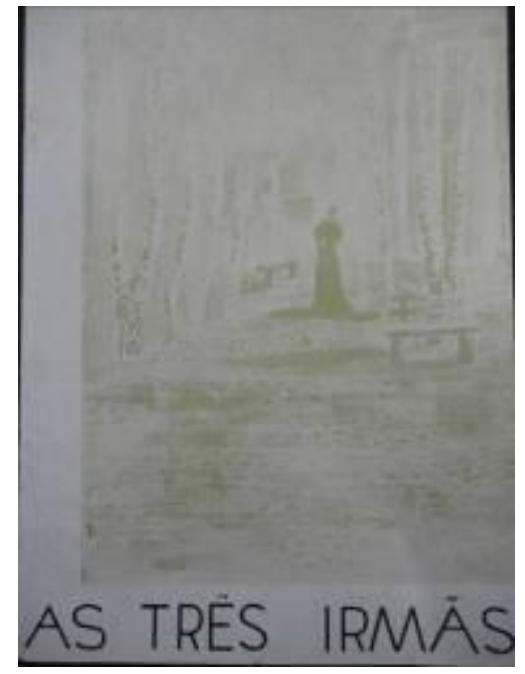

Programa Completo (esquerda) e Programa Resumido (direita). As Três Irmãs, dir. Gianni Ratto, Salvador, 1958. (Acervo: Centro de Documentação e Informação em Arte da FUNARTE RJ)

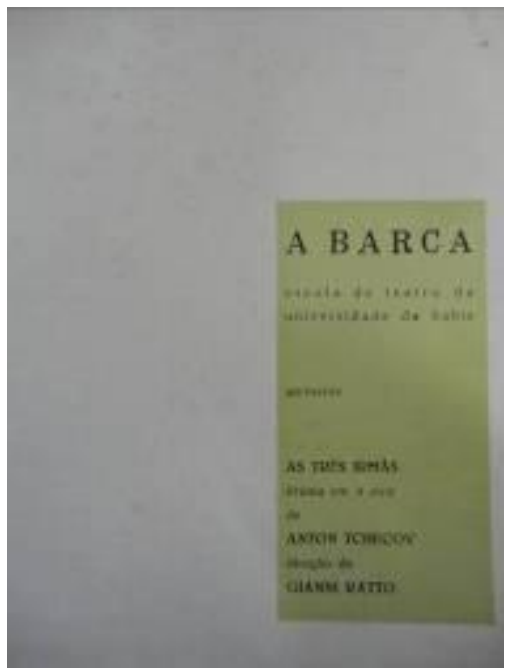

\section{AS TRÊS IRMÃS. Rio de Janeiro, 1960.}

Produção: Teatro Nacional de Comédia (TNC)

Direção: Ziembínski

Tradução: Maria Jacinta

Elenco: Glauce Rocha (Olga); Wanda Lacerda (Macha); Elizabeth Gallotti (Irina); Rodolfo Arena (Ivan Roumanovitch Tchecoutykine); Paulo Serrado (Barão Nicolai Lvovitch Tousenbach); Walter Alves (Vassilli Vassillievitch); Lícia Magna (Anfissa); Ferreira Maia (Ferapont); Rodolfo Mayer (Alexandre Ignatievitch Verchinime); Josef Guerreiro (André Sergueievitch Prosorov); Sebastião Vasconcellos (Fiodor Ilitch Kuulyhguine); Beatriz Veiga (Natacha); Ivan Cândido (Aleixei Petrovich Fedotik); Miguel Carrano (Vladimir Karlovitch Rodet).

Cenografia: J. Maria dos Santos; Figurino: Odette; Contra-Regra: Mario Figueiredo; Maquinista: Jardel;

Estreia dia 12 de janeiro de 1960 no Teatro Serrador, Rio de Janeiro (com avant-première no dia 07 de janeiro, dedicada a Escolinha de Arte no Brasil).

DOCUMENTOS ICONOGRÁFICOS: 1 Bilhete de Peça, 1 Notícia, 3 Artigos de Jornal, 2 Programas de Peça (Acervo: Centro de Doc. e Informação em Arte da FUNARTE RJ) 


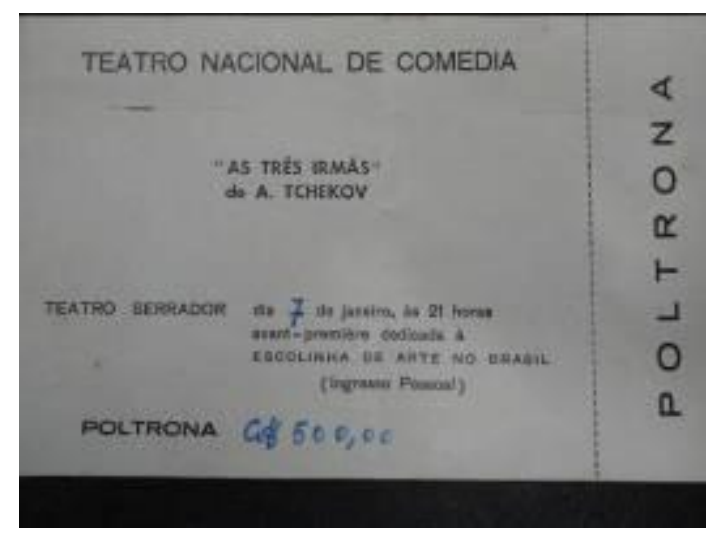

Bilhete da avantpremière (Acervo: Centro de Documentação $e$ Informação em Arte da FUNARTE RJ)

Capa do Programa da Peça (Acervo: Centro de Documentação $e$ Informação em Arte da FUNARTE $R J)$

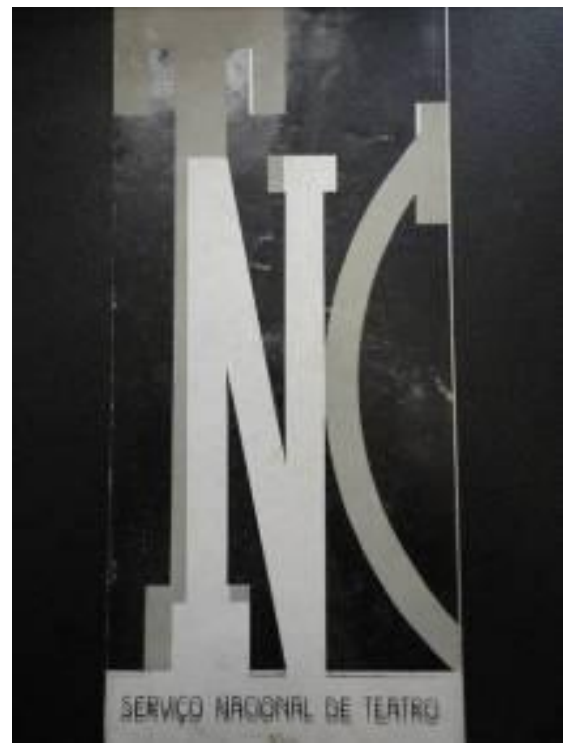

\section{ANTON TCHEKOV - UM FESTIVAL. Salvador, 1962.}

Produção: A Barca/ Escola de Teatro da Universidade da Bahia

Direção: Luiz Carlos Maciel

\section{O Pedido de Casamento:}

Elenco: Ronaldo Bonfim (Stepan Stepanichi Tchouvoukov); Sônia dos Humildes (Natalia Stepanovna); Roberto Assis (Ivan Vassilievitch Lomov).

\section{Trágico à Força}

Elenco: Eduardo Cabús (Ivan Ivanitch Tolkatchov); Leonel Nunes (Alexei Alesievitch Murachkin)

\section{O Jubileu}

Elenco: Ronaldo Bonfim (Chiputchin Andrei Andreitch); Sônia dos Humildes (Tatiana Alexeievna); Anatólio Oliveira (Kirine Kusmá Nicolitch); Dulce Shwabacker (Mertchutkina Feodorovna); Lenel Nunes, Roberto Assis e Eduardo Gabús (Empregados e Membros do Conselho).

Cenografia e Trajes: Norman Westwater; Assistente de Direção: Eduardo Cabús; Diretor de Cena: João Gama; Contra-Regra: Miguel Huertas;

Estreia no Teatro Santo Antonio da Escola de Teatro da Universidade Federal da Bahia, em abril de 1962, Salvador. Logo após, o mesmo Festival foi levado ao Festival de Teatro do Estudante, em Porto Alegre. 
DOCUMENTOS ICONOGRÁFICOS: 2 Programas de Peça (Acervo: Centro de Documentação e Informação em Arte da FUNARTE RJ)
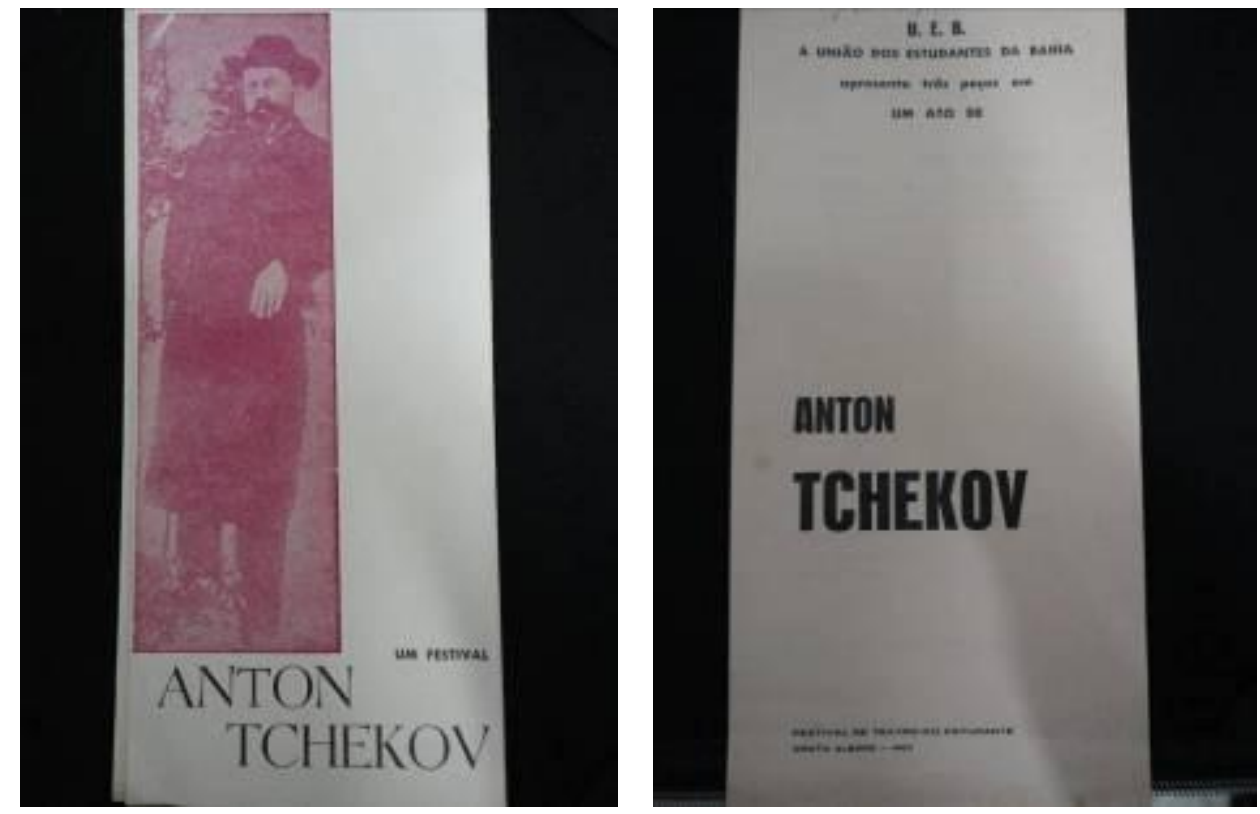

Programa da Encenação em Salvador (à esquerda) e Programa da Encenação em Porto Alegre (à direita). Anton Tchecov - um festival, dir: Luiz Carlos Maciel, 1962.

(Acervo: Centro de Documentação e Informação em Arte da FUNARTE RJ)

\section{TIO VÂNIA. São Paulo, 1962.}

Produção: Escola de Arte Dramática (EAD)

Direção: Alberto D'Aversa

Tradução: Aníbal Machado

Elenco: Vanya Santana (Marina); Edgard Gurgel Aranha (Mihail); Ricardo de Lucca (Tio Vânia); Luiz Nagib Amary (Serebriakov); Aracy Balabanian (Sonia); Lourdes de Moraes (Helena); Luiz Uchôa/ Ademir Rocha (Ilia); Carlos de Moura/Luiz Uchôa (Efim).

Cenografia: Nestor Soriano; Guarda-Roupa: Cláudia Gennari; Iluminação: Luiz Uchôa, Roberto Conforti e Benedito Silva; Sonoplastia: Mônica Joseph; Maquinista: João Sabiá.

Estreia em 29 de Julho de 1962, no Teatro de Arte Israelita Brasileiro, São Paulo. Seguiu em 04 de agosto para Ouro Preto, com Apresentação no Teatro Municipal. Logo após, apresentação entre os dias 28 de agosto e 07 de setembro de 1962, no XI Festival Universitário de Arte de Minas Gerais, Belo Horizonte.

DOCUMENTOS ICONOGRÁFICOS: 01 Programa de Peça e Livro EAD 4868 - Alfredo Mesquita (sem autor, p. 131). (Acervo: Centro Cultural São Paulo - Arquivo Multimeios) 
UM PEDIDO DE CASAMENTO. Belo Horizonte, 1962.

Direção: Luiz Nagib Amary

Tradução: Victor Merinov

Elenco: Ricardo de Lucca (Ciubicov); Grelciano Carlos Marcello (Lomov) e Luiz Uchôa (Natália).

Iluminação: Luiz Uchôa, Roberto Confortti e Benedito Silva; Maquinista: João Sabiá.

Espetáculo continha 3 peças em um ato: Sarrapalha, de Renata Pallottini (dir. Alberto D'Aversa), Rumo a Cardiff, de Eugene O'Neill (dir. Alberto D'Aversa) e Pedido de Casamento, de Tchekhov (dir. Luiz Nagib Amary).

Estreia entre 28 de agosto e 07 de setembro de 1962, no XI Festival Universitário de Arte de Minas Gerais, Belo Horizonte.

DOCUMENTOS INCONOGRÁFICOS: 01 Programa de Peça (Acervo: Centro Cultural São Paulo - Arquivo Multimeios).

\section{FESTIVAL TCHECOV. Belo Horizonte, 1964.}

Produção: Sérgio Mibielle / Pequeno Teatro de Arte

Sobre Os Males que o Fumo Produz/ O Urso e O Canto do Cisne.

Direção: Sérgio Mibielle e Marcelo Ranni.

Estreia em 11 de julho de 1964, no Teatro da Rádio Itatiaia, Belo Horizonte.

DOCUMENTOS ICONOGRÁFICOS: 1 Notícia que faz referência retrospectiva a esta encenação treze anos depois (Acervo: Centro de Documentação e Informação em Arte da FUNARTE RJ)

\section{UM PEDIDO DE CASAMENTO/ O ANIVERSÁrio. Porto Alegre, 1966}

Produção: Curso de Formação de Atores do CAD (Curso de Arte Dramática) da UFRGS

Direção: Prof. Cláudio Heemann

Tradução: Prof. Cláudio Heemann

\section{Um Pedido de Casamento}

Elenco: Alberto de Los Santos (Chubukov); Célio Alvarez (Lomov); Claudette Soibelmann (Natalia). 


\section{O Aniversário}

Elenco: Elálio Faria (Girim); Paulo J. Silveira (Seputchim); Adelar Mazetto (Um Criado);

Ida Celina Silveira (Tatiana); Neila C. Kiesling (Merchutkina); Alberto de Los Santos, Adelar Mazetto, Célio Alvarez, Claudette Soibelmann (A Delegação).

Cenografia: Carlos Alberto Mayer; Figurinos: Ubirajara G. Felix;

Estreia em julho de 1966, no Teatro Álvaro Moreyra, Porto Alegre, como Exercício Público de Interpretação apresentado pelos aluno do $2^{\circ}$ e $3^{\circ}$ anos de interpretação do Curso de Formação de Atores do C.A.D (Curso de Arte Dramática) da Faculdade de Filosofia da Universidade Federal do Rio Grande do Sul.

DOCUMENTOS ICONOGRÁFICOS: 1Programa de Peça e 2 Notícias de Jornal (Acervo: Centro de Documentação e Informação em Arte da FUNARTE RJ)

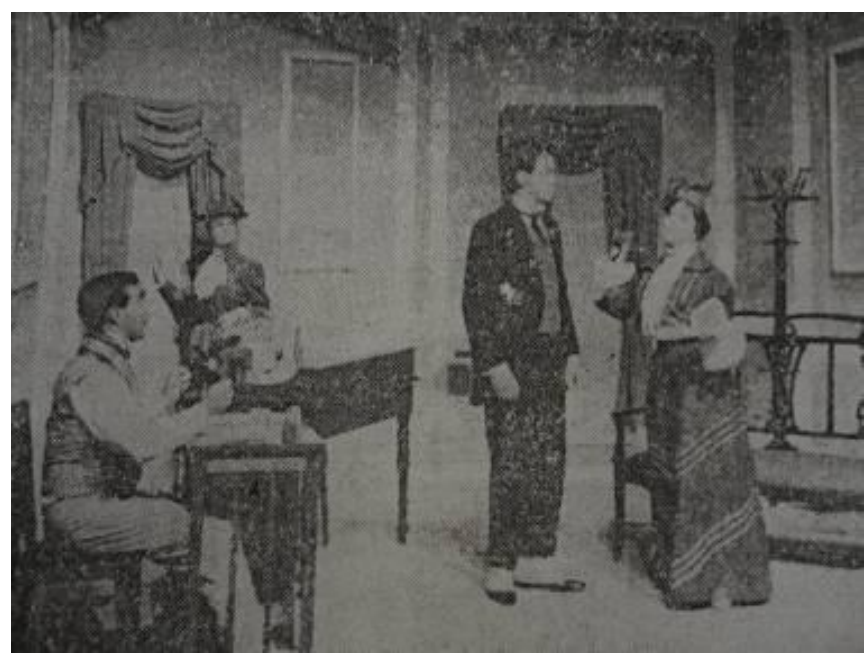

Foto de $O$ Aniversário em notícia "Teatro de Tchekov Cômico pelo CAD", Correio do Povo, Porto Alegre, 05 de julho de 1966 (sem créditos)

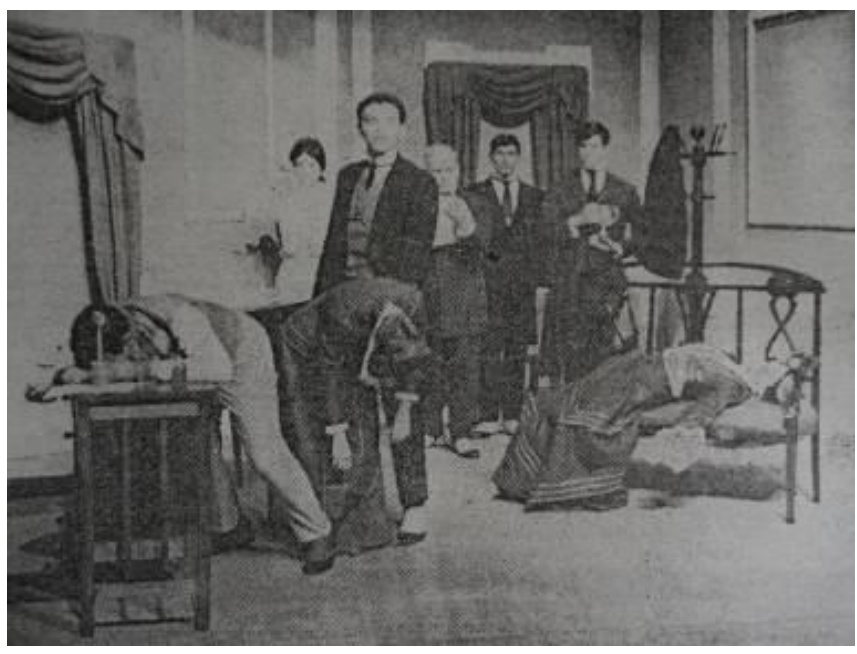

Foto de $O$ Aniversário notícia "Tchecov pelo CAD", Folha da Tarde, Porto Alegre, 05 de julho de 1966 (Créditos: Léo Guerreiro) 


\section{O PEDIDO DE CASAMENTO. Rio de Janeiro, 1966.}

("peça adaptada para o interior do Brasil, inclusive com o nome dos personagens")

Produção: Grupo de Teatro dos Alunos do Estúdio Raquel Levi.

Direção: Maria Helena Magalhães

Elenco: Guilherme Rodrigues (Ivanildo Limoeiro); Francisco Miranda (Severino Caximbá); Lilian Marques da Costa (Natalina Caximbá).

Cenários, Figurinos, Sonoplastia e Maquiagem: trabalho de grupo.

Espetáculo no qual constam outras duas peças em um ato: Blue Concerto, de Marvin Seiger e Antes do Café, de Eugene O'Neill. Apresentado no III Festival de Teatro Amador no dia 25 de novembro de 1966, no Colégio da Mabe, Rio de Janeiro.

DOCUMENTOS ICONOGRÁFICOS: 1 Programa de Peça (Acervo: Centro de Documentação e Informação em Arte da FUNARTE RJ)

\section{PEDIDO DE CASAMENTO. Marília, 1966.}

Produção: Grupo de Teatro André Luiz (GATAL)

"As peças 'Pedido de Casamento', 'Uma Consulta' e 'Lição de Botânica' foram encenadas pelo Grupo de Teatro André Luiz (GATAL) no espetáculo intitulado 'Festival de Comédias""

(Documento do Instituto Nacional de Artes Cênicas)

DOCUMENTOS ICONOGRÁFICOS: 1 Registro em Documento do Instituto Nacional de Artes Cênicas - INACEN/ Divisão de Documentação (Acervo: Centro de Documentação e Informação em Arte da FUNARTE RJ)

\section{UM PEDIDO DE CASAMENTO/ O JUBILEU. Rio de Janeiro, 1967.}

Produção: Fundação Brasileira de Teatro - FBT/ Dulcina de Moraes

Elenco: sem detalhes de elenco.

Estreia (sem detalhes de dia, mês e local) em 1967 como peças de formatura anual.

DOCUMENTOS ICONOGRÁFICOS: Registro no site Enciclopédia de Teatro Itaú Cultural: http://www.itaucultural.org.br/aplicexternas/enciclopedia_teatro/index.cfm?fu $\underline{\text { seaction }=\text { cias biografia\&cd } \_ \text {verbete }=491}$ 


\section{AS TRÊS IRMÃS. Belo Horizonte, 1967.}

Produção: Teatro Universitário da UFMG

Direção: Haydée Bittencourt

Elenco: Irene dos Reis (Olga); Patrícia Vivacqua (Irina); Maria Olivia (Macha); João Marcos (Tuzenbach); Luiz Gonzaga (Chebutikin); Herton Roitman (Solioni); Elza Lanza (Anfissa); Julio Quirino (Ferapont); Antonio Eustáquio (Vershinin); José Maria Mendes (Kuligin); Edivar Resende (Andrei), Romilda Leão (Natália), Moacir Salviano (Fedotik); Paulo Kassini (Vladimir Rode); Solange Deslandes (Arrumadeira),

Sonoplastia: Walden Carvalho; Iluminação: Alfio Coacci; Fotografia: Mauro Láper; Figurinos: Herton Roitman.

Estreia em 15 de setembro de 1967, no Teatro Marília, em Belo Horizonte.

De acordo com o Jornal Estado de Minas (14/09/1967), trata-se da primeira encenação da peça em Minas Gerais. Em Fevereiro de 1968 o mesmo espetáculo participou do V Festival Nacional de Teatro dos Estudantes, no Rio de Janeiro.

DOCUMENTOS ICONOGRÁFICOS: 1 Programa da apresentação em Belo Horizonte, 1 Programa da apresentação no Rio e 3 Notícias de Jornal (Acervo: Centro de Documentação e Informação em Arte da FUNARTE RJ)
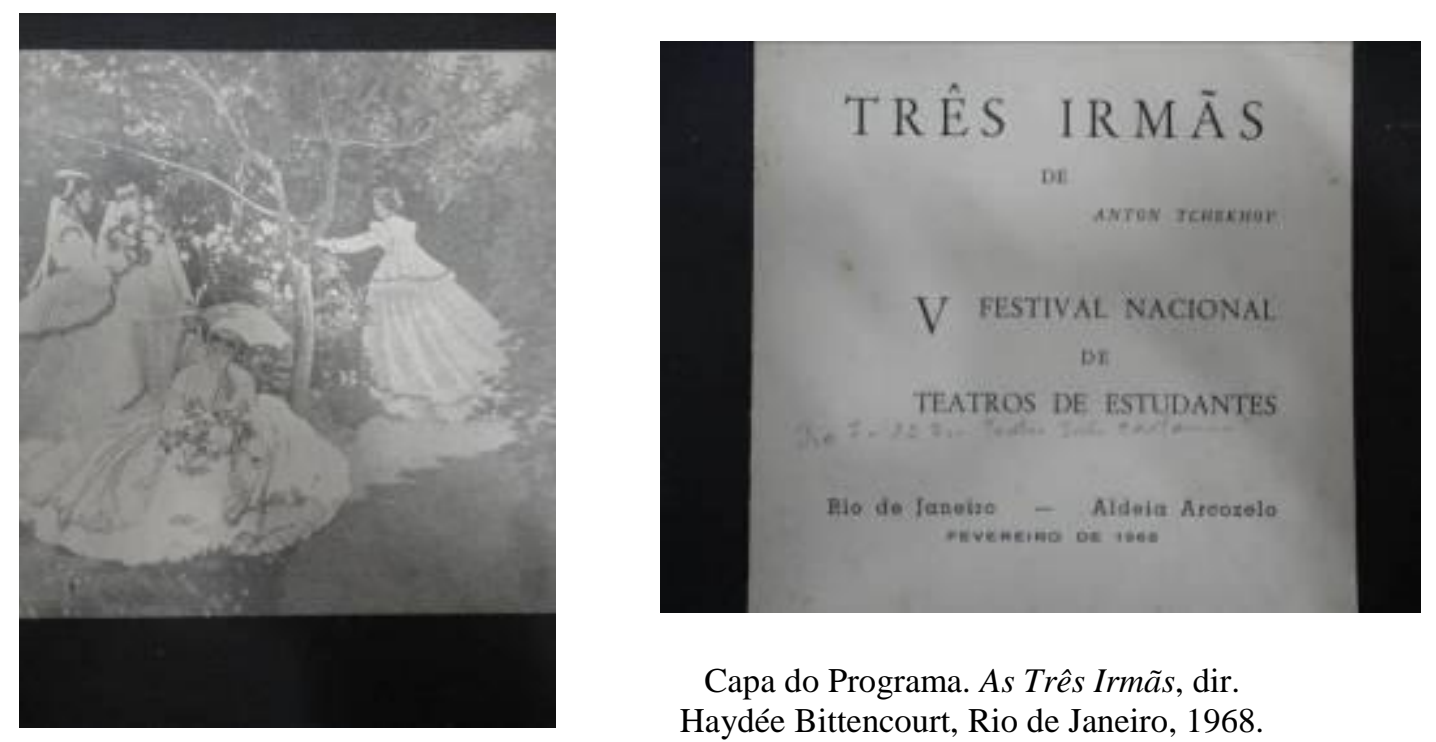

Capa do Programa. As Três Irmãs, dir. Haydée Bittencourt, Rio de Janeiro, 1968.

Capa do Programa. As Três

Irmãs, dir.Haydée Bittencourt, Belo Horizonte, 1967. 


\section{TIO VÂNIA. Curitiba, 1968.}

Produção: Teatro de Comédia do Paraná

Direção: Cláudio Correa e Castro

Tradução: Aníbal Machado

Elenco: Joel de Oliveira (Mihail Lvovich Atrov); Guimomar Pimenta (Niania); Salete Volokita (Ivan Petrovich Voinitski - Nânia); Edson D'Avila (Alexandre Vladimirovich Serebriakov); Rosinha de Castro (Sofia Alexandrovna - Sonia); Rachel Muniz (Helena Andreievna); Hugo Duarte (Ilia Ilich Teleguine); Esmeralda Mayo (Maria Vasilienvna Voiniskaia); Juve Garcia (Efim).

\section{Cenografia e Figurinos: Napoleão Moniz Freire}

Estreia no Tatro Guaíra de Curitiba, em 23 de maio de 1968.

DOCUMENTOS ICONOGRÁFICOS: 3 Notícias, 1 Artigo e 1 Programa (Acervo: Centro de Documentação e Informação em Arte da FUNARTE RJ)
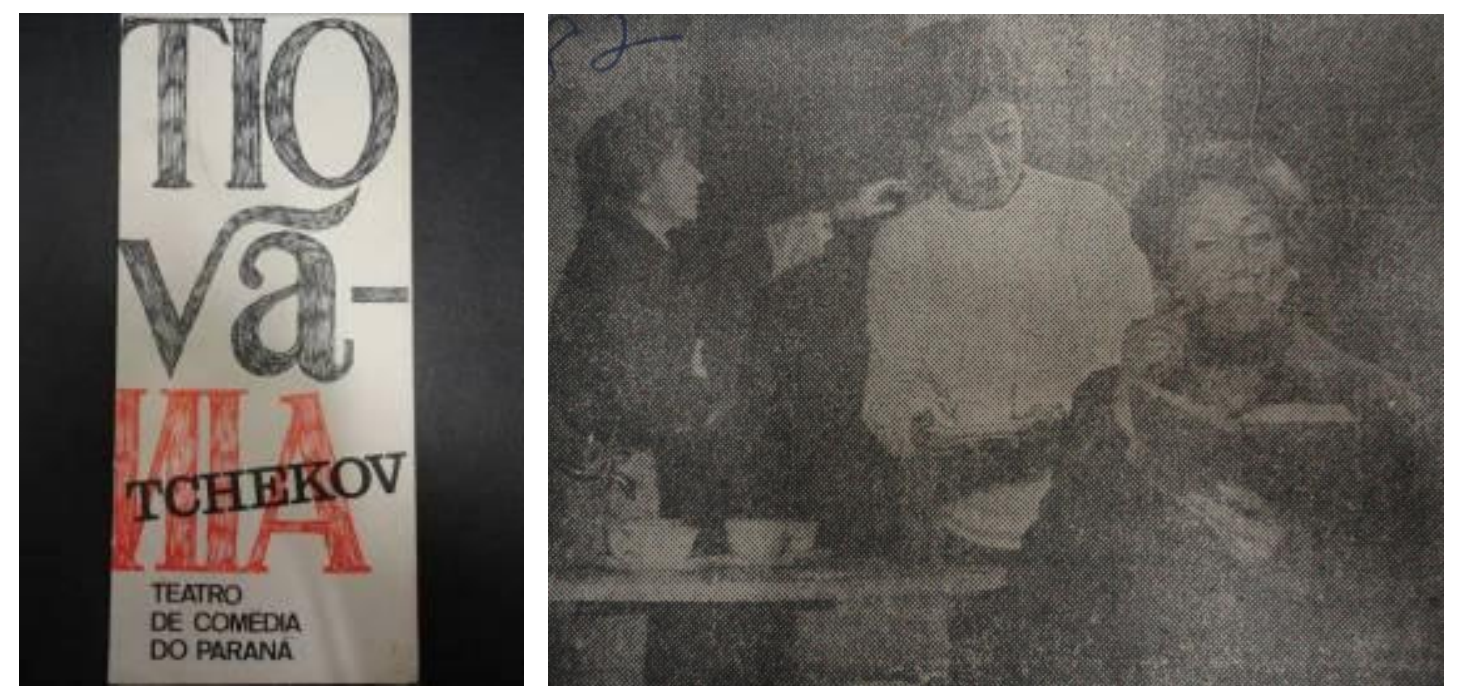

Programa da Peça (à esquerda). Tio Vânia, dir: Claudio Correia e Castro, Curitib a, 1968; e Foto de Cena da Peça (à direita), notícia "Começa dia 23 no Guaira termporada de 'Tio Vania"', O Estado do Paraná, 21 de maio de 1968 (sem créditos).

\section{O JARDIM DAS CEREJEIRAS. Rio de Janeiro, 1968.}

Produção: Grupo do Rio

Direção: Ivan de Albuquerque

Tradução: Eugenio Kusnet

Elenco: Vanda Lacerda (Lhubóv Andreivna Ranhévskaia); Leila Ribeiro (Anha, sua filha); Vera Gerdel (Vária, sua filha adotiva); Hélio Ari (Leonid Andrêievitch Gáiev, irmão de Lhubóv); Carlos Eduardo Dollabella (Iermolái Aleksêievitch Lopákhin, negociante); Rubens Corrêa (Piotr Seguêievitch 
Trofimov, estudante); José Fretias (Boris Borisovitch Iepikkodov, administrador); Antonio Victor (Firs, mordomo); Suzana Moraes (Dunhacha, empregada); Ênio Carvalho (Iacha, criado); Ivan Albuquerque (Um Passante); Adauto Novaes (Chefe da Estação); Antonio Miranda (Empregado do Correio); Lionel Linhares e Ney Mandarino (Empregados);

Cenografia: Marcos Flaksman; Figurinos: Kalma Murtino; Coreografia: Klaus Viana

Músicos: Luis Paulo Horta, Nilto Cavalcanti Filho, Eliseu Miranda.

O espetáculo inaugurou o Teatro de Ipanema, no Rio de Janeiro, em outubro de 1968. A peça fazia parte de um conjunto de espetáculos denominado "Ciclo Russo", no qual constavam Diário de Um Louco, de Gógol e A Mãe, de Górki/ Brecht.

DOCUMENTOS ICONOGRÁFICOS: 8 Notícias, 6 Artigos, 2 Anúncios e 1 Programa (Acervo: Centro de Documentação e Informação em Arte da FUNARTE RJ).

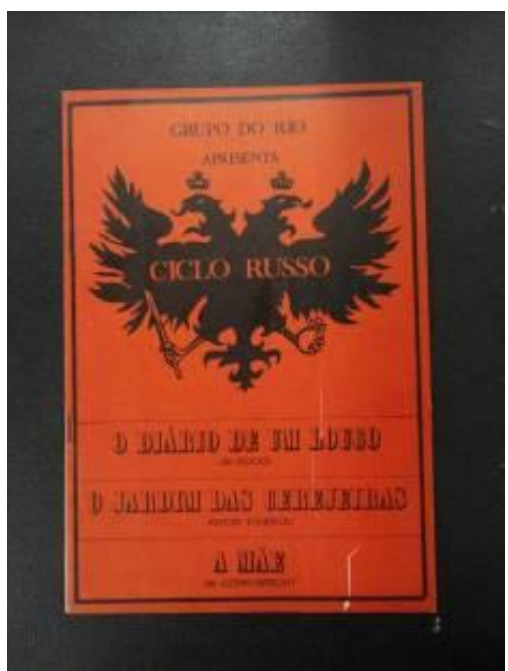

Programa de "O Ciclo Russo", no qual constavam as peças Diário de Um Louco, de Gógol, A Mãe, de Górki/ Brecht e O Jardim das Cerejeiras. (Acervo:

Centro de Documentação e Informação em Arte da FUNARTE RJ).

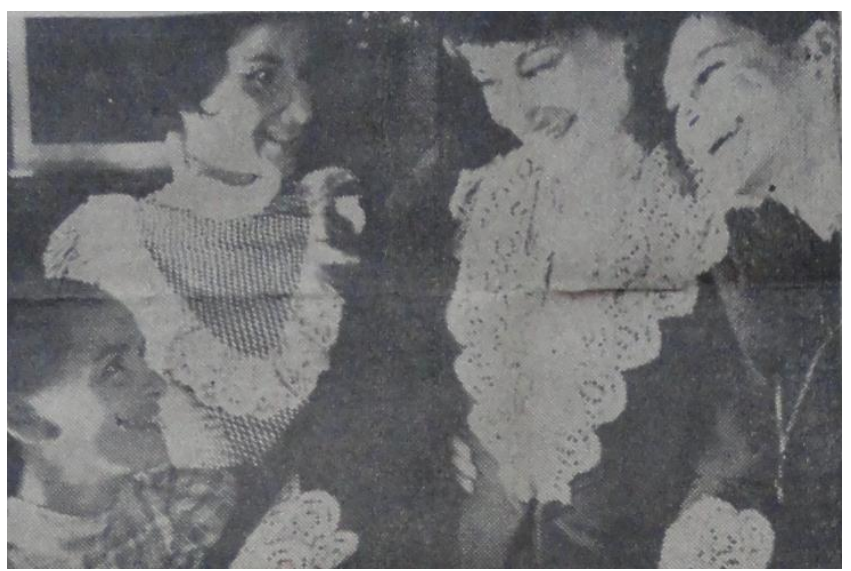

Da esquerda para a direita: Leila Ribeiro, Susana de Morais, Vanda Lacerda e Vera

Gertel. (Foto de notícia " O jardim das cerejeiras ou A comédia do mundo em transformação", Jornal do Brasil, Rio de Janeiro, 07 de outubro de 1968 - sem créditos) 


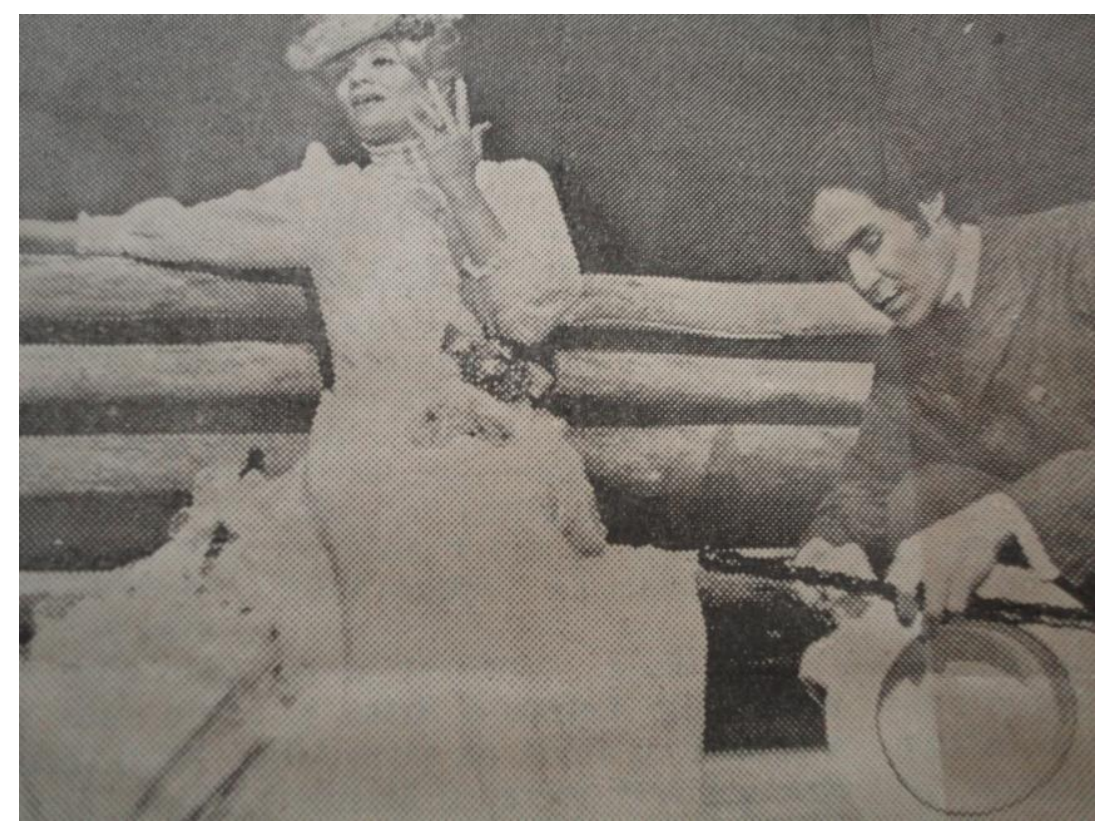

Vanda Lacerda (Ranhévskaia ) e Ênio Carvalho (Iacha) em Cena de O Jardim das Cerejeiras (Foto de notícia "O Jardim das Cerejeiras", Jornal do Comércio, Rio de Janeiro, 27 de outubro de 1968 - sem créditos)

\section{TRÁGICO À FORÇA/ O URSO. São Paulo, 1969.}

Produção: Grupo de Teatro Casarão

Direção: João Ribeiro Chaves

Elenco: (sem informação)

Estreia em 1969, no Teatro do Grupo Casarão, São Paulo.

DOCUMENTOS ICONOGRÁFICOS: Registro no site Enciclopédia de Teatro Itaú Cultural: http://www.itaucultural.org.br/aplicexternas/enciclopedia_teatro/index.cfm?fu $\underline{\text { seaction }=\text { cias_biografia\&cd_verbete }=492 \& c d \_i t e m=26}$

\section{AS TRÊS IRMÃS. São Paulo, 1972}

Produção: Teatro Oficina

Direção: José Celso Martinez Correa.

Tradução: José Celso Martinez Correa

Elenco: Maria Fernanda (Olga); Kate Hansen (Macha); Analú Prestes (Irina), Othon Bastos(Barão de Tusenbach); Lorival Parisi (Verchinina (sic)); José Celso M. Correa (Tchebutikin); Joel Cardoso (Ferraponte); Henrique Nurmbergber (Solioni); Flávio São Tiago (Koliguine); Celso Lopes (A. P. Fedotikin); Cidinha Milan (Natacha); Luiz Antonio M. Correa(Rode); Cecília Rabelo (Anfissa); Intérpretes em substituições: Fernado Peixoto (Andrei); Nelson Xavier (Barão de Tusenbach); Paulo César Pereio (Verchinine); Marcos Flaksman (Andrei). 
Música (Mendigos): Carlos W. Hartleb, Ricardo Rizek, Marcos Colmenero Lima, Jorge Varela, Geraldo Darbilli, Eneas Souza Jesus Filho.

Cenografia: Arthur Ricardo Piva; Figurino: Edinísio Ribeiro; Música: Carlos Hartleb e Ricardo Rizek.

Estreia dia 26 de dezembro de 1972 no Teatro Oficina, em São Paulo.

DOCUMENTOS ICONOGRÁFICOS: 01 Programa de Peça (Acervo: Centro Cultural São Paulo - Arquivo Multimeios). 87 fotos, 6 pastas com anotações de direção em caderno e em texto, 2 anúncios de jornal, 7 notícias e 2 artigos (Acervo: Arquivo Edgar Leuenroth - AEL-UNICAMP); 4 Notícias, 5 Artigos e 1 Entrevista (Acervo: Centro de Documentação e Informação em Arte da FUNARTE RJ)

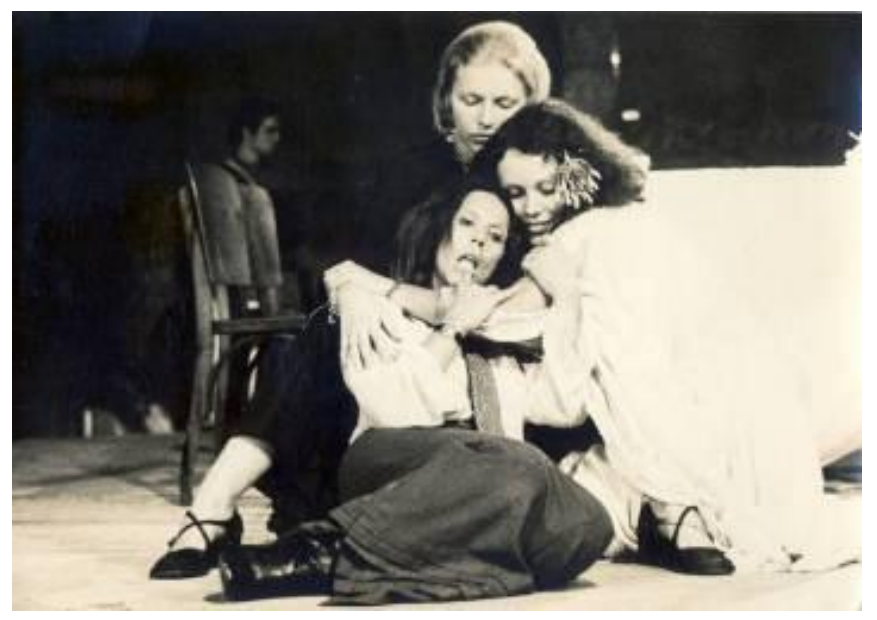

Foto: $4^{\circ}$ Ato, cena final - Maria Fernanda (Olga); Kate Hansen (Macha); Analú Prestes (Irina). (Acervo: AEL - Unicamp)

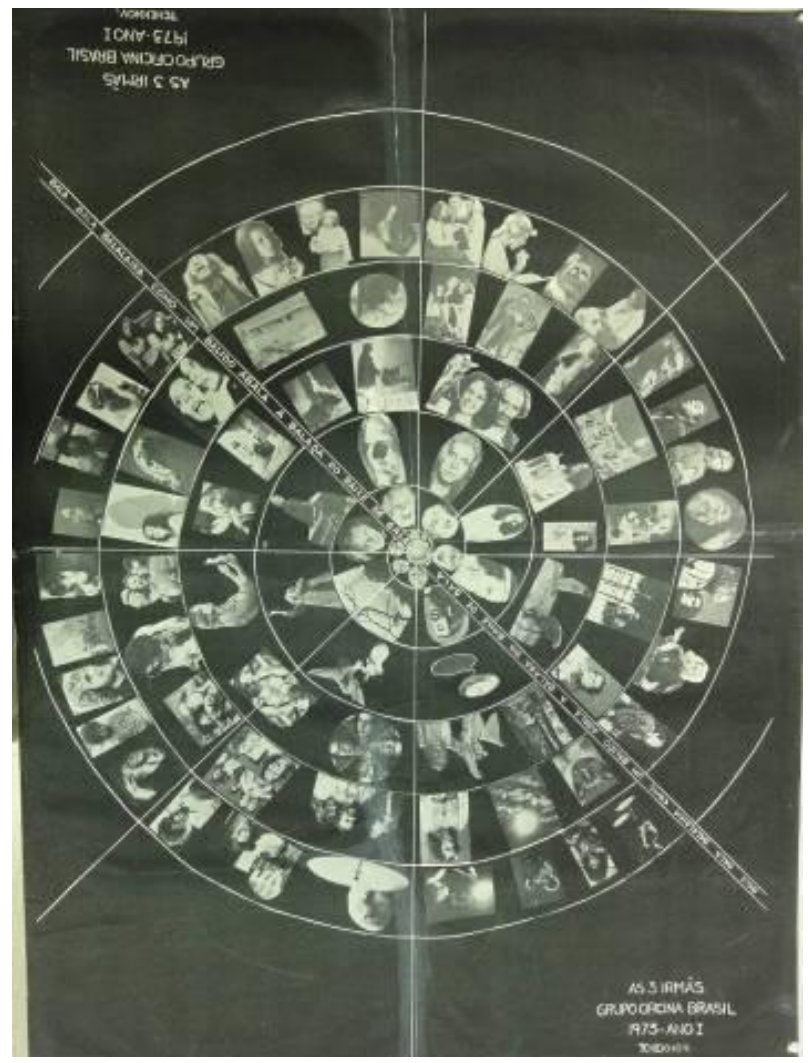

Foto: Cartaz de divulgação da peça. (Acervo: Unicamp) 


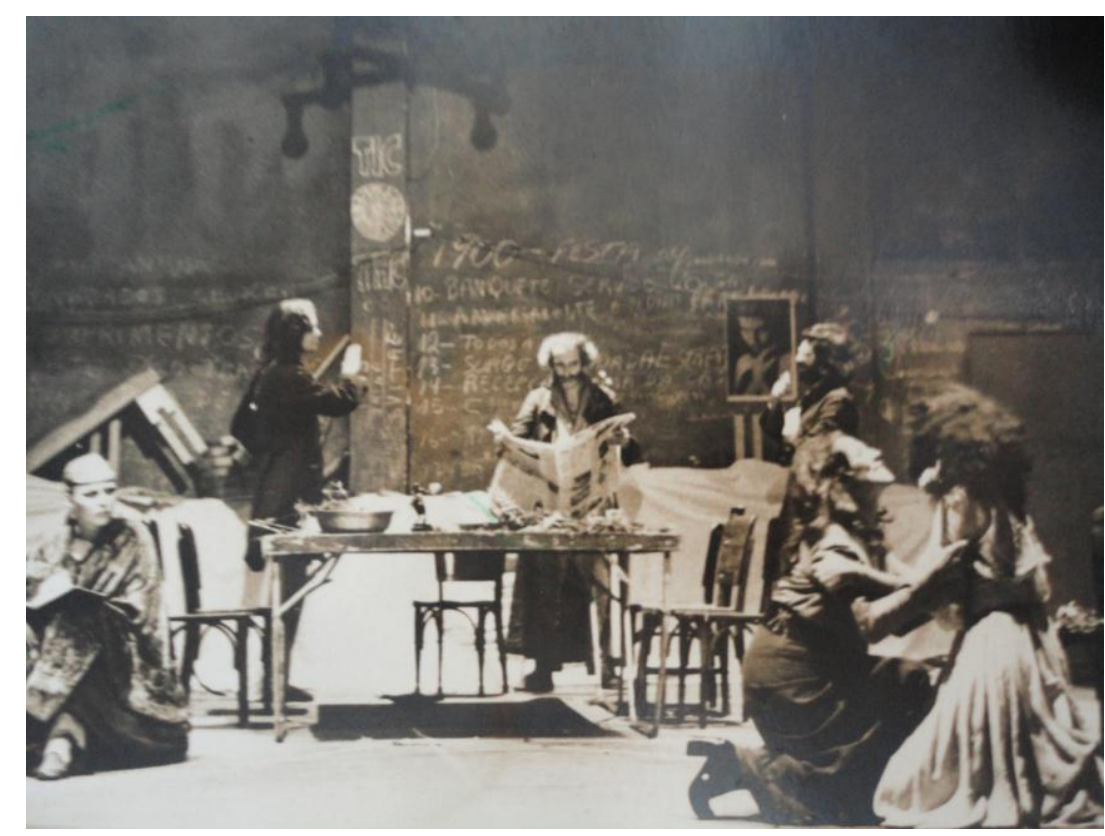

Foto: Cena do $1^{\circ}$ ato. Kate Hansen (Macha), Bastos (Barão de Tusenbach), José Celso M. Correa (Tchebutikin), Henrique Nurmbergber (Solioni), Maria Fernanda (Olga) e Analu Prestes (Irina). (Acervo: AEL - Unicamp)

A GAIVOTA. Rio de Janeiro, 1974.

Direção: Jorge Lavelli

Tradução: Bárbara Heliodora

Elenco: Wilson Mancio (Empregado); Reinaldo Amaral (Jacov); Thaise Costa (Empregada); René de Vielmond (Masha); David Pinheiro (Medvedenko); Luis de Lima (Sorin); Carlos Augusto Strazzer (Treplev); Renata Sorrah (Nina); Sérgio Britto (Dr. Dorn); Monah Delacy (Paulina); Tereza Rachel (Arkádina); Helio Ary (Shamraev); Cecil Thiré (Trigorin).

Dispositivo Cênico e Figurinos: Cláudio Segovia; Iluminação: Jorginho Carvalho; Sonoplastia: Enzo Miglietta e Plinio S. Barreto; Assistência de Direção: Hector Grillo; Execução de Figurinos: João Jorge Trintah; ContraRegra: Edgar dos Santos.

Estreia dia 29 de março de 1974 no Teatro Municipal do Rio de Janeiro.

DOCUMENTOS ICONOGRÁFICOS: 09 Notícias, 04 Artigos, 01 Programa de Peça e 01 Ficha Técnica de Registro no Serviço Federal (Acervo: Centro de Documentação e Informação em Arte da FUNARTE RJ) 


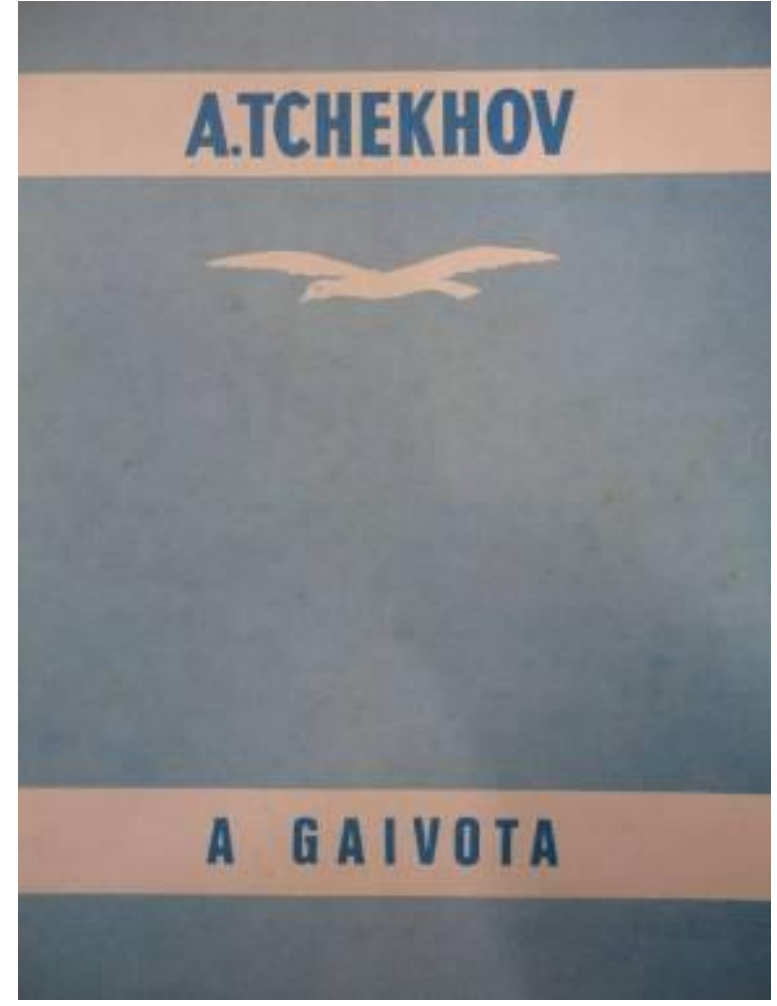

Capa do Programa de A Gaivota, dir. Jorge

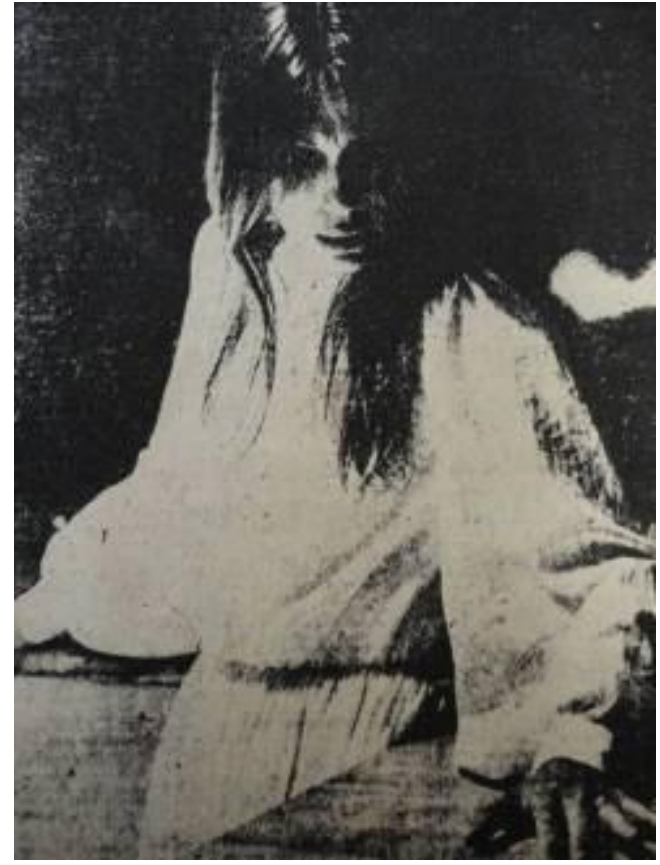

Renata SoraRenata Sorah (Nina) em cena do $1^{\circ}$ Ato de $A$ Gaivota (Fonte: $O$ Diário do Espírito Santo, Vitória, 29 de março de 1974.

Lavelli, Rio de Janeiro, 1974.

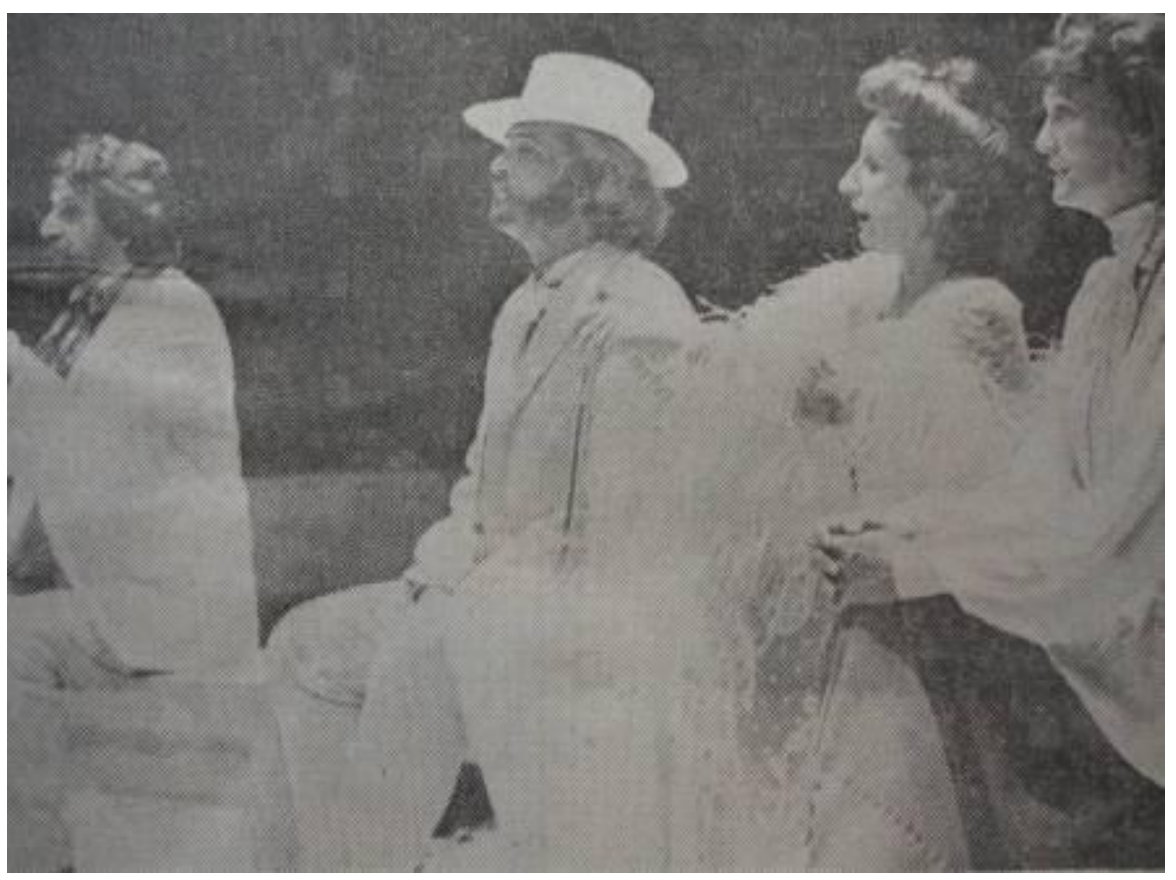

Foto: Cena do $1^{\circ}$ Ato de A Gaivota - Da esquerda para a direita - Luis de Lima (Sorin), Sérgio Britto (Dr Dorn), Tereza Raquel (Arkádina) e Monah Delacy (Paulina). (Fonte: Jornal do Brasil, Rio de Janeiro, 03 de abril de 1974 - sem créditos) 


\section{TIO VÂNIA. Salvador, 1974.}

Produção: Teatro Livre da Bahia

Direção: Álvaro Guimarães

Tradução: João Augusto

Elenco: Passos Neto (Alexandre); Sônia dos Humildes (Helena); Maria Idalina (Sônia); Jurema Pena (Maria); Jurandir Ferreira (Vânia); Benvindo Siqueira (Astrov); Fernando Lona (Bexiga); Carmen Bittencourt (Nânia); Carlos Nascimento (Efim).

Ambientação: Álvaro Guimarães; Iluminação: Suzuki; Som: Maria Íris; Carpintaria: Francisco de Paula; Gráfica e Publicidade: Haroldo Cardoso e Xisto Camardelli; Assistente de Direção: Lia Silveira; Assistente de Direção: Wilson D'Argolo.

Estreia: 05 de junho de 1974, no Teatro Vila Velha - Passeio Público, Salvador, Bahia.

DOCUMENTOS ICONOGRÁfICOS: 01 Programa de Peça (Acervo: Centro de Documentação e Informação em Arte da FUNARTE RJ)

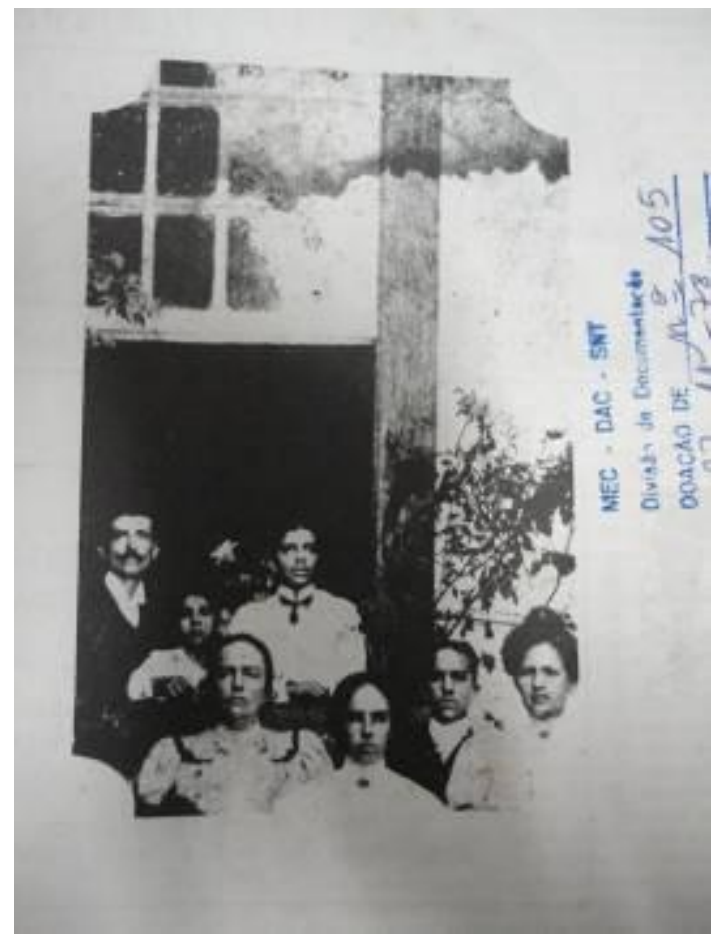

Contracapa do Programa com Foto do Elenco. Tio Vânia, dir: João Augusto, Salvador, 1974.

\section{O JUBILEU. Rio de Janeiro, 1975.}

Direção: Beto Diniz.

Tradução: Brutus Pedreira e Eugênio Kusnet. 
Elenco: Carlos Eugênio Dora (Andrei Andréievitch Chipútchin); Carmen Lúcia Borges (Delegação) ; Eduardo Torreão (Kusmá Nicoláievitch Khírin) ; Fátima Lopes (Tatiana Alekséievna); Felismino Menezes (Delegação); Márcia Farias (Nastássia Mertchútkina) ; Maria Lúcia Fernandes (Delegação).

Cenografia: Aracélie Coutinho e Beto Diniz ; Figurino: Beto Diniz, Fátima Lopes e Márcia Farias; Trilha Sonora: Beto Diniz e Paulo Severo; Iluminação: Beto Diniz e Paulo Severo; Coreografia: Beto Diniz; Eduardo Torreão e Maria Lúcia Fernandes.

Estreia em 1975.

DOCUMENTOS ICONOGRÁFICOS: Registro no site Enciclopédia de Teatro Itaú Cultural: http://www.itaucultural.org.br/aplicexternas/enciclopedia teatro/Enc_Cias/ds p_dados_evento.cfm?id_evento=535491\&st_evento=0\%20Jubileu

\section{UM PEDIDO DE CASAMENTO. Brasília (DF), 1975.}

Produção: ATARD

Direção: J. B. Galvão

Elenco: Gizele Lemper (Natália Chubucov); Carlos Gaio (Stepan Chubucov); Gê Martuchelli (Ivan Lomov).

Sonoplastia: Peixoto Júnior; Figurino: Piera; Maquilagem: Gininha Gaio; Cenário: Darlan; Som: Peixoto Júnior.

Estreia: 21 de abril de 1975, no Teatro Martins Pena, Brasilia. Peça fazia parte do Programa Teatro das Segundas-Feiras.

DOCUMENTOS ICONOGRÁFICOS: 01 Programa de Peça (Acervo: Centro de Documentação e Informação em Arte da FUNARTE RJ)

\section{TIO VÂNIA. São Paulo, 1975.}

Produção: Grupo Heros

Direção: Emilio Di Biasi

Tradução: Emilio Di Biasi

Elenco: Bri Fiocca (Marina); Odilon Fagner (Mihail Lvovich Astrov); Walter Martins (Ivan Petrovich Voinitzki - Vânia); Raimundo Matos (Alexandre V. Serebriakov); Stela Freitas (Sofia Alexandrovna - Sonia); Thereza Freitas (Helena Andreiévna); Maria Alice Costa (Maria Vassilievna Voinitzkaia); Carlos Alberto Seidl (Iliá Ilitch Teleguine); Carlos Fischer (Efin).

Figurinos: Grupo Heros; Cenografia: Emilio Di Biasi; Iluminação: Carlos Siqueira ; Assistente de Direção: Valéria Silveira; Música: Carlos Fischer; Cartaz e Programação Visual: Carlos Schmidt; 
Estreia dia 9 de maio de 1975 no Teatro Ruth Escobar, em São Paulo. Primeira montagem profissional deste texto na cidade.

DOCUMENTOS ICONOGRÁFICOS: 10 Notícias, 04 Artigos e 01 Programa de Peça (Acervo: Centro de Documentação e Informação em Arte da FUNARTE RJ)

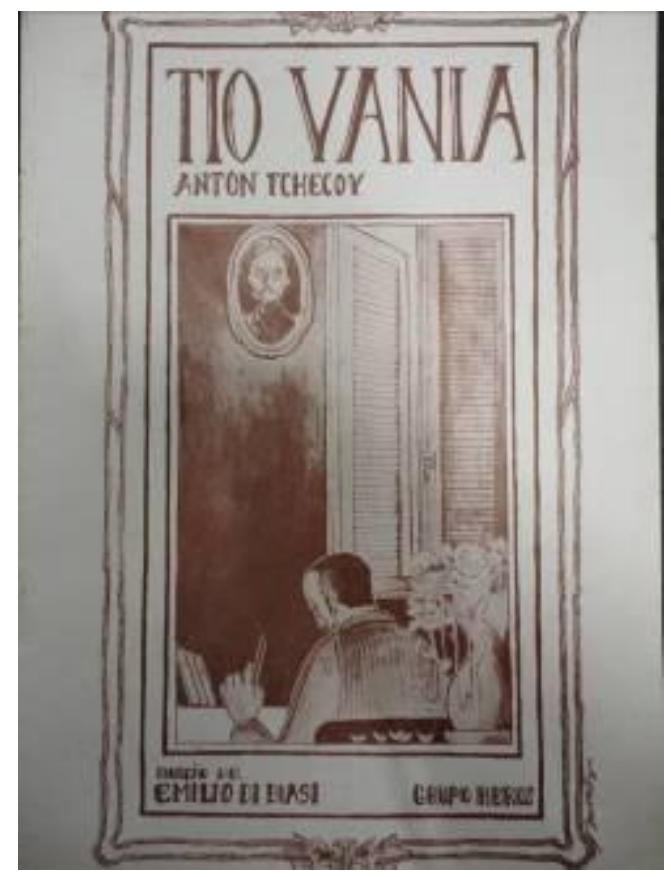

Programa da Peça Tio Vânia, dir. Emilio Di Biasi, São Paulo, 1975.

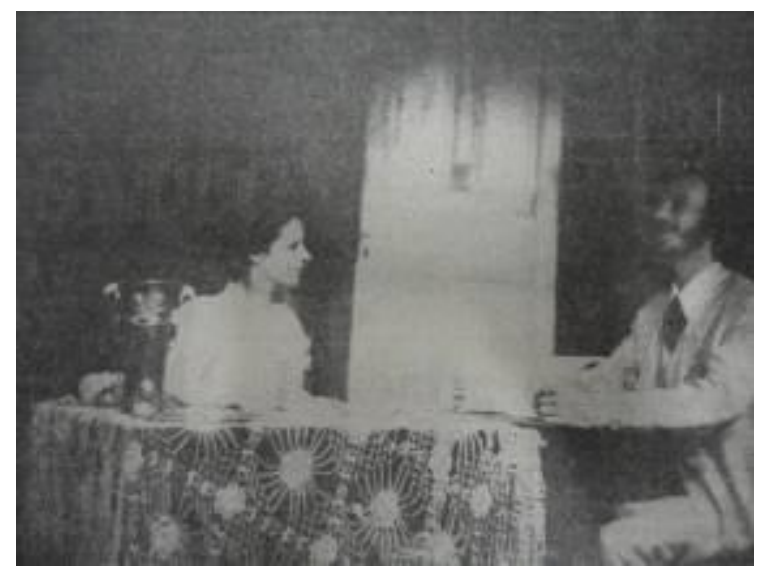

Thereza Freitas (Helena) e Odilon Fagner (Astrov) (Foto retirada de notícia "Grupo Eros Mostra a Visão Amarga do Cotidiano de Tchecov", Tribuna de Santos, em 27 de julho de 1975 sem créditos)

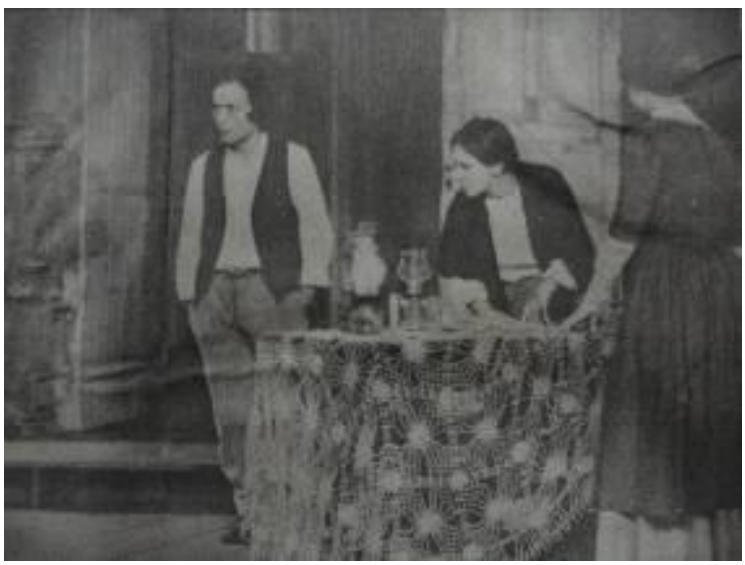

Walter Martins (Vânia) e Stela Freitas (Sônia) (Foto retirada de notícia "Uma peça famosa, que quase ninguém viu", Jornal da Tarde, 09 de maio de 1975 - sem créditos) 


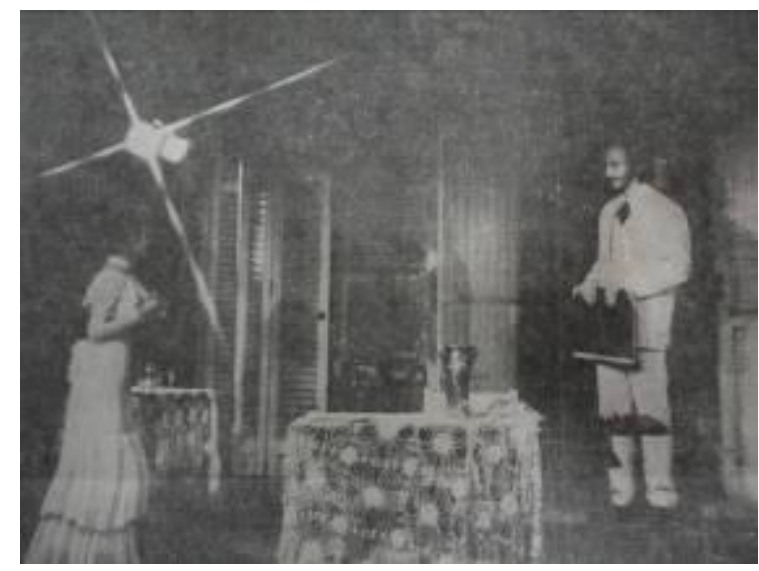

Thereza Freitas

(Helena) e Odilon Fagner (Astrov) (Foto retirada de notícia "Dois dias para ver o teatro de Tchecov", A Tribuna de Santos, em 23 de julho de 1975 sem créditos)

\section{UM PEDIDO DE CASAMENTO/ O URSO/ SOBRE OS MALES QUE TRAZ O TABACO. Araraquara, 1976 (?)}

Produção: Araken Toledo Pires/ Teatro Experimental de Comédia de Araraquara.

\section{Um Pedido de Casamento}

Direção: Wallace Leal V. Rodrigues

Tradução: Leonid Timochenko

Elenco: Mario Barra (Ciusicov); Oscar Rodrigues (Lomov) e Alice de Oliveira (Natalia Stepanovna).

\section{O Urso}

Direção: Wallace Leal V. Rodrigues

Tradução: Wallace Leal V. Rodrigues

Elenco: Mario Barra (Luká); Maria Aparecida Assis (Elena Popovna) e Moacir Marchese (Simirnov)

\section{Sobre os Males que Traz o Tabaco}

Direção: Wallace Leal V. Rodrigues

Tradução: Wallace Leal V. Rodrigues

Elenco: Mario Barra Ivan (Ivanovitch Husmeadorov).

Assistentes de Direção: Mario Barra, Antonio Reis da Silva, Oscar Rodrigues; Assistente de Produção: Pedro Peiró; Cenografia: Diego da Vega; Maquilagem: Leda de Oliveira, John Brown e Arthur Batelli; Iluminação:; Figurinos: Felipe Luiz; Sonoplastia: Everton Atávolli;

Estreia sem data específica. 
Peças faziam parte de repertório amplo do Teatro Experimental de Comédia de Araraquara, no qual constavam, além das já mencionadas: A Mão do Macaco, de William Jacobs; Xeque Mate, de Keneth Goodman; Os Dois Faladores, de Cervantes; Se os Homens Jogassem Cartas como as Mulheres, de George Kaufman; O Menino de Moony não Chora, de Tennesse Williams; Amigos de Viagem, de Noel Coward, Ressonâncias, de Alice Gerstemberg e O Protocolo, de Machado de Assis.

DOCUMENTOS ICONOGRÁFICOS: 01 Encarte com Repertório Completo do Grupo (Acervo: Centro de Documentação e Informação em Arte da FUNARTE RJ).

\section{O URSO. Vitória, 1976.}

Produção: Diretório Acadêmico Carlos Cavalcanti

Direção: José Guilherme de Castro Alves

Elenco: José Guilherme (Lucas (sic)); Paula Cunha Moraes (Popova) e Antonio Dutra (Smirnov).

Cenografia: Paulo César Jeveaux; Figurino: Simone Guimarães; Assistente de Direção: Márcia Braga; Sonoplastia: Sérgio Luis Garcia; Iluminação: Sérgio Luis Garcia; Contra-Regra: Nádia Batista.

Estreia dia 06 de junho de 1976, no Teatro Carlos Gomes (sessão única). Outra apresentação a 26 de outubro, no Auditorio das Obras Combonianas, ambas em Vitória, Espírito Santo. Logo após, a montagem foi levada a Sergipe, no Festival de Arte Moderna de São Cristóvão.

DOCUMENTOS ICONOGRÁFICOS: 01 Notícia de Jornal e 01 Registro no Serviço Nacional de Teatro (Acervo: Centro de Documentação e Informação em Arte da FUNARTE RJ).

O CASAMENTO DE NATAlina. São Paulo, 1977.

Adaptação de Célia Helena para a peça $O$ Pedido de Casamento.

Direção: Carlos Augusto Strazzer.

Elenco (sem especificação de personagens): Célia Helena, Augusto Strazzer e Ana Maria

Estreia em 1977, São Paulo. Espetáculo fazia parte da I Vivência Integrada de Teatro e era destinado a adolescentes, para ser apresentado em espaços de assistência social, a antiga FEBEM e escolas.

DOCUMENTOS ICONOGRÁFICOS: Registro no site Enciclopédia de Teatro Itaú Cultural: 
http://www.itaucultural.org.br/aplicExternas/enciclopedia_teatro/Enc_Cias/d sp_dados_evento.cfm?id_evento $=402997 \&$ st_evento $=0 \% 20$ Casamento $\% 20 d$ e\%20Natalina. Registro também em Licia, Nydia. Célia Helena - uma atriz visceral. São Paulo: Imprensa Oficial, 2010, p. 68.

\section{PEDIDO DE CASAMENTO/ O URSO. SÃO PAULO, 1977.}

Produção: Grupo de Teatro Anhangá - Faculdade Comunicação Social Anhembi-SP

Direção: Pedro Marcos

\section{Pedido de Casamento}

Elenco: Luiz Antonio, Fernando e Vera Lúcia Araújo.

\section{O Urso:}

Elenco: Alex Millim, Zaira Bellicana, Pedro Marcos e Guilherme Cícero.

Estreia em São Paulo em 1977 (temporada de três meses). Estreia em Belo Horizonte em 27 de maio de 1977. Em seguida, o grupo dirigiu-se a Salvador e Rio de Janeiro.

DOCUMENTOS ICONOGRÁFICOS: 02 Notícias (Acervo: Centro de Documentação e Informação em Arte da FUNARTE RJ).
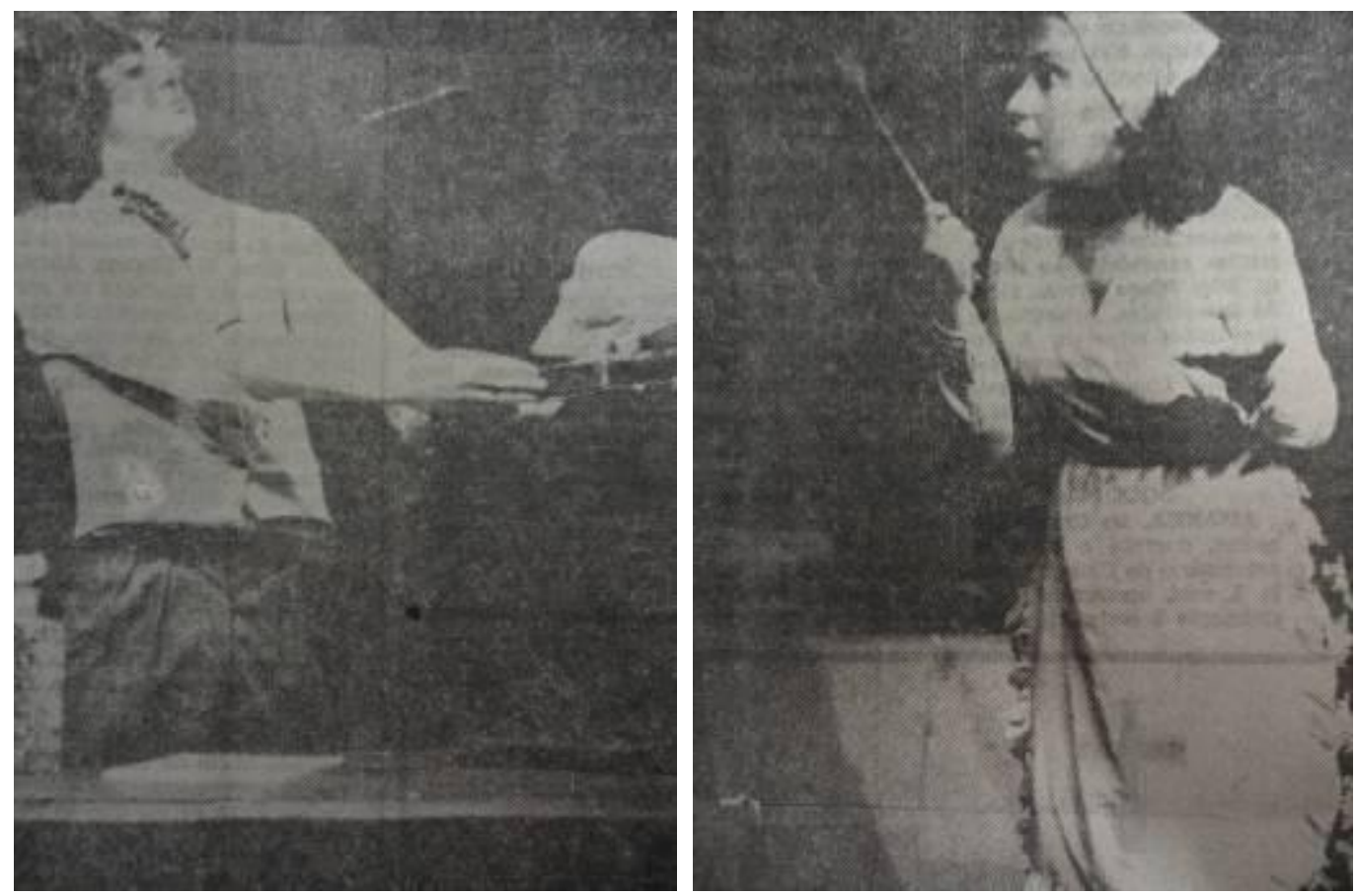

À esquerda, cena de $O$ Urso, Alex Millim (Smirnov); à direita, cena de $O$ Pedido de Casamento, Vera Lúcia (Natacha). (Fotos retiradas de Notícia "Duas Peças de Tchékhov no Teatro Marília", Diário da Tarde, Belo Horizonte, 27 de maio de 1977 - sem créditos). 


\section{PLATONOV. Rio de Janeiro, 1980.}

Produção: Escola O Tablado

Direção: Maria Clara Machado

Tradução: Ronald Fucs

Elenco: Vicentina Novelli (Ana Petrovna); Octávio Moraes (Serguei Pavlovitch Voinitzev); Bia Nunes (Sofia Egorovna Voinitzev); Bernardo Jablonski (Mikhail Vassilievitch Platonov); Maria Clara Mourthé (Sacha Ivanovna Platonov); Ricardo Kosovski (Nicholas Ivanovitch Triletski); Juarez Assumpção (Ivan Ivanovitch Triletski); Fernando Berditchevski (Abram Abramovitch Vengerovitch); Toninho Lopes (Petrin); Ovídio Abreu (Porfiry Glagolaev); Raul Penido (Kirl Glagolaev); Silvia Nunes (Maria Efimova Grekova); Carlos Wilson (Ossip); Eduardo Bueno (Yakov); Maria Lucia Veiga (Kátia); Markov (Janser Barreto); Pedro Pimentel (Criança); André Nunes (Criança); Andréa Veiga (Criança); Ernesto Picollo (Criança); Eliane Contrim (Dama); Silvia Fucs (Dama); Regina Lopes (Dama); Wilson Spinola (Cavalheiro).

Preparação Corporal: Regina Miranda; Cenografia: Helio Eichbauer; Figurinos: Kalma Murtinho; Iluminação: Cláudio Neves. Contra-Regra: José Severino da Silva e Octávio Moraes.

Estreia em 26 de maio de 1980, no Teatro Tablado, Rio de Janeiro.

DOCUMENTOS ICONOGRÁFICOS: 01 Programa de Peça, 03 Notícias, 04 Artigos e 01 Ficha de Registro no SNT (Acervo: Centro de Documentação e Informação em Arte da FUNARTE RJ).

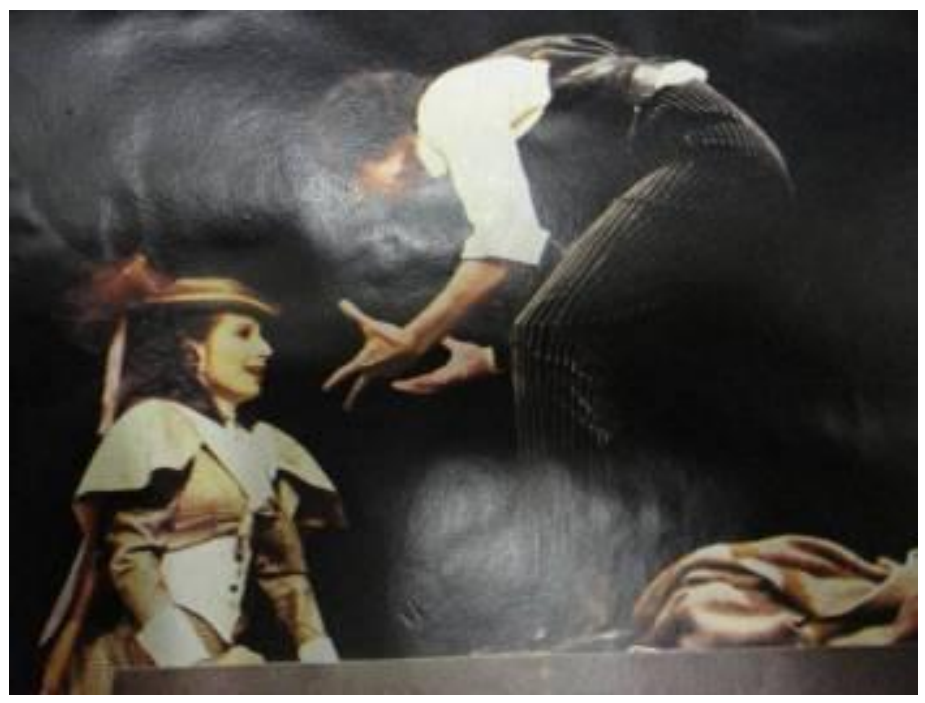

Bia Nunes (Sofia), à direita e Bernardo (Platonov) Jablonski

(Fonte: "Leveza Russa", Revista Veja, 04 de junho de 1980 Foto: Fernando Pimentel) 


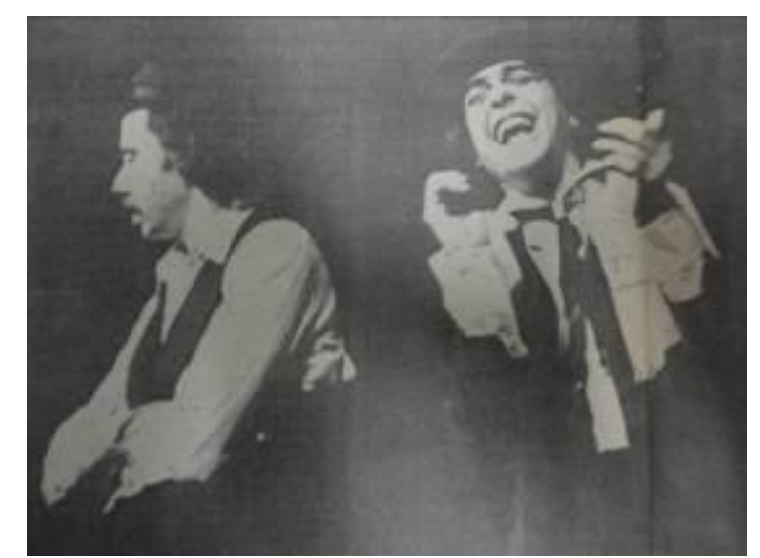

Bernardo Jablonski (Platonov), à esquerda, e Toninho Lopes (Petrin), à direita. (Fonte: " Maria Clara Machado, a direção para adultos", Jornal do Brasil, Rio de Janeiro, 03 de junho de 1980 - sem créditos)

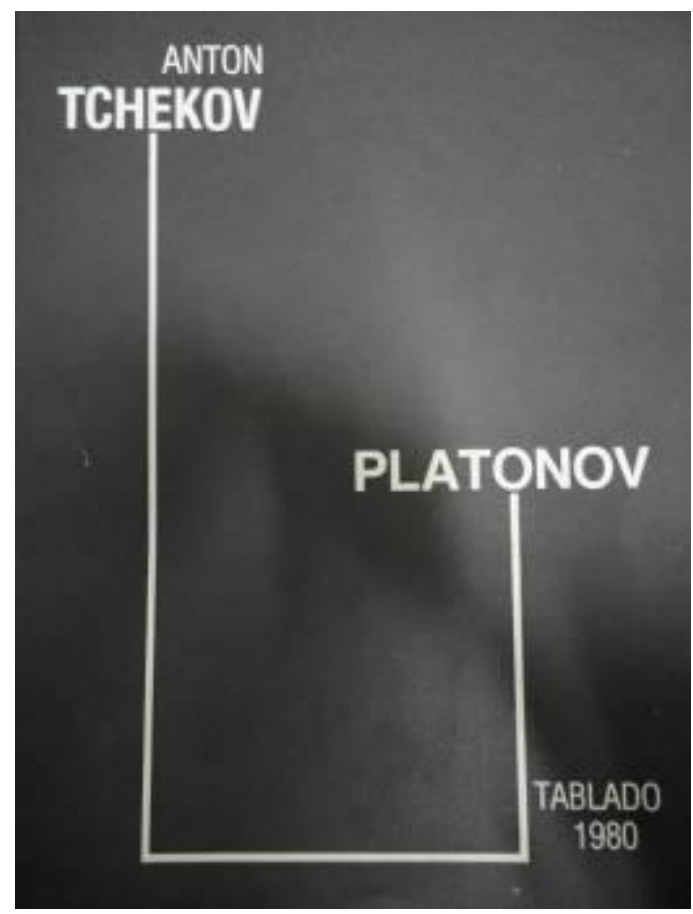

Programa da Peça. Platonov, dir. Maria Clara Machado, Rio de Janeiro, 1980.

\section{O JARDIM DAS CEREJEIRAS. São Paulo, 1982.}

Produção: Stromboli Produções Artísticas

Direção: Jorge Takla

Tradução: Millôr Fernandes

Elenco: Cleyde Yaconis (Liubov Andrêievna Raniévskaia); Ednei Giovenazzi (Iermolai Alexêievitch Lopakhine); Walderez de Barros (Vária); Francarlos Reis (Leonid Andreiêvitch Gaiév); Abrahão Farc (Firs); Ileana Kwasinski (Charlotte Ivánovna); Eugênia de Domenico (Ânia); George Otto (Pétia Trofimov); Sérgio Ropperto (Epikhodov); Carlos Silveira (Iacha); Noemi Gerbelli (Duniacha); Osmar Di Pieri (Simionov Pichtchik); Rubens Rollo (Viajante e Fucionário dos Correios); João Paulo Mendonça (Convidado do Baile). 
Cenografia: Sonia Mota; Figurinos: Kalma Murtinho; Consultoria para língua russa: Tatiana Junod; Trilha Sonora: Tunica.

Estreia no Teatro Anchieta, em São Paulo em 14 de janeiro de 1982

DOCUMENTOS ICONOGRÁFICOS: 06 Artigos, 03 Notícias e 01 Programa de Peça

(Acervo: Centro de Documentação e Informação em Arte da FUNARTE RJ).01 Programa de Peça (Acervo: Centro Cultural São Paulo - Arquivo Multimeios).

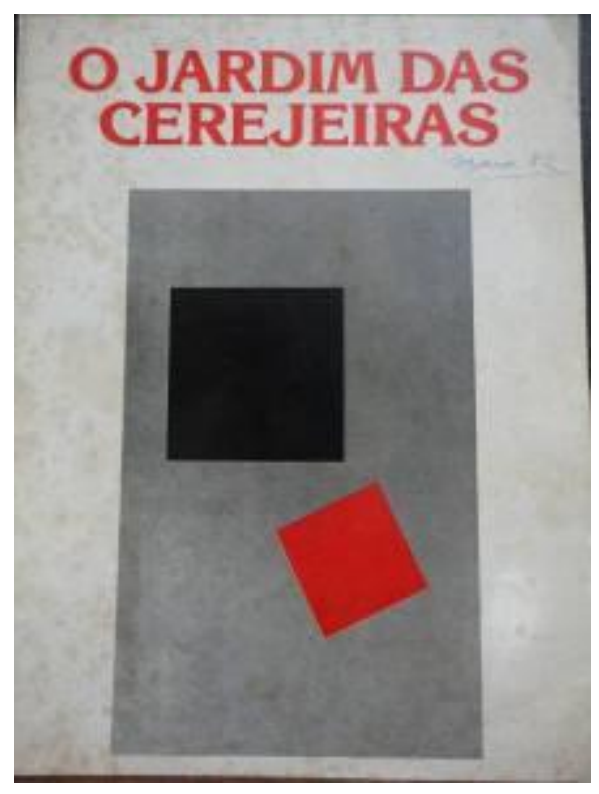

Programa da Peça. O Jardim das Cerejeiras, dir. Jorge Takla, São Paulo,1982.

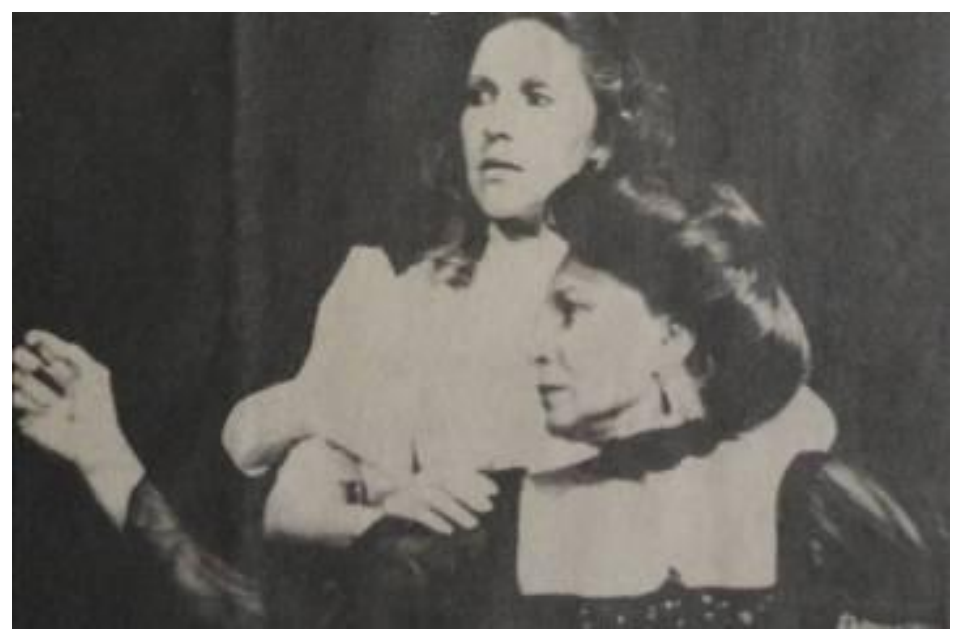

Foto: da esquerda para a direita, Eugênia de Domenico (Ânia) e Cleyde Yáconis Ranévskaia). (Fonte: "Tchekov - a burguesia falida, medrosa e hipócrita", Jornal Cidade de Santos, Santos, 13 de junho de 1982 sem créditos). 


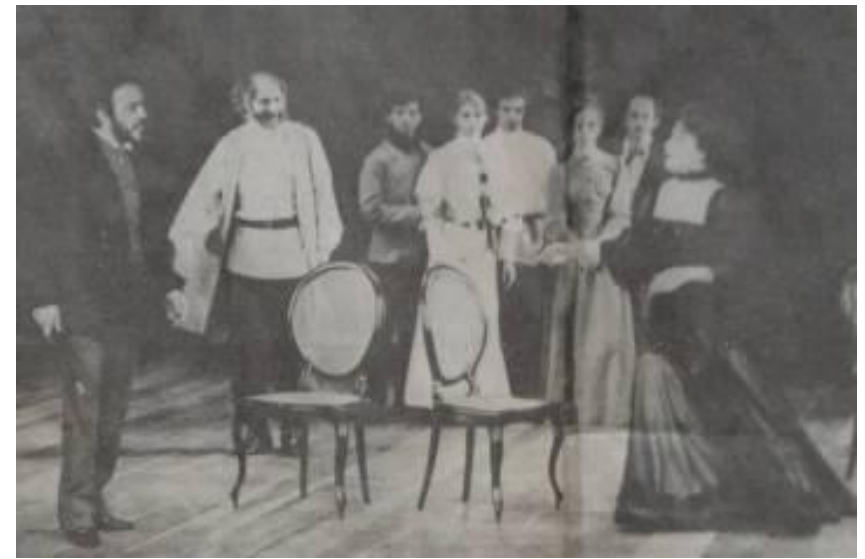

Foto: No primeiro plano, Ednei Giovenazzi (Iermolai Alexêievitch Lopakhine), Osmar Di Pieri (Simionov Pichtchik) e Cleyde Yaconis (Liubov Andrêievna Raniévskaia). (Fonte: "Um Jardim das Cerejeiras muito fiel a Checov", Jornal da Tarde, São Paulo, 14 de janeiro de 1982 - sem créditos)

\section{O TRÁGICO À FORÇA. São Paulo, 1982.}

Direção: Marcio Aurélio

Tradução: Antonio Miranda Catarino

Adaptação Livre de Márcio Aurélio, Edith Siqueira e Elias Andreato que reunia os textos de Tchékhov: Malefícios do Fumo, Pedido de Casamento, $O$ Trágico à Força e O Urso e O Canto do Cisne.

Elenco: Elias Andreato; Edith Siqueira; Tato Fischer; Rodrigo Matheus e Maurício Maia

Direção Musical: Tato Fischer; Assitência de Direção: Iolanda Huzak e Maurício Maia;

Estreia em São Paulo, no dia 23 de junho de 1982, no Studio São Pedro, São Paulo.

DOCUMENTOS ICONOGRÁFICOS: 07 Artigos, 06 Notícia, 01 Programa de Peça, 01 Registro Técnico do INACEN e 01 Documento Interno do Grupo com detalhes do Processo de Trabalho e Montagem. (Acervo: Centro de Documentação e Informação em Arte da FUNARTE RJ).

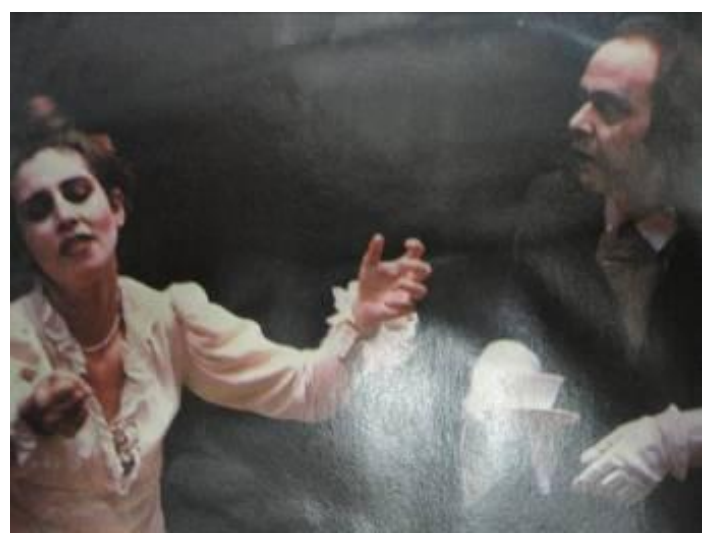

Edith Siqueira e Tato Fischer em Trágico à Força. (Fonte: "A alentadora volta aos clássicos", Revista Isto É, 07 de julho de 1982 Foto: Renata Falzoni) 


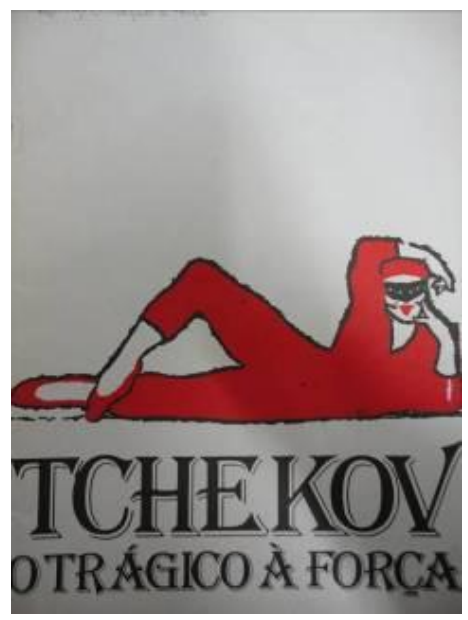

Programa da Peça. O Trágico à Força, dir. Márcio Aurélio, São Paulo, 1982.
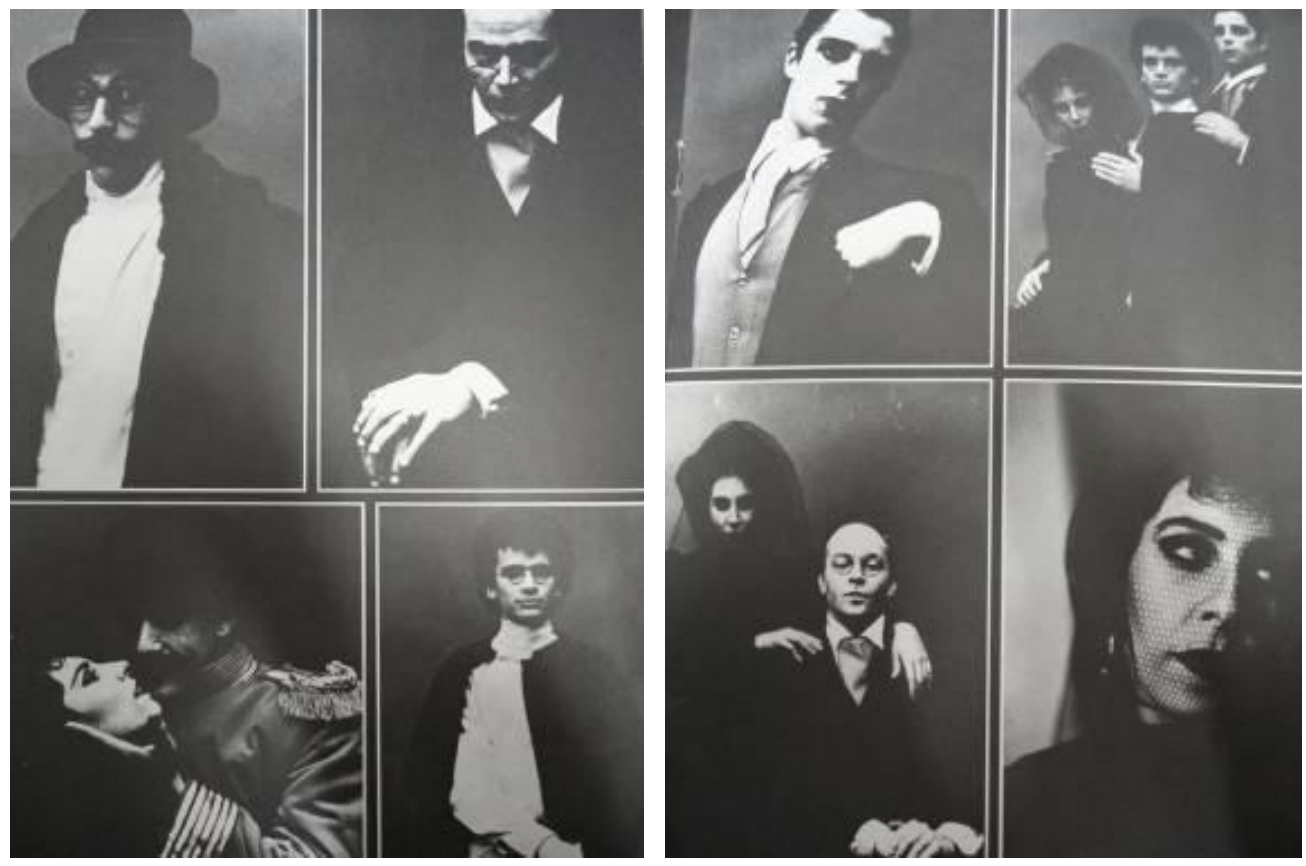

Elias Andreato (esquerda, acima), Tato Fischer (direita, acima), Edith Siqueira e Elias Andreato (esquerda, abaixo),Mauricio Maia (direita, abaixo). Foto 2 (à direita): Rodrigo Mateus (esquerda, acima), Edith Siqueira, Maurício Maia e Rodrigo Mateus (direita, acima), Edith Siqueira e Tato Fischer (esquerda, abaixo) e Edith Siqueira (direita, abaixo) (Fonte: Programa da Peça - Seção de Fotos do Elenco/Personagens)

\section{O PEDIDO DE CASAMENTO. Rio de Janeiro, 1982.}

Produção: Ciganos Produções Artísticas

Direção: Adalberto Nunes

Tradução: Maria José de Carvalho

Elenco: Procópio Mariano (Ciusicov); Deoclides Gouveia (Lomov) e Lene Nunes (Natalia Stepanova).

Iluminação: Adalberto Nunes; Cenografia e Figurino: Paulo Bibiano; Direção Musical: Adalberto Nunes; Sonoplastia: Rose Araújo. 
Estreia em 26 de novembro de 1982 no Auditório da Fundação Casa do Estudante do Brasil, no Rio de Janeiro.

DOCUMENTOS ICONOGRÁFICOS: 02 Fichas de Inscrição no INACEN e 02 Artigos de Jornal (Acervo: Centro de Documentação e Informação em Arte da FUNARTE RJ).

\section{O JARDIM DAS CEREJEIRAS. Curitiba, 1984.}

Produção: Curso Permanente de Teatro do Paraná.

Direção: Lala Schneider.

Elenco: Laerte Rech (Lopakhin); Mercedes Piloti (Duniacha); Edison Bueno (Iepikhodov); Maria Ivete (Anha); Eliane Karas (Varvara - Vária); Silvia Maria Monteiro (Ravneskaia (sic)); José Claudemir Scarazin (Leonid Gaiev); Antonio Carlos Faiz (Charlota); César Almeida (Simeonov); André Sampaio (Iacha); Owidson Aloisio (Firs); Aldice Lopes (Trofimov); Jorge Luiz (Transeunte).

Cenografia: José Carlos Proença; Figurinos: Luis Afonso Burigo; Iluminação: Juba Machado; Cenografia: José Carlos Proença; Contra-Regra: Jorge Luiz; Maquinistas: Equipe da FTG; Assistente de Direção: Luiz Melo.

Estreia em 28 de junho de 1984, no Teatro Guaíra, Curitiba. Término da temporada em 06 de julho de 1984.

DOCUMENTOS ICONOGRÁFICOS: O1 Programa de Peça (Acervo: Centro de Documentação e Informação em Arte da FUNARTE RJ). Livro "Entreatos: Teatro em Curitiba de 1981 a 1995", de Ignácio Dotto Netto e Marta Morais da Costa (Acervo: Biblioteca do Instituto de Artes da Unicamp)

\section{TIO VÂNIA. Rio de Janeiro, 1984.}

Produção: Teatro dos Quatro

Direção: Sérgio Britto

Tradução: Millôr Fernandes

Elenco: Ronaldo Mota (Iéfim); Armando Bógus (Vânia); Norma Geraldy (Nunú); Rodrigo Santiago (Astróv); Nildo Parente (Serebriákov); Denise Weiberg (Sofia); José de Freitas (Iliá); Cristiane Torloni (Helena); Lícia Magna (Maria).

Cenografia: Paulo Mamede; Figurinos: Minina Roveda; Iluminação: Aurélio De Simoni; Contra-Regra: Edson Herdade.

Estreia no dia 11 de julho de 1984, no Teatro dos Quatro, Rio de Janeiro. 
DOCUMENTOS ICONOGRÁFICOS: 08 Artigos de Jornal, 03 Notícias, 03 Anúncios e 01 Programa de Peça (Acervo: Centro de Documentação $e$ Informação em Arte da FUNARTE RJ).
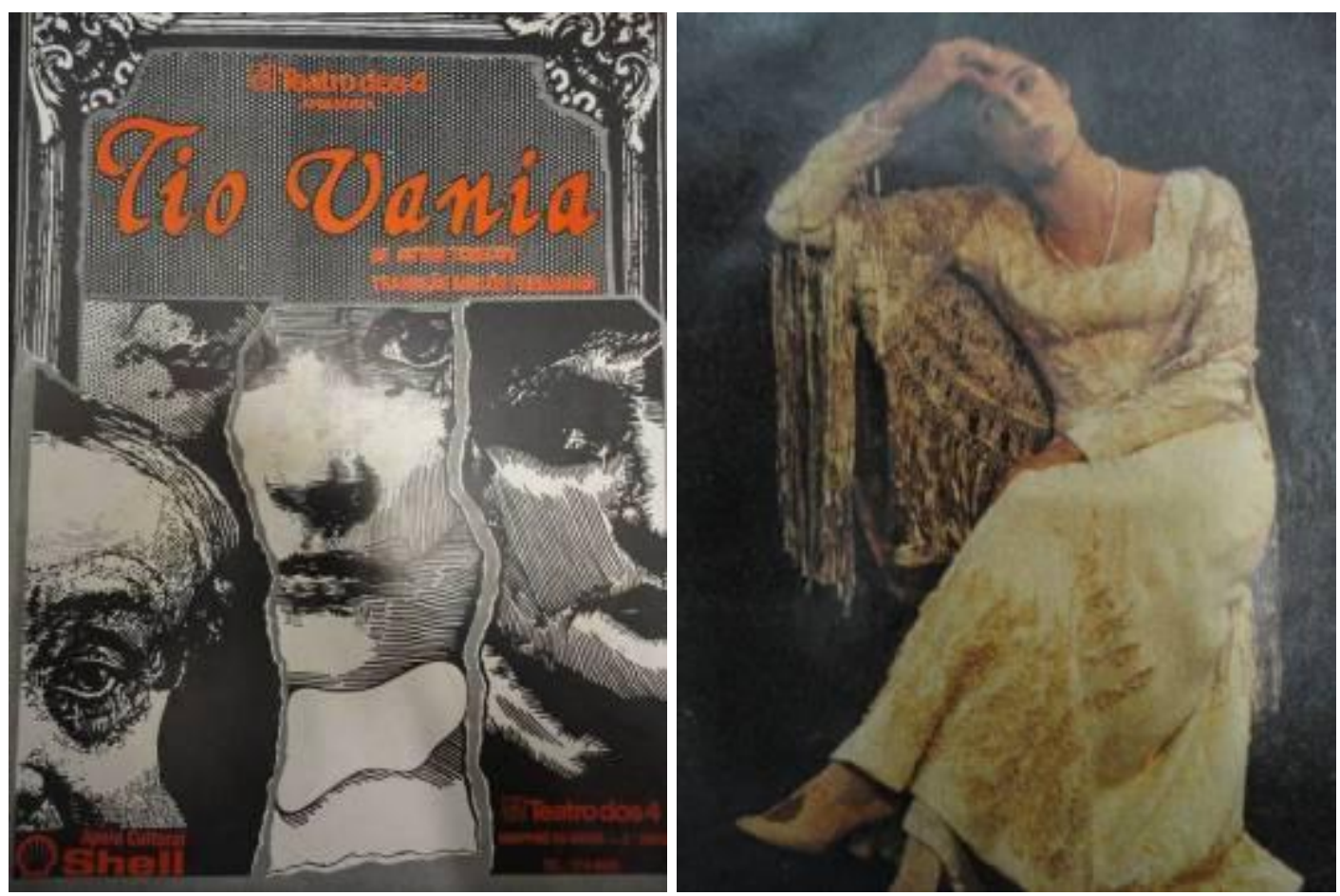

Imagem à esquerda, Programa da Peça. Tio Vânia, dir. Sérgio Britto, Rio de Janeiro, 1984. Imagem à direita, Cristiane Torloni (Helena) em cena da peça - (Fonte: "Clássico de Volta", Revista Veja, 18 de julho de 1984 - Foto: Rogério Reis)

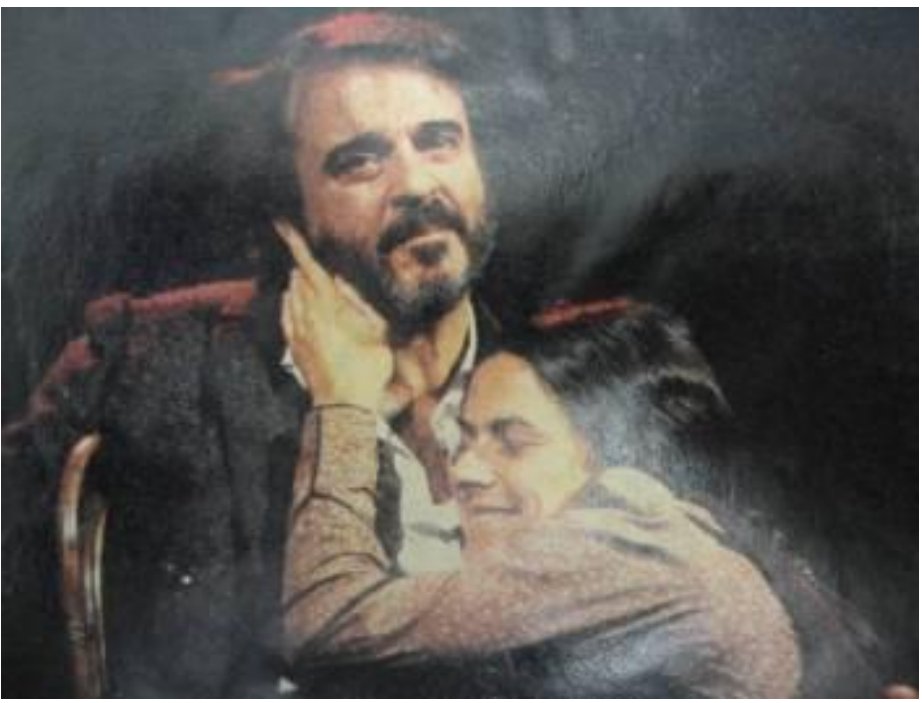

Armando Bógus (Vânia) e Denise Weiberg (Sônia) - (Fonte: "Clássico de Volta", Revista Veja, 18 de julho de 1984 - Foto: Rogério Reis)

IRRESISTIVEL AVENTURA. Rio de Janeiro, 1984.

Direção: Domingos Oliveira

Tradução: Marcos Ribas de Faria

O Urso de Anton P. Tchekov 
Elenco: Dina Staf (Elena Ivanovna Popova); José Mayer (Gregori Stepanovitch Smirnov); Thelma Reston (Lukaia); Hélio Ary (O Retrato).

Cenografia e figurinos: Rosa Magalhães; Iluminação: José Augusto. Assistentes de Direção: Antonio Gilberto e Lenita Plonczynski; Sonoplastia: Anderson Santos; Contra-Regras: Natan e Marcelo

Espetáculo reunia 4 peças curtas: O Amor de D. Prelimplim com Belissa em seu Jardim, de Federico Garcia Lorca; O Oráculo, de Artur Azevedo; A Dama da Lavanda, de Tennessee Williams.

Estreia em 09 de agosto de 1984, no Teatro de Arena, Rio de Janeiro. A peça percorreu diferentes estados, dentre eles Manaus, Belém, São Luiz, Fortaleza, Natal, Recife, Vitória, Goiânia, Brasília, Porto Alegre, Belo Horizonte, Curitiba, São Paulo.

DOCUMENTOS ICONOGRÁFICOS: 04 Artigos, 02 Notícias, 01 Programa de Peça e 01 Bilhete de Peça (Acervo: Centro de Documentação e Informação em Arte da FUNARTE $R J)$.

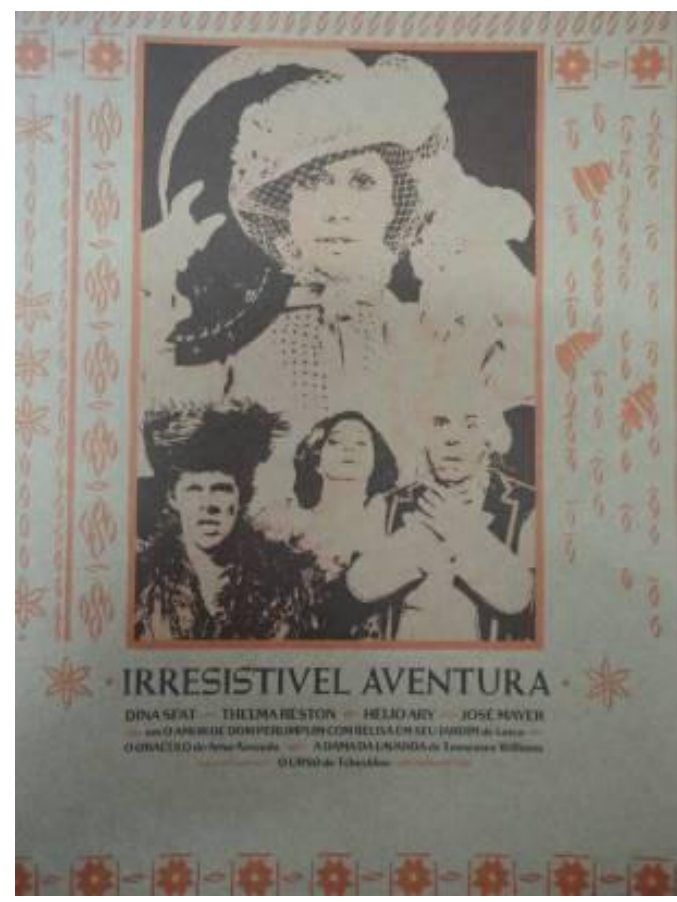

Programa da Peça. Irresistível Aventura, dir. Domingos Oliveira, Rio de Janeiro, 1984.

\section{O CAMALEÃO}

Adaptação de Renata Pallottini dos contos Um empresário debaixo do divã, A pamonha, $O$ camaleão e $O$ gordo e o magro e da peça $O s$ males do tabaco e $O$ aniversário.

Direção: Reinaldo Santiago

Cenografia: Marcio Tadeu

Iluminação: Sidney Lima

Elenco: Ginius Giguê, Marcília Rosário, Reinaldo Santiago, Ronaly Moreno.

Estreia no teatro Sérgio Cardoso, em São Paulo, no dia 26 de setembro de 1985. 
DOCUMENTOS ICONOGRÁFICOS Noticias de Jornal e Programa da Peça - Biblioteca Jenny Klabin Segall.

NATASHA. Curitiba, 1987.

Adaptação (sem referência ao texto base)

Produção: Companhia Molière

Direção: Zelia Hurman

Estreia em 23 de setembro de 1987, com término da temporada em 27 de setembro de 1987.

DOCUMENTOS ICONOGRÁFICOS: Livro "Entreatos: Teatro em Curitiba de 1981 a 1995", de Ignácio Dotto Netto e Marta Morais da Costa (Acervo: Biblioteca do Instituto de Artes da Unicamp)

\section{OS MALES QUE O FUMO PRODUZ. Belo Horizonte, 1988.}

Produção: Hélio Zolini

Direção: Ronaldo Brandão

Elenco: Eduardo 'Duca' Rodrigues (Niukhin)

Figurinista: Zeca Perdigão; Cenografia: Paulo Martinez;

Estreia em dezembro de 1988 (com duas apresentações) e retomada em 18 de janeiro de 1989 no Restaurante Pasta Asciutta (nos dias seguintes passou por espaços alternativos, como a Central Contato de Produções e o Adro da Residência dos Artistas Eid Ribeiro, Sérgio Lara e Alexandre Marques, em Belo Horizonte).

DOCUMENTOS ICONOGRÁFICOS: 01 Anúncio e 03 Notícias (Acervo: Centro de Documentação e Informação em Arte da FUNARTE RJ).

\section{O URSO. Porto Alegre, 1988.}

Produção: O Grupo

Direção: Antonio Oliveira.

Elenco: Luciana Monteiro (Popova - A Gata); Luciano Fleck (Smirnov - O Urso) e Clóvis Massa (Lucas - O Cão).

Estreia no dia 08 de fevereiro de 1988, no Porto de Elis, Porto Alegre. Informação em Arte da FUNARTE RJ). 


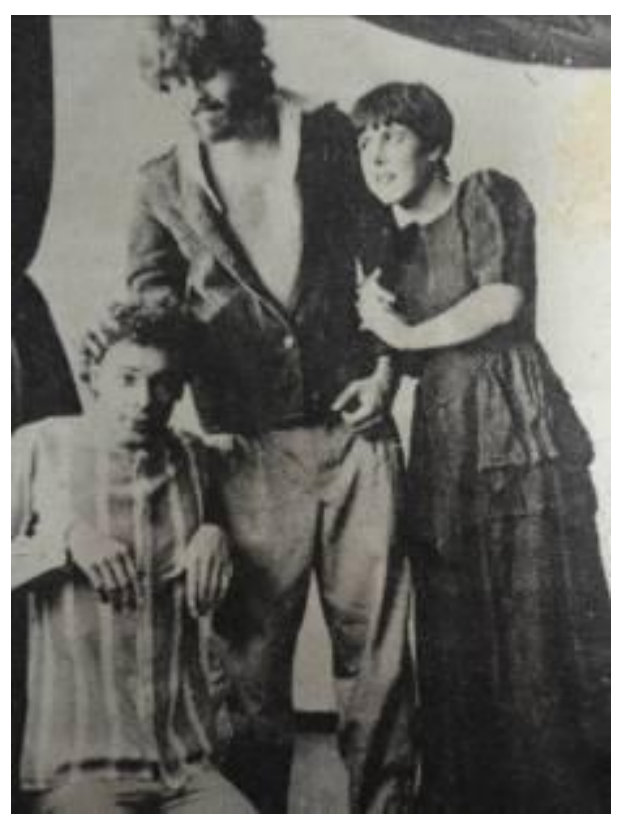

Da esquerda para a direita: Luciano Fleck (Smirnov - O Urso, Clóvis Massa (Lucas - O Cão) e Luciana Monteiro (Popova - A Gata) em cena de O Urso. (Fonte: "Fábula para adultos de Anton Tchecov", Jornal do Comércio, 21 de março de 1988 - Porto Alegre - Foto: Bira Dias)

\section{LAGO 21. São Paulo, 1988.}

Espetáculo experimental baseado em trechos dos textos Hamlet, de William Shakepeare e A Gaivota, de Anton Tchekhov

Direção: Jorge Takla

Elenco: Walderez de Barros; Elias Andreato e Mariana Muniz

Musica: Guta Petri; Iluminação: Jorge Takla.

Estreia em 30 de maio de 1988, no Teatro Procópio Ferreira, São Paulo.

DOCUMENTOS ICONOGRÁFICOS: Referências no site na Enciclopédia de Teatro Itaú Cultural: http://www.itaucultural.org.br/aplicexternas/enciclopedia_teatro/index.cfm?f $\underline{\text { useaction }=\text { espetaculos_biografia } \& c d \_ \text {verbete }=168}$

\section{PEDIDO DE CASAMENTO. João Pessoa, 1988.}

Produção: Grupo de Teatro Apocalipse.

Direção: Elpídio Navarro.

Tradução: Altimar Pimentel

Elenco (sem especificação de personagens): Fernando Mercez; Anunciada Fernandez; Nodge Filgueiras e Ednalva.

Iluminação: Elpídio Navarro.

Estreia (sem dia especificado) em junho de 1988, no Teatro da Fundação Casa de José Américo. 
DOCUMENTOS ICONOGRÁFICOS: 01 Registro de Espetáculo da Fundação Nacional de Artes Cênicas - FUNDACEN (Acervo: Centro de Documentação e Informação em Arte da FUNARTE RJ).

\section{TIO VÂNIA. São Paulo, 1988.}

Produção: Escola de Arte Dramática - EAD/USP

Direção: Celso Frateschi

Tradução: Millôr Fernandes

Elenco: Josenildo Marinho (Serebriakov); Joyce Ruiz (Elena); Elizabeth Dorgam (Sonia); Claudia Carli (Maria); Pedro Veneziani (Vânia); Ricardo Homuth (Astrov); Antonio Galeão (Telegine (sic)); Elisa Prado (Marina);

Estreia 1988, no Espaço Cultural Mambembe, São Paulo.

DOCUMENTOS ICONOGRÁFICOS: O1 Notícia de Jornal (Acervo: Centro de Documentação e Informação em Arte da FUNARTE RJ).

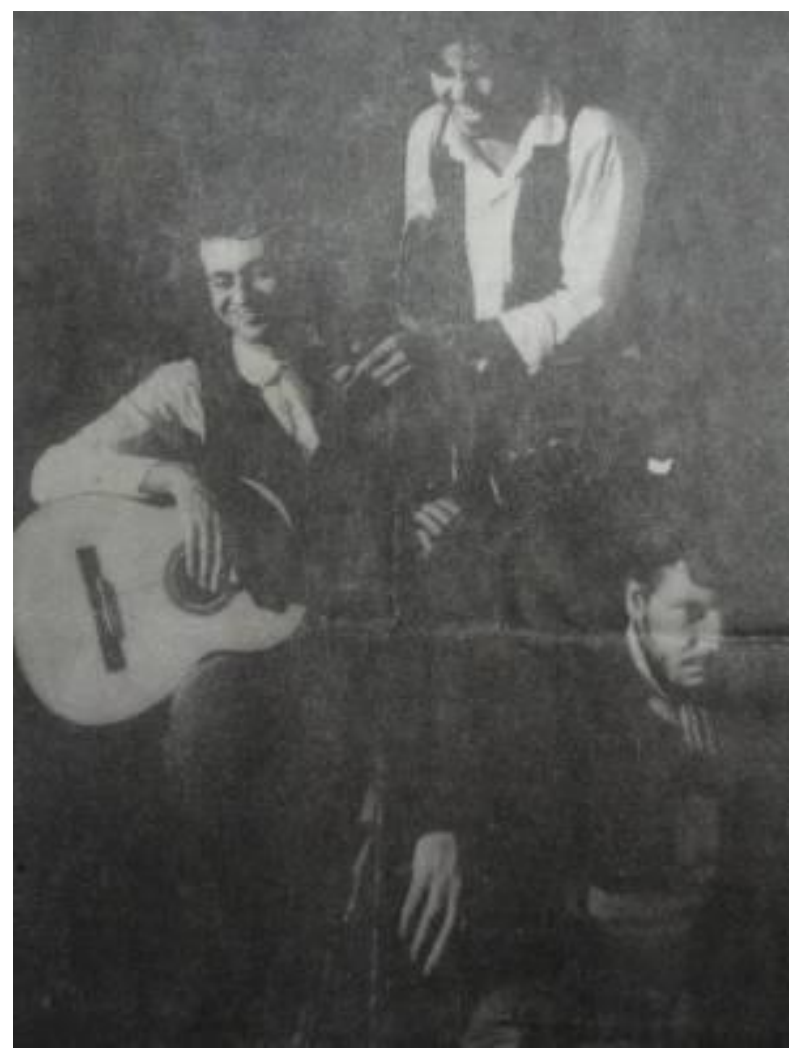

Antonio Galeão (Telegine (sic)), Ricardo Homuth (Astrov) e Pedro Veneziani (Vânia) em cena da peça. (Fonte: "Direção de Celso Frateschi acerta no tempo cênico de Tio Vânia", Folha de São Paulo, 08 de março de 1989. Foto de Divulgação: $\quad$ sem créditos)

\section{UM PEDIDO DE CASAMENTO. Brasília (DF), 1989.}

Direção: Roberto Parkinson

Tradução: Altimar Pimentel

Elenco (sem especificação de personagens): Galina Babhakhina; Timotheo Porto e Delduque Jr.

Estreia em 08 de junho de 1989, no Escola Parque, Brasília (DF). 
DOCUMENTOS ICONOGRÁFICOS: 01 Notícia de Jornal (Acervo: Centro de Documentação e Informação em Arte da FUNARTE RJ).

\section{O JARDIM DAS CEREJEIRAS. Rio de Janeiro, 1989.}

Direção: Paulo Mamede

Tradução: Paulo Mamede (a partir da adaptação de Luigi Lunari e Giorgio Strehler)

Elenco: Othon Bastos (Lopakhine); Emília Rey (Duniacha); André Valle (Epikodov); José Lewgoy (Firs); Clarisse Derzié (Ania); Nathalia Timberg (Liuba); Renée de vielmond (Varia)

Sérgio Britto (Gaiev); Ada Chaseliov (Charlotte); Nelson Dantas (Pichtchnik); Camilo Bevilaqua (Iacha); Edwin Luisi (Trofimov); Virgínio Liberti (Viajante);

Músicos: Homero Gelmini (Violino), Eugenio Martins (Flauta); Carlos Ramonda (Arcodeon); Cenografia: Paulo Mamede; Figurinos: Mimina Roveda; Iluminação: Maneco Quinderé; Direção Corporal: Angel Vianna;

Estreia em 25 de julho de 1989, no Teatro dos Quatro, Rio de Janeiro. DOCUMENTOS ICONOGRÁFICOS: 04 Notícias de Jornal, 08 Artigos, 01 Programa de Peça e 01 Ficha Técnica de Banco de Dados do INACEN (Acervo: Centro de Documentação e Informação em Arte da FUNARTE RJ).

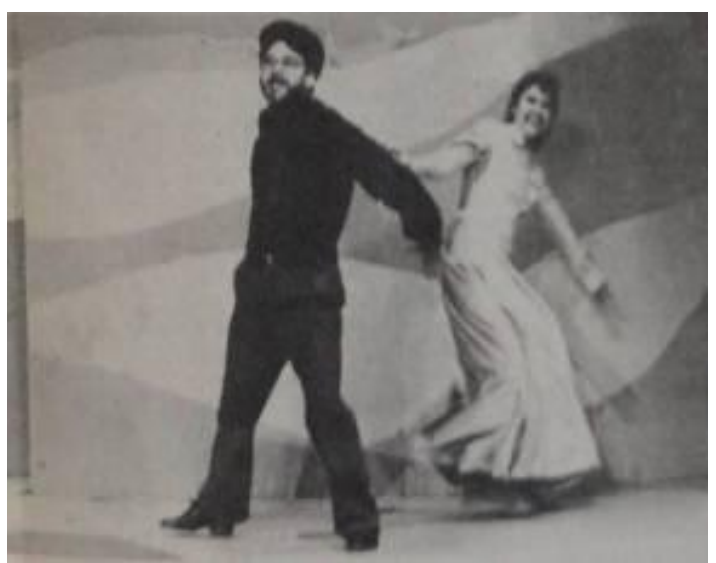

Foto: Edwin Luisi (Trofimov) e Clarisse Derzié (Ania) (Fonte: "Pelo Viés da Memória", Tribuna da Imprensa, Rio de Janeiro, 07 de agosto de 1989 - sem créditos) 


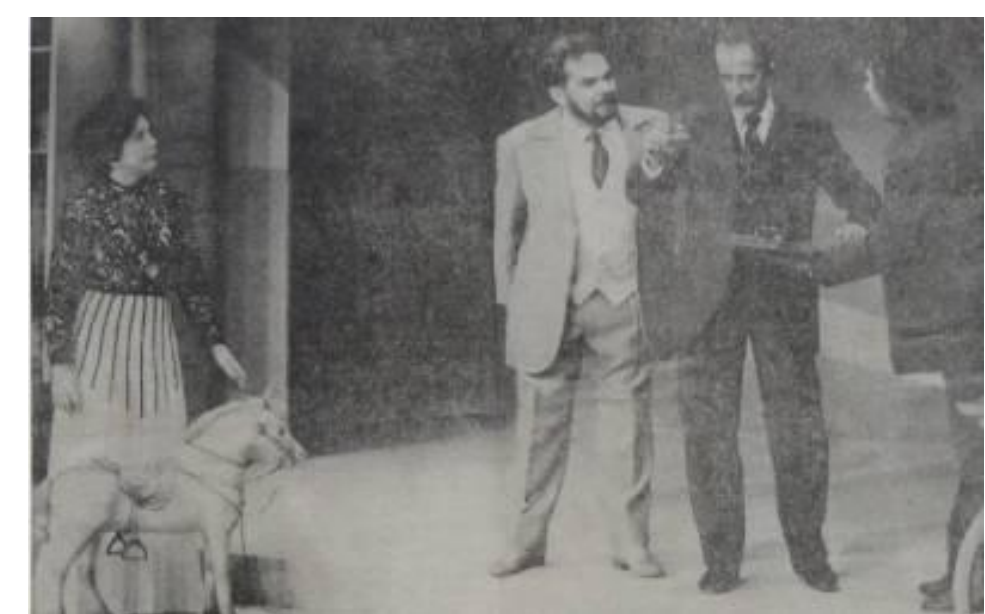

Foto: Da esquerda para a direita: Nathalia Timberg (Liuba); Othon Bastos (Lopakhine); André Valle (Epikodov) (Fonte: "Comédia da Decadência", Jornal do Brasil, Rio de Janeiro, 25 de julho de 1989 - sem créditos).

\section{A GAIVOTA. Porto Alegre, 1989.}

Produção: Luciano Alabarse.

Direção: Luiz Paulo Vasconcellos.

Tradução: Luiz Paulo Vasconcellos.

Elenco: Araci Esteves (Polina); Clóvis Massa (Medvedenko); Fábio Neto (Sorin); Leverdógil de Freitas (Dorn); Marília Rossi (Nina); Nelson Ribas (Trigorin); Rosângela Batistela (Macha); Rui Almeida (Shamrayev); Sandra Dani (Irina); Sérgio Vieira (Iakov); Zé Adão Barbosa (Treplev).

Cenografia e Figurinos: Luiz Paulo Vasconcellos.Iluminação: João Acir.

Estreia em 22 de setembro de 1989, no Teatro da EPATUR, Porto Alegre.

DOCUMENTOS ICONOGRÁFICOS: 01 Notícia de Jornal (Acervo: Centro de Documentação e Informação em Arte da FUNARTE RJ).

\section{O JARDIM DAS CEREJEIRAS. Recife, 1990.}

Produção: Companhia Teatro de Seraphim

Direção: Antonio Cadengue

Dramaturgia: George Moura ; Paulo Michelotto e Roseli Accioly .

Tradução: Paulo Michelotto e Roseli Accioly.

Adaptação: Antonio Cadengue.

Elenco: André Filho (Epikodov); Cira Ramos (Vária); Cristiana Mariz (Duniacha); Eduardo Vaz (Transeunte; Funcionário dos Correios e Criado); Francisco de Souza (Simeónov-Pichtchik); Hilton Azevedo (Pétia Trofimov); Ivan Soares (Leonid Gaiév); Karla Cascão (Ânia); Kéops Vasconcelos (Yacha); Lúcia Machado (Liúba Andréievna); Manuel Carlos (Firs); Marcus Vinícius 
(Ermolai Lopakhine); Ril Gouveia (Charlotta Ivanovna) .

Cenografia: Anibal Santiago e Manuel Carlos ; Figurinos: Anibal Santiago; Trilha Sonora: André Filho e Antonio Cadengue; Iluminação: Augusto Tiburtius; Assistente de Direção: Lúcia Machado.

Estreia em 10 de agosto de 1990, no Cineteatro José Carlos Cavalcanti Borges, Recife.

DOCUMENTOS ICONOGRÁFICOS: 01 Programa de Peça (Acervo: Centro de Documentação e Informação em Arte da FUNARTE RJ) e referências no site na Enciclopédia de Teatro Itaú Cultural: http://www.itaucultural.org.br/aplicExternas/enciclopedia_teatro/Enc_Cias/d $\underline{\text { sp_dados_evento.cfm? id_evento }=516788 \& \text { st_evento }=0 \% 20 \mathrm{Jardim} \% 20 \mathrm{das}}$ \%20Cerejeiras

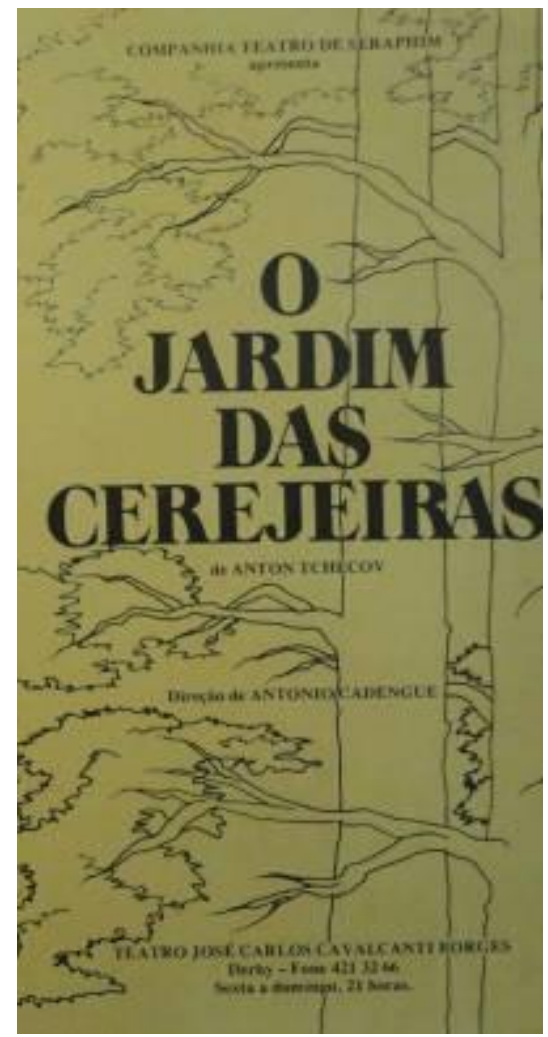

Programa da Peça. O Jardim das Cerejeiras, dir: Antonio Candengue, Recife, 1990.

\section{A PROPOSTA. São Paulo, 1991.}

Produção: Os Satyros.

Tradução: Irineu Franco Perpétuo.

Adaptação da peça 'Um Pedido de Casamento" por Rodolfo García Vázquez e Ivam Cabral.

Direção: Rodolfo García Vázquez

Elenco: Angela Leme; Emerson Caperbat; Luiz Augusto Alper; Renata Sêpa; Rosemeri Ciupak e Valéria Di Pietro. 
Cenografia: Kinkas Neto; Figurinos: Kinkas Neto; Trilha Sonora: Emerson Caperbat

Flávio Guerra; Iluminação: Rodolfo García Vázquez.

Estreia em abril de 1991, no Teatro Bela Vista, São Paulo.

DOCUMENTOS ICONOGRÁFICOS: Referências no site na Enciclopédia de Teatro Itaú Cultural:

http://www.itaucultural.org.br/aplicexternas/enciclopedia_teatro/Enc_Cias/d sp_dados_evento.cfm?id_evento $=401595 \&$ st_evento $=A \% 20$ Proposta

\section{SERAPHINS REVISÕES. JARDIM DAS CEREJEIRAS. Recife, 1992.}

Continuação da Proposta de 1990, com alterações.

Produção: Companhia Teatro de Seraphim

Direção: Antonio Cadengue

Dramaturgia: George Moura ; Paulo Michelotto e Roseli Accioly .

Tradução: Paulo Michelotto e Roseli Accioly.

Adaptação: Antonio Cadengue.

Elenco: André Filho (Epikodov); Cira Ramos (Vária); Fábio Lira (Funcionário dos Correios e Criado); Hilton Azevedo (Pétia Trofimov); Hyeda Romão (Duniacha); Ivan Soares (Leonid Gaiév); Karla Cascão (Ânia); Lúcia Machado (Liúba Andréievna); Manuel Carlos (Firs); Marcus Vinícius (Ermolai Lopakhine) Nino Fernandes (Simeónov-Pichtchik); Paulo de Pontes (Yacha); Ricardo Angeiras (Transeunte e Criado); Zuleica Ferreira (Charlotta Ivanovna).

Cenografia: Anibal Santiago e Manuel Carlos ; Figurinos: Anibal Santiago ; Trilha Sonora: André Filho e Antonio Cadengue; Iluminação: Augusto Tiburtius.

Estreia em 21 de maio de 1992, no Teatro Barreto Júnior, Recife.

DOCUMENTOS ICONOGRÁFICOS: Referências no site na Enciclopédia de Teatro Itaú Cultural:

http://www.itaucultural.org.br/aplicExternas/enciclopedia_teatro/Enc_Cias/d sp_dados_evento.cfm?id_evento $=518526 \&$ st_evento $=$ Seraphins $\% 20$ Revis $\%$ C3\%B5es.\%200\%20Jardim\%20das\%20Cerejeiras

\section{A GAIVOTA. São Paulo, 1994.}

Produção: Cia. do Bexiga/ Grupo de Teatro do Bixiga/ Marco Ricca

Direção: Francisco Medeiros

Tradução: Tatiana Belinky 
Elenco: Walderez de Barros (Arcádina); Marco Ricca (Treplev); Mayara Magri (Nina); Genézio de Barros (Trigórin); Oswaldo Mendes; Bri Fiocca; Maria Letícia; Cacá Soares; Luiz Carlos Rossi (Chamráiev); Ricardo Homuth; Nilton Bicudo.

Cenografia: J. C. Serroni; Assistente de Cenografia: Gustavo Siqueira Lanfranchi ;Figurinos: J. C. Serroni; Iluminação: Wagner Freire; Coreografia: Fernando Lee;

Estreia prévia em janeiro de 1994 no $4^{\circ}$ Festival Internacional de Artes Cênicas de São Paulo e em 16 de maio de 1994, no Centro Cultural São Paulo, São Paulo.

DOCUMENTOS ICONOGRÁFICOS: 02 Artigos, 01 Notícia e 01 Programa de Peça (Acervo: Centro de Documentação e Informação em Arte da FUNARTE RJ). Referências também disponíveis no site da Enciclopédia de Teatro Itaú Cultural: http://www.itaucultural.org.br/aplicExternas/enciclopedia_teatro/Enc_Cias/d sp_dados_evento.cfm?id_evento $=390482 \&$ st_evento $=A \% 20$ Gaivota

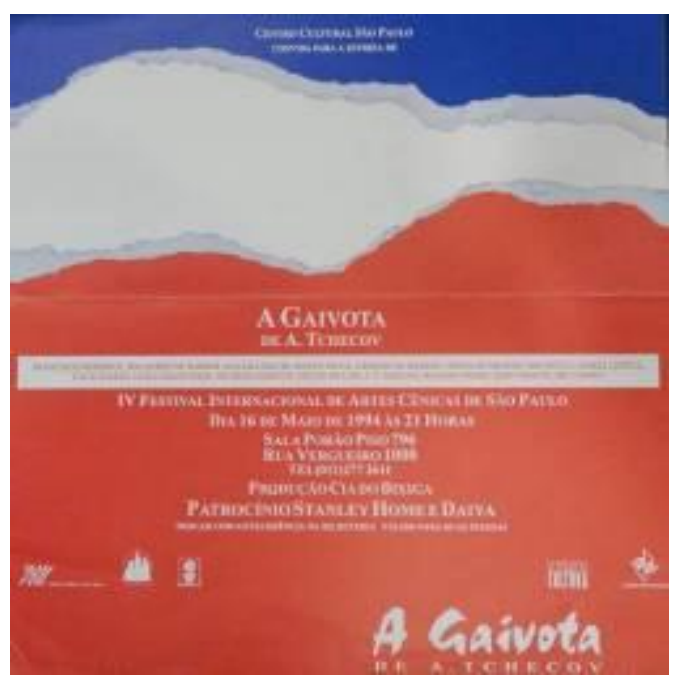

Programa da Peça. A Gaivota, dir.

Francisco Medeiros, São Paulo, 1994.

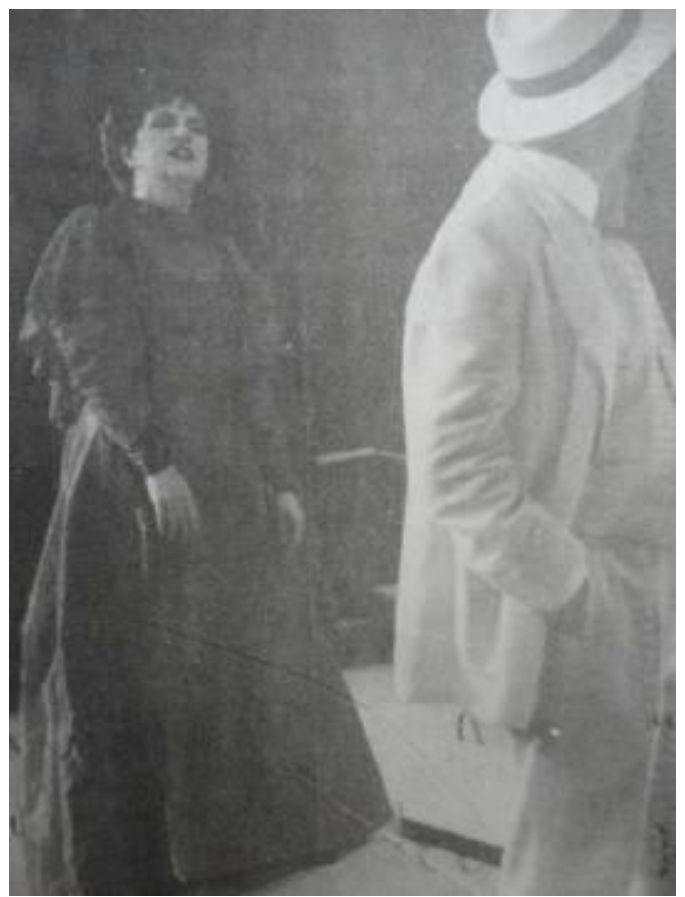

No primeiro plano, de frente, Walderez de Barros (Arcádina) (Fonte: " 'A Gaivota' prova atualidade de Tchecov", Folha de São Paulo, 18/01/1994 - Foto de Divulgação - sem créditos) 
A GAIVOTA. Rio de Janeiro, 1995.

Direção: David Herman.

Elenco: Antonio Claudio (Sorine); Maria Henriques (Arkádina); Renato Costa (Kostia); Marta Paret (Nina); (faltam detalhes)

Cenografia: Claudio Torres Gonzaga; Iluminação: Wilson Reis; Figurinos: Cristina Augusto e Claudio; Assistente de Direção: Silvia Carvalho.

Estreia em 1995 no Teatro Cacilda Becker, Rio de Janeiro.

DOCUMENTOS ICONOGRÁFICOS: 01 Notícia (Acervo: Centro de Documentação e Informação em Arte da FUNARTE RJ).

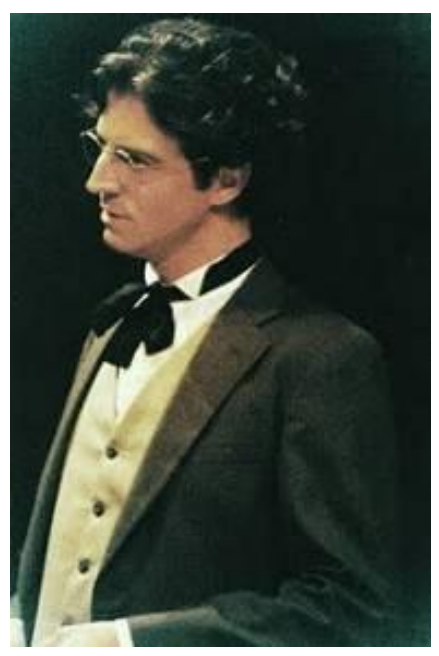

Silvio Pozzatto em cena de A

Gaivota (Foto de Cláudia

Ribeiro)

\section{A GAIVOTA. Rio de Janeiro, 1996.}

Direção: Jorge Takla

Tradução: Bárbara Heliodora

Elenco: Diogo Dahl (Semion); Andrea Cavalcanti (Masha); Roberto de Cleto (Sorine); Charles Moeller (Treplev); Samanta Monteiro (Nina); Ada Chaseliov (Paulina); Nildo Parente (Dorn); Camilo Bevilacqua (Ilia); Walderez de Barros (Arkádina); Elias Andreato (Trigôrine); Celso André Monteiro (Iácov); Antonio Gomes (Cozinheiro).

Figurinos: Kalma Murtinho; Cenografia e Iluminação: Jorge Takla.

Estreia no Teatro Nelson Rodrigues, no Rio de Janeiro, dia 18 de janeiro de 1996.

DOCUMENTOS ICONOGRÁFICOS: 03 Notícias, 03 Artigos e 01 Programa de Peça (Acervo: Centro de Documentação e Informação em Arte da FUNARTE RJ). 


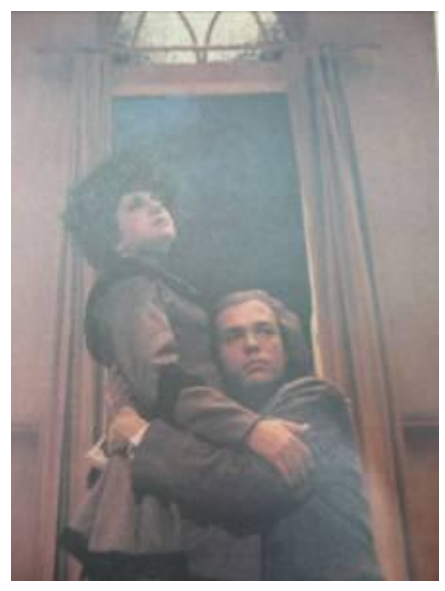

Walderez de Barros (Arkádina) e Charles Moeller (Treplev). (Fonte: " 'A Gaivota' Tchekov por Jorge Takla, numa montagem cheia de emoção como pede o texto centenário", Revista Programa, 12 de janeiro de 1996.

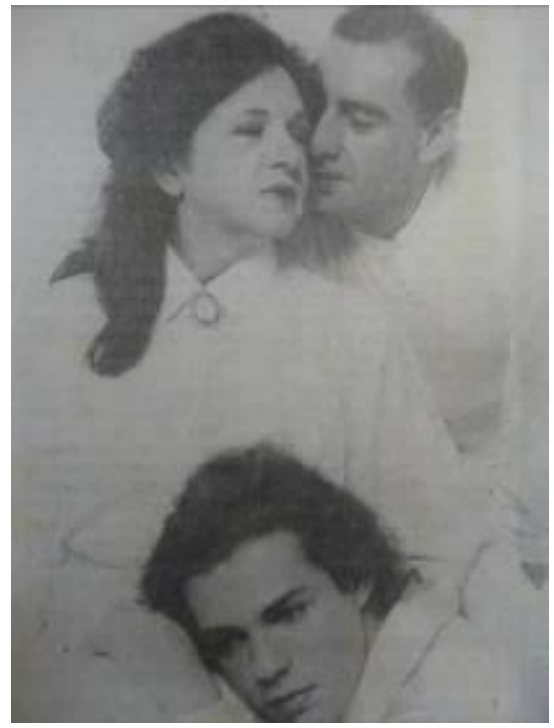

Foto: Walderez de Barros (Arkádina), Elias Andreatto (Trigôrine) e Charles Moeller (Treplev) (Foto de Divulgação: Livio Campos).

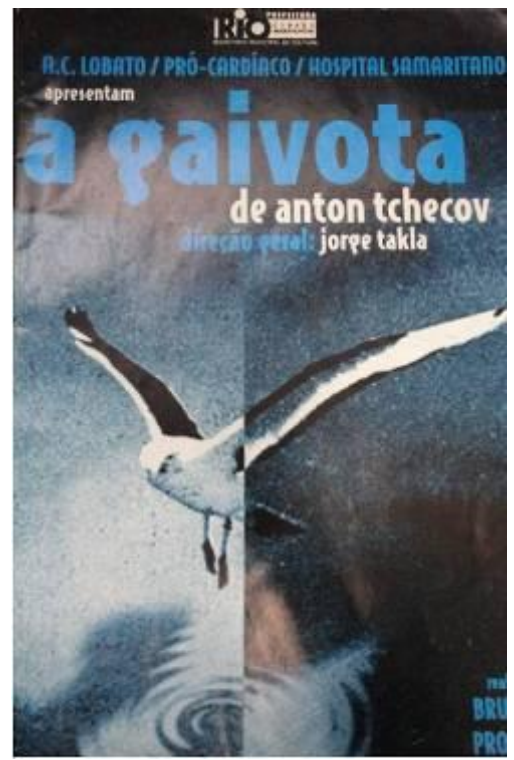

Programa da Peça. A Gaivota, dir. Jorge Takla, Rio de Janeiro, 1996. 
UM PEDIDO DE CASAMENTO. Rio de Janeiro, 1996.

Direção: Marcus Alvisi

Elenco: Rubens Araújo, Luiz Henrique Nogueira e Cristiana Kalache.

Figurino: Kalma Murtinho. Coreógrafa e Preparadora corporal: Daniella Visco. Iluminação e Trilha Sonora: Marcus Alvisi.

Estreia em 1996, no Teatro II do Centro Cultural Banco do Brasil, Rio de Janeiro.

DOCUMENTOS ICONOGRÁFICOS: Referências disponíveis no site da Enciclopédia de Teatro Itaú Cultural: http://www.itaucultural.org.br/aplicexternas/enciclopedia teatro/Enc_Cias /dsp_dados_evento.cfm?id_evento $=398286 \&$ st_evento=Um\%20Pedido $\% 2$ $\underline{\text { 0de\%20Casamento }}$

\section{A ARTE DE DIZER NÃO. São Paulo, 1997.}

Espetáculo composto das peças A Moça que Falou Assim, de Marta Góes, e Trágico à Força (Involuntariamente Trágico), de Anton Tchékhov.

Direção: Maria Lúcia Pereira.

Sem especificações de estreia e local.

DOCUMENTOS ICONOGRÁFICOS: Referências disponíveis no site da Enciclopédia de Teatro Itaú Cultural:

http://www.itaucultural.org.br/aplicexternas/enciclopedia_teatro/Enc_Cias /dsp_dados_evento.cfm?id_evento $=427858 \&$ st_evento $=$ A $\% 20$ Arte $\% 20$ de \%20Dizer\%20N\%C3\%A3o

\section{O MALFEITOR. Rio de Janeiro, 1997.}

Adaptação do conto homônimo de Tchékhov feita por Rosyane Trotta.

Direção: Rosyane Trotta.

Adaptação: Rosyane Trotta.

Elenco: Carmen Leonora e Mário Mendes

Cenografia: Lidia Kosovski - Prêmio Shell

Estreia no Rio e retorna em 28 de março de 1998, no Teatro da Caixa, como parte da programação do Fringe 2008.

DOCUMENTOS ICONOGRÁFICOS: Referências disponíveis no site da Enciclopédia de Teatro Itaú Cultural: http://www.itaucultural.org.br/aplicexternas/enciclopedia_teatro/Enc_Cias /dsp_dados_evento.cfm?id_evento=393809\&st_evento=0\%20Malfeitor 


\section{TIO VÂNIA. Curitiba, 1998.}

Produção: Teatro Promíscuo/ Renato Borgui Produções Artísticas LTDA.

Direção: Élcio Nogueira Seixas.

Tradução: Vadim Nikitin

Elenco: Renato Borghi (Tio Vânia); Mariana Lima (Yelena); Leona Cavalli (Sônia); Luciano Chirolli (Dr. Astrov); Wolney de Assis (P. Serebriakov); Abrahão Farc (Tielhêguim (sic)); Geisa Gama (Bá Marina) e Jolanda Gentileza (Maman).

Cenografia e Figurinos: Marcos Pedroso; Iluminação: Cibele Forjaz. Trilha Sonora: Élcio Nogueira Seixas; Montagem: Zero Freitas;

Estreia Nacional no $7^{\circ}$ Festival de Curitiba em 28 de março de 1998, no Teatro Guaíra. Estreia em São Paulo em abril de 1998, no TBC.

DOCUMENTOS ICONOGRÁFICOS: 01 Notícias, 02 Artigos e 01 Programa de Peça e 01 Folder de Divulgação (Acervo: Centro de Documentação e Informação em Arte da FUNARTE RJ).

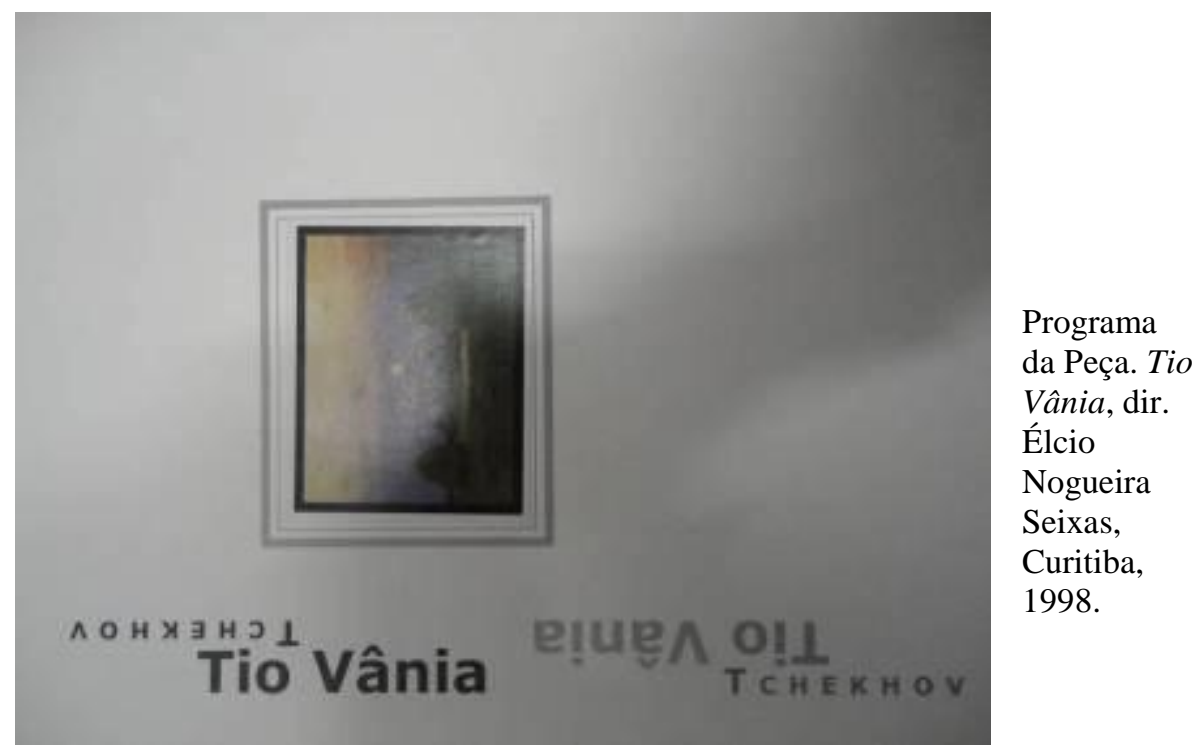




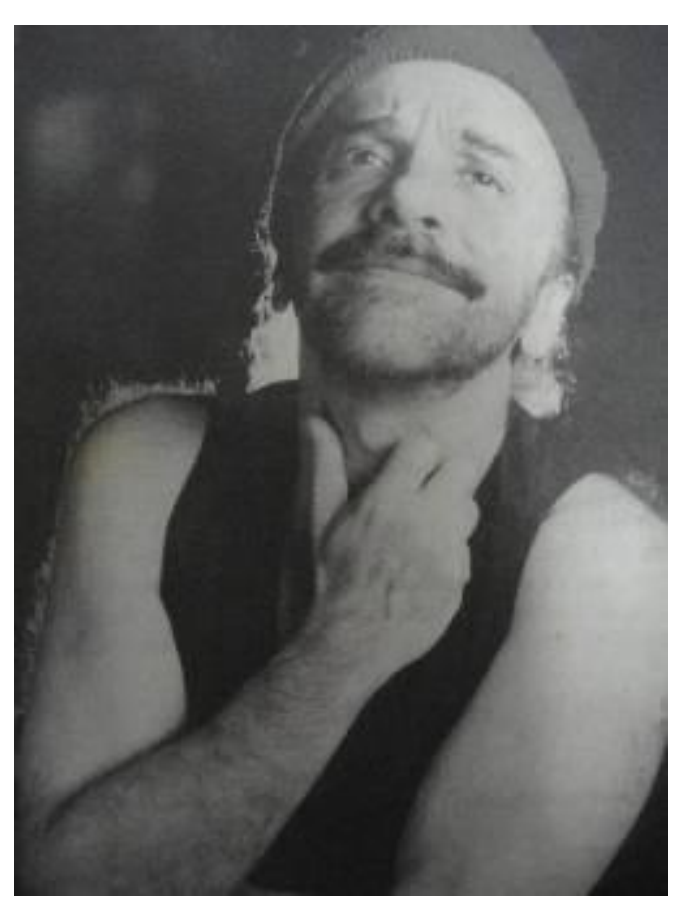

Renato Borghi (Vânia) (Fonte:" O Vânia de Borghi", Jornal do Brasil - Revista de Domingo de 11/09 a 17 de novembro de 1998. Foto de Divulgação: sem créditos)

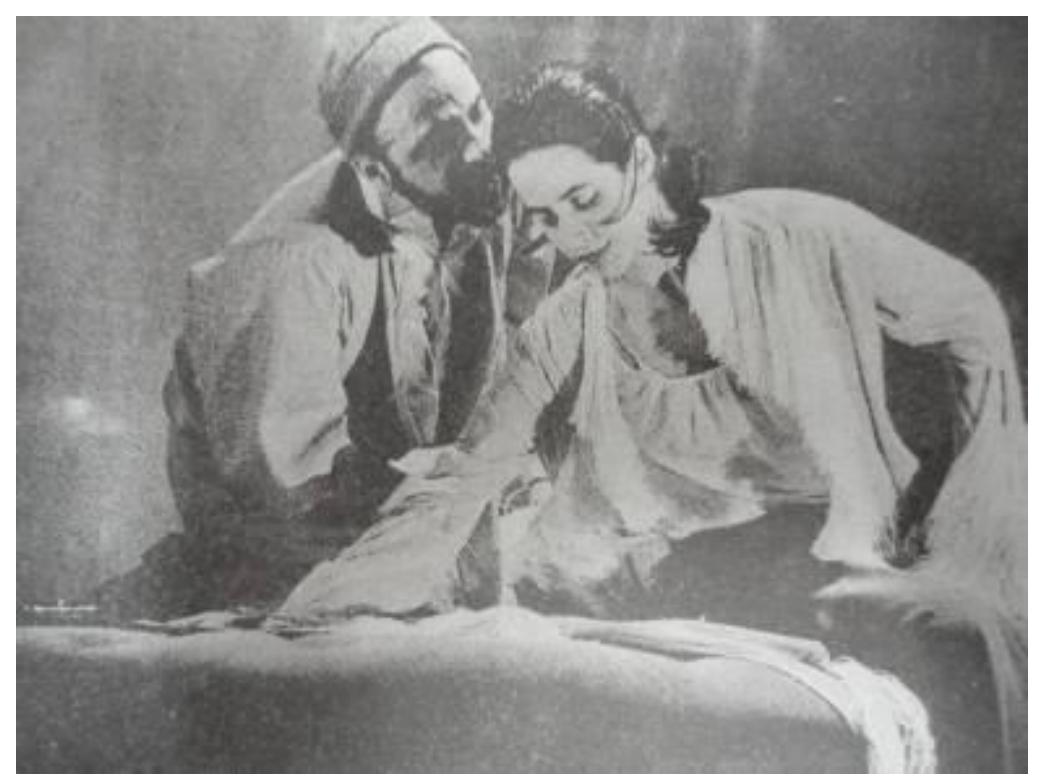

Foto: Renato Borghi (Vânia) e Mariana Lima (Yelena) (Fonte: "Desencontros inspirados em Tchecov", Jornal do Comércio Porto Alegre, 25 de setembro de 1998. sem créditos)

\section{O URSO. Rio de Janeiro, 1998.}

Direção: José Henrique

Elenco: Antonio Alves (Smirnov), Ricardo Leite (Luká) e Silvia Monte (Popova).

Cenografia: José Henrique.

Estreia em 1998, no Espaço 2 do Teatro Villa-Lobos, São Paulo.

DOCUMENTOS ICONOGRÁFICOS: 01 Notícia (Acervo: Centro de Documentação e Informação em Arte da FUNARTE RJ) 


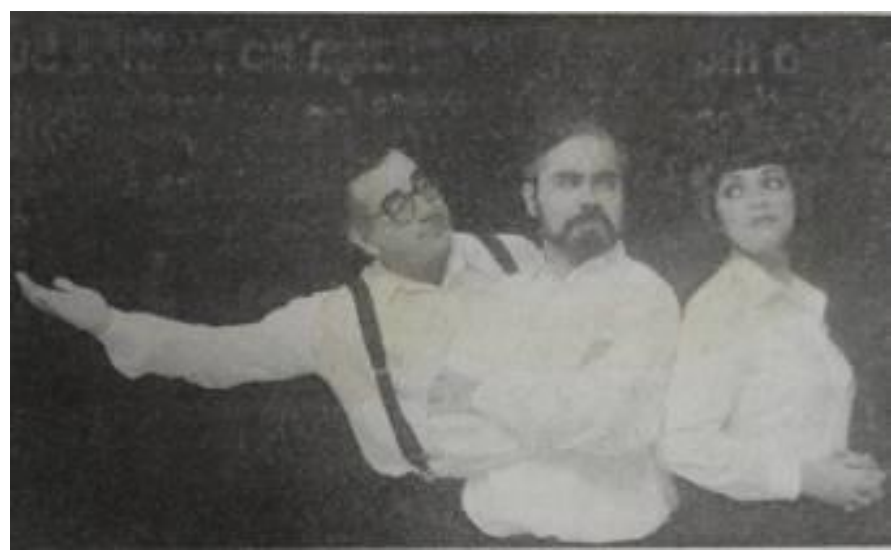

Foto: Ricardo Leite, Antonio Alves e Silvia Monte em cena de $\mathrm{O}$ Urso. (Fonte: Jornal do Brasil, 11 de dezembro de 1998. - sem créditos)

\section{IVANOV. São Paulo, 1998.}

Produção: Grupo TAPA.

Direção: Eduardo Tolentino de Araújo.

Tradução: Arlete Cavaliere e Eduardo Tolentino.

Elenco: José Carlos Machado (Ivanov); Denise Weimberg; Clara Caravalho; A.ndré Garolli; Brian Tenido; Bruno Perillo; Cândido Lima; Chico Martins; Cristina Cascioli; Elizabeth Gasper; Genésio de Barros; Inês de Carvalho; Milton Andrade; Paulo Marcos; Riba Carlovich; Sandra Corveloni; Sônia Oiticica;

Tony Giusti.

Cenografia: Renato Scripilliti; Figurinos: lola Tolentino; Iluminação: Guilherme Bonfanti.

Estreia em 24 de março de 1998, no Teatro Guairinha, em Curitiba. E em abril de 1998, no Teatro Aliança Francesa, São Paulo.

DOCUMENTOS ICONOGRÁFICOS: Referências disponíveis na Dissertação de Geraldo Peçanha de Almeida "Palco Iluminado, o Festival de Teatro de Curitiba" (UFPR, 2002) e no no site da Enciclopédia de Teatro Itaú Cultural:

http://www.itaucultural.org.br/aplicexternas/enciclopedia_teatro/Enc_Cias/dsp_dado s_evento.cfm?id_evento=390372\&st_evento=Ivanov

\section{DA GAIVOTA. Santo André, 1998.}

Direção: Daniela Thomas.

Adaptação: Daniela Thomas.

Elenco: Fernanda Montenegro (Arkádina); Antonio Abujamra (Chamráiev); Celso Frateschi (Trigorin); Matheus Nachtergaele (Treplev); Nelson Dantas (Sorin); Fernanda Torres (Nina).

Cenografia e Figurinos: Daniela Thomas; Efeitos Especiais: Antonio Joaquim de Aguiar (Efeito Água); 
Operação de luz Carlos Eduardo Moraes ; Cenotécnica Cenotécnica Artes Técnicas Ltda; Criação Fernanda Montenegro; Fernando Torres ; Camareira Ieda Silva Santos; Costureira Lu Pimenta; Técnico de palco Marcos Sgubim; Maquiagem Mauro Freire; Efeitos especiais; Sérgio Flores (Efeito Vôo); Direção de cena Yara Leite; Autoria Anton Tchekhov; Direção (assistente) Luiz Paëtow; Marcelo Larrea; Cenografia (assistente) France Bicudo; Verônica Julian; Figurino (assistente) Foquinha; Trilha sonora Raul Teixeira; Iluminação Carlos Eduardo Moraes e Daniela Thomas.

Estreia em 02 de julho de 1998, no Teatro Municipal de Santo André. Logo após em Curitiba, em 10 e 11 de julho de 1998, no Teatro Guaíra. Salvador nos dias 17 e 18 de julho, no Teatro Castro Alves. Rio de Janeiro de 24 a 30 de agosto, no Teatro Leblon. São Paulo de 03 de setembro a 04 de outubro, no SESC Vila Mariana.

DOCUMENTOS ICONOGRÁFICOS: 01 Crítica e 01 Notícia (Acervo: Centro de Documentação e Informação em Arte da FUNARTE RJ) e referência no no site da Enciclopédia de Teatro Itaú Cultural: http://www.itaucultural.org.br/aplicexternas/enciclopedia_teatro/Enc_Cias/dsp_dados_event o.cfm?id_evento $=576539 \&$ st_evento $=$ Da\%20Gaivota

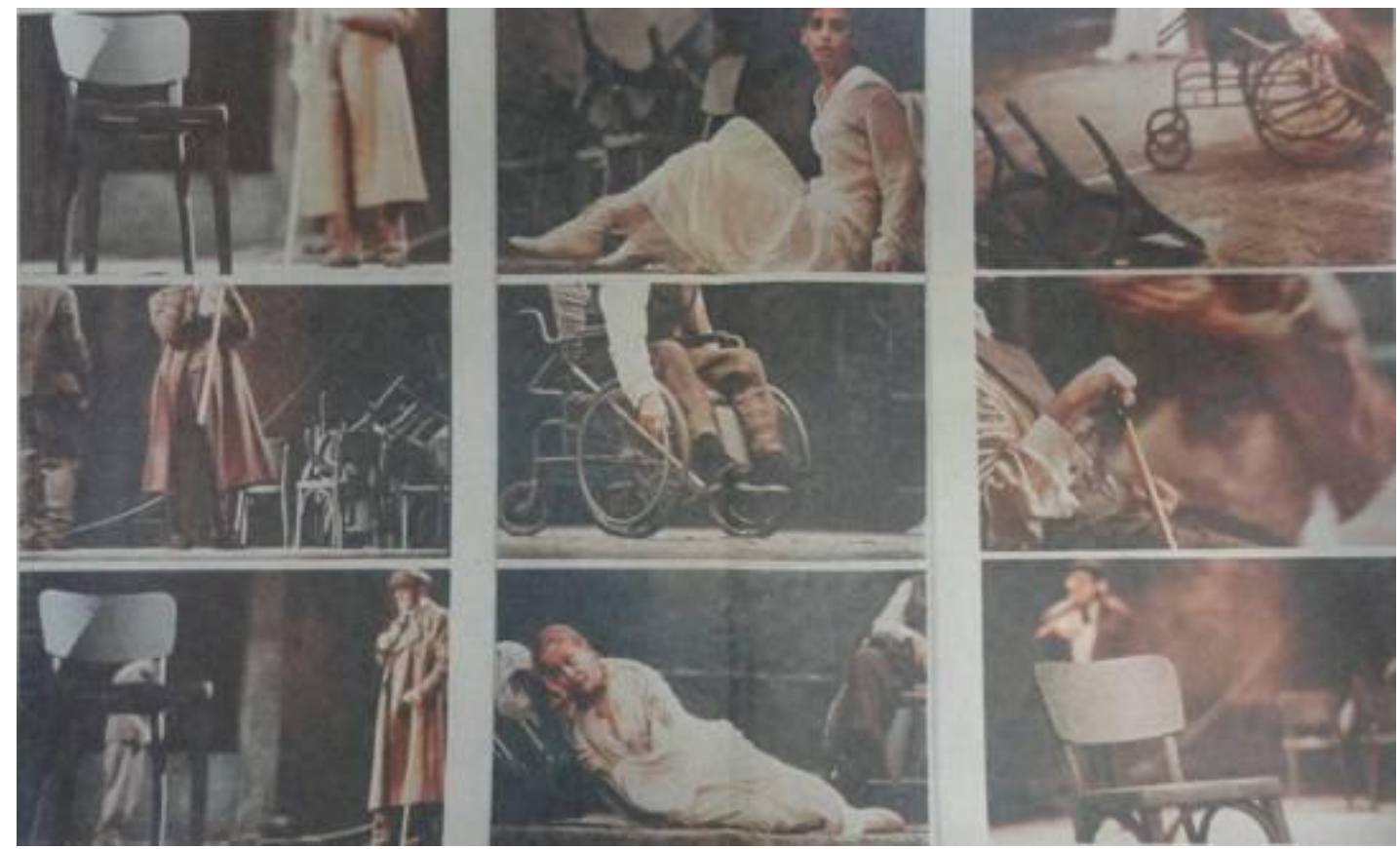

Fotomontagem de Lenise Pinheiro (Fonte: "Gaivota opõe no palco gerações da arte", Folha de São Paulo, 10 de janeiro de 1998) 


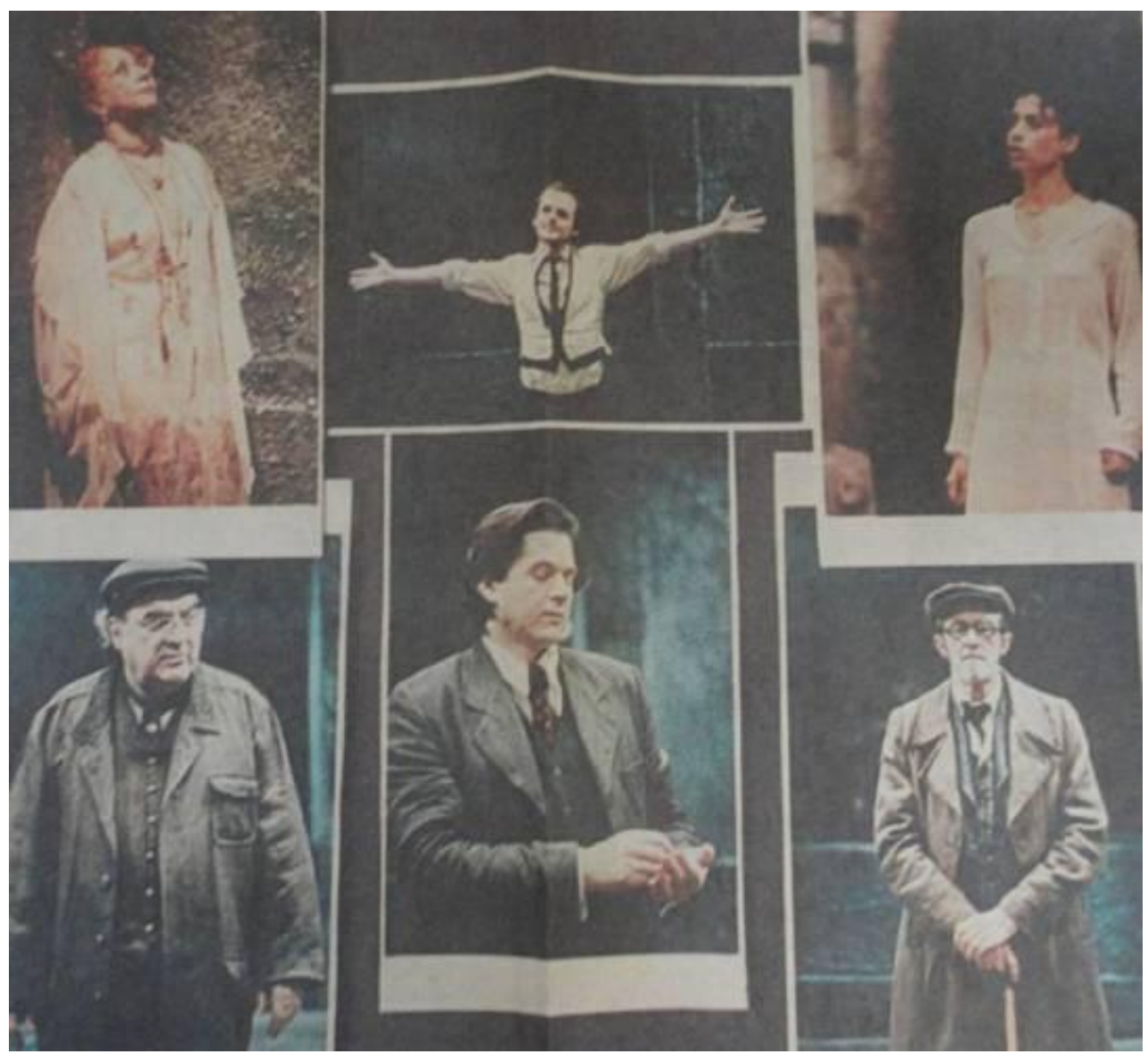

Acima, da esquerda para a direita: Fernanda Montenegro (Arkádina); Matheus Nachtergaele (Treplev) ; Fernanda Torres (Nina). Abaixo, da esquerda para a direita: Antonio Abujamra (Chamráiev); Celso Frateschi (Trigorin) e Nelson Dantas (Sorin). (Fotomontagem de Lenise Pinheiro em "Gaivota opõe no palco gerações da arte", Folha de São Paulo, 10 de janeiro de 1998)

\section{AS TRÊES IRMÃS. Rio de Janeiro, 1998.}

Direção: Bia Lessa.

Tradução: José Celso Martinez Corrêa

Elenco: Ana Beatriz Nogueira; Ana Dias; Antonio Cuesta; Dany Roland;Deborah Evelyn; Emilio de Mello; Fernando Alves Pinto; Giselle Guimarães; Karine Teles; Lorena da Silva; Luiz Henrique Nogueira; Marcelo Galvan; Miguel Lunardi; Renata Sorah; Thierry Tremouroux e Vadim Nikitin.

Cenografia e Projeto Gráfico: Gringo Cárdia e Cristina Novaes; Iluminação: Cibele Forjaz; Figurinos: Kalma Murtinho; Assistentes de Figurino: Valéria Stefani e Vivian Miranda; Assistente de Direção: Alexandre Gabriel

Estreia no dia 07 de outubro de 1998, no Centro Cultural Banco do Brasil, Rio de Janeiro e em 17 de julho de 1999 no Teatro Popular do Sesi, São Paulo. 
DOCUMENTOS ICONOGRÁFICOS: 07 Artigos, 02 Notícias e 01 Programa de Peça (Acervo: Centro de Documentação e Informação em Arte da FUNARTE RJ) $e$ referência no no site da Enciclopédia de Teatro Itaú Cultural:

http://www.itaucultural.org.br/aplicexternas/enciclopedia_teatro/Enc_Cias/dsp_dad os_evento.cfm?id_evento $=402644 \&$ st_evento $=A s \% 20 T r \% C 3 \% A A s \% 20 I r m \% C 3 \% A$ $3 s$

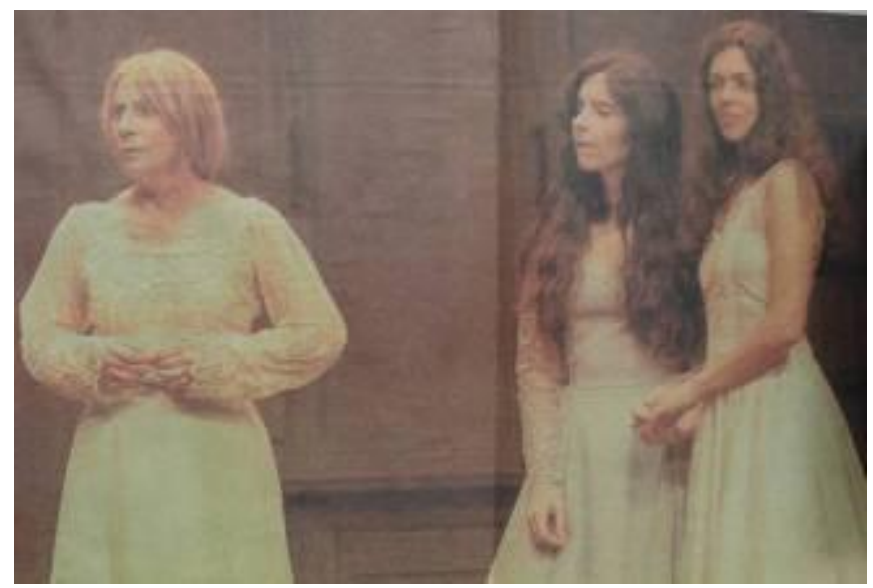

Renata Sorah, Deborah Evelyn e Lorena da Silva (Fonte: "As Três Irmãs na banalidade cotidiana", $O$ Globo, 09 de outubro de 1998 - Foto: Marizilda Cruppe)
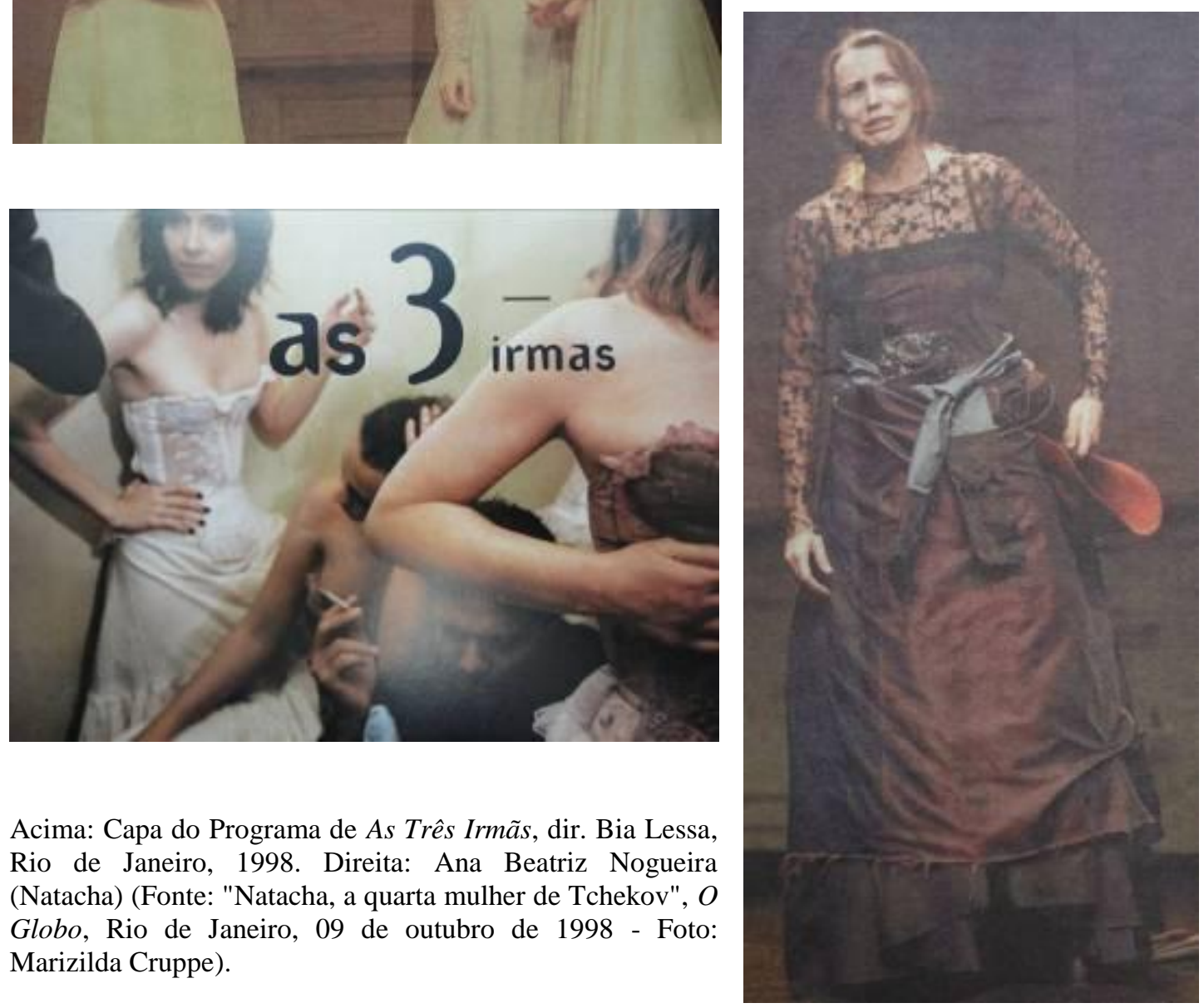

Acima: Capa do Programa de As Três Irmãs, dir. Bia Lessa, Rio de Janeiro, 1998. Direita: Ana Beatriz Nogueira (Natacha) (Fonte: "Natacha, a quarta mulher de Tchekov", $O$ Globo, Rio de Janeiro, 09 de outubro de 1998 - Foto: Marizilda Cruppe). 


\section{AS TRÊS IRMÃ̃S. Rio de Janeiro, 1999.}

Direção: Enrique Diaz.

Tradução e Adaptação: Edla Van Steen.

Dramaturgia: Elena Soarez

Elenco: André Barros (Andrei); Antonio Pedro (Tchebutykin); Celso Frateschi (Vershinin); Cláudia Abreu; Débora Duboc (Natacha); Fernando Eiras (Tuzenbach); Julia Lemmertz (Olga); Luciano Chirolli (Kulyguin); Maria Padilha (Macha); Paulo Trajano (Solioni) e Yolanda Cardoso (Anfissa).

Cenografia: Helio Eichbauer; Figurinos: Marcelo Olinto; Iluminação: Maneco Quinderé; Assistente de Direção: Johana Albuquerque; Assitente de Figurino: Letícia Jacques;

Estreia no dia 15 de janeiro de 1999, no Teatro Leblon, Rio de Janeiro. Em 12 de março de 1999, no Teatro SESC Vila Mariana, São Paulo.

DOCUMENTOS ICONOGRÁFICOS : 06 Críticas, 02 Notícias, 01 Encarte e 01 Programa de Peça (Acervo: Centro de Documentação e Informação em Arte da FUNARTE RJ).

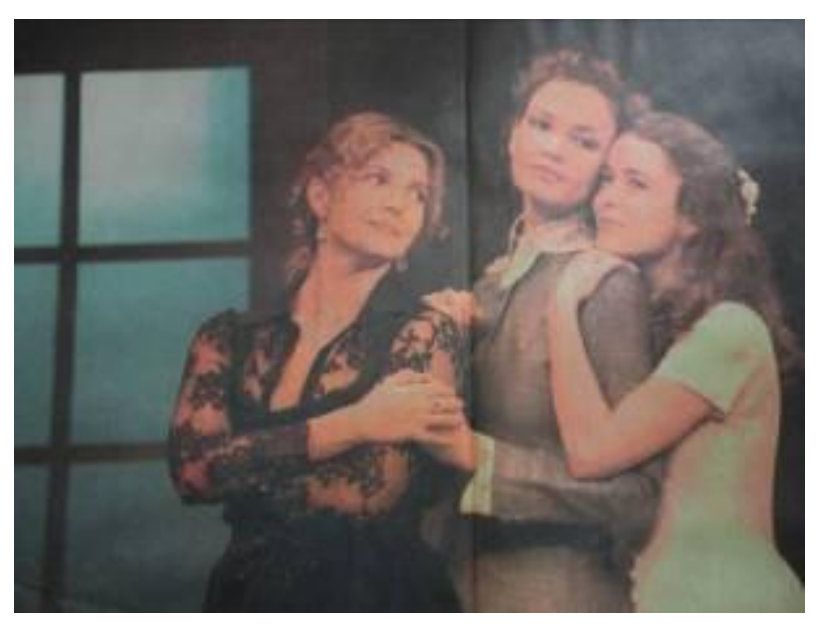

Maria Padilha (Macha), Julia Lemmertz (Olga) e Maria Padilha (Irina) (Fonte: "Amizade em Família", O Globo, 02 de janeiro de 1999 - Foto: Ana Branco).

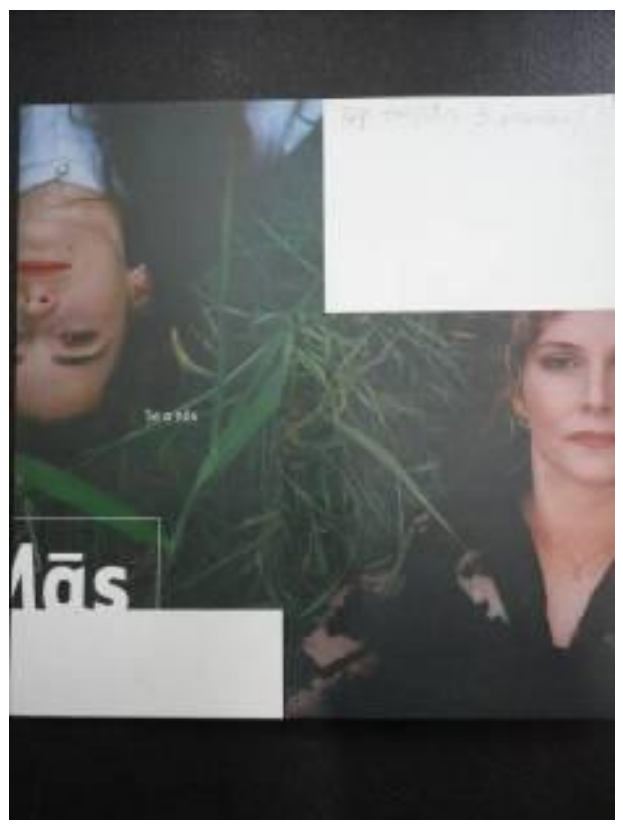

Programa da Peça. As Três Irmãs, dir. Enrique Diaz, Rio de Janeiro, 1999.

\section{TIO VÂNIA. São Paulo, 2000.}

Produção: Teatro Ágora (peça de inauguração)

Direção: Celso Frateschi.

Adaptação: Celso Frateschi.

Elenco: Mario Augelli (Astrov); Fábio Herford (Vânia); Nádia de Lion (Sônia);

Daniela Carmona (Helena); Cinthia Zaccariotto (Marina); Augusto Juncal

(Teleguine) e Luis Guilherme (Serebriakov). 
Cenário e Figurinos: Sylvia Moreira; Iluminação: Roberto Lage; TrilhaSonora: Aline Meyer;

Estreia em 2000, no Teatro Ágora, São Paulo. Em 2003 estreia no Rio, no Teatro do Planetário/Maria Clara Machado, com algumas alterações no elenco.

DOCUMENTOS ICONOGRÁFICOS: 03 Críticas e 01 Notícia (Acervo: Centro de Documentação em Arte- FUNARTE RJ).

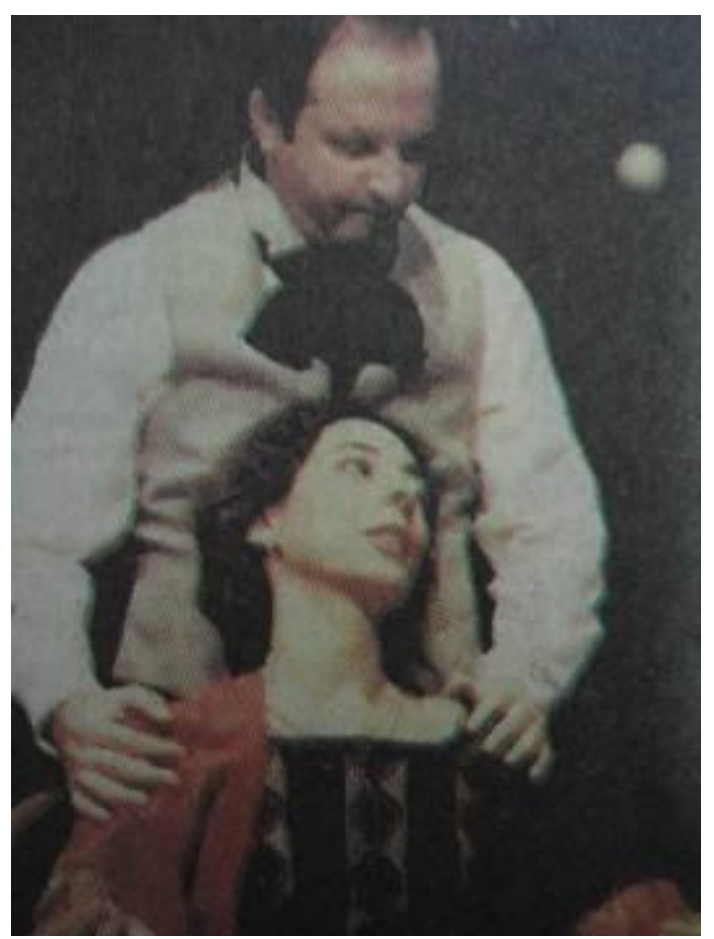

Fabio Herford (Vânia) e Daniela Carmona (Helena) - (Fonte: "Ágora põe em cena um Chekhov impecável", $O$ Estado de São Paulo, 16 de fevereiro de 2001. Foto: João Caldas/Divulgação)

\section{O JARDIM DAS CEREJEIRAS. São Paulo, 2000.}

Direção: Élcio Nogueira Seixas.

Tradução: Vadim Mikitin

Elenco: Tônia Carreiro (Lhuba Andrêievna Raniévskaia); Renato Borghi (Leonid Gáief); Beth Goulart (Vária); Milhem Cortaz (Lermolai Aleksêievitch Lapákhin); Ana Kutner (Ánia), Roberto Alvim (Pétia Serguêievitch Trafimof); Kaio Caesar (Semion Pantebêievitch Epikbodof); Nilton Bicudo (Iacba); Iara Jamra (Duniácha); Abrahão Farc (Boris Boríssovitch Semeônof Pichtchik); Roger Avanzi (Firs) e Dirce Migliaccio (Charlotta Ivánovna).

Cenografia: Helio Eichbauer; Figurinos: Simone Mina; Iluminação: Wagner Pinto.

Estreia no dia 15 de dezembro de 2000, no Teatro do SESC Vila Mariana, São Paulo. No Rio, estreou no dia 30 de março de 2001, no Teatro Nelson Rodrigues.

DOCUMENTOS ICONOGRÁFICOS : 01 folder, 01 notícia e 01 crítica de jornal (Acervo: Centro de Documentação e Informação em Arte da FUNARTE RJ). 


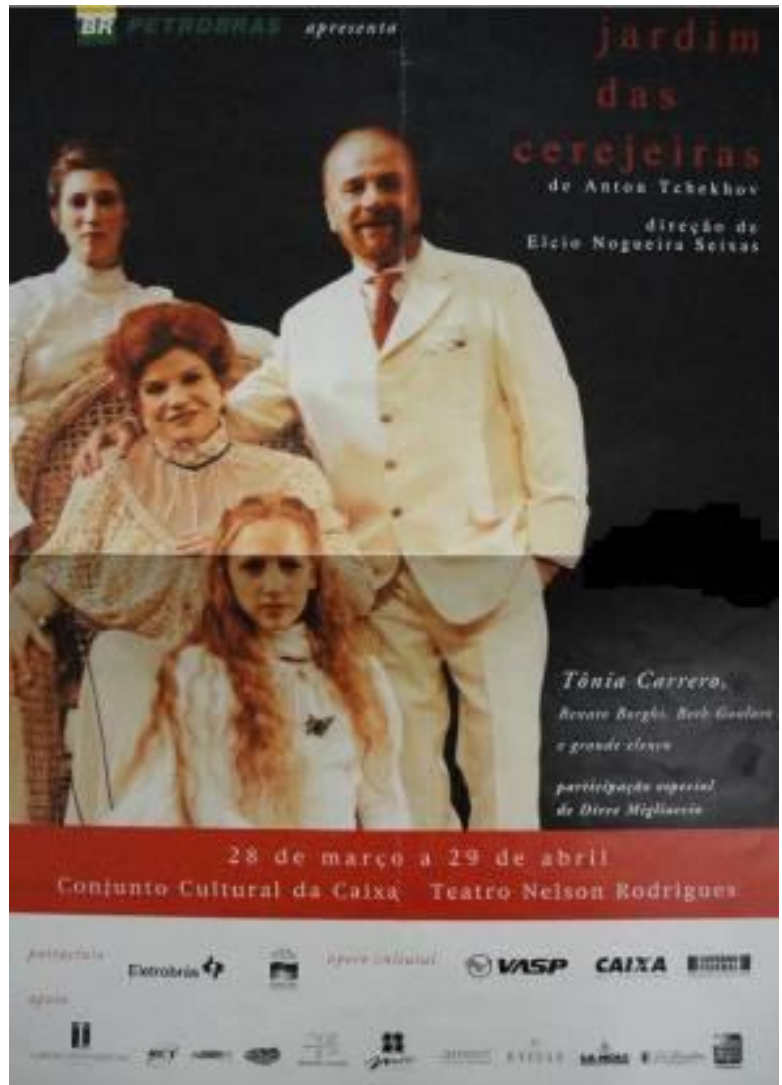

Cartaz de Divulgação da Peça. O Jardim das Cerejeiras, dir. Élcio Nogueira Seixas, 2000.

\section{A PROPOSTA. São Paulo, 2002.}

Adaptação livre da peça "Pedido de Casamento" Produção: Bravos Atores

Direção: Rodolfo García Vázquez

Adaptação: Rodolfo García Vázquez e Ivan Cabral.

Elenco: Luiz Augusto Alper; Valéria Di Pietro; Emerson Caperbá; Rosemeri Ciupak; Renata Sêpa; Ângela Leme.

Elenco (em 2003): Daniel Gaggini; Patrícia Vilela; Eduardo França, Priscilla Carvalho e Mônica Negro

Estreia no dia 26 de julho de 2002, no Centro Cultural São Paulo, São Paulo. Entrou em cartaz novamente em 02 de abril de 2003, no Teatro Folha, São Paulo.

DOCUMENTOS ICONOGRÁFICOS : 01 bilhete de peça e 02 críticas de jornal (Acervo: Centro de Documentação e Informação em Arte da FUNARTE RJ). 


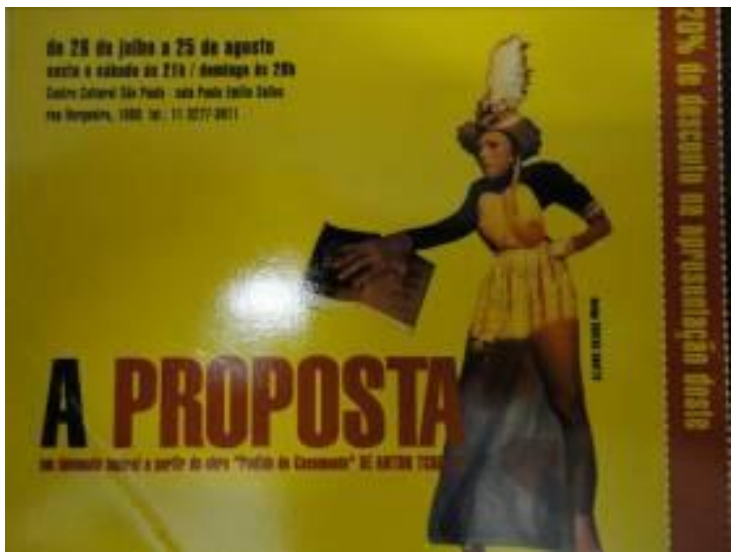

Bilhete da peça $A$

proposta, dir.

Rodolfo García

Vázquez, São Paulo,

2002.
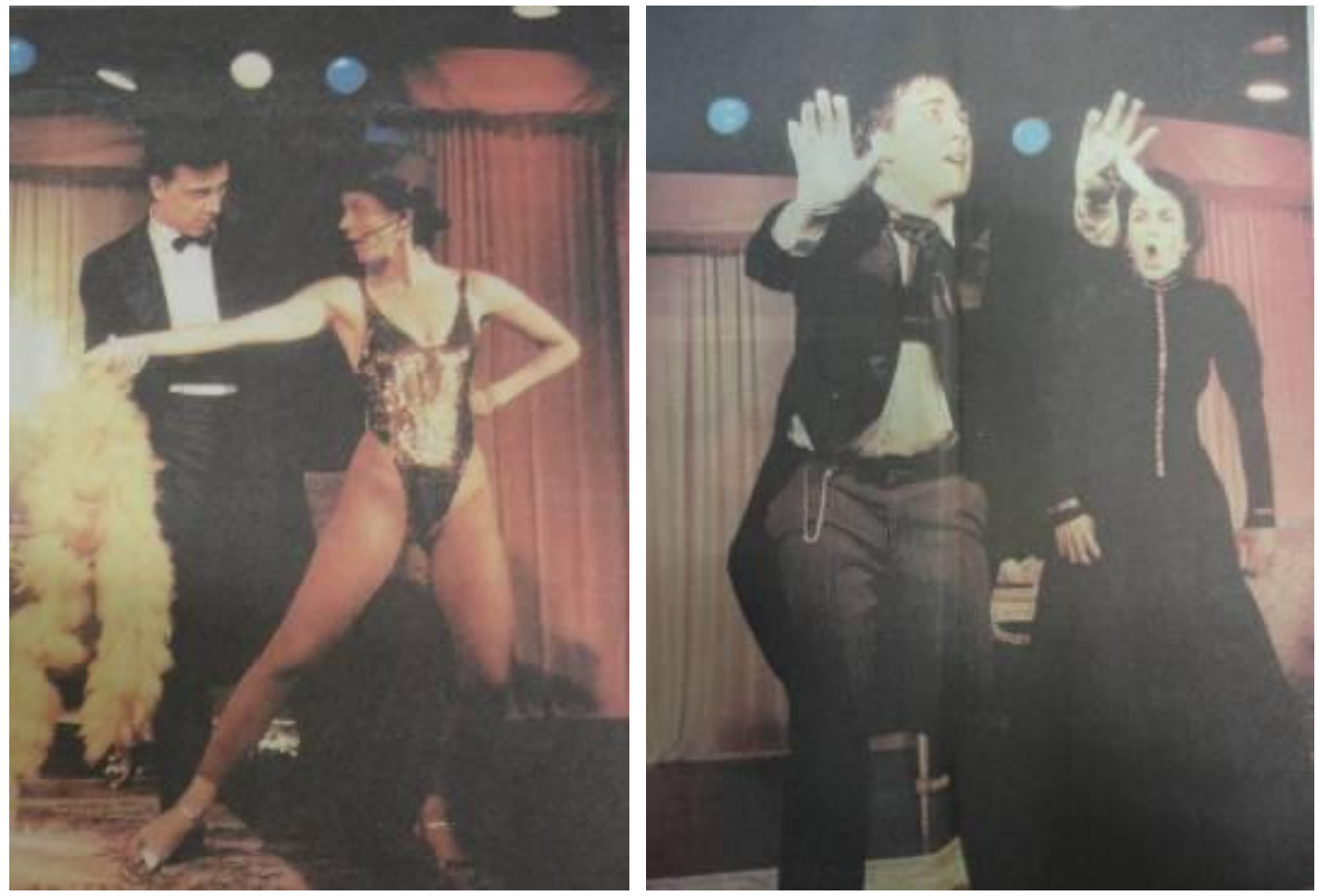

Cenas do espetáculo - sem identificação de atores/personagens. (Fonte: à esquerda - " Chekhov na visão bem-humorada dos Bravos Atores", O Estado de São Paulo, São Paulo, 02 de abril de 2003/ à direita: "'A Proposta' mostra com graça clichês do poder", O Estado de São Paulo, São paulo, 24 de agosto de 2002.)

TIO VÂNIA. Rio de Janeiro, 2003.

Direção: Aderbal Freire-Filho.

Tradução: Millôr Fernandes.

Elenco: Diogo Vilela (Tio Vânia); Débora Bloch (Helena); Daniel Dantas (Astrov); Bel Kutner (Sônia); Rogério Fróes (Professor Serebriácov); Suzana Faíne (Maria Vassilievna); Alby Ramos (Teléguine) e Ida Gomes (Ba). 
Figurinos: Marcelo Pies; Iluminação: Maneco Quinderé; Assistente de Iluminação: Carlos Lafert; Cenografia: Daniela Thomas; Assistente de Cenografia: Patrícia Rabbat; Direção Musical: Tato Taborda.

Estreia no dia 06 de junho de 2003, no Parque Lage, Rio de Janeiro.

DOCUMENTOS ICONOGRÁFICOS : 01 encarte, 04 críticas de jornal, 02 notícias e 01 programa de peça (Acervo: Centro de Documentação e Informação em Arte da FUNARTE RJ).

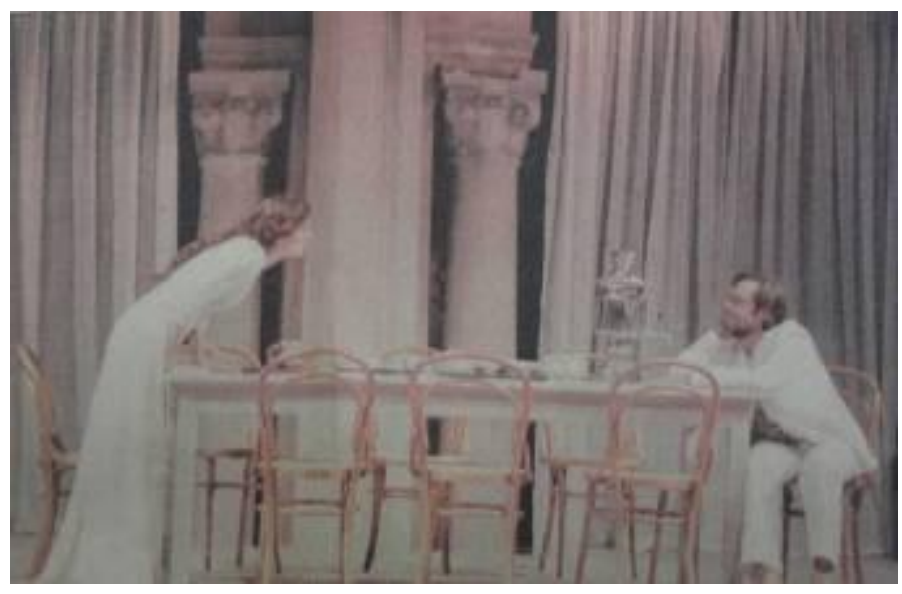
Deborah Bloch (Helena) e Diogo Vilela (Vânia) (Fonte: "'Tio Vânia' fala do fracasso do homem contemporâneo", $\quad O$ Estado de São Paulo, 08 de agosto de - Foto: Divulgação)

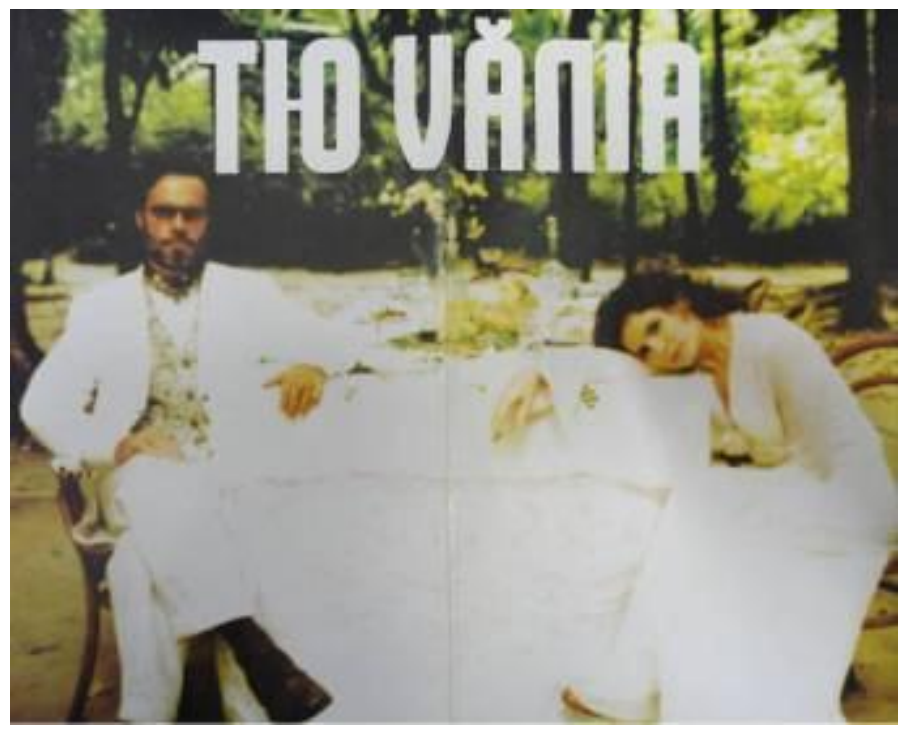

Capa do Programa da Peça. Tio Vânia, dir. Aderbal Freire-Filho, Rio de Janeiro, 2003.

\section{A GAIVOTA. Rio de Janeiro, 2006.}

Produção: Cia dos Atores

Direção: Enrique Diaz.

Adaptação/Criação: Enrique Diaz.

Elenco: Bel Garcia; Emilio de Mello; Enrique Diaz; Felipe Rocha; Gilberto Gawronski; Malu Gallo; Isabel Teixeira e Mariana Lima.

Cenografia: Afonso Tostes; Figurinos: Marcelo Olinto; Iluminação: Maneco Quinderé; Trilha Sonora: Lucas Marcier, Rodrigo Marçal e Estúdio APR X; Direção de Produção: Rossine A. Freitas. 
Estreia no dia 06 de dezembro de 2006, no Teatro Poeira, Rio de Janeiro permaneceu em cartaz até o final de março de 2007. O espetáculo foi apresentado em 09 países, incluindo uma excursão pela França e Espanha. No Brasil, foi apresentado em 15 cidades no ano de 2008.

DOCUMENTOS ICONOGRÁFICOS : 01 programa de peça (Acervo: Centro de Documentação e Informação em Arte da FUNARTE RJ).

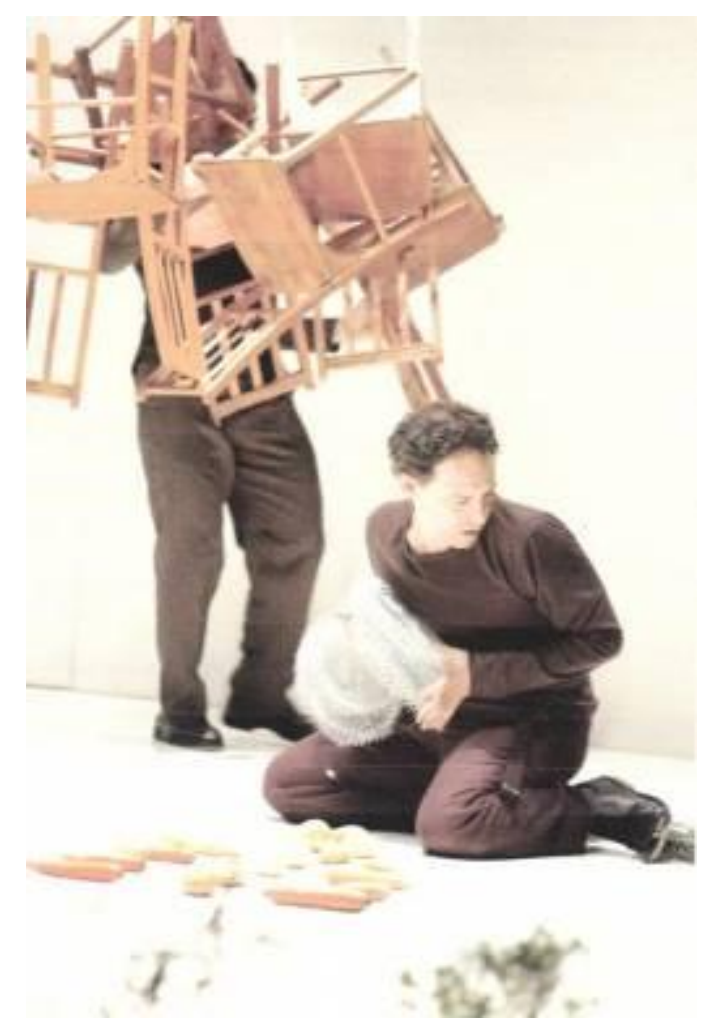

Emílio de Melo em cena de Gaivota - tema para um conto curto. (Acervo: Centro de Documentação $e$ Informação em Arte da FUNARTE RJ)

\section{A FARSA. Porto Alegre, 2007.}

Espetáculo reunia as seguintes peças em um ato: Os Faladores, de Cervantes; $O$ Urso, de Tchekhov; O Médico Saltador, de Moliére; Ciúmes de um Pedestre, de Martins Pena.

Direção: Luiz Artur Nunes.

Elenco: Marcos Breda; Sérgio Marone; Mário Borges; Cláudia Ohana; Bianca Byington e Luciana Braga.

Cenografia: Hélio Eichbauer; Figurinos: Coca Serpa; Iluminação: Paulo César Medeiros; Música: Alexandre Elias.

Estreia em 02 de agosto de 2007, no Theatro São Pedro, Porto Alegre. Foi apresentado no Rio de Janeiro, em temporada no SESC Ginástico. Logo após, excursionou por algumas cidades brasileiras. 
DOCUMENTOS ICONOGRÁFICOS: Referências disponíveis no site da Enciclopédia de Teatro Itaú Cultural: http://www.itaucultural.org.br/aplicexternas/enciclopedia_teatro

\section{O JARDIM DAS CEREJEIRAS. Rio de Janeiro, 2008.}

Direção: Moacir Chaves.

Tradução: Gabor Aranyi.

Elenco: Débora Evelyn (Liubov Andreievna); André Stock (Epikhodov); Claudia Sardinha (Ánia); Elisa Pinheiro (Vária); Gláucio Gomes (Gaiev); Julia Marini (Duniacha); Leandro Daniel Colombo (Lopakhin); Marcos Marjan (Trofimov); Monica Biel (Charlota); Peter Boos (Iacha) e Sidy Correa (Pichtchik).

Cenografia: Fernando Mello da Costa; Figurinos: Inês Salgado; Iluminação: Aurélio de Simoni; Direção Musical: Tato Taborda.

Estreia em 08 de maio de 2008, no Teatro Municipal Maria Clara Machado, Rio de Janeiro.

DOCUMENTOS ICONOGRÁFICOS : 04 críticas de jornal, 02 notícias, 01 bilhete e 01 programa de peça (Acervo: Centro de Documentação e Informação em Arte da FUNARTE RJ).
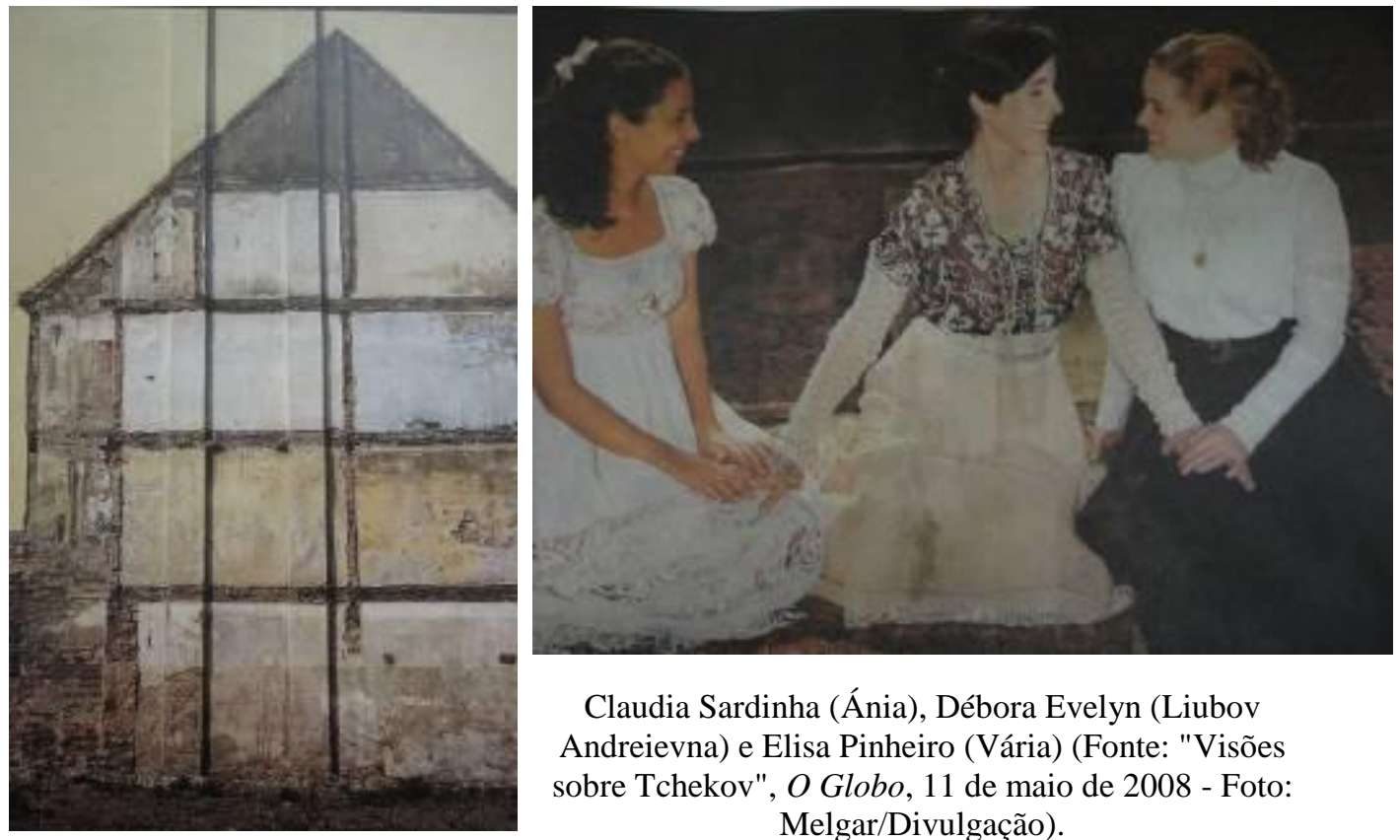

Claudia Sardinha (Ánia), Débora Evelyn (Liubov Andreievna) e Elisa Pinheiro (Vária) (Fonte: "Visões sobre Tchekov", O Globo, 11 de maio de 2008 - Foto: Melgar/Divulgação).

Programa da Peça. $O$ Jardim das Cerejeiras, dir. Moacir Chaves, Rio de Janeiro, 2008. 


\section{TIO VÂNIA. São Paulo, 2008.}

Produção: Grupo Ágora.

Direção: Celso Frateschi.

Adaptação: Celso Frateschi e Edith Siqueira

Elenco: Elizabeth Hartmann; Ângelo Brandini; Arô Ribeiro; Cinthya Chaves; Christiane Galvan; Gisela Millás; Heitor Goldfus; Sidney Santiago e Adriana Mazzoni.

Cenografia e Figurinos: Sylvia Moreira; Iluminação: Roberto Lage.

Estreia em São Paulo em 2008, no Teatro Ágora, São Paulo.

DOCUMENTOS ICONOGRÁFICOS: Referências disponíveis no site da Enciclopédia de Teatro Itaú Cultural: http://www.itaucultural.org.br/aplicexternas/enciclopedia_teatro 


\section{Anexo 3}

\section{Edições Brasileiras (Contos e Teatro)}

A listagem inclui textos traduzidos, mas não publicados (encontrados em arquivos de grupos teatrais, na SBAT e na FUNARTE) e textos traduzidos e publicados em livro. De antemão é preciso ressaltar que tal levantamento pode ter pecado por omissões para as quais, de antemão, pedimos desculpas.

\section{SEM DATA}

Tchekov, Anton Pavlovith. Os Males que o tabaco produz. (seguido dos títulos: Os Males do Tabaco, Os Males que o Fumo Produz e Malefícios do Tabaco). $<19 . . .>$

- 8f - mimeografado - Tradutor não indicado. Ano não Indicado.

$\mathrm{Na}$ primeira página constam referências aos seguintes textos (possivelmente fontes para a tradução: Lês méfaits du tabac (in. Théatre III. trad. do russo por Denis Roche. Paris: Livrairia Plon. S/D), Les mafaits du tabac (in: Théatre. trad de André Barsacq. Paris: Editons Denoël, 1958) e Sobre el danõ que hace el tabaco (in: Chejov. Teatro Completo. Trad do russo por Salvador Bordoy. Madrid: Aguilar, 1959).

(Acervo: FUNARTE - RJ - CEDOC)

TCHEKOFF, Anton. Um drama na caça. Tradução de Manuela Pôrto e João Gaspar Simões. Lisboa: Portugália Editora, LDA. s/d (Acervo: Biblioteca do IEL-UNICAMP/ Acervo Brito Broca)

TCHEKHOV, Anton. Tio Vânia - cenas da vida no campo. Tradução de Jorge Silva Melo. Lisboa: Editorial Estampa. s/d.

- Tradução possivelmente feita do original russo;

(Acervo: Biblioteca do Instituto de Artes da UNICAMP)

Tchekow, Anton. O urso. Tradução de José Maria Monteiro e Jardel Jercolis. Biblioteca da Aldeia. $\langle 19 . . .>$

- 13f - memeografado. Constam detalhes de atores que fizeram as personagens (Elena Ivanovna Popova - Ana Edler / Grigori Stiepanovich Smirnov - Armando Carlos Magno / Luká - Fernando Cezar).

(Acervo: FUNARTE - RJ - CEDOC)

Tchekov. Os mais brilhantes contos de Tchekov. Tradução de Yolanda Vettori. Rio de Janeiro: Livraria das Edições de Ouro, <19...>

- Sem fonte da Tradução.

- Índice de contos: Um caso de clínica média/ Ivane Matvêitch/ A Farmacêutica/ Tentação/ Um Homem Feliz/ O Fósforo Sueco/ Então, Era Ela!/ Perpetuum Mobile/ História Sem Título/ O Espelho Mágico/ Nos Banhos/ Fracasso/ Diário de Um Homem Genioso/ Desfecho Feliz/ O Espelho/ Uma Boda/ O Marido Enganado/ Uma Vingança/ O Implicante/ A Oportunidade Feminina/ Um 
Homem Conhecido/ Veraneio/ Perdidos/ Noturno/ Os Indesejável/ O Beijo.

(Acervo: FUNARTE - RJ - CEDOC).

Tchecov. A Gaivota. Tradução de Tatiana Belinky. <19...>

- Texto adquirido em 20 de abril de 1989 pelo Departamento de Artes Cênicas da Unicamp.

(Acervo: Biblioteca do Instituto de Artes da Unicamp)

Tchekov, Anton. O Jardim das Cerejeiras. Tradução de Paulo Mamede. <19...>

- 92 f - mimeografado. Sem Data. Algumas anotações indicam a existência da tradução do Millôr e a de Olba Obry e Pontes de Paula Lima.

(Acervo: FUNARTE - RJ - CEDOC).

Tchekhov, Anton. Tio Vania. Tradução de Annibal Machado. <19...>

- 42f - mimeografado. Sem data de publicação/tradução. Possivalmente feita do francês (presença de nomes como Teleguine).

(Acervo: FUNARTE - RJ - CEDOC).

Chekov, Anton. O Canto do Cisne. Tradução de Flávio de Campos. <19...>

- 9f - mimeografado. Tradução feita possivelmente a partir do francês presença de transliterações como "Pouchkine".

(Acervo: FUNARTE - RJ - CEDOC).

Tchekhov, Anton. O Aniversário no Banco. Tradução de Correia Alves. <19...>

- 18f - cópia mimeografada. Sem fonte da Tradução. Doação de Flávio Cerqueira em 23/10/1978.

(Acervo: FUNARTE - RJ - CEDOC).

Tchekhov, Anton. O Camaleão. Tradução e adaptação de Renata Pallottini. <19...>

- 49f - mimeografado. Lux In Tenebris Produções Artísticas LTDA.

- Confusão na catalogação. Conferir se se trata de um espetáculo que reúne várias cenas, ou se tudo foi encenado separadamente. Textos reunidos: Um empresário debaixo do divã/ Pedido de Casamento/ Pamonha/ Os malefícios do tabaco/ Camaleão/ O Gordo e o Magro/ O Aniversário.

(Acervo: FUNARTE - RJ - CEDOC).

Tchekov, Anton. O Jubileu. Tradução de Brutus Pedreira e Eugenio Kusnet. <19...>

- 16f - mimeografado. Sem fonte da tradução e sem data especificada.

(Acervo: FUNARTE - RJ - CEDOC)

Tchecov, Anton. O Jardim das Cerejeiras. Tradução de Eugenio Kusnet. <19...>

- Cópia memeografada pela JFM/Curitiba, em 8 de setembro de 1969 (Seção de Mimeo Datilografia do Teatro Guaíra).

(Acervo: Biblioteca do Instituto de Artes da Unicamp)

Tchekhov, Anton. 6 peças em um acto. Porto: Tip. Primavera, <19..> Prefácio de Deniz Jacinto. 
O Canto do Cisne: versão portuguesa de Rui Siqueira (não consta fonte original)

O Urso: versão portuguesa de Luiz Francisco Rebello

Um Pedido de Casamento: versão portuguesa de Correia Alves

O Trágico à Força: versão portuguesa de Correia Alves

$O$ aniversário do Banco (*nome dado para $O$ Jubileu): versão portuguesa de Correia Alves

Os malefícios do tabaco: versão portuguesa de Luiz Francisco Rebelo

(Acervo: FUNARTE - RJ - CEDOC).

Chekhov, Anton. Peças em 1 Acto. Lisboa: Editorial Minotauro. $2^{\mathrm{a}}$ ed. <19...> Prefácio de Deniz Jacinto.

O Canto do Cisne: versão portuguesa de Rui Siqueira (não consta fonte original)

O Urso: versão portuguesa de Luiz Francisco Rebello

Um Pedido de Casamento: versão portuguesa de Correia Alves

O Trágico à Força: versão portuguesa de Correia Alves

$O$ aniversário do Banco (*nome dado para $O$ Jubileu): versão portuguesa de Correia Alves

Os malefícios do tabaco: versão portuguesa de Luiz Francisco Rebelo

(Acervo: FUNARTE - RJ - CEDOC).

\section{DÉCADA DE 30}

TCHECOFF, Anton. Os Inimigos - Contos. Tradução de Georges Selzoff e F. Olandim. São Paulo: Edições Cultura - Georges Selzoff, 1931.

- Tradução do Russo por Iuri Zéltzov (comerciante russo emigrado que assinava como Georges Selzoff), fundados desta editora que em parceria com brasileiros fazia traduções do russo.

- É parte, junto com o livro "O Pavilhão no 6" da coleção "Biblioteca de Autores Russos". Contém os contos: Os inimigos/ Delírio (Gussieff)/ Algazarra em família/ No carro/ Verotchka/ Estudante/ Lenda Sueca (o conto do jardineiro chefe)/ Zinotchka/ Uma noite atroz.

(Acervo: Biblioteca do IEL - UNICAMP/ Coleção AIDA COSTA)

\section{DÉCADA DE 40}

TCHECKOFF, Anton. A Estepe. Tradução de Cordeiro de Brito. Lisboa: Editorial Inquérito, 1940.

- Coleção: "Os melhores romances dos melhores romancistas".

- Tradução feita possivelmente do francês (na pequena apresentação ocorrem nomes como Tolstoï e Dostoïevsky).

(Acervo: Biblioteca do IEL - UNICAMP) 
TCHEKHOV, Anton. Amor Impossível. Tradução de Marina Salles Goulart de Andrade e Gilberto Galvão. Rio de Janeiro: Casa Editora Vecchi LTDA, 1945.

- Sem referência do original para tradução;

- Coleção Os Grandes Nomes. Volume sem apresentação ou prefácio. Possui o "romance" Amor Impossível e os contos como O bilhete premiado/ No restaurante postal/ Um animal de raça/ O enxoval.

(Acervo: Biblioteca do IEL - UNICAMP)

TCHECOF, Anton P. Olhos Mortos de Sono. Tradução de Carlos M. A. Bittencourt. São Paulo: Editôra Assunção Limitada, 1945.

- Contém os contos: Olhos mortos de sono/ Os nervos/ A condecoração/ Medidas preventivas/ A vingança/ O orador/ As sensações fortes/ Um bom final/ A obra de arte/ Uma noite de terror/ História de uma enguia/ O medo/ Entre meninos/ A jóia roubada/ Dois valentes/ O vingador/ Ivan Matveievitch/ O álbum/ Língua comprida/ Grischa/ Celebridades/ Na hospedaria/ Os veranistas.

(Acervo: Arquivo Edgar Leuenroth - UNICAMP - Coleção HFL)

\section{DÉCADA DE 50}

TCHECOV. Contos. Tradução de Costa Neves. São Paulo: W. M. Jackson, 1957.

- Tradução feita possivelmente do francês (presença de nomes como Pushkine). Seleção e Prefácio de Henrique de Campos. Volume XXXVII. Coleção Clássicos Jackson.

- Contos: La Cigale/ Sonhos/ O Buraco/ O Beijo/ Varka/ A Estepe.

- Prefácio e pequena Bibliografia inicial mostram a escassez de textos críticos disponíveis sobre o autor para o leitor ocidental;

(Acervo Biblioteca Nacional - Obras Gerais - Rio de Janeiro)

TCHEKHOV, A. P. A dama do cachorrinho e outros contos. Tradução de Boris Schnaiderman. Rio de Janeiro: Civilização Brasileira, 1959.

- Tradução feita diretamente do russo. Pósfácio e notas de Boris Schnaideraman.

(Acervo: Biblioteca do IEL - UNICAMP)

TSCHECOV, Anton. Histórias Imortais. Tradução de Tatiana Belinky. São Paulo: Editôra Cultrix LTDA, 1959.

- Tradução feita do Russo.

-Contém os contos: A morte do funcionário/ Menino Malvado/ No departamento dos correios/ O Malfeitor/ Vanka/ Brincadeira/ Senhoras/ Gricha/ O vingador/ A mulher do farmacêutico/ Camaleão/ Um homem conhecido/ Falta de que fazer (Romance de férias)/ Veraneiro/ Aniuta/ Sobrenome Cavalar/ Inimigos, Angústia/ A descoberta/ Ninharias da vida/ A corista/ O marido/ Libertinagem/ O investigador/ Meninos/ Zinotchka/ $\mathrm{O}$ bilhete de loteria/ O médico/ O mendigo/ Inadvertência/A duquesa/ Do amor/ A aposta/ "Amorzinho"/ A esposa/ Ana no pescoço.

- Parte da Coleção "Os maiores contistas de Todos os Tempos". (Acervo: Biblioteca do Instituto de Artes - UNICAMP) 


\section{DÉCADA DE 60}

TSCHECOV, Anton. O Beijo e outras histórias. Tradução de Boris Schnaiderman. São Paulo: Boa Leitura Ed. S/A, 1961.

- Tradução feita diretamente do original russo;

- Contém os contos: O Beijo/ Kaschtanka/ Viérotchka/ Uma Crise/ Uma

História Enfadonha/ Enfermaria n 6 .

(Acervo: Biblioteca do IEL - UNICAMP)

Tchekhov, Anton. 2 Peças em um Acto. Porto: Tipografia Primavera Ltda, 1961.

Peças: A Boda/ Na Estrada Real.

- Tradução e Edição de António Pinheiro Guimarães e prefácio de Carlos Porto.

- Sem referências à origem da tradução (possivelmente do francês presença de transliterações como Evodkime, Ivane etc)

(Acervo: FUNARTE - RJ - CEDOC).

Tchekov, Anton. A Gaivota e O Cerejal. Tradução de Eusébio de Carvalho. Lisboa: Editorial Presença, 1963.

- Tradução feita possivelmente do francês (presença de nomes como Trigorine). (Acervo: FUNARTE - RJ - CEDOC).

Tchekhov, Anton. O Urso. Tradução de Gastão de Holanda. <1963>

- 16f - mimeografado. Material da Universidade do Recife - Escola de Belas Artes.

(Acervo: FUNARTE - RJ - CEDOC)

Tchêcon (sic), Anton. O Aniversário. Tradução de Osmar Cruz. In: Teatro da Juventude ${ }^{\circ}$ 4 e 5, out. e nov. de 1965.

- Tradução do espanhol feita por Osmar Cruz. Coleção Teatro da Juventude (dir. Tatiana Belinky). Publicação do Governo do Estado de São Paulo.

(Acervo: FUNARTE - RJ - CEDOC)

Tchekhov, Anton. As Três Irmãs. Tradução de Augusto Pastor Fernandes. Lisboa: Editorial Presença, 1965.

- Tradução feita possivelmente a partir do francês (presença de nomes como Tcheboutykine, Feraponte).

(Acervo: FUNARTE - RJ - CEDOC/ Biblioteca Florestan Fernandes FFLCH USP).

TCHEKOV, Anton. O Urso - Teatro Pilhéria em um ato. Tradução de Tatiana Belinky. In: Cadernos de Teatro, $\mathrm{n}^{\circ}$ 29. Rio de Janeiro: Instituto Brasileiro de Educação, Ciência e Cultura (IBECC), Janeiro/Março de 1965.

(Acervo: Biblioteca do Instituto de Artes da Unicamp) 
Tchekov, Anton. Ivanov. Tradução de José Sinde Felipe. Lisboa: Editorial Presença, 1965.

- Confirmar origem da tradução. Possivelmente do francês (transcrição dos nomes é 'afrancesada': "Borkine")

(Acervo: FUNARTE - RJ - CEDOC)

TSCHECOV. Contos da Velha Rússia. Tradução de Tatiana Belinky. Rio de Janeiro: Edições de Ouro, 1966.

- Tradução feita diretamente do original russo;

- Contém os contos: Duas palavras de explicação/ A morte do funcionário/ Menino malvado/ No departamento dos correios/ O malfeitor/ Vanka/ Brincadeira/ Senhoras/ Gricha/ O vingador/ A mulher do farmacêutico/ Camaleão/ Um homem conhecido/ Falta de que fazer (Romance de Férias)/ Veraneio/ Aniuta/ Sobrenome Cavalar/ Inimigos/ Angústia/ A descoberta/ Ninharias da vida/ A corista/ O marido/ Libertinagem/ O investigador/ Meninos/ Zinotchka.

(Acervo: Biblioteca do IEL - UNICAMP)

Tchecov, Anton P. O Jardim de Cerejeiras. Tradução de Olga Obry e Pontes de Paula Lima. Rio de Janeiro: Edições GRD, 1967.

- Traduzido do original russo (segundo consta no livro). Coleção Teatro de Ontem e de Hoje. Dir. de Martim Gonçalves.

(Acervo: FUNARTE - RJ - CEDOC).

Tchekhov, Anton. O Selvagem. Tradução de Carlos Grifo. Lisboa: Editorial Presença, 1968.

- Tradução feita possivelmente do francês (transcrição dos nomes é 'afrancesada': "Leônidas Stepanovitch Jeltukine").

(Acervo: FUNARTE - RJ - CEDOC)

Tchecov, A. P. Dos Males do Fumo. Tradução de Tatiana Belinky. In: Teatro da Juventude n ${ }^{\circ}$ 28. São Paulo, 1969.

- tradução direta do russo por Tatiana Belinky. Coleção Teatro da Juventude (dir. Tatiana Belinky). Publicação do Governo do Estado de São Paulo.

(Acervo: FUNARTE - RJ - CEDOC)

\section{DÉCADA DE 70}

CHEKOV, Anton. Vera, um episódio - entre outras. Rio de Janeiro: Editora Monterrey, $<1972$ ?>

- Tradução do conto de Tchekhov por Luis Osvaldo Cunha (especial para a Monterrey). Coleção Avec (Histórias fabulosas de grandes autores clássicos e modernos). Editora marcada pela publicação de textos ligeiros para entretenimento, fofocas e histórias picantes.

- No número: Vera, um Episódio (Verotchka)- Anton Chekhov/ O desaparecimento do trem especial - Conan Doyle/ O poder do dinheiro (Mamon e o Arqueiro) - O'Henry/ Pombos em Caçarola - Bessie Breuer/ Somos todos irmãos (The Raid) - John Steinbeck.

(Acervo Biblioteca Nacional - Obras Gerais - Rio de Janeiro) 
Tchekov, Anton. A Enfermaria n ${ }^{\circ} 6$ e outros contos. Tradução de Maria Luísa Anahory e Editorial Verbo. Lisboa: Editorial Verbo/Gris Impressores, 1972.

- Não consta referência para tradução. Biblioteca Básica Verbo - volume 67. Livros RTP.

- Índice de contos: A enfermaria $\mathrm{n}^{\circ}$ 6/ Vizinhos/ Dô-doce/ Um assassinato/ O Mendigo/ Sem título/ O adulador/ A boticária/ Uma corista.

(Acervo: FUNARTE - RJ - CEDOC).

TCHECOV. Contos de Tchecov. Tradução de Maria Jacintha. São Paulo: Editora EDIBOLSO, 1975.

- Tradução feita possivelmente através do inglês e do francês;

- Contém os Contos: Estória Alegre/ A Feiticeira/ Fatalidade/ Pesadelo/ Aniuouta/ Réquiem/ Um Belo Tumulto/ O Marido/ O Caso da Champanha/ Mártires/ O Professor de Literatura/ O Bispo/ O Duelo. (Acervo: Biblioteca Florestan Fernandes - FFLCH USP).

TCHEKHOV, Anton . As Três Irmãs. Tradução de Maria Jacintha. São Paulo: Abril Cultural, 1976

- Coleção Teatro Vivo. $1^{\text {a }}$ Edição. Introdução de Boris Schnaiderman (Acervo: FUNARTE - RJ - CEDOC)

\section{DÉCADA DE 80}

TCHEKHOV. Contos. Rio de Janeiro: Otto Pierre Editores, 1982.

- Tradução não nomeada, possivelmente oriunda do francês (copyright cedido a Editions Ferni, Genève.

- Contos e Novelas: O louco/ Camponeses/ O conselheiro secreto/ Pelo Caminho/ $\mathrm{O}$ fósforo sueco/ $\mathrm{O}$ beijo/ Os indesejáveis/ "Perpetuum mobile".

(Acervo Biblioteca Nacional - Obras Gerais - Rio de Janeiro)

TCHEKHOV, Anton . As Três Irmãs / Contos. Tradução de Maria Jacintha e Boris Schnaiderman. São Paulo: Abril Cultural, 1982.

Índice: As Três Irmãs/ O Beijo/ Kaschtanka/ Viérotchka/ Uma crise/ Uma história enfadonha/ Enfermaria n ${ }^{\circ}$ 6/ Apêndice.

(Acervo: FUNARTE - RJ - CEDOC/ Acervo Biblioteca Nacional - Obras Gerais - Rio de Janeiro)

Tchecov, Anton. O Jardim das Cerejeiras. Tradução de Millôr Fernandes. Porto Alegre: L \& PM, 1983.

- Tradução que não foi feita diretamente do russo, mas baseada em 10 traduções diferentes. Consultora para língua russa: Tatiana Junod. Presença de uma Nota do Tradutor explicando as diferenças entre $\mathrm{O}$ Cerejal e $\mathrm{O}$ jardim das Cerejeiras.

(Acervo: FUNARTE - RJ - CEDOC/ Acervo da Biblioteca Nacional Obras Gerais - Rio de Janeiro) 
- 4f - mimeografado. Tradução a partir da edição francesa de Genia Cannac e Georges Perros. Paris: Gallimard 1966.

(Acervo: FUNARTE - RJ - CEDOC).

TCHEKHOV, Anton. A dama do cachorrinho e outros contos. Tradução de Boris Schnaiderman. São Paulo.

$1^{\text {a }}$ Edição - Editora Civilização Brasileira, 1959.

$2^{\mathrm{a}}$ Edição (revista e refundida da $1^{\mathrm{a}}$ pela Editora Max Limonad), 1985.

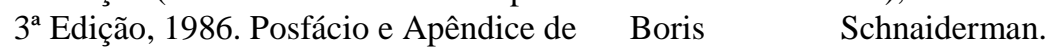

Traduções diretas do russo.

Contos (índice da edição Max Limonad): A dama do cachorrinho e outros contos/ Nos banhos/ Pamonha/ Fantasiados/ Caso com um clássico/ A morte do funcionário/ Do diário de um auxiliar de guarda-livros/ Camaleão/ Casa-se a cozinheira/ Crime premeditado/ Subtenente Prichibiéiev/ Aflição/ Um dia no campo/ A corista/ Criançada/ Sonhos/ Vanka/ Um conhecido/ Gente supérflua/ Na primavera/ Angústia/ Senhoras/ O acontecimento/ Bilhete premiado/ Volódia/ Tifo/ Inimigos/ Ilegalidade/ Olhos mortos de sono/ O sapateiro e a força maligna/ Ventoinha/ Volódia grande e Volódia Pequeno/ Um caso clínico/ Homem num estojo/ Queridinha/ A dama do Cachorrinho.

(Acervo da Biblioteca Nacional - Obras Gerais - Rio de Janeiro)

TCHEKHOV, Anton. Contos de Tchekhov. Tradução de Tatiana Belinky. São Paulo: Editora Cultrix, 1985.

- Tradução do russo, seleção e introdução de Tatiana Belinky.

- Contos: A morte do funcionário/ Menino malvado/ No departamento dos correios/ O malfeitor/ Vanka/ Brincadeira/ Senhoras/ Gricha/ O vingador/ A mulher do farmacêutico/ Camaleão/ Um homem conhecido/ Falta do que fazer (Romance de férias)/ Veraneio/ Aniuta/ Sobrenome cavalar/ Inimigos/ Angústia/ A descoberta/ Ninharias da vida/ A corista/ O marido/ Libertinagem/ O investigador/ Meninos/ Zínotchka/ $\mathrm{O}$ bilhete de loteria/ O médico/ O mendigo/ Inadvertência/ A duquesa/ Do amor/ A aposta/ "Amorzinho"/ A esposa/ Ana no pescoço.

(Acervo Biblioteca Nacional - Obras Gerais - Rio de Janeiro)

TCHEKOV, Anton. O Homem no Estojo. Tradução de Tatiana Belinky. São Paulo: Global Editora, 1986.

- Tradução direta do russo e Apresentação de Tatiana Belinky. Coleção "Histórias Inesquecíveis", dir (Edla van Steen).

- Contos: Angústia/ Desgraça Alheia/ O Malfeitor/ Vanka/ Um dia no campo (ceninha)/ Em casa/ Pavores/ Champanha (relato de um velhaco)/ Velhice/ O homem no estojo/ O mendigo/ Desregramento/ Um homem extraordinário/ No asilo para velhos e doentes incuráveis/ História desagradável/ O relato do jardineiro-chefe/ Trapaceiros à força (historinha de Ano-Novo)/ Amor de peixe/ Senhoras/ Camaleão/ Um filha de Albion/ O sapateiro e a força maligna. (Acervo Biblioteca Nacional - Obras Gerais - Rio de Janeiro)

TSCHECOV (sic), Anton. O Malfeitor e Outros Contos da Velha Rússia. Tradução de Tatiana Belinky. São Paulo: Editora Tecnoprint, <1987?>

- Tradução do russo, seleção e introdução de Tatiana Belinky, cedidas pela Editora Cultrix. Coleção Universidade de Bolso. Ilustrações de Poty.

- Contos: A morte do funcionário/ Menino malvado/ No departamento dos correios/ O malfeitor/ Vanka/ Brincadeira/ Senhoras/ Gricha/ O vingador/ A mulher do farmacêutico/ Camaleão/ Um homem conhecido/ Falta do que fazer (Romance de férias)/ Veraneio/ Aniuta/ 
Sobrenome cavalar/ Inimigos/ Angústia/ A descoberta/ Ninharias da vida/ A corista/ O marido/ Libertinagem/ O investigador/ Meninos/ Zínotchka/ O bilhete de loteria/ O médico/ O mendigo/ Inadvertência/ A duquesa/ Do amor/ A aposta/ "Amorzinho"/ A esposa/ Ana no pescoço.

(Acervo Biblioteca Nacional - Obras Gerais - Rio de Janeiro)

TCHÉKHOV, Anton. Os Melhores Contos de Tchékhov. Tradução de Tatiana Belinky. São Paulo: Círculo do Livro, 1987.

- Tradução do russo, seleção e introdução de Tatiana Belinky, cedidas pela Editora Cultrix.

- Contos: A morte do funcionário/ Menino malvado/ No departamento dos correios/ O malfeitor/ Vanka/ Brincadeira/ Senhoras/ Gricha/ O vingador/ A mulher do farmacêutico/ Camaleão/ Um homem conhecido/ Falta do que fazer (Romance de férias)/ Veraneio/ Aniuta/ Sobrenome cavalar/ Inimigos/ Angústia/ A descoberta/ Ninharias da vida/ A corista/ O marido/ Libertinagem/ O investigador/ Meninos/ Zínotchka/ O bilhete de loteria/ O médico/ O mendigo/ Inadvertência/ A duquesa/ Do amor/ A aposta/ "Amorzinho"/ A esposa/ Ana no pescoço.

(Acervo Biblioteca Nacional - Obras Gerais - Rio de Janeiro)

TCHEKHOV, Anton. Contos e Novelas. Tradução de Andrei Melnikov. Moscovo (sic): Edições Ráduga, 1987.

- Tradução direta do Russo por Andrei Melnikov. Impresso na URSS. Texto Introdutório "À Memória de Tchekhov", por A. Kuprin.

Contos: A Morte de um Funcionário/ O Dote/ O Gordo e o Magro/ Camaleão/ Uma Máscara/ O Caçador/ O Pianista/ Passou das Marcas/ Uma Brincadeira/ Entre Veraneantes/ O Marido/ Vanka/ Borboleta/ A Enfermaria $n^{\circ} 6 / \mathrm{O}$ Homem Encafuado/ Acerca do Amor/ Ionitch/ Meu Anjo/ A Dama do Cãozinho/ No Barranco/ A Noiva.

(Acervo Biblioteca Nacional - Obras Gerais - Rio de Janeiro)

TCHEKHOV, Anton. O Monge Negro. Tradução de Moacir Werneck de Castro. Rio de Janeiro: Rocco, 1987.

- Tradução da novela possivelmente feita do russo. Consta referência ao título original (Tchiornii Moarkh). Coleção Novelas Imortais, organizada por Fernando Sabino. $2^{\mathrm{a}}$ Edição.

(Acervo: FUNARTE - RJ - CEDOC/ Biblioteca Florestan Fernandes FFLCH USP)

\section{DÉCADA DE 90}

TCHEKHOV, Anton. O Violino de Rothschild e outros contos. Tradução de Noé Silva. Mairiporã: Veredas, 1991.

- Seleção, Tradução direta do russo e notas de Noé Silva.

- Contos: Alegria/ Na Barbearia/ No departamento dos correios/ Uma natureza enigmática/ Enxoval/ Perpetuum mobile/ O professor particular/ Livro de reclamações/ Leitura/ As botas/ Os nervos/ O agrimensor passou das medidas/ Recordações de um idealista/ O escritor/ Malogro/ Desfecho feliz/ Sem título/ Frontalvo/ Gússiev/ O violino de Rothschild/ A casa de mezanino/ A groselheira/ Sobre o amor. (Acervo Biblioteca Nacional - Obras Gerais - Rio de Janeiro) 
TCHEKOV, Anton. O Marido Enganado e Outros Contos. Tradução de Yolanda Vettori. São Paulo: Ediouro, 1992.

- tradução feita possivelmente a partir do francês (presença de nomes como Milkine).

- Coleção Clássicos de Bolso.

- Contos: Um Caso de Clínica Médica/ Ivane Matvêitch/ A Farmacêutica/ Tentação/ Um Homem Feliz/ O Fósforo Sueco/ Então, Era Ela!/ Perpetuum Mobile/ História sem Título/ O Espelho Mágico/ Nos Banhos/ Fracasso!/ Diário de um Homem Genioso/ Desfecho Feliz/ O Espelho/ Uma Boda/ O Marido Enganado/ Uma Vingança/ O Implicante/ A Oportunidade Feminina/ Um Homem Conhecido/ Vernaneio/ Perdidos/ Noturno/ Os Indesejáveis/ O Beijo.

(Acervo Biblioteca Nacional - Obras Gerais - Rio de Janeiro)

TCHEKHOV, Anton. Teatro I: A Gaivota/ Tio Vânia. Tradução de Gabor Aranyi. Mairiporã: Editorial Veredas, 1998.

- Tradução supostamente feita do Russo, tendo em vista que a editora cita o nome original russo. No entanto, na edição da novela O Duelo, o tradutor se utiliza de uma versão francesa para traduzir a novela.

(Acervo: Biblioteca do IEL-UNICAMP)

TCHEKHOV, Anton. Teatro II: As Três Irmãs/ O Jardim das Cerejeiras. Tradução de Gabor Aranyi. Mairiporã: Editorial Veredas, 1998.

- Tradução supostamente feita do Russo, tendo em vista que a editora cita o nome original russo. No entanto, na edição da novela O Duelo, o tradutor se utiliza de uma versão francesa para traduzir a novela.

(Acervo: Biblioteca do IEL-UNICAMP)

TCHEKHOV, Anton. Ivanov. Tradução Arlete Cavaliere e Eduardo Tolentino. São Paulo: EDUSP, 1998.

- Tradução direta do russo. Sério Em Cena. Apresentação de Arlete Cavaliere e Eduardo Tolentino.

(Acervo: FUNARTE - RJ - CEDOC)

TCHECOV, Anton. Um Papel Trágico ("Trágico a Força"). Tradução de Ricardo Hofstetter. In: Cadernos de Teatro, no 157 - Abril, Maio e Junho de 1999.

- Tradução feita a partir do inglês;

- Texto vem acompanhado de um artido de Isaac Bernat, "Despojamento e Invenção".

(Acervo: Biblioteca do Instituto de Artes da UNICAMP)

TCHEKHOV, Anton. A Noiva e Outros Contos. Tradução de Marcos Mutti. São Paulo/Rio de Janeiro: SCRINIUM/ PRIMEIRA LINHA/ CONTRA CAPA, 1999.

- Tradução feita do original russo;

- Contém os contos: A Cigarra/ A Noiva/ A Carroça

(Acervo: Biblioteca do IEL-UNICAMP)

TCHEKHOV, Anton. A dama do cachorrinho e outros contos. Tradução de Boris Schnaiderman. São Paulo: Editora 34, 1999.

- Tradução feita a partir do original russo;

- $4^{\mathrm{a}}$ Edição;

- Contém os Contos: A dama do cachorrinho e outros contos/ Nos banhos/ Pamonha/ Fantasiados/ Caso com um clássico/ A morte do funcionário/ 
Do diário de um auxiliar de guarda-livros/ Camaleão/ Casa-se a cozinheira/ Crime premeditado/ Subtenente Prichibiéiev/ Aflição/ Um dia no campo/ A corista/ Criançada/ Sonhos/ Vanka/ Um conhecido/ Gente supérflua/ Na primavera/ Angústia/ Senhoras/ O acontecimento/ Bilhete premiado/ Volódia/ Tifo/ Inimigos/ Ilegalidade/ Olhos mortos de sono/ O sapateiro e a força maligna/ Ventoinha/ Volódia grande e Volódia Pequeno/ Um caso clínico/ Homem num estojo/ Queridinha/ A dama do Cachorrinho.

(Acervo da Biblioteca Nacional - Obras Gerais - Rio de Janeiro/ Biblioteca do IEL-UNICAMP)

\section{$2000-2010$}

TCHEKHOV, Anton. O Cerejal. Tradução de Barbara Heliodora. São Paulo: EDUSP, 2000.

- Tradução feita possivelmente do inglês, com cotejo francês (confirmar há traduções de nomes como Lopakhine). Série Em Cena. Apresentação de Bárbara Heliodora. (Acervo: FUNARTE - RJ - CEDOC)

Tchékhov, A. P. A Gaivota. Tradução de Barbara Heliodora. São Paulo: EDUSP, 2000.

- Tradução a partir do francês e do inglês. Série Em Cena. Apresentação de Barbara Heliodora. (Acervo: FUNARTE - RJ - CEDOC).

TCHEKHOV, Anton. Os Males do Tabaco e outras peças em um ato. Seleção, Organização e Notas Homero Freitas de Andrade. São Paulo: Ateliê Editorial, 2001.

Todas as traduções feitas diretamente do russo:

Os Males do Tabaco (primeira versão): tradução de Aurora Fornoni Bernardini;

O Canto do Cisne (Calchas): tradução de Homero Freitas de Andrade e Eliana Pereira Miura;

O Urso: tradução de Denise Regina de Sales;

O Pedido de Casamento: tradução de Homero Freitas de Andrade;

Trágico à Força: tradução de Homero Freitas de Andrade;

As Bodas: Noé Silva

O Jubileu: Sônia Regina Martins Gonçalves

Os Males do Tabaco (segunda versão): tradução de Aurora Fornoni Bernardini

(Acervo: FUNARTE - RJ - CEDOC)

TCHEKHOV, Anton. O Assassinato e outras histórias. Tradução de Rubens Figueiredo. São Paulo: Cosac \& Naify, 2002.

- Tradução direta feita do original russo/ Coleção Prosa do Mundo;

- Contém os Contos: O professor de Letras/ O Assassinato/ Os Mujiques/ Iônitch/ Em Serviço/ No Fundo do Barranco. Apêndice: Cinco Cartas de A. Tchekhov.

(Acervo: Biblioteca do IEL-UNICAMP) 
TCHEKHOV, Anton. O Bispo. Tradução de Rubens Figueiredo. Rio de Janeiro: 7 Letras/ Viveiros de Castro Editora LTDA, 2003.

- Tradução feita diretamente do original russo.

(Acervo: Biblioteca do IEL-UNICAMP)

TCHEKHOV, Anton. A Gaivota. Tradução de Rubens Figueiredo. São Paulo: Cosac \& Naify, 2004.

- Tradução direta feita do original russo.

(Acervo: Biblioteca do IEL-UNICAMP)

TCHEKHOV, Anton. O Duelo. Tradução de Gabor Aranyi. Mairiporã: Editora Veredas, 2004.

- Tradução do francês (DUEL) com cotejo do russo, feito por Magda Palotás. Livro parte da coleção Grandes Escritores. Edição comemorativa , "Homenagem ao autor no centenário de seu falecimento"

(Acervo: Biblioteca do IEL-UNICAMP)

TCHÉKHOV, Anton. As Três Irmãs. Tradução de Klara Gouriánova. São Paulo: Ed. Peixoto Neto, 2004.

- Tradução direta do Russo. Coleção Os grandes dramaturgos (vol. 9). Prefácio de Elena Vássina. $\quad 1^{a}$ Edição.

(Acervo: FUNARTE - RJ - CEDOC)

TCHEKHOV, Anton. Enfermaria n ${ }^{\circ}$ 6. Tradução de Aurora Fornoni Bernardini. Mairiporã: Editorial Veredas, 2005.

- Tradução feita do original russo;

(Acervo: Biblioteca Florestan Fernandes - FFLCH USP)

Tchékhov, Anton. O Silvano. Tradução de Tatiana Lárkina. São Paulo: Globo, 2005.

- Tradução feita a partir do russo. Coleção Clássicos Globo (coord. Manuel da Costa Pinto)

- Nota Introdutória, Posfácio e Cronologia por Tatiana Lárkina. Nota introdutória trata do descaso da crítica que reservou a esta peça apenas a condição de "primeira versão esmaecida" de Tio Vânia.

(Acervo: FUNARTE - RJ - CEDOC)

TCHEKHOV, Anton. Estranha Confissão/ Um drama na caça. Tradução Bernanrdo Ajzemberg. São Paulo: Editora Planeta do Brasil, 2005.

- Tradução feita do espanhol;

(Acervo: Biblioteca do IEL-UNICAMP)

Tchekhov, Anton. Teatro I (A Gaivota/ Tio Vânia). Tradução de Gabor Aranyi. São Paulo: Editora Veredas, 2007.

- Tradução feita possivelmente do russo, como indica "título original".

(Acervo: FUNARTE - RJ - CEDOC) 
Traduções para o Castelhano que merecem destaque e que circularam nos meios teatrais:

Chéjov, Anton. Teatro Completo. Tradução de Galina Tomacheva e Mario Kaplun. Buenos Aires: Editorial Sudamericana, $1950\left(1^{\mathrm{a}} \mathrm{ed}\right)-1954\left(2^{\mathrm{a}} \mathrm{ed}\right)$.

- Edição pertencia a João Angelo Labanca - Rio.

- Peças: Ivanov, A Gaivota, Tio Vania, Sobre el daño que hace el tabaco, El Canto del Cisne, Las Tres Hermanas, El Jardín de los Cerezos, El camino Real, El oso, El pedido de Mano, Un tragico a pesar de suyo, El aniversario, El casamento. (Acervo: FUNARTE - RJ - CEDOC). 


\section{ANEXO 4: Seleção de Textos Críticos}

Seleção de Textos Críticos a partir de pesquisa feita em jornais, revistas e publicações acadêmicas nos arquivos da FUNARTE-RJ, Casa Rui Barbosa, Biblioteca Jenny Klabin Segall-São Paulo e Arquivo Egard Leuenroth-Campinas. A seleção privilegiou sobretudo a apresentação de informações relevantes para a discussão sobre encenações de Tchékhov no Brasil. Pedimos desculpas antecipadamente por eventuais omissões.

\section{Suplemento Literário do Estado de São Paulo, 13 de outubro de 1956.}

\section{As Três Irmãs \\ Gilda de Mello e Souza}

No momento em que se multiplicam os conjuntos teatrais e os diretores se atropelam a procura de textos, é sintomático que as peças de um escritor da importância de Tchecov continuem presentes apenas nas representações de amadores. Ainda há pouco, os alunos da Escola de Arte Dramática de São Paulo encenaram Três Irmãs; foi esta a segunda vez - se bem me lembro - que se representou no Brasil uma de suas quatro maiores peças, pois Tio Vânia já tinha sido levada a cena pelo grupo do Tablado, no Rio.

Ao mesmo tempo que afugenta os diretores profissionais, Tchecov atrai, pois, os aprendizes de teatro. E é justo que assim aconteça. Para os primeiros, que jogam a sua responsabilidade na perfeição do espetáculo, estes textos, aparentemente despojados e tão semelhantes à vida, representam uma das provas mais sérias da carreira. Desprovidos de ação dramática e personagens de exceção, correm a todo o momento o perigo de cair na monotonia se o diretor não conseguir encontrar o tom exato, valorizando cada detalhe, suprindo pela atmosfera a ausência de situações de conflito e pelo matiz do comportamento a falta de contrastes vivos, fáceis do público apreender. Paradoxalmente, portanto, encenar Tchecov é tarefa mais ingrata que encenar um texto clássico. Pois nestes, o enredo, a peripécia, o poder encantatório das imagens apoia a representação suprindo possíveis deficiências do artista ou da montagem. Para os profissionais de teatro Tchecov é tarefa sempre adiada, ambição de apogeu na carreira.

No entanto, as dificuldades que afastam dele os profissionais acabam atraindo amadores. Para estes, as peças de atmosfera reapresentam excelente campo de pesquisa, exercício de contenção, da voz do corpo, enfim de todo o jogo que se orienta no sentido de harmonia do conjunto. Além disso, a ausência de heróis, banindo a possibilidade de interpretações excepcionais, dá praticamente a todos os atores as mesmas oportunidades de brilho. Neste sentido, Tchecov é uma disciplina admirável.

Parece-nos, pois, acertada a escolha que a EAD fez, elegendo Três Irmãs para um de seus textos de exame. E se não assistirmos a um espetáculo impecável tivemos a ocasião de ver como funciona no palco uma peça que muito de nós conhecíamos na leitura. Foi esta oportunidade que me sugeriu alguns dos problemas que passarei a analisar com o leitor.

A realidade que Tchecov coloca diante de nossos olhos no palco não se delineia nitidamente logo à subida do pano. "Tchecov tem como os impressionistas, diz Tolstoi, uma forma própria. Observando-o trabalhar, vemo-lo espelhar as cores como se não procedesse a nenhuma escolha, dispondo-as aparentemente ao acaso dos gestos, como se as pinceladas não tivessem nenhuma relação entre si. Mas se não afastamos um pouco para olhar, recebemos uma impressão extraordinária do conjunto: diante de nó está um quadro claro, indiscutível." Assim, é a custo, como quem vai distinguindo feições vagas na bruma, que divisamos os vários temas que urdem a trama de suas peças e estabelecemos o nexo secreto que une tantos monólogos desencontrados. Com esta técnica fragmentada, o autor constrói a sua atmosfera peculiar, de desencanto, melancolia, poesia nostálgica - atmosfera anti-heroicas por excelência- onde as personagens desfilam vítimas passivas do destino, paralisadas na ação.

A galeria do escritor é a dos vencidos, que afetam em suas quatro peças os vários graus da derrota e da frustração. Ninguém luta encarniçadamente por um ideal, nenhum homem se eleva sobre os demais como a encarnação da paixão pessoal ou da grandeza de caráter. E se há sempre um abismo separando o sonho da realidade, poucos procuram transpô-lo, perseguindo a realização consciente de sue próprio fim. Nas Três Irmãs, Olga sonha com um marido que pudesse querer bem, uma casa onde pudesse descansar; no entanto acaba aceitando, exausta e contra a vontade, a direção do colégio. Irina, que 
esperou anos a fio o amor romântico, curva-se afinal à corte do feio Tuzenbach, com quem vai lentamente "deslizando para um precipício". André, em quem as três irmãs depositam tantas esperanças, e que havia se preparado intimamente para a vida universitária, vê-se reduzido com o tempo e o marido enganado e membro obscuro de uma comissão municipal. E mesmo Macha, a fogosa Macha, que toca tão bem piano, recita versos de Puchkin e pensara ter-se casado com um homem inteligente, só muito tarde percebe que Kuliguin é apenas caricatura da inteligência: um professor pedante de ginásio, que cita latim errado.

Neste mundo de frustrações e mal-entendidos, a escolha quase nào ocorre e a conduta é imposta do exterior para o interior. Na medida em que o indivíduo aceita o papel que lhe é atribuído, está sufocando para sempre o herói que porventura trazia dentro de si. Da luta inglória restará sobre cada um a garra segura do comportamento sancionado que, destruindo a liberdade própria do homem, se estampa exteriormente na marca do uniforme, de funcionário público, de oficial de exército. Alguns, é verdade, acomodam-se perfeitamente a esta forma, que no fundo corresponde ao seu ideal de vida. E longe de sentir os membros tolhidos, agitam-se eufóricos, pavoneando as frases feitas e o otimismo de quem se sente realizado contido na norma. É o caso de Kuliguin. Para Olga, no entanto, o vestido azul-marinho de professora de ginásio é opressivo: dentro dele vai ficando dia a dia mais velha, magra e ressequida, como quem se conforma com um papel atribuído que a distancia da vida e do humano.

Como passa na vida mesquinha, nas tarefas miúdas cumpridas sem amor, estabelece-se de vez em quando na casa de Prozorof - por exemplo, no fim de um dia cansativo, por ocasião de um aniversário- um espaço fictício e recluso, isolado do espaço real da cidade provinciana. Nele vemos mover-se em tácito entendimento aqueles que participam da mesma comunidade de lembranças: os oficiais da guarnição, temporariamente alojados na cidade, e as filhas do falecido general, que vieram de Moscou. Não é então difícil descobrir, por trás das frases engraçadas em que as personagens se comunicam, dois leitmotives principais, que estão constantemente se cruzando: o tema das irmãs e o tema dos oficiais.

Olga, Irina e Macha procuram abolir o presente. Fogem dele enquanto esperam ansiosas o dia em que afinal, irão para Moscou e novamente vai adquirir sentido aquilo que na cidade do interior parece ser um luxo inútil: as boas maneiras, as várias línguas que conhecem, o amor pela música e pela poesia. $\mathrm{O}$ seu tema é ir para Moscou, ou melhor, voltar para Moscou, rever os lugares antigos em que se morou, as ruas de que ainda guardam os nomes. Moscou é o tema da memória e do passado.

Mas se as três Irmãs - e também André - esperam o dia em que vão voltar para o passado, os oficiais - Verchinin e principalmente Tuzenbach - anseiam pelo futuro, por um tempo em que o trabalho redimirá o presente. O seu tema é trabalhar; é sufocar na tarefa cumprida com esforço o sentimento de culpa de sua classe, o remorso das botas outrora tiradas pelo mordomo: "A avalanche vem e se aproximando de nós, o temporal já está perto e logo varrerá a preguiça, a indiferença, o ódio ao trabalho, o fastio corrompido de nossa sociedade".

As personagens se vinculam, portanto, à nostalgia do passado ou à premonição do futuro, formando dois grupos distintos. Contudo, desligada de ambos, delineia-se a figura de Natacha, a única a se mover no presente. Ela não se inscreve no território comum das lembranças, em que vivem as três irmãs e os oficiais; e, por isso, entra para o círculo restrito dos Prozorof como elemento perturbador de desorganização. Natacha não é apenas a intrusa, a estranha que vem de fora para lhes roubar o irmão e romper o equilíbrio de um universo ordenado ( como a vêem as cunhadas); é, na verdade, a erupção brusca do presente no mundo das saudades e visões. Encarada nas perspectivas das irmãs (e do passado), talvez pareça vulgar e má. No entanto, do ponto de vista do presente, é a única pessoa viva da casa, tão viva que, às vezes, parece a André “antes um animal que um ser humano". Ela representa, possivelmente, a vitalidade dos pequenos comerciantes em ascensão, dos filhos dos servos há pouco libertados, que capitalizaram em silêncio a energia que agora despendem. Só ela persegue, determinada, a realização de um fim, só ela se afirma colocando-se no primeiro plano, em detrimento dos demais. Por isso, quando os irmãos recuam como sombras para o passado, vai estendendo o seu domínio sobre a casa, planejando substituir velhas arvores por canteiros de flores, alastrando os filhos pelo quarto de que expulsou marido e cunhadas, instalando o amante na sala, rompendo com a tradicional cordialidade entre senhores e empregados, destruindo André e toda a antiga harmonia dos Prozorof.

Assim, a oposição entre passado e futuro não encontra na peça de Tchecov nenhuma conciliação além de Natacha. Só ela tem direito ao presente. Quando os últimos clarins da guarnição se tiverem perdido ao longe, Irina e Olga irão petrificar-se nos uniformes; Macha, talvez continue se refugiando no sonho e André afogará a derrota no jogo. Mais do que antes irá estender-se sobre a casa do Prozorof, o enorme cansaço do fim do dia, símbolo de um presente abolido. Pois "para aqueles que não têm objetivos imediatos ou remotos, só resta na alma um grande espeço vazio". 


\section{Última Hora, 1960 (sem dia e mês)}

\section{Teatro Nacional de Comédia - é contra o povo e fracassa. Paulo Francis}

O governo anualmente permite que o serviço nacional do teatro gaste milhões para manter uma companhia de teatro - este ano, segundo informações colhida na fonte foram 8 milhões. Até ai tudo bem. O povo não vai a teatro no Rio, pois o teatro custa, em média,... 120,00 cruzeiros por poltrona, o que exclui mais de dois terços da população, principalmente nos dias de hoje onde toda a espécie de crise de subsistência ameaça a bolsa do povo.

O serviço nacional de teatro criou o teatro nacional de comédia. Esperava uma empresa que se dirigisse ao povo. O povo é inculto, logo seria necessário começar do início, encenando clássicos de maneira popular como Jean Villar fez na França: ou procurando estabelecer uma consciência do Brasil moderno, abrindo as porta aos escritores de hoje; ou ainda, tentando reestabelecer a tradição de teatro, realizando uma obra didática de escavação nas nossas bibliotecas.

Tudo isso foi esperado do teatro nacional de comédia. Vejamos a temporada de 1959: ela começou com uma peça comercial de segunda categoria, que esteve nas mãos de vários empresários Inclusive Cacilda Becker - que a recusaram por diversos motivos. Trata-se de "A beata Maria do Egito", de Raquel de Queiróz, esta, uma romancista de renome, está engatinhando em técnica teatral e parece completamente ausente de qualquer realidade política e social do Nordeste - sua terra. Assim, começou o TNC, em 1959. O espetáculo era também um blefe, sem direção, com dois atores de qualidade perdidos no palco (Glauce Rocha e Sebastião e Sebastião Vasconcelos), sob o cerco de dois canastrões. O público não compareceu, ficando o Serrador as moscas.

Dai a "D. João Tenório de Zorilla. O autor pertence a decadência do romantismo espanhol. O TNC importou um picareta para dirigir o espetáculo - segundo se diz, por quinhentos mil cruzeiros - e trouxe também, cenários horrendos e horrendamente executados de Salvador Dalí. Ainda que se admire Dalí - e ainda restam uns tradicionalistas que, ingenuamente se consideram de "AVANTGARDE" e que admiram Dalí - ele nada tem a ver com o romantismo. O espetáculo foi castigado pela crítica do Rio, com violência inaudita. Um profissional chegou a escrever que "D. João" também permaneceu as moscas, a despeito da profusa distribuição de entradas da direção da companhia.

Por fim, um grande texto e um diretor que ajudou a escrever a história do teatro brasileiro: "As Três Irmãs”, de Checov e Ziembinski. O elenco, entretanto, fracassou, convertendo o espetáculo numa oscilação de apatia ao tédio. E, novamente, o público fica m casa. O que comparece, sai em partes, no meio do espetáculo. Ziembinski não teve condições de trabalho. Seus ensaios foram interrompidos para que o picareta D. Luis Escobar ( amigo do ditador franco) pudesse perpetrar "D. João", ensaios que foram retomados depois de uma longa pausa, o que, com o elenco bisonho e principiante do TNC significa começar tudo de novo.

Esta é a história do TNC, em 1959, entrando por 1960. Oito milhões foram gastos para obter esse resultado. E o povo? O TNC cobra 120,00 cruzeiros por entrada, o TNC que tem verba do governo e que recolhe o dinheiro d bilheteria ao tesouro nacional (exclamação). Estes são os fatos, a quem interessa resposta.

\section{Última Hora, 20 de fevereiro de 1960}

\section{Elenco e política do TNC}

O elenco do Teatro Nacional de Comédia arruinou "As três Irmãs", no entender da crítica responsável da cidade. Havia o diretor e o texto, o que faltava em "A beata Maria do Egito" de Raquel de Queiróz, e de "D. João Tenório", de Zorilla. A direção de Ziembinski é clara para quem entende muito de teatro, mas o público entende pouco de teatro e precisa dos atores pra explicar as coisas.

Ziembinsky cometeu diversos erros. O primeiro foi aceitar a direção de "As três Irmãs"com aquela gente. Compreendo, mas discordo, de sua maneira de trabalhar. Ele, infelizmente, não tem 
compromissos com qualquer realidade cultural. É um diretor de qualidade, mas não é o artista “engagé"de que a nova geração necessita. Trata-se de um profissional, puro e simples.

Ziembinsky colocou Beatriz Veiga em Natasha. Ela não é o tipo e não é atriz. A parte isso, aparece com uma linha de birutice inexistente no texto. Este erro cabe a Ziembinsky, que anulou uma parte decisiva da peça. Beatriz Veiga, nula como é, não passa de um elo secundário.

A produção dos espetáculos do TNC, por motivos burocráticos, começa tarde no ano, o que não permite a seus dirigentes contratarem mais atores que prestem para alguma coisa, pois estes, a essa altura, já estão empregados. A má qualidade do histrionismo do TNC tem aqui sua primeira explicação.

Em “As três Irmãs”, por exemplo, a exceção de Glauce Rocha, Sebastião Vasconcelos e Josef Guerreiro, os demais atores ou não tem maturidade para fazer Tchecov, como é o caso de Elizabeth Gallotti, ou são subatores, como Vanda Lacerda e Paulo Serrado, ou não devia estar num palco como Beatriz Veiga. Sebastião Vasconcelos está "miscast". Deveria ser o "Solione", que se coaduna com sua aparência e temperamento. Não entendo o que faz no pedagogo, que exigiria um intérprete mais frágil. Josef Guerreiro ainda está enferrujado depois de uma longa ausência de palco. Tenho a impressão de que lhe falta fôlego e que não consegue se concentrar o suficiente. Glauce Rocha, a despeito das restrições que lhe fiz, é a única a dar a Tchecov o que é de Tchecov.

Esses meus comentários não deviam ser feitos em reação a uma companhia oficial, que devia ter um programa cultural legítimo, já que dispõem dos meios econômicos para subsistir sem bilheteria.

É fácil prever o que constará dos relatórios do Ministério da Educação sobre a temporada de 1959. Os burocratas brasileiros tem seu "newspeak", a linguagem de que fala George Orwell, em 1984. Sobre "A Beata Maria do Egito" será ressaltado o nome de raquel de Queiróz, a " celebrada escritora patrícia", apesar da celebrada não ter a mais remota noção do que seja teatro. Sobre "D. João"se falará no teatro romântico espanhol, apesar da decadência que representa Zorila. e nos cenários e figurinos de Salvador Dalí, o "internacionalmente famoso pintor", que é a delícia dos novos-ricos que gostam de posar como avançados. Dalí nada tem a ver com o romântismo, se é que é necessário dizer alguma coisa. E , por fim, Tchekov e Ziembinsky serão usados.

Enquanto isso o povo não vai ao teatro, pois o TNC cobra preços de uma companhia comercial. Aliás, ninguém vai mesmo a seus espetáculos, pagando ou não. As entradas são distribuídas e o público se retira no meio do espetáculo, como tem acontecido com "As três Irmãs". Pensem que este público ingênuo está não criando só o mau hábito de ir ao teatro de graça, como, ao ver Tchekov pela primeira vez tão mal levado, certamente continuará preferindo Pedro Bloch.

É inútil escrever sobre o TNC. A companhia gasta uma fortuna para importar o picareta D. Luís Escobar, da Espanha, enquanto todo o teatro brasileiro se processa uma revolução de jovens diretores. $\mathrm{O}$ picareta Escobar está, no momento, em Nova York, onde a crítica dará cabo dele. Apesar de todos esses desacertos, os dirigentes da empresa acham que os protestos da imprensa fazem parte de uma companhia política contra eles. Política de que, para que? A crítica não gosta, o público idem. Alguma coisa deve estar errada.

Oito milhões de cruzeiros foram postos fora. A direção do TNC é do senhor Edmundo Moniz, Sra. Beatriz Veiga e sr. Agostinho Olavo. Eles devem ter resposta a todos esses argumentos. Devem explicar qual é o critério que preside na escolha do repertório, do elenco, da queimação de dinheiro, em suma. Podem também nos dizer a que público se dirige o TNC cobrando 120,00 cruzeiros.

Todas as grandes companhias de teatro no mundo se dedicaram a encenar os clássicos, a revelar autores nacionais de seu país ou a um programa didático qualquer. O TNC não segue nenhum desses caminhos. Segue apenas os caprichos de alguns indivíduos ao meu entender. Se o dinheiro fosse deles, ninguém teria nada com isso, mas o fato é que o dinheiro pertence ao tesouro nacional, ao público em suma.

Nenhum crítico do Rio de Janeiro quer destruir o Teatro Nacional de comédia. Abro um exceção para os carreiristas, que esperam lucro elogiando a presente administração - críticos que tem peças na gaveta, ou livros sem editor, etc. Estes querem destruir a idéia de uma companhia do governo, nos prestigiando a que existe, como existe. Mas a gente decente quer apenas que o TNC entre nos eixos, que seja a melhor companhia do país, como deve ser a companhia oficial. E ninguém quer o emprego do sr. Edmundo Moniz, a quem todos respeitam como individuo, ou qualquer vantagem da companhia ou do serviço nacional de teatro. Este aliás tem sido o teor dos artigos publicados aqui por Cláudio Melo e Sousa e por mim, assim como o da maioria dos críticos responsáveis. 


\section{Folha Datilografada. Acervo de Antonio Callado. Sem referência a local de publicação, 1960 (?)}

\section{Chekov \\ Antonio Callado}

Apesar de perfeitamente branco, racialmente falando, Anton Chekov, se tivesse nascido no Brasil, seria socialmente mulato. Ele tinha muito, em si, de mulato que se educou e que trabalhou herculeamente para mostrar ao branco opressor que a cor da pele nada tem a ver com êxito na vida e com padrões de decência. Chekov, homem de primeira classe (tão mulato e tão de primeira classe que dá uma grande vontade de escrever todo um artigo comparando-o a Machado de Assis, mas resistiremos à tentação: todo o mundo hoje em dia escreve sobre Machado) praticamente arrebentou sua saúde sustentando uma família de segunda classe e que nem era a sua mas a de seu pai.

Se querem saber como um homem racialmente branco pode ser socialmente mulato a explicação é simples: a família de Chekov (que nasceu em 1860) só deixou de ser serva, isto é escrava, em 1841. Apesar de ser seu avô quem comprou a alforria da família vê-se pela data que, quando o fez, seu filho Pavel, pai de Chekov, era escravo. Aliás, numa famosa e dolorosa passagem autobiográfica Chekov escreveu:

"Um moço, filho de um servo, que trabalhou numa lojinha, pertenceu ao coro da igreja, foi forçado a respeitar as hierarquias, a beijar mão de padre e a se curvar às ideias alheias; que agradeceu toda e qualquer migalha de comida que teve e que apanhou muitas vezes (...) que brigou na rua, maltratou bichos, que adorava jantar com parentes ricos, que era hipócrita diante de Deus e dos homens sem precisar sê-lo (...) este moço espremeu de si mesmo o escravo, gota a gota, até acordar um belo dia e ver que não era sangue de escravo, aquilo que lhe corria nas veias, mas verdadeiro sangue de gente". Eis a tentação de volta: assim teria escrito Machado, se não fosse ainda muito mais hipócrita diante de Deus e dos homens.

Poucos escritores estrangeiros são mais intrinsecamente "brasileiros" do que Anton Chekov. E sua obra tem um pungente "brasileirismo" atual . De Dostoievski ou Tolstoi - os grandes contemporâneos de Chekov - só se pode dizer que sejam brasileiros naquilo que têm de universal: a angústia metafísica, a luta pelo aperfeiçoamento, a preocupação pela injustiça social vista como pecado, etc.

Chekov, não. Equilibrado sensato, cuidadoso das aparências, mais "europeu" do que russo, viu perfeitamente, viu tão bem quanto o grande Dostoievski, a revolução que se acercava, mas viu-a de forma muito mais nossa: as elites russas não eram elites nenhumas, os fazendeiros e senhores de engenho não eram nem maus nem bons, mas estúpidos e imprevidentes, todo o mundo via o errado de tudo, mas ninguém queria dar-se o trabalho de endireitar nada, todos falavam muito em cultura mas ninguém a conhecia fora dos livros, cultura viva, inventada, fecunda. Sua peça "O Cerejal" ou "O Pomar de Cerejas" ou como a chamemos, podia desenrolar-se numa fazenda de café, assim como "As Três Irmãs" podia acontecer num engenho de açúcar. O russismo que tenham essas peças - atmosfera enfumaçada por samovares enormes, luz difusa, vozes estranguladas - vem da pouco feliz marca que deixou Stanislávski em Chekov. Como todo diretor tirânico Stanislávski tinha seu lado Diaghilev, e, a despeito dos protestos do próprio Chekov, manteve a linha que dera inicialmente às peças e que fora um sucesso. Mas Chekov, se tem um estilo determinado de olhar a vida, esse é um estilo moderno, tipo Christopher Isherwood, o estilo câmera eye. As peças de Chekov não são pudins russos em que todo o mundo deve aparecer seu tanto desequilibrado e dizer coisas simples como se quisesse anunciar a Segunda Vinda de Cristo. Chekov era um grande artista mas era também um cronista da vida russa. Aliás é curioso notar que nos seus anos iniciais, quando trabalhava como um mouro para sustentar mãe e irmãos, Anton chegou até a afazer algo como uma "coluna" social. O que há de quase lancinante, se quiserem, no "Cerejal" é que a desmiolada família que ali vemos vivendo seus últimos dias de verão, é inocente do que lhe acontece; não sabe de nada, nunca se preocupou com coisas sérias, não entende de bancos e empréstimos. A angústia que nos comunica a peça é que essa angústia de vermos crianças brincando num despenhadeiro: mas os tipos em cena são vivos, alegres, curiosos, são um jardim humano que não sabe e que significa a nuvem de gafanhotos que vai baixando. É inútil querer apontar o segredo de um artista mágico como Chekov. Mas um deles é esse: frisar a falta de relação existente entre o barco e o naufrágio entre o cutelo e o pescoço. Existem, no mundo, tempestades e navios. As primeiras frequentemente rugem sós, rasgando solidões físicas e indiferentes. Os segundo veem (?), frequentemente, em mares azuis e aportam a praias brancas. Mas às vezes, em pleno mar, a tempestade se encarniça sobre o barco e o barco está cheio de gente que se põe de joelhos no convés, arranca os cabelos, tenta arriar escaleres... Que tragédia foi essa? Natural ou humana? Determinada por Deus ou fruto do mais infame dos acasos? Chekov não responde, não é metafísico. Nem sequer nos convence de que se deviam encontrar, aquela tempestade que ele analisou tão 
bem, aquela gente de barco, seus parentes, seus irmãos. É o poeta do acontecido. Chekov parece dizer, com a ironia de Pascal:

"Les prephéties étaient équivoques: elles ne le sent plus."

$* * *$

O teatro moderno - que apenas ensaia não se sabe bem o quê com Beckett, Ionesco e Adamov continua dominado pelas figuras monumentais do século passado: Ibsen e Chekov. Ibsen, pai de Shaw (exceto na chekoviana "Hearthbreak House") e da maior parte dos dramaturgos modernos, não é muito representado no Brasil. Mas como sua família é toda uma legião, sabemos bastante bem o que é o teatro de Ibsen, seu teatro de grande força humana, de enredo, de Mal reconhecido, que brota de dentro do homem até que, como na alucinação de Blake, transforma-se numa maçã de verdade, pendurada numa macieira de quintal:

"And it grew, both day and night

Till it bore an apple bright..."

Ora, Chekov, de certa forma mais difícil de representar do que Ibsen, tem para nós uma grande vantagem: o seu brasileirismo. Na boa Introdução que escreveu para a edição americana de "Cartas" de Chekov, Lillian Hellman escreveu que "as raízes de onde brotou Chekov foram muito especiais: o lugar em que nasceu, sua educação, sua família, sua religião, sua natureza sexual, todo o niveau da sua vida eram muito diferentes dos nossos".

Perfeito. E muito semelhantes aos nossos. Chekov, neto e ainda filho de escravos, foi, ao mesmo tempo, estudante de medicina, jornalista de toda obra, escritor, sustentador da família, viveu e foi parte de um país brilhante, inteligente, inculto, desesperado com seu atraso, humilhado ainda pela escravidão de data recente, esmagado pelo latifundiarismo, conhecendo todos os seus erros mas limitando-se a falar neles, nos cafés, nos botequins, nas mesas de jantar. Certos momentos no teatro de Chekov são verdadeiramente reveladores. Não se trata mais de brasileiros falando. Já se tem a impressão de ouvir a leitura de um artigo de fundo de jornal brasileiro. Ouçam o médico Astrov, em Tio Vânia: "Por que não havemos de esquentar o fogão com carvão mineral e construir o celeiro de tijolo, em vez de madeira? Vá lá estou de acordo em que vocês derrubem árvores, quando for preciso, mas por que destruir as florestas? (...) Milhões de árvores perecem, some a habitação de bichos selvagens e de passarinhos, os rios estão minguando e secando (...) tudo porque o homem indolente não tem a ideia de se curvar para o chão e apanhar o combustível. (...) É preciso ser um selvagem sem raciocínio para queimar tanta beleza num fogão, para destruir o que não sabemos criar". A força centrípeda de Moscou causando o êxodo rural, a cegueira das elites, as revoltas de estudantes, tudo do Brasil de hoje está em Chekov.

E, no entanto, como Chekov é mal produzido e mal representado entre nós: Lillian Hellman tem razão em apontar a estranheza da formação de Chekov em relação à formação dinâmica, masculina e superficial dos Estados Unidos. No Brasil, Chekov devia ser servido nature, sem molho de Stanislávski. Ninguém viu tão bem quanto ele a Rússia pré-revolucionária e ninguém a descreveu tão bem e tão do ponto de vista brasileiro, que foi o seu, de quem não se mete, de quem espera, contra a razão, que reformas nasçam em galho de árvores e não custem suor e sangue. Ouçam, em Trofimov, a disposição brasileira de falaram mal do Brasil: "Onde estão as creches de que tanto se fala, e as bibliotecas? Só existem nos romances: na vida real, nada. Na vida real há sujeira, vulgaridade e apatia asiática". E Lopahin: "Às vezes fico acordado de noite e penso: 'Oh, Deus, vós nos destes florestas imensas, planícies ilimitadas, os mais largos horizontes. Vivendo aqui, nós devíamos ser verdadeiros gigantes". E a resposta de Lyubov: "Olha ele pedindo gigantes! Eles só servem nas histórias infantis; na vida real assustam".

Quando Chekov escrevia isto os mais temíveis gigantes da História Russa já haviam nascido: Lenin, Trotski, Stalin, Kruchev. Eles assustariam, efetivamente, Chekov. Dostoievski, pelo menos, poderia exclamar, com alegria de profeta que teria razão: "Ei-los aí, os meus possessos, os meus Karamazov em marcha. São os homens-deuses que eu anunciei com terro, e que vinham destronar o Deus-homem. Já querem igualá-lo em tudo. Com suas toscas foices e martelos já fizeram uma coivara no céu para lá plantar a safra das novas estrelas".

Chekov, não. Como tanto "profeta" brasileiro de hoje ele se limitaria a balançar a cabeça e dizer: "Não disse! E agora?"

****

Por que é que esse mulato russo é tão mal representado no Brasil? Nós vivemos aqui o tempo que ele viveu na Rússia e ele reagia ao seu tempo como a maioria dos brasileiros ao nosso. Por que o enfumaçamos e desaceleramos e desfiguramos tanto?

O remédio é, talvez, agora que temos tantos diretores jovens e brilhantes, escolher o mais brilhante e mais chucro desses meninos e lhe entregar uma adaptação de "Cerejal", por exemplo, 
passando-se a ação da peça num engenho de açúcar em Pernambuco. Sairá uma obra-prima. O moderno teatro brasileiro pode renovar Chekov para o mundo inteiro.

\section{Última Hora, 11 de outubro de 1968.}

\section{Cerejeiras quase sem flor Tato Taborda}

A atual representação de Jardim das Cerejeiras ( Teatro de Ipanema), não conseguiu tirar minhas dúvidas sobre o gênero teatral em que se encontra enquadrada esta peça de Checov. A polêmica é antiga. $\mathrm{O}$ autor protestou até sua morte contra a direção dada por Stanislavski que, segundo ele havia tornado sua leve comédia num choroso drama. Ivan Alburquerque preferiu seguir a linha do autor acentuado o ridículo de Gaiev (Hélio Ari) e Iepiknodov (Nildo Parente) para atingir a comicidade. Esta é a fórmula da comédia direta, onde o "divertido" significa em realidade "desaventurado". Para o sucesso do gênero é indipensável que a miséria seja transcendida pela alegria, não é esta a impressão que fica da peça.

Madame Ranhevskala volta de Paris premida por dividas e buscando com o auxílio de uma invisível tia (Condêssa Iakubovska) pagar a hipoteca do Jardim das Cerejeiras, magnífica propriedade, último vestígio de um passado próspero. Gaiev, seu irmão, não se perturba com vãs questões materiais, preferindo fazer discursos e jogar carambeia. Varia, Vera Gertel sua filha adotiva, tímida e agressiva, terminará por ficar sozinha. O Jardim será arrematado por Lopakhin (Carlos Dollabella), filho de um servo ele mesmo antigo servo de Renhevskaia. Consumada a venda a Madame volta para Paris, Galev foi trabalhar num banco e na casa abandonada Firs, o velho mordomo, fica esquecido e dorme ao som dos machados que derrubam as cerejeiras.

Ivan Albuquerque, baseando-se provavelmente na concepção defendida por Stanislavski - um dos mais reputados diretores soviéticos - deu realce a dois personagens secundários: Ania, Leila Ribeiro filha de Ranhevskaia, e Trorimov (Rubens Correa) o eterno estudante que simboliza a vida nova, justificando a faixa que encima do palco - Comedia de um mundo em transformação. Mas, a entonação dada tanto as falas de Trolimov quanto a partida de ambos ao final da peça, enlaçados e dizendo "Adeus caasa! Adeus, velha vida! Bom dia, vida nova! parece-me mais ajustada ao romantismo de Gorki do que ao realismo - $\quad$ sempre reafirmado -

O jardim concentra sua ação dramática em quatro personagens: o sucesso ou mal gosto está avidamente relacionado com os seus desempenhos. O irresponsável Gaiev encontrou em Hélio Ari um intérprete perfeito. Correta entonação de voz, desembaraço em cena e uma bem cuidada expressão corporal. Unidos a, fazem do jovem ator a melhor figura do elenco. Vanda Lacerda tem uma interpretação discreta. Sua principal fama foi não ter encontrado o sorriso de Ivannevskaia. E sem esse sorriso , a leviana e fútil Liuba não pode mostrar a angustia e a bondade, característica maiores de sua personalidade. Carlos Lacerda, forte, exuberante mesmo, tem físico para desempenhar Lopakhin ninguém melhor para mostrar o vigoroso filho de servo que se tornou milionário. Entretanto para compor o tipo, Dollabella deveria ter adicionado ao físico uma boa dose de engenho, condição indispensável para dar veracidade ao complexo e comovente personagem. Charlotte Ivanovna, a governanta inglesa ou alemã que faz mágicas, figura trágica, velha palhaça desesperada e solitária, também não encontrou em Ivone Hoffmann a interprete ideal.

A soma das interpretações básicas não favorece O Jardim... Embora, seja conveniente frisar que Vanda Lacerda foi chamada para papel menos de 30 dias antes da estréia, solucionando o problema criado com a partida de Domitila Amaral.

De resto merecem louvor os figurinos de Kalma Murtinho, louvor que não se estende ao cenário de Marcos Flacksmann, que não conseguiu transmitir o clima de decadência indispensável à peça. 


\section{Jornal do Brasil, 22 de outubro de 1968.}

\section{Um jardim florido e amigo (I) Yan Michalski}

O Jardim das cerejeiras é um desses textos que fazem com que o critico diário lamente as limitações intrínsecas do seu trabalho: um mundo de riquezas humanas, uma infinidade de interpretações possíveis, um permanente estímulo À pesquisa e ao debate, esbarram na necessidade primordial de dar ao leitor, em poucas linhas, uma idéia geral da forma e do conteúdo da obra. Que o leitor saiba pelo menos, desde já, que debaixo de cada cerejeira desse enorme jardim está enterrado um tesouro de sensibilidade humana, À espera do explorador que, sentado à platéia, se disponha a desencavá-lo com os olhos, os ouvidos e o coração.

Como sempre em Tchecov, o enredo é extremamente simples: uma decadente família aristocrática, que se obstina em continuar vivendo no mundo irreal de sua grandeza passada, perde a sua fazenda - orgulho e símbolo vivo dos seus bons velhos tempos - que é vendida em leilão, em conseqüência das dividas acumuladas pelos imprevidentes e desorientados proprietários. O novo dono da fazenda é filho de antigos servos da família, agora um negociante objetivo, prático e próspero.

"Comédia de um mundo em transformação", esclarece um painel que domina o palco; e a definição dificilmente poderia ser mais acertada. O Jardim das cerejeiras é quase um ritual de rendimento de guarda. Com uma lucidez profética e uma imparcialidade impressionante. Tchecov realiza uma dissecação poética do processo de transformação que se desencadeara na Rússia em torno de 1900, e explodiria, 13 anos após a criação da peça e a morte do autor, na Revolução de 1917. A inevitabilidade desse processo é demonstrada através do exame de seus principais elementos morais, sociais e econômicos. O mundo que sai de cena não é condenado naquilo que representa a sua escala de valores morais herdada das gerações anteriores; muito pelo contrário, vários desses valores são tratados com um nostálgico respeito: a efetividade, a delicadeza de sentimentos, o culto das tradições consideradas não como uma estratificação de formas varias, mas como uma sedimentação de conquistas nobres do espírito humano.

Mas este mundo é condenado, isto sim, através de uma demonstração dialeticamente implacável de sua inadaptabilidade Às novas condições que já assumem a forma de uma fatalidade. A fazenda, economicamente improdutiva, só vai à falência porque os donos se recusam a transformá-la num loteamento para veranistas - imagem expressiva de uma realidade nova e irreversível. Mas também essa realidade nova não é nem aprovada globalmente, nem condenada globalmente. Ela constitui uma fatalidade irreversível e corresponde ao curso natural da História - mas, ao mesmo tempo, ela escapa desde já ao controle daqueles que a defendem e que por ela lutam: estes se dividem, com efeito, entre os que são capazes de compreender o seu significado uma forma concreta, e os conquistadores que implantam realmente uma nova ordem, mas não se dão conta do seu sentido profundo.

\section{Suave agonia}

Este vasto painel de um processo de transformação social cujas repercussões, queiramos ou não, atuam profundamente sobre a existência de cada um de nós é de um interesse fascinante; mas uma grande parte desse interesse se deve menos à lucidez da visão social de Tchecov do que à autenticidade de sua compreensão da alma humana. Esse mundo em transformação é claro, convincente e fascinante porque cada uma das peças que o compõem- ou seja, cada personagem - constitui, por sua vez, um mundo; um mundo complexo, confuso e sofrido, sucessivamente atraído e repelido por outros mundos, parecidos com ele, que o cercam. Não só de cada um dos protagonistas, mas também cada um dos personagens secundários, é apaixonada e genialmente apresentado com uma riquíssima matéria- prima da qual poderia sair, potencialmente, um ser humano privilegiado - mas da qual não saiu, e nunca mais sairá nada além de uma contradição ambulante entre a intensidade das aspirações e a incapacidade de realiza - las. Desde a aristocrata Ranhévskaia até o infeliz Iapikhodov, desde a criada Dunhacha até o intelectual Trofimov, desde a sonhadora Anha até a governanta Charlota, todos querem ou já quiseram ser outra coisa do que aquilo que são ou jamais serão; e todos sofrem profundamente - às vezes têm se que se dar lucidamente conta disso - em virtude da total frustração dos seus melhores e mais fortes impulsos.

A linguagem teatral de Tchecov, sem deixar de ser tradicionalmente realista, impressiona pela atualidade dos recursos contrapontísticos que definem seu estilo. Com uma noção de dosagem admirável, Tchecov deixa a emoção surgir suavemente e evoluir até o ponto exato, quando então a corta bruscamente através de um irresistível efeito cômico. Essa constante mistura de comédia e drama constitui talvez a maior dificuldade para qualquer encenação de O Jardim das cerejeiras, desde a pré-estréia mundial da peça, dirigida por Stanislávski, e que na opinião do autor foi estragada pelo famoso diretor, que teria 
enfatizado excessivamente o aspecto trágico da obra e omitido o aspecto cômico, que na opinião de Tchecov deveria ser primordial.

Coisas importantíssimas, vitais, estão em jogo na peça, mas a maior parte do tempo os personagens falam de banalidades, e ainda por cima para dizer coisas que em geral não são muito inteligentes. Tanto ou mais talvez do que nas outras peças de Tchecov, o que conta aqui não são tanto as palavras considerada como um elemento avulso, mas a inimitável atmosfera que o grande poeta cria através de todo o conjunto de elementos sugestivos: as palavras, ditas e não ditas;os gestos, completados ou apenas esboçados; o silêncio, os olhares, os risos e os sorrisos, os importantíssimos efeitos de sonoplastia, as variações do ambiente luminoso. Todos esses efeitos, sabiamente dosados por Tchecov, criam um clima de amarga e grotesca melancolia, no qual o tempo que passa adquire um peso quase físico, esmagando os personagens, passo a passo, minuto por minuto, contra sua própria mediocridade e falta de perspectivas.

O Jardim das cerejeiras é mais do que um peça: é um amigo do qual nunca mais nos separamos, desde o dia em que aprendemos a conhecê-lo.

Jornal do Brasil, 23 de outubro de 1968.

\section{Um jardim florido e amigo (II) Yan Michalski}

Não faltarão observadores apressados que torcerão o nariz para a encenação de O Jardim das Cerejeiras, classificando - a de convencional, e talvez até de tebecista. Ora, o aspecto possivelmente mais importante - pelo menos do ponto de vista polêmico - da admirável direção de Ivan de Albuquerque reside, a meu ver, no fato de ela revelar o quanto pode haver de invenção numa encenação realista, quando ela se empenha em esmiuçar meticulosamente as infindáveis sugestões de um grande texto, também ele realista. Invenção no sentido de criar, dentro das convenções antigas, novas inflexões, novos gestos, novas trocas de olhares, novos detalhes de relacionamento entre os personagens - em suma, novas maneiras de extrair do fundo da alma humana e seus mais íntimos segredos e dar-lhes um significado pessoal e inconfundível. Neste sentido, não hesito em definir a direção de Ivan de Albuquerque como intensamente inventiva.

Qualquer uma das obras-primas tchecovianas, e muito especialmente O jardim das cerejeiras, constitui uma dura prova de fogo para qualquer diretor. O texto é de uma tal complexidade e riqueza humana que cada um de nós, após ter lido, passa ater seu próprio Jardim das Cerejeiras, que poderá divergir, em vários aspectos, daquela com o qual Ivan de Albuquerque inaugura o Teatro Ipanema. Mesmo assim, ressalvando eventuais divergências subjetiva de detalhe, é impossível deixar de reconhecer o acerto básico do encenador nos principais aspectos da realização: a criação do clima; uma dosagem convincente de tons doloridos e cômicos; um ritmo firme, evitando os arrastamentos que tantas vezes desvirtuam as montagens tchecovianas, mas também sem acelerar artificialmente o andamento; e uma humanização profunda, minuciosa, carinhosa dos personagens, que proporciona uma projeção nítida de todo o sistema de conflito da peça. Acrescentemos a isso a grande beleza visual do espetáculo - na qual, alem dos excelentes cenários e figurinos, também a particularmente elaborada iluminação desempenha um papel de destaque - bem como uma homogeneidade poucas vezes vista no teatro brasileiro, por parte de um elenco de quinze atores - e teremos enumerado os principais motivos que fazem da montagem de O jardim das cerejeiras aquilo que ela é: disparado, o melhor Tchecov já realizado no Brasil.

\section{Um certo sorriso}

Sem prejuízo da calorosa emoção na qual envolve a platéia, o espetáculo é quase todo ele surpreendentemente alegre: ri - se muito, e ruidosamente, no casarão de Liubov Ranhevskala - talvez até um pouco demais; mas sorri-se também muito, e sempre bem, sempre na medida. Ousaria dizer, até, que o fato de ter o diretor encontrado, para o espetáculo, uma certa e muito especial qualidade de sorriso ocupa um lugar importantíssimo na densidade de ambiente que foi conseguida; esse sorriso, que é a expressão de um certo tipo de alegria, ternura, mas também disfarce de um profundo sentimento de frustração, de angustia e de medo, e que esta sempre pronto a se desmanchar em lágrimas, acaba por se transfromar numa espécie de leitmotiv da encenação.

Em todos os momentos do espetáculo sente-se perfeitamente que ele foi muito mais longamente trabalhado, ensaiado e amadurecido do que praticamente todas as realizações que nos tem sido servidas nas últimas temporadas : há aqui um jogo de minúcias na arte de contracenar, uma adaptação profunda dos intérpretes uns em relação aos outros, uma noção de bom acabamento e de riqueza de detalhes 
interpretativos que o pouco tempo de ensaios da maioria das atuais produções fez virtualmente desaparecer dos palcos brasileiros.

A solução de Marcos Flaksman para a cenografia de $\mathrm{O}$ jardim das Cerejeiras me pareceu extremamente inteligente. Impedido, por motivos técnicos, de realizar os três cenários realistas que a peça em principio pedia, o cenógrafo construiu uma única estrutura básica, cujo elemento principal é uma única parede, no fundo de cenário. Os diferentes ambientes são obtidos através de mudanças de elementos menores, procedidas brechtianamente à vista do público, e através de variações do clima luminoso. O resultado é excelente, um verdadeiro tour de force: por meio de um trabalho eminentemente anti-realista e moderno, Flaksman criou uma atmosfera perfeitamente realista, de grande força sugestiva, a tal ponto que nem sequer sentimos falta da presença física das cerejeiras: elas não aparecem visualmente, e no entanto sente-se que estão presentes, logo ali, ao alcance da vista.

Os deslumbrantes figurinos de Kalma Murtinho estão entre os melhores figurinos de época que eu já tenha visto no Brasil. A harmonia do seu colorido para a criação do clima geral do espetáculo, a perfeição do caimento, a adequação de cada peça do vestuário à psicologia e à posição social do personagem que a usa, a pesquisa do detalhe, a imaginação na escolha usados no sentido de criar a ilusão de outros materiais, impossíveis de serem empregados numa posição teatral - tudo isso contribui decisivamente para que o impacto visual do espetáculo se torne comparável aos das produções de alto gabarito internacional. Uma única exceção: o figurino de Nildo Parente, que dá ao ator um aspecto muito brasileiro.

A tradução de Eugênio Kusnet, a coreografia de Klaus Viana e os sóbrios e expressivos efeitos de sonoplastia também concorrem para o êxito dessa bela realização, com a qual o Teatro Ipanema se coloca, desde o dia da sua inauguração, entre os principais centros de cultura teatral do país.

\section{Jornal do Brasil, 24 de outubro de 1968.}

\section{Um jardim florido e amigo (III) Yan Michalski}

O elenco de O Jardim das Cerejeiras é um dos mais homogêneos que já tenha sido reunido no Brasil, nunca uma peça de tamanha dificuldade e complexidade interpretativa. Num grupo de dezesseis pessoas, ninguém destoa, e ninguém deixa de realizar um trabalho em profundidade, pesquisando as infinitas facetas e nuanças dos respectivos personagens, e procurando incorporá-las num conjunto orgânico e, sobretudo, sincero. Em termos relativos, portanto, estamos diante de um pequeno milagre interpretativo, e o conjunto dos desempenhos consegue criar o especialíssimo clima da peça, todo ele feito de meios- tons, de subentendidos, de ternura, de sorriso amargo, de gestos esboçados e não acabados.

Se fôssemos examinar a interpretação em termos absolutos, poderíamos, paradoxalmente, chegar à conclusão de que ela constitui o elemento menos satisfatório do espetáculo: os atores brasileiros, mesmo os maiores, não têm ainda escola nem estilo suficiente para ir realmente até o fim na exploração interpretativa dos grandes - e até dos pequenos - personagens tchecovianos, para dar todo o peso e significado exato a cada um dos seus silêncios. Mas não precisamos ficar com complexos: só ao aproximar-se do nível de um Laurence Oliver é que um ator se torna capaz de interpretar Tchecov de uma maneira completa.

\section{Um por um}

Vanda Lacerda tem um desempenho de grande dignidade e força no papel de Lhubov Ranhevskaia; elegante, bonita, com grande capacidade de interiorização, a atriz acerta particularmente nos aspectos mais dramáticos do personagem, e atinge seu momento mais feliz na sua reação muda à noticia de que a fazenda foi vendida. Faltou a Vanda Lacerda, a meu ver, maior ênfase no aspecto inconsequente, exacerbadamente feminino, coquete (às vezes até maldosamente coquete ) do personagem. O Gaiev de Hélio Ari é um dos desempenhos mais detalhadamente elaborados, mais ricos e inteligentes, mais divertidos, mas preocupação da composição cômica sobrepõe-se excessivamente, em certos momentos, à humanização do personagem. Os seus momentos discursivos são, não obstante, excelentes. A mesma restrição que fiz ao trabalho de Hélio Ari aplica-se, em grau maior, ao de Nilon Parente: ele está extremamente engraçado e é recebido com risadas em todas as cenas que aparece; é certo que seja assim: Iepikhodov é, sem duvida, um personagem essencialmente cômico; mas por trás dessa comicidade há uma enorme carga de frustração e sofrimento, que nem sempre aparece com a devida clareza. O ator está, aliás, prejudicado pelo único figurino menos satisfatório, e por uma caracterização - principalmente o 
bigode - demasiadamente grotesca. Também Ivone Hoffmann distancia- se em alguns momentos, embora muito mais raramente, da verdade interior de Charlota Ivanovna, devido a uma excessiva preocupação com o colorido cômico do desempenho; mas, para compensar estes momentos, há no seu trabalho um aspecto extravagante extremamente saudável, e uma espécie de alegria melancólica tipicamente eslava e tipicamente tchecoviana. José de Freitas compõe, no papel de Pistchik, uma figura grotesca, bastante feliz, e conduz bem a sua grande cena, quando se despede da família Lhubóv, pagando uma pequena parcela de suas dividas.

A interpretação que me emocionou talvez mais profundamente foi a de Vera Gertel. Sua composição do personagem de Vária é uma maravilha de sensibilidade, e suas estranhas transições de choro para o riso e vice- versa são simplesmente magníficas; aqui esta uma atriz de rara personalidade, que sabe tirar do seu instrumento interpretativo sons de notável delicadeza. Outro desempenho muito bom - embora possa passar algo despercebido, devido a sua sobriedade e à antipatia do personagem - é o de ÊNIO Carvalho no papel de Iacha: uma composição surdamente ameaçadora, extremamente violenta na sua discreta simplicidade. Carlos Eduardo Dolabella é responsável por uma das grandes surpresas do espetáculo: muitos furos acima do que seus desempenhos anteriores poderiam deixar prever, seu Lopákhin é perfeito como tipo físico, convincente e adequando como interpretação. Outra surpresa agradável é o trabalho de Susana de Morais, que transmite bem a espontaneidade, a tolice e a ingênua ambição de Dunhacha.

Leila Ribeiro empresta a Anha o adequado encanto juvenil, faltando-lhe apenas um pouco mais de calor em algumas cenas. O Trofimov de Rubens Correia tem a inteligência e a estranha simplicidade patética que constituem a marca registrada desse ótimo ator; mas também a ele falta - talvez por um cuidado de sobriedade levado ao excesso - uma dose maior de calor e de força de convicção ; esse mesmo calor e força de convicção que ele transmite exemplarmente na cena do quarto com Lopákhin, mas que não chega a comunicar com a mesma felicidade nas grandes cenas com Anha e Lhubóv. Antônio Vitor dá ao velho Firs uma máscara impressionante e uma presença adequadamente frágil e alienada; seu grande momento - maior mesmo do que o comovente final- é o seu curto monólogo sobre as cerejas secas nos bons velhos tempos : creio que o veterano ator atinge, nessas poucas linhas, o ponto maios alto de toda sua longa carreira. Em corretas aparições episódicas, Ivan de Albuquerque, Adauto Novais, Antônio Miranda, Lionel Linhares e Nei Mandarino completam a distribuição.

Um senhor elenco este que, todas as noites, consegue nos convencer por algumas horas que “... a humanidade caminha para a grande verdade, para a maior felicidade que é impossível na terra."

Para isso, como acrescenta Trofimov, é preciso estar na primeira fila.

\section{Jornal do Comércio, 24 de outubro de 1968.}

\section{O jardim das cerejeiras Elisa Schaffman}

O grupo do Rio lançou- se em um projeto por demais ambicioso, inaugurando seu novo teatro com o "Ciclo Russo". Antes de mais nada, uma palavra sobre o Teatro de Ipanema , que é realmente um jóia. Decorado com simplicidade mas com apurado gosto, promete ser uma das casas de espetáculo das mais agradáveis de nossa cidade.

O Ciclo foi iniciado com o "Jardim das Cerejeiras", a que se seguirão "O diário de um louco" de Gogol e a "Mãe" de Gorki - Brecht. A primeira peça, de Checov, é difícil, e exige interpretes excepcionais, o que infelizmente esta encenação não conseguiu reunir. Os problemas da decadência da aristocracia russa já foram amplamente ventilados, e não apresentem nenhuma novidade, só tendo justificativa em um espetáculo de virtuosismo interpretativo que trouxesse uma contribuição artística ao cenário do teatro nacional.

O superficialismo de Liuba Renevsky, o mundo de fantasia de seu irmão Galev são um momento do passado que não toca mais nenhuma corda em nossa emoção. Aquele amor pelo cerejal, que não lhes permitia decidirem-se a dele se desfazerem para por em ordem suas finanças, parece estéril e sem sentido. O drama interior daquela família, que por toda sua tradição e modo de vida não poderia jamais tomar decisões praticas, em uma encenação estereotipada adquirir um aspecto vazio e banal. A ascensão de Lopákhin, neto de um servo de gleba à condição de burguês rico, envolvido em um romance forçado, e sem conseqüência com Vária, na era do "self-made man" é apenas um lugar-comum. O velho e fiel criado Firs é caricato, e os demais personagens do povo demonstram apenas futilidade e uma ambição 
medíocre de limitarem seus patrões. O personagem de quem mais se espera uma mensagem, uma evolução que dê sentido à sua vida, que é o eterno estudante Piotr, interpretado por Rubens Corrêa, trazno também uma desilusão, pois sua palavra não apresenta a profundidade de pensamento que esperamos encontrar. Talvez fosse ainda cedo na evolução social e suas idéias não estivessem ainda plenamente claras, mas o fato é que suas ações resumem-se em um palavrório inconseqüente e uma bravata desprovida de verdadeira coragem.

Vanda Lacerda ( Liuba) é sem dúvida uma atriz experimentada, mas não transmite a angústia que deveria sentir ao ver sua vida desmoronar-se. O único personagem que tem algo de russo é Gaiev ( Hélio Ari), um verdadeiro fidalgo, consumindo sua fortuna em bombons. Lopákhin ( Carlos Eduardo Dollabella) está muito à vontade, em seu papel. Vária ( Vera Gertel), em seu inalterável mau-humor dá a impressão de estar sempre fazendo caretas. A figura feminina mais simpática é a da criada Dunhacha interpretada com graça por Susana de Moraes, apaixonada pelo valet Iacha ( Enio Carvalho) que tanto absorveu o ambiente parisiense em seus cinco anos no exterior que se enquadraria perfeitamente em um "dure" das comedias de boulevard. Ele assumiu um papel importante na peça e ficamos a nos perguntar qual a razão desse realce, quando ele não tem nada a dizer.

Parece-nos que o Ivan de Albuquerque nãos conseguiu foi "atmosfera". Os papeis estão bem decorados, mas não há unidade e nenhum dos interpretes viveu seu papel. A Rússia esta tão distante da encenação do Grupo do Rio que é preciso um esforço para nos lembrarmos estamos diante de uma peça de Chekov. A tensão que esta sempre presente em suas peças passa desapercebida, e as catástrofes se desenrolam com um bom-humor desconcertante.

Liuba parte para a França com seu eterno sorriso como se fosse um alivio ver-se livre do Cerejal. O abandono da propriedade que significava a derrocada de todo um modo de vida, o desmoronamento de uma sociedade, é efetuado dentro de um ambiente festivo, e parece que todos estão se preparando para ir passar férias à beira-mar. Enfim, se era tão pouco importante derrubar o Cerejal, para que desperdiçar duas horas afiando o machado?

\section{O Estado de São Paulo, 28 de dezembro de 1972.}

\section{O Oficina revigora a atualidade da peça Mariângela Alves de Lima}

Como último trabalho do ano o teatro Oficina apresenta uma das obras-primas da dramaturgia universal. Simbolicamente, um texto que se refere a uma realidade histórica do começo do século XX. "As três irmãs" mostra a ideologia, as aspirações e o modo de vida de uma família de pequenos aristocratas russos, sufocados pela ascensão da burguesia.

O traço delicado de Tchekov trabalha na interioridade de suas personagens. Enquanto o mundo se transforma, a família do coronel Prosorov sonha com o retorno a Moscou, com valores culturais e morais que não podem mais subsistir no novo século. E a isso se deve seu aniquilamento final. Acreditam que a estagnação em que se encontram pode ser solucionada com um comportamento discursivo. Para os Prosorov, o homem feliz surgirá espontaneamente, sem necessidade da interferência humana. Finalmente o novo mundo expulsa Prosorov de sua própria casa. Um novo mundo construido com atos, não com palavras.

Não é difícil perceber porque o Oficina, depois de ter realizado o trabalho mais atuante do teatro brasileiro, retoma, no mesmo ano, uma das peças clássicas do século. Em “Gracias, Señor”, o espetáculo fazia emergir a vivencia atual do espectador. Com "As três irmãs" a vivencia "é situada através de uma analogia, no processo histórico. Basta substituir a expressão "pequena aristocracia" que caracteriza os personagens de Tchekov por "pequena burguesia". Reconhecemos em 1972 a impressionante atualidade da peça. O comportamento de Prosorov pode ser aplicado também a uma situação cultural. Um exemplo oportuno é o próprio teatro brasileiro: marcado por um compasso de espera, e por uma ingênua confiança de que os belos dias do futuro estão calmamente aguardando a nossa chegada. Enquanto isso decoram com cores agradáveis a fachada de uma construção antiga.

Nesse sentido a Oficinaé um caso a parte. Faz história ao invés de esperar por ela. Há 12 anos que o trabalho do grupo é comprometido com o momento presente e sintonizado com o futuro. Cada trabalho é avaliado nas suas consequências, antes do salto para o próximo. 
Se existe uma evolução formal na encenação de "As três irmãs, ela é indispensável na ideia que se quer transmitir. O trabalho de José Celso Martinez imprimiu a cada ato um simbolismo próprio: nascimento, espera, incêndio e morte. A ideia de processo exclui a possibilidade de fatalismo. O espectador fica sabendo que o que acontece com os Prosorov é resultado de uma passividade que poderia ser interrompida.

Ao mesmo tempo são conservados todos os processos de consciência construídos através das pequenas pinceladas de Tchekov. Há uma decadência gradual, revelada através da expressão facial, da postura física e da redução do espaço cênico. Finalmente, os discursos filosóficos são cada vez mais mecânicos, cada vez mais discordantes com a exasperação interna das personagens. No final do terceiro ato há uma nova realidade em cena. As últimas palavras de Olga, tentando reanimar o velho sonho, são abafadas pelas frases cada vez mais pressionante de Tcheboutikine: "Que importância tem isso? que importância terá tudo isso?

Essas respostas cabem ao espectador. Mas a importância desse trabalho do Oficina é positivamente indiscutível. Mostra que o teatro pode ser bem feito, pode contar ideias e pode ser vanguarda sem perder pontos em nenhum campo. Um argumento contra quem acredita na adaptação e no conformismo.

\section{O Globo, 13 de janeiro de 1973.}

\section{Ainda uma vez, quatro horas com o Oficina Gilberto Tumscitz}

Uma grande decepção, antes de mais nada, foi essa estréia do Oficina. Porque depois de "Gracias, Señor", com o excelente texto de Tchecov, esperava-se tudo ( a velha garra de "pequenos burgueses") ou nada ( um fracasso que levasse a dissolução do grupo). E "A s três irmãs" não é uma coisa nem outra. É , isto sim, um espetáculo que já podíamos esperar do diretor confuso de "Na selva das cidades", com grandes qualidades e defeitos extremamente irritantes. Do pesadelo que foi "Gracias Señor"ficaram apenas algumas frases isoladas, estranhas, que não vêm evidentemente do texto de Tchecov, e cujo sentido, confesso, não consegui captar muito bem. Ainda mais uma vez sensível a moda da vanguarda teatral, José Celso Martins usou a belíssima peça russa para como um roteiro para um espetáculo de exaltação de sua figura de diretor, agora fortalecida por sua própria presença em cena, num dos papéis principais, com segurança surpreendente, por sinal. Mas "As três irmãs é um desses textos que perdem muito a qualquer modificação de rubrica. Mesmo a poderosíssima concepção visual do espetáculo me parece menos forte do que seria o cenário realista pedido pelo autor. Porque a peça vive de uma análise minuciosa do cotidiano. Tentar torná-la vibrante e grandiosa e tirar-lhe grande parte do sopro poético. A boa música pop, a euforia da montagem, tudo o que pontilha a ação faz com que o fio narrativo se dilua. Acredito mesmo que não conhece o original terá dificuldade em acompanhar a narração, tão límpida a simples leitura do texto. Sem a envolvência climática do dia a dia dessa família patética, e com acréscimos quase sempre supérfluos, o espetáculo fica inclusive extremamente maçante, em suas quatro horas de duração, das quais uma pode e deve ser cortada. A favos de José Celso, ficam momentos isolados de plasticidade incrível, que valoriza uma iluminação requintada, e - com a esperança de dias melhores para o Oficina - um excelente trabalho com alguns atores. Maria Fernanda tem, no papel de Olga, o maior momento de sua carreira desde Blanche Dubois. Seu rosto, mistura de medo a uma tentativa comovente de ser amável, numa das últimas cenas, quando agredida pelo povo, valeria por si só uma ida ao teatro. Outra grande figura é a jovem Analu Prestes, que consegue um equilíbrio fantástico entre a naturalidade e a exacerbação, uma Ítala Nandi outra vez.Ainda animadora, se bem que desdosada, como a própria montagem, a interpretação de Kate Hansen. Aconselho o programa aos aficionados mais pacientes. Mas só depois de uma noite muito bem dormida e dia bem calmo. E se possível, levando farnel. 


\section{Última Hora, 21 de janeiro de 1973}

\section{A grande missão das três irmãs}

A partir de hoje, o grupo oficina mostra o outro lado de uma crise que, segundo José Celso Martinez, seu diretor, serviu apenas para amadurecer o espetáculo com o qual surge o Oficina Depois do Sonho. As nove da noite, um elenco de vinte atores começa a representar na Gláucia Gill As três Irmãs, do dramaturgo russo Tchecov, definido com "Uma viagem na consciência dos intelectuais inúteis, que duro um ciclo de quatro anos - do Renascimento dessa consciência ( 1900), do seu tempo de escravidão e espera ( 1901), da sua Quebra e Queima (1902/3) e da sua Morte ( 1904) e um quinto tempo de sua primeira Ressurreição (1905).

Com esse espetáculo, que representa formalmente uma guinada de noventa graus na trajetória da Oficina - ela se dirigia mais no sentido do trabalho fechado e agora volta ao encontro de todo o público José Celso pretende produzir uma síntese entre seu teatro, radicalmente de vanguarda e o tradicional, com o qual ele praticamente nunca teve grande intimidade. Essa proposta não se limita aos critérios de encenação, mas s e reflete inclusive na composição do elenco, encabeçado por Maria Fernanda, um dos mais respeitáveis nomes do nosso palco.

\section{O que tem Tchecov}

Nas três irmãs - informa José Celso - abordamos o ciclo de formação da vida ( nascimento, juventude, maturidade e morte) que precede a primeira revolução do século XX. Nós passamos a limpo nós que terminamos em 72 nossa morte - e nos preparamos para a última grande transformação do século $\mathrm{XX}$, isto é, o fim das relações patológicas do século XIX, para entrarmos no século XXI.

Tchecov - afirma - é o autor da época da inação, mas de gestação, nos seus silêncios e subentendidos, das grandes tempestades. Cada personagem e situação falam em seu quotidiano, em termos de séculos, de tempo, de história e de vida e seu movimento. Segundo ele, esse é "um espetáculo feito dos últimos livros, dos últimos pedaços da consciência e do teatro burguês, de tudo o que se esvanece e o vento leva para a entrada que atravessa o ciclo de morte, plumas, maquilagens, flores, acordes doidos de violão, malas, personagens - esvanecimento; perda, o fracasso, o exílio necessário que prepara a barra pesada, explosiva e vital da consciência e do corpo que mudam a vida, que deixam correr livre o dia da vida, da ação."

"Grande a ópera existencial, onde a alegria e a dor da vida são mordidas com volúpia, As três Irmãs mostra um Tchecov explosivo, colorido com o jogo da vida, como o amor e a luta. O texto é uma sinfonia, um musical dedicado a vida, principalmente a vida de vinte anos, quando grita contra a morte e vence finalmente a morte".

\section{Um jogo livre}

Para José Celso, o importante nessa montagem é que os atores fazem um jogo livre, emocional, aberto entre si. olga ( Maria Fernanda) - consciência ( o começo e o fim do ciclo), Macha ( Kate Hansen), a inconsciência e o instinto vital; Irina ( Analu), a vida em movimento; o trabalho, a ação; André ( Marcos Flakesman) - a divisão, a esquisofrenia; Verchinine ( Lourival Parist) a esperança no futuro, o que vem de fora; Barão de Tousenbach ( Paulo César Pereio) - a vontade de mudar, a bondade, a bondade etodo o impedimento de classe; Tcheboutykine ( eu) o médico que crê que o doente não tem mais cura, pois acima de tuudo é preciso voar; Fedotite e Rode ( Luís Antônio Corrêa e Celso Lucas), os mágicos, os viajentes, os transeiros; Natasha ( Maria Aparecida Milan), a caretice o poder, a mulher bem sucedida dos novos tempos; Kouliguine ( Paulo Augusto) - o burocrata que quer formalizar a vida para subir, concorrer."

Mais dois personagens formam o elenc: "Rock around the clock, mais o mensageiro e construtor de postes; Ferraponte e a feiticeira empregada - Anfissa ( Cecilia Rabelo), mais o conjunto de mendigos e portadores e do vento; Paulo ( orgão), Carlinhos ( guitarra), Jorge ( baixo), Geraldo ( bateria) e Enéas. 


\section{Última Hora, 25 de janeiro de 1973}

\section{Oficina - um sonho, uma crise.}

No auge da sua criação artística, o grupo oficina, 15 anos de teatro, está em crise. "Estamos passando por uma situação de rotina - afirma seu diretor, José Celso Martinez Correia - situação de rotina, para quem, como nós, tem tentado uma transformação absoluta, completa, não só no teatro, como nos meios de comunicação direta. Essa crise econômica é consequência de quatro anos em que, depois de dez em que formamos grande público nosso, ganhamos muito dinheiro, decidimos, por livre opção, por uma experiência, longe da experiência da empresa convencional de teatro. É que a partir dessa época, passamos a perceber que para fazer teatro como nós queríamos fazer, isto é, o teatro vivo, era necessário mudar não só a forma de encenação das peças, interpretação, mas toda a forma de relacionamento, produção, relacionamento humano e relacionamento interno. “"

Com o trabalho de Tchecov - As três irmãs - para iniciar sua carreira definitiva no Rio, o grupo pretende fazer frente as dificuldades criadas por sua opção não empresarial, " Que significou manter sob a responsabilidade do teatro, embora muito modestamente, cerca de trinta pessoas, tendo ou não espetáculo em cartaz". Mas como essa atitude utópica granjeou muitas simpatias, muita gente se somou aos esforços para fazer frente as dividas: Gilberto Gil e Maria Alcina se ofereceram para realizar shows em benefício do grupo e a Petite Galerie se pôs a disposição para a realização do leilão de arte.

\section{Roteiro da crise}

Para José Celso, 35 anos, a crise da Oficina é apenas o preço cobrado pelo sonho de sua proposta: um grupo que se dedica o ano inteiro elaboração artística, independente do que possa entrar em dinheiro, não poderia sobreviver sem crise. "Decidimos por esse tipo de trabalho não só pelo amor que temos por ele, mas porque achávamos que a única condição que havia para criar dentro de todo um contexto era essa - estávamos fugindo de uma envolvência social em que todo o aparelhamento da produção está a serviço da destruição da criação, então compreendemos que tínhamos que partir para uma estrutura independente, totalmente independente, que se relacionasse com esse sistema destrutivo de criação, mas que se relacionasse sempre com um todo"

“Compreendemos - insiste- que para criar nós tínhamos que nos isolar. Tínhamos sempre que ter ao nosso lado indivíduos de absoluta confiança, teríamos que mudar a relação entre nós. As relações não poderia mais incentivar a concorrência, a disputa de poder, entravando a criação e estimulando apenas o fácil consumo, sujeitando-nos a todos os valores que nunca tiveram e não tem a ver com a criação artística".

"Então partimos para um trabalho de criação e nos atiramos de cabeça nisso, sem nenhuma experiência anterior - não há no Brasil nenhum caso antes do nosso, nem mesmo em outros setores de informação. Nossa experiência era completamente inédita. Por isso cometemos muitos erros nesses últimos quatro anos, mas descobrimos muitas coisas. É óbvio que a principal dificuldade numa fase como essa é a dificuldade de criar uma organização, uma estrutura e uma economia adequadas a um tipo de criação nova que se propõe, principalmente quando a gente é uma gota d'água.

"Realmente, nesses quatro anos nó apenas resistimos. Mas não conseguimos o que queríamos exatamente. Nós só conseguimos viver nossos grandes momentos quando estivemos no sertão do nordeste, pois foi o momento em que nosso grupo conseguiu viver como uma pequena república, como um espécie de comunidade com leis próprias e tudo mais. E nesse tempo, todos nunca abdicamos de nossas ideias. Nisso, fazemos sacrifícios que, se fôssemos medir o custo pelo que cada um deu de si, seria uma loucura. Mas isso pesou pouco. Nossa escala de valores não se mede por esse tipo de raciocínio. $\mathrm{O}$ importante é que aprendemos a viver modestamente e a nos fortalecer diante de uma engrenagem que ativa um consumo inútil e nos aprisiona."

\section{$O$ resultado de uma crise}

Essa proposta utópica de José Celso, além de gerar um crise financeira de um grupo que, por eu potencial, tem seu próprio teatro e um bom público, trouxe também, em contraposição, resultados positivos: "Estivemos sempre trabalhando com mais ou menos trinta pessoas - narra José Celso - e do nosso trabalho o público conhece muito pouco. Setenta por cento do nosso trabalho está nas gavetas, está nos filmes que temos conosco - está tudo documentado - mas é um trabalho que vai aparecer no futuro e ter suas consequências no futuro. Se eu tivesse tempo, agora, gostaria muito de ordenar essa trabalho, escrever, porque tenho certeza que ele terá continuidade e grande importância no futuro".

Amargo, José Celso se queixa das dificuldades de comunicação que enfrenta: "Não temos meios para divulgar nosso trabalho, que não pelo próprio teatro. Por isso a maior parte dele corre o risco de se 
perder. Se isso não for feito, todo esse trabalho de quatro anos corre o risco de se perder, se destruir. É por isso que nesse instante, estamos fazendo um esforço de sobrevivência econômica para ter condições de dar continuidade ao trabalho. Agora, é necessário uma retomada econômica, para que nosso trabalho possa ser sustentado mais tarde, possa começar a influir de uma maneira mais clara, não só no teatro, mas em todos os setores da atividade artística."

\section{Diário de Notícias, 18 de maio de 1975.}

\section{No palco, um sonho de Anton Tchecov. Hilton Viana}

Em cartaz no teatro do Meio, a rua dos ingleses, 209, a peça Tio Vânia, de Anton Tchecov. A direção foi de Emilio di Biasi, também responsável pela tradução e cenários. Os figurinos são de autoria do Grupo Heros, também responsável pela produção e montagem do espetáculo.

No momento uma onda de nostalgia varre a mundo em todos os campos da arte e o teatro não podia ficar de lado. Em todas as partes do mundo e de um modo especial nos Estados Unidos, Ibsen, O'Neil, Gorki e Tchecov estão em cartaz permanentemente. E para a montagem brasileira do espetáculo o diretor Emílio di Biasi, dá suas explicações. E notamos que também o diretor usa a palavra nostalgia. Tanto que diz:

\section{"As personagens de Tchecov tem a nostalgia da ação."}

Esta pequena definição tão ampla seu significado, atinge a todos nós, quer seja artista, quer público. Procurávamos um texto cuja problemática fosse comum a todos. Não foi fácil. Durante um mês lemos todos os gêneros, de todas as origens. Nada que nos motivasse e que pudesse tocar a sensibilidade do público, dentro da nossa possibilidades financeiras, afirma.

Bastante jovens, mas já com uma bagagem incrível, Emílio di Biasi fala como um verdadeiro veterano. Ainda referindo-se a escolha do texto de Tchecov, diz:

"Tínhamos que pensar em nós como artistas, satisfazendo nossa vontade de "agir" e nas poucas moedas que tínhamos para a montagem. Claro que existem mil textos e autores importantes, que interessariam a todos vê-los encenados. Ma s arriscar em produções que exigem cenários, muitos atores e vesti-los. Alguns produtores poderiam fazer isso, mas só eles não estão interessados em nossas ofertas. Para nós só restavam uma única opção: a independência total e a pobreza, mas como decorrência do "agir

Nesse momento o grupo há tanto tempo esperado aparece. E com ele o eu batismo "Heros". Não nos pergunte porque e o que significa, pois ele pertence só a nós. Talvez só os puros conseguem penetrar nessa palavra. E agora "Tio Vânia". E nossa força vem dessa contradição: ao mesmo tempo que mostramos personagens que não fazem nada, nós estamos fazendo, afirma Emílio di Biasi. Ao anunciarmos que tínhamos decidido pelo "Tio Vânia" houve sustos e exclamações tipo "eu é que devia ter feito".

Emilio diz que até agora no Brasil só houve uma montagem do texto de Tchecov na Escola de Arte Dramática. E quando falei que ia montar "Tio Vânia" eu lia nos olhos o que estavam pensando: "Imagine", "Tio Vânia com um elenco jovem". E no entanto eu só vejo a peça com um elenco jovem Tchecov a escreveu eu 36 e naturalmente, mais do que ninguém, sentia tudo que está em sua obra, pois sabe-se que costumava por suas afirmações na boca de vários personagens.

$\mathrm{O}$ atores mais velhos já se tornaram estrelas e a peça perderia seu sentido mais atual, tendo justificativa a presença de estrelas interpretando grandes papéis. Todo o acomodamento das personagens estaria bem justificado pela velhice. Ora - diz Biasi - o que mais nos interessa na peça o porque de a termos escolhido, a sua importância no dia de hoje é o acomodamento. 
Folha da Tarde, 23 de maio de 1975.

\section{Ver "Tio Vânia" é sua opção Paulo Lara}

É animador saber que existe mais um elenco profissional em São Paulo, como o caso do grupo Heros, responsável pela montagem de "Tio Vânia" que o Teatro do Meio, apresenta, de terça a domingo. E mais ainda se esse grupo é composto de elementos cuja contribuição ao teatro, até agora, tem sido positiva, e quando não, pelo menos honesta e bem intencionada. A obra de Checov, escolhida pelo Heros, escrita no final do século passado, pertence ao período clássico realista do teatro russo, onde Anton Checov, o autor, retrata uma sociedade desestimulada, com conceitos filosóficos, exigindo uma reformulação. Sem ser política, a obra insere essa necessidade de renovar.

Até que ponto Emílio di Biasi conseguiu atingir nesse novo trabalho onde ele acumula as funções de tradutor, cenógrafo e diretor? No primeiro caso, ele não consegue um resultado dos melhores, talvez porque tenha preferido uma fidelidade ao texto que não se julga tão necessária nos mínimos detalhes. O mis importante, parece, seria a idéia global da obra. A forma de expressar esse contexto, julgamos não exigir tanta preocupação por parte de um tradutor. Como cenógrafo, Di Biasi, fez exatamente o que se afirmou dele quanto ao trabalho de tradução. Livra-se dos detalhes, apela para a imaginação - obviamente por problemas de encarecimento da montagem - e com isso dissocia duas partes tão fortemente ligadas numa montagem de tal natureza. Como diretor seu maior pecado foi exatamente o de nào definir nada. Esperar que o texto se bastasse para fornecer tudo. Isso deu um clima por demais intimista a montagem indo fluir diretamente na representação do elenco.

Dentro dessa afirmação, contudo, alguns trabalhos conseguem um nível mais destacado. Como é o caso de Odilon Wagner, como "o médico Mihail Astrov", num comportamento cênico agradável, equilibrado. Walter Marins cometendo alguns exageros com a inflexão despersonaliza seu "Tio Vânia"constantemente.Há falta de um crescendo para justificar as explosões do personagem. Bri Friocca, uma das nossas boas atrizes, pouco segura com os elementos cênicos fazendo uma dança realmente perturbadora com as xícaras e samovar que serve de rotina no ambiente russo para chá. Thereza Freitas, como "Helena" numa composição estranha, pausas demasiadas, deixando clara as marcações dadas pelo diretor. Carlos Aberto Seidl, é talvez a interpretação mais solta do elenco. Sem estar preocupado ( no sentido negativo,é claro), ele consegue a melhor das interpretações vistas nessa montagem. Carlos Fischer , mantém- se num desligamento pouco natural e numa atitude introvertida que não deixa se saber se é do ator ou do personagem. Raimundo Matos ( o professor Alexandre), Stele Freitas (Sonia) e Maria Alice Costa ( Maria Vassilíevna), também não alcançam um ponto ideal que era de se esperar.

"Tio Vânia", dessa forma, não obstante os esforços de todos, não chega a ser um bom espetáculo. Vale pela honestidade com que foi realizado, atitude essa que, com o correr dos anos de vida do Heros, frutificara nos erros que o passado ensinou.

\section{A Tribuna de Santos, 23 de julho de 1975}

\section{Dois dias para ver o teatro de Tchecov}

"Ao contrário do que conhecemos dos dramaturgos ocidentais, em Tchecov não teremos o conflito de heróis e heroínas que lutam até a vitória ou a derrota total. Quando se abre o pano, já houve derrota. Os personagens não lutam, não tem vontade, são oprimidos e são vencidos a priori pela fatalidade; entregam-se a ela paralisados. Até Tchecov, a tragédia consistia na morte material ou espiritual dos heróis. Em Tchecov, temos um final mais atroz, isto é, a condenação de continuar a viver a tragédia, e arrastar a existência cinzenta, sem porquês; igual a ontem, será o amanhã. Há, depois, uma noite consciente de pessoas que sentem, no seu íntimo um forte desejo de vida, mas apenas para intensificar mais ainda aquela existência. Insinua-se uma meta luminosa no meio da nebulosidade deste estado de alma; é mais uma miragem de uma Terra prometida, infelizmente inatingível. A sociedade, o mundo, o meio ambiente exprimem de fato, inexoravelmente, o indivíduo. Embotado em sua própria dor, não le resta mais nada do que confessar sua própria importância, frente as forças que o oprimem”.

É como o crítico Sílvio D’Ámico analisa o teatro de Anton Tchecov,autor russo nascido em 1860 e considerado um dos mestres do teatro de protesto. Uma de suas peças, montada pela primeira vez por grupo profissional no Brasil, será mostrada em Santos nos dias 28 e 29, em promoção da Sectur e da 
Federação Santista de Teatro Amador. É Tio Vânia, escrita quando Tchecov tinha 36 anos. Nessa peça ele mostra personagens típicos do seu teatro, passivos e indiferentes a tudo que ocorre no mundo.

\section{Contradição}

Para o diretor Emílio di Biasi, a montagem do grupo Heros chega mesmo a apresentar contradições: o grupo pretende realizar um trabalho de importância, mostrando personagens que nada fazem cena. A nossa força vem dessa contradição: os personagens nada fazem, mas nós estamos fazendo".

O elenco é formado por jovens: Bri Friocca, Odilon Wagner, Walter Martins, Raimundo Matos, Stela Freitas, Thereza Freitas, Maria Alice Costa, Carlos Alberto Seidl e Carlos Fischer. Justificando a escolha de atores jovens, Biasi diz que "os velhos já se tornaram estrelas, e a peça perderia seu sentido mais atual, tendo como justificativa a presença de estrelas interpretando grandes papéis."

Biasi salienta ainda que todo o acomodamento dos personagens estaria também justificado pela velhice. "Ora, o que mais nos interessa na peça, o porquê e a termos escolhido, a sua importância no dia de hoje, é o acomodamento dos jovens". Afirma que, quando se refere aos jovens, não fala exclusivamente dos adolescentes, mas dos que têm de 28, a 40 anos, já estabeleceram suas vidas e se conformaram.

"Não percebem nada a sua volta e sonha com u futuro mais feliz. Mas não fazem nada para que isto aconteça hoje. O sonho de Tchecov, sua angústia por vê-lo distante, tornaram- se nosso sonho e nossa angústia, conclui o direto.

\section{A Tribuna de Santos, 30 de agosto de 1975}

\section{O jovem no teatro}

Os seis jovens acomodam-se entre as peças do cenário, no palco do teatro. São 19:30 horas e dentro de uma hora e meia eles estarão ali mesmo, vivendo outras vidas. São atores do grupo Heros, de São Paulo, que há algum tempo esteve em Santos com "Tio Vânia"um texto escrito por Anton Tchecov, quando tinha 36 anos de idade. Emílio di Biasi, o diretor, explica o motivo de ter escolhido "Tio Vânia"para montar somente com jovens atores: "Todo o acomodamento dos personagens estaria justificado pela velhice. Ora, o que mais interessa na peça, o porquê de a termos escolhido, a sua importância no dia de hoje, é o acomodamento dos jovens. Muito mais terrível é um jovem decadente.

$\mathrm{Na}$ semi-escuridão do palco, os seis jovens atores se acomodam. Logo eles trocariam suas calças compridas e blusas coloridas pelo figurino da peça. Em vez de contarem seus sonhos e dramas estariam transmitindo ao público os sonhos e dramas dos personagens de Tchecov. Mas, por enquanto, ele falam deles próprios:

"estamos juntos desde "O boca de ouro". Alguns participaram de "A Morta"e agora nos reunimos novamente em 'Tio Vânia". Em vez de atores mais velhos e grandes estrelas, estamos nós. As grandes estrelas limitariam nossa proposta: um velho acomodado é mais fácil de aceitar do que um jovem acomodado. Um jovem que já não luta é muito mais terrível."Mas certamente esse não é o caso dos jovens do grupo Heros. Eles lutam e muito para conseguir seus objetivos:

"Noventa por cento da classe teatral é jovem. São atores como nós, relativamente desconhecido do grande público.O restante e constituído por grande estrelas e jovens que já estão em cartazes. A maioria dos $90 \%$ está desempregada. São raríssimos os casos de jovens atores que conseguem sobreviver só no teatro. E a situação é igual no Rio ou em São Paulo.

A explicação que encontra para o fato: "é um problema de estrutura econômica e da própria sociedade". A tentativa de minorar o problema : "É fazer o que estamos fazendo, teatro de grupo, sem empresário. Lutamos com grande dificuldade, mas é uma saída. Não há individualidades no grupo. Sobrevivemos a medida que cada um da o seu sangue pelo grupo. E todos temos outras atividades, além do teatro, para mantermos".

Dará certo essa iniciativa? Levará alguma coisa a atitude tomada apelo Heros? Eles pensam antes de responder: "Qualquer resultado vem sempre a longo prazo. Para o grupo Oficina aconteceu, embora eles tenham tido ajuda financeira. Mas foi um momento histórico, estouraram".

A maior dificuldade para levar a frente seus planos, segundo os atores do grupo Heros, é a falta de sala própria. Aliás, nem sala, ou salão, ou teatro. Um galpão os deixaria satisfeitos. Significaria não ter mais problemas com aluguel, com falta de lugar para ensaiar: "Se existir um local, o público sempre vai, no nosso caso , uma sala própria nos possibilitaria um trabalho mais profundo, maior número de ensaios. $\mathrm{Na}$ situação atual, quando montamos uma peça, temos que fazer ensaios nos lugares mais diferentes. $\mathrm{Na}$ 
sala onde vai ser apresentada ao público ensaiamos pouquíssimas vezes. E ainda há outro problema. Por exemplo, se a prefeitura cede um teatro, para ali realizarmos uma temporada, é somente o dia determinado. Acabou a temporada temos que ir embora. Isso já não aconteceria com uma sala própria.

Então o jovem no teatro não tem saída? Parece que não: "Ele concorre com grandes estrelas, com a organização dos empresários. Estes, como todos que estão ligados ao teatro correm o risco de não ter sucesso numa iniciativa. Mas eles podem aguentar. Nós, não. Não temos estrutura financeira para isso".

Mesmo assim, a saída para o círculo vicioso, segundo Heros, é uma só: "Trabalho de grupo. Ao contrário, fica-se eternamente a espera de um papel que não vem. Além disso, num caso como nosso , pode-se montar o que se deseja, o que realmente se quer mostrar ao público, sem empresários exigindo, "cobrando" É verdade que trabalhamos como se fôssemos amadores, carregando cenários nas costas, cuidando de figurinos etc. Não visamos lucro, mas sim fazer teatro do jeito que a gente gosta. E isso já compensa".

\section{O Estado de São Paulo, 14 de janeiro de 1982.}

\section{Viagem a Rússia pré-revolucionária}

Depois das tentativas reformistas de Alexandre II , a Rússia caiu numa situação sombria e reacionária sob a égide de Alexandre III. Naquela época, Konstatin Pobiedonostesev, o procurador do santo Sínodo, era o orientador do país. Escolheram-se vários caminhos que resultaram insatisfatórios e o novo czar escolheu sua saída: deixou de fazer concessões ao povo russo, acabou com a abertura política, e baixou uma rígida censura ideológica. É dentro desse clima que se vai encontrar o escritor Anton Checov, que extraiu uma facção da sociedade, a aristocracia decadente, e a colocou na trama da peça "O jardim das cerejeiras" que estreia hoje, as 21 horas, no Teatro Anchieta. Mais que isso, além de criar uma peça sobre um momento histórico, ele preconizou a revolução de 917 ( a peça foi escrita em 1903).

Jorge Takla é o produtor e diretor do espetáculo, para ele um sonho acalentado há três anos. Estudiosos das obras de Checov, Takla aos poucos percebeu a importância literária das obras do escritor, apaixonando-se pelo "O Jardim das Cerejeiras".

$\mathrm{Na}$ verdade, a peça foi um encontro de paixões. O segundo da lista é Millor Fernandes, o tradutor do texto.Havia, de acordo com o diretor, pelo menos dez traduções diferentes do original.Todas, no entanto, de difícil adaptação para o público e teatro brasileiro, ou melhor, com passagens que se tornariam delicadas durante a montagem. Jorge Takla não teve duvidas e, depois de muitos encontros e conversas para convencer Millor Fernandes a traduzir, entregou ao dramaturgo uma cópia do mesmo original utilizado na primeira montagem, a de 1904. Foram dois meses de trabalho intercalados de reuniões, telefonemas e troca de ideias. E o resultado: "Uma tradução sensível, sem cair no panfletário, dando a obra grande dimensão humana e valor literário.”

O valor literário foi também o elemento ressaltado por Jorge Takla na direção: " Sem dúvida a intenção foi de valorizar a obra, sem deturpações e intelectualizações, como vi nas montagens anteriores da mesma peça, realizadas fora do Brasil, tentou reencontrar a alma russa, impulsiva, emocional, poética, violenta e amorosa. E, nesse sentido, acredito, o texto tem o sabor do brasilleiro; nós também somos assim".

Jorge Takla precisava encontrar todos esses adjetivos numa só atriz, e por isso convidou Cleide Yáconis, completando 30 anos de teatro, para viver o personagem de Liuba Raneuskaia, uma aristocrata que, depois de viver muitos anos em Paris, volta para a Rússia, a propriedade da família, ao Jardim das Cerejeiras, antes uma fonte de renda e depois uma região pobre e podre, que Liuba vai perder durante um leilão. Ela se recusa a enfrentar a realidade e entra em confronto com Lopakhine ( Edney Giovenazzi), próspero comerciante, filho de escravos que trabalharam para os pais de Liuba.

Para Jorge Takla, Liuba é uma personagem "deliciosamente pecadora de grande força dramática, a altura de Cleide Yáconis, assim como estão a altura os figurinos confeccionado por Kalma Murtinho". As estampas foram especialmente desenhadas para a peça, num total mais de 40 trajes, vestido pelos 14 atores do espetáculo.

Mas num tempo de recessão no teatro brasileiro, vale a pena um empreendimento de tamanha grandeza? Jorge Takla, apesar de ter gasto 5 milhões de cruzeiros, acredita que sim. Ele contratou até a bailarina Sônia Mota para coreografar a cena do baile, em que todas as mulheres estarão de espartilho, além de reunir todo o seu material de pesquisas, croquis, desenhos de figurinos e fotografias de antigas encenações internacionais, e da própria Rússia de 1904 para montar uma exposição instalada no saguão do teatro. 
- Vale o esforço de um sonho que não pude realizar antes por falta de dinheiro. E me senti mais a vontade ainda depois que tive de acumular as funções de iluminador e cenógrafo. Mas confesso que minha equipe contribui muito para o desenvolvimento do trabaho.

"O Jardim das Cerejeiras" é encenada pela primeira vez em São Paulo e participam ainda do elenco Walderez de Barros, Francarlos Reis, Abraão Farc, Eugênia di Domênico, e Ileana Kwasinski, entre outros.

\section{A última e histórica peça de Tchecov}

"O Jardim das Cerejeiras" foi a última peça escrita por Anton Tchecov, em 1903, um ano antes de sua morte. Encenada no ano seguinte, no Teatro de Arte de Moscou, recebeu comentários favoráveis dos críticos locais e teve sucesso de público. Somente 24 anos depois o texto ganhou uma nova montagem, desta vez na Broadway, consagrando de vez a história. Daí para cá, sucederam-se várias montagens - Paris, Roma, Bucarest e Buenos Aires, entre outros - até chegar ao Brasil, em 68, numa montagem carioca no teatro Ipanema.

Mas este não foi o primeiro contato do público brasileiro com a honra de Checov. Pouco antes, Ziembinsky dirigiu Glauce Rocha e Rodolfo Maior em “As três irmãs”, também no Rio de Janeiro, além de, em 1961, a companhia teatral de Jean Louis Baurrault ter trazido para o Brasil e sua versão de "O Jardim das Cerejeiras".

Com a estreia de "O Jardim” amanhã, no Teatro Anchieta ( veja matéria acima), o público paulistano terá a oportunidade de conhecer pela primeira vez a história da personagem Liuba, aristocrata decadente e proprietária do grande cerejal. São Paulo, no entanto, j; a assistiu pelo menos quatro encenações de textos de Checov, todos montados pela Escola de Arte Dramática da Universidade de São Paulo, São eles: : "Pedido de Casamento" , "O Urso", "Tio Vania"e "As três Irmãs". Dois outros clássicos do escritor - "A gaivota" e "Ivanov" e entretanto, continuam desconhecidos do público brasileiro. Mas não é somente através da dramaturgia que Anton Checov chegou ao Brasil. Não se pode esquecer dos contos publicados em revistas sob o pseudônimo de Antosha Chekhonte, traduzidos para o português como "O Guarda-Bosque", "A Morte de um Oficial”, "A Casa da Sacada, "Felicidade", "O Matrimônio do Cozinheiro", "Relato Triste"e "O Natal e um Menino".

Anton Pavlovich Checov nasceu em 17 de Janeiro de 1860, em Tanganrog, no Mar de Azov. Frequentou o primário e ginásio em sua cidade natal, seguindo depois para a Universidade de Moscou, onde se formou em Medicina, a profissão que exerceu somente durante a epidemia de cólera em 1892. Embora se tenha iniciado nas letras quando estudante, só em 1887 escreveu sua primeira peça, "Ivanov".

\section{Jornal da Tarde, 14 de janeiro de 1982.}

\section{Um jardim das cerejeiras muito fiel a Tchekov.}

Jorge Takia (foto) esperou um bom tempo por este momento. Afinal, os riscos eram muitos e tinham que ser calculados com rigor. Assim, foi com uma disposição muito estudada que o diretor Jorge Takia decidiu montar $\mathrm{O}$ jardim das Cerejeiras, que estréia hoje, às 21 horas, no Teatro Anchieta, com um elenco encabeçado por Cleide Yaconis, Francarlo Reis e Ednei Giovenzzi.

Todo esse cuidado era necessário, conforme a argumentação de Takia, porque se tratava de levar ao palco um texto que é consideraado uma obra-prima da dramaturgia moderna, escrita pelo russo Tchekov, um pouco antes de morrer,. Jorge Takia chega a ser até um pouco místico quando afirma que "esse texto é de uma sensibilidade tão imensa que só poderia ter sido escrito por alguém que já estava-se desligando desta vida."

- O texto mexe comigo emocionalmente de uma forma particular. Talvez por isso eu tenha demorado tanto tempo para montar a peça. Desde que cheguei ao Brasil, há seis anos, fui-me preparando aos poucos para $\mathrm{O}$ Jardim das Cerejeiras. Agora, acho que atingi um ponto razoável como diretor e também reuni as condições necessárias para produzir a peça pessoalmente, com a ajuda de apenas de meu irmão, Hábib Takia.

Em 1973, Jorge Takia participou de uma leitura dramática deste texto em Nova York, com o grupo La Mama, mas não esteve presente quando, algum tempo mais tarde, o diretor Andrei Serban apresentava a sua montagem de O Jardim das Cerejeiras com o mesmo grupo. O diretor Peter Brook também dirigiu o texto em Paris, abolindo os cenários e utilizando um único figurino para os atores. Já a direção de Jorge Takia não pretende nada além do que respeitar fielmente Tchekov, levando inclusive em consideração as críticas que o autor russo fez, em 1904, a montagem de Stanislawsky: 
- Eu nõ ouso nada ais do que exprimir em todas as formas as grandeza do texto que, acima de tudo, é um painel de belos retratos humanos. Se o público deixar o Teatro Anchieta comentando apenas a riqueza do texto e o talento do elenco já ficarei imensamente satisfeito.

A passagem da obra para o português foi encomendado a Millôr Fernandes que se valeu para tanto de 12 traduções diferentes e dos conselhos de uma consultora russa. Assim, o que o público verá nesta montagem será um trabalho muito diferente do realizado em 1968, pelo teatro Ipanema do Rio, na primeira vez em que O Jardim das Cerejeiras foi exibido no Brasil. nesta ocasião, os atores fizeram uma montagem coletiva, " aliás muito apropriada para o momento político que passava, esclarece Jorge Takia:

- Eu não quis fazer uma direção planfletária nem intelectualizada. Eu procurei mostrar a peça como ela é, um texto de muitas camadas, de vários níveis de compreensão. O Jardim das Cerejeiras ocupa um momento muito particular na obra de Checov. A peça foi escrita no último ano de sua vida, quando ele já estava doente. Havia nele uma preocupação de limpar o texto, de ser conciso, de dar precisão as idéias. Como um pintor que em rápidas pinceladas, consegue traços marcantes.

Jorge Takia também aponta a lucidez histórica que reveste o texto - escrito em 1903 - e que profetiza as principais mudanças políticas e econômicas que ocorreriam na Rússia anos mais tarde.

Os cenários de O Jardim das Cerejeiras também foram imaginados por Jorge Takia que, em 1980, levou ao público seu último trabalho, um espetáculo de dança chamado Fedra 1980. Já a tarefa de criar os figurinos para O Jardim da Cerejeiras coube a Kalma Murtinho, que teve que providenciar um guarda-roupa com 40 trajes diferentes - alguns deles confeccionados com tecidos exclusivos de Larmod.

O espetáculo ficará em cartaz normalmente de quarta a domingo em horários diferentes.

\section{Folha de São Paulo, 16 de janeiro de 1982.}

\section{Cerejeiras floridas no fim de uma época. Jeferson del Rios}

"O jardim das cerejeiras" de Anton Checov leva de saída a vantagem de ser um espetáculo baseado em um dos mais belos exemplares da literatura dramática do teatro Ocidental. E evidente que a sensibilidade do público atual talvez tenha sido influenciado por outros estilos e experimentações literárias e a nós pareça, quem sabe, um tanto longo o detalhismo de Checov, sua necessidade de juntar os fios de todas as histórias num final convincente e tecnicamente irretocável. Não importa. $\mathrm{O}$ toque de gênio do dramaturgo ao descrever uma decadente família russa do começo do século permanece inteiro na capacidade de emocionar e convencer. $\mathrm{O}$ texto prenuncia o futuro e agride as injustiças do presente ao narrar descompassos emocionais entre pessoas, frustrações amorosas intensas porém dissimuladas aos limites do patético, a dolorosa impotência face aos tempos novos que corroem, social, econômica e psicologicamente, o universo outrora fastigioso em que viviam.Numa mesma casa em que convivem aristocratas rurais decadentes, arrivistas e empregados deturpados pela subserviência, tudo é possível: da tragédia ao ridículo. $\mathrm{O}$ autor sabe trabalhar magistralmente este quadro explosivo e ao mesmo tempo outonal e melancólico retrato de uma Rússia czarista, definida por Tchecov, como um país estúpido e absurdo.

O diretor Jorge Takla aproximou-se da obra com discreta intenção de apenas transcrevê-la cenicamente com absoluta fidelidade ao original. O resultado é elogiável, o melhor conseguido pelo encenador em sua recente carreira. A realização tem elegância e respeita efetivamente Tchecov. Renderia mais se eliminasse os tempos mortos nas mudanças de ato. Eles quebram o ritmo, ameaçando esfriar a ação dramática. São problemas de ordem artesanal perfeitamente contornáveis. Desafio maior será harmonizar o elenco num tom mais denso. A interiorização ou o domínio psicológico dos personagens não foi completado de modo uniforme. Detalhe visível quando há disparidade entre o esforço e a maturidade artística exigida pelo papel e a pouca vivência ou recurso técnico (voz principalmente) do intérprete Cleide Yáconis - comemorando 30 anos de carreira- comanda o espetáculo com altivez verdadeiramente tchecoviana, apesar de repentinos lances de super representação sublinhando desnecessariamente os sentimentos. Ela tem o porte, sonoridade vocal e vibração nervosa que a tarefa impõe. Valderez de Barros, contida e emocionadíssima, estaria perfeita se pudesse usar melhor a voz para reforçar o impacto do rosto expressivo, olhares eloquentes, e gestos definidores de sentimentos contraditórios. ão observações iniciais; como o elenco é extenso, vale a pena comentá-lo, brevemente, em outra crítica.

Jorge Takla sonhou longamente com "O jardim das cerejeiras". Encomendou a tradução (esplêndida) de Millor Fernandes. Os figurinos requintados são de Kalma Murtinho (pena que façam contraste com a cenografia insípida do diretor, que preenche o espaço sem poder de sugestão). Houve empenho e carinho. Poderia haver audácia, maior sopro poético e transcendência. Afinal, estamos 
(felizmente) mal acostumados com os espetáculos russos do Teatro Oficina. Takla está, entretanto, ao que parece, afinando seus instrumentos, reinando a coragem para um instante pleno de invenção. O ponto em que chegou já é suficiente para que se possa dizer bem do seu!!!

\section{Folha de São Paulo, 19 de janeiro de 1982}

\section{Alguns reparos no "jardim" Jeferson del Rios}

"O jardim das cerejeiras" ( de que já foi publicada, sábado, a primeira parte desta crítica, sob o título de "Cerejeiras Floridas no Fim de Uma Época" ) é, no gera, um espetáculo bonito, ainda que preso a soluções visuais superadas. O encenador inglês Peter Brook usou durante algum tempo esse mesmo tipo de transposições de quadros ( ou estilo de pintura)célebres para o palco. Ou seja: fazer cenas, estáticas ou em movimento, que sugerem pinturas e ou fotografias. Seria interessante outra invenção, mas em todo caso o que foi feito funciona dentro do correto convencionalismo.

Um espetáculo oferece dois instigantes desafios ao diretor: a transformação do texto em ação coordenada, dinâmica, atraente e, se possível, original; e, em segundo lugar, a façanha de dominar o elenco como o resgate de orquestra faz com os músicos, extraindo de cada um o máximo de suas potencialidades. Reger atores e atrizes é difícil. Existem obstáculos objetivos e subjetivos. Desde o ato de adequar o tipo físico do intérprete ao papel até contornar resistências, pequenas (e grandes) manias e cacoetes que determinado membro do elenco tem e obstina-se em não abandonar. $\mathrm{O}$ diretor precisa ser criativo e enérgico, o que não é nada simples.

Jorge Takla, diretor de "o jardim das cerejeiras, conseguiu a uniformidade média sem a qual a uniformidade média sem a qual o espetáculo seria insustentável. Não há desníveis gritantes numa linha de atuação que começa com Cleide Iáconis ( 30 anos de profissão ) e chega aos bem novos na carreira. Falta agora pulso, imaginação e paciência para amadurecer e retocar o que se conseguiu até a estreia. Há, por exemplo, um trio composto por Cleide, Francarlos Reis e Ednei Giovenazzi. Por uma questão, talvez de impostação dada ao trabalho pelo próprio Takla, a atriz carrega nos olhares transtornados enquanto todos exageram nos risos descontrolados, com o possível ( e desnecessário ) objetivo de insinuar a um ambiente de deterioração psíquica dentro da inconfundível família "fim de raça". O texto basta e inflexões naturais seriam suficientemente impressionantes.

Francarlos Reis, ator de físico privilegiados, magro, elegante e ágil, usa estes atributos dentro de sua natural tendência ( ou facilidade ) para posturas irônicas ou cômicas. Mas desta vez o personagem requer um tom de patética decadência que Francarios deixa de explorar, preferindo uma afetação que dilui a essência do parasita social sonhador e simpático. Ednei Giovenazzi está na parte exterior do pape, com gestos e alterações de voz visíveis e rumorosos mas que não passam o cerne da criatura a que lhe cabe dar vida. Seu personagem é o nítido contraponto social a aristocracia rural arruinada: e isto comporta sutilezas que dispensam batidas de pé no chão, gritos e pancadinhas na cabeça. E a verdade interior? O intérprete teatral brasileiro tem, em grande parte, um penoso despreparo vocal. Este vital instrumento de trabalho não é levado em conta no Brasil (sim, todos sabemos que as aulas de voz custa caro, etc.). Eugênia di Domenico tem tudo pra ser uma ótima heroína: tem juventude, beleza e chama interior. Mas como vencer a barreira da voz, sempre juvenil-voluntariosa? Ileana Kwasinki tem porte, voz, tipo, intensidade. Atriz convincente, apesar do papel complicado por estar desvinculado com o tema central (o mesmo acontece com Carlos Silveira só que em grau maior; ele tem que se fazer notar quando não há nada que o envolva de fato). Noemi Gerbelli sabe tirar proveito do tipo, idade, voz, na criação da empregada. Na área da composição. Abraão Fare e Sérgio Ropperto estabelecem figuras marcantes: Abraão apoiando-se mais na maquiagem-figurino e na repetição de determinados tiques. Ropperto, explorando as características risíveis do papel. Para tanto valoriza a magreza, o jeito de andar, e o domínio das pausas sincronizadas com o olhar atônito e desamparado. George Otto tem ímpeto, físico, energia e torna sua presença digna de atenção. Houvesse voz com maior autoridade e estaria impecável. Os demais participantes do elenco sabem dar conta de suas partes com cuidado. 
Folha da Tarde, 02 de fevereiro de 1982

\section{Um Checov inverossímel. No palco do Anchieta. Paulo Lara}

Quanto mais profunda a obra, maior o esforço a fazer para se conseguir atingi-la plenamente. E, neste ano, parece que os produtores paulistas estão empenhados nesse tipo de proposta. Em pouco mais de trinta dias já tivemos, pelo menos, um "Othello", de Shakepeare, um "Hamlet", numa adaptação de Giovanne Testtori sobre a obra homônima também de Shakespeare, e ainda, dentro do "clássico", e pendendo mais para um teatro naturalista e realista, "O jardim das cerejeiras", de Checov, que o Teatro Anchieta mantém em cartaz, há algumas semanas.

Tentar uma reanálise sobre esta obra, a extensão de sua mensagem e sua consequente importância ao retratar o mundo russo do fim do século passado e início deste, em seu contexto sóciopolítico em declínio, não pode escapar de uma esfera redundante.Mesmo assim nunca é demais se afirmar que neste "O jardim das cerejeiras", Checov nos fornece um amplo painel da sociedade russa dos primeiros anos deste século. A aristocracia falida, rota, sem saída, em dissolução irreversível, por um lado.Por outro, uma juventude insatisfeita, ansiosa pela renovação social e política. E, como um futurologista, Checov parece preconizar, com quatorze anos de antecedência, a Revolução Socialista de 1917, a mesma que depôs o czar, instalando o comunismo na Rússia.

Resta saber agora, como deva ser encarado esse clássico do teatro naturalista. Sob uma perspectiva mais humanística ou mais política?

Ao que tudo indica, a genialidade de Checov consegue reconciliar essa ambivalência enquanto proposta de texto, mas que a direção de Jorge Takla, ou não procurou averiguar mais detalhadamente, ou não conseguiu chegar lá. A verdade é que o espetáculo transcende uma superficialidade comprometedora, partir da estrutura psicanalítica de seus personagens.

Assim posto, ficamos apenas com a cancha do elenco, de um bom currículo em sua maioria. Isso entretanto poderia se tornar suficiente para que a grandiosidade da obra fluísse para alguma coisa realmente vivida e não simplesmente representada? Em nossa opinião consideramos, infelizmente, que nem isso foi alcançado. Porque grande parte das interpretações se fundamentaram, equivocadamente, em "composições" estereotipadas criando um conflito com o naturalismo da obra. Por isso, não parece muito significativo destacar este ou aquele trabalho de interpretação, embora as preseças de Eugênia De Domênico e Walderez de Barros, num esforço sobre-humano, consigam fazer passar alguma coisa dentro do caos criado pela proposta do encenador e que desencadeou uma montagem que se frusta em seus anseios maiores.

Também é bom que se lamente que a enxuta a tradução de Millor Fernandes não tivesse sido aproveitada adequadamente.

E, para que não se aleguem leviandade e todas estas afirmações, bastam alguns atores que, em cena, transformam seus vestuários em algo que parece perturbá-los do que auxiliá-los.

Mas, embora esse clima de inverossimilhança, este "O jardim das cerejeiras" não é uma produção nem pobre, nem negligente. Há bons e bem executados figurinos, serve- se o chá em serviço de prata, e tapetes presas impedem que se ouça o andar dos atores no palco. Mas é só isso.

\section{Jornal da Tarde, 18 de fevereiro de 1982.}

\section{O Jardim das Cerejeiras : Um raro requinte Sábato Magaldi}

Bela montagem, por muitos títulos, a de O Jardim das Cerejeiras, cartaz do Teatro Anchieta. Desde o admirável Checov, traduzido por Millôr Fernandes com uma fluência que parece original brasileiro, a cuidada, séria e erudita montagem de Jorge Takla, passando pelo bom escolhido elenco, numa produção que não poupou esforços para atingir o requinte artístico.

Aí estão valores que situam o espetáculo num nível a que a força da economia, originária da falta de recursos, nos está desabituando. Sente-se que todos os meios foram postos a disposição do encenador, para que não se comprometesse o rendimento, em virtude da necessidade de permanecer no acordo pela metade. Ao menos aparentemente, chega- se a conclusão de que se $\mathbf{O}$ jardim não ambicionou outros elementos é porque não quis. 
Há uma primeira virtude na direção de Jorge Takla: os diálogos chegam a platéia sem nenhum hermetismo. Eu quase diria clareza didática, se na expressão não estivesse contido um qualificativo estranho ao mundo de Checov. De qualquer forma, o recado da peça está transmitido meridionalmente os vários pontos de vista se alternam e encontram perfeito equilíbrio cênico, sem que o diretor tenha tomado partido, torcendo o significado global da obra. A perspectiva de hoje não deturpou Checov: ressaltou-lhe a clarividência contemporânea.

Outro mérito da montagem está no gosto dos cenários e da iluminação do próprio Takla, acompanhado pelos figurinos de Kalma Murtinho. A feliz combinação desses valores dá ao palco, a cada momento, um colorido impressionista de valiosa plasticidade, sublinahda pelo desenho das marcações. A partir do primeiro ato, que se passa no quarto das crianças, poetizado por uma tela transparente, transportando as personagens para uma atmosfera de quase irrealidade, vê-se que o encenador não teve medo da linguagem lírica escolhida por Checov.

Sabe-se que o mestre russo "desdramatizou" o teatro, no sentido de fugir no sentido de fugir aos conflitos altissonantes, que reclamam paixões no clímax. Era ideal de Checov fazer uma peça em que as personagens "chegam, vão embora, almoçam, falam da chuva e do bom tempo, jogam baralho - e tudo isso não pela vontade do autor, mas porque é assim que isso se passa na vida verdadeira". Pode-se pensar, por esse motivo, que os textos de Checov não tem ação, quando, de fato, esgarçam o enredo, em benefício de uma ação subterrânea. É essa característica que transmite a O Jardim bem como a Três Irmãs, Tio Vânia e A Gaivota, uma secreta pungência, que emociona profundamente o espectador.

As qualidades plásticas do espetáculo de Jrge Takla talvez sejam responsáveis, paradoxalmente, pela falha que seria possível imputar-lhe: os efeitos pictóricos, permanentemente perseguidos, roubam um pouco da espontaneidade dos movimentos, impedindo uma comunicação mais calorosa. $\mathrm{O}$ embalo visualem quadros que se inspiram na melhor pintura, esfriam a palavra e a dramaticidade implícita da situação.

A progressão lenta dos episódios seria compensada pela inevitabilidade premente dos "monólogos paralelos".

É certo que essa observação não prejudicará o aplauso do público sensível, interessado numa experiência enriquecedora. Ainda mais que todos os desempenhos estão muito bem defendidos. Assinalese a emoção contida de Cleyde Yáconis como Liubov Andrêievna Raniévskaia, a aristocrata que deixa a propriedade escapar de suas mãos. Francarlos Reis, no papel de seu irmão Leonid Andreievitch Gaiév, tem a mesma finura impotente. No outro pólo, estuante de vitalidade ascensional, está Ednei Giovenazzi, o Iermolai Alexêievitch Lopakhine que comprou a fazenda, onde seu avô e seu pai foram servos, que nem na cozinha podiam entrar.

Merecem registro a sensibilidade de Eugênia De Domenico (Ânia) e Walderez de Barros (Vária), a composição de Abrahão Farc (o quase monagenário criado Firs), o hierstismo mágico de Ileana Kwasinski (a governanta de passado circense), o ímpeto de George Otto (Pétia Trofímov, o jovem professor otimista que prenuncia os heróis positivos de Górki), e a correta silhueta dos demais intérpretes, sobretudo de Carlos Silveiras.

O Jardim das Cerejeiras mostra a inevitabilidade da queda da aristocracia rural, quando incapaz de lutar pela conservação de seu mundo. Trofímov denuncia o erro que perdeu os protagonistas, vivendo a custa de pessoas que eles nem deixam transpor o limiar de sua sala. Mas Checov não faz proselitismo de nenhuma espécie - limita-se a descrever uma situação, cujo desfecho são os golpes de machado abatendo as cerejeiras, enquanto os antigos proprietários tentam sobreviver na nova realidade.

O que faz de O Jardim das Cerejeiras uma obra-prima é a extraordinária capacidade de sintetizar a modificação de uma sociedade, isolando-se como peça paradigmática. Dela descende expressiva corrente da dramaturgia contemporânea, a qual pertencem, inclusive, alguns dos mais reveladores textos de um Jorge Andrade.

\section{Cidade de Santos, 13 de junho de 1982}

\section{Tchecov - A burguesia falida, medrosa e hipócrita.}

O jardim das cerejeiras estréia na quinta em Santos, no teatro municipal. A obra - prima de Anton Tchecov fala das inevitáveis mudanças sociais e da teimosa burguesa em não aceitar as alterações em seu universo.

O jardim das cerejeiras, de Anton Tchecov, que estreia na quinta - feira em Santos, no teatro municipal Brás Cubas, e considerado a obra - prima do dramaturgo, alem de uma das melhores pecas da literatura universal de todos os tempos. O texto e perfeito, ao captar a tendência da burguesia de não tocar, ao nível dos costumes familiares, em temas desagradáveis; de dissimular a hipocrisia, a ruptura dos laços afetivos e de parentesco, mesmo quando o universo em que vive esta desmoronando. 
Esta e a segunda montagem da peca, (a primeira foi no Rio em 1968) com uma tradução brilhante de Millor Fernandes e no elenco, Cleide Yáconis, Carlos Koppa, Walderes de Barros, Francarlos Reis, Abrahao Farc, Ileana Kwasisnki, Eugênia Di Domenico, George Otto, Sergio Ropperto, Raul Toledo, Noemi Gerbelli, Osmar di Pieri, Rubens Rollo e Ronaldo Lamar, dirigido por Jorge Takla.

Escrita em 1903 e encenada no ano seguinte, o mesmo da morte de Tchecov, no Teatro de Arte de Moscou, " O jardim da cerejeiras" foi em sua primeira montagem um sucesso de publico e critica, mas só recebeu nova encenação 24 anos depois , na Broadway, para a consagração mundial. O inicio da carreira do dramaturgo - quando ainda era um estudante de medicina - foi em 1889, no teatro Alexandre, em São Petersburgo, com "Ivanov" , um fracasso.

Fracasso também seria sua peca seguinte, encenada no mesmo teatro em 1896, " A gaivota". E parecia uma carreira marcada pelo desastre ate que Vladimir Danchenko e Constantin Stanislavski, dois outros artistas inovadores, foram resgata - lo do ostracismo.Eles perceberam naquelas estórias uma nova maneira de fazer teatro e, a partir da associação do dramaturgo com o revolucionário método de interpretação do teatro de arte de moscou, foram consagradas, não só a mesma " A Gaivota" , como também parte da futura produção do escritor, como "As três rimas" e " O jardim das cerejeiras".

O teatro de Tchecov mostra geralmente o vazio existencial, a alienação e a mesquinharia infeliz da pequena burguesia, incapaz de inverter as mudanças sociais. São pecas caracterizadas pela economia de ações, habitadas por personagens que falam interminavelmente, com notável falta de sentido. As falas não disfarçam a pobreza de espírito e a exiguidade de caráter de gente sem horizonte.

A etiqueta descabida, o formalismo social, comentários da ocasião, prevalecem sobre os fatos concretos que todos parem empenhados em ignorar. E assim que um " O Jardim das Cerejeiras" , uma família perde a propriedade rural fingindo ignorar a venda inevitável que vai causar grandes alterações no cotidiano feito de omissões e mentiras,

A ação começa com o retorno de Liubov Andreievna Ranievskala a sua casa na Rússia, depois de cinco anos de ausência, passados em Paris. A propriedade e, exatamente, O jardim das cerejeiras, cujo titulo original,pela sua entonação, tem exatamente a conotação de algo inútil, que " esconde na sua brancura florida a grande poesia da vida aristocrática que se acaba. Cresce apenas para a beleza, para os olhos dos estetas privilegiados", como descreveu o próprio Tchecov a Stanislavski.

E esse jardim que não e produtivo tem que ser vendido para evitar a completa ruína da família, uma verdade que os proprietários burgueses teimam em enxergar. Com toques de humor, lampejos cômicos e critica ferina, Tchecov bombardeia uma ordem socioeconômica em extinção. A obra e uma síntese extraordinária da codificação de uma sociedade, até o seu desfecho, os golpes de machado abatendo as cerejeiras enquanto os antigos proprietários tentam sobreviver na nova realidade.

\section{Folha de São Paulo, 30 de junho de 1982.}

\section{Tchecov visitado pelo humor de Groucho Marx Jefferson del Rios}

Cinco pequenos e preciosos textos de Anton Tchekov compõem o espetáculo "Trágico a força". A simples escolha do autor já é um convite tentador: não há nada na obra desse sagaz observador da frustração humana que não tenha peso e brilho.

Tchekov é sempre lembrado pela capacidade de insinuar ao invés de dizer e de situar os fatos e personagens numa zona ambígua onde o trágico e risível se tocam. As figuras Tchecovianas vivem sonhando com o que não puderam ser; ou se iludem, arquitetando existências e situações que a realidade não confirma. Tudo sutil, pianíssimo, com o toque humano outonal da velha ordem czarista que desabaria em breva na Rússia.

O elenco de "Trágico a força" estudou longamente a literatura dramática de Tchekov na tentativa de prender os mecanismos delicados da balança cômico-patética do dramaturgo: ele fala da família, das pequenas situações domésticas, mas, no fundo, está criando o papel de uma época. Como bem notou o diretor, Tchekov é mordaz e revela de maneira simples as relações mais complexas.

Ocorre, porém, o inesperado na montagem atual: o espetáculo baseia-se na comédia de pastelão do cinema mudo, um tipo de humor direto em que o esforço físico substitui a irônica e impõe a graça. Tudo bem, mas onde a profundidade pretendida, a poesia do escritor? O espetáculo como o famoso trocadilho, é marxista da "linha Groucho".

Mas com paixão e beleza tudo se resolve ou se conserta. 'Trágico a força"tem um elenco encantador Elias Andreatto reencontra a chave d o seu estilo: o ator naturalmente simpático de quem o público gosta 
com facilidade. Edith Siqueira caminhando para ser uma estrela, tem o que falta atualmente nos jovens intérpretes: autoridade. Tato Fischer - além de bom músico - se dá ao luxo de interpretar "Os malefiçios do Cigarro". Tem tipo convincente e lance no olhar, embora apoiado em perigoso truques de composição que criam cacoetes. Rodrigo Matheus e Maurício Maia transitam folgadamente em cenas mas sem maiores oportunidades. Falta-lhes maior densidade.

Tchekov foi um crítico compassivo de um mundo destinado a perecer. Era um poeta maravilhoso. Sempre é preciso vê-lo. Márcio. Elias, Maurício, Rodrigo e Edith foram redescobri-lo. Ótimo.

Folha de São Paulo, 08 de março de 1989.

\section{Direção de Celso Frateschi acerta no tempo cênico de "Tio Vânia" Marco Veloso}

Reestréia hoje no Espaço Cultural Mambembe a peça "Tio Vânia", de Anton Tchekhov ( 18601904), com direção de Celso Frateschi, 37. A montagem que tem no elenco um grupo de alunos da Escola de Arte dramática foi a última a entrar em cartaz, entre os espetáculos que, além de servirem como exame público, também intencionam homenagear os 40 anos de existência do instituto de ensino.

"Tio Vânia", de Anton Tchekhov, é um dos mais conhecidos da dramaturgia moderna. A força com que so personagens estão em cena, além de fulminante linguagem dramática expressa na precisa sequência de cenas, tornam essa peça um dos alvos principais de qualquer ator.

A atual montagem, dirigida Celso Frateschi, possui pelo menos uma qualidade relevante: a organização do tempo de espetáculo. Celso conseguiu o mais difícil numa peça como "Tio Vânia", ajustar a sequência das situações cênicas de modo com que os quatros atos do texto encontrassem uma expressão rítmica correta. O primeiro ato foi bem realizado no sentido de apresentar os personagens que irão dar sequência a trama. Já o segundo ato desenvolve os temas do tédio e da inação, centrais na dramaturgia de Tchekhov, de modo tal que o intervalo que foi posto entre este e o terceiro ato vem bem a calhar. Os dois atos seguintes conseguem reverter o clima frio e estático, anteriormente construído, e atingem o núcleo da peça: a explosividade aparente não revela uma tensão não resolvida entre os personagens, mas, muito mais, o quanto é ilusória a ação dos possíveis sobre a necessária realidade, no caso, a da passividade russa.

Quanto a participação dos atores vale destacar o trabalho de Pedro Veneziani, 37, no papel de Vânia, e o de Elisabeth Dorgam, 31, a interpretação de Sônia, sobrinha de Vânia. De uma maneira geral, o elenco, incluindo aquele dois atores, que têm uma boa performance, mesmo que num ou noutro momento exagerem os caracteres de seus personagens e causem uma certa quebra do ritmo, bem orquestrado do espetáculo.

\section{Folha de São Paulo, 18 de janeiro de 1994}

\section{"A Gaivota" prova atualidade de Tchecov Nelson de Sá \\ Montagem de Francisco Medeiros evidencia a distancia entre os autores nacionais e as questões da contemporaneidade.}

Três, quatro anos atrás, quando escrevi sobre os clássicos, era para ser por um tempo. Shakespeare, os seiscentistas, os gregos, eles vinham para mostrar que a palavra tinha lugar no teatro, num momento que o teatro brasileiro parecia não mais acreditar na palavra, como de resto, o teatro do mundo.

Também o teatro do mundo passava por seu renascimento, no qual os clássicos ocupavam o centro do palco. Mas o passo seguinte, como está sendo com autores novos como Tony Kushner ou velhos como Artur Miller, seria a valorização da dramaturgia contemporânea. Não é o caso, por enquanto, do Brasil.

Por aqui, quanto mais clássicos se montam, mais eles se provam quase perfeitos autores contemporâneos - como no titulo do livro de Jan Kott sobre o " nosso contemporâneos " Shakespeare, o qual, aliás, não sai mais de cartaz, tendo sido montado mais de um terço de sua obra, desde o inicio da década. 
“A Gaivota", um clássico moderno, é a evidência mais recente. Na montagem de Francisco Medeiros, a peça espelha, como pouca vezes se viu o teatro brasileiro recente, a ambição por uma arte maior, na dramaturgia. A peça parece ter sido dirigida e até mesmo escrita para falar de autores nacionais.

Autores que seguem intimidados em dar grandes proporções humanas aos seus personagens, aos seus heróis, por mínimos realistas que sejam. Pois é o que fazem Tchecov e Shakespeare e Tony Kushner - ou Howard Korder, para citar um jovem americano, também com visões, ideais, sonhos maiores no teatro.

\section{Jogo de referências}

Tchecov tinha sonhos maiores quando escreveu "A Gaivota”. A peça faz um óbvio jogo de referências com “ Hamlet”, que é até citada mais de uma vez. Treplev é Hamlet, Arcádina é Gertrudes, Nina é Ofélia, Trigórin é Cláudio. Reescrevendo a história de Elsinore, Tchecov espelhava a sua Rússia.

Mas, espelhava a si mesmo e à arte russa num momento maior, como havia sido também aquele dos elizabetanos. "A Gaivota" fala, entre muito mais, da própria arte. Da futilidade do confronto entre velho e novo, das mentiras das formas, da busca da espontaneidade ou da pureza e do desespero em vê-la perdida.

Como em 'Hamlet', não há lugar para o simplismo, para maniqueísmo. Não é possível descrever as emoções que ela proporciona, quando bem encenada. É Francisco Medeiros, com a clássica e complexa "A Gaivota", conseguiu muito mais do que uma encenação correta- que é sempre o temor em casos assim.

O diretor tornou Tchecov um "nosso contemporâneo". Quando Treplev monta a sua peçadentro-da-peça, é do teatro de "imagens" ou de "impressões", o mesmo de hoje, de que se fala. Quando Arcádina é citada como "rotina", como "convenção", o tema é a rotina e a convenção do teatro brasileiro.

\section{O novo e o velho}

Quando ambos são denunciados, o novo e o velho, é para o teatro de hoje que se esta clamando. Francisco Medeiros realça, não apenas esses, mas outros pontos semelhantes, com pequenos ajustes de voz, de cenografia. Sem exageros, com a sintonia fina na interpretação do texto, faz com que a peça viva.

Para isso, o grande coloborador é J.C. Serroni. O subsolo do Centro Cultural São Paulo, tão mal adaptado para “ Áulis”, desta vez estava envolvente, acolhedor até. Com o concreto recortado da obra recortado da obra completando-se em harmonia com aquele do piso da própria cena. Há unidade, afinal, para um teatro.

E a crueza do concreto, nos blocos do palco, repete aquela do palco erguido ás pressas, trste, esquecido, de Treplev, na peça-dentro-da-peça. Um palco que merecia porem, ser maisn bem iluminado. Do jeito que esta, seus ângulos, níveis, fendas -a sua complexidade não recebe o realce que deveria.

$\mathrm{Na}$ interpretação, mantida em patamar regular pelo elenco, há um destaque para cima e outro para baixo. Walderez de Barros, no papel de Arcádina, esta próxima da exatidão, saltando do sarcasmo das cenas iniciais ao carinho e, nessa mesma cena que faz com o filho, à extrema agressividade, à ira.

Em apenas um momento seria possível lapidar o trabalho da atriz no papel de Arcádina - uma primeira atriz, também ela. É naquele em que seduz Trigórin. Quando se joga aos pés dele, e antes, quando se sente insultada na sua beleza, a personagem pede muito mais, em cólera patética e humilhação.

O destaque para baixo é Mayara Magri, que chega a dar impressão de só haver sido escalada porque a personagem diz ter consciência de "estar representando verdadeiramente o mal". Fora a brincadeira, a atriz não consegue, em momento algum, refletir a pureza, a imagem de uma gaivota morta em seu vôo.

Sem a imagem de Nina e sua paixão juvenil pelos artistas, a ponto de confundir a gloria com a fama, um dos temas tocados pela peça. "A Gaivota" perde muito, mas muito mesmo. Nina, por Mayara Magri, não parece um anjo caído, mas uma menina que já começou na futilidade e daí terminou como bem merecia.

Marco Ricca, que faz Treplev, que ama Nina, acaba perdendo assim uma face de seu personagem. E também cai, aqui e ali, em excessos do que parece acreditar ser a correta empostação clássica. Bobagem, mas também ele esta reconhecendo terreno. Esta aprendendo a falar. E, como Treplev, tem muito a dizer. 


\section{O Estado de São Paulo, 02 de abril de 1994.}

\section{Anton Tchecov ressurge com força nos palcos paulistanos Jotabê Medeiros}

Morto há 90 anos, Anton Tchecov ressuscita nos palcos de São Paulo. Duas montagens de A Gaivota - sua segunda peça escrita em 1896 e já encenada na Cidade - estão em gestação. A primeira dirigida por Francisco Medeiros e produzida por Marco Ricca, estréia dia 16 de Maio, como maior atração nacional do terceiro festival internacional de Artes Cênicas. A segunda de Willian Parreira, só no segundo semestre.

Fracasso instantâneo na estréia no Teatro Alexandrinski em São Petersburgo. A gaivota vem sendo assimilada aos poucos como um novo passo dentro da linguagem teatral, com sua abordagem metalinguística. Quando estreou em Londres em 1921, a crítica britânica foi unânime em afirmar que a peça abria uma nova era na arte dramática. Ainda assim, a peça não atraiu encenadores paulistanos durante todo o século. O Jardim das Cerejeiras (1903), a última peça de Tchecov, foi a campeã das montagens, até pelo seu caráter de extrema unção - Tchecov morreria no ano seguinte.

E foi menos pela importância histórica de A gaivota e mais pela "capacidade de se manter como uma visão atual da natureza humana" que o ator Marco Ricca resolveu se aventurar com o texto. Há dois anos ele alimentava o sonho de a peça "mas tinha que ser no porão", ele conta. "O Porão" é um espaço de 3.000 metros quadrados no subsolo do centro Cultural São Paulo para o qual o cenógrafo J.C Serroni projetou uma de suas mais ambiciosas intervenções visuais - todo espaço é parte integrante da peça, onde cabem até instalações.

A Gaivota de Marco Ricca é uma montagem que parte da tradução feita por Tatiana Belinky para o texto de Tchecov. Tem Mayara Magri, Cacá Soares e Walderez de Barros - 30 anos de carreira mais 30 anos peças no currículo - no elenco Walderez já é algo “ íntima” de Tchecov. Ela fez "Lago 21”, de Jorge Takla, que misturava diálogos de Hamlet com algund de A Gaivota, e foi protagonista de O Jardim das Cerejeiras, também dirigida por Takla " $\mathrm{O}$ interessante de Tchecov é que ele não tem elucubrações. Você está no cotidiano das pessoas, tem a impressão de que não está acontecendo nada e, na verdade, tudo está acontecendo", diz Walderez.

Willian Pereira não sabia que Ricca tensionava produzir uma montagem da peça quando ligou para integrar "sua" A Gaivota "Ah, você também está montando?", assustou-se, " Foi uma concidência engraçada, por que somos da mesma turma" diz Ricca, que gastou até agora 90.000 dólares com a produção. Ele não sabe até quando ainda vai durar a produção, mas estima em mais de duas horas. Também não sabe a duração da temporada, além das três apresentações no festival de ruth Escobar. "É uma produção cara, e também não sabemos se vamos encontrar outro local tão adequado quando o Porão do Centro Cultural para a montagem", diz.

$\mathrm{Na}$ verdade, a escolha do porão parece paradoxal, já que A Gaivota se passa no campo, no palco ao ar livre "O lugar não importa muito" diz Ricca "Assim com Tchecov colocou a ação no campo, para enfatizar a disponibilidade das personagens em férias, nós fomos ao subterrâneo, para frisar a discussão existencial que ele propõe"

\section{Dramaturgo odiava subjetividade}

Anton Pavlovich Tchecov, dramaturgo e contista russo, nasceu em 17 de janeiro de 1860, em Tangarog, no Mar de Azov. Morreu em 1904, em Badenweiller, na Floresta Negra. Segundo suas próprias palavras, ele pretendia " retratar a vida em seus verdadeiros aspectos e mostrar o quanto esta vida está aquém da vida ideal"

Filho de um comerciante servo de origem humilde e um tanto quanto autoritário. Tchecov teve que se virar para pagar seus estudos na universidade de Moscou, onde cursou medicina. Sua primeira peça, Ivanov, foi escrita em 1887. A um de seus livros, ilha de Sakalina ( 1891) se atribuiu a amenização do regime penal que revigorava na época. Tuberculoso, casou-se em 1901 com a atriz Olga Knipper. Amigo de toda a intelectualidade de sua época, renunciou ao posto de membro honorário da acadêmia de ciência Russa quando a eleição de Máximo Górki foi anulada pelo Czar.

Dele, Górki escreveu: " Tchecov tinha a arte de descobrir e pôr em relevo a mediocridade". Tchecov foi bastante sucinto em definir seu leitmotiv artístico: "Subjetividade é uma coisa terrível. É má em si mesma, porque denúncia a mão e o pé do autor." 
O Globo, 06 de dezembro de 1995.

\section{Uma leitura fiel de Tchecov Barbara Heliodora}

Tchecov é um autor de dificuldade à altura de seu magistral talento, e a falta de dinheiro é sempre apontada como fonte principal dos erros e fracassos do teatro nacional. No entanto, no Teatro Cacilda Becker, um grupo está apresentando a montagem de "A Gaivota" que, certamente sem ser uma obra-prima, consegue superar boa parte de seus problemas e fazer uma leitura em seu todo muito fiel ao clima do universo tchecoviano e à instabilidade emocional russa que ele com tanto amor retrata.

A falta de dinheiro está bastante presente nas soluções cênicas: abrindo mão de qualquer realismo visual, Claudio Torres Gonzaga cria uma espécie de boca de cena em torno de uma perspectiva forçada - com o auxílio da luz de Wilson Reis - sugere o importante lago em cujas margens vivem todos os personagens. Os figurinos ( de Cristina Augusto e Cláudio) sofrem, mas estão, timidamente, no caminho certo. Obviamente o responsável pelo que há de positivo no espetáculo é a direção de David Herman, principalmente porque é raro vermos um elenco pouco experiente como este e dar nítida impressão de que, em todos os momentos, todos sambem a razão de ser de suas falas, bem como o que cada reação significa na criação de seu personagem. $O$ diretor não tem medo de mostrar incoerências emocionais ou até mesmo ridículos no comportamento na convivência de um grupo que se conhece muito bem e reage alternadamente com amor ou irritação aos excessos e caprichos uns dos outros.

A força da direção fica mais aparente, infelizmente, em função das consideráveis limitações do elenco. Tchecov exige atuações de altíssimo nível, a fim de que todas as suas nuances e sutilezas possam transparecerer cada atuação. Isso não chega a acontecer nesta modesta mas simpática montagem, mas pelo menos tudo que é tentado corresponde à estrutura essencial da obra.

Todo o elenco tem rendimento modesto, mas como todos compreenderam pelo menos seus personagens, o espetáculo consegue caminhar e, em alguns momentos, chega mesmo a comover. É um trabalho limpo, despretensioso, que tem o notável mérito de ter, como objetivo, a apresentação do texto proposto. E dentro de limites, realmente o apresenta.

\section{O Globo, 15 de janeiro de 1996.}

\section{Abalos sísmicos do cotidianos Barbara Heliodora}

Em “ A Gaivota” de Tchecov, em cartaz no Teatro Nelson Rodrigues, Masha ama Nina, que ama Trigorin, que... e o autor/médico diagnostica implacavelmente todos os desencontros que são causados pela catalisadora Arkádina, que ama acima de tudo a si mesma. Tendo o russo a reputação de emotivos, apaixonados e instáveis, Tchecov abriu para o mundo o universo riquíssimo das tragédias do pequeno desastre cotidiano, da frustração corriqueira, simplesmente por reconhecer que para que o sofre, qualquer acidente emocional adquire dimensões sísmicas. A percuciência de sua visão só é igualada pela delicadeza e a compaixão com que expressa.

A presença da atriz Arkádina e as atenções que da ao seu amante Trigorin põem a mostra indigência e o desamor que cerca a vida de seu filho, que sonha também com o teatro diferente dos dramalhões que dão fama à mãe. E o amor e a falta de amor perpassam todo o universo em que a mesmice de vida precipita as explosões passionais. Jorge Takla procurou criar essa ambivalência e criou cenários quase realistas não inteiramente satisfatórios mas beneficiados por uma boa luz. Os figurinos de Kalma Murtinho são excepcionais.

A direção de Takla procura por um lado a intimidade entre aquele grupo de pessoas ( o elemento estranho, Trigorin, é intensamente perturbador) e, por outro, a decantada instabilidade emocional russa; o caminhos está certo, mas há exageros. Nem todo o elenco corresponde com o mesmo rendimento às intenções do diretor. Walderez de Barros tem grande desenvoltura e vários acertos, mas por vezes exagera ( mesmo mostrando bem que não sabe lidar com Kostia). Elis Andreato faz um Trigorin discreto ( e menos charmoso que deveria). Charles Moeller hesita no complexo Kostia mas não está de todo mal, Samantha Monteiro é melhor como Nina e enfrenta bem a cena final. Andrea Cavalcanti e Nildo Parente defendem-se bem, Roberto de Cleto está fraco, como Diogo Dahi, com Camillo Bevilaqua num exagero inadmissível. No conjunto o espetáculo tem aspectos bem positivos e mostra um Tchecov pleno de vida. 


\section{$<$ Sem Fonte $>28$ de março de 1996}

\section{Agonia terminal à beira do lago Armindo Blanco}

1. Numa Rússia que estava chegando ao fundo do poço. Anton Tchecov criou um teatro novo, fonte do que veio depois Não só ele , claro: também Ibsen e Strindberg. Mas ninguém com Tchecov atingiu o que Gorki chamou de " o ápice da simplicidade”. Suas obras-primas - A Gaivota, O jardim das Cerejeiras, Tio Vânia e As Três Irmãs- figuram uma humanidade em fase crepuscular, expressão poética de um mundo imobilizado pelo medo da mudança.

Em A Gaivota, ele reúne, numa casa de campo à beira do um lago, personagens de sólida estrutura dramática que representam essa agonia terminal: a atriz Arkádina, diva 24 horas por dia; o escritor Triforin, cabotino mais ciente de que nunca será um Turgueniev; o medíocre professor Medvenko e sua mulher Mascha, apaixonada sem esperança por Treplev, filho da atriz e dramaturgo vanguardista, por sua vez apaixonado pela sonhadora Nina.

Drummond diria que Nina amava Triforin, que amava Arkádina, que Medvenko amava Mascha, que amava Treplev, que amava Nina. Polina, mulher de Schamraev, ex-militar que se tornara prepotente administrador da fazenda do velho Sorin, irmão de Arkádina, também se casara com o homem errado, com sua filha Mascha: amava o medico Dorn, cavalheiro mulherengo que, já enfastiado dos seus encantos, não pensava em continuar a consolá-la e menos ainda fugir com ela.

2. Mas o epicentro do enredo é Nina, a quem trazem uma gaivota morta e que inspira a Trigorin o tema de um conto trágico: "Nas margens de um lago vive uma jovem. (...) Esta jovem ama o lago e é feliz e livre como uma gaivota. Mas um dia de modo casual, chega um homem que a vê e , para fazer alguma coisa, mata-a, como fizeram com a gaivota".

3. Nesta montagem dirigida por Jorge Takia, a grande presença em cena é Walderez de Barros, atriz de poderosa presença, e dotada de extraordinário aparelho vocal. Ela é uma Arkádina mais estelar do a própria personagem, a ponto de se sobrepor-se aos demais atores, em detrimento de uma unidade interpretativa que a " atmosfera" tchecoviana exige. Carlos Moelle e Samantha Monteiro não tem estofo ( e experiência) para traduzir os "estados da alma" de Treplev e Nina. Mas se empenham com notável bravura. Elias Andreato desenha um Triforim ambíguo, que escapa à compreensão do público. Clovis Bevilacqua é um Schamraev à beira do caricato. A caráter estão Nildo Parente, sóbrio e elegante com Dorn, Ada Chaseliov como Polina e Andréa Cavalcanti na dilacerada Mascha. Roberto de Cl4eto, como Sorin, limita-se a passear na cadeira de rodas.

4.

A cenografia ( Jorge Takia) é pobre, desinspirada , exceto quando inundada de girassóis; e os figurinos ( Kalma Murtinho) assemelham-se ao elenco com seus altibaixos (Walderez esta bem servida, mas a maioria veste roupas de brechó mal-ajustadas ao corpo).

Acredito que no Teatro de Arte de Moscou, com a supervisão do próprio Tchecov. A Gaivota voou mais alto no céu da compaixão. Mas Jorge Takla não chega a feri-la de morte. Vale a pena ver, apesar das ressalvas e de um certo sabor requentado a teatrão.

Bravo, número 07, Ano 1, abril de 1998, p. 106-109. Esta versão contém pequenas correções.)

\section{Tchekhov conta Brasil.}

Por que o dramaturgo russo do século XIX será um dos autores mais encenados neste ano no país. Sérgio de Carvalho 
Anton Tchekhov, contista e dramaturgo russo morto em 1904, será um dos autores mais encenados neste ano no Brasil. São muitos os motivos que explicam o fenômeno. De um modo geral, Tchekhov fazia no teatro o mesmo que em sua literatura. Era um maravilhoso retratista não dos conflitos interpessoais e dos desenlaces necessários, mas da crise da ação na vida, principalmente quando vivida em situação de intervalo como naquela Rússia mal saída do arcaísmo feudal e já acossada pelos cambiantes desejos da sociedade moderna.

A afinidade do Brasil com a Rússia de Tchekhov é mais evidente se comparada à escassez nos palcos nacionais de outros grandes autores do final do século 19, como o norueguês Henrik Ibsen e o sueco August Strindberg. Um ator brasileiro disse que o Ibsen é um escritor maior, mas o mecanismo teatral é tão admirável que parece inatingível. Tchekhov, ao contrário, pareceria estar sempre muto próximo de nós. A comparação é discutível, mas a sensação, justa. Alguma coisa no realismo tchekhoviano não envelheceu, até mesmo, quem sabe, porque sua técnica teatral era, de fato, menos aparente do que a de seus contemporâneos e, também, porque a "desdramatização" viria a se tornar um padrão frequente na representação das relações das classes médias a partir da entrada do século 20.

A dificuldade cênica de suas peças reside também nesse ponto. Tchekhov é um autor complexo. Em suas personagens o falhamento psíquico corresponde a causalidade social. Historicamente, a força teatral de suas personagens desdramatizadas só foi reconhecida graças a um gênio do palco como Stanislavksi, que conseguiu estabelecer meios técnicos para que os atores abandonassem os padrões grandiloquentes da interpretação romântica, vigente até então, e se aproximassem dos meios-tons das personagens que interpretavam. Sua meta era apresentar indivíduos com particularidades nítidas e intransferíveis. Na montagem de "A Gaivota", primeira grande realização do Teatro de Arte de Moscou, Stanislavski criou para a cena de abertura, em que Macha caminha pela vereda enquanto explica o motivo de sua roupa preta ("Estou de luto pela minha vida"), uma série de pequenas ações, como quebrar castanhas ou se desviar de troncos caídos pelo caminho. Esse particularismo teatral, inédito para os padrões da teatralidade da época, vinha como tentativa de tradução gestual do comportamento interno das personagens.

Essa atenção ao característico não desagradava Tchekhov, ainda que estivesse mais interessado em outra modalidade de caracterização. O melhor de sua literatura está nos detalhes aparentemente insignificantes, como um relógio que, de repente, cai do bolso e se quebra. Afirmava que suas personagens não lhe surgiam da cabeça "vindas da espuma do mar, nem do intelectualismo, nem do acaso; elas são o resultado da observação e do estudo da vida".

O problema com sua peças hoje está na medida (e na finalidade) do seu realismo. À parte toda a dificuldade com esse estilo desgastado não só pelo naturalismo primário da televisão brasileira, como pelo desdém tecnicista da turma da "pesquisa de linguagem", as personagens de Tchekhov pedem um realismo intensificado pelo enfoque moral e político. Não é qualquer particularidade individualizadora que resultará justa no palco, conforme à matéria dramatúrgica daquela Rússia em suspensão. Seus delicados e muitas vezes patéticos retratos não se realizam na procura de uma atmosfera acabada de tédio, ou através da apresentação empática do impasse diante das dificuldades. As personagens estão em cena para mostrar (como exemplos negativos) que é possível viver de maneira diferente da que se tem vivido até hoje, naquelas condições.

Ao comentar a experiência de escrever "Ivanov", Tchekhov confessou seu sonho de avançar na tradição literária russa e "resumir tudo o que até agora se escreveu a respeito de gente que vive em lamentação e em melancolia". Já na primeira de suas peças, não se escapa do sentimento de uma passagem irrevogável e inútil do tempo. Mas a perspectiva crítica se anuncia. As personagens aguardam seu destino em uma situação de lapso, conscientes de uma vida que ruma para a mediocridade, mas nada fazem para evitar esse estrago sutil e cotidiano. Tchekhov substitui, assim, o movimento dramático dos amplos acontecimentos por uma polifonia de pequenas dramaticidades melancolicamente inoperantes. $\mathrm{O}$ patetismo cresce porque suas personagens têm o despudor de falar diretamente sobre o que sentem, de expressar em escancaro suas perspectivas internas, com lucidez inesperada diante de condição mesquinha e preguiçosa. O que em qualquer outro autor seria incompetência (considera-se rasa a personagem de drama que expõe abertamente seus desejos íntimos), em Tchekhov se torna recurso teatral na medida em que a confissão não encontra interlocutor. A precariedade do drama se torna, assim, temática, parte do próprio assunto da peça. É emblemático que Andrei, em "As três irmãs”, desabafe com um empregado surdo que vem a seu quarto lhe trazer livros. O crítico Peter Szondi afirmou que essa solidão individual, 
absorvida na solidão coletiva, não é apenas efeito de teatro. Os russos, segundo ele, dizem francamente coisas que outro europeu diria só embriagado. Por isso, embora se expressem em diálogos, os temas das personagens tchekhovianas são os da confissão lírica: o amor, a queixa existencial, o insucesso. Falam em monólogos que parodiam diálogos.

A complexidade desse tipo de realismo (e também a maior de suas sutilezas) é que o retrato da melancolia está ali como passagem crítica, que envolve a própria tradição de representação dramática. $\mathrm{O}$ que se descreve em cena não é só a particularidade individual, mas a exemplaridade social de tipos concretos. A organização da peça contém não só uma descrição, mas uma clara opinião sobre o assunto. É nesse sentido que esse dramas críticos daquela Rússia pré-revolucionária podem e devem mesmo ser lidos como seu autor gostaria que fossem, como "alegres comédias", indicação que nunca foi levada a sério desde que se difundiu a imagem do "clima tchekhoviano" - um estado difuso de amplas tristezas, ruídos de grilos e lusco-fusco -, celebrizado antes por obra de Stanislavski do que dele.

Bom seria, neste ano de tantas montagens brasileiras, que o amor às personagens de Tchekhov viesse também acompanhado de compreensão da nossa experiência da vida atual. No limite da forma dramática, entre a angústia e o ridículo, a obra do médico Tchekhov costuma ser mais viva para os que não se identificam com as confusões de alma que ela retrata. Aqueles que vão a ela em busca apenas da vivência do "abismo existencial das grandes personagens" (ou à procura de uma mercadoria artística elevada) costumam deixá-la com cheiro de mobília antiga, assim como os cultores de sua suposta "imprecisão formal" costumam deixá-la abstrata e cinzenta.

O grande aprendizado teatral com Tchekhov é o da objetividade crítica. Da mesma forma que o sentimentalismo nunca é apresentado de um ponto de vista sentimental, o detalhe concretizador comporta um sentido no mínimo moral. Não a moralidade tola como aquela do sujeito que condenava um conto de ficção porque a descrição dos ladrões de cavalos não vinha acompanhada da advertência: "roubar cavalos é mau". A isso Tchekhov respondeu: "Já era sabido antes de mim." Mas uma outra moralidade, a de uma posição humana ativa, que opõe o trabalho à apatia, a felicidade ao engano, em que algumas ações valem mais do que outras. Como se lê em suas cartas:"Se o público sair do teatro com a ideia de que os Ivanovs são canalhas, e os drs. Lvovs são grandes homens, serei obrigado a pedir demissão e jogar a minha pena para o diabo".

\section{Jornal do Brasil, 12 de setembro de 1998.}

\section{Desencontros inpirados em Tchecov Macksen Luiz}

Tchecov considerava as suas peças como comédias. Na verdade, o conceito de humor do autor russo é bem mais elástico do que revelam os seus grandes textos, nos quais a vida é um fardo que se carrega repleto de desejos, mas vazios de possibilidades de realizá-los. A comédia estaria entre esses dois pontos, na imponderabilidade de uma insatisfação difusa, no desesperado tédio de vidas sempre adiadas, na condenação por continuar a levar o que se tem pra viver ou na escolha da morte. Nada mais longe de qualquer forma de humor, mas que Tchecov com a fina ironia de um niilista joga como mais um elemento de contradições da vida.

O realismo da dramaturgia de Tchecov que está sempre rodando o melodramático e que se avizinha do patético,traz, no entanto, a pulsação interna dos sentimentos delicados de almas aflitas, a contenção de um desespero que mina o cotidiano da pequena humanidade de sobreviventes de si mesmos. Em Tio Vânia, a presença de Serebriakov e sua jovem mulher Helena na fazenda que Vânia e sua sobrinha Sônia mantêm com dedicação de um tributo, desagrega e expõe os sentimentos de cada um com a violência de desejos silenciosos.

Os personagens usurpam, uns dos outros, aquilo que não conseguem confessar nem a si mesmos. O silêncio repleto de ruídos traz a vinda de Serebriakov, as frustrações pelo tempo perdido nos desejos tardiamente confessados ou permite revelações que desvendam o caráter íntimo das suas frustrações. Em Tio Vânia, como nos maiores textos de Tchecov, a narrativa é conduzida serenamente, com movimentos interiores que assinalam os gestos que provocam a imobilidade. Por mais que os personagens se desloquem - parece estar sempre chegando ou projetando a partida - , e por mais exuberantes que possa 
ser algumas de suas atitudes - a dramaticidade de sentimentos irrompe como um barulho discreto -, há uma serenidade determinista que emana dos personagens e que o conflito entre eles os interioriza ainda mais.

A encenação de Élcio Nogueira, que está em temporada até amanhã no teatro Carlos Gomes, explora a aparência melodramática de Tio Vânia, reiterando um texto que vive da essência dos desencontros. O espetáculo exterioriza por meio de uma representação que expande a tessitura dos personagens, a paisagem humana da peça, transformando-a em cenário de conflitos injustificados. As razões que impelem os atores desse drama de almas não estão em seus atos exteriores.

O realismo de Tchecov é apenas um recurso narrativo, já que o poderoso universo humano se cria num plano em que se movem os sentimentos. Sem a atmosfera que recria esse universo, tudo parecerá um jogo de salão que poderá, ora assumir ares de melodrama, ora vagos ares de tragicomédia. A montagem de Élcio Nogueira torna a cena explícita, sem alcançar a realidade que cerca os personagens, feitos de um material pouco sensível simplificação dramática.

A tradução de Vadím Nikitin procura ser coloquial no seu sentido banalizador. Dessa maneira, os diálogos adquirem falsa espontaneidade e naturalidade que empobrece e dificulta o estabelecimento de atmosfera que se ligue ao mundo tchecoviano. A solução de usar o proscênio confere a montagem uma perspectiva tosca, não só pelo cenário tristemente amador, mas também com a proximidade com a platéia, que torna reveladora uma cena sem qualquer clima. A concepção cenografia é outro dos pontos fracos do espetáculo, com a delimitação do palco através das cortinas que se abrem até o desvendamento da estrutura cênica. $\mathrm{O}$ efeito é apenas um truque sem relação com a própria cena. Os figurinos de Marcos Pedroso e a iluminação de Cibele Forjaz muito pouco para dar o clima a representação.

Ranato Borghi imprime nervosismo e agitação ao torturado Vânia, numa intensidade que faz o ator perder as nuanças do personagem e não marcar as sutis mudanças por que passa. Mariana Lima toca em alguns momentos a dubiedade de Helena, enquanto Andréia Lopes não constrói as decepções de Sônia até o belíssimo monólogo final. Luciano Chirollo desenha em algumas cenas a consciência cínica de Astrov, Jolanda Gentilezza, como a mãe, e Wolney de Assis, como Serebriakov, têm atuções mecânicas, Abraão Farc não encontra a fraqueza de Tielhênguim e Geisa Gama perde-se um pouco como a empregada testemunha e não transmite sua perplexidade simplória diante do que assiste.

\section{O Globo, 19 de setembro de 1998.}

\section{A arte do cotidiano}

\section{Bia Lessa parte de hábitos com escovar os dentes para ensair "As três irmãs, de Tchekov Roberta Oliveira}

Os banheiros, os quartos, o jardim, as salas e uma cozinha de uma mansão de Santa Teresa serviram de cenário para os ensaios de "As três irmãs, versão da peça de Tchecov que estréia dia 9 de outubro no teatro 1 do CCBB, influenciada pelas cenas que assistiu em suas andanças pelo interior do Brasil durante as filmagens de "Crede em mim", seu primeiro longa metragem, e mais recentemente de "Brasil" ( seu novo filme, sem data de estréia), a diretora Bia Lessa queria que o elenco despisse de qualquer preconceito com os personagens e a peça e fossem buscar em hábitos corriqueiros como escovar os dentes, tomar banho, lavar o cabelo e beber chá o caminho da encenação.

Usei este expediente, além de brincadeiras de criança e exercícios de improvisação, para tornar Tchekov um companheiro de trabalho, e não em fantasma dos grandes autores clássicos - explica Bia, que não gosta de usar as palavras "naturalismo"e "realismo"para classificar o trabalho dos atores -Na verdade, o que tentamos fazer é chegar na vida da forma mais simples possível. Não fui em busca de uma interpretação naturalista ou realista, e sim de depoimentos pessoais.

\section{Diretora pede para que atores falem de forma coloquial}

Se em "Crede em mim"a diretora se valeu da inexperiência de um grupo de moradores da região do Cariri, no Ceará, para filmar uma adaptação de "O eleito", de Thomas Mann, e em "Brasil"ela conta a história de uma brasileira a partir de fases marcante na vida de várias mulheres, em "As três irmãs"Bia tentou fazer com que os atores deixassem de lado o glamour e os estereótipos da profissão e passassem a atuar como os moradores do Cariri.

Não gosto quando o personagem está a frente do ator - diz Bia- Estamos num tempo em que todos os modelos de representação da vida já não corresponde mais a realidade e em que devemos prestar mais atenção nas pessoas do que nos atores. Para tocar de fato na vida, temos que entender e respeitar a 
realidade de cada cena. Se um dos atore, por exemplo, tem que dizer para o outro que não gosta dele, ele tem que analisar até que ponto isso é verdade e pensar como ele agiria se tivesse na mesma situação. As falas têm que ser coloquiais.

O cinema não mudou apenas a relação de Bia com os atores. Pela primeira vez, a diretora tem feito a questão de não mexer excessivamente no texto. No entanto, para jogar com o volume das vozes dos atores, alternando diálogos sussurrados e falas ditas em alto e bom som, Bia vai literalmente legendar as cenas.

Além de me oferecer a chance de pôr dois atores em cena contando um segredo, este efeito sublinha uma característica dos personagens: o fato de eles nunca realizarem na prática os sonhos que dizem querer realizar - diz Bia, que idealizou um cenário que lembra da ópera "suor Angélica", por causa das paredes por onde sobem os atores e de pequenas portas atrás das quais aparecem objetos do dia-a-dia - É como se a vidinha deles tivessem sempre compartimentada.

Um time de futebol. É assim que Bia (que já declarou sua paixão pelo esporte na peça "Futebol”) vê o elenco que dará vida a história de Olga (Renata Sorrah), Macha (Débora Evelyn) e Irina ( Lorena da Silva), as irmãs que sonham em deixar a cidade do interior da Rússia em que vivem e voltar para Moscou. A expressão não remete apenas ao entrosamento dos ensaios, mas principalmente as características de cada um dos atores.

Escolhi o elenco pensando nas diferentes personalidades - diz Bia, que foi buscar em São Paulo o talento de Fernando Alves Pinto ( do filme, "terra estrangeira") e Dionísio Neto ( polêmico diretor da peça “Opus Profundum”), enquanto no Rio apostou em nomes como Emílio de Mello e Miguel Lunardi São pessoas com interesses em novas linguagens.

\section{Ensaios em casarão reforçam concepção de Bia}

Um clíma de festa permanente parece reinar entre vários quartos da mansão de Santa Teresa em que até hoje, por decisão de Bia Lessa ("tem o clima de casinha que quero imprimir no espetáculo"), o elenco de "As três irmãs"ensaia. Ana Beatriz Nogueira, que interpreta Natacha, a cunhada das três irmãs, brinca que, assim como os três mosqueteiros são quatro, quatro também são as personagens centras da peça de Tchekov.

- Ele é um autor tão generoso que não há como dizer que um personagem é mais ou menos importante que outro - avalia ela, que, ao lado de Déborah Evelyn, está a frente da produção de "As três irmãs"faz dois anos - Escolhemos esse texto porque nos oferecia bons personagens femininos, mesmo quando ainda pensava em fazer uma das irmãs, eu jogava um olhar ganancioso sobre Natacha. Quando Bia decidiu que este seria meu personagem, fiquei animada, porque ela é bem diferente de tudo que fiz até hoje.

\section{O Globo, 09 de outubro de 1998.}

\section{As três Irmãs na banalidade cotidiana Daniela Name}

Uma Rússia muito próxima do cotidiano dos brasileiros ganha o palco do teatro 1 do centro cultural do Banco do Brasil a partir desse fim de semana, quando começa os ensaios abertos de As três irmãs. Palas mãos da diretora Bia Lessa, a peça de Tchekov perdeu a aura de texto clássico e ganhou cenas baseadas nas atividades do dia-a-dia.

- Ensaiamos num casarão de Santa Theresa, e buscamos um Tchekov muito próximo do que conhecíamos - explica Bia- Os atores vão escovar os dentes, costurar e pentear o cabelo em cena, com o máximo de naturalidade e coloquialidade possível. Os russos são muito parecidos com os brasileiros, gostam de beber e cantar. E Tchekov apresenta no texto uma questão absolutamente contemporânea: a diferença entre o discurso e a ação. O tempo todo, os personagens dizem uma coisa, mas fazem sempre outra.

Renata Sorrah, Débora Evelyn e Lorena da Silva são Olga, Marcha e Irina, as Três irmãs que sonham em deixar a província e voltar para Moscou de sua infância. No início do século (a peça, uma das últimas de Tchekov, é de 1901), as personagens-título já sentem as transformações que desembocariam na revolução russa. A nobreza da qual fazem parte está decadente e se vê obrigada a abandonar o ócio e as rodas filosóficas para abraçar o trabalho.

Para Renata, que comemora 30 anos de carreira com a peça, o bonito na obra de Tchekov é que a imobilidade na vida das personagens - a viagem para Moscou vai sendo progressivamente adiada - é apenas aparente. 
A vida delas muda o tempo todo, nas pequenas coisas - diz ela, que interpreta Olaga, a mais velha das três irmãs, espécie de porta-voz do pensamento de Tchekov - No fim da peça, ela diz que o sofrimento das três poderia ser a alegria das futuras gerações. Podia fazer a Olga reprimida e problemática. Mas vi que ela só queria viver um grande amor e que o sofrimento acaba fazendo dela uma mulher com os pés na realidade.

\section{O Globo, 26 de outubro de 1998}

\section{Agitação além da dose resulta em montagem inexpressiva Barbara Heliodora}

Em "As três irmãs" Tchekov apresenta a insatisfeita inércia que aprisionava todos os russos de vida mais ou menos confortável: o quadro da família Prózorov é memorável, com as sensíveis e culta Olga, Macha e Irina sonhando extremamente com a volta a Moscou mas imobilizadas no província, e o irmão Andrey com sua inutilidade dominada pela grosseria da ambiciosa Natacha. Sonhando com o futuro melhor mas incapaz de tomar qualquer providência, o coronel Vershinin fala na felicidade de um futuro distante, enquanto o único a quere tomar uma atitude concreta. Tusenbach, é morto em um duelo inútil. A peça é uma forte candidata a obra-prima do autor (embora haja outras candidatas também fortes)

A encenação em cartaz no teatro 1 do CCBB peca por excessos de vários tipos: o cenário de Gringo Cardia é mais bonito do que funcional ( em relação ao texto), e serva para vário atores subirem e descerem escadas e reentrâncias sem razão de ser, com o piso coberto de um quase pó negro que não tem qualquer justificativa. O s figurinos de Kalma Murtinho são por vezes prejudicados por exigências de se fazer as irmãs usarem roupas pouco indicadas. A música é insatisfatória e a iluminação arbitrária.

Tudo reflete a direção de Bia Lessa que peca pelo excesso em tudo: há marcas demais pela inércia pedida pelo autor, há gritos demais, um número excessivo de ator cai no chão, se empurra, corre, atira coisas, no primeiro ato Soliony fica mostrando um caderno com números, durante o tempo todos há projeções de palavras (um pouco a la Brecht, o que também acontece com as falas que vêm ser ditas a platéia). Com todo esse excesso de atenção ao detalhe, fica prejudicado o todo, e o clima da obra desaparece por que não há organicidade na apresentação da ação essencial.

O elenco sofre com tudo isso, além de ser muito desigual: Renata Sorrah, Evelyn e Lorena da Silva, as irmãs são as mais satisfatórias, apesar dos constantes exageros, enquanto Ana Beatriz Nogueira falha em uma linha errada de Natacha, a cunhada.

Sofre ainda mais o elenco masculino: o papel de Vershinin virtualmente desapareceu e Miguel Lunardi não consegue se impor; Emilio de Mello, o melhor ator, está totalmente desperdiçado no papel o médico, que deveria ser um velho; Vádim Nikitin como Andrey fraquíssimo, enquanto Dany Roland não tem a patética paixão de Tusenbach, Fernando Alves Pinto não cumpre seu papel de apaixonado por Irina, deixando o duelo aparecer sem razão prévia, o ator Dionísio Neto é quem mais procura dar sentido ao seu personagem, como Kuligin, o humilhado marido de Macha. Sem nada em sua atuação que o justificasse, Thierry Tremouroux faz a velha babá. Outros integrantes só fazem uma figuração um tanto inútil. É possível que com menos agitação "As três irmãs" tivesse um resultado em um resultado menos morno e inexpressivo.

\section{O Globo, 16 de novembro de 1998.}

\section{Peça se transforma em divisor de águas nas trajetórias do três encenadores. Zé Celso lembra que sua montagem rachou o teatro oficina \\ Roberta Oliveira}

Escrita na virada do milênio, mais especificamente em 1901, “As três Irmãs”é comparado por Zé Celso como um rito de passagem. Um rito que, na opinião do diretor, tem a capacidade de unir personalidades distintas mas que, ao mesmo tempo, pode destruir parcerias construídas em anos de convivência. Foi durante a primeira temporada de "As três Irmãs, por exemplo, que o teatro Oficina enfrentou uma de suas maiores crises: depois de uma apresentação da peça, na passagem de 1972 para 1973, que metade dos integrantes do grupo decidiu deixar o Oficina. 
Recebemos esta peça como um ato sagrado e alguns de nós o fizeram com tanto fervor que ele fez em pedaços a companhia. Mesmo já tendo feito Brecht, o texto foi uma revolução na forma de pensar teatro - diz Zé Celso, que em Cacilda interpreta Ziembínsky, coincidentemente o diretor de As três Irmãs de 1960 - Era uma montagem bonita, mas chata. Glauce Rocha era deslumbrante como Olga, mas a peça era arrastada.

\section{Enrique afirma que quer apostar nos textos e nos atores}

"As três irmãs" não afetou profundamente apenas Zé Celso. Enquanto Bia Lessa diz ter podido através do texto de Tchekov, buscar um tipo de interpretação mais próximo do cotidiano. Enrique Diaz preferiu deixar de lado as experimentações desenvolvidas com a sua companhia de atores e apostar mais na sintonia entre texto e atuação.

O meu costume sempre foi pegar o objeto de estudo e buscar as fragmentações e as relações internas insuspeitas que existiam nele. Desta vez, não quero impor minha visão de diretor - conta Diaz, que nunca pensou em entrar em cena como ator - Se os ensaios não fossem tão puxados, talvez eu fizesse Solione, porque ele é bem louco.

\section{Um texto, três versões}

Zé Celso: O diretor compara Tchekov a um cogumelo, o que dá a dimensão lisérgica da peça de 1972. Embalados por mescalina, os ensaios desembocaram numa montagem que o próprio Zé Celso descreve como um ritual sagrado.

Bia Lessa: Depois das filmagens de dois longas- metragens em que a ficção se mistura a realidade, a diretora reviu seus conceitos de interpretação. A pesquisa desembocou num processo que a personalidade dos atores, nos ensaios e na montagem, parece estar mais presente que a dos personagens, criando uma representação próxima do cotidiano.

Enrique Diaz: Apostando na integração entre texto e atores, o diretor tem buscado encontrar um equilíbrio entre cada personagem e o painel coletivo da peça. Nos ensaios, ele tenta fazer com que os atores transformem suas falas em depoimentos pessoais. Na sua visão Tchekov acredita que "o ator ideal é natural, intenso, patético e belo.

\section{O Globo, 16 de novembro de 1998.}

\section{3 vezes Tchekov - “As três Irmãs”une Bia Lessa, Zé Celso e Enrique Dias.}

Esparramado entre os abraços de Enrique Diaz e Bia Lessa, o diretor José Celso Martinez faz questão de refazer uma conta.

Não são seis irmãs, são nove, porque em “Cacilda!" também temos três irmãs: Dyrce, Cleide Yáconis e a própria Cacilda Becker - soma Zé Celso, referido- se, ao mesmo tempo, ao seu atual espetáculo e as duas montagens de "As três Irmãs", de Tchekov, sob o comando dos outros dois diretores,

De passagem pelo Rio para fazer uma palestra justamente sobre "As três Irmãs", peça que encenou em 1972, e para tirar uma folga de "Cacilda!", em cartaz no teatro oficina, em São Paulo, Zé Celso aproveitou para brindar a coincidência com Bia e Enrique num almoço no restaurante Florentino.

Quando fui convidada para dirigir As três Irmãs, eu não pensava em votar a fazer teatro porque estava envolvida em outros projetos - lembra Bia, que assina a versão em cartaz no Teatro 1 do Centro Cultural Banco do Brasil, com Débora Evelyn, Renata Sorrah e Lorena Silva nos papéis principais - um dos fatores que me fazem aceitar o convite foi haver outra montagem de As três Irmãs. A função original do teatro é justamente dar possibilidade ao público de conhecer olhares diferentes a partir do mesmo tema, dando a cada um a possibilidade de pensar um jeito.

Depois de declinar o convite das Fernandas Montenegros e Torres para dirigir uma versão de A Gaivota, também de Tchekov, Enrique titubeou bastante antes de aceitar a proposta da atriz Maria Padilha, que produz e estrela ao lado de Cláudia Abreu e Júlia Lemmertz, a montagem de As três Irmãs que estreará em Janeiro no teatro Leblon.

Nunca imaginei Tchecov batendo em mim como encantador, porque sempre o imaginei misterioso e chato! - lembra Enrique, que justifica a coincidência da montagem traçando um paralelo entre os sentimentos presentes em As três Irmãs e a realidade desse fim de milênio -Como nós nesse fim de milênio, os personagens de Tchekov vivem como podem, tentam buscar um novo caminho. 


\section{Para Zé Celso, peça apontava para a revolução brasileira.}

Sensação muito distinta da experimentada por Zé Celso no início da década de 70, quando em plena ditadura As três Irmãs significava para os integrantes da Oficina, a metáfora da busca da nova revolução.

Tínhamos a sensação de que As Três Irmãs (parte cortada do jornal) para passar a limpo a revolução Russa e que a última revolução do século seria a brasileira - lembra Zé Celso que toma o universo tchecoviano em Cacilda - Incluíndo Arkádina, de A Gaivota, porque ( parte cortada) iria com Cacilda Becker. São elas que fazem a junção entre passado e o que ainda está por vir.

\section{O Globo, 11 de maio de 2008}

\section{Um cerejal com ordem-unida Barbara Heliodora}

A montagem de "O jardim das cerejeiras" é o resultado de um trabalho a respeito de visão cênica que Moacir Chaves já vem realizando há algum tempo e que chega, aqui, a sua mais integral realização. A proposta é essencialmente anti-Stanislawski e, por isso mesmo, em claro conflito com o clima essencial da dramaturgia de Anton Tchekov. Rigidamente disciplinado, com marcas geométricas que mais lembram ordem-unida, o texto é apresentado quase ao nível de uma leitura branca, subtraída ao tom da leitura patética e inoperante decadência da família de Liubov Andreivna face às transformações sociais e econômicas que a família nem compreende e nem aceita. Como em Tchekov, eles estão condenados, porém, ao contrário do que acontece em Tchekov, não há compaixão para com eles.

\section{Figurinos masculinos atrapalham os atores.}

A tradução de Gabor Aranyi é fluente, e a encenação é despojada e corresponde a visão diretorial. O cenário de Rostand Albuquerque é composto por piso de tapetes e pequenos espaços de grama, mais quatro brancos. Os figurinos de Inês Salgado são bonitos para as mulheres, inexpressivos ou enganados para os homens. A luz de Aurélio de Simoni é fria e precisa como pede a direção, e a música de Tato Taborda também opta pelo impessoal ( é as vezes alta demais atrapalhando os atores).

As leituras das rubricas transforma o espetáculo em uma espécie de demonstração, ou de leitura branca, que incomoda mais que ajuda. Tudo é feito com cuidado, com um ponto de vista específico, infelizmente para "O jardim das cerejeiras", o caminho não parece bem sucedido.

O elenco sofre com isso. Deborah Evelyn, Claudia Sardinha, Elisa Pinheiro e Marcos Marjan são os que melhor escapam, com permissão para um pouco mais de emoção; Leandro Daniel Colombo não tem o físico ( nem o figurino) para Lopakhin, enquanto Glaucio Gomes tem o tipo para Lopakhin mas não para o fraco e decadente Gaiev. Aurélio de Simoni procura sugerir fragilidade, porém é moço e saudável demais para o velho Fírs. Julia Mirini, André Stock, Mônica Biel e Sidy Correa fazem modestas contribuições, e o mais fraco é o afrancesado empregado de Liubov.

\section{O Globo, 11 de maio de 2008}

\section{Os inefáveis limites do novo Tania Brandão}

Deixar fluir a alma nas letras, falar dos males de seu povo: este seria o objetivo de Tchekov diante de seu tempo. É a chave de leitura de "O jardim das Cerejeiras" para Moacir Chaves. O que se pretende é contar o teatro do autor. A proposta é atual, busca o atrito com as tradições teatrais. O texto surge sob uma ótica narrativa, econômica; é quase uma demonstração, em lugar de encenação. A concepção da direção domina toda a montagem. Quem se interessa pelo teatro do nosso tempo deve ir ver.

O jogo surge de saída na cenografia, de Fernando Mello da Costa e Rostand Albuquerque. Em lugar dos cenários propostos pelo original, um mosaico de tapetes coloridos sugere um chão precioso, opressivo, recortado por pequenas áreas verdes de grama, metáforas do cerejal em liquidação. Rústicos bancos de madeira, movimentados pelo elenco, marcam os atos da peça. As ações, portanto, não tem apoio realista: são teatrais e até usam rubricas de descrição da ação, do texto. A iluminação requintada 
(Aurélio de Simoni) constrói uma geometria de áreas de luz e sombra e poucos clímax emocionais. O figurino ( Inês Salgado) faz personagens tipos, qualidades de alma ou condição social.

\section{Falta densidade técnica de Aurélio de Simoni}

Sob este desafio são construídas as atuações, a parte mais problemática da montagem. A busca do novo através de um clássico pretende usar um painel da velha Rússia, um quadro de miséria social e existencial, para denunciar nosso deserto humano atual. Vale a pena conferir os resultados obtidos, afetados por uma discutível tentativa: impor a distância ao arrebatamento. Deborah Evelyn domina a cena inconsequente e frívola, um bibelô, mas sob tons patéticos ofuscados; Leandro Daniel Colombo tem impacto rústico perfil de Lopakhin; Julia Marini é uma Duniacha emblemática; Peter Boos sublinha o cinismo de Iacha. André Stock, Elisa Pinheiro, Gláucio Gomes, Marcos Marjan e Sidy Corea sofrem com a falta de momentos de explosão emocional. Mônica Biel e Claudia Sardinha têm atuações mecânicas demais. O ponto mais fraco, porém, é Aurélio de Simoni ( Firs) - uma figura forte, mas sem densidade técnica para a proposta: fazer do passado nosso contemporâneo.

\section{O Globo, 11 de maio de 2008}

\section{Experimentação elegante e fria Jefferson Lessa}

Considerada, mui justamente, a obra prima de Tchekov, "O jardim das Cerejeiras" é, também, uma eterna tentação para diretores. Clássica, com um equilíbrio absurdo entre momentos dramáticos e cômicos, elegante ao extremo, a peça é um convite a um tratamento convencional e a experimentações várias. No caso dessa montagem de Moacir Chaves, não foi diferente: o diretor imprime sua marca ao decidir levar à cena as rubricas do próprio Tchekov. Assim no começo de cada ato, um ator "diz" as marcações: "Firs caminha a passos curtos porém firmes etc. etc. etc.".

Funciona? Depende. A medida que o espetáculo avança, o estranhamento inicial dá lugar ao mergulho na beleza do texto e na profundidade da história. Uma história multifacetada, rica e muito complexa, que emociona o mundo ao tratar de uma aldeia. Assim, repetir o truque a cada começo de ato fica sobrando.

\section{Deborah Evelyn brilha como Liubov}

Reduzir a montagem em questão a esse momento-pesquisa, porém, seria extremamente injusto. O cenário minimalista de Fernando Mello da Costa e Rostand Albuquerque, feito de longos bancos de madeiras, muito simples, que o próprio elenco muda de lugar a cada ato, e tapetes orientais forrando o chão, com trecho de grama aparecendo, é sensacional. Sugere, com esses poucos elementos, o contraste entre os ambientes fechados e abertos da aristocrática mansão.

A luz de Aurélio de Simoni, elegantíssima, nao se desperdiça: ilumina ( mesmo) o essencial com síntonia finíssima. Os mesmo adjetivos valem para a música de Tato Taborda, delicadíssima. e os figurinos de InÊs Salgado são um deslumbramento, funcionando quase a perfeição para indicar classes sociais, intenções, idades e disposições de espírito dos personagens.

O elenco, como um todo, esforça-se e obtém resultados bastante satisfatórios, com altos e baixos. Mas o palco é de Deborah Evelyn, no papel de Liubov, asfixiada pela sociedade em transição e pela perda irrevogável de seu mundo, mas, ainda assim, viva. Vivíssima, aliás, como a interpretação da atriz, que cresce em nuance a medida que a peça avança.

Essa vivacidade acaba sendo essencial a um espetáculo que optou por uma certa frieza. Mas que, ainda assim, merece ser visto e comentado.

\section{O Globo, 11 de maio de 2008}

\section{Um diálogo com o espetáculo Stella Miranda}

“O jardim das Cerejeiras" é a última peça do dramaturgo russo Anton Tchecov (1860/1904) e pode ser considerada como um testamento. Mais que o retrato da transformação social e cultural de uma época ou país, esse clássico é um fluxo incessante de profundos movimentos interno dos personagens. 
Eles aparecem em cena, monologam e voltam a mergulhar na melancolia e no naturalismo tchekovianos. São quase como agulhar em um bordado.

Mas, de forma peculiar, o espetáculo de Moacir Chaves não é naturalista, pelo contrário, tudo, inclusive rubricas, é narrado quase que artificialmente. Essa opção impõe um distanciamento deliberado ao espetáculo, que chega assim ao público, filtrado. É um código narrativo que esfria emoções. Talvez essa seja uma crítica "impressionista" sem valor "científico", mas quero dialogar com o espetáculo, mesmo que seja para discordar. Parece que o diretor também quis dialogar com o autor, mas a sua maneira.

\section{Liubov com leveza diáfana e intensidade sutil.}

Este "O jardim das Cerejeiras" é mais do diretor Moacir Chaves do que do autor Tchekov. Que assim seja. A iluminação de Aurélio de Simoni, em poucas e precisas pinceladas, sussurra com o mosaíco de tapeçarias russas do cenário de Tato Taborda, outrora exuberante, aqui é mais contida, evocando balalaicas emoções. Os figurinos de Inês Salgado deram voz aos personagens femininos.

Poucos brasileiros já desfilaram Liubovs históricas. A de Déborah Evelyn traz uma leveza diáfana e uma intensidade sutil. É emocionante assistir a uma colega tão talentosa se entregar despudoradamente ao seu personagem. No elenco destacam-se a Duniacha pulsante de Julia Marini e o Epikhodov trapalhão de André Stock. O único nao ator do elenco, o digníssimo Aurélio di Simon, sempre a margem, carrega sozinho o peso da alma russa em busca do tempo perdido. Firs parece o próprio Tchekov observendo o espetáculo de Moacir Chaves.

Talvez a minha seja mais uma crônica do que uma crítica. Procurei uma perspectiva. Tentei manter distância, mas minha paixão pelo teatro fala mais alto. Para mim, como dizia o saudoso crítico Décio de Almeida Prado, "a crítica tem que ser cúmplice”. Viva o Teatro, Rio Feliz.

\section{Folha de São Paulo, 10 de julho de 1998.}

\section{"Gaivota" opõe no palco gerações da arte Fernanda Montenegro vive a atriz "fechada em idolatria"}

Fernanda Montenegro, ao entrar no palco em "Da Gaivota", num ensaio aberto, foi aplaudida. Mas ela não se considera uma diva, que é o seu personagem, a atriz Arkádina, representa. Mas considera o papel "um exercício muito engraçado", porque " não tem bom-mocismo nem com filho, nem com ninguém".

Folha- Como você construiu a Arkádina? Qual a relação que você fez entre ela e você?

Fernanda Montenegro- A Arkádina tem o vício do divismo. Eu acho que hoje, no campo das artes cênicas, restou um certo saudosismo desse poder mágico, misterioso, de as pessoas seguirem o ator com carruagens. Fica na memória, porque nos estamos muito perto desse século que acabou há cem anos. Mas hoje a gente tem uma visão crítica e vê que é uma deformação. A ultima grande veneração foi ( Maria) Callas. Foi a ultima grande diva, na medida em que compreendo uma grande diva, que fica na memória do mundo.

Folha - Mas é quase imediato que se faça uma relação de diva com você, no Brasil.

Montenegro - É, mas não acho que eu seja uma diva. Eu não sou uma atriz romântica. O divismo está ligado também a essa divisão exacerbada do romantismo. Dentro da estrutura clássica do teatro, ninguém passava diante e ninguém dava as costas para a grande figura, ao sair de cena. As pessoas saiam de costas.

Isso tudo é muito interessante, como matéria de trabalho. Mas não corresponde mais. Você pode ser reverenciado, você pode ser respeitado, mas não se chega a essa medida. No Brasil, figuras nacionais, do sul ao norte, eu vi com Procópio ( Ferreira). Vi um pouco com Dulcina. Eu vi o Procópio em cena. Era um fogo vivo. Um ator no esplendor dessa herança do ator brasileiro, do improviso, de presença dinâmica, dele com a platéia.

Folha- Você esta construindo a Arkádina, que é isso.

Montenegro - É acho as divas desumanas. São fechadas num culto a si mesmo, numa idolatria. Não que não tenham sentimentos por outras zonas da vida, mas estão bloqueadas numa trajetória altamente competitiva e autocompetitiva. Não tem bom-mocismo o nesse nível das divas. Não tem. 
Folha - Mas existe alguma coisa de Fernanda Montenegro nesse personagem que você esta construindo? Montenegro - Existe alguma referencia de algumas extraordinárias atrizes que eu vi. Eu trabalhei três anos com ( Henriette) Morineau. E ela era, segundo Décio de Almeida Prado, um primeiro-ministro em cena. Pisava forte. Tem também um "se exibir" um "olha minha luz". Não tem nenhuma modéstia. A sua figura é maior do que a arquitetura do teatro. É o teatro. Um exercício muito engraçado, porque não tem bom-mocismo. Nem com filho, nem com ninguém. É por cima mesmo. Mata que for.

Folha- Obviamente, você não é uma romântica.

Montenegro- Acho que não sou. Talvez eu não queira me reconhecer uma romântica.

\section{Folha de São Paulo, 01 de janeiro de 1999}

\section{Olga, Macha e Irina \\ Erika Salum \\ Produtora 'importou' atores de São Paulo}

$\mathrm{Na}$ entrada do teatro do Leblon, no Rio, um vendedor de doces avisa as pessoas na fila: "são quase duas horas de espetáculo, sem balinha não dá!”. Lá dentro 11 atores insistem”, diriam alguns, em apresentar "As três irmãs" do russo Anton Tchekov.

O espetáculo, que estréia em São Paulo no próximo dia 12, se detém em cinco anos da vida de três irmãs, Olga ( Julia Lemmertz), Macha ( Maria Padilha) e Irina ( Cláudia Abreu). Nesse período, não acontece nada...

Todos os sonhos das moças - principalmente, sair da pequena província de Moscou - vão sendo deixados para trás. Para muita gente, um texto quase impossível de ser encenado.

Não é o que acha Maria Padilha, experiente atriz de teatro ( "A falecida"), cinema (Ös matadores") e televisão. Apaixonada desde os 20 anos pelas obras do médico russo que trocou os doentes pela escrita, Padilha decidiu ela mesma produzir a montagem.

"Convidei diversos atores, mas todos recusaram minha proposta dizendo que era um texto sem ação", disse a FOLHA. Para completar o elenco, acabou "importando "três atores de São Paulo: Celso Franteschi, D’bora Duboc e Luciano Chirolli.

Para dirigir a peça, ela chamou um jovem artista, Enrique Diaz ( "A Bao a Qu”), da Companhia dos Atores - que enfrenta pela primeira vez um "texto clássico".

O passo inicial do diretor foi evitar, a todo custo, a criação de uma "linguagem cênica". E, principalmente, trabalhar o que há de humano nos personagens.

"A beleza de Tchekov é que ele fala de desejos, fracassos e frustrações inerentes ao homem. E o mais bonito é que o autor mostra que esses sonhos e decadências vão continuar existindo", diz. Quase não há cenários. Uma cadeira aqui, um samovar ( espécie de bule usado para ferver e manter quente o chá) ali.

Preocupação em evitar o tédio que várias montagens de Tchekov provocam na platéia? "não dei importância para isso. tentei ser o mais humilde possível. E Tchekov é tão brilhante que mesmo a melhor montagem de um texto dele vai ser pouco".

"As três irmãs" acontece em quatro atos. O primeiro se passa ao meio-dia, o segunda, as 20h, o terceiro, às $3 \mathrm{~h}$, e o último, ao meio-dia novamente. Em um período de cinco anos, ciclicamente.

\section{O tempo}

Se, no início, o que se vê são rostos felizes vidas cheias de esperança, ao longo da peça tudo vai desmoronando, bem devagar. É o fím do século 19, a decadência da nobreza, o dia que não passa. Para piorar, as três irmãs, cultas, finas, bem-educadas, gastam a vida no interior da Rússia, pensando em se mudar para a capital.

"Todos ficam sonhando com o futuro e relembrando o passado de tal forma que não são capazes de lidar com o presente", afirma Julia Lemmertz, a irmã mais velha.

Apesar de o título dar crédito apenas a trinca de mulheres "As três irmãs" não possui um protagonista definido. Há um irmão, Andrei, tão fracassado quanto o resto, e sua esposa, Natacha, pessoa pouco refinada. E, ainda, um médico que largou a medicina (como Tchekov), uma serviçal octogenária, um professor.

Mas, se existe uma ação, é quando chega a pequena cidade o comandante Verchinin (Frateschi). Causando frisson nas jovens românticas, termina por ter um caso com única delas que é casada, Macha (Padilha). 
Assim como as moças nunca vò a Moscou, ele também não larga a esposa doente por seu amor por Macha. Mais uma vez, a vida e os sonhos passam.

"Ao mesmo tempo que Tchekov o trata como um canalha, mostra para a platéia que o comandante é corajoso, que não deixou a mulher nem os filhos. É uma obra muito sutil, rica em detalhes e diversidades", Frateschi-Verchinin.

Maria Padilha admite: "Provoca muito medo montar Tchekov, medo de que aquilo não vai interessar a ninguém do público...". "Não dá para fazer Tchecov impunemente”, completa Frateschi.

\section{O Estado de São Paulo, 02 de abril de 2003.}

\section{Chekhov na visão bem humorada dos Bravos Atores. Ubiratan Brasil}

A companhia Bravos Atores decidiu montar uma das pequenas peças escrita pelo dramaturgo Anton Chekhov (1860-1904). Escolheu pedido de casamento, mas os atores não queriam simplesmente representar sua versão do texto- pretendiam, na verdade, oferecer uma visão particular da obra, onde pudessem comentar também as diferentes formas de interpretação. Surgiu A Proposta, que volta hoje a programação, agora n palco do Teatro Folha.

A adaptação foi feita por Ivan Cabral e Rodolfo Garcia Vazquez, fundadores do grupo O Satyros, em 1989. Tal origem já denuncia, portanto, o caráter humorístico de A Proposta - durante 65 minutos, é contada a história do jovem Ivan Vassílievich que vai a casa d a vizinha Akoulina pedir sua filha, Natalia, em casamento . A moça não esconde que deseja matrimônio, mas ainda não sabe que seu pretendente já pedira sua mão. Assim, Natalia inicia uma briga com Ivan por um pedaço de terra que caberia tanto a sua família quanto a do seu amado.

Não bastasse essa disputa, eles discutem também sobre o futuro casamento, cada qual defendendo seu palmo de terra. A briga só acaba quando o representante de um dos lados morre.

O clima, porém, não é de drama, mas de comédia. Para isso, os autores instituíram um novo personagem, o diretor, que comanda as cenas sob diferente enfoques. É o exemplo clássico de metalinguagem, que surpreende o público com as diferentes manifestações do encenador.

Assim, le intervém em diferentes momentos do ensaio, ora dirigindo os atores ao estilo Antunes Filho (todos encapotados andando em grupo como Medéia), ora em estilo desbundado e evocativo ao prazer de viver, como faz José Celso Martinez Corrêa. Em todas as situações, o diretor busca o caminho ideal nas suas representações.

O texto original de Chekhov sofreu ainda outra alteração, com a inclusão de uma empregada e a substituição do papel do pai no texto original por uma mãe.

Quando fizeram a adaptação em 1991, Cabral e Garcia Vazquez criaram um determinad número de quadros, mas, até a estréia do espetáculo, em Julho do ano passado, novos números foram criados e acrescentados, tornando as cenas mais atuais.

$\mathrm{Na}$ estréia do espetáculo, Vazquez declarou ao Estado que ele pretendia, junto de Cabral, fazer uma autocrítica do próprio trabalho, uma vez que já havia realizado produções como "Os cantos de Maldoror (1998)" e "Pacto de Sangue - Melodrama para Marionetes e Silhuetas ( 200)". "Tínhamos um trabalho permeado de violência e loucura e,quando estreamos a primeira versão da peça, nosso lado cômico se mostrou inteiro", afirmou, na época.

Jornal do Brasil, 13 de junho de 2003.

\section{Um "Tio Vânia"mais duro Macksen Luiz}

Em Tio Vânia, como na maioria das peças de Anton Tchecov, a realidade dos personagens se localiza na vaga região entre a imponderabilidade de uma insatisfação difusa e o desesperado tédio de vidas sempre adiadas ou condenadas a imobilidade, por fastio de conseguir transformá-la. Viver, para essa pequena burguesia russa pré-revolucionária desgarrada de si mesma, é comprovar que o ato de existir parece tão solitário quanto a comunicabilidade impossibilitada por intermináveis monólogos interiores que fazem com que cada um gravite em torno do gesto que alcança o outro nunca completá-lo. 
Não importa o que aconteça com a chegada do casal Serebriacov, os desejos frustrados permanecem e todos voltam ao ponto de partida, preso a um circulo de sentimentos. A vida é um fardo, repleto de desejos, mas vazio de possibilidades. Sônia, a mulher que abandona o trabalho monótono diante do amor ignorado do médico Astrov, expressa os sentimentos dos demais personagens ao reduzir a existência a um tempo de espera até que seja possível alcançar a paz e a felicidade pela transcendência da morte. Não há nada a fazer, completa Astrov, apenas se deixar perder num cansaço de cortar a respiração.

Tchecov capta em pleno vôo de queda a pulsação dessas almas aflitas, o surdo desespero acomodado de sobreviventes que perpetuam o desencontro definitivo com a existência. Neste texto niilista, o sentido imutável que sustenta a (in)ação dos personagens, contamina aqueles seres até a absoluta desesperança. Um grupo que abdica, com medo de não alcançar aquilo que já deu por perdido, se esvai num cotidiano melancólico, apenas interrompido pela presença do velho Serebriacov e da bela mulher Helna. Vânia e sua sobrinha Sônia mantêm a fazenda com a dedicação de um tributo (a quem? a quê?), acumulando ruidosamente, sentimentos silenciados. É este silêncio, embutidos de ruídos, que ganha eco na passagem do casal pela propriedade.

\section{O Estado de São Paulo, 11 jul. 2007.}

\section{Liberdade da arte faz Gaivota voar alto Mariangela Alves de Lima}

Repetidas vezes, ao longo de seus escritos, Clarice Lispector definiu sua obra como uma espécie de resíduo, sobra inevitável de uma busca malograda. Não por acaso ela é uma das musas protetoras da Cia. dos Atores. Desde que se apresentaram em São Paulo pela primeira vez, há quase duas décadas, esses artistas cariocas liderados por Enrique Diaz têm trabalhado sobre uma constante que, sob o rótulo um tanto pedante de 'desconstrução', encobre uma poética dedicada a celebrar as operações simbólicas. A coisa pronta, o ponto final e a procura do sentido unívoco são, ao que parece, fantasmagorias de uma etapa da história da arte que o grupo contesta por meio de espetáculos onde se sobrepõem efeitos visuais e sonoros, afirmações filosóficas e elocuções impregnadas de emotividade. De um modo geral, seus trabalhos enfatizam a pluralidade de sentidos contidos nos signos teatrais.

E é sobre essa linha mestra, exteriorizada com frequiência suficiente para caracterizar a identidade estética do grupo, que se organiza a encenação de Gaivota. Diante da peça-símbolo do Teatro de Arte de Moscou e marco fundador da modernidade teatral, o coletivo carioca exercita um trabalho de investigação e faz desse estudo um espetáculo. E o que chega à cena é, não a peça de Anton Chekhov, mas o resultado de uma aproximação que cerca o objeto por vários lados. Ou, para usar um mote de Jorge Luiz Borges, outro gênio protetor do grupo, o espetáculo seria uma promessa que não se cumpre, revelação iminente 'que não se produz'.

A aventura da busca e a agonia da dúvida são estados anímicos antagônicos nos processos de criação artística e o espetáculo explora intensidades e variações desse pêndulo energético por meio das personagens chekhovianas. Há intérpretes-criadores questionando o texto e experimentando personagens, cenas e arranjos espaciais sem que isso se estabilize em uma narrativa seqüencial. Há perguntas, inclusive, que poderiam ser endereçadas a qualquer outra peça. Estão em relação de simetria com os temas da peça, mas não é indispensável recorrer à narrativa original para compreender as vertentes artísticas que se abrem em leque por meio dessa proposta pluralista. O escritor Trigorin, por exemplo, pode não ser tão grande quanto Tolstoi, mas é representado no espetáculo como algo mais do que o homem vaidoso e egótico que a trama indica. Isolado da continuidade narrativa (uma vez que o episódio da sedução não interessa ao recorte do espetáculo), torna-se antes de tudo o criador obcecado para quem a vida interessa apenas como matéria para a ficção. Cada personagem, enfim, insinua um prisma da arte contemporânea e, a um só tempo, um movimento psíquico comum às mais diferentes tendências artísticas e etapas históricas. E não é preciso rememorar a evolução da arte no final do século 19 porque o diálogo travado entre personagens chekhovianos e atores-personagens, ambos situados em um esquema narrativo fragmentado, expõe o mecanismo analógico que associa os diferentes tempos. Ou seja, a correspondência que o espetáculo põe em relevo é a da filosofia da criação com seu caráter especulativo e abstrato.

Enquanto personagens do autor russo, os quatro artistas têm limites impostos pela verossimilhança e cada um se identifica com uma tendência artística. Examinados em sobrevôo por intérpretes do século 21, as duas atrizes e os dois escritores da história se amalgamam em uma discussão 
estética que interessa a todos exatamente porque não pode mais afirmar valores com segurança ou permanecer em uma única trincheira.

É a flutuação sobre um espaço amplo, branco e de início desguarnecido que sintetiza a concepção intelectual do espetáculo. Afonso Tostes faz aquela cenografia sutil que tem até zona de ocultamento, mas não se percebe. Aos atores compete - por meio da figura que nos faz tomar a parte pelo todo - trazer ao palco a mansão rural, o lago, o bosque, a lua. Sob esta ótica é também tarefa dos intérpretes desmanchar o encanto e devolver o material usado em cena à inércia significativa. Constantemente fazendo, desfazendo, transportando, vestindo e desvestindo, esta Gaivota transfigura em teatro um sentimento da arte contemporânea que é o de estar em absoluta liberdade, exultante e à deriva.

\section{Sala Preta (USP), v. 7, p. 225-228, 2007}

\section{Diálogo da Gaivota}

\section{Luiz Fernando Ramos e Sílvia Fernandes}

Luiz Fernando Ramos: O espetáculo Gaivota - tema para um conto curto encantou as platéias que o assistiram no teatro do Sesc Pinheiros de São Paulo, em 2007. Seria interessante pensar o que, exatamente, é tão fascinante naquele espetáculo, bem como sugerir porque, de algum modo, ele representa o ápice de um processo de radicalização, envolvendo o seu encenador, Enrique Diaz, a Cia dos Atores, comemorando 18 anos de trabalho, e os atores e atrizes agregados ao projeto. Esse conjunto de talentos encontrou na obra de

Tchecov o aliado mais potente e, talvez, insuperável no radicalismo, na sua reconhecida trajetória de exploração de novos caminhos para a cena brasileira.

O mais surpreendente nessa encenação da Gaivota é como, mesmo abandonando completamente a preocupação de desenvolver o texto de forma literal, o espetáculo se revela tão ou mais fiel ao original do que o faria uma montagem convencional. A falta de uma narrativa sem fissuras, que buscasse a ilusão verossímil de ações emolduradas em uma situação dramática estável, não impede que um espectador que nunca tenha ouvido falar da peça possa acompanhar o seu desenvolvimento dramático essencial e mergulhar na alma de seus personagens. Ao contrário, a opção pela instabilidade constante - tanto da cena, que se vai construindo como um esboço com permanentes ajustes dos traços, como dos personagens, que se vão substituindo entre os atores e muitas vezes se triplicando, atuando como coros favorece uma compreensão muito mais profunda da peça. E esse é o primeiro mistério do espetáculo que valeria elucidar.

Uma das características dos processos de construção dramática no teatro contemporâneo é a ampliação dos limites do que antes se convencionava como o ato de atuar. Ainda vigente na maioria dos processos de criação ficcional que ocorrem no cinema e na televisão, o padrão do naturalismo histórico, em que o ator se esconde completamente no personagem, vem cada vez mais se reduzindo no âmbito do teatro, restando ainda, principalmente, nas encenações mais convencionais e que buscam o êxito comercial fácil. Muitos são os fatores que geraram essa transformação histórica nos últimos sessenta anos, mas a influência mais crucial talvez tenha sido a das idéias de Antonin Artaud, reverberadas nos anos 1960 no teatro de Jerzy Grotowski e, posteriormente, nas metodologias de Eugênio Barba e outros criadores das últimas décadas do século XX. Para sintetizar o sentido principal dessa transformação, vale dizer que a atitude do ator de se entregar plenamente à encarnação de um personagem, rendido à sua lógica e às circunstâncias ficcionais que o condicionam, é colocada em xeque. Nessa nova perspectiva, é inadmissível que não haja um diálogo entre a pessoa do ator e o personagem, uma negociação que, no mais das vezes, se sobressai aos próprios aspectos funcionais de suas participações no drama e acaba indo para a cena como matéria prima do encenador. Num certo sentido, poder-se-ia argumentar, o trabalho clássico de preparação do ator do naturalismo proposto por Stanislavski, de que o ator utilizasse suas experiências de vida como andaimes para a construção do personagem, avança o sinal das coxias e tornase o tijolo mesmo da construção que chega aos olhos do público. O que fascina na montagem de Diaz de A Gaivota é que esse jogo de fusão das matérias primas dos atores e dos personagens não se esgota na busca da obtenção de um melhor desempenho, mas torna-se também pretexto para uma abertura do texto, de sua estrutura dramática, ao exame do público. Isso quer dizer que o trabalho interno de montagem, e toda a especulação que atores e encenador engendraram no processo dos ensaios chegam na cena em igualdade de condições com o tecido ficcional traçado pelo dramaturgo. O resultado é um transbordamento do dramático e da ficção que, ao invés de enfraquecer o envolvimento do público, intensifica a fruição do espetáculo e atualiza os significados latentes da peça em termos muito mais 
vibrantes do que o fariam a simples compreensão da trama, ou o empático envolvimento emocional com os personagens.

Esses procedimentos são comuns a muitas companhias que vêm atuando contemporaneamente no Brasil e no exterior. A própria Cia dos Atores vem de uma bem sucedida aplicação desse método sobre um outro clássico da dramaturgia, Hamlet de Shakespeare. Ensaio. Hamlet foi um espetáculo que marcou o amadurecimento de companhia e a tornou conhecida internacionalmente. Assim como em A Gaivota, ali o texto oferecia um vasto material para que o próprio ato de encenar um espetáculo fosse abordado e problematizado, e o jogo dos atores, trançando-se com os personagens para abrir a estrutura dramática ao exame do público, permitisse, também, uma leitura original e estimulante da peça. Dessa vez, talvez porque a peça de Tchecov seja mais explicitamente evocativa dos processos de encenação contemporâneos, o rendimento dessa dissecação de um clássico resultou ainda mais interessante. A opção por centrar a encenação em torno de um aspecto da peça nem sempre enfatizado - o fracasso da encenação do jovem Treplev diante de sua mãe, a grande atriz, Arkádina, que reverbera em todas as ações posteriores - permitiu que o tema central do espetáculo fosse a sua própria realização e a ameaça iminente dele próprio sucumbir. Esse trazer a ação à tona da cena, como que a deixando em carne viva diante do espectador, experimentou nesse caso um feliz e produtivo encontro: a tensa convivência entre a estrutura dramática genial criada pelo dramaturgo russo, que faz do abismo da criação artística o tema central da obra, e as próprias inquietações da companhia, lançada na aventura da criação e assumindo os riscos abismais de uma forma aberta e mutante.

Outro aspecto fascinante na montagem de Diaz é a discussão que estabelece com a idéia de representação. A começar do próprio ícone central da peça, a gaivota - representada de inúmeras e inusitadas maneiras, mas nunca de forma figurativa - um tema que perpassa todo o espetáculo é o da possibilidade de, no teatro, alcançar-se o máximo de significados com o mínimo de recursos. Assim, do lago que se forma a partir do café derramado, às asas que se armam a partir do foco de luz, há uma economia rigorosa a favorecer a condição de esboço, traço fugidio, que toda a encenação transpira. Como requinte máximo, nesse sentido, cite-se a tela inteiramente branca que, no mais das vezes, só é tingida sutilmente por figuras geométricas nas cores básicas. É uma evocação explícita das telas de Maliêvitch, o grande artista russo que primeiro, e de forma mais radical na história da pintura moderna, recusou a necessidade da pintura se apresentar a partir de um referente externo. A tela inteiramente branca, ou preta, terá como única referência a sua própria materialidade, ou cor. Da mesma forma, o espetáculo da Cia dos Atores, faz de si próprio, enquanto atualização contemporânea do teatro, o seu tema principal. A geringonça teatral desmontada, e exposta ao exame de seus procedimentos, oferece-se como matéria para a construção da poética cênica. Não é um poema fácil, ou pelo menos não busca a adesão irrestrita de um público acostumado às facilidades. Mas tem a simplicidade das grandes obras e se apresenta aos olhos com o carisma dos fatos inesquecíveis.

Sílvia Fernandes: Sem dúvida, o núcleo da cena é mesmo a capacidade que Enrique Diaz tem de abrir a estrutura do texto e os processos de ensaio permitindo que o trabalho interno da montagem chegue ao palco em igualdade de condições com a ficção tchekhoviana, como você diz bem. Nesse sentido, o abismo da criação artística é, de fato, o tema mais evidente do trabalho. Mas, quando o espetáculo terminou, tive a certeza de ter visto algo antológico, uma experiência de turning point no teatro brasileiro, como foram, para mim, Macunaíma, de Antunes Filho, Trate-me Leão, do Asdrúbal Trouxe o Trombone, Eletra com Creta, de Gerald Thomas e O livro de Jó, do Teatro da Vertigem. Talvez por isso, tenha ficado com a impressão de haver, na montagem, algo além da abertura de estruturas dramáticas e de representação, pois isso já estava no Ensaio.Hamlet e, com intensidade semelhante, em Melodrama e até em A bao a qu. A primeira encenação que Enrique Diaz apresentou em São Paulo com a Companhia dos Atores, também escolhia, como tema e forma, os processos de criar. Não por acaso $A$ bao a qu se apresentava como um "canteiro de obras teatral". Quase quinze anos depois da estréia, em 1991, a montagem ainda funciona como súmula de procedimentos que Enrique Diaz retoma e modifica em sua trajetória, e ainda surpreendem pela radicalidade.

Da mesma forma que espetáculos estreados na mesma época, como M.O.R.T.E., de Gerald Thomas, de 1990 e Exercício n. 1, de Bia Lessa, de 1987, A bao a qu também expunha o processo da criação artística num work-inprogress animado por um autor que encenava a metáfora da criação, usando a palavra concreta, a fisicalidade do ator, a materialidade do objeto e a disjunção espacial. Lembro, até hoje, do palco italiano do teatro João Caetano sendo paulatinamente preenchido por cadeiras, tijolos e vários tipos de pneus que, lançados aleatoriamente no espaço, desestabilizavam partituras de atuação e iluminação absolutamente rigorosas. Essa interferência do acaso (o espetáculo se inspirava no "Lance de dados", de Mallarmé) criava um movimento incessante de construção e desconstrução da cena, que às vezes envolvia os atores em fragmentos de tramas, supostamente dramáticas, intercaladas a partituras rítmicas que prescreviam tarefas de palco muito objetivas e relações pontuais com os objetos. 
Se pensarmos nesse aspecto, de revelação dos mecanismos construtivos da cena e da atuação, $A$ Gaivota é a radicalização de um princípio anterior de criação. E que você detecta quando diferencia esse processo contemporâneo das propostas de Stanislavski, por exemplo. No caso do espetáculo de Enrique Diaz, o que mais interessa é mostrar como o ator chega ao personagem a partir de si mesmo, e não como lança mão de uma série de procedimentos para chegar à construção de uma personagem específica, que o precede enquanto concepção e conformação dramática.

E é exatamente dessa constatação que vem a pergunta. O que acontece na Gaivota que não acontecia nos outros trabalhos? É difícil dizer. Talvez o que o diferencie seja uma inquietação existencial latente, acentuada pelos processos que a dramaturgia de Tchekhov mobiliza (ou seria o inverso? Procurase Tchekhov pela inquietação?). A verdade é que esse espetáculo abre um abismo na superfície carioca bem humorada que prevalecia e que permitia, em geral, que o espectador se divertisse sem angústia. $\mathrm{O}$ problema é que, mesmo no humor, Tchekhov não costuma transigir, ainda mais em seu texto maior sobre os processos de criar. Treplev, o dramaturgo, suicida-se no final da peça. Nina, a aspirante a atriz, fracassa e quase enlouquece. Trigorin, o escritor consagrado, continua a passarpela vida em brancas nuvens, empalhando moças. Quanto à Arkádina, a grande dama dos realismos de Dumas Filho, continua a representação previsível de protagonistas tuberculosas. Mas é especialmente pela via da turbulência interior dos artistas/protagonistas da Gaivota que Tchekhov pergunta se é mais difícil criar ou viver.

Lendo o texto inteligente que Enrique Diaz publica no programa do espetáculo, é possível pensar na questão da temporalidade na cena, que o diretor enfatiza, depois de mencionar a "continuação de uma pesquisa de narrativa, de desconstrução, de uma relação particular com os clássicos, com os objetos e sobretudo com o tempo". A partir dessa referência, em grifo no original, dedicar o espetáculo aos filhos e aos pais faz todo sentido. Pois a instabilidade da vida e da criação teatral parece ser o núcleo volátil da peça. E o como fazer para articular a passagem do tempo de lá para o tempo de cá, o tempo do drama russo para o tempo da cena de hoje, é a pergunta que Diaz faz e o espetáculo responde. Articular os tempos é encontrar equivalentes dessa angústia da transitoriedade, da fugacidade da vida de uma sociedade e de um de teatro do final do século XIX que está neles e, de outra forma, em nós, que nascemos no XX e chegamos ao XXI como parceiros solidários dessa disjunção ao vivo ou, como você diz melhor, em carne viva: o fracasso do filho diante da mãe e do novo teatro frente ao tradicional, o desencontro amoroso, a vaidade, a cegueira, a superficialidade e a hipocrisia da atriz (e da representação?), necessidade de criar um mundo especular diante da precariedade da vida, que acaba gerando uma instabilidade ainda maior. O lampejo temporal da situação passageira de um tipo de classe e de teatro é desdobrado na cena que não permanece, que é inconsistente até o inapreensível, a ponto de o espectador só perceber certas soluções quando elas já se dissolveram, como acontece com a relação nômade entre os atores e as várias personagens por onde passam, na projeção de uma cena migratória, indicada, por exemplo, nas fugazes asas de luz de Nina à beira do lago.

Há cerca de dois anos, assisti, no Rio de Janeiro, a um exercício que Enrique Diaz apresentou com seu grupo de intervenção urbana, o Coletivo Improviso, influenciado pela experiência com Anne Bogart, com quem estagiou no Saratoga International Theatre Institute. Diaz se aproxima dos viewpoints da encenadora americana quando estimula o ator a desenvolver a mestria dos movimentos e a definir seu desempenho também como domínio de formas plásticas no espaço, orientando-se por pontos de vista como o tempo, a repetição, a duração, o gesto, a forma, o padrão de trajetórias, as respostas cinestésicas e, evidentemente, o espaço.

E é fascinante constatar como os múltiplos pontos de vista aparecem radicalmente na Gaivota, especialmente nas soluções cênicas que se desmontam diante de nós para se remontarem mais à frente a partir de outro ângulo, como se o texto de Tchekhov fosse submetido a um caleidoscópio de pontos de vista e girasse sem parar, fisicamente, conforme quem assume o comando do olhar. E esse comando é dado pela subjetividade de uma visão singular, ou alguma coisa parecida com isso. Quando Mariana Lima, grávida de Enrique Diaz, fala do aborto de um filho imaginário, gerado pela personagem ficcional, cria o índice mais claro da performance dos atores.

Mas talvez o que mais impressione na Gaivota - tema para um conto curto seja a junção do trabalho de teatro, em sentido concreto, e da criação da cena imaginária, que aparece numa das indicações do lago, quando as três atrizes varrem a terra do chão enquanto formam seu contorno. Elas limpam o palco - são trabalhadoras de teatro - e ao mesmo tempo constroem a cena - são atrizes de teatro. Jamais personagens. Esse tempo já passou. 
O Globo, 30 de janeiro de 2009.

\section{Nome de Tchecov é usado em vão Bárbara Heliodora}

Não é justo atribuir a Tchecov a responsabilidade ou a culpa pelo espetáculo "A proposta", em cartaz na Casa Gávea, que usa seu nome mesmo que com a desculpa de "baseado em" na divulgação. Na ficha técnica, no entanto aparece "uma ideia original de Rodolfo Gracia Vazquez e Ivan Cabral", aos quais deve ser atribuído o desastroso espetáculo. Só com um máximo de imaginação e boa vontade é possível admitir que o título tenha o sentido duplo de referência a proposta de casamento de Tchecov e a idéia de uma proposta de uma variação de linguagens cênicas, já que o resultado é imperdoável, seja como conceituação, seja como execução. Não há nada que não seja infeliz e mal realizado. Tudo começa, devemos admitir, com uns 15 minutos de uma catastrófica interpretação da peça de Tchecov, composta por caricaturas grotescas, seja no visual, seja nos pulos, requebros e inanidades em todas a s atuações.

\section{Um alívio: texto original é, aos poucos, esquecido}

Quando um suposto espectador se levanta e protesta contra a má qualidade do que é apresentado, acontece o único momento de verdade na encenação, pois esse novo elemento se diz diretor e começa a sugerir uma série de novas concepções do texto, que ainda é repetido no Nordeste, porém vai, aos poucos ( para alívio de Tchecov), sendo esquecido, em favor de "criações"de igual ou pior falta de qualidade

O cenário de Sérgio Marimba é constituído por duas cadeiras, um tapete de face dupla e uma espécie de bar, tudo muito feio, enquanto os figurinos, péssimos, não tem atribuição. O que mais surpreende é consta na ficha técnica responsáveis por preparação corporal e coreografia, pois os movimentos são contraindicados, caricatos e infelizes. A direção é de Danny Oliveira, que parece toda concebida na linguagem de teatro em casa, amador, que gostaria de mostrar que sabe muitas coisas a respeito do teatro, e se exibe com a convicção da ignorância.

\section{Conclusão: o espetáculo é um completo equívoco}

O elenco é formado por Thiago Luciano, Danny Oliveira, Rodrigo Feldman, Marcos Baô e Beto Schultz, todos igualmente insatisfatório, todos, ao que parece, convencidos que estão fazendo alguma coisa que valha a pena, o que não é verdade. O uso do nome Tchecov na publicidade é enganador, e o desrespeito com o autor é lamentável. "A proposta", não sei se é autoral ou diretorial, é desastrada e trabalha contra a dignidade do teatro. É um engano total. 